\title{
Geograficzno-polityczne uwarunkowania sytuacji Ukraińców, Łemków, Białorusinów i Litwinów w Polsce po 1944 roku
}


Kamilce i Maćkowi 


\section{MAREK BARWIŃSKI}

\section{Geograficzno-polityczne uwarunkowania sytuacji Ukraińców, Łemków, Białorusinów i Litwinów w Polsce po 1944 roku}

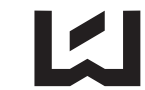


Marek Barwiński - Katedra Geografii Politycznej i Studiów Regionalnych

Wydział Nauk Geograficznych, Uniwersytet Łódzki, 90-142 Łódź, ul. Kopcińskiego 31

\author{
RECENZENT \\ Prof. dr hab. Marek Koter \\ OPRACOWANIE REDAKCYJNE I SKŁAD \\ Anna Araszkiewicz \\ RYSUNKI \\ Anna Wosiak \\ PROJEKT OKŁADKI \\ Andrzej Frydel
}

Na okładce wykorzystano zdjęcia Autora

Badania terenowe, których wyniki wykorzystano w książce, zrealizowano ze środków Narodowego Centrum Nauki przyznanych na podstawie decyzji numer DEC-2011/01/B/HS4/02609

Wydrukowano z gotowych materiałów dostarczonych do Wydawnictwa UŁ

(C) Copyright by Uniwersytet Łódzki, Łódź 2013

Wydane przez Wydawnictwo Uniwersytetu Łódzkiego

Wydanie I. (dodruk) W.06087.13.1.H

ISBN 978-83-7525-785-4

e-ISBN 978-83-7969-907-0

Wydawnictwo Uniwersytetu Łódzkiego

90-131 Łódź, ul. Lindleya 8

www.wydawnictwo.uni.lodz.pl

e-mail: ksiegarnia@uni.lodz.pl

tel. (42) 66558 63, faks (42) 6655862

Druk i oprawa: Quick Druk 


\section{SPIS TREŚCI}

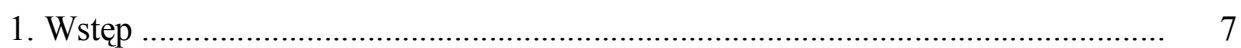

1.1. Wyjaśnienia terminologiczne ...................................................................... 9

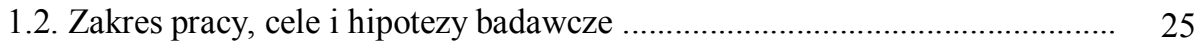

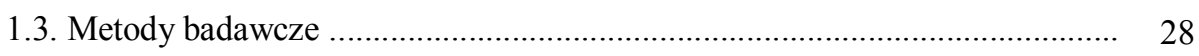

1.4. Literatura przedmiotu .......................................................................... 31

2. Geneza i dzieje Ukraińców, Łemków, Białorusinów i Litwinów na ziemiach polskich do 1944 roku - zarys problematyki ..................................................... 39

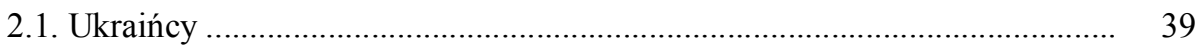

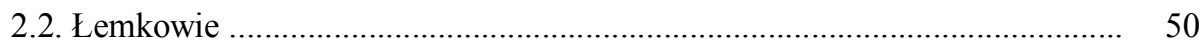

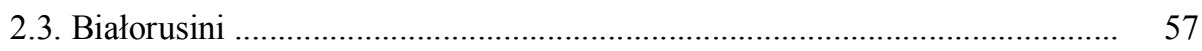

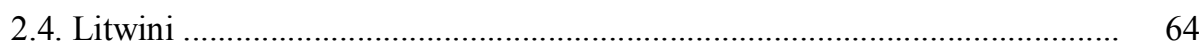

2.5. Liczebność i rozmieszczenie Ukraińców, Łemków, Białorusinów i Litwinów na podstawie wyników międzywojennych spisów ludności ........ 69

3. Sytuacja mniejszości ukraińskiej, łemkowskiej, białoruskiej i litewskiej

w Polsce na tle przemian politycznych po 1944 roku........................................... 78

3.1. Pierwsze lata po II wojnie światowej - prześladowania, przesiedlenia, dyskryminacja 78

3.1.1. Przesiedlenia do ZSRR w latach 1944-1946 ...................................... 85

3.1.2. Sumaryczny spis ludności z 1946 roku ............................................... 100

3.1.3. Akcja „Wisła” .................................................................................. 101

3.1.4. Przełom lat 40. i 50. XX wieku ....................................................... 115

3.2. Sytuacja w latach 1952-1989 - podporządkowanie, kontrola, asymilacja .... 119

3.2.1. Zmiany polityczne w 1956 roku i ich wpływ na sytuację mniejszości narodowych .............................................................................. 121

3.2.2. Dekada lat 60. XX wieku ………………………………………..... 135

3.2.3. Dekada lat 70. XX wieku ............................................................... 142

3.2.4. Dekada lat 80. XX wieku ................................................................ 146

3.3. Okres po 1989 roku - demokratyzacja, pluralizm, zmiany prawne .............. 152

3.3.1. Nowe uwarunkowania prawne pierwszej dekady XXI wieku ............. 154

3.3.2. Działalność polityczna i organizacyjna mniejszości ........................... 162

3.3.3. Szkolnictwo mniejszości narodowych …………………………....... 197

3.4. Stosunki międzypaństwowe w kontekście sytuacji mniejszości narodowych 208 
4. Współczesne rozmieszczenie i liczebność Ukraińców, Łemków, Białorusinów i Litwinów w Polsce

4.1. Analiza wyników spisu powszechnego z 2002 roku

4.2. Analiza wyników spisu powszechnego z 2011 roku

4.3. Analiza porównawcza wyników spisów powszechnych z początku XXI wieku

5. Studium porównawcze sytuacji społeczno-politycznej Ukraińców, Łemków, Białorusinów i Litwinów w Polsce 309

6. Wnioski 325

Literatura . 329

Od Redakcji 349

Aneks 351 


\section{WSTĘP}

Podczas ostatnich kilkudziesięciu lat Polska przechodziła wiele istotnych przeobrażeń politycznych, gospodarczych i społecznych - od kształtowania granic, przesiedleń ludności, narzucenia systemu komunistycznego, przez narastający nadzór władz partyjnych i aparatu bezpieczeństwa nad wszelkimi formami działalności, aż po demokratyzację i liberalizację systemu politycznego oraz integrację z politycznymi, gospodarczymi i militarnymi strukturami Europy Zachodniej. Zmiany te - przeprowadzane niejednokrotnie drogą rewolucyjną, a nie ewolucyjną - nie mogły nie mieć wpływu na sytuację poszczególnych mniejszości narodowych i etnicznych. W istotnym stopniu zmieniły ich rozmieszczenie, liczebność, tożsamość, relacje z polską większością, sytuację prawną, działalność organizacyjną, kulturalną, szkolnictwo. Wpływ ten nie był jednolity w perspektywie czasowej, terytorialnej i etnicznej. Był odmienny w różnych latach, w różnych regionach Polski oraz wobec różnych narodowości. Głównymi punktami zwrotnymi były daty kryzysów i przełomów politycznych, które wyzwalały aktywność środowisk mniejszości narodowych, a niejednokrotnie powodowały także zmiany $\mathrm{w}$ prawie oraz $\mathrm{w}$ praktyce postępowania $\mathrm{z}$ obywatelami niepolskiej narodowości.

Podmiotem badań są zamieszkujący Polskę Ukraińcy, Łemkowie, Białorusini i Litwini, natomiast przedmiotem badań są geograficzno-polityczne uwarunkowania ich sytuacji na tle przemian politycznych po $1944 \mathrm{r}$. Analizowane zbiorowości stanowią najliczniejsze mniejszości narodowe i etniczne wschodniego i południowo-wschodniego pogranicza Polski. Należą do tzw. mniejszości tradycyjnych, od wieków zamieszkujących w ramach państwa polskiego, są swoistym reliktem wielonarodowej Rzeczypospolitej. Mniejszości te, w wyniku II wojny światowej oraz polityki władz komunistycznych uległy bardzo istotnym przeobrażeniom terytorialnym, ilościowym, instytucjonalnym, społecznym i kulturowym. Zamieszkiwane przez nie regiony zostały podzielone granicami państwowymi, a ludność objęta akcjami przesiedleńczymi o różnej skali, natomiast poczucie odrębności narodowej było osłabiane asymilacyjną polityką władz, prowadzoną $\mathrm{w}$ ramach budowania społeczeństwa monoetnicznego.

Przekształcenia struktury narodowościowej zapoczątkowane zmianami terytorialnymi i politycznymi II wojny światowej nie zakończyły się wraz z trans- 
formacją polityczną i ustrojową początku lat 90. XX w. Uległy zmianie realia polityczne, prawne i instytucjonalne, nastąpiło wyraźne odejście od dotychczasowej polityki narodowościowej oraz uaktywnienie środowisk poszczególnych mniejszości, jednak nie wygasły dawne konflikty i wzajemne urazy oraz nie zahamowano procesów asymilacji i akulturacji. Wyniki spisów powszechnych przeprowadzonych na początku XXI w. dostarczyły, często dyskusyjnych i kontrowersyjnych, danych dotyczących liczebności i rozmieszczenia poszczególnych narodowości. Uznanie przez demokratyczne władze różnorodności etnicznej Polski, wprowadzenie kompromisowych rozwiązań prawnych, obecność mniejszości narodowych w przestrzeni publicznej, spowodowały zmiany w relacjach niepolskich narodowości z większością społeczeństwa, co z jednej strony prowadzi do ich upodmiotowienia, z drugiej wywołuje krytyczne opinie i spory, zwłaszcza na poziomie lokalnym.

Praca jest poświęcona przemianom narodowościowym, jakie zachodziły w Polsce po 1944 r., ze szczególnym uwzględnieniem mniejszości narodowych i etnicznych wschodniej Polski, gdzie zmiany te, zwłaszcza w aspekcie terytorialnym i ilościowym, były bardzo dynamiczne i wewnętrznie silnie zróżnicowane. Po upływie kilkudziesięciu lat i licznych przekształceniach sytuacji politycznej i prawnej można pokusić się o zbadanie, w jaki sposób polityka państwa, zarówno w warunkach ustroju totalitarnego, jak i demokratycznego, wpływa na strukturę narodowościową. W jaki sposób system polityczny i jego zmiany warunkują relacje między większością a mniejszościami narodowymi? Jak w różnych okresach kształtowała się tożsamość narodowa oraz instytucjonalizacja działalności społecznej i kulturalnej mniejszości narodowych i etnicznych „skazanych” przez władze na rozproszenie i stopniową asymilację? Co było głównymi przyczynami zróżnicowanej sytuacji społeczno-politycznej omawianych mniejszości w okresie PRL? Czy zmiany ustrojowe, zapoczątkowane w 1989 r., umożliwiły w praktyce równoprawne funkcjonowanie poszczególnych mniejszości narodowych i etnicznych? W jaki sposób liderzy omawianych mniejszości postrzegają i oceniają obecną sytuację narodowości, które reprezentują? Tak sformułowane pytania są zasadniczymi problemami badawczymi podjętymi w niniejszej pracy.

Problematyka narodowościowa jest przedmiotem zainteresowania wielu nauk, m.in.: historii, statystyki, demografii, politologii, socjologii, etnologii, etnografii. Także geografii, która zwraca szczególną uwagę na element przestrzenny związany z rozmieszczeniem poszczególnych narodów, z przyczynami i konsekwencjami jego zmian oraz genezą skupisk mniejszości narodowych. W ramach geografii ludności, czy szerzej antropogeografii, funkcjonuje, obok geografii 
religii i geografii języków, także geografia narodowości ${ }^{1}$, zajmująca się określeniem liczebności oraz oceną i analizą struktur etnicznych w różnych skalach przestrzennych. Badania struktur narodowościowych i ich przemian są powszechne zwłaszcza w geografii politycznej, która poświęca problematyce mniejszości zarówno narodowych, etnicznych, językowych, jak i religijnych najwięcej miejsca spośród nauk geograficznych. Dzięki umiejętności badania zjawisk w kontekście przestrzennym i czasowym ułatwia ona poznanie i zrozumienie wzajemnych relacji czynników politycznych, demograficznych, społecznych i kulturowych. Badania takie mają szczególne uzasadnienie w sytuacji wyraźnej zależności zmian narodowościowych od przekształceń terytorialnych i politycznych, czyli elementów będących w centrum zainteresowania geografii politycznej. Sytuacja taka ma miejsce w przypadku mniejszości narodowych i etnicznych zamieszkujących wschodnią Polskę.

Studia nad mniejszościami narodowymi i etnicznymi w polskiej geografii politycznej mają długą tradycję badawczą i bogaty dorobek naukowy, zwłaszcza $\mathrm{z}$ okresu międzywojennego oraz ostatnich dwudziestu lat ${ }^{2}$. Badania te, w latach PRL epizodyczne, współcześnie przeżywają renesans. Geografia polityczna, zajmując się problematyką narodowości, korzysta z dorobku innych dyscyplin, zwłaszcza historii, statystyki, socjologii i politologii. Podstawowym punktem odniesienia wszelkich analiz specyfiki etnicznej pozostaje przestrzeń, środowisko geograficzne oraz warunki społeczno-gospodarcze, przy jednoczesnym uwzględnieniu wpływu uwarunkowań historycznych i politycznych. Bliskie powiązania geografii politycznej z geografią historyczną oraz historią, które to dyscypliny naukowe badają i wyjaśniają naturalną zmienność zjawisk w czasie i przestrzeni, umożliwiają odwołanie się do niezbędnego w tego typu pracy kontekstu społeczno-historycznego.

\subsection{Wyjaśnienia terminologiczne}

Tematem badań są mniejszości narodowe i etniczne, dlatego podstawowym zagadnieniem jest wyjaśnienie terminów związanych z tymi kategoriami. Są one rozpatrywane, wbrew pozorom, nie tylko według kryteriów ilościowych, ale również historycznych, prawnych i socjologicznych. Istotny jest także kontekst przestrzenny, w odniesieniu do którego termin „mniejszości” jest definiowany,

${ }^{1}$ O geografii narodowości pisali m.in. B. Zaborski i A. Wrzosek (1939), A. Maryański (1994) oraz P. Eberhardt (2010b).

${ }^{2}$ Obszernie pisali na ten temat m.in. P. Eberhardt (2004a, 2010b) i M. Sobczyński (2008b, 2008c). 
oraz status, jaki zajmują w społeczeństwie, zwykle niższy zarówno pod względem politycznym, społecznym, jak i ekonomicznym.

Pojęcie mniejszości narodowej pojawiło się stosunkowo późno, dopiero w połowie XIX w., kiedy kształtowała się współczesna świadomość narodowa, powstawały współczesne narody, zanikały natomiast dominujące wcześniej tradycyjne podziały stanowe. Jest ono, podobnie jak bezpośrednio z nim związane pojęcie narodu i narodowości, wieloznaczne, przez co należy do zagadnień szczególnie skomplikowanych, dyskusyjnych, a często i drażliwych. W nauce istnieje cała gama definicji narodu oraz mniejszości narodowej. Wiele z nich jest zbyt ogólnikowych bądź nieprecyzyjnych. Inne z kolei, jeżeli potraktować je dosłownie, pozostawiają poza swoim zakresem, często celowo, niektóre realnie istniejące zjawiska (Tomaszewski 1991, Żołędowski 2003).

Odpowiedzi na pytania „co to jest naród?” oraz „co to jest mniejszość narodowa?" w dużej mierze zależą od tego, kogo pytamy, w jakich okolicznościach i w jakim okresie historycznym. Inaczej do tych problemów podchodzi etnograf czy geograf ludności, zupełnie inaczej polityk, a jeszcze inaczej historyk lub socjolog. Odpowiedzi będą także zależeć od wyznawanych przez pytanego poglądów politycznych, a nawet filozoficznych (Sobczyński 1996b). Definicje narodu i mniejszości narodowej mają bowiem bardzo często charakter instrumentalny, służyły i służą celom politycznym i ideologicznym. Częstokroć stanowiły podstawę odmowy uznania określonych grup za naród (lub mniejszość narodowa), bądź przeciwnie, miało z nich wynikać, że dana zbiorowość jest narodem, w związku z czym przysługują jej określone uprawnienia (Waldenberg 1992). Nadal aktualne jest stwierdzenie L. Wasilewskiego (1929), że ,pojęcie narodowości, narodu zmienia się w zależności od tego, kto to pojęcie formułuje”.

Brak jednoznacznej, powszechnie akceptowanej definicji wynika nie tylko z wielości dyscyplin naukowych zajmujących się tą tematyką oraz problemów z obiektywizacją stosowanych pojęć, ale przede wszystkim ze zróżnicowania grup mniejszościowych. Obrazują to m.in. liczne typologie i klasyfikacje mniejszości narodowych, zarówno socjologiczne (Lewandowski 1993, Żołędowski 2003, Łodziński 2005, Budyta-Budzyńska 2010), nawiązujące głównie do relacji mniejszości z zamieszkiwanym terytorium oraz charakteru więzi łączącej członków mniejszości, jak i geograficzne (Koter 1993, 1995a, b, 1998), opracowane z punktu widzenia etniczno-terytorialnego oraz genetycznego.

Podstawową kwestią jest ustalenie, czy dana grupa spełnia cechy mniejszości narodowej. Odpowiedź nie jest prosta i zależy od wielu elementów, a zasadnicze znaczenie mają przyjęte kryteria. Najczęściej wymieniane jest kryterium arytmetyczne (grupa znajdująca się w liczebnej mniejszości wobec pozostałej ludności), wyróżniające (grupa odróżniająca się od większości m.in. wspólnymi 
cechami etnicznymi, kulturowymi, językowymi, religijnymi) oraz rodzaj relacji z większością (grupa niedominująca, podporządkowana pod względem politycznym, społecznym, ekonomicznym). Jednak najistotniejsze jest ustalenie, czy dana zbiorowość jest częścią narodu, czy ma świadomość odrębności narodowej i jako taka może być określana jako mniejszość narodowa, w odróżnieniu od np. mniejszości ideologicznych, światopoglądowych czy seksualnych. Jest to często niejednoznaczne i kontrowersyjne.

Trudności wynikają ze ścierania się dwóch odmiennych, czy raczej uzupełniających się, teorii narodu: obiektywnej i subiektywnej. Pierwsza z nich zakłada, iż o przynależności do narodu decydują cechy obiektywne, niezależne od woli i świadomości jednostek, takie jak zamieszkiwane terytorium, przekonanie o wspólnym pochodzeniu, własne państwo, które zamieszkuje przynajmniej część narodu, język, który uznaje za ojczysty, własna historia, kultura, religia, gospodarka. Druga teoria zakłada, iż przynależność do narodu jest aktem woli jednostki w zależności od jej subiektywnych przekonań, z reguły uwarunkowanych historycznie i kulturowo, przejawiającej się w poczuciu świadomości narodowej, wzajemnej więzi emocjonalnej, identyfikacji z własną grupą oraz odrębności od innych narodów (Bokszański 1996, Sobczyński 1996b, Michna 2004, Budyta-Budzyńska 2010).

Najczęściej w definiowaniu narodu oraz mniejszości narodowej wymieniane są zarówno cechy obiektywne, jak i subiektywne. Jednak odwoływanie się wyłącznie do cech obiektywnych lub kładzenie na te cechy głównego nacisku może często prowadzić do nieuznawania za naród zbiorowości, które ewidentnie je tworzą. Są bowiem liczne przykłady narodów, które istnieją, mimo że nie posiadają lub długo nie posiadały własnego państwa (np. Kurdowie, Tybetańczycy, Tamilowie, Baskowie, Katalończycy, Palestyńczycy, Bośniacy, Słoweńcy), nie mają wspólnego języka ojczystego (Szwajcarzy), nie zamieszkują w większości zwartego terytorium (Żydzi, Romowie). Dlatego uznano, że precyzyjniejsze jest określanie przynależności jednostki do narodu na podstawie cech subiektywnych, zwłaszcza z zakresu uczuć, woli i świadomości. Jest to współcześnie dominujący pogląd, głównie w krajach demokratycznych. Takie podejście jest szczególnie istotne na obszarach pograniczy narodowościowych, gdzie dochodzi do przenikania się i przemieszania różnych narodów, gdzie częstym źródłem konfliktów jest negowanie samoidentyfikacji narodowej poszczególnych osób czy społeczności, przypisywanie im innej przynależności narodowej niż ta, z którą się identyfikują (Barwiński 2004a, b).

Ponadto o tym, czy dana grupa posiada status mniejszości narodowej, decydują postanowienia prawa międzynarodowego oraz wola państwa osiedlenia. W okresie międzywojennym podstawowym kryterium zaliczenia do mniejszości 
narodowej było zamieszkiwanie „od zawsze” zwartego terytorium, obywatelstwo państwa osiedlenia, bycie odłamem narodu posiadającego własne państwo i kultywowanie własnej odrębności. Współcześnie dominują dwa podejścia: historyczno-prawne i socjologiczne. W pierwszym podkreśla się przede wszystkim państwowy stan posiadania, status obywatelski, kryterium liczbowe, niezajmowanie pozycji dominującej w społeczeństwie, lojalność wobec państwa oraz czynniki obiektywne (pochodzenie, język, religia, zamieszkiwane terytorium). W podejściu socjologicznym, które podkreśla, że to cechy zbiorowości, a nie państwo, decydują czy jest ona zaliczana do mniejszości narodowych, doszło do pewnego ujednolicenia stanowiska poprzez uznanie mieszanej zasady subiektywno-obiektywnej. Przy ustalaniu przynależności narodowej członków mniejszości najistotniejsze jest subiektywne poczucie przynależności do danego narodu, wola bycia mniejszością, świadomość przynależenia do określonych wartości i symboli, poczucie więzi z tą a nie inną zbiorowością, natomiast cechy obiektywnej odrębności od większości odgrywają rolę pomocniczą (Chałupczak, Browarek 1998, Budyta-Budzyńska 2010).

W polskiej literaturze, głównie socjologicznej i geograficznej, pojęcie mniejszości narodowej omawiało i definiowało wielu autorów, m.in. J. Wiatr (1973), J. Byczkowski (1976), S. Ossowski (1984), A. Sadowski (1991a, 1995a, 2009), J. Tomaszewski (1991), K. Kwaśniewski (1992, 2005), M. Waldenberg (1992, 2000), G. Janusz (1993), M. Koter (1993, 1995a, 1998), A. Maryański (1994), E. Michna (1995, 2004), P. Eberhardt (1996, 2006, 2008), A. Kłoskowska (1996), G. Babiński (1997), H. Chałupczak, T. Browarek (1998), M. Baczwarow, A. Suliborski (2002), M. Budyta-Budzyńska (2003, 2010), C. Żołędowski (2003), M. Barwiński (2004a, b), Z. Kurcz (2005), S. Łodziński (2005), Z. Rykiel (2006), M. Sobczyński (1996b, 2000), R. Szul (2009). W licznych definicjach mniejszości narodowej można wyróżnić kilka najczęściej powtarzających się elementów wspólnych. Jest to zbiorowość, która na danym obszarze, na skutek różnych przyczyn historycznych (np. zmian granic, migracji), jest mniej liczna od pozostałej ludności, odróżnia się od reszty obywateli cechami etnicznymi, językowymi, kulturowymi lub religijnymi oraz ma świadomość odrębności narodowej, subiektywną wolę bycia mniejszością i podkreśla swą odrębność. Ponadto jej relacje z większością charakteryzują się podporządkowaniem $\mathrm{w}$ aspekcie prawnym, politycznym, ekonomicznym lub prestiżowym. Ważnym elementem jest ,zasiedziałość” danej zbiorowości etnicznej oraz jej „tradycyjny" związek z zamieszkiwanym terytorium. Grupy imigrantów, często zdecydowanie liczniejsze od tzw. tradycyjnych mniejszości, z reguły nie są uznawane za mniejszości narodowe, nie są także chronione odrębnymi przepisami prawnymi. 
Jako przykład adekwatny do sytuacji Ukraińców, Białorusinów i Litwinów w Polsce może posłużyć definicja H. Chałupczaka i T. Browarka (1998), którzy charakteryzują mniejszość narodową jako „grupę obywateli danego państwa, pozostającą w mniejszości w stosunku do pozostałej częśsi jego ludności i niezajmującej pozycji dominującej, wyróżniającą się cechami etnicznymi, językowymi lub religijnymi, wspólnie dążącą do zachowania swej odrębności kulturowej i posiadającą aspiracje ujmowane w kategoriach państwa".

Niejednokrotnie wraz z pojęciem mniejszości narodowej pojawia się kategoria mniejszości lub grupy etnicznej. Grecki termin ethnos oznacza: thum, lud, rasę, plemię, naród, klasę ludzi, ma więc bardzo szeroki zakres pojęciowy, dlatego często określenia te używane są jako substytuty lub synonimy.

W socjologii wyróżnia się szersze i węższe znaczenia pojęcia mniejszości etnicznej. W ujęciu szerszym (preferowanym w krajach anglosaskich), kategoria mniejszości etnicznej jest nadrzędna wobec mniejszości narodowej, która jest traktowana jako jej podtyp, wraz z mniejszościami niedającymi określić się jako narodowe. Takie definiowanie zakłada zmienność jej form i obejmuje wszelkie zbiorowości, od plemion, grup regionalnych czy etnograficznych, aż do narodów. W węższym znaczeniu, powszechniej stosowanym, mniejszość etniczna jest grupa posiadającą świadomość własnej odrębności kulturowej, językowej, historycznej, często terytorialnej, ale nietworzącą jeszcze odrębnego narodu. Jest postrzegana jako zbiorowość, której brakuje pewnych cech, by stać się mniejszością narodową, zwłaszcza wykształconego poczucia odrębności narodowej oraz własnego państwa, zagranicznej ojczyzny ${ }^{3}$ (Pawluczuk 1972, Sadowski 1995a, Michna 2004, Budyta-Budzyńska 2010). Jak pisze S. Łodziński (2005), nawiązując do Maxa Webera, „dla członków mniejszości etnicznej ważne pozostaje ustalenie, kim nie są, natomiast dla członków mniejszości narodowej ważne jest to, kim są".

H. Chałupczak i T. Browarek (1998) pod określeniem „mniejszość etniczna” rozumieją „wspólnotę obejmującą obywateli danego państwa powstałą w wyniku procesu historycznego, posiadającą poczucie swej odrębności, trwałe formy integracji na podstawie wspólnego pochodzenia, języka lub religii, ale niemającą aspiracji ujmowanych w kategoriach państwa". Zgodnie z takim podejściem, mniejszości etniczne, w odróżnieniu od narodowych, nie posiadają państwa macierzystego i nie wysuwają postulatów typu państwowego. Odróżnianie mniejszości narodowych od etnicznych według kryterium „posiadania państwa”, lub twierdzenie, iż mniejszość narodowa jest zawsze większością w innym państwie, natomiast mniejszość etniczna w żadnym państwie nie jest większoś-

3 Pojęcie zagranicznej ojczyzny będzie rozumiane jako państwo tworzone przez naród, z którym dana mniejszość odczuwa wspólnotę etniczną (Żołędowski 2003). 
cią, jest współcześnie rozpowszechnione (choć niepowszechnie przyjęte), zarówno w socjologii, jak i w geografii politycznej (Baczwarow, Suliborski 2002, Łodziński 2005, Rykiel 2006, Budyta-Budzyńska 2010).

Pojęcie grupy etnicznej jest trudne do zdefiniowania. Przede wszystkim dlatego, że w różnych społeczeństwach i w różnym czasie miało inną treśćc ${ }^{4}$. Określanie mniejszości etnicznej jako zbiorowości, której „czegoś brakuje” (zwłaszcza z zakresu elementów kultury i świadomości), żeby można było ją nazwać mniejszością narodową, współcześnie wydaje się anachronicznym i absurdalnym powrotem do XIX-wiecznych koncepcji podziałów na narody „lepsze i gorsze”, mniej lub bardziej „cywilizowane”. Fenomen etniczności kształtuje się na bazie odmienności od otoczenia społecznego. Najogólniej rzecz biorąc, mniejszość etniczna to wspólnota ludzi w jakiś sposób odmiennych od większości zamieszkujących dane terytorium (Mikołajewska 1987). W takim ujęciu pojęcie mniejszości etnicznej będzie zawierać w sobie pojęcie mniejszości narodowej i będzie miało znaczenie synonimiczne. Powszechne w naukach socjologicznych rozróżnianie mniejszości etnicznej i narodowej oraz budowanie na tym rozróżnieniu różnorakich teorii niejednokrotnie nie ma znaczenia, ponieważ społeczności określane jako etniczne i jako narodowe w zasadzie dążą do tego samego, czyli zachowania własnej tożsamości i podmiotowości (Szul 2009).

Powyższe rozważania wykazują, iż określenie przynależności danej zbiorowości do konkretnej mniejszości narodowej czy etnicznej jest sprawą bardzo złożoną. Trudności pojawiają się przy próbie ustalenia, czym jest badana grupa społeczna, czy stanowi wspólnotę narodowa, etniczną, czy jest częścią jakiegoś etnosu nieukształtowanego jeszcze w samodzielny naród. Może też stanowić odrębną wspólnotę polityczną, religijną, rasową, obyczajową, językową czy inną. Ponieważ w wielu krajach istnieją zbiorowości nadal poddawane procesom konsolidacji i asymilacji, stanowiące formy przejściowe o bardzo płynnym stopniu świadomości narodowej, noszące cechy dualizmu narodowego, ich zaszeregowanie może być sprawą nadzwyczaj trudną, o ile w ogóle wykonalną. W szczególności dotyczy to grup regionalnych oraz mieszkańców pogranicza etnicznego, gdzie zazwyczaj występuje wzajemne przenikanie i mieszanie różnych grup etnicznych. Nie zawsze mieszkańcy określonego terytorium są w stanie wytworzyć jednolitą świadomość narodową, nawet jeśli wywodzą się z lokalnej wspól-

${ }^{4}$ Poza wspomnianymi powyżej szerszym i węższym postrzeganiem tego pojęcia w socjologii, szeregiem różnic w poszczególnych definicjach oraz wyróżnianiem według kryterium braku państwa macierzystego, mniejszości etniczne utożsamia się niekiedy także z grupami imigrantów i charakteryzuje jako rozproszone, napływowe społeczności „imigrantów etnicznych”, ulegające dobrowolnej asymilacji w państwie osiedlenia (Burszta, Jaskułowski 2005). 
noty o dość jednolitej tradycji i kulturze (Byczkowski 1976, Sobczyński 1996b). Ponadto dla jednostki przynależność do mniejszości narodowej czy etnicznej zawsze będzie zdeterminowana urodzeniem w określonej zbiorowości i w jakiejś mierze wynikiem własnego wyboru. Dlatego nie jest ani w pełni przypisana (obiektywna), ani całkowicie dobrowolna (subiektywna) (Łodziński 2005).

W przyjętych w Polsce po 1990 r. rozwiązaniach prawnych normą stało się uznanie liberalnej zasady samookreślenia narodowego, mówiącej, że „każdy jest tym, za kogo się uważa”. Zgodnie z tym, czynnikiem decydującym o przynależności do poszczególnych mniejszości powinien stać się indywidualny, subiektywny wybór jej członków. Jednak w praktyce zasadę tę ograniczono do tzw. mniejszości tradycyjnych, odmawiając jej np. Ślązakom. Ponadto we współczesnym definiowaniu, klasyfikowaniu i różnicowaniu poszczególnych narodowości oraz zaliczaniu ich lub wykluczaniu z grona mniejszości narodowych i etnicznych, zasadnicze znaczenie ma wymóg (lub jego brak) posiadania obywatelstwa kraju zamieszkania, wieloletniego zamieszkiwania określonego terytorium oraz posiadania zagranicznej ojczyzny, czyli cechy obiektywne.

W Polsce, po kilkunastu latach sporu parlamentarnego, 1 maja 2005 r. weszła w życie Ustawa o mniejszościach narodowych i etnicznych oraz języku regionalnym, uchwalona przez sejm 6 stycznia 2005 r. Znaczenie ustawy jest na tyle istotne, że jest nazywana „konstytucją mniejszości narodowych”, Określa m.in. warunki, na jakich państwo polskie może uznać daną zbiorowość za mniejszość narodową lub etniczna, zamieszcza wykaz narodowości, które zostały oficjalnie za takie uznane, oraz prawa, jakie w związku z tym faktem im przyznaje. Według ustawy mniejszością narodową jest grupa, która spełnia łącznie następujące warunki ${ }^{6}$ :

- jest mniej liczebna od pozostałej części ludności Rzeczypospolitej Polskiej,

- posiada polskie obywatelstwo,

- w sposób istotny odróżnia się od pozostałych obywateli językiem, kulturą lub tradycją,

- dąży do zachowania swojego języka, kultury lub tradycji,

- ma świadomość własnej historycznej wspólnoty narodowej i jest ukierunkowana na jej wyrażanie i ochronę,

- jej przodkowie zamieszkiwali obecne terytorium Rzeczypospolitej Polskiej od co najmniej 100 lat,

- utożsamia się z narodem zorganizowanym we własnym państwie.

\footnotetext{
${ }^{5}$ Szczegółowe zapisy ustawy zostały szerzej omówione w dalszej części pracy.

${ }^{6}$ Dz.U. nr 17, poz. 141, art. 2.
} 
Definiując mniejszość etniczną, ustawodawca zmienił ostatni warunek, czyli „utożsamianie się z narodem zorganizowanym we własnym państwie”, który od mniejszości etnicznej nie jest wymagany.

Według tych kryteriów wyróżniono w Polsce dziewięć mniejszości narodowych. Należą do nich: Białorusini, Czesi, Litwini, Niemcy, Ormianie, Rosjanie, Słowacy, Ukraińcy, Żydzi. Natomiast do zapisanych w ustawie czterech mniejszości etnicznych należą: Karaimi, Łemkowie, Romowie, Tatarzy.

Ustawa, definiując mniejszości narodowe i etniczne, odwołuje się do uwarunkowań powszechnie występujących w różnorakich definicjach, jednak wyraźnie preferując cechy obiektywne. Zawiera także dwa kontrowersyjne zapisy, tj. „utożsamianie się z narodem zorganizowanym we własnym państwie”, jako podstawowym elementem różnicującym mniejszości narodowe od etnicznych, oraz ,zamieszkiwanie obecnego terytorium Rzeczypospolitej Polskiej od co najmniej 100 lat". Są to warunki dyskusyjne, a ich wprowadzenie do ustawy ma daleko idące konsekwencje. Zmniejsza liczbe „oficjalnych”, „uznanych” mniejszości narodowych i etnicznych w Polsce, ograniczając je do niektórych spośród tzw. mniejszości tradycyjnych (historycznych), jednocześnie wykluczając szereg grup narodowościowych z zapisanych w ustawie przywilejów (m.in. Ślązaków, Greków, Macedończyków, Wietnamczyków, Włochów, Francuzów), często grup liczniejszych od niektórych spośród ,ustawowych mniejszości”, co ma istotne następstwa dla ich członków, m.in. oświatowe, finansowe, formalnoprawne. Ponadto o zaliczeniu danej zbiorowości do mniejszości narodowej lub etnicznej decydują bieżące wydarzenia polityczne (np. deklaracja suwerenności państwowej czy utrata odrębności państwowej), a o wpisaniu do ustawy może decydować wręcz kalendarz. Kryteria aktualnego posiadania lub nieposiadania państwa narodowego, tak samo jak cezura 100 lat ,zasiedziałości” (a nie np. 50 czy 500 lat) są uznaniowe, sztuczne, zewnętrzne i zmienne. Ponadto współcześnie z reguły nie mają zasadniczego wpływu na poczucie tożsamości i odrębności narodowej, dlatego nie powinny stanowić przyczyn kategoryzacji mniejszości narodowych i etnicznych.

Jednak te rozróżnienia, bezzasadne z perspektywy liberalnej, są istotne z punktu widzenia pragmatyki rządzenia państwem i niosą ze sobą konsekwencje polityczne, choćby dlatego, że według takiego rozumienia mniejszości etnicznej nie ma ona „uprawnień” do domagania się suwerenności państwowej. Ponadto zamiarem ustawodawcy było zawężenie przywilejów wynikających z ustawy do tzw. mniejszości historycznych, a wyłączenie z nich m.in. grup imigrantów (Łodziński 2005, 2010, Nijakowski 2005).

Pomimo zastrzeżeń do części zapisów, ustawa z 2005 r. jest aktem prawnym najpełniej regulującym wiele kwestii związanych z prawami mniejszości naro- 
dowych i etnicznych, używania języków mniejszości, funkcjonowania oświaty, kultury oraz relacji między mniejszościami a władzami centralnymi i samorządowymi. Jest także aktualnie obowiązującym w Polsce prawem. Ponadto w praktyce politycznej, a niniejsza praca poświęcona jest m.in. wpływom polityki, przemian politycznych na sytuację mniejszości narodowych, definicje formułowane z polityczno-prawnego punktu widzenia są bardziej adekwatne od stricte socjologicznych. Dlatego też pojęcie mniejszości narodowej i etnicznej $\mathrm{w}$ przedstawianej pracy będzie rozumiane zgodnie z zapisami powyższej ustawy. Ukraińcy, Białorusini i Litwini posiadający polskie obywatelstwo oraz świadomość odrębności i wspólnoty narodowej będą określani jako mniejszości narodowe, a Łemkowie (ci, którzy nie poczuwają się do wspólnoty z narodem ukraińskim) jako mniejszość etniczna.

Kolejnym pojęciem jest „narodowość”, najczęściej utożsamiana z przynależnością narodową lub z obywatelstwem ${ }^{7}$. Już kilkadziesiąt lat temu B. Joseph (1929), słusznie krytykując utożsamianie obywatelstwa z narodowością, uważał, że ,zasadnicza różnica pomiędzy narodowością a obywatelstwem polega na tym, że narodowość jest subiektywna, podczas gdy obywatelstwo jest obiektywne. Pojęcie narodowości odnosi się do warunków myśli, uczucia lub sposobu życia; obywatelstwo natomiast to status polityczny". Samoświadomość jednostki jest podstawowym, najogólniejszym kryterium, według którego możemy określić przynależność narodowa - czyli narodowość - konkretnej osoby. Narodowość rozumianą jako subiektywny wybór przynależności do określonego narodu. Wybór ten nigdy nie jest całkowicie wolny, zawsze jest mniej lub bardziej zdeterminowany czynnikami historycznymi i kulturowymi, jest jednak możliwy (Rykiel 2006). Jak zauważył J. Wiatr (1973): „Ten jest Polakiem, kto się Polakiem czuje. Nie można być członkiem narodu wbrew swojej woli, co oznacza również, że kto się do przynależności do danego narodu poczuwa, ten winien być za członka tego narodu uznany”. Należy jednak pamiętać o zastrzeżeniach wysuwanych m.in. przez E. Gellnera (1991) i I. Hencocka (1998), którzy stwierdzili, że do uznania danej jednostki za przedstawiciela tego a nie innego narodu nie wystarczy wyłącznie jej wola, ale konieczna jest również akceptacja przez innych jego przedstawicieli oraz postrzeganie przez „obcych” jako reprezentanta danego narodu. Deklaracja subiektywnego poczucia narodowości podczas powszechnych spisów ludności, z reguły niezależnie od obywatelstwa oraz dekla-

${ }^{7}$ Pojęcie ,narodowość” jest także stosowane do określenia wspólnoty etniczno-kulturowej stanowiącej przednarodową formę integracji etnicznej, niebędącej jeszcze w pełni ukształtowanym narodem (Maryański 1994, Otok 2003, Sobczyński 1996b). $\mathrm{W}$ takim rozumieniu nie będzie stosowane w niniejszej pracy. 
racji języka ojczystego (lub języka używanego na co dzień w kontaktach domowych), jest współcześnie podstawą opracowywania statystyki narodowościowej.

W niektórych państwach, m.in. na Litwie, w Austrii i Niemczech, często celowo nie używa się terminu „mniejszość narodowa”, zastępując je określeniem „grupa narodowościowa”. Jest to spowodowane m.in. brakiem skojarzeń z czymś słabszym, podporządkowanym, mniej ważnym, dużo większą jednoznacznością pojęcia „narodowość” (dotyczy zbiorowości etnicznych), w odróżnieniu od wieloznaczności pojęcia „mniejszość” (oprócz narodowych czy etnicznych mogą być m.in. wyznaniowe, ideologiczne, polityczne) oraz podkreślaniem związku, wspólnoty danej grupy narodowościowej z narodem, którego jest częścią i dążeniem do zachowania odrębności narodowej (Budyta-Budzyńska 2010).

Narodowość zarówno pewnej grupy ludzi, jak i poszczególnych jednostek nie zawsze jest czymś stałym, niezmiennym. Może ulegać i często ulega zmianom, można także równocześnie odczuwać więź z więcej niż jednym narodem lub kulturą narodową (niekoniecznie w jednakowym stopniu), a narody, zwłaszcza na pograniczach etnicznych, są ,zbiorami rozmytymi” (Rykiel 2006). Wynika to z oddziaływania różnych czynników zewnętrznych. Głównymi elementami, mogącymi wpłynąć na zmianę narodowości jednostki lub poczucie dualizmu narodowego, są migracje, oddziaływanie innej zbiorowości narodowej, zamieszkiwanie na pograniczu etnicznym oraz wpływ polityczny, kulturowy, edukacyjny, propagandowy państwa osiedlenia (Sadowski 1995a, Shils 1996, Barwiński 2004a).

Z pojęciem narodowości związana jest tożsamość. Samo słowo „tożsamość”, którą zajmują się przede wszystkim nauki społeczne, a zwłaszcza socjologia, psychologia, historia, może mieć bardzo wiele znaczeń i może być w różny sposób rozumiane. Jak zauważa A. Sadowski (1995a), tożsamość jest jedną $\mathrm{z}$,najbardziej uniwersalnych ludzkich potrzeb, potrzeb przynależności lub bycia akceptowanym, potrzeb bezpieczeństwa” oraz „tożsamość jest najszerszą kategorią do opisu poczucia samego siebie oraz siebie na tle innych”. Tożsamość to zdolność określenia, kim się jest, do jakiej grupy się należy, z jaką grupą człowiek się identyfikuje i do jakiej się przyznaje (Budyta-Budzyńska 2010).

Na potrzeby pracy skupiono się głównie na tożsamości narodowej zarówno jednostek, jak i całych zbiorowości. Tożsamość najczęściej kojarzy się z pytaniem „kim jestem?” i jest zasadniczo odnoszona do jednostek. Tożsamość narodową jednostki można rozumieć jako rezultat identyfikacji z daną zbiorowością. Stanowi wówczas podstawę różnicowania pomiędzy „my” i „oni” i jest ściśle powiązana z postawą, wiedzą i zachowaniem (Michna 2006). Tak też pojęcie tożsamości będzie rozumiane $\mathrm{w}$ niniejszej pracy. 
Można przyjąć - za E.A. Ardenerem (1992) - że ustalanie tożsamości to „sposoby, w jakie jestem identyfikowany (aspekt bierny) i w jakie ja identyfikuję (aspekt czynny)". Stosunkowo często występują zasadnicze różnice pomiędzy autoidentyfikacją jednostki a jej zaklasyfikowaniem przez innych. W sytuacjach, w których występują wyraźne rozbieżności między indywidualnym wyobrażeniem o sobie a zewnętrznym identyfikowaniem jednostki bądź grupy, której dana jednostka jest członkiem, może wytworzyć się poczucie tzw. marginalizacji jednostkowej bądź grupowej. Społeczność większościowa określa etniczność mniejszych grup zgodnie z własnymi odczuciami lub interesami. Narzuca tym grupom własną identyfikację, często niezgodną z ich samookreśleniem. Kim innym członkowie danej grupy się czują, a za kogo innego są uważani. Może to doprowadzić do kryzysu tożsamości wśród przedstawicieli mniejszości, kryzysu wyrażającego się w dramatycznym pytaniu „kim naprawdę jestem?" (Sadowski 1995a, Domagała 1996). Odmienne są również sposoby identyfikacji danej jednostki przez osoby pochodzące $z$ tej samej lub z innej grupy. W tym drugim przypadku będzie to identyfikacja jednostkowa poprzez pryzmat identyfikacji grupowej, czyli będzie ona ściśle związana z wyobrażeniami na temat całej grupy, której dana osoba jest członkiem. Taki grupowy wizerunek często ma formę stereotypów - obiegowych, potocznych wyobrażeń, przez które postrzegamy jednostki i całe grupy etniczne. Prowadzi to niekiedy do kształtowania się postaw nietolerancji, uprzedzeń, szowinizmu, wrogości lub - przeciwnie - sympatii, przyjaźni, akceptacji, odczuwanych w stosunku do danej osoby wyłącznie na podstawie wyobrażenia o grupie narodowej, której jest członkiem (Kłoskowska 1996, Domagała 1996).

Stereotypowe wyobrażenia mogą dotyczyć obcych i własnych grup narodowościowych. Poglądy stereotypowe, zarówno oceniające, jak i poznawcze, są zazwyczaj bardzo uproszczone, schematyczne, nie dostrzegają faktów sprzecznych z obiegową opinią, przez co prowadzą do błędów poznawczych oraz często powodują powstanie negatywnych uprzedzeń. W relacjach między poszczególnymi narodowościami charakter stereotypów - pozytywnych, neutralnych lub negatywnych - w bardzo dużym stopniu zależy od rodzaju relacji między tymi narodami. Im bardziej stosunki są antagonistyczne, tym łatwiej o negatywne stereotypy i uprzedzenia. Charakterystyczną cechą stereotypów narodowościowych jest ich sztywność, odporność na bezpośrednie, osobiste doświadczenia. Często osoba, która ma bardzo pozytywną opinię o znanym jej osobiście przedstawicielu danego narodu (np. Żydzie lub Ukraińcu), żywi zarazem zdecydowane uprzedzenia w stosunku do Żydów czy Ukraińców w ogóle (Kłoskowska 1996). Ponadto stereotypowe wyobrażenia narodów i grup etnicznych odznaczają się znaczną długotrwałością w czasie, sięgającą setek lat (Bokszański 1995). 
Tożsamość narodowa jest pojęciem wielowątkowym, w skład którego wchodzą liczne elementy. Do najistotniejszych należą: postawy wobec własnej grupy, stopień identyfikacji z grupa, zakres wiedzy, oceny tworzone na podstawie tej wiedzy oraz oceny samej wiedzy (faktów, procesów), stopień akceptacji wartości i norm grupowych, przestrzeganie etnicznych zachowań i gotowość podjęcia określonych działań (Nikitorowicz 1995, Babiński 1997). Nie zawsze wszystkie te składniki są obecne w tożsamości narodowej, jak również zróżnicowany jest poziom ich wykrystalizowania. Istnieją różne fazy rozwoju tożsamości pomiędzy poszczególnymi narodami i w obrębie jednego narodu. Niesie to za sobą niebezpieczeństwo oceniania, wartościowania ludzi oraz całych zbiorowości, w zależności od poziomu rozwoju ich tożsamości, na tych „prawdziwych” i tych „niepełnych”.

Jak już wspomniano, pojęcie tożsamości odnosi się do podstawowej potrzeby zarówno jednostek, jak i grup - potrzeby przynależności. Identyfikowanie jednostki z dziedzictwem grupy, jej dorobkiem, systemem wartości i symbolami nadaje sens poczuciu przynależności. Identyfikacja wymaga istnienia „innych”, w stosunku do których możemy się określić, wskazać na różnice, odrębności. Definiujemy siebie w znacznej mierze poprzez odniesienia do tego, czym lub kim nie jesteśmy. Częste są sytuacje, gdy tzw. tożsamość negatywna - „wiem, kim nie jestem” - poprzedza tworzenie się tożsamości pozytywnej - „wiem, kim jestem". Prowadzi to do wyznaczania granic między tym, co własne i tym, co obce. Współcześnie granice te częściej mają charakter symboliczny niż realny. Jednak ta symbolika bywa silniejsza niż bariery materialne. Pojawia się świadomość dystansu społecznego i kulturowego dzielącego odrębne grupy, który jest niezbywalną częścią tożsamości (Nikitorowicz 1995, Bokszański 1996). Silne poczucie tożsamości narodowej przejawia się zazwyczaj dopiero w konkretnych sytuacjach, do których najczęściej należą: zagrożenie, konflikt, konfrontacja lub nawet samo spotkanie, obcowanie z odrębną grupą narodową. Typową okolicznością wpływającą na potrzebę samookreślenia się jest zamieszkiwanie na obszarze zróżnicowanym narodowościowo. Sytuacja taka z reguły wzmacnia tożsamość narodową, powoduje jej krystalizację (Babiński 1997, Sobecki 1997).

Nie jest to jednak prosta zależność, ponieważ właśnie na pograniczach narodowych szczególnie intensywnie przebiega asymilacja rozumiana jako przyjęcie przez daną jednostkę zwyczajów, języka, wartości kulturowych innej grupy, wytworzenie postaw solidarności z nową grupą, silniejszych niż więzi z grupa, z której osoba się wywodzi, ukształtowanie się poczucia przynależności do nowego narodu, do którego nie należeli rodzice. Asymilacją etniczną nazywa się zazwyczaj proces „roztopienia” uprzednio odrębnego etnosu lub jakiejś jego 
części pośród drugiego, przeważnie większego narodu. Można wyróżnić asymilację naturalną i przymusową. Pierwsza $z$ nich zachodzi przy bezpośrednim łączeniu, z reguły niesymetrycznym, różnych grup etnicznych i wynika $z$ tendencji do usprawnienia ich wzajemnych więzi w życiu społecznym, kulturowym i gospodarczym, zacierania różnic, integracji. Asymilacja rzadko przebiega „,bezboleśnie”, zwłaszcza przymusowa, mająca na celu wynarodowienie. Z reguły wywołuje u grupy poddanej procesom asymilacyjnym poczucie krzywdy i upośledzenia, prowadzi do narastania konfliktów, wywołuje opór, często przynosząc odwrotny skutek - powoduje umacnianie poczucia odrębności grup mniejszościowych (Wasilewski 1929, Tomaszewski 1985b).

Według C. Żołędowskiego (2003), procesom asymilacji mniejszości narodowych w państwach Europy Środkowej i Wschodniej szczególnie sprzyjały:

- bliskość językowa, wyznaniowa, kulturowa, a także fizyczna, większości i mniejszości,

- podobieństwo struktur społecznych większości i mniejszości,

- polityka państwa nastawiona na asymilację,

- brak stałego zasilania grup mniejszościowych przez imigrantów,

- postrzeganie większości jako grupy atrakcyjnej pod względem kulturowym i ekonomicznym.

Do tych czynników można jeszcze dodać, występującą zwłaszcza w przypadku Polski, wyraźną dysproporcję liczebną większości i mniejszości oraz silne rozproszenie terytorialne niektórych mniejszości.

Asymilacja w sytuacji ciagłego i bezpośredniego kontaktu odmiennych systemów społeczno-kulturowych może również przybierać formę akulturacji, czyli procesu przekształceń kulturowych, polegających na adaptacji obcych treści do własnej kultury, przy jednoczesnym eliminowaniu lub modyfikowaniu własnych wzorców. Akulturacja prowadzi do wzrostu podobieństw między kontaktującymi się kulturami i społecznościami, zazwyczaj polega na przejmowaniu elementów kultury powszechnie uważanej za „wyższą”, „lepszą” przez grupę traktującą własną kulturę jako coś „gorszego” (Kłoskowska 1996).

W wyniku procesów asymilacyjnych dochodzi do osłabienia lub zaniku związków z grupą pochodzenia, czego konsekwencją może być konwersja indywidualnego poczucia tożsamości narodowej, własnej identyfikacji. Linie podziału narodowościowego mogą przebiegać nawet wewnątrz poszczególnych rodzin (Śliwiński 1992, Koter 1995a). Asymilacja może również doprowadzić do ukształtowania się podwójnej tożsamości - zwłaszcza na obszarze pogranicza etnicznego - co przejawia się w byciu np. Mazurem i Polakiem, Niemcem i Warmiakiem, Ślązakiem i Polakiem czy też białoruskim Polakiem. Charakterystyczna dla społeczności pogranicza wielość tożsamości nie musi prowadzić 
do ich wykluczania się, wręcz przeciwnie, mogą się one wzajemnie uzupełniać. Zjawisko takie jest często niezrozumiałe dla osób posiadających jedna, silnie rozwiniętą tożsamość narodową oraz nieorientujących się w zawiłościach społeczności pograniczy i traktowane jest przez nich w kategoriach koniunkturalizmu lub nawet zdrady narodowej (Sakson 1998, Rykiel 2006).

Indywidualne poczucie tożsamości jest często uznawane za jedno z zasadniczych kryteriów określania narodowości. Jest to wskaźnik szczególnie istotny na obszarze zróżnicowanym narodowościowo, gdzie obiektywne kryteria przynależności narodowej mieszkańców (np. język, terytorium, religia, wspólna historia, kultura, gospodarka) często nie ukazują rzeczywistej struktury etnicznej. W takiej sytuacji odwołanie się do subiektywnego poczucia tożsamości narodowej może dać najbardziej wiarygodny obraz struktury narodowościowej (Gellner 1991). Zgadzając się z tym stwierdzeniem, w niniejszej pracy również przyjęto zasadę analizowania struktury narodowościowej i językowej na podstawie subiektywnego poczucia tożsamości osób zamieszkujących dany obszar, wyrażanego m.in. podczas spisów powszechnych.

Poczucie tożsamości narodowej grup mniejszościowych oraz natężenie i skuteczność procesów asymilacyjnych są warunkowane relacjami między większością a mniejszościami narodowymi w państwie, czyli między zbiorowościami zajmującymi niesymetryczne pozycje w obrębie wspólnych struktur politycznych. E. Nowicka (1989) określiła te stosunki nazwą „sytuacji mniejszościowej”, uzależnionej od miejsca, jakie grupa zajmuje w relacjach z większością (od całkowitej równości, po podporządkowanie i dominację), proporcji liczebności grupy mniejszościowej i większościowej, stopnia izolacji i wzajemnych kontaktów oraz rodzaju trwałych więzi w obrębie grup (od braku poczucia odrębności, po całkowicie zamknięty charakter grup). Z kolei A. Sadowski (1991a, b, 1995b, c) relacje te określa jako „współżycie międzyetniczne”, przez co rozumie wszelkie kontakty i wzajemne oddziaływania zarówno między całymi grupami narodowościowymi, jak i ich poszczególnymi przedstawicielami.

Jednak relacje między większością a mniejszościami narodowymi nie ograniczają się tylko do kwestii wewnętrznych, często są uzależnione także od sytuacji zewnętrznej państwa oraz od uwarunkowań geopolitycznych. Zwraca na to uwagę R. Brubaker (1998), stosując do analizy struktury narodowej państw Europy Środkowowschodniej koncepcję „,potrójnej zależności relacyjnej”. Zgodnie z nią, stosunki narodowościowe rzadko ograniczają się wyłącznie do relacji większości z mniejszością, natomiast bardzo często $\mathrm{w}$ ich kształtowaniu uczestniczą zagraniczne ojczyzny mniejszości narodowych, co powoduje, że mają one „charakter trójstronny”. Znaczenie transgranicznych kontaktów mniejszości dla relacji etnicznych $\mathrm{w}$ danym państwie zależy od ich charakteru, intensywności 
oraz stosunku do nich grupy dominującej. Ścisłe relacje w obrębie wspólnoty etnicznej wzmacniają tożsamość mniejszości, natomiast ich słabość, lub wręcz brak, sprzyja procesom asymilacyjnym. $Z$ kolei brak akceptacji większości dla relacji mniejszości z jej zagraniczną ojczyzną może wywoływać konflikty.

Według autora, najbardziej wszechstronną klasyfikację uwarunkowań stosunków etnicznych między mniejszościami a większością, przy odwołaniu się do aspektów historycznych, społeczno-demograficznych, kulturowo-cywilizacyjnych oraz politycznych, zarówno wewnętrznych, jak i zewnętrznych, zaproponował C. Żołędowski (2003). Według niego, zasadnicze znaczenie dla rodzaju relacji etnicznych w państwie mają:

- historyczne podłoże wzajemnych relacji większości i mniejszości,

- liczebność i rozmieszczenie przestrzenne mniejszości,

- charakter tożsamości grupowej mniejszości,

- uwarunkowania religijne,

- instytucjonalizacja życia narodowościowego mniejszości,

- stosunek do sytuacji mniejszościowej,

- położenie społeczno-ekonomiczne wobec grupy dominującej,

- charakter więzi ideologicznej grupy większościowej,

- sposób definiowania współżycia międzyetnicznego przez grupę większościową,

- ustrojowo-polityczne uwarunkowania uczestnictwa mniejszości w życiu publicznym,

- stosunek mniejszości do zagranicznej ojczyzny,

- wspieranie mniejszości przez zagraniczne ojczyzny w sferze polityczno-prawnej, społeczno-kulturalnej i ekonomicznej.

W poszczególnych rozdziałach niniejszej pracy przedstawiono m.in. analizę powyższych uwarunkowań w odniesieniu do relacji polskiej większości z mniejszościami ukraińską, łemkowską, białoruską i litewską, ze szczególnym uwzględnieniem czynników geograficznych, historycznych i politycznych.

Jednym z zasadniczych elementów przedstawianej pracy jest analiza wpływu polityki państwa na przekształcenia struktury narodowościowej. Polityka poszczególnych państw wobec mniejszości narodowych jest realizowana według różnych modeli, uzależnionych głównie od ustroju państwa z punktu widzenia jego charakteru (federalny, unitarny) oraz sposobu organizacji i działalności rządu (m.in. dyktatura, monarchia, republika). Ponadto zależy od liczebności i genezy mniejszości narodowych, przyjętych wewnętrznych rozwiązań prawnych oraz umów międzynarodowych, niekiedy także od wielkości własnej mniejszości poza granicami. W państwach określanych jako narodowe (z wyraźnie dominującą i uprzywilejowaną grupą narodową oraz językiem państwo- 
wym, takich jak np. Polska), najczęściej można wyróżnić dwie koncepcje polityki narodowościowej: pluralistyczną i integracyjną, choć niejednokrotnie w praktyce politycznej łączy się cechy obu modeli ${ }^{8}$ (Kwaśniewski 1992).

W koncepcji pluralistycznej podstawową zasadą jest równość grupowa, dlatego państwo stosuje preferencyjne kwoty dla poszczególnych mniejszości (w administracji, edukacji, działalności politycznej), dopuszczalna jest także autonomia terytorialna mniejszości i dwujęzyczność w administracji. Zabezpiecza to udział mniejszości w życiu publicznym oraz wspomaga zachowanie tożsamości i odrębności etnicznej, jednocześnie może osłabiać jedność państwa i społeczeństwa oraz wzmacniać podziały i utrwalać segregację poszczególnych narodowości.

W koncepcji integracyjnej podstawową zasadą jest równość indywidualna, dlatego nie ma żadnych preferencji ani praw dla poszczególnych jednostek lub grup narodowościowych. Obowiązuje zasada równości praw człowieka, co wyklucza jakiekolwiek dodatkowe prawa dla wybranych mniejszości narodowych lub etnicznych. Taki model polityki państwa ma wymuszać integrację mniejszości z większością oraz jednolitość administracyjną, prawną i polityczną. Państwo akceptuje różnorodność kulturową jako przejaw wolności indywidualnej obywateli, ale w żaden szczególny sposób jej nie wspiera. Może to prowadzić do asymilacji, zaniku tożsamości etnicznej grup mniejszościowych. Stosowanie przez władze państwowe uniwersalnych praw człowieka w stosunku do wszystkich obywateli chroni i faworyzuje w głównej mierze większość, czyli naród dominujący (Kwaśniewski 1992, Jasiewicz 1977, Budyta-Budzyńska 2003, 2010).

W praktyce koncepcja integracyjna jest realizowana w trzech różnych odmianach. Najbardziej niekorzystną sytuacją dla mniejszości jest prowadzenie przez państwo przymusowej asymilacji (dyskryminacji denacjonalizacyjnej). Charakteryzuje się szybkim dążeniem do asymilacji mniejszości narodowych poprzez zakaz tworzenia odrębnych etnicznych instytucji kulturalnych, oświatowych i politycznych, rozproszenie i dezintegrację terytorialną skupisk mniejszości (w wersji skrajnej usunięcie tych grup poza granice państwa) oraz jej dyskryminację językową, kulturowa, społeczną, ekonomiczną, wyznaniową.

${ }^{8}$ Poza tymi dwoma podstawowymi modelami istnieje jeszcze, rzadko występujący, model segregacyjny (dyskryminacji segregacyjnej), gdzie państwo nie dąży ani do integracji, ani do asymilacji, lecz wprowadza separację narodowości (zakaz tworzenia wspólnych instytucji dla wszystkich grup etnicznych, zakaz korzystania z części praw, zawodów i stanowisk dla niektórych grup narodowościowych, czasami także zakaz heteroetnicznych małżeństw). Polityka taka polega na utrzymaniu wzajemnych odrębności i podziałów etnicznych, w konsekwencji prowadzi do wyraźnego wyodrębnienia się mniejszości zarówno w strukturze społecznej, jak i terytorialnej oraz powstania gett narodowościowych (Jasiewicz 1977, Łodziński 2005, 2010, Budyta-Budzyńska 2010). 
Zróżnicowanie narodowe jest postrzegane jako potencjalne źródło zagrożeń dla państwa i społeczeństwa, a wartością nadrzędną jest wspólnota narodowa. Politykę taką prowadziły polskie władze wobec mniejszości narodowych i etnicznych (z wyjątkiem Żydów) od połowy lat 40. do połowy lat 50. XX w.

Drugą odmianą koncepcji integracyjnej jest akceptacja różnic (najczęściej tylko kulturowych, folklorystycznych), ale bez ich instytucjonalnego wspierania. Państwo dostrzega różnice, nie walczy z nimi, ale także nie wspiera mniejszości pod względem organizacyjnym i finansowym, zakładając, że doprowadzi to z czasem do samoczynnego zaniku zróżnicowania. Pod wieloma względami taka koncepcja jest adekwatna do polityki władz PRL, prowadzonej wobec mniejszości narodowych od połowy lat 50. praktycznie do końca lat 80., z największym nasileniem w latach $70 . \mathrm{XX}$ w.

Trzecią odmianą koncepcji integracyjnej, zawierającą pewne cechy modelu pluralistycznego, jest akceptacja różnic (odrębności) i ich ochrona. Państwo, dostrzegając zróżnicowanie etniczno-kulturowe społeczeństwa, prowadzi politykę wspomagania mniejszości narodowych przez wsparcie finansowe i organizacyjne (m.in. społeczne i kulturalne stowarzyszenia narodowościowe, dwujęzyczne szkolnictwo), nie zezwalając jednak - w odróżnieniu od koncepcji pluralistycznej - na autonomię terytorialną oraz nie stosując preferencyjnych kwot w administracji lub szkolnictwie. Podstawą integracji jest wspólnota obywatelska, którą cechuje równość praw bez względu na pochodzenie etniczne. Nie wyklucza to możliwości tworzenia odrębnych regulacji prawnych i rozwiązań instytucjonalnych dotyczących członków mniejszości, których celem jest zagwarantowanie nie tylko formalnej, ale przede wszystkim faktycznej możliwości korzystania z praw przysługujących wszystkim obywatelom (Jasiewicz 1977, Łodziński 2005, 2010, Budyta-Budzyńska 2010). Tego typu polityka narodowościowa realizowana jest w Polsce od 1989 r.

\subsection{Zakres pracy, cele i hipotezy badawcze}

Zakres przestrzenny pracy jest bezpośrednio związany $\mathrm{z}$ obszarami zamieszkanymi przez Ukraińców, Łemków, Białorusinów i Litwinów w Polsce po 1944 r., zarówno pierwotnie, czyli wzdłuż wschodniego i południowo-wschodniego pogranicza, jak i wtórnie, po powojennych przymusowych przesiedleniach oraz późniejszych, dobrowolnych migracjach, w konsekwencji których zostali rozproszeniu na obszarze całej Polski.

Wybór Ukraińców, Łemków, Białorusinów i Litwinów jako podmiotu badań dotyczących przekształceń struktury narodowościowej Polski pod wpływem 
uwarunkowań politycznych był spowodowany wieloma czynnikami: znaczeniem politycznym, historycznym i kulturowym tych narodowości dla XX-wiecznej Rzeczypospolitej, niejednokrotnie wspólnotą losów, potencjałem demograficznym, zamieszkiwanym obszarem, a zwłaszcza skalą i różnorodnością zmian politycznych, społecznych i terytorialnych, których doświadczyli podczas ostatnich kilkudziesięciu lat. Obok ludności niemieckiej i żydowskiej to właśnie mniejszości narodowe wschodniego pogranicza odegrały najważniejszą rolę w powojennej polityce państwa polskiego, miały podstawowe znaczenie dla wdrażania działań zmierzających do homogeniczności etnicznej obywateli Polskiej Rzeczypospolitej Ludowej. W badaniach geograficznych, w których zasadnicze znaczenia ma aspekt przestrzenny, kluczowe było zwarte zamieszkiwanie omawianych narodowości w latach 40 . XX w. wzdłuż kształtującego się wschodniego i południowo-wschodniego pogranicza Polski, od Puńska i Sejn na północy, przez Podlasie i Lubelszczyznę, po Bieszczady i Beskid Niski na południu. Zachodzące wówczas zasadnicze zmiany polityczno-terytorialne dotyczyły zarówno tego obszaru, jak i zamieszkującej go ludności, zwłaszcza ludności niepolskiej. Ukraińcy, Białorusini i Litwini byli najistotniejszymi mniejszościami narodowymi wschodniego pogranicza, o bardzo dużym znaczeniu politycznym i geopolitycznym, stanowili „odcięte” granicą państwową fragmenty narodów, dla których utworzono socjalistyczne republiki radzieckie, przekształcone $\mathrm{w}$ momencie rozwiązania ZSRR w niepodległe państwa. Łemkowie nie odgrywali tak istotnej roli politycznej, nie zamieszkiwali bezpośrednio przy wschodniej granicy, nie posiadali także zagranicznej ojczyzny. Jednak z powodu utożsamiania ich przez władze komunistyczne (oraz przez część Łemków i większość Ukraińców) z narodem ukraińskim i w konsekwencji wspólnoty losów, nie można rozpatrywać powojennej sytuacji politycznej, społecznej i narodowościowej Ukraińców w oderwaniu od sytuacji Łemków, głównie dlatego, że przez kilkadziesiąt lat byli traktowani jako jedna grupa.

Na obszarze wschodniego pogranicza zamieszkiwały także inne niepolskie narodowości (m.in. Tatarzy, Rosjanie, Romowie, Ormianie, Karaimi), jednak z powodu zdecydowanie mniejszego potencjału demograficznego oraz niewielkiej roli w powojennej polityce polskich władz zostały one pominięte w przedstawianej pracy.

Zakres czasowy pracy obejmuje okres od 1944 r., czyli wycofania się Niemców ze wschodniej Polski i zajęcia tego obszaru przez Armię Czerwoną oraz komunistyczną administrację - polską i radziecką. Dla powojennego pogranicza polsko-radzieckiego rok 1944 jest istotniejszą cezurą czasową niż formalne zakończenie II wojny światowej w maju 1945 r., zwłaszcza w odniesieniu do zmian struktury narodowościowej. Już w 1944 r. rozpoczęły się przesiedlenia 
ludności według kryterium etnicznego, co doprowadziło do trwałej zmiany struktury narodowościowej. Mniejszości narodowe zamieszkujące wschodnią Polskę dotknęły także, obok zmian liczebnych i terytorialnych, istotne zmiany polityczne i geopolityczne, które zostały zapoczątkowane w momencie opanowania tych ziem przez Armię Czerwoną, czyli w połowie 1944 r. Dla pełniejszego przedstawienia sytuacji omawianych mniejszości, w sposób bardzo skrótowy przedstawiono ich dzieje na ziemiach polskich przed zasadniczym początkiem przyjętego w pracy zakresu czasowego. Studia nad omawianą tematyką kończą się w 2012 r. Jest to rok, w którym przeprowadzono zarówno ostatnią część badań terenowych, jak i uzyskano wstępne, częściowe dane dotyczące drugiego w XXI w. spisu ludności z 2011 r. Materiał ten umożliwił autorowi uzupełnienie części merytorycznej oraz opracowanie analizy porównawczej z wcześniejszymi danymi statystycznymi.

W przedstawianej pracy autor postawił następujące cele badawcze:

- wyjaśnienie wpływu przemian politycznych zachodzących w Polsce od 1944 r. na rozmieszczenie, liczebność, tożsamość narodową oraz instytucjonalizację społeczno-kulturalną Ukraińców, Łemków, Białorusinów i Litwinów;

- określenie przyczyn zróżnicowania sytuacji społeczno-politycznej omawianych mniejszości bezpośrednio po II wojnie, w okresie PRL oraz współcześnie;

- dokonanie analizy uwarunkowań i zmian przestrzennego rozmieszczenia Ukraińców, Łemków, Białorusinów i Litwinów na obszarze Polski bezpośrednio po II wojnie i na początku XXI w.;

- przeprowadzenie analizy porównawczej sytuacji społeczno-politycznej Ukraińców, Łemków, Białorusinów i Litwinów w Polsce.

Opierając się na postawionych celach badawczych, przyjęto następujące hipotezy:

- założono, że głównym czynnikiem kształtującym sytuację mniejszości narodowych i etnicznych w Polsce w latach 1944-1989 było dążenie władz, przy wyraźnym poparciu społecznym, do marginalizacji i asymilacji mniejszości, w celu realizacji idei państwa jednonarodowego;

- przyjęto, że przemiany polityczne w połowie lat 50. XX w. przyczyniły się do relatywnej poprawy sytuacji mniejszości narodowych, jednak dopiero zmiany ustrojowe zapoczątkowane w 1989 r. spowodowały ich upodmiotowienie i uznanie różnorodności etnicznej społeczeństwa, co nie zahamowało procesów asymilacji, wywołało nowe problemy i spory oraz zmieniło relacje pomiędzy mniejszościami a większością społeczeństwa;

- założono, że pomimo funkcjonowania w takich samych uwarunkowaniach politycznych, prawnych i państwowych stosunek władz do omawianych mniej- 
szości narodowych i etnicznych w okresie PRL nie był jednolity, a ich współczesna sytuacja społeczno-polityczna jest zróżnicowana, zwłaszcza pod względem instytucjonalnym.

\subsection{Metody badawcze}

Badanie zjawisk dotyczących zagadnień narodowościowych napotyka na wiele trudności, które ogólnie można podzielić na endo- i egzogeniczne. Podstawowe znaczenie mają bariery o charakterze endogenicznym, których pokonanie ma decydujący wpływ dla prowadzonych badań (Sobczyński, Grabowska 1993).

Żaden badacz nie jest wolny od określonej przynależności narodowościowej i wychowania w określonym duchu religijnym. Są to determinanty poważnie obciążające i występują niezależnie od tego, czy wywodzi się on spośród większości społeczeństwa, czy jest przedstawicielem mniejszości i stanowią główną barierę o charakterze endogenicznym oraz podstawową trudność w podjęciu badań mniejszości narodowych. Aby ją przełamać, badacz musi odrzucić własne, indywidualne podejście do rzeczywistości, by stać się neutralnym światopoglądowo i móc w miarę obiektywnie przedstawić fakty.

Grupa barier egzogenicznych jest znacznie bardziej rozbudowana i w dużej mierze zależna od aktualnej sytuacji społeczno-politycznej. Wśród barier tej grupy największy problem stanowi dostęp do obiektywnej i rzetelnej dokumentacji statystycznej oraz kwestia przełamania nieufności respondentów. Tak jak główną barierą endogeniczną jest przełamanie świadomości narodowej i religijnej badacza, tak podstawową egzogeniczną barierą społeczną jest analogiczna świadomość obiektu badawczego, czyli przedstawiciela mniejszości. Chociaż teoretycznie możliwe są badania mniejszości bez osobistego kontaktu badacza z ich przedstawicielami, to jednak wartość poznawcza takich badań jest niewielka. Szczególne trudności napotyka się przy badaniach mniejszości narodowych, które mają negatywne doświadczenia historyczne, doznały krzywd i prześladowań ze strony państwa bądź większości społeczeństwa i obawiają się powrotu tendencji nacjonalistycznych (Sobczyński, Grabowska 1993). Dotyczy to, choć w różnym stopniu, wszystkich badanych mniejszości przedstawionych w pracy.

W badaniach nad mniejszościami kontekst badawczy i interakcja „badaczpodmiot badania" zawsze jest obciążony uwarunkowaniami etniczności lub dychotomii „swój-obcy”, dlatego też konieczne jest uwzględnienie tła społecznego danej sytuacji badawczej, wynikającego z uwarunkowań politycznych, kulturowych, religijnych i etnicznych. W warunkach postępującej demokraty- 
zacji nieufność oraz obawy o ujawnienie poglądów i postaw przez respondentów wywodzących się z mniejszości wydają się odchodzić w przeszłość (Sobczyński 2012). Obiektywna i rzetelna ocena relacji między większością a mniejszością narodową w państwie jest dodatkowo utrudniona różnymi celami, interesami i punktami widzenia obu stron. Mniejszość narodowa zawsze funkcjonuje w poczuciu zagrożenia o utratę własnej tożsamości, jest skłonna dopatrywać się w polityce państwa celowych działań asymilacyjnych. Z kolei naród dominujący bardzo często nie rozumie, czy wręcz nie dostrzega, problemów poszczególnych mniejszości (Halczak 2006).

Do realizacji postawionych celów badawczych zastosowano zarówno metody studialne (kameralne i terenowe), jak i techniczne (kartograficzne i statystyczne). Podstawową była analiza i synteza przetworzonego materiału źródłowego, zwłaszcza historycznego, zawartego w literaturze. Odwołanie się do materiałów historycznych, także kartograficznych, było niezbędne w celu rzetelnego przedstawienia powojennych przemian sytuacji politycznej, narodowościowej i społecznej mniejszości narodowych, z wyraźnym odniesieniem do konkretnej przestrzeni geograficznej.

Temat pracy i jego dynamiczne ujęcie skłonily do zastosowania metody porównawczej podczas analizy procesów politycznych, narodowościowych oraz społecznych w aspekcie czasowym (pomiędzy kolejnymi powojennymi „dekadami przemian politycznych”), geograficznym (pomiędzy poszczególnymi regionami Polski oraz jednostkami podziału administracyjnego) i etnicznym (pomiędzy poszczególnymi badanymi mniejszościami narodowymi).

Punktem wyjścia do części analiz, zwłaszcza w ujęciu przestrzennym, oraz swoistą bazą danych były wyniki spisów powszechnych z 2002 r. i 2011 r. Po raz pierwszy od kilkudziesięciu lat uwzględniły one dwa kryteria etniczności: narodowość oraz język, co m.in. pozwoliło na weryfikację wcześniejszych subiektywnych szacunków dotyczących liczebności mniejszości narodowych i etnicznych, umożliwiło kartograficzne przedstawienie struktury narodowościowej Polski oraz jej zmian w pierwszej dekadzie XXI w. Niestety, w obu spisach ludności zastosowano odmienne metody pozyskiwania danych, co utrudniło, ale nie uniemożliwiło, przeprowadzenie studiów porównawczych. Także wyniki obu spisów (w części dotyczącej kwestii narodowości) oraz procedury ich przeprowadzenia wzbudziły duże kontrowersje i spowodowały liczne zarzuty'. Wszelkie statystyki narodowościowe, co słusznie podkreślali m.in. J. Toma-

${ }^{9}$ Szerzej metody przeprowadzenia spisów powszechnych z 2002 r. oraz 2011 r., sformułowanie pytań dotyczących narodowości, a także kontrowersje związane z ich wynikami zostały omówione w rozdziale IV. 
szewski (1985a, b, 1991), P. Eberhardt (1996), H. Chałupczak i T. Browarek (1998) oraz A. Gawryszewski (2005), dotyczą kwestii bardzo delikatnych, subiektywnych i trudno mierzalnych, dlatego zawsze będą obarczone błędami, a ich wyniki będą budzić większe lub mniejsze emocje i kontrowersje oraz wymagać bardzo ostrożnej interpretacji. Ponadto ich wiarygodność jest niejednokrotnie wypadkową aktualnej polityki narodowościowej państwa w okresie spisowym. Mimo to statystyka narodowościowa nie tyle nawet $\mathrm{w}$ aspekcie ilościowym, co w szczególnie istotnym dla geografów aspekcie przestrzennym, umożliwiającym ukazanie za pomocą metod kartograficznych rozmieszczenia poszczególnych mniejszości narodowych i etnicznych, jest bardzo ważnym narzędziem badawczym. Zwłaszcza że w Polsce przez kilkadziesiąt lat była narzędziem niedostępnym.

Istotne znaczenie, szczególnie przy weryfikacji danych dotyczących aktualnej sytuacji mniejszości narodowych oraz ich działalności instytucjonalnej, miały socjologiczne badania jakościowe. Autor zastosował metodę tzw. wywiadu pogłębionego, polegającą na rozmowie $\mathrm{z}$ respondentem na podstawie zapewniającego porównywalność - scenariusza wywiadu, zawierającego wyłącznie pytania otwarte, dające całkowitą swobodę wypowiedzi (Kvale 2011, Flick 2012, Gudkova 2012). Podczas tego typu wywiadu badacz, śledząc odpowiedzi, ma możliwość zadawania kolejnych pytań pogłębiających i uszczegółowiających temat (Sommer, Sommer 1997). Respondenci zostali wybrani metodą doboru celowego. Wywiady zostały przeprowadzone przez autora wiosną i latem 2012 r., metodą bezpośrednich spotkań z liderami zarządów głównych oraz oddziałów lub kół terenowych następujących organizacji reprezentujących poszczególne mniejszości:

- Związku Ukraińców w Polsce (Warszawa, Szczecin, Olsztyn, Gorzów Wielkopolski),

- Związku Ukraińców Podlasia (Bielsk Podlaski, Białystok),

- Towarzystwa Ukraińskiego (Lublin),

- Stowarzyszenia Łemków (Legnica, Wrocław, Gorzów Wielkopolski),

- Zjednoczenia Łemków (Gorlice, Gorzów Wielkopolski),

- Stowarzyszenia Młodzieży Łemkowskiej „Czuha” (Legnica),

- Białoruskiego Towarzystwa Społeczno-Kulturalnego (Białystok),

- Rady Programowej Tygodnika „Niwa” (Białystok),

- Białoruskiego Zrzeszenia Studentów (Warszawa),

- Stowarzyszenia Litwinów w Polsce (Puńsk),

- Litewskiego Towarzystwa Św. Kazimierza (Sejny).

Celem wywiadów było poznanie opinii najbardziej aktywnej i zarazem kompetentnej grupy działaczy organizacji narodowościowych oraz porównanie po- 
glądów liderów różnych organizacji zarówno tej samej, jak i różnych mniejszości. Wywiady dotyczyły m.in. funkcjonowania poszczególnych organizacji, ich struktur przestrzennych, głównych postulatów zgłaszanych do władz lokalnych i centralnych, zasadniczych punktów spornych, sukcesów i porażek poszczególnych stowarzyszeń, współpracy z innymi organizacjami narodowościowymi, ewentualnego wsparcia ze strony państwa macierzystego, postrzegania wpływu przemian politycznych na dawną i obecną sytuację mniejszości, a także opinii dotyczących wyników spisów powszechnych oraz funkcjonowania ustawy o mniejszościach narodowych.

Wykorzystano także dane, wiedzę i doświadczenie z badań terenowych przeprowadzonych przez autora $\mathrm{w}$ drugiej połowie lat 90. ubiegłego wieku wśród mniejszości łemkowskiej i ukraińskiej na Łemkowszczyźnie oraz białoruskiej i ukraińskiej na Podlasiu (Barwiński 1995, 1998, 1999, 2001a, c, d, 2004a, 2005a, b, c).

\subsection{Literatura przedmiotu}

Tematem badań jest zamieszkująca Polskę mniejszość ukraińska, łemkowska, białoruska i litewska. W XIX w. ludność ta bardzo rzadko była przedmiotem opracowań naukowych. Polscy geografowie przełomu XIX i XX w. oczywiście doceniali rolę i naukowe znaczenie problematyki narodowościowej, jednak z powodu ówczesnych uwarunkowań politycznych podejmowali badania dotyczące rozmieszczenia i liczebności ludności polskiej na ziemiach poszczególnych zaborów, a nie mniejszości narodowych. W drugiej połowie XIX w., w zaborze austriackim i pruskim przeprowadzono nowoczesne spisy ludności, w których pytano m.in. o cechy etniczne. Spis w zaborze rosyjskim przeprowadzono dopiero w 1897 r. Opublikowanie ich wyników dało geografom dokumentację statystyczną, umożliwiającą sporządzenie analiz dotyczących struktury narodowościowej, nie tylko ziem polskich, ale praktycznie całej Europy Środkowej, które zostały m.in. wykorzystane w atlasach opracowanych przez E. Romera.

Mimo to z początku XX w. oraz okresu międzywojennego pochodzi niewiele literatury traktującej bezpośrednio o omawianych mniejszościach narodowych. Do istotnych prac z pewnością należy zaliczyć trzytomowe dzieło W. Wakara pt. Rozwój terytorialny narodowości polskiej (1917), przynoszące opis i ocenę struktury narodowościowej ziem polskich na przełomie XIX i XX w., także na obszarach spornych, silnie zróżnicowanych. Liczne informacje o strukturze etnicznej międzywojennej Polski możemy znaleźć w opracowanych przez 
geografów atlasach i mapach obrazujących rozmieszczenie oraz liczebność poszczególnych grup narodowościowych ${ }^{10}$. Mniejszości narodowe wschodniego pogranicza zostały omówione m.in. przez A. Krysińskiego w pracach pt. Liczba i rozmieszczenie Biatorusinów w Polsce (1928) oraz Liczba i rozmieszczenie Ukrainców w Polsce (1929), a także w książce Z. Urbańskiego pt. Mniejszości narodowe w Polsce (1932). Kilka artykułów dotyczących struktury narodowościowej wschodniej Polski opublikował geograf J. Wąsowicz. Na Łemkowszczyźnie prowadził badania geograf i geolog W. Goetel (O Łemkowszczyźnie, 1935) oraz etnograf R. Reinfuss, który opublikował ich wyniki już po wojnie, w pracy pt. Łemkowie jako grupa etnograficzna (1948). Osobnym źródłem informacji są liczne opracowania historyka L. Wasilewskiego, dotyczące stosunków polityczno-narodowościowych między Polską, Litwą i Białorusią - Ukraina i sprawa ukraińska (1911), Kresy wschodnie (1917), Litwa i Białoruś. Zarys historyczno-polityczny stosunków narodowościowych (1925), Istotna liczba Ukraińców w Polsce (1927) oraz fundamentalne dzieło dotyczące teoretycznych zagadnień kwestii narodowościowych pt. Sprawy narodowościowe w teorji $i$ w życiu (1929). Cennymi pozycjami z tego okresu są statystyczne opracowania polskich spisów ludności z 1921 r. i 1931 r. Ponadto w latach 1927-1939, nakładem Instytutu Badań Spraw Narodowościowych ukazywał się kwartalnik „Sprawy Narodowościowe", w którym były publikowane prace socjologów, historyków, demografów, etnografów oraz nielicznych geografów, m.in. W. Ormickiego i J. Smoleńskiego.

Przez wiele lat po II wojnie światowej naukowcy nie zajmowali się badaniem problematyki narodowościowej w Polsce. Było to uwarunkowane głównie czynnikami politycznymi i ograniczeniami cenzury. W zmienionej sytuacji polityczno-ustrojowej, przy obowiązującej tezie, zgodnie z którą po zmianach granic i przesiedleniach ludności Polska stała się krajem jednonarodowym, wszelkie pozycje traktujące o mniejszościach narodowych były ,politycznie szkodliwe". Wiele tematów stanowiło swoiste tabu, np. przesiedlenia. Istotnym problemem była także trudność w dostępie do materiałów źródłowych oraz brak danych statystycznych. Pierwsze naukowe opracowania dotyczące mniejszości narodowych w Polsce pojawiły się dopiero w latach 60. i 70. XX w. Na uwage zasługują m.in. prace K. Kersten $(1963,1974)$, głównie o mniejszościach żydowskiej i niemieckiej, A. Kwileckiego (1963, 1964, 1970, 1974) o Łemkach oraz J. Byczkowskiego (1976) o mniejszościach narodowych w państwach europejskich. Publikacje dotyczące dziejów społeczności ukraińskiej, białoruskiej lub litewskiej wynikały natomiast z badań nad historią społeczną i ekonomiczną,

${ }^{10}$ Zostały one zestawione przez A. Gawryszewskiego $(1969,1995)$. 
które nie miały bezpośrednich odniesień politycznych. Ponadto były to prace historyków traktujące o sytuacji gospodarczej w okresie międzywojennym, m.in. opracowanie Z. Landaua i J. Tomaszewskiego pt. Druga Rzeczpospolita. Gospodarka - spoleczeństwo - miejsce w świecie (1977). Większość pochodzących z tego okresu pozycji literatury, traktujących o powojennych losach przedstawicieli mniejszości narodowych w Polsce, dotyczyła głównie okresu „utrwalania i kształtowania władzy ludowej” i była pisana zgodnie z duchem ówczesnej oficjalnej propagandy, a co z tego wynika - ma ograniczoną wartość poznawczą.

W drugiej połowie lat 80 . ubiegłego wieku pojawiło się kilka monografii przygotowanych przez historyków, dotyczących sytuacji mniejszości narodowych w okresie międzywojennym, m.in. bardzo jednostronne, lewicowe opracowanie A. Bergman pt. Sprawy biatoruskie w II Rzeczypospolitej (1984), dzieje mniejszości litewskiej przedstawione przez B. Makowskiego Litwini w Polsce 1920-1939 (1986) oraz prace J. Tomaszewskiego pt. Ojczyzna nie tylko Polaków (1985) i Rzeczpospolita wielu narodów (1985), w których omówiono geneze, rozmieszczenie oraz strukturę społeczną poszczególnych grup mniejszościowych, ze szczególnie interesującą, krytyczną analizą wyników międzywojennych spisów ludności. Prace te stanowią inspirację do wnikliwej i uważnej interpretacji wyników współczesnych spisów ludności.

Zdecydowana intensyfikacja badań miała miejsce dopiero po 1989 r. Ponownie decydujący był czynnik polityczny - likwidacja cenzury i szeroki dostęp do źródeł archiwalnych. Zmiana ustroju przywróciła pełną wolność badań naukowych. Nastapił swoisty renesans badań narodowościowych. W pewnym stopniu został „sprowokowany” rosnącą aktywnością i aspiracjami poszczególnych, nawet niewielkich, mniejszości narodowych. W wielu ośrodkach akademickich (m.in. w Łodzi, Warszawie, Krakowie, Białymstoku, Opolu, Wrocławiu, Lublinie) przystąpiono do badań nad mniejszościami narodowymi, etnicznymi i religijnymi. W Poznaniu, w 1992 r. reaktywowano „Sprawy Narodowościowe”, ponadto artykuły dotyczące różnych aspektów struktury narodowościowej Polski zaczęly ukazywać się w czasopismach geograficznych, historycznych i socjologicznych. Mimo niewielkiej liczebności mniejszości narodowych we współczesnej Polsce, tematyka ta stała się bardzo popularna, jednak w różnym stopniu dotyczy poszczególnych zbiorowości. Najwięcej prac poświęcono tematyce mniejszości żydowskiej i niemieckiej, a zdecydowanie mniej grupom wschodniosłowiańskim, wśród których najliczniejsze są opracowania dotyczące Ukraińców.

Wiele wartościowych materiałów, informacji i analiz zawierają prace zbiorowe, m.in. Mniejszości narodowe w Polsce pod redakcją Z. Kurcza (1997), Mniejszości narodowe w Polsce 1918-1995 autorstwa H. Chałupczaka i T. Bro- 
warka (1998), Mniejszości narodowe w Polsce. Państwo i spoleczeństwo polskie a mniejszości narodowe w okresach przetomów politycznych (1944-1989) pod redakcją P. Madajczyka (1998) oraz Mniejszości narodowe i etniczne w Polsce po II wojnie światowej pod redakcją S. Dudry i B. Nitschke (2010). Opracowania te stanowią próbę uogólnienia problematyki narodowościowej w powojennej Polsce, zebrania w jednej publikacji wyników prac wielu naukowców specjalizujących się $\mathrm{w}$ tematyce dotyczącej poszczególnych mniejszości, w tym Ukraińców, Łemków, Białorusinów i Litwinów. Przedstawiają zmiany sytuacji politycznej, organizacyjnej, społecznej i demograficznej niepolskich narodowości, ale także ewolucję poczucia tożsamości narodowej. Szczególnie frapujące i bardzo rzadko wcześniej poruszane są zagadnienia wzajemnego stosunku aparatu państwowego i społeczeństwa polskiego do poszczególnych mniejszości w momentach powojennych przełomów politycznych.

Geografowie badają mniejszości narodowe głównie w aspekcie przestrzennym, demograficznym i regionalnym. Obszerny rozdział poświęcony strukturze narodowościowej Polski znalazł się w monografii autorstwa A. Gawryszewskiego pt. Ludność Polski w XX wieku (2005). Na szczególną uwagę zasługuje cykl prac P. Eberhardta, dotyczących początkowo struktury narodowościowej Białorusi (1994a), Ukrainy (1994b) i Litwy (1998), a następnie przemian narodowościowych całej, szeroko pojętej Europy Środkowo-Wschodniej w XX w. Między Rosja a Niemcami (1996). Cennym opracowaniem geograficznym, dotyczącym przesiedleń i deportacji mieszkańców Polski, w tym Ukraińców, Białorusinów, Litwinów i Łemków, jest kolejna praca P. Eberhardta pt. Migracje polityczne na ziemiach polskich (1939-1950) (2010). Z kolei M. Sobczyński w pracy pt. Struktura narodowościowo-wyznaniowa Polski (2000) przedstawił współczesne zróżnicowanie religijne społeczeństwa polskiego na tle struktury narodowościowej. Jednocześnie autor poddał krytycznej analizie niezwykle silne w Polsce stereotypy łączące poszczególne wyznania religijne z przynależnością do konkretnych narodowości. Przemiany struktury narodowościowej Polski w XX w. omawiał także P. Eberhardt $(2006,2008)$, a w odniesieniu do struktury religijnej A. Rykała (2006, 2011). Z kolei M. Kowalski (1998, 2000) oraz R. Matykowski (1994, 1997, 2008), zajmując się geografią wyborczą Polski, zwracali uwagę na charakterystyczne zachowania elektoralne przedstawicieli poszczególnych mniejszości narodowych i religijnych, w tym zwłaszcza Białorusinów. Z punktu widzenia tematyki niniejszej pracy szczególnie przydatne są liczne prace geograficzne dotyczące analiz struktury narodowościowej na pograniczach, m.in. polsko-słowackim (M. Barwiński 1995, 1998, 1999, 2002b, 2012, M. Soja 2001a, b, 2010), polsko-białoruskim (M. Barwiński 2001a, c, d, 2004a, 2005a, b, c, M. Kowalski 2002), białorusko-litewskim (M. Kowalski 2008b), 
polsko-litewskim (P. Eberhardt 1997, A. Rykała 2008, M. Barwiński 2009c), polsko-ukraińskim (M. Barwiński 2009b).

Dużym ułatwieniem statystycznym i impulsem kolejnych prac, wzbogaconych pokaźnym materiałem kartograficznym, było opublikowanie wyników spisu powszechnego z 2002 r., zawierającego pytanie o narodowość. Umożliwiło to weryfikację subiektywnych szacunków i przedstawienie zarówno liczebności, jak i współczesnego rozmieszczenia mniejszości narodowych i etnicznych w Polsce. Prace tego typu zostały przedstawione m.in. przez geografów: M. Barwińskiego (2006a, 2008a, 2009a) i K. Szczygielskiego (2006) oraz demografa, T. Wysockiego (2006, 2010).

Z opracowań teoretycznych, na szczególną uwagę zasługuje propozycja typologii mniejszości narodowych z punktu widzenia etniczno-terytorialnego oraz genetycznego, zaproponowana przez M. Kotera w pracy pt. Geographical classifications of ethnic minorities (1993) oraz typologia pograniczy i zamieszkujących je mniejszości, przedstawiona w pracy pt. Ludność pogranicza - próba klasyfikacji genetycznej (1995), a następnie rozszerzana i pogłębiana w kolejnych opracowaniach: A genetic classification of frontier peoples and multicultural border zones in Poland, Bohemia and Slovakia (1995) oraz Frontier peoples - origin and classification (1998).

Problematyka mniejszości narodowych w Polsce, mimo że niewątpliwie stanowi obiekt zainteresowania geografii politycznej zarówno pod względem teoretycznym, jak i empirycznym, w ogóle nie była podejmowana w podręcznikach akademickich J. Barbaga pt. Geografia polityczna ogólna (1987) oraz S. Otoka (2003) pt. Geografia polityczna. Geopolityka - państwo - ekopolityka, a zaledwie kilka stron poświęcił tej tematyce Z. Rykiel w książce pt. Podstawy geografii politycznej (2006).

Sytuacja mniejszości narodowych i etnicznych zamieszkujących Polskę jest często przedmiotem badań historycznych. Wśród historyków mających największy dorobek w tej tematyce należy wymienić m.in. R. Drozda, S. Dudrę, P. Madajczyka, E. Mironowicza, E. Misiło, L. Olejnika, K. Tarkę, J. Tomaszewskiego, M. Waldenberga. Najczęściej podejmowano próby badania i analizy jednej mniejszości, dużo rzadziej pojawiały się publikacje dotyczące wielu rożnych narodowości, przeważnie były to prace zbiorowe. Oczywiście nie wszystkie mniejszości narodowe i etniczne były w jednakowym stopniu reprezentowane w publikacjach naukowych. Zainteresowanie historyków - z powodu znaczenia tych mniejszości w życiu politycznym, społecznym i gospodarczym kraju, konfliktogenności, zaszłości historycznych, liczebności - koncentrowało się głównie na tematyce dotyczącej Niemców, Żydów i Ukraińców. W badaniach nad bardzo skomplikowaną problematyką ukraińską, licznie reprezento- 
wani są historycy wywodzący się z tej społeczności (m.in. R. Drozd, B. Halczak, I. Hałagida, J. Hawryluk, E. Misiło). Prace tych naukowców są bardzo wartościowe poznawczo, oparte na rzetelnych badaniach, jednak czasami obarczone subiektywizmem, jednostronnością osądów. Można w nich dostrzec tendencję do obarczania władz polskich pełną odpowiedzialnością za wszelkie krzywdy, które spotkały w latach powojennych Ukraińców, przy jednoczesnym bagatelizowaniu wpływu działań zbrojnych oddziałów ukraińskich na zachowania polskich władz i polskiego społeczeństwa wobec Ukraińców. Prześladowania Ukraińców w Polsce w połowie XX w. są faktem bezspornym, jednak nie można ich rozpatrywać w oderwaniu od uwarunkowań, które do nich doprowadziły. W pracach historyków ukraińskich można także zauważyć powszechną tendencję do negowania odrębności etnicznej Łemków.

W pierwszych latach XXI w. ukazały się dwie obszerne monografie dotyczące problematyki polityki narodowościowej władz polskich w okresie powojennym: Polityka narodowościowa PRL E. Mironowicza (2000) oraz Polityka narodowościowa Polski w latach 1944-1960 L. Olejnika (2003). Opracowane przez historyków, na podstawie wszechstronnej analizy archiwalnych materiałów źródłowych, są bardzo cennym źródłem faktograficznym. Pierwsza z nich wbrew tytułowi - koncentruje się głównie na pierwszych dekadach powojennych, późniejsze lata potraktowane są skrótowo, a analiza faktycznie kończy się w latach 70. XX w., nie obejmując całego okresu Polski Ludowej. Ponadto Autor całkowicie pomija kilka mniej licznych mniejszości narodowych i etnicznych, natomiast zdecydowanie preferuje tematykę dotyczącą mniejszości białoruskiej, w odniesieniu do której ma bardzo bogaty i uznany dorobek naukowy. W kontekście tematu niniejszego opracowania jest to duża zaleta omawianej monografii. Z kolei praca L. Olejnika - jak wskazuje tytuł - dotyczy tylko pierwszych kilkunastu lat bezpośrednio po wojnie. Dla historyków zajmujących się tematyką przemian sytuacji narodowościowej w Polsce jest to niewątpliwie okres najciekawszy, bez zrozumienia którego niemożliwa jest analiza zmian w kolejnych dekadach. Autor bardzo rzetelnie omówił politykę narodowością władz w odniesieniu do wszystkich zamieszkujących wówczas Polskę mniejszości, jednak najwięcej uwagi poświęcił Niemcom, Żydom i Ukraińcom.

W kontekście tematu pracy szczególnie wartościowe są także monografie autorstwa K. Tarki pt. Litwini w Polsce 1944-1997 (1998) oraz R. Drozda i B. Halczaka pt. Dzieje Ukrainców w Polsce w latach 1921-1989 (2010), a także liczne prace naukowe R. Drozda (m.in. 1997, 2001, 2011) dotyczące powojennych dziejów ludności ukraińskiej, zwłaszcza dramatycznego okresu przymusowych przesiedleń. Szeroko pojętej tematyki łemkowskiej dotyczą m.in. artykuły, które są plonem cyklicznych konferencji naukowych organizowanych 
przez Uniwersytet Zielonogórski i od 2007 r. systematycznie publikowane w kolejnych tomach: Łemkowie, Bojkowie, Rusini - historia, współczesność, kultura materialna i duchowa pod redakcją m.in. S. Dudry, B. Halczaka, R. Drozda. Obszernie o sytuacji powojennej Łemków, zwłaszcza na Dolnym Śląsku i ziemi lubuskiej, pisał także S. Dudra (2008). Dzieje mniejszości białoruskiej oraz przekształcenia jej sytuacji politycznej, społecznej i etnicznej zostały natomiast wszechstronnie opracowane przez historyka pochodzenia białoruskiego E. Mironowicza (m.in. 1992a, b, 1993, 1998, 2005, 2010a, b).

Prace historyczne koncentrują się przede wszystkim na przedstawieniu faktografii, tła historycznego oraz - co bardzo istotne - relacji między polską większością a poszczególnymi mniejszościami. Charakteryzują się jednak bardzo nieproporcjonalnym traktowaniem poszczególnych dekad. Zdecydowana większość opracowań skupia się na omówieniu sytuacji mniejszości narodowych bezpośrednio po zakończeniu wojny oraz w latach 50. ubiegłego wieku, czyli w okresie najbardziej dramatycznych zmian i wydarzeń. Pobieżnie natomiast są traktowane lata III Rzeczypospolitej, mimo że początek lat 90. XX w. przyniósł bardzo istotne zmiany sytuacji niepolskich narodowości, które po upływie ponad 20 lat powinny doczekać się większej liczby opracowań historycznych.

Obok prac geograficznych i historycznych dotyczących omawianych mniejszości narodowych bardzo przydatne w pełniejszym i wszechstronniejszym zrozumieniu specyfiki poszczególnych grup mniejszościowych okazały się prace napisane przez socjologów. Opracowania socjologiczne można rozpatrywać na poziomie rozważań teoretycznych oraz empirycznych. Prace teoretyczne dotyczą m.in. metodologii badań narodowościowych, szeroko pojętego aspektu społecznego, kulturowego, etnicznego, typologii mniejszości narodowych i relacji z większością oraz państwem zamieszkania, a także tożsamości narodowej, jej kształtowania oraz przemian. Spośród tego typu prac na uwagę zasługują m.in. publikacje E. Gellnera pt. Narody i nacjonalizm (1991), A. Kłoskowskiej pt. Kultury narodowe u korzeni (1996), G. Babińskiego pt. Metodologiczne problemy badań etnicznych (1998) oraz M. Budyty-Budzyńskiej pt. Socjologia narodu i konfliktów etnicznych (2010).

Socjologowie zajmują się również - obok zagadnień ogólnych, teoretycznych - także praktycznym, empirycznym badaniem obszarów zróżnicowanych narodowościowo, religijnie i kulturowo, licznie występujących na obszarze Polski. Opracowania te oparte są w głównej mierze na wynikach socjologicznych badań terenowych, przeprowadzanych bezpośrednio wśród przedstawicieli grup mniejszościowych. Stąd ich duża wartość poznawcza. Na szczególną uwagę - w kontekście tematu niniejszej pracy - zasługują opracowania: G. Babińskiego pt. Pogranicze polsko-ukraińskie. Etniczność, zróżnicowanie religijne, tożsamość 
(1997), D. Wojakowskiego pt. Polacy $i$ Ukraińcy. Rzecz o pluralizmie i tożsamości na pograniczu (2002), E. Michny pt. Kwestie etniczno-narodowościowe na pograniczu słowiańszczyzny wschodniej $i$ zachodniej. Ruch rusiński na Stowacji, Ukrainie i w Polsce (2004) oraz A. Sadowskiego pt. Pogranicze polsko-biatoruskie. Tożsamość mieszkańców (1995).

Kolejną tematyką poruszaną przez socjologów i politologów po 1990 r., ściśle związaną z problematyką omawianą w niniejszej pracy, jest analiza relacji „państwo-mniejszość narodowa”. Wpływ zmian prawnych, ustrojowych i politycznych na stosunki mniejszości narodowych z państwem polskim w trakcie ostatnich 20 lat został wnikliwie omówiony m.in. przez S. Łodzińskiego w opracowaniu pt. Równość i różnica. Mniejszości narodowe w porzqdku demokratycznym w Polsce po 1989 roku (2005) oraz w pracy pod redakcją L. Nijakowskiego pt. Polityka państwa polskiego wobec mniejszości narodowych i etnicznych (2005). Z kolei politolog, C. Żołędowski, tego typu problematykę omówił na przykładzie mniejszości białoruskiej i litewskiej w Polsce oraz polskiej w obu tych krajach - Białorusini i Litwini w Polsce, Polacy na Biatorusi i Litwie. Uwarunkowania wspótczesnych stosunków między większościq i mniejszościami narodowymi (2003).

$\mathrm{W}$ niniejszym tomie, autor, korzystając $\mathrm{z}$ wcześniejszych prac geografów, historyków i socjologów oraz wyników własnych badań, zamierza przedstawić syntetyczne opracowanie dotyczące najliczniejszych mniejszości narodowych i etnicznych wschodniego pogranicza Polski w długim, prawie siedemdziesięcioletnim okresie. Analizie poddano przyczyny i konsekwencje przekształceń przestrzennych i społecznych poszczególnych zbiorowości, zróżnicowany wpływ zmiennej polityki państwa oraz ich odmienną współczesną sytuację instytucjonalna, terytorialną i liczebną. Istotnymi elementami, niespotykanymi we wcześniejszych opracowaniach, będzie analityczne przedstawienie zmian liczebności i rozmieszczenia omawianych mniejszości na obszarze Polski w pierwszej dekadzie XXI w. (w świetle wyników spisów powszechnych z 2002 r. i 2011 r.) oraz opracowanie studium porównawczego, obejmującego swym zakresem szerokie spektrum politycznych i społecznych uwarunkowań zróżnicowanej sytuacji Ukraińców, Łemków, Białorusinów i Litwinów w ciagu ostatnich kilkudziesięciu lat. 


\section{GENEZA I DZIEJE UKRAIŃCÓW, ŁEMKóW, BIAŁORUSINÓW I LITWINÓW NA ZIEMIACH POLSKICH DO 1944 ROKU - ZARYS PROBLEMATYKI}

\subsection{Ukraińcy}

Na obszarze należącym w różnych okresach historycznych do państwa polskiego ludność ruska (rusińska, ukraińska) zamieszkuje od kilkuset lat. Pierwsze kontakty Polaków i Rusinów ${ }^{1}$ miały charakter zbrojnych potyczek, rzadziej dużych wypraw wojennych, z których najistotniejsza była wyprawa Bolesława Chrobrego na Kijów i przyłączenie Grodów Czerwieńskich w 1018 r. W połowie XIV w. rozpoczęła się ekspansja państwa polskiego na wschód, która dzięki skutecznym podbojom, a zwłaszcza zawieranym układom i uniom, na kilkaset lat zmieniła sytuację etniczną, wyznaniową i polityczną ziem ukraińskich. Kazimierz Wielki przyłączył do Polski w 1344 r. ziemię sanocką i przemyską, a w 1349 r. - Lwów, Chełm, Bełżec, Brześć i Włodzimierz Wołyński. Po kolejnych walkach polsko-litewskich o ziemie rusińskie, w $1366 \mathrm{r}$. zawarto pokój z Litwą, w wyniku którego Ruś Halicką i część Podola, wraz z Przemyślem, Lwowem, Haliczem i Kamieńcem Podolskim, ostatecznie włączono do Polski, natomiast Wołyń do Litwy. Konsekwencją tych zdobyczy było przyłączenie ziem trwale zasiedlonych przez ludność rusińską. Po zawarciu polsko-litewskiej unii personalnej w Krewie w 1385 r., Polska umocniła swoje panowanie na tym obszarze. Ziemie ukraińskie rozdzielono granicą pomiędzy Koroną a Wielkim Księstwem Litewskim (ryc. 1) (Serczyk 2001).

Prawie 200 lat później, po zawarciu kolejnej, tym razem realnej unii polsko-litewskiej w Lublinie w 1569 r., do Polski wcielono Podlasie oraz województwo wołyńskie, bracławskie i kijowskie. Po raz pierwszy w historii niemal cała późniejsza Ukraina znalazła się w granicach państwa polskiego. Rzeczpospolita odtąd nie była już tylko ojczyzną wyznających katolicyzm Polaków i Litwinów

\footnotetext{
${ }^{1}$ Nazwa Rusin początkowo była używana jako określenie wszystkich wschodnich Słowian i wskazywała głównie na przynależność konfesyjną (Michna 2004).
} 
oraz ludności żydowskiej, lecz także prawosławnych Rusinów (Ukraińców oraz Białorusinów). Konsekwencją zawarcia unii lubelskiej było powstanie Rzeczypospolitej Obojga Narodów - polskiego i litewskiego. Nieuwzględnienie w nazwie nowego państwa i w jego systemie społeczno-politycznym ludności ukraińskiej było jedną z przyczyn późniejszych tragicznych wydarzeń, które w dużym stopniu przyczyniły się zarówno do upadku I Rzeczypospolitej, jak i ekspansji rosyjskiej na Ukrainie (Sobczyński, Barwiński 2009).

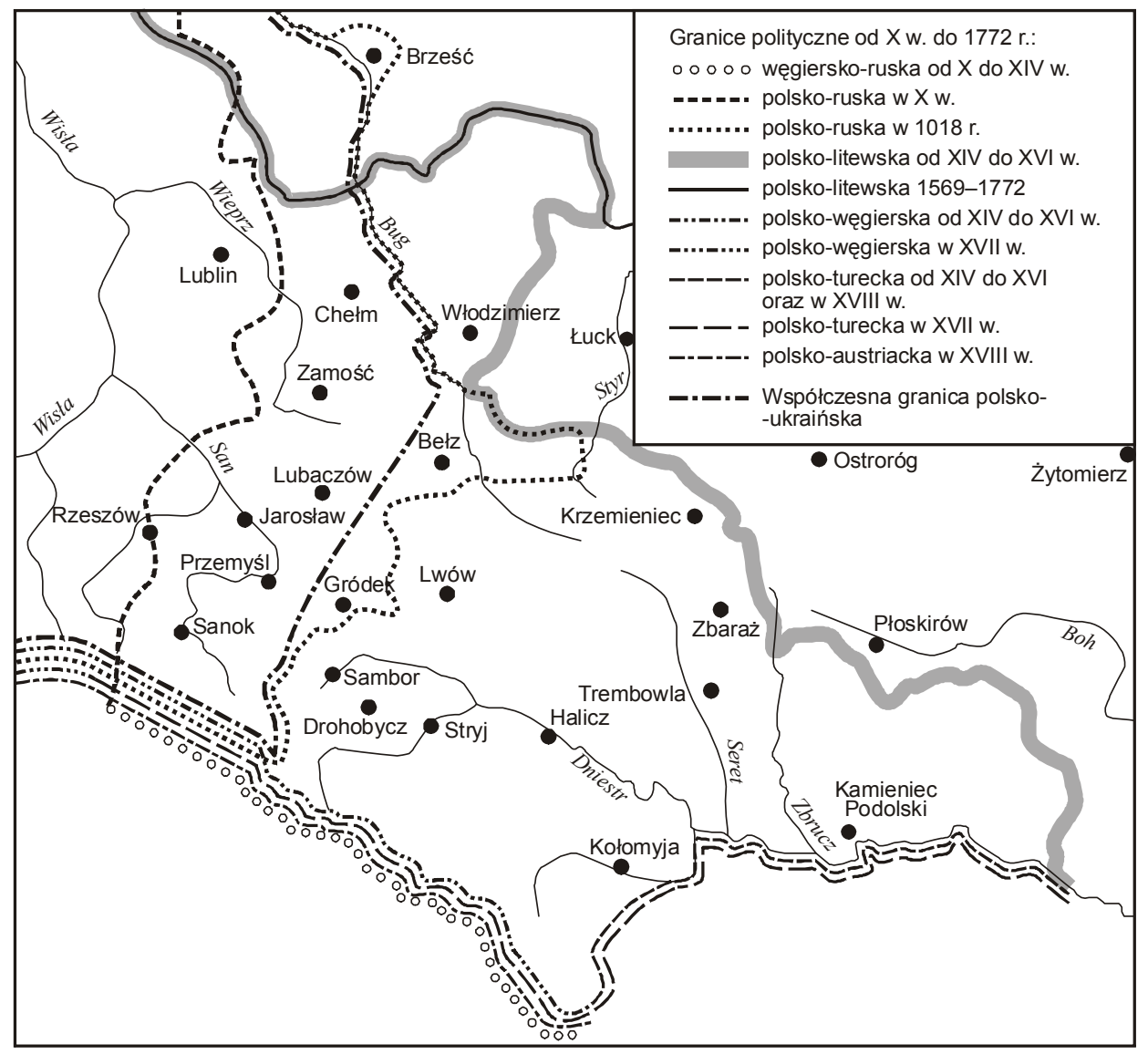

Ryc. 1. Przebieg głównych granic na pograniczu polsko-ruskim (ukraińskim) od X w. do XVIII w. Źródło: opracowanie własne

Przyłączenie ziem ukraińskich do Korony utorowało drogę na ten obszar polskiej szlachcie oraz przyczyniło się do powstania wielkich latyfundiów magnackich. Rzeczpospolita, chcąc utworzyć ze wschodniej części nowo przy- 
łączonych ziem swego rodzaju ochronny pas, broniący Korony przed najazdami tatarskimi i tureckimi oraz oddzielający je od państwa moskiewskiego, zachęcała szlachtę do zakładania majątków na Ukrainie poprzez różnego rodzaju czynniki ekonomiczne oraz rozdawanie ziemi za zasługi wojenne. Działania takie, jak i panująca wówczas koniunktura na zboże, sprzyjały szybkiemu wzrostowi znaczenia gospodarczego Ukrainy oraz zmieniały jej strukturę narodowościową (Serczyk 2001). Ówczesna szlachta, nie tylko magnateria, miała bardzo duże przywileje i swobody, przejawiające się m.in. w nieograniczonej władzy na obszarze swoich posiadłości, które były całkowicie wyłączone spod jurysdykcji instytucji publicznych. Były to swoiste, suwerenne ,państwa magnackie" $\mathrm{z}$ własnymi, niezależnymi od władzy królewskiej strukturami sądowniczymi, administracyjnymi, wojskowymi, dworskimi, z całkowitą władzą nad poddanymi. Magnaci, często wywodzący się ze spolonizowanej arystokracji litewskiej i rusińskiej, prowadzili własną politykę, nie tylko wewnętrzną, ale także zagraniczna, często sprzeczną z interesami Rzeczypospolitej (Kowalski 2008a). Ogromne bogactwo magnaterii, jej wybujałe ambicje, samowola, pycha, nieuznawanie żadnej władzy, także królewskiej, prześladowanie poddanych, w ogromnym stopniu przyczyniło się do wybuchu powstań chłopskich na Ukrainie, rozbicia spoistości wewnętrznej państwa, a w konsekwencji utraty ziem ukraińskich.

W tym okresie na wschodnich kresach Rzeczypospolitej wytworzyła się swoista mozaika etniczno-religijno-stanowa. Na zróżnicowanie narodowościowe nakładała się różnorodność wyznaniowa, a zwłaszcza rywalizacja wschodniego i zachodniego chrześcijaństwa. Z kolei na podziały etniczno-wyznaniowe nakładało się zróżnicowanie stanowe, społeczne, kulturowe, ekonomiczne. Na Ukrainie przez wieki Polacy byli katolikami, głównie mieszczanami lub szlachtą, natomiast zdecydowana większość Rusinów (Ukraińców) to mieszkający na terenach wiejskich prawosławni (później grekokatoliccy) chłopi. Rusińska szlachta, zwłaszcza magnateria, głównie z powodów ekonomicznych i społecznych, już w XVI w. przechodziła na katolicyzm i ulegała szybkiej polonizacji. Najbardziej zróżnicowane pod względem etniczno-religijnym były miasta, gdzie dominowała ludność napływowa, głównie Polacy, Niemcy, Żydzi, Ormianie, natomiast obszary wiejskie były w większości zamieszkane przez prawosławnych Rusinów. Tak wielopłaszczyznowe zróżnicowanie musiało rodzić napięcia oraz konflikty (Koter 1997, Rykała, Sobczyński 2003).

Pod koniec XVI w. podjęto decyzję o zawarciu kolejnej unii, tym razem religijnej, tzw. unii brzeskiej, która wywarła bardzo silne piętno na losach Ukrainy i trwale zmieniła strukturę wyznaniową jej mieszkańców. Została zawarta w 1596 r., na synodzie w Brześciu Litewskim, między królem Polski 
Zygmuntem III oraz hierarchą Kościoła rzymskokatolickiego a częścią biskupów prawosławnych wschodniej Rzeczypospolitej. Uznali oni zwierzchnictwo papieża i dogmaty katolickie, jednak zachowali odrębną liturgię, hierarchię, kalendarz i prawo kanoniczne. Powstał tzw. Kościół unicki (greckokatolicki²), którego wyznawcy, należąc formalnie do Kościoła katolickiego, modlą się w obrządku wschodnim (Kłoczowski 2000c, Rykała 2011).

Głównym celem unii było ograniczenie zasięgu prawosławia, oderwanie ludności prawosławnej i ziem przez nich zamieszkanych od wpływów Moskwy, pełniejsze scalenie ziem ukraińskich z Koroną oraz stworzenie sojuszu przeciwko islamowi. Mimo że była to unia religijna, kwestie wyznaniowe nie były najistotniejsze, ważniejsze były interesy polityczne, społeczne i gospodarcze państwa polskiego (Serczyk 2001). Z punktu widzenia papiestwa synod w Brześciu był potwierdzeniem aktu zjednoczenia prawosławia i katolicyzmu, natomiast z punktu widzenia Kościoła prawosławnego w Moskwie i Konstantynopolu był to akt rozbicia jedności prawosławia. Wśród prawosławnej ludności wschodniej Polski oraz dużej części kleru prawosławnego unia była przyjmowana $\mathrm{z}$ olbrzymimi oporami, bardzo niechętnie, często krwawo. Sytuacja częściowo ustabilizowała się dopiero na początku XVIII w., ponad 100 lat po jej formalnym podpisaniu, kiedy do unii przystąpiły „zbuntowane” diecezje przemyska i lwowska, a większość Ukraińców i Białorusinów mieszkających na ziemiach zachodniej Ukrainy należała już do Kościoła greckokatolickiego. Jednak wschodnia Ukraina, zwłaszcza diecezja kijowska, pozostała przy prawosławiu (Kłoczowski 2000c, Rykała 2011).

Podpisanie i wprowadzenie unii brzeskiej było wydarzeniem niezwykle istotnym, nie tylko pod względem religijnym, ale również politycznym, kulturowym, narodowościowym, którego konsekwencje odczuwalne są do dzisiaj. Nastąpił trwały i bardzo konfliktogenny podział wyznaniowy ludności ukraińskiej - unici coraz silniej ciążyli do Korony, natomiast prawosławni do carskiej Rosji. Z czasem stało się to jednym z powodów prowadzących do podziału terytorialnego i politycznego Ukrainy. Od XVIII w. rozpoczęła się, trwająca praktycznie do dzisiaj, latynizacja Kościoła greckokatolickiego, który zaczął coraz bardziej oddalać się od prawosławia. Przynależność części Ukraińców do Kościoła greckokatolickiego, zwłaszcza w XIX i XX w., stała się istotną częścią ukraińskiej tożsamości narodowej i czynnikiem chroniącym ją przed rusyfikacją.

${ }^{2}$ Nazwa najbardziej rozpowszechniona, pochodzi z XIX w., wywodzi się od nazwy obrządku obowiązującego w tym Kościele, zwanego właśnie greckim lub bizantyjskim, który sam kształtował się na bazie liturgii greckiej i syryjskiej. Obecnie oficjalną nazwą dawnego Kościoła unickiego jest Kościół Bizantyjsko-Ukraiński (Wojewoda 1994). 
Podziały wśród Rusinów wywołane ekspansją grekokatolicyzmu, negatywny stosunek władz polskich do prawosławia, próby ograniczenia przez Rzeczpospolitą rosnącej potęgi i niezależności Kozaków, prześladowania i wyzysk chłopów przez magnaterię, rosnące różnice stanowe i ekonomiczne, zahamowały dalszą integrację ziem ukraińskich z Koroną i przyczyniły się do wystąpienia bardzo silnych tendencji odśrodkowych, zwłaszcza ze strony społeczności kozackiej. Dobrze zorganizowani pod względem wojskowym, prawosławni, rusińscy Kozacy, w naturalny sposób stanęli na czele powstań i buntów Rusinów, które były wymierzone bezpośrednio przeciwko magnaterii i szlachcie, a pośrednio przeciwko Rzeczypospolitej (Serczyk 2003). Spośród wielu powstań kozackich w XVI i XVII w., najistotniejsze konsekwencje terytorialne i polityczne zarówno dla Ukrainy, jak i Polski miało powstanie Bohdana Chmielnickiego z lat 1648-1656. Przerodziło się ono w wojnę z państwem polskim o niepodległą Ukrainę, do której włączyła się Moskwa, co w konsekwencji doprowadziło do podporządkowania wschodniej Ukrainy carskiej Rosji.

W 1658 r. została podpisana między państwem polskim a Kozakami tzw. ugoda hadziacka, która zmieniała, zawartą sto lat wcześniej, polsko-litewską unię lubelską. Przewidywała ona poszerzenie Rzeczypospolitej o trzeci, równorzędny składnik, tj. Księstwo Ruskie, z prawem posiadania własnych urzędów, wojska i trybunału. Rzeczpospolita Obojga Narodów przekształciła się w Rzeczpospolitą Trojga Narodów - polskiego, litewskiego, ukraińskiego, wyznanie prawosławne otrzymało pełne prawa, na terenie Rusi zniesiono unię brzeska, umożliwiono Kozakom nobilitację, unieważniono zawarte przez nich wcześniej sojusze i zabroniono hetmanom kozackim prowadzenia samodzielnej polityki zagranicznej. Umowa hadziacka uwzględniała postulaty kozackie, zachowywała jedność terytorialną Rzeczypospolitej i mogła stanowić podstawę do trwałego uregulowania stosunków polsko-ukraińskich. Była to jednak decyzja bardzo spóźniona, spotkała się z oporem chłopstwa ukraińskiego, części Kozaków i Rosji. Doszło do buntów oraz podziałów wśród Kozaków i już rok po podpisaniu umowa hadziacka, a wraz z nią Rzeczpospolita Trojga Narodów, przestała funkcjonować (Kłoczowski 2000a, b, Rykała, Sobczyński 2003).

Rozbiory Polski w drugiej połowie XVIII w. położyły kres Rzeczypospolitej szlacheckiej i polskiej państwowości na ponad 120 lat. Doprowadziły do podziału ziem ukraińskich między dwa Cesarstwa - Rosyjskie i Austriackie. Dokonując rozbiorów, zaborcy nie kierowali się żadnymi kryteriami narodowościowymi, gospodarczymi czy historycznymi, granice były całkowicie sztuczne (ryc. 2). Obaj zaborcy starali się jak najsilniej związać przyłączone ziemie ukraińskie z własnymi państwami, zwłaszcza że tereny te nigdy wcześniej nie należały bezpośrednio ani do Rosji, ani do Austrii. Na skutek różnej polityki 
zaborców, w XIX w. utrwalił się kolejny podział Ukrainy, tym razem wzdłuż Zbrucza. Przejawiał się głównie w sferze świadomości narodowej i społecznej, strukturze wyznaniowej i językowej, życiu gospodarczym (Serczyk 2001). Podział ten okazał się bardzo trwały, jest widoczny także wśród współczesnych mieszkańców Ukrainy, zwłaszcza w ich postawach narodowych, religijnych i politycznych.

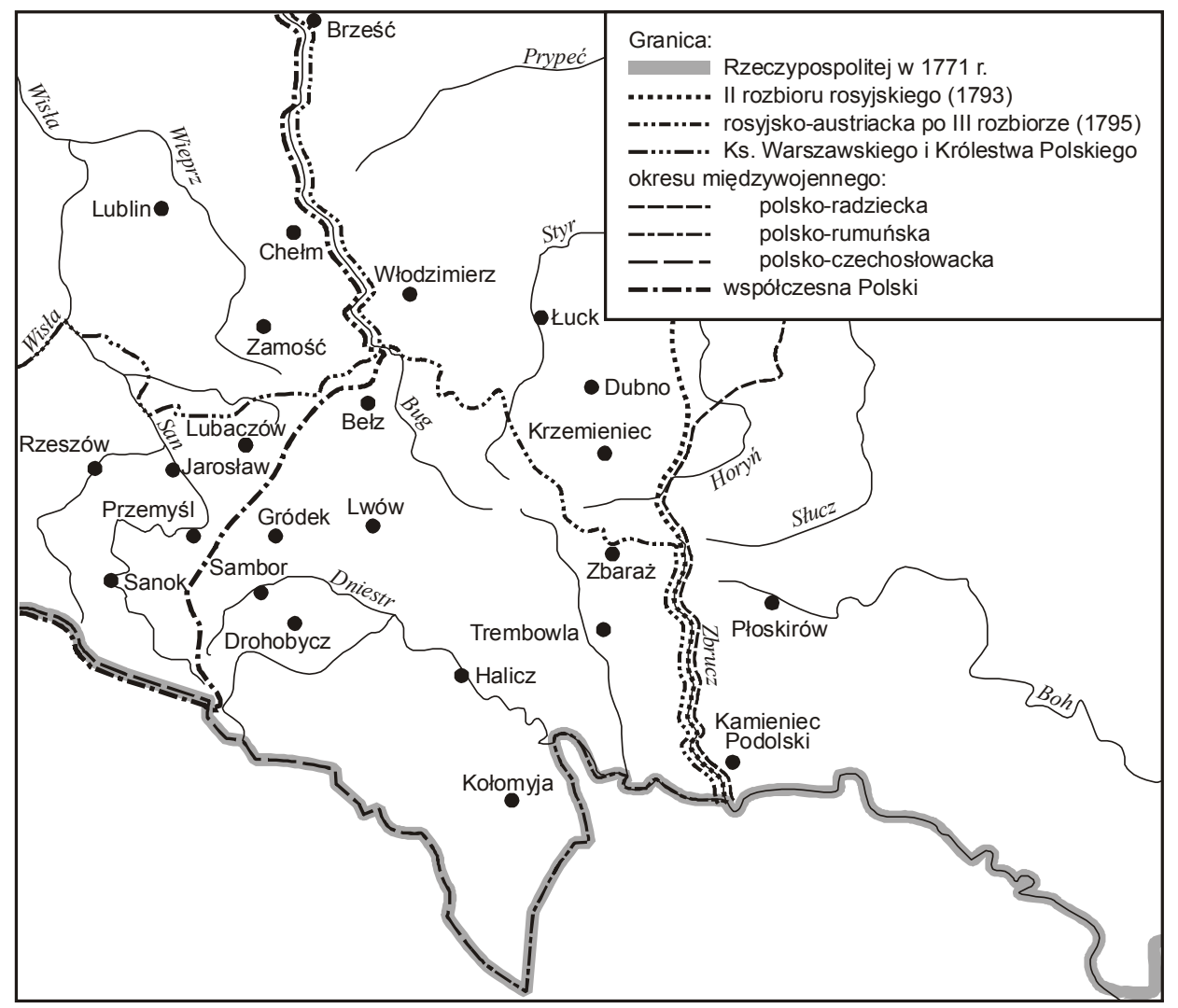

Ryc. 2. Przebieg głównych granic na pograniczu polsko-ruskim (ukraińskim) od XVIII w. do końca lat 30. XX w. Źródło: opracowanie własne

Aby przypieczętować zabór ziem ukraińskich, Rosjanie, którzy nie uznawali odrębności narodowej Ukraińców, zaczęli nazywać ludność rusińską Małorusinami, następnie ziemie ukraińskie stały się „Małą Rosją”, a władcy rosyjscy mówili już o jednym „ludzie rosyjskim” oraz o jednej „Wszechrusi”, jednoczącej całą ludność prawosławną. Austriacy natomiast nadal używali nazwy Rusini. W połowie XIX w. w Galicji powstał narodowy ruch ukraiński, podkreślający 
odrębność narodową Rusinów od Rosjan, który wprowadził oraz upowszechnił określenia: „Ukraina”, „ukraiński”, „Ukraińcy” (Beauvois 2000, Gawryszewski 2005).

Rozbiorowe podziały terytorialno-polityczne ziem ukraińskich miały także bardzo istotny wpływ na strukturę religijną. Rosja stopniowo, ale bardzo konsekwentnie likwidowała Kościół greckokatolicki na zajętych przez siebie obszarach, aż do jego oficjalnej kasacji w 1839 r. W świadomości rosyjskiej unia brzeska była symbolem zachodniego spisku, wrogich działań Polski, zagrażających rosyjsko-prawosławnej tożsamości. Likwidacja struktur Kościoła greckokatolickiego odbywała się pod hasłami dobrowolnego powrotu wiernych do starej wiary prawosławnej. Na ziemiach ukraińskich, włączonych do Cesarstwa Rosyjskiego, w połowie XIX w. już całkowicie panowało prawosławie, które dla władz rosyjskich stało się głównym i bardzo skutecznym narzędziem rusyfikacji Ukraińców. Natomiast na ziemiach Rzeczypospolitej, zajętych przez katolicką Austrię, Kościół greckokatolicki nie tylko nie uległ likwidacji, ale dynamicznie się rozwijał, stając się Kościołem narodowo-ukraińskim, który w ogromnej mierze przyczynił się do rozwoju ukraińskiej tożsamości narodowej.

Okres rozbiorów nie przyniósł upadku magnaterii na Ukrainie i nie zachwiał potęgą, zarówno społeczną, jak i ekonomiczna, polsko-litewsko-rusińskiej arystokracji. Władze rosyjskie i austriackie potwierdzały dawne tytuły arystokratyczne oraz nadawały nowe. Bardzo rozlegle terytorialnie magnackie latyfundia nadal ogrywały ważną rolę w życiu gospodarczym, społecznym i administracyjnym ziem ukraińskich, nadal także były bardzo istotnym czynnikiem różnicującym i antagonizującym Polaków i Ukraińców, podtrzymującym wśród ludności wiejskiej nienawiść do „polskiego pana” (Kowalski 2008a).

W drugiej połowie XIX w., wśród Polaków i Ukraińców nasiliły się tendencje narodowe i niepodległościowe, co na obszarze silnie zróżnicowanym pod względem etnicznym, religijnym i językowym nieuchronnie musiało doprowadzić do konfliktu, zwłaszcza że tożsamość ukraińska rozwijała się najczęściej w opozycji do Rzeczypospolitej oraz ludności polskiej. Konflikt ten był najbardziej widoczny na obszarze zachodniej Ukrainy, włączonej do Austrii, gdzie w wyniku stosunkowo liberalnej polityki mogła się rozwijać zarówno polska, jak i ukraińska działalność społeczna, edukacyjna, kulturalna, religijna, a nawet polityczna. Dzięki temu w Galicji miało miejsce odrodzenie ukraińskiej tożsamości narodowej, wyraźnie wspierane przez władze austriackie jako przeciwwaga dla dążeń polskich. Niedające się pogodzić uprzedzenia i polsko-ukraińskie aspiracje narodowościowe w Galicji przerodziły się w otwartą walkę, która wielokrotnie w XX w. destabilizowała sytuację Rzeczypospolitej (Beauvois 2000, Davies 2001). 
Podczas I wojny światowej w Galicji toczyły się walki austriacko-rosyjskie, a Ukraińcy, podobnie jak Polacy, walczyli w różnych armiach, często przeciwko sobie. Korzystając z upadku caratu, w 1917 r. na ziemiach ukraińskich należących do Rosji została proklamowana Ukraińska Republika Ludowa, której władze podpisały traktat pokojowy z Niemcami. Rok później, po rozpadzie Austro-Wegier, Ukraińcy proklamowali powstanie Zachodnio-Ukraińskiej Republiki Ludowej ze stolicą we Lwowie. W Galicji starły się przeciwstawne dążenia ukraińskie i polskie, mające na celu utworzenie własnego państwa. Na początku listopada 1918 r. rozgorzały zacięte walki polsko-ukraińskie o Lwów, które następnie objęły Wołyń, Podole i Chełmszczyznę. Do połowy 1919 r. oddziały polskie opanowały całą Galicję Wschodnią, a wojska ukraińskie zostały wyparte za Zbrucz. Podczas wojny polsko-bolszewickiej w latach 19191921 i wyprawy Józefa Piłsudskiego na Kijów doszło do chwilowego rozejmu i sojuszu z atamanem Semenem Petlurą w celu wspólnej walki z bolszewikami ${ }^{3}$. Po zakończeniu wojny z Rosją i podpisaniu pokoju ryskiego, Polska odzyskała Galicję, a ziemie ukraińskie zostały ponownie podzielone wzdłuż rzeki Zbrucz, tym razem między Polskę a Rosję Radziecką. Od 1921 r. część wschodniej granicy Polski miała identyczny przebieg jak wcześniejsza XIX-wieczna granica między Austrią a Rosją (ryc. 2). W konsekwencji takiego podziału terytorialnego, w granicach odrodzonej Polski zamieszkiwała najbardziej świadoma swej tożsamości i odrębności narodowo-religijnej część narodu ukraińskiego.

W okresie międzywojennym Ukraińcy stanowili najliczniejszą oraz najbardziej skonfliktowaną z państwem polskim mniejszość narodową. Świeża była pamięć o krwawych walkach polsko-ukraińskich oraz upadku ukraińskiej państwowości. W tym okresie spór polsko-ukraiński dotyczył spraw podstawowych, takich jak posiadanie własnego państwa, możliwość rozwoju i kształtowania własnej tożsamości narodowej, odrębności językowej i kulturowej. W warunkach bardzo zróżnicowanego etnicznie i kulturowo pogranicza, obszaru uznawanego przez obie narodowości za własny, z reguły sukces jednej strony był porażką drugiej, a kompromis był praktycznie niemożliwy. W tych uwarunkowaniach, w południowo-wschodniej Polsce nie uległy likwidacji, a wręcz zaostrzyły się, istniejące od pokoleń polsko-ukraińskie podziały narodowościowe, wyznaniowe, językowe, stanowe, społeczne i gospodarcze. Wzajemna nieufność przybierała drastyczne formy. Ukraińcy bojkotowali pobór do wojska, wybory, przymus szkolny, organizowali strajki. Stosowali nie tylko opór bierny, ale także

${ }^{3}$ Układ z Petlurą zawierał m.in. zgodę na rezygnację przez Ukraińców z Galicji Wschodniej i części Wołynia na rzecz Polski, co było powodem jego ostrej krytyki przez ukraińskich działaczy narodowych. 
czynny - dywersję, sabotaż i terror skierowany przeciwko polskim urzędom, politykom, ziemianom, osadnikom ${ }^{4}$. Najważniejsze partie ukraińskie za główny cel stawiały sobie oderwanie wschodnich województw od Rzeczypospolitej i stworzenie niepodległej Ukrainy. Z kolei polskie władze przeprowadzały akcje pacyfikacyjne $\mathrm{z}$ użyciem oddziałów wojska, stosowały odpowiedzialność zbiorową, aresztowały działaczy, zwalniały ukraińskich urzędników, wprowadzały sądy doraźne, zamykały siedziby organizacji, likwidowały szkoły ukraińskie, wprowadzając na ich miejsce nauczanie dwujęzyczne, burzyły cerkwie prawosławne na Chełmszczyźnie ${ }^{5}$ a zapowiadana autonomia Galicji Wschodniej nigdy nie weszła w życie. Prowadzono także ,politykę regionalizacji” polegającą na podkreślaniu odrębności Rusinów, Łemków, Bojków, Hucułów, Poleszuków, Wołyniaków.

Takie działania polskich władz z jednej strony powodowały wzrost nacjonalizmu i radykalizację postaw Ukraińców, potęgowały wzajemną wrogość między Ukraińcami a Polakami. Z drugiej strony przez cały okres międzywojenny mniejszość ukraińska w Polsce miała możliwość prowadzenia aktywnej działalności organizacyjnej, politycznej, gospodarczej, kulturalnej, edukacyjnej, wydawniczej, religijnej. Funkcjonowały liczne ukraińskie organizacje, partie polityczne, spółdzielnie, banki. W sejmie zasiadała reprezentacja posłów ukraińskich. Działalność duszpasterską, oświatową i charytatywną prowadził Kościół greckokatolicki i prawosławny (Chałupczak, Browarek 1998, Drozd, Halczak 2010). Był to zakres swobód dużo większy niż w powojennym okresie Polski Ludowej i nieporównywalny z tym, czego doświadczali Ukraińcy na ziemiach włączonych do ZSRR.

Na początku II wojny światowej, w ramach realizacji ustaleń paktu Ribbentrop-Mołotow ${ }^{6}$ ZSRR zaatakował 17 września 1939 r. Polskę i zagarnął obszar

${ }^{4}$ W latach 1921-1939 nacjonaliści ukraińscy z UWO i OUN przeprowadzili 63 zamachy, w których zginęło kilkadziesiąt osób, m.in. minister spraw wewnętrznych B. Pieracki, poseł na sejm T. Hołówka, kurator szkolny S. Sobiński. Część zamachów była nieudana, m.in. na marszałka J. Piłsudskiego i prezydenta Polski S. Wojciechowskiego (Gawryszewski 2005).

${ }^{5}$ W 1938 r. wojsko i policja przeprowadziły na Chełmszczyźnie akcję burzenia świątyń prawosławnych. Ogółem zniszczono 91 cerkwi, 10 kaplic, 26 domów modlitwy, ponadto kilka cerkwi przekazano Kościołowi rzymskokatolickiemu. Miało to m.in. skłonić ludność prawosławną do przechodzenia na katolicyzm. Akcja spowodowała masowe protesty Ukraińców (Drozd, Halczak 2010).

${ }^{6}$ Radziecko-niemiecki pakt o nieagresji, podpisany 23 sierpnia 1939 r. w Moskwie przez ministrów spraw zagranicznych III Rzeszy i ZSRR (stąd jego nazwa). Równocześnie został podpisany dodatkowy tajny protokół, który zawierał uzgodnienia dotyczące podziału stref wpływów III Rzeszy i ZSRR w Europie, w tym także w Polsce. 
po Pisę, Narew, Bug i San. Na podstawie radziecko-niemieckiego układu z 28 września 1939 r. granica między Trzecią Rzeszą a ZSRR w południowej Polsce została wyznaczona wzdłuż Sanu, Sołokiji i Bugu, a ziemie na wschód od tej linii, na podstawie pozorowanych wyborów, zostały w listopadzie przyłączone do Ukraińskiej Socjalistycznej Republiki Radzieckiej (USRR) jako tzw. Zachodnia Ukraina (ryc. 7). Wielu ukraińskich działaczy narodowych uznało władzę radziecką za kolejnych okupantów i wyemigrowało, spośród tych, którzy pozostali, wielu (zwłaszcza inteligencja i duchowni) było represjonowanych przez radziecki aparat bezpieczeństwa, aresztowanych i deportowanych w głąb ZSRR $^{7}$. Jednak nowe władze skupiły się przede wszystkim na prześladowaniu i dyskryminowaniu Polaków, wśród których najpowszechniej dostrzegano „wrogów klasowych".

$\mathrm{Na}$ ziemiach okupowanych przez Niemcy, władze hitlerowskie, prowadząc politykę „dziel i rządź”, podsycały wzajemne antagonizmy narodowościowe, preferowały ludność ukraińska, która m.in. mogła przejmować gospodarstwa wysiedlonych Polaków i Żydów, uzyskała przywileje w prowadzeniu działalności gospodarczej, spółdzielczej, edukacyjnej oraz kulturalnej. Zezwolono na funkcjonowanie szkolnictwa ukraińskiego, działalność Organizacji Ukraińskich Nacjonalistów (OUN), a także zwrócono Ukraińcom prawosławny sobór w Chełmie wraz z kilkudziesięcioma cerkwiami (Chałupczak, Browarek 1998).

Dla Ukraińców, a zwłaszcza ukraińskich nacjonalistów i działaczy politycznych, atak Niemiec na ZSRR w czerwcu 1941 r. mógł wydawać się wstępem do realizacji marzeń o państwie ukraińskim, tym bardziej, że hitlerowcy sugerowali poparcie idei niepodległości Ukrainy. Jednak nadzieje na własne państwo, choćby pod protekcją Niemiec, bardzo szybko okazały się złudne. Niemcy przyłączyli Galicję Wschodnią do Generalnej Guberni i nie akceptowali prób proklamacji państwa ukraińskiego podejmowanych latem i jesienią 1941 r. przez ukraińskich działaczy niepodległościowych. Między władzami niemieckimi a działaczami OUN zaczął narastać konflikt, większość kierownictwa aresztowano. Mimo to III Rzesza traktowała Ukraińców jak sojuszników w wojnie

Podział ten w Polsce miał przebiegać wzdłuż rzek Narew-Wisła-San, jednak już w trakcie działań wojennych doszło do istotnych zmian wcześniejszych ustaleń. Konsekwencjami zawarcia paktu była niemiecka i radziecka agresja na Polskę we wrześniu 1939 r., podział terytorium Polski między ZSRR i Niemcy (tzw. czwarty rozbiór Polski) oraz trwająca prawie dwa lata radziecka okupacja wschodniej Polski.

${ }^{7}$ Od września 1939 r. do czerwca 1941 r. co najmniej 24 tys. Ukraińców zamieszkujących okupowaną przez ZSRR wschodnią Polskę aresztowało NKWD, a 32,9 tys. Ukraińców władze radzieckie wywiozły do Kazachstanu i na Syberię. Stanowili oni 10,5\% wszystkich deportowanych wówczas z tego obszaru (Hryciuk 2008). 
z ZSRR, formowała i uzbrajała ukraińskie jednostki wojskowe (m.in. dywizję SS Galizien), zwłaszcza od 1943 r., kiedy została zmuszona uzupełniać coraz większe straty frontowe. Część ukraińskich nacjonalistów współpracowała z Niemcami i głosiła lojalność wobec władz hitlerowskich, ale jednocześnie w 1942 r. zaczęła tworzyć własne siły zbrojne, Ukraińską Powstańczą Armię (UPA), która miała prowadzić walkę o niepodległą Ukrainę zarówno z Rosjanami, Polakami, jak i Niemcami.

W lutym 1943 r. ukraińskie ugrupowania wojskowe rozpoczęły działania zmierzające do likwidacji skupisk Polaków na Wołyniu, których największe nasilenie przypadło na miesiące letnie. Oddziały UPA oraz ukraińscy chłopi pacyfikowali polskie wsie, okrutnie mordując mieszkańców, rabując i paląc zabudowania. Czystki etniczne organizowane i przeprowadzane przez ukraińskich nacjonalistów miały wszelkie cechy ludobójstwa ludności polskiej. Wybuchły krwawe walki polsko-ukraińskie, które z Wołynia rozprzestrzeniły się na wschodnią Galicję, południowe Polesie oraz południowo-wschodnią Lubelszczyznę i Chełmszczyznę. Według różnych szacunków, zamordowano wówczas od 70 do 100 tys. Polaków i od kilkunastu do 20-30 tys. Ukraińców ${ }^{8}$, którzy ginęli najczęściej w odwetowych akcjach oddziałów Armii Krajowej i polskiej samoobrony (Torzecki 1993, Chałupczak, Browarek 1998, Gawryszewski 2005, Motyka 2011a).

Głównymi przyczynami tej zbrodniczej działalności było dążenie do fizycznej likwidacji Polaków na ziemiach uważanych przez nacjonalistów ukraińskich za przyszłe terytorium niepodległej Ukrainy, dążenie Ukraińców do utworzenia państwa narodowego, uniknięcie powtórzenia się sytuacji, która miała miejsce pod koniec I wojny światowej.

Masowe mordy ludności polskiej na Wołyniu w 1943 r. są jedną z najbardziej tragicznych i okrutnych kart w dziejach polsko-ukraińskich, częścią polskiej pamięci historycznej, nadal wzbudzającą bardzo silne emocje.

${ }^{8}$ Według H. Chałupczaka i T. Browarka (1998), tylko w latach 1943-1944 zginęło 70-100 tys. Polaków i ok. 30 tys. Ukraińców, według A. Gawryszewskiego (2005) liczba Polaków zabitych przez Ukraińców w latach 1941-1947 wahała się od 75 do 100 tys. osób, w tym na Wołyniu 50-70 tys., w Galicji Wschodniej 20-25 tys., w granicach współczesnej Polski 5-6 tys., natomiast według szacunków G. Motyki (2011a), w latach 1943-1947 z rąk Ukraińców poniosło śmierć ok. 100 tys. Polaków, w tym na Wołyniu 40-60 tys., w Galicji Wschodniej 30-40 tys., w granicach współczesnej Polski ok. 6-8 tys.; straty ukraińskie w tym samym okresie szacuje na ok. 10-15 tys. osób, w tym na Wołyniu 2-3 tys., w Galicji Wschodniej 1-2 tys., w granicach współczesnej Polski 8-10 tys. 


\section{2. Łemkowie}

Polscy historycy i etnografowie, opierając się na rezultatach badań naukowych, uważają Łemków za ludność napływową na obszar północnych Karpat. Według tej teorii, ich przodkowie przybyli z falą osadnictwa wołosko-ruskiego, między XIV a XVI w. Kolonizacja ta posuwała się wzdłuż głównego łańcucha Karpat, z obszaru współczesnej Rumunii ku północy i zachodowi (Leszczycki 1935, Smoleński 1935, Reinfuss 1948, 1990, Trajdos 1990, 1992, Czajkowski 1992, Parczewski 1992). Łemkowie są grupą etniczną, która ukształtowała się w długim procesie historycznym, przyjmując i asymilując różne elementy narodowe. Mieli w tym udział zarówno osadnicy polscy, słowaccy, jak i wołoscy pasterze. Największe znaczenie miało osadnictwo ruskie, które w XV i XVI w. zdominowało liczebnie wcześniejsze grupy etniczne, asymilując je językowo i w dużej mierze kulturowo, równocześnie przejmując pewne cechy od swoich poprzedników, np. liczne geograficzne nazwy miejscowe i wysokogórski typ pasterstwa. Pochodzenie etniczne, odrębny język, religia i kultura zdecydowanie odróżniały Łemków (Rusinów) od sąsiedniej ludności polskiej, słowackiej i węgierskiej (Reinfuss 1948, 1990).

Naukowcy ukraińscy negują kolonizację wołosko-ruską i w ogóle jakąkolwiek obecność Wołochów w Beskidach, są zwolennikami tezy o autochtonizmie Rusinów w Karpatach (Tarnowycz 1936, Krasowski 1992, Drozd, Halczak 2010). Spory o pochodzenie Łemków toczą się już od kilkudziesięciu lat i prawdopodobnie toczyć się będą nadal. Często mają wyraźny podtekst polityczny i tak też są wykorzystywane w dyskusjach między działaczami i naukowcami polskimi, ukraińskimi, łemkowskimi oraz wewnątrz środowiska łemkowskiego.

Nazwa „Łemko” pojawiła się późno, dopiero w pierwszej połowie XIX w. Początkowo miała charakter przezwiska. Pochodzi od często używanego przez Łemków słowa łem, zapożyczonego od słowackiego lem, używanego w znaczeniu tylko lub ale, niewystępującego w innych gwarach ukraińskich. Słowo to śmieszyło Bojków, którzy nazywali swych zachodnich sąsiadów Łemkamy (Reinfuss 1990). Początkowo nazwy Łemko używano tylko na pograniczu łemkowsko-bojkowskim, skąd rozpowszechniła się jako określenie wszystkich rusińskich mieszkańców Beskidu Niskiego i Sądeckiego (Czajkowski 1992). Przyczyniło się do tego kilku XIX-wiecznych autorów piszących o mieszkańcach Beskidu Niskiego, którzy spopularyzowali lokalne przezwisko ${ }^{9}$. Określenie

\footnotetext{
${ }^{9}$ W literaturze pierwszy raz użył nazwy Łemko na określenie Rusinów wschodniej Słowacji etnograf J. Čaplovič w 1820 r. w pracy pt. Etnografické pozorowania
} 
Łemkowie nie jest więc tworem sztucznym, tylko wprowadzonym do literatury ludowym przezwiskiem. Nazwa ta została dopiero w okresie międzywojennym przyjęta jako własna przez Rusinów z północnej strony Karpat. Natomiast po stronie słowackiej używane są etnonimy Rusin lub Rusnak. Nie zmienia to faktu, że pod względem etnicznym, kulturowym i językowym Rusini mieszkający po obu stronach Karpat, zarówno „polscy” Łemkowie, jak i „słowaccy” Rusnacy, stanowią jedną grupę (Sapoliga 1992). Rusini zamieszkujący północne Karpaty (w Polsce, Słowacji, Ukrainie) są także określani nazwą Karpatorusini (Magocsi 2002, Michna 2004, Horbal 2010).

Do końca XVI w. powstała zdecydowana większość wsi na obszarze północnych Karpat. Ukształtowała się wówczas wyraźna granica etniczna i kulturowa między Rusinami a Polakami, która istniała aż do połowy lat 40. XX w. Łemkowie zamieszkiwali zwarty obszar Beskidu Niskiego i Krynickiego, od Popradu na zachodzie, aż po źródła Solinki na wschodzie. Ten najdalej wysunięty na zachód obszar zamieszkany przez Rusinów został znacznie później nazwany Łemkowszczyzną. Był to obszar pod względem etnicznym przez kilkaset lat zdominowany przez Łemków, a nieliczna ludność polska, żydowska, słowacka i niemiecka zamieszkiwała jedynie w kilku miastach (ryc. 3) (Reinfuss 1990, Czajkowski 1992).

Delimitacji Łemkowszczyzny jako odrębnego regionu podjął się pod koniec okresu międzywojennego etnograf R. Reinfuss (1948, 1990). Podstawowym kryterium było poczucie przynależności grupowej, różnice kulturowe i wyniki badań językoznawczych. R. Reinfuss na podstawie własnych badań terenowych określił dokładne granice Łemkowszczyzny, a więc de facto polsko-łemkowską granicę etniczną ${ }^{10}$ (ryc. 3). W tym okresie był to region jednorodny pod względem etnicznym, zdecydowanie wyróżniający się z otaczającej przestrzeni, co bardzo ułatwiło jego precyzyjne wydzielenie. Najwięcej kontrowersji i dyskusji wzbudzała wschodnia granica Łemkowszczyzny, tj. kwestia rozgraniczenia

z Uhorska. W Polsce jako pierwszy posłużył się tym określeniem O. Lewicki w 1834 r. w pracy pt. Grammatik der ruthenischen oder kleinrussichen Sprache in Galizien.

10 Według badań R. Reinfussa, granicznymi wsiami Łemkowszczyzny były (począwszy od zachodu): Wierchomla Wielka, Roztoka Mała, Składziste, Maciejowa, Łabowa, Bogusza, Królowa Ruska, Binczarowa, Florynka, Wawrzka, Brunary Niżne, Jaszkowa, Klimkówka, Łosie, Bielanka, Rychwałd, Ropica Ruska, Pstrążne, Męcina Wielka, Rozdziele, Bednarka, Wola Cieklińska, Folusz, Kłopotnica, Pielgrzymka, Świeżowa Ruska, Jaworze, Desznica, Hałbów, Myscowa, Hyrowa, Trzcianka, Zawadka Rymanowska, Kamionka, Królik Wołoski, Wisłoczek, Bałucianka, Deszno, Wólka, Wołtuszowa, Tarnawka, Rudawka Rymanowska, Puławy, Darów, Wisłok Wielki, Jawornik, Rzepedź, Szczawne, Turzańsk, Duszatyn, Michów, Wola Michowa, Maniów, Szczerbanówka, Żebracze i Solinka (Reinfuss 1990). 
Łemków i Bojków. Została ona wyznaczona przez J. Falkowskiego oraz B. Pasznyckiego (1935) według kryteriów etnograficznych i socjologicznych. Porównując wyniki badań R. Reinfussa $(1948,1990)$ z pracą D. Zubrzyckiego (1849) oraz ustaleniami historyka Z. Budzyńskiego (1992), który dowiódł, że zasięg jurysdykcyjny Kościoła unickiego w XVIII w. dokładnie pokrywał się z granicami osadnictwa łemkowskiego, można stwierdzić, że terytorium zamieszkane przez Łemków w północnych Karpatach nie zmieniło się zasadniczo przez co najmniej dwa stulecia, począwszy od XVIII w. do drugiej połowy lat 40. XX w.

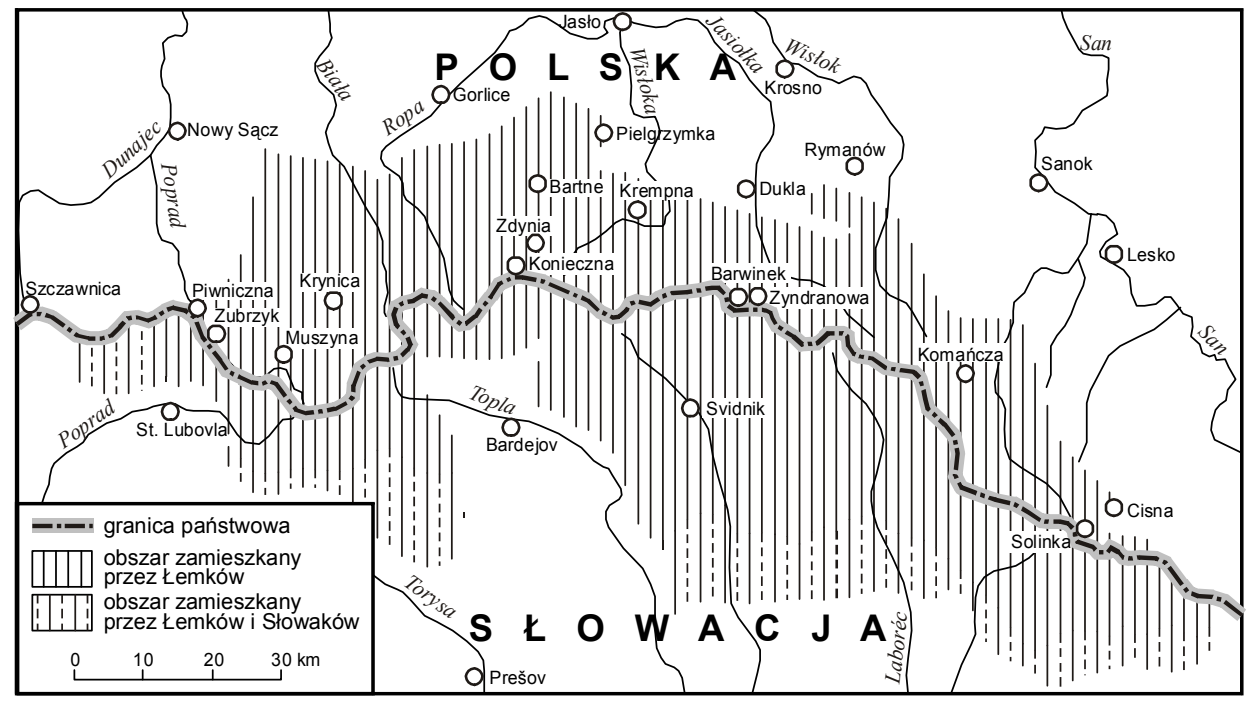

Ryc. 3. Obszar zamieszkany przez Łemków w Karpatach (stan z 1944 r.) Źródło: R. Reinfuss (1990, s. 14)

Zarówno pasterze wołoscy, jak i Rusini przybywający w XIV-XVI w. na obszar polskich Karpat byli wyznania prawosławnego. W 1595 r. w Brześciu Litewskim na synodzie cerkwi prawosławnej większość biskupów prawosławnych ze wschodnich terenów Rzeczypospolitej opowiedziało się za unią z Rzymem. Do unii nie przystapiły m.in. diecezje przemyska i lwowska. Spory na tle religijnym trwały w Beskidach przez następne 100 lat, prawie do końca XVII w. i wygasły dopiero po 1692 r., kiedy zlikwidowano w Przemyślu biskupstwo prawosławne, a w diecezji przemyskiej (obejmującej Łemkowszczyznę) zapanowała niepodzielnie unia. Diecezja lwowska przystąpiła do unii jeszcze później, bo w 1700 r. Jednak te dwie diecezje, które najpóźniej przyjęły unię, stały się później ostojami Kościoła greckokatolickiego. Zadecydowały o tym rozbiory i podział terytorium Polski między Rosję i Austrię. W diecezjach, które znalazły 
się na obszarach zagarniętych przez prawosławną carską Rosję, unia była prześladowana, a z czasem całkowicie zlikwidowana. Natomiast diecezje przemyska i lwowska weszły w skład zaboru austriackiego, gdzie grekokatolicyzm był oficjalnie uznawany, a nawet popierany.

W XIX w., głównie dzięki poczuciu odrębności kulturowej, językowej i religijnej Łemków od Polaków, zaczęła rozwijać się wśród nich świadomość przynależności do szerszej grupy ogólnołemkowskiej i do grupy najszerszej, narodowej. Łemkowie znaleźli się pod wpływem trzech rywalizujących ze sobą orientacji polityczno-narodowych: staroruskiej, ukraińskiej i rusofilskiej. Przez ostatnie dwa wieki bardzo duży wpływ na przemiany tożsamości narodowej Łemków miała geografia i geopolityka: peryferyjne położenie Łemkowszczyzny oraz w różnych okresach historycznych zmienny wpływ zewnętrznych centrów politycznych - austriackiego, rosyjskiego, ukraińskiego, polskiego, niemieckiego.

W połowie XIX w. powstała w Galicji Wschodniej narodowa orientacja staroruska, nawiązująca do tradycji Rusi Kijowskiej, lojalna w stosunku do Austrii. W wyniku ewolucji poglądów działaczy staroruskich, w okresie Wiosny Ludów pojawiła się orientacja rusofilska. Podkreślała związki Rusi z Rosją. Głosiła ideę zjednoczenia wszystkich narodów ruskich pod panowaniem cara i propagowała prawosławie. Kierunek rusofilski objął również Łemkowszczyznę, jego popularność wśród Łemków wiązała się m.in. z pokrewieństwem kulturowym Rusinów i Rosjan oraz wsparciem potężnego imperium carów. W latach 60. XIX w. z ruchu staroruskiego wyodrębniła się kolejna orientacja narodowa - ukraińska. Powstała ona wśród ruskiej inteligencji we Lwowie, nawiązywała do tradycji kozackiej, akcentowała odrębność narodu ruskiego od Rosjan, uznawała jedność Rusinów galicyjskich oraz Ukrainy kijowskiej i wysuwała jako cel powstanie wolnego państwa ukraińskiego. Gdy pod koniec XIX w. popsuły się stosunki polityczne między Cesarstwem Austro-Węgierskim a Rosją, Austria zaprzestała popierania orientacji staroruskiej, kierując swe poparcie dla stronnictwa ukraińskiego. Hasła proukraińskie szybko opanowały wschodnią Galicję, spotykając się jednak z niechęcią na Łemkowszczyźnie. Łemkowie pozostali przy swych staroruskich i rusofilskich sympatiach ${ }^{11}$. Propagandę ukraińską na Łemkowszczyźnie prowadziła głównie, posłuszna dyrektywom rządu austriackiego, Cerkiew greckokatolicka, co powodowało liczne konflikty między Łemkami a duchowieństwem greckokatolickim, doprowadzając nawet do odejścia części Łemków od Kościoła unickiego (Michna 1995, 2004, Moklak 2007, Horbal 2010).

${ }^{11} \mathrm{~W}$ tym okresie charakterystyczną cechą obu orientacji było ich słabe rozróżnianie przez Rusinów, częste było współdziałanie starorusinów i rusofili (Moklak 2007). 
Między poszczególnymi stronnictwami - reprezentującymi odmienne ideologie - rozgorzała walka polityczna, toczona w atmosferze pomówień i oszczerstw. Dotyczyło to w głównym stopniu inteligencji rusińskiej. Dla ludności chłopskiej, niepiśmiennej, bardzo konserwatywnej, żyjącej w biedzie i izolacji, przynależność narodowa nie była istotnym problemem (Michna 2004). Jednak konsekwencje ścierania się orientacji narodowych na Łemkowszczyźnie w okrutny sposób odbiły się na Łemkach podczas I i II wojny światowej, są także wyraźnie widoczne do dzisiaj, nadal dzielą tę społeczność.

Już w miesiąc po wybuchu I wojny światowej, we wrześniu 1914 r., w Beskidzie Niskim doszło do walk wojsk carskich z oddziałami austro-węgierskimi. Austriacy, tłumacząc swe niepowodzenia szpiegowską działalnością Łemków o orientacji rusofilskiej, zastosowali wobec nich akcję represyjną. W wyniku aresztowań ok. 5 tys. chłopów, nauczycieli i duchownych greckokatolickich, trafiło do więzień lub do obozu w Thalerhofie koło Grazu. Wśród Łemków silne było przekonanie, utrzymujące się do dzisiaj, że czynny udział w akcji represyjnej brali Ukraińcy, którzy wykorzystali zaistniałą sytuację do wyeliminowania swoich przeciwników politycznych ${ }^{12}$. W pamięci Łemków Thalerhof zachował się jako miejsce narodowej kaźni, o wymiarze zdecydowanie antyukraińskim (Duć-Fajfer 1992, Horbal 2010).

W tym samym czasie, w części Galicji zajętej przez Rosjan rozpoczęły się prześladowania Ukraińców. Zakazane było używanie języka ukraińskiego, likwidowano wyznanie greckokatolickie. Wielu Ukraińców wywieziono na Sybir. W represjach tych współdziałali, korzystając ze swej przewagi, rusofile. Lata I wojny światowej wprowadziły głębokie podziały wśród Łemków, zaostrzając konflikt między zwolennikami kierunku rusofilskiego i ukraińskiego. Ustaliły także geograficzne strefy wpływów obu orientacji polityczno-narodowych: na zachodzie Łemkowszczyzny dominowali zwolennicy stronnictwa staroruskiego i rusofilskiego, natomiast na wschodzie - ukraińskiego (Reinfuss 1990, Michna 1995, 2004).

Polityczne rezultaty I wojny światowej, a zwłaszcza rozpad monarchii austro-węgierskiej, powstanie niepodległej Polski i Czechosłowacji, poprowadzenie wzdłuż łuku Karpat granicy polsko-czechosłowackiej, zapowiadało przerwanie swobodnych relacji między Rusinami z północy i południa Karpat. Groziło to negatywnymi konsekwencjami zwłaszcza dla Łemków, ekonomicznie związanych ze Słowacją i Węrami, głównie przez sezonowe roboty rolne i wymianę

${ }^{12}$ Współpraca Ukraińców z władzami austriackimi na Łemkowszczyźnie podczas I wojny światowej jest negowana przez niektórych historyków polskich i ukraińskich (Moklak 1993). 
handlową. Poza wymiarem gospodarczym, powiązania miały także charakter rodzinny, towarzyski i religijny. Dlatego też, po zakończeniu wojny Łemkowie uaktywnili się politycznie.

W grudniu 1918 r., we wsi Florynka ogłoszono powstanie Ruskiej Rady. Jej wpływy ograniczały się do zachodniej Łemkowszczyzny. Władze Ruskiej Rady nie miały jednakowych poglądów co do przyszłości tego regionu. Wspólne było dążenie do stworzenia niepodzielonej Łemkowszczyzny. Początkowo najwięcej zwolenników miała koncepcja przyłączenia Łemkowszczyzny do carskiej Rosji, jednak z powodu wybuchu rewolucji w Rosji ta rusofilska deklaracja nie została zrealizowana. Postanowiono wówczas nawiązać współpracę z Rusinami z południowej strony Karpat i przyłączyć Łemkowszczyznę do Czechosłowacji. Z powodu braku odzewu władz w Pradze zamiar ten także nie doczekał się realizacji. Ruska Rada została zlikwidowana przez władze polskie w 1920 r. W tym samym czasie, w okresie walk polsko-ukraińskich o Lwów, na Łemkowszczyźnie wschodniej powstała proukraińska Republika Komańczańska, która zgłosiła akces do Zachodnio-Ukraińskiej Republiki Ludowej, tym samym weszła w orbitę walk polsko-ukraińskich. Została zlikwidowana zbrojnie przez Wojsko Polskie w styczniu 1919 r. (Nowakowski 1992, Moklak 1993, Michna 1995, 2004, Horbal 2010).

Wydarzenia te pokazały, że z jednej strony Łemkowie na początku XX w. czuli potrzebę samodzielnego decydowania o swoim losie, mieli świadomość wspólnoty z Rusinami zamieszkującymi południowe stoki Karpat i dążyli do niepodzielności łemkowskiego obszaru etnicznego. Proklamacje ,republik łemkowskich" i próby secesji tego obszaru były także dowodem, że Łemkowie postrzegali zamieszkiwane przez siebie terytorium jako jednorodny region etniczny, historyczny i polityczny, zdecydowanie wyróżniający się na tle sąsiadujących obszarów, zwłaszcza zamieszkanych przez ludność polską. Z drugiej strony unaoczniły, iż podczas przełomów politycznych (a takim niewątpliwie była I wojna światowa) uzewnętrzniły się podziały polityczno-narodowe wewnątrz środowiska łemkowskiego, że mimo niewielkiej liczebności tej społeczności już wówczas był wyraźny dualizm narodowy łemkowsko-ukraiński.

Po zakończeniu wojny polsko-bolszewickiej uszczelniono granicę polsko-czechosłowacką, co w znacznym stopniu ograniczyło przemyt i nielegalny ruch przygraniczny, ale równocześnie skutecznie odcięło Łemków północnych od ich kontaktów rodzinnych, zarobkowych i handlowych z Rusinami w Słowacji (Nowakowski 1992). Granica biegnąca wzdłuż łuku Karpat stała się barierą rozwoju kontaktów międzyludzkich i z niewielkimi tylko zmianami pełniła tę funkcję aż do początku lat 90 . XX w. 
W okresie międzywojennym jednym z ważniejszych problemów na Łemkowszczyźnie stała się kwestia wyznaniowa. Przyczyniła się do tego polityka personalna greckokatolickiej diecezji przemyskiej, która na miejsce duchownych, sprzyjających nurtowi rusofilskiemu, przysyłała młodych proboszczów, zdeklarowanych Ukraińców. Propaganda proukraińska głoszona w cerkwiach oraz konflikty na tle materialnym między klerem greckokatolickim a wiernymi doprowadziły w latach 1926-1932 do fali masowych konwersji na prawosławie. Okres ten został później nazwany „wojną religijną w górach”. Największą falę przejść na prawosławie zanotowano w latach 1926-1928. Na początku lat 30. ruch ten osłabł i ok. 1933 r. zanikł praktycznie całkowicie ${ }^{13}$.

Dla zahamowania przejść na prawosławie papież Pius XI utworzył dla Łemków obrządku greckokatolickiego Apostolską Administrację Łemkowszczyzny (AAŁ). Powstała ona przez wydzielenie dziewięciu dekanatów z greckokatolickiej diecezji przemyskiej i poddanie ich bezpośrednio pod władzę Watykanu. Głównymi zwolennikami powstania AAŁ byli Łemkowie rusofile. Według nich było to jedyne rozwiązanie, które w radykalny sposób odcięło by Łemków od propagandy ukraińskich ośrodków politycznych i kościelnych w Przemyślu oraz Lwowie. Bardzo zbliżone motywy miał polski rząd, któremu również zależało na odizolowaniu Łemków od wpływów ukraińskich. $Z$ kolei powstanie AAŁ wywołało protesty środowisk ukraińskich (Krochmal 1992, Nowakowski 1992, Prach 1992).

W latach 30. XX w. rywalizacja stronnictw rusofilskich i ukraińskich, chcących pozyskać ludność łemkowska, przybrała największe rozmiary. Objęła sferę wyznaniową, polityczną, kulturalną, oświatową i gospodarczą. Po umocnieniu się w Rosji władzy bolszewików, orientacja rusofilska nawiązująca do Rosji carskiej ewoluowała w stronę orientacji narodowo rusińskiej, podkreślającej odrębność narodową Rusinów karpackich zarówno od Rosjan, jak i Ukraińców. Władze polskie wyraźnie wspierały ruch rusiński, promowały rozwój odrębnej łemkowskiej świadomości narodowej, widząc w tym możliwość osłabienia wpływów ukraińskich w Karpatach, a w późniejszej perspektywie asymilacji Łemków (Duć-Fajfer 1992, Michna 1995, 2004, Moklak 1997, 2007).

${ }^{13}$ Według danych GUS ze spisu powszechnego z 1931 r., liczba prawosławnych na Łemkowszczyźnie wynosiła 15902 osoby, co stanowiło wówczas ok. 12\% Łemków. Mimo konwersji zdecydowanie dominowali grekokatolicy, choć proces zmian wyznania jeszcze wtedy trwał. Trudno jednoznacznie ocenić, czy podziały wśród Łemków miały charakter bardziej narodowościowy i polityczny czy wyznaniowy, obie kwestie ściśle się ze sobą łączyły. 
Podczas II wojny światowej Łemkowszczyzna w całości dostała się pod okupację niemiecką. Dla Łemków był to początek trzech fal przesiedleń, które przerwały ciągłość osadniczą tego regionu oraz całkowicie zmieniły jego strukturę etniczno-religijną.

W listopadzie 1939 r. sojusznicze wówczas rządy Niemiec i ZSRR podpisały porozumienie o wymianie ludności ukraińskiej (w tym także łemkowskiej) mieszkającej w Generalnej Guberni na Niemców, którzy chcieli przenieść się z ZSRR do Rzeszy. W wyniku agitacji sowieckich komisarzy w latach 19401941 dobrowolnie zgłosiło się do przesiedlenia ok. 25 tys. Łemków, faktycznie jednak wyjechało do ZSRR tylko ok. 5 tys. spośród nich, gdyż reszta, uświadomiona o sowieckich realiach przez uchodźców z Ukrainy, zrezygnowała z wyjazdu (Nowakowski 1992).

Po ataku Niemiec na ZSRR w 1941 r., Ukraińcy, korzystając ze swej uprzywilejowanej pozycji, obsadzili całą wiejską administrację na Łemkowszczyźnie i utworzyli policję ukraińską. Dało im to możliwość rozrachunku ze swymi przeciwnikami politycznymi - rusofilami. Powtórzyła się sytuacja z okresu I wojny światowej, przeprowadzano masowe aresztowania wśród rusofilów, oskarżając ich o szpiegostwo (Reinfuss 1990).

Druga wojna światowa, mimo akcji przesiedleńczej z początku lat 40. oraz działań frontowych, nie przyniosła istotnych zmian narodowościowych na Łemkowszczyźnie, a najtragiczniejsze dla Łemków wydarzenia nastąpiły, paradoksalnie, już po wyzwoleniu tego obszaru spod okupacji niemieckiej, w latach 1944-1947.

\subsection{Białorusini}

Pojęcie „Ruś Biała” wywodzi się z czasów państwa staroruskiego, rozciągającego się nad Dźwina, w pobliżu Połocka i Witebska. Obszar ten w średniowieczu był wielokrotnie najeżdżany przez władców Nowogrodu i Kijowa oraz Litwinów i Tatarów. Szybko został uzależniony od Wielkiego Księstwa Litewskiego, do którego ziemie białoruskie należały przez kilkaset lat. Mimo politycznej zależności od Litwinów, białoruska kultura, a zwłaszcza język ${ }^{14}$, zachowały pozycję dominująca, utraconą dopiero na przełomie XVII i XVIII w. na rzecz kultury polskiej (Chałupczak, Browarek 1998).

${ }^{14}$ Język starobiołoruski był uznawany za urzędowy na obszarze Wielkiego Księstwa Litewskiego, sporządzono w nim dokumenty od XIV w. aż do początku XVIII w. (Wasilewski 1925, Tomaszewski 1991). 
Przesunięcie granic Rzeczypospolitej na wschód po unii polsko-litewskiej w 1569 r., poza nielicznymi wyjątkami, nie objęło ziem zamieszkanych przez Białorusinów. Obszary na wschód od Brześcia, Hajnówki i Białegostoku nadal, przez ponad 200 kolejnych lat, pozostały w granicach Litwy. W okresie rozbiorów ziemie białoruskie $\mathrm{w}$ całości dostały się pod panowanie rosyjskie, a po kongresie wiedeńskim zostały, wraz z częścią Podlasia, włączone bezpośrednio do Cesarstwa Rosyjskiego. Wschodnie Podlasie weszło w skład państwa polskiego dopiero po I wojnie światowej (ryc. 4).

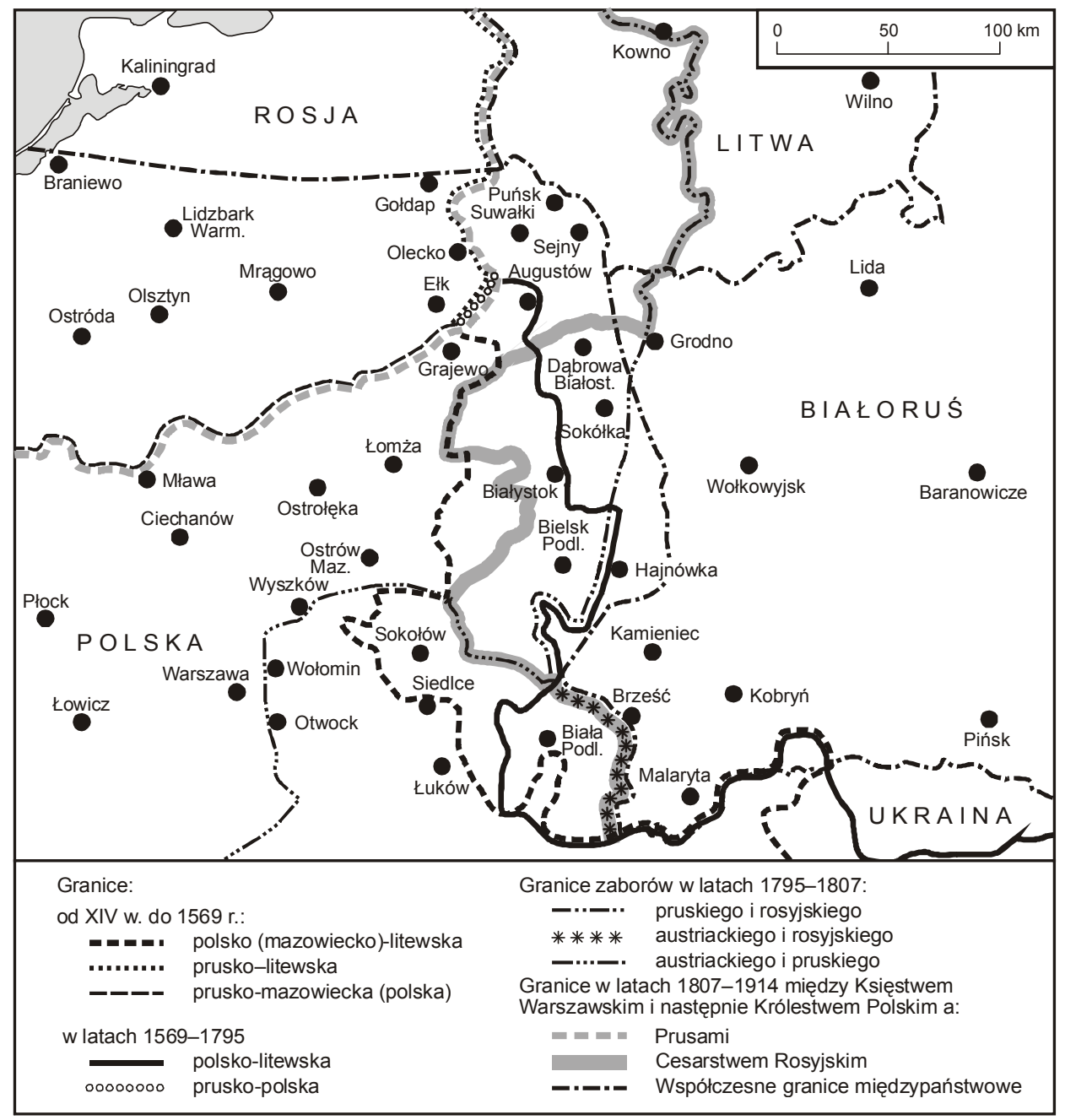

Ryc. 4. Przebieg głównych granic na pograniczu prusko-polsko-litewsko-ruskim od XIV do XIX w.

Źródło: opracowanie własne 
W XIX w. władze carskie prowadziły bardzo intensywną rusyfikację, likwidując grekokatolicyzm, siłą nawracając unitów na prawosławie. Głównymi przyczynami późnego i powolnego kształtowania się białoruskiej świadomości narodowej było nieliczne i w bardzo dużym stopniu spolonizowane lub zrusyfikowane środowisko szlacheckie, brak burżuazji i zamożnego mieszczaństwa oraz całkowita dominacja ubogiego, niewykształconego chłopstwa. Ponadto brak tradycji własnej państwowości, sąsiedztwo silnych organizmów etniczno-kulturowych (polskiego, litewskiego i rosyjskiego), zacofanie społeczno-gospodarcze, podobieństwo języka białoruskiego do rosyjskiego i ukraińskiego oraz dominacja prawosławia, która ułatwiała rusyfikację. Jeszcze pod koniec XIX w. większość ludności chłopskiej miała niezwykle niską świadomość narodową. Co prawda mówiła językiem białoruskim (lub zbliżoną gwarą), kultywowała lokalny folklor, ale określała się jako „tutejsi” lub ,prości”, a swoją religię jako „ruską” (prawosławną) lub „polską” (katolicką). Nazwy Białoruś i Białorusin coraz powszechniej pojawiały się w drugiej połowie XIX w., ale wśród chłopów były praktycznie nieznane i nieużywane. Dopiero na początku XX w. powstały zalążki politycznego ruchu narodowego. Garstka inteligentów utworzyła Białoruską Socjalistyczną Hromadę, pierwszą białoruską partię polityczną. Po rewolucji 1905 r. ruch narodowy sprowadzał się w zasadzie wyłącznie do redagowania tygodnika „Nasza Niwa”, głoszącego tezę o odrębności narodu białoruskiego. Jednak działania inteligencji nie odbiły się wówczas szerszym echem wśród ogółu społeczności białoruskiej (Wasilewski 1917, 1925, Sadowski 1991a, Waldenberg 1992, Eberhardt 1994a).

Proces kształtowania się białoruskiej świadomości narodowej, podobnie jak ukraińskiej i litewskiej, uległ przyspieszeniu pod wpływem wydarzeń I wojny światowej oraz rewolucji 1917 r. Powstawały wydawnictwa w językach narodowych, zaczęła rozwijać się działalność polityczna o charakterze narodowym. Pod koniec I wojny okupacyjne władze niemieckie, wykorzystując aspiracje ludów podbitych przez Rosję, sprzyjały powstawaniu narodowych systemów oświaty oraz zależnych od siebie organów państwowych. Rewolucja rosyjska i upadek caratu przyniosły szansę utworzenia niepodległych państw w Europie Środkowo-Wschodniej. Po raz pierwszy w historii ,naród białoruski, który do tej pory raczej współistniał niż istniał" (Wróbel 1990), usiłował stworzyć swoją własną, niezależną państwowość. Przywódcy białoruskiego ruchu narodowego domagali się w Wersalu utworzenia niepodległej Białorusi, obejmującej nie tylko całe Polesie, ale także okolice Brześcia, Bielska, Białegostoku, Brańska, Grajewa, Augustowa, Suwałk, Wilna i Dźwińska, czyli części Podlasia i Wileńszczyzny. Nie zdołali jednak uzyskać na konferencji pokojowej statusu oficjalnego przedstawicielstwa. Ponadto dalsze wydarzenia, zwłaszcza wynik wojny 
polsko-bolszewickiej, uczyniły ich żądania nierealnymi (Wróbel 1990, Darski 1994).

Konsekwencją ,pokoju ryskiego" z 1921 r. była m.in. rezygnacja przez Polskę z regionu Mińska ${ }^{15}$. Wytyczona granica, która była praktycznie linią tymczasowego przerwania ognia w swym środkowym odcinku (czyli m.in. na ziemiach białoruskich), miała przypadkowy przebieg i była pozbawiona podstaw geograficznych oraz historycznych (choć była zbliżona do przebiegu granicy II rozbioru). Przecinała w poprzek terytorium Białorusi i całkowicie niweczyła plany budowy białoruskiej niepodległości. Podzieliła Białorusinów, podobnie jak Ukraińców - część ich zamieszkiwała w Polsce, część w ZSRR. Zawarcie pokoju w Rydze i wytyczenie wschodniej granicy Polski było także fiaskiem koncepcji federalistycznej, propagowanej przez J. Piłsudskiego, zakładającej utworzenie na wschód od ziem polskich niepodległej Białorusi i Ukrainy, które miały pełnić funkcję bariery, „kordonu sanitarnego”, chroniącego Polskę przed ekspansją bolszewickiej Rosji.

Białorusini Polski międzywojennej byli typową społecznością chłopską. Około 92\% z nich utrzymywało się z pracy na roli, głównie w drobnych gospodarstwach. Według szacunków, robotników było zaledwie ok. 7\%, ponadto zdecydowanie przeważali wśród nich robotnicy rolni. Taka struktura zawodowa była w dużej mierze wynikiem bardzo niskiego poziomu wykształcenia Białorusinów, wśród których analfabeci stanowili ponad $77 \%$, a wyższe wykształcenie miało zaledwie $0,17 \%$ społeczności. Środowiska białoruskiej inteligencji czy przedsiębiorców były bardzo nieliczne. Nie zaszły w tym względzie żadne radykalne zmiany w porównaniu z okresem zaborów (Landau, Tomaszewski 1977). Proces rodzenia się, również wśród chłopów, białoruskiej świadomości narodowej był praktycznie niedostrzegany przez polskie społeczeństwo, a zwłaszcza prawicowych polityków, którzy w zdecydowanej większości nadal traktowali wieś białoruską, ,jako rezerwat prymitywizmu, jako środowisko egzotyczne, które ulegnie w krótkim czasie polonizacji” (Tomaszewski 1985b).

Uboga, słabo wykształcona ludność chłopska była bardzo podatna na propagandę komunistyczną, zwłaszcza głoszoną z Białoruskiej Socjalistycznej Republiki Radzieckiej. Komuniści nawoływali do antypolskiego powstania, działań dywersyjnych, stworzenia zjednoczonej republiki białoruskiej pod władzą „włościańsko-robotniczą”. W latach 20. XX w. dużą popularność wśród

${ }^{15}$ Podczas pertraktacji w Rydze, strona polska, pod wpływem polityków związanych z Narodową Demokracją, dobrowolnie zrezygnowała z regionu Mińska, nie chcąc włączać do terytorium Polski obszarów ze zbyt dużą liczbą ludności białoruskiej (Eberhardt 1993). 
Białorusinów zdobyła Hromada, założona przez białoruskich posłów lewicowa partia polityczna o wyraźnym antypolskim nastawieniu, zlikwidowana już dwa lata po utworzeniu. Głównymi zarzutami przeciwko Hromadzie była współpraca z nielegalnymi organizacjami komunistycznymi oraz ,przygotowywanie zbrojnego powstania”. W latach 30. XX w. lewicowy ruch białoruski został wyraźnie osłabiony w wyniku działania polskich władz i napływających z ZSRR informacji o terrorze i kolektywizacji rolnictwa. Coraz silniej postępowała polonizacja, likwidowano białoruskie szkolnictwo, organizacje, prasę. Białorusini, poza Romami, znaleźli się w najgorszej sytuacji oświatowej spośród wszystkich mniejszości narodowych w ówczesnej Polsce (Gomółka 1992, 1994, Bergman 1984).

W okresie międzywojennym białoruska świadomość narodowa, podobnie jak ukraińska, wzrastała głównie jako przejaw negatywnego stosunku do państwa polskiego i jego instytucji. Złożyło się na to wiele przyczyn, głównie warunki ekonomiczne, zacofanie gospodarcze i społeczne, negatywnie oceniana działalność polskiej administracji, prowadzenie polskiej akcji osiedleńczej na kresach, asymilacyjna i polonizacyjna polityka władz państwowych i struktur Kościoła katolickiego.

W konsekwencji podpisania paktu Ribbentrop-Mołotow, działań wojennych we wrześniu 1939 r. oraz ustaleń niemiecko-radzieckich z 28 września, terytorium Polski zostało podzielone między Rzeszę Niemiecką a ZSRR. Cały obszar zamieszkany przez mniejszość białoruską został zajęty przez Rosjan. Na Podlasiu granica III Rzeszy i ZSRR biegła wzdłuż Bugu, dochodziła do miejscowości Nur, skąd skręcała na północ i w linii prostej dochodziła do Narwi w okolicach Ostrołęki. Następnie biegła wzdłuż Narwi i Pisy, aż do byłej granicy Polski i Prus Wschodnich (ryc. 6). Nie miała żadnego uzasadnienia historycznego, a często również etnicznego, zwłaszcza na odcinku między Bugiem a granicą Prus Wschodnich, gdzie przecinała obszary czysto polskie (Eberhardt 1993).

Większość Białorusinów przyjęła wkroczenie Armii Czerwonej z sympatią, a część wręcz entuzjastycznie. Stawiano bramy triumfalne, oficerów witano chlebem i sola, dekorowano domy czerwonymi flagami - Rosjan witano jak wyzwolicieli. Entuzjazm Białorusinów był bardzo źle odbierany przez Polaków, którzy wkroczenie Armii Radzieckiej przyjmowali z przygnębieniem i poczuciem utraconej niepodległości. Miało to bardzo duży wpływ na negatywne relacje między Polakami a Białorusinami w okresie okupacji i w pierwszych latach powojennych (Wróbel 1990, Mironowicz 1993).

Białostocczyzna już jesienią 1939 r. została włączona w skład Białoruskiej Socjalistycznej Republiki Radzieckiej (BSRR) na podstawie wyników „wyborów" przeprowadzonych pod nadzorem NKWD. Charakterystyczną cechą tych 
„wyborów” był brak regionalnego zróżnicowania wyników na całym obszarze zajętym przez ZSRR. Nawet w okolicach Łomży, gdzie nie było w ogóle Białorusinów, ponad $90 \%$ głosujących opowiedziało się za przyłączeniem do BSRR (Eberhardt 1993).

Jednym z następstw włączenia Podlasia w skład BSRR było przedłużenie do linii Bugu granicy między radzieckimi republikami - białoruską i ukraińską. Konsekwencjami tej decyzji było uznanie przez radziecką administrację całej ludności prawosławnej zamieszkującej na obszarze BSRR za Białorusinów. Dotyczyło to również etnicznie mieszanej (białorusko-ukraińskiej) społeczności Podlasia ${ }^{16}$ i spowodowało wpisywanie „,narodowości białoruskiej” w dokumentach wszystkich prawosławnych mieszkańców Białostocczyzny, a co za tym idzie „likwidację” mniejszości ukraińskiej na północ od Bugu. Odtąd konsekwentnie przez następne kilkadziesiąt lat, a niejednokrotnie i współcześnie, stereotypowo utożsamia się całą ludność prawosławną Podlasia z Białorusinami (Barwiński 2004a, 2008b).

Początkowo nowa władza komunistyczna prowadziła politykę korzystną dla Białorusinów: chłopom rozdawano ziemię skonfiskowaną „kułakom”, język białoruski został podniesiony do rangi państwowego, rozbudowano szkolnictwo białoruskie. Najistotniejsza była możliwość awansu społecznego i politycznego ludności chłopskiej. Terenowa administracja została obsadzona głównie przez Białorusinów i Żydów, choć nie brakowało również polskich komunistów. Jednak szybko zaczęło pojawiać się rozczarowanie wobec nowej władzy. Było spowodowane aresztowaniami „kułaków” wśród prawosławnych chłopów, aresztowaniami białoruskich działaczy politycznych (zarówno narodowych, jak i komunistycznych), prześladowaniami duchowieństwa, początkami kolektywizacji oraz pogorszeniem sytuacji ekonomicznej. Mimo to dla większości chłopów terror stalinowski był nieodczuwalny, a władza radziecka, jako „ruska”, „swojska”, była w dużo większym stopniu akceptowana niż „pańska” władza polska.

Sytuacja zmieniła się w 1941 r. po ataku Niemiec na ZSRR. Od samego początku okupacji hitlerowcy postępowali podobnie jak na innych, zróżnicowanych etnicznie, okupowanych terenach, według zasady „dziel i rządź”, starając się skłócić poszczególne narodowości. W pierwszych miesiącach okupacji Niemcy mordowali białoruskich aktywistów komunistycznych i ukrywających się żołnierzy Armii Radzieckiej, polskim właścicielom ziemskim

${ }^{16}$ Według badań historyków i językoznawców oraz wyników XIX-wiecznych spisów ludności, na obszarze południowo-wschodniego Podlasia, między Bugiem a Narwią, od średniowiecza zamieszkiwała ludność ukraińska (szerzej m.in. Barwiński 2004a). 
przekazali ponownie majątki rozparcelowane wcześniej przez bolszewików i masowo obsadzali lokalną administrację ludnością polską. Utworzono policję pomocniczą składającą się z Polaków. Działania te tworzyły pozory „przywracania Polski” i były wrogo odbierane przez Białorusinów. Po kilku miesiącach Niemcy zaczęli faworyzować Białorusinów, utrzymując białoruskie szkolnictwo i organizacje kulturalne, tworząc odrębne, bardziej liberalne przepisy karne, rozbudowując administrację białoruską, formując podporządkowaną SS policję białoruską, mamiąc niesprecyzowaną wizją niezależnego państwa. Z Niemcami zaczęli współpracować, wywodzący się jeszcze z okresu I wojny światowej, proniemieccy, antykomunistyczni nacjonaliści białoruscy, liczący - podobnie jak nacjonaliści ukraińscy - na powstanie państwa białoruskiego pod protektoratem Niemiec. Nie mieli jednak dużego poparcia wśród chłopów białoruskich, którzy byli najczęściej nastawieni nieufnie - niechętnie lub obojętnie. W kolejnych miesiącach hitlerowcy wzmogli działania faworyzujące Białorusinów, aż do powstania marionetkowego „rządu” białoruskiego w Mińsku. Jednocześnie likwidowali wszelkie przejawy samodzielności działaczy białoruskich, bezwzględnie eksploatowali ziemie białoruskie, masowo wywozili ludność na roboty do III Rzeszy, przeprowadzali krwawe pacyfikacje.

Na Polesiu i Podlasiu - mimo ożywionej działalność polskich i radzieckich oddziałów partyzanckich, które, poza walką z okupantem niemieckim, równie często walczyły między sobą - nie dochodziło do otwartych walk między Polakami i Białorusinami, jak miało to miejsce między Polakami i Ukraińcami na Wołyniu i w Galicji. Jednak walczące z Armią Krajową oddziały radzieckiej partyzantki składały się w dużym stopniu z Białorusinów i często miały poparcie miejscowej, prawosławnej ludności. Wiele uzbrojonych oddziałów zajmowało się zwykłym złodziejstwem i bandytyzmem, napadając bez względu na narodowość i wyznanie. Po okresie okupacji hitlerowskiej oraz dwukrotnym przejściu frontu niemiecko-radzieckiego przez ziemie białoruskie, region ten należał do najbardziej zniszczonych i wyludnionych podczas II wojny światowej w skali całej Europy (Mironowicz 1993, Turonek 1993).

Według E. Mironowicza (1993), postawy Białorusinów w czasie okupacji niemieckiej były zróżnicowane. Część była nastawiona proradziecko i wyraźnie antyhitlerowsko, część proniemiecko i nacjonalistycznie, jednak zdecydowana większość biernie, obojętnie, ale jednocześnie antyokupacyjnie. 


\subsection{Litwini}

W 1385 r. Polska zawarła w Krewie unię z Litwą, na mocy której wielki książę litewski Jagiełło, w zamian za rękę Jadwigi i tytuł króla polskiego, zobowiązał się do przyjęcia chrztu w obrządku łacińskim (co wiązało Litwę z kulturą zachodnią) oraz połączenia Litwy i ziem ruskich z Polską na zasadzie unii personalnej. Był to moment zwrotny w dziejach Polski i Litwy, który istotnie zaważył na losach tej części Europy w ciągu następnych kilkuset lat, a jego konsekwencje religijne, etniczne, kulturowe i społeczne są wyraźnie widoczne także współcześnie. Po latach wyniszczających walk polsko-litewskich oba kraje stały się bliskimi sojusznikami. Powstało mocarstwo, które rozbiło potęgę krzyżacką, zintensyfikowało podboje na wschodzie, rozszerzyło zasięg katolicyzmu, a Polacy czynnie, pod względem politycznym, religijnym, militarnym, kulturowym, społecznym, włączyli się w życie swoich wschodnich sąsiadów.

Początki osadnictwa litewskiego na Suwalszczyźnie sięgają XV w. Na podstawie ustaleń traktatu krzyżacko-litewskiego z 1422 r. zapoczątkowano zasiedlanie terenów wyludnionych $\mathrm{w}$ wyniku eksterminacji Jaćwingów ${ }^{17}$. Litwini zamieszkujący współcześnie w północno-wschodniej Polsce są ludnością autochtoniczną, żyjącą na tym obszarze od czasów Wielkiego Księstwa Litewskiego (Chałupczak, Browarek 1998). Poza Litwinami na Suwalszczyźnie już od XVI w. osiedlali się także Polacy, Niemcy, Żydzi oraz sporadycznie Białorusini i Tatarzy.

Coraz większe upodabnianie się Polski i Wielkiego Księstwa Litewskiego pod względem prawnym, ustrojowym i społecznym oraz wspólne zagrożenie tatarskie i rosyjskie przyspieszyło decyzję o kolejnej unii, tym razem unii realnej, która została zawarta w Lublinie w 1569 r. Terytorialną konsekwencją unii było przesunięcie granicy polsko-litewskiej na wschód i włączenie w skład Korony ziem ukraińskich oraz województwa podlaskiego (ryc. 4). Rzeczpospolita w wyniku unii stała się państwem federacyjnym, składającym się z dwóch równoprawnych członów: Korony i Wielkiego Księstwa Litewskiego. Integracja Korony i Litwy

${ }^{17}$ Granica litewsko-krzyżacka ustanowiona w 1422 r., przebiegająca m.in. w pobliżu Wiżajn, Olecka i Rajgrodu, przetrwała aż do rozbiorów. Początkowo rozdzielała Wielkie Księstwo Litewskie od zakonu krzyżackiego, a po sekularyzacji zakonu od Prus Książęcych. W XIX w. pełniła funkcję granicy między Królestwem Polskim a Prusami, w okresie międzywojennym oddzielała Prusy Wschodnie od Polski, obecnie w części południowej stanowi granicę województw warmińsko-mazurskiego oraz podlaskiego, a w części północnej granicę między Republiką Litewską a Obwodem Kaliningradzkim. 
sprowadzała się do posiadania wspólnego władcy, sejmu, monety i polityki zagranicznej, natomiast oba państwa zachowywały odrębność administracji, sądownictwa, wojska i skarbu. Wprowadzono także swobodę osiedlania się szlachty w całym państwie. Mimo unii realnej granica polsko-litewska, częściowo zmieniając swój przebieg na równoleżnikowy, nadal istniała, ponieważ zachowano odrębność Polski i Litwy w nowym, wspólnym państwie o nazwie Rzeczpospolita. Granica była barierą prawną i ekonomiczną, będąc jednocześnie bardzo przepuszczalną - praktycznie wyłącznie z zachodu na wschód - w sensie kulturowym i społecznym, czego konsekwencją była szybka polonizacja społeczeństwa Wielkiego Księstwa Litewskiego, zwłaszcza szlachty i magnaterii (Sobczyński 2008a).

Rozbiory położyły kres Rzeczypospolitej Obojga Narodów. Nie udało się wprowadzić w życie postanowień pogłębiających dotychczasową, liczącą ponad 400 lat, integrację Polski i Litwy. Rozbiory uniemożliwiły realizację zapisanego w Konstytucji 3 Maja zniesienia odrębności państwowej Korony i Litwy, w wyniku którego Rzeczpospolita miała stać się państwem jednolitym. Litwa dostała się pod panowanie Rosji, a po kongresie wiedeńskim jej terytorium zostało podzielone wzdłuż Niemna - część wschodnią (z Wileńszczyzną) włączono bezpośrednio do Cesarstwa Rosyjskiego, natomiast część zachodnia (z Suwalszczyzną) weszła w skład autonomicznego Królestwa Polskiego, tzw. Kongresówki. Po raz pierwszy Suwalszczyzna znalazła się pod polską administracją, choć niewątpliwie zależną od władz carskich (ryc. 4).

Struktura etniczna tego obszaru, a zwłaszcza powiatu sejneńskiego, przez który przebiegała polsko-litewska granica narodowościowa, była bardzo zróżnicowana. Był on podzielony na dwie części: północno-wschodnią, gdzie większość mieszkańców stanowili Litwini, oraz południowo-zachodnią o przewadze ludności polskiej. Według danych spisu rosyjskiego z 1897 r., na jego obszarze zamieszkiwało $62,4 \%$ Litwinów oraz $22 \%$ Polaków, natomiast kilkanaście lat późniejsze dane niemieckiego spisu powszechnego z 1916 r. podały, że w powiecie sejneńskim zamieszkiwało 51\% Litwinów oraz 43,3\% Polaków (Wakar 1917a).

Na początku XX w. stosunki polsko-litewskie uległy znacznemu pogorszeniu. Miało to związek ze wzrastającą litewską i polską świadomością narodową. W relacjach między obu narodami pojawiły się wzajemna niechęć, nieufność oraz wrogość, które zostały spotęgowane w okresie I wojny światowej, a zwłaszcza odbudowy litewskiej i polskiej państwowości.

Polscy politycy mieli sprzeczne poglądy wobec przyszłych relacji polsko-litewskich. Wysuwane były zarówno koncepcje federalistyczne (J. Piłsudski), jak i inkorporacyjne (R. Dmowski). Jakiekolwiek próby utworzenia wspólnego 
państwa spotkały się jednak ze stanowczym sprzeciwem Litwinów. Politycy litewscy, obawiając się polskiej dominacji, byli nieufni wobec dużo większego i ludniejszego sąsiada, dążyli do stworzenia własnego państwa.

Zależne od Niemiec państwo litewskie ze stolicą w Wilnie zostało proklamowane 11 grudnia $1917 \mathrm{r}$. Suwerenny rząd litewski został utworzony 16 lutego 1918 r., kilka miesięcy później litewscy komuniści sformowali Tymczasowy Rząd Robotniczo-Włościański, który zapowiedział powstanie litewskiej republiki radzieckiej.

Po odrzuceniu przez rząd litewski kolejnej propozycji federacji polsko-litewskiej uznano, że Litwa musi zostać zbudowana nie na zasadach historycznych, lecz etnograficznych. Jednak pojęcie „Litwa etnograficzna” było różnie rozumiane w Polsce i na Litwie. Strona polska za Litwę etnograficzną uznawała obszar, gdzie zdecydowanie dominowała ludność posługującą się językiem litewskim i posiadająca litewską świadomość narodową, czyli północną części guberni suwalskiej, gubernię kowieńską oraz zachodnią część guberni wileńskiej, ale bez Wilna ${ }^{18}$. Z kolei Litwini żądali przyłączenia do nowo tworzonego państwa całej guberni wileńskiej z Wilnem, guberni suwalskiej aż po Biebrzę, guberni grodzieńskiej po Białystok i Brześć, ponadto część guberni mińskiej i fragmenty Kurlandii. Kwestia przynależności państwowej obszarów pogranicza polsko-litewskiego stała się przedmiotem międzynarodowych przetargów i wielu, wzajemnie wykluczających się, projektów (Kowalski 2008b, Łossowski 1996).

Wobec niemożności pogodzenia rozbieżnych interesów na Suwalszczyźnie, dowództwo Suwalskiego Okręgu POW podjęło decyzję o rozpoczęciu 23 sierpnia 1919 r. powstania. Jego celem było odzyskanie kontrolowanych przez Litwinów obszarów w okolicach Sejn; 28 sierpnia 1919 r., po odparciu kontrataku litewskiego, walki zostały zakończone. W powstaniu sejneńskim zginęło 37, a rannych zostało 70 Polaków. Nie ma danych dotyczących strat po stronie litewskiej (Buchowski 2004). W trakcie burzliwych i krwawych wydarzeń związanych z kształtowaniem się polskich granic po I wojnie światowej, powstanie sejneńskie było mało znaczącym epizodem, nie oznaczało także zakończenia walk na Suwalszczyźnie ${ }^{19}$. Jednak w skali lokalnej miało bardzo istotne znaczenie. Było jednym z nielicznych powstań zakończonych sukcesem militarnym oddziałów polskich, w jego konsekwencji wytyczona została granica państwowa między Polską a Litwą na odcinku suwalskim, pozostawiająca Puńsk i Sejny po

18 Według wyników niemieckiego spisu ludności z 1916 r. wśród mieszkańców Wilna Polacy stanowili 51\%, Żydzi 43\%, a Litwini zaledwie 2,6\%.

${ }^{19}$ W latach 1918-1920 Sejny 13 razy przechodziły z rąk do rąk (Buchowski 2004). 
polskiej stronie. Jest to jedyny odcinek polskiej granicy wschodniej, który przetrwał bez zmian od lat 20. XX w. do czasów współczesnych ${ }^{20}$ (ryc. 6).

O bardzo negatywnym stosunku mniejszości litewskiej do państwa polskiego w okresie międzywojennym $\mathrm{w}$ głównej mierze zadecydowało zajęcie Wilna w październiku 1920 r. przez „zbuntowane” oddziały Wojska Polskiego pod dowództwem gen. L. Żeligowskiego i utworzenie na Wileńszczyźnie autonomicznego ,państwa” Litwy Środkowej. Wbrew Litwinom w 1922 r. zorganizowano wybory do Sejmu Wileńskiego, który następnie przyjął uchwałę (potwierdzona przez Sejm Rzeczypospolitej) o zjednoczeniu z Polską. Oznaczało to inkorporację regionu uważanego przez Litwinów za najważniejszą część ich ziem historycznych i spowodowało, trwający przez cały okres międzywojenny, stan wrogości i nieufności między Republiką Litewską a Rzecząpospolitą oraz między mniejszością litewską a państwem polskim. Litwini głosili hasła przyłączenia Wileńszczyzny do Litwy, podkreślali swój separatyzm oraz bierność i niechęć wobec polskiego życia politycznego. $Z$ kolei polskie władze stosowały administracyjne restrykcje wobec mniejszości litewskiej, m.in. dyskryminację w urzędach i samorządach, ograniczanie szkolnictwa i możliwości funkcjonowania organizacji, polonizację struktur Kościoła katolickiego. Zmobilizowano cały aparat administracyjny w celu podtrzymania i rozwinięcia polskości na Wileńszczyźnie. Dopiero w 1938 r. doszło do, wymuszonego polskim ultimatum, nawiązania stosunków dyplomatycznych między Polską a Litwą, co tylko nieznacznie i krótkotrwale poprawiło wzajemne relacje.

Litwini, broniąc swej odrębności i tożsamości, zakładali liczne organizacje społeczne, polityczne i gospodarcze oraz dynamicznie rozwijali własne prywatne szkolnictwo. Utworzyli dobrze funkcjonujący ruch narodowy, którym kierował Tymczasowy Komitet Litwinów z siedzibą w Wilnie. Do najważniejszych ówczesnych litewskich stowarzyszeń można zaliczyć Litewskie Towarzystwo Oświatowe, Litewskie Towarzystwo Św. Kazimierza oraz Litewskie Towarzystwo Rolnicze. Bardzo dużą rolę w funkcjonowaniu organizacji litewskich odegrał rząd Litwy, który wspomagał finansowo działające w Polsce litewskie szkolnictwo, prasę oraz organizacje gospodarcze (Łossowski 1997, Makowski 1986).

W okresie międzywojennym Litwini nie stanowili poważnego problemu w polityce wewnętrznej II Rzeczypospolitej, zwłaszcza w porównaniu z Ukraińcami. W ówczesnej strukturze narodowościowej byli niezbyt liczną społeczno-

${ }^{20}$ Przebieg tej granicy był bardzo zbliżony do jednego z wcześniejszych (lipiec 1919 r.) francuskich projektów polsko-litewskiej linii demarkacyjnej, tzw. linii Focha, która nie została zaakceptowana przez Litwinów. 
ścią, zamieszkującą peryferyjne regiony kraju. Odgrywali jednak bardzo istotną rolę w relacjach Polski i Litwy. Spory między obu państwami przekładały się bezpośrednio (najczęściej negatywnie) na sytuację mniejszości litewskiej w Polsce oraz polskiej na Litwie, wielokrotnie kwestie dotyczące mniejszości były wykorzystywane jako karta przetargowa.

We wrześniu 1939 r. większość ziem zamieszkanych przez mniejszość litewską w granicach II Rzeczypospolitej zajęła Armia Czerwona. Początkowo przekazano je Litwie, a następnie w ramach Litewskiej Socjalistycznej Republiki Radzieckiej (LSRR) włączono w skład ZSRR. Było to konsekwencją paktu Ribbentrop-Mołotow. Według pierwotnych ustaleń tego paktu, Litwa miała znaleźć się w niemieckiej strefie wpływów, jednak w wyniku zajęcia przez Niemców obszaru między Wisłą a Bugiem (który miał przypaść ZSRR) Stalin zaproponował nową linię demarkacyjną wzdłuż Bugu, pozostawiającą po stronie niemieckiej Lubelszczyznę i wschodnie Mazowsze, w zamian strona niemiecka rezygnowała, na rzecz ZSRR, z roszczeń terytorialnych wobec Litwy.

Jedynym fragmentem terytorium Polski zamieszkanym przez Litwinów, który w 1939 r. znalazł się pod okupacją niemiecką, była Suwalszczyzna, odstąpiona przez ZSRR na osobistą prośbę Ministra Spraw Zagranicznych III Rzeszy J. Ribbentropa. Jak pisał P. Eberhardt (1993), „Ribbentropowi zależało, aby przy ustalaniu ostatecznej granicy okręg Suwałk przyznany został Niemcom, gdyż w rejonie tym w lasach augustowskich znajdują się wspaniałe jelenie". Choć wydaje się to nieprawdopodobne, to jednak o przebiegu niektórych granic w Europie w połowie XX w. decydowała atrakcyjność terenów łowieckich i możliwość organizowania polowań.

Granica na tym odcinku przebiegała równoleżnikowo, od Prus Wschodnich do Niemna, pozostawiając Augustów po stronie radzieckiej, natomiast Suwałki, Sejny, Puńsk po niemieckiej (ryc. 6). Jedną z konsekwencji włączenia Suwalszczyzny do III Rzeszy było objęcie tego obszaru porozumieniem niemiecko-rosyjskim o wymianie ludności w rejonach przygranicznych. Masowo wysiedlano Litwinów, umieszczając ich w poniemieckich gospodarstwach na Litwie, a w ich miejsce osiedlano Niemców z włączonych do ZSRR republik bałtyckich. Przesiedlenia z lat 1939-1941 doprowadziły do usunięcia ponad 70\% Litwinów z Suwalszczyzny. Część powróciła do swoich domów po zajęciu Litwy przez Niemców, część dopiero po zakończeniu wojny (Chałupczak, Browarek 1998, Tarka 1998).

Podczas II wojny konflikt polsko-litewski nie tylko nie wygasł, ale jeszcze bardziej zantagonizował oba narody. Dochodziło do wzajemnych walk, zwłaszcza na Wileńszczyźnie. Litwini współpracowali przeciwko Polakom z władzami radzieckimi, a po zajęciu Litwy latem 1941 r. przez III Rzeszę także z Niem- 
cami $^{21}$. Pod koniec okupacji hitlerowskiej doszło do zaostrzenia sytuacji na Wileńszczyźnie, m.in. po antypolskich akcjach policji litewskiej oraz Saugumy, ściśle współpracujących z hitlerowcami. Z kolei zbrojne akcje przeciwko Litwinom przeprowadzały oddziały Armii Krajowej.

\subsection{Liczebność i rozmieszczenie Ukraińców, Łemków, Białorusinów i Litwinów na podstawie wyników międzywojennych spisów ludności}

Dokładne określenie liczebności i rozmieszczenia mniejszości narodowych w okresie międzywojennym nie jest sprawą łatwą, głównie z powodu polityki polskiego rządu dotyczącej spisów powszechnych i wątpliwej ich wiarygodności w kwestii mniejszości narodowych, o czym obszernie pisze J. Tomaszewski (1985a, b, 1991). Podczas spisów ludności dochodziło do bezpośredniego fałszowania wyników (zwłaszcza w województwach południowo-wschodniej Polski), tendencyjnego zadawania pytań, stosowania nierzetelnych metod zbierania i opracowywania danych oraz bojkotu spisu przez niektóre grupy narodowościowe nieuznające polskiej suwerenności.

Pierwszy po wojnie spis ludności przeprowadzono 30 września $1921 \mathrm{r}$. Jego wyniki nie mogą być brane pod uwagę głównie ze względu na ich niekompletność. W momencie przeprowadzania spisu terytorium Polski nie było definitywnie ustalone. Spis nie objął Wileńszczyzny i Górnego Śląska, został zbojkotowany przez dużą część społeczności ukraińskiej, ponadto trwały jeszcze masowe repatriacje ludności z Rosji i powojenne wewnętrzne ruchy migracyjne. Dlatego wyniki spisu z 1921 r. są niewystarczające dla poznania struktury narodowościowej Polski, mimo że formularz spisowy zawierał pytania dotyczące narodowości, języka ojczystego i wyznania (Gawryszewski 2005). Ponadto część ludności utożsamiała pytanie o narodowość z obywatelstwem odrodzonego państwa polskiego, co wpłynęło na obniżenie liczebności mniejszości narodowych (Eberhardt 2006).

Dla zobrazowania liczebności i rozmieszczenia mniejszości narodowych w okresie międzywojennym stosuje się z reguły wyniki kolejnego spisu z $1931 \mathrm{r}$. Ich wiarygodność, zwłaszcza w odniesieniu do zamieszkanej przez Ukraińców

${ }^{21}$ Przejawiało się to m.in. w utworzeniu organizacji Ypatingasis Bürys (Oddział Specjalny), litewskiej policji bezpieczeństwa Saugumy (Saugumo), współpracującej z gestapo, paramilitarnej organizacji szaulisów oraz dywizji generała P. Plechavičiusa (Żołędowski 2003). 
i Białorusinów wschodniej Polski, była podważana już w okresie międzywojennym, natomiast w pierwszych latach powojennych, były prezes Głównego Urzędu Statystycznego z lat 30., Edward Szturm de Sztrem ${ }^{22}$, podał informacje o licznych manipulacjach i fałszerstwach zarówno w trakcie spisu, jak i na etapie obróbki danych. Najpowszechniejszym fałszerstwem na szczeblu starostwa powiatowego było skreślanie przez urzędników w rubryce ,,język ojczysty” słowa „białoruski” lub „ukraiński” i wpisywanie języka polskiego. Skala manipulacji była tak duża, że władze GUS domagały się ponownego przeprowadzenia spisu w województwach wschodniej Polski, na co nie wyraziło zgody MSW. Wymowny jest również brak publikacji wyników spisu w odniesieniu do gmin, co łatwo mogło wykazać fałszerstwa i manipulacje (Tomaszewski 1985a, b, Chałupczak, Browarek 1998, Gawryszewski 2005).

W trakcie spisu w 1921 r. pytanie o narodowość często błędnie utożsamiano z pytaniem o obywatelstwo. Głównie z tego powodu w spisie w 1931 r. zlikwidowano pytanie o narodowość, natomiast strukturę narodowościową postanowiono ustalić na podstawie odpowiedzi na pytanie o język ojczysty ${ }^{23}$, w przekonaniu, że zmniejszy to możliwość nieporozumień. Jednak powszechnie uważa się, że kryterium językowe zawyżyło liczbę Polaków. Lepszym sposobem szacunkowego określenia narodowości - choć często również zawodnym i obarczonym trudnymi do uniknięcia błędami oraz uproszczeniami - była deklaracja wyznania, która, zwłaszcza w województwach wschodniej Polski, lepiej oddawała narodowość mieszkańców niż kryterium językowe (Zaborski 1937, Eberhardt 1996, 2006, Chałupczak, Browarek 1998).

Wyznawana religia nie jest oczywiście kryterium narodowościowym, choć można doszukać się pewnych zależności. W Polsce z jednej strony bardzo silny i w dużym stopniu uzasadniony jest stereotyp Polaka-katolika, choć tradycja polskości związana jest również z wyznaniem protestanckim (m.in. na Mazurach i Śląsku Cieszyńskim). Z drugiej strony w międzywojennej Polsce wyznanie rzymskokatolickie było powszechne wśród zdecydowanej większości Litwinów i Słowaków, części Białorusinów (szczególnie na Podlasiu i Wileńszczyźnie), Niemców oraz nielicznych Ukraińców. Podobny stereotyp utożsamiał wyznanie greckokatolickie z Ukraińcami byłego zaboru austriackiego, a prawosławie wy-

${ }^{22}$ W latach 1929-1939 prezes GUS, po wojnie (1946-1950) rektor Akademii Nauk Politycznych, następnie w latach 50. XX w. profesor Szkoły Głównej Planowania i Statystyki.

${ }^{23} \mathrm{~W}$ formularzu spisowym wymieniono język ,ppolski, ukraiński, ruski, żydowski, białoruski, niemiecki, litewski, rosyjski, czeski lub jaki inny". W instrukcji spisowej wyjaśniono, że jako język ojczysty należy wpisać ,,język, który dana osoba uważa za najbliższy sobie". 
łącznie z Rosjanami, Ukraińcami i Białorusinami dawnego zaboru rosyjskiego. Jest to również $\mathrm{w}$ dużym stopniu prawdziwe, jednak trzeba pamiętać, że w Polsce mieszkali, choć w zdecydowanie mniejszej liczbie, także Polacy wyznania greckokatolickiego oraz prawosławnego.

Szacunki struktury narodowościowej (tak samo jak dane samych spisów) mają jedną istotną wadę: zakładaja jednoznaczność podziałów narodowościowych, uniemożliwiają określenie liczebności środowisk o pośredniej lub kształtującej się dopiero świadomości narodowej, które z pewnością w ówczesnej Polsce, szczególnie wschodniej, istniały. Część ludności określała się w kategoriach regionalnych (np. „tutejsi”, Poleszucy, Huculi, Łemkowie, Ślązacy). Było to spowodowane wieloma czynnikami, głównie niechęcią do jednoznacznej deklaracji narodowościowej, słabo wykształconą świadomością narodową, wpływem wielokulturowych pograniczy etnicznych, ale także postępującym procesem krystalizowania się nowych tożsamości narodowych. Z powodu braku możliwości określenia liczebności takich grup, w praktyce przypisywano je do poszczególnych narodowości zamieszkujących Polskę, co często prowadziło do błędów. Ponadto typowe dla wielu mieszkańców wschodniej Polski złe warunki życia, niski poziom oświaty (często wręcz analfabetyzm), niewielka świadomość polityczna i narodowa, ułatwiały manipulacje podczas spisów ludności i zaniżanie liczebności grup mniejszościowych.

J. Tomaszewski $(1985 \mathrm{a}, \mathrm{b})$ na podstawie informacji dotyczących metod fałszowania wyników na wszystkich szczeblach ich obróbki oraz porównania danych dotyczących deklaracji języka ojczystego i wyznania skorygował wynik spisu powszechnego z 1931 r. oraz dokonał własnych szacunków ówczesnej struktury narodowościowej Polski.

Ludność deklarującą jako ojczysty język ruski ${ }^{24} \mathrm{~J}$. Tomaszewski zaliczył do mówiącej po ukraińsku. Rozróżnienie Rusinów i Ukraińców, a co za tym idzie języka ruskiego i ukraińskiego, miało wówczas charakter polityczny. Określenie Ukrainiec, w sensie narodowości, rozpowszechniło się stosunkowo późno, dopiero w XIX w. Wcześniej, przez stulecia posługiwano się etnonimem Rusin,

${ }^{24}$ Umieszczenie w formularzu spisowym zarówno języka ojczystego ukraińskiego, jak i ruskiego było spowodowane identyfikowaniem przez część Ukraińców i Łemków, zwłaszcza w województwach południowo-wschodnich, własnego języka jako ruskiego, a nie ukraińskiego. Ponadto osobne uwzględnienie w oficjalnych wynikach spisu ludności ukraińskiej i rusińskiej było korzystne z punktu widzenia ówczesnej polityki polskich władz. Natomiast w formularzu dla województwa poleskiego wyraz ,ruski” został pominięty, ponieważ większość miejscowej ludności prawosławnej używała określenia „ruski” dla narodowości ukraińskiej, białoruskiej oraz rosyjskiej i zastąpiony, wyłącznie w tym województwie, określeniem ,język tutejszy”. 
który miał szersze znaczenie, ponieważ obejmował $\mathrm{w}$ przeszłości również ludność mówiącą po białorusku. Wraz z kształtowaniem się narodowej świadomości ukraińskiej, określenie Rusin zaczęto stosować dla grup odrębnych od Polaków, ale niechętnych narodowej ideologii ukraińskiej, np. Łemków. Polskim władzom podtrzymywanie takiego podziału przynosiło duże korzyści, przede wszystkim dzieliło społeczność ukraińską, zmniejszało liczbę deklaracji ukraińskich, zwiększało wieloetniczny charakter niektórych regionów Polski (w województwach południowo-wschodnich udział deklaracji języka ruskiego osiagał 25\%), pozwalało liczebnie dominować ludności deklarującej język polski $^{25}$.

Zaskakująco duża była liczba osób innojęzycznych (ponad 700 tys.) wykazanych w spisie z 1931 r. W tej kategorii umieszczono ok. 707 tys. osób, które tylko w województwie poleskim zadeklarowały jako ojczysty język ,tutejszy”. Występowanie kategorii osób, które nie potrafią określić swego języka ojczystego lub przynależności narodowej, nie jest zjawiskiem specyficznym ani dla Polski, ani tym bardziej dla Polesia. Ludność „tutejsza” (lub mówiąca językiem „tutejszym”) występowała i występuje na wielu obszarach pograniczy etnicznych (Barwiński 2004a). Dla województwa poleskiego specyficzną cechą była masowość zjawiska ludności „tutejszej” (ponad 50\% mieszkańców nie było w stanie określić swego języka ojczystego, a co za tym idzie narodowości) oraz ograniczenie terytorialne tych deklaracji wyłącznie do jednego województwa. Według J. Tomaszewskiego (1985a, b) nie było to spowodowane prześladowaniami narodowościowymi ani bezpośrednimi fałszerstwami, ale bardzo niskim i dopiero rodzącym się poczuciem świadomości narodowej wśród części mieszkańców Polesia. Z powodu jednoczesnych deklaracji wyznania prawosławnego tej grupy ludności oraz - co bardzo istotne - na ogół wyższego wśród Ukraińców niż Białorusinów stopnia świadomości narodowej, J. Tomaszewski szacuje, że mieszkańcy Polesia, deklarujący język ,tutejszy”, faktycznie w 3/4 posługiwali się językiem białoruskim, a w 1/4 ukraińskim.

Kolejną kontrowersyjną kwestią jest porównanie deklaracji języka ojczystego i wyznania, a szczególnie liczby osób, które przy języku polskim podały wyznanie prawosławne lub greckokatolickie. Według danych spisu liczba wyznawców prawosławia i grekokatolicyzmu była o ok. 800 tys. wyższa od łącznej

${ }^{25}$ Podczas spisu w 1931 r. język ukraiński jako ojczysty zadeklarowało 3221,9 tys. osób, natomiast język ruski 1219,6 tys. osób, co świadczyło o dużej popularności określeń Rusin, ruski, rusiński wśród ówczesnych mieszkańców południowo-wschodniej Polski. W województwie krakowskim, obejmującym m.in. zachodnią i środkową Łemkowszczyznę, język ruski zadeklarowało 58038 osób, a ukraiński zaledwie 1366 osób. 
liczby Ukraińców, Białorusinów i Rosjan. Ponadto według oficjalnych danych w okresie zaledwie 10 lat (1921-1931) nastapił bardzo duży, 35\% wzrost liczby Polaków-grekokatolików, których według danych spisowych miało być w południowo-wschodniej Polsce aż 487 tys. Trudno zgodzić się z wiarygodnością tych liczb. J. Tomaszewski (1985a, b), optując przy szacowaniu struktury narodowościowej za wyższością deklaracji wyznaniowych nad językowymi, uważał, że osoby wyznania prawosławnego i greckokatolickiego w zdecydowanej większości nie były narodowości polskiej. P. Eberhardt (2006) zwracał uwagę, że wielu Ukraińców, Białorusinów i Żydów mogło deklarować język polski jako ojczysty, podkreślając w ten sposób lojalność wobec państwa polskiego. Oczywiście nie zmieniało to ich narodowości, było natomiast kolejnym argumentem wyższości statystyki wyznaniowej nad językową.

Największe różnice między oficjalnymi wynikami spisu z $1931 \mathrm{r}$. a szacunkami opracowanymi przez J. Tomaszewskiego dotyczyły liczby Ukraińców oraz Białorusinów i wynikały zarówno $\mathrm{z}$ bezpośrednich fałszerstw (zwłaszcza zaniżania liczby Ukraińców), jak i z różnego traktowania ludności deklarującej język ojczysty „tutejszy” lub polski, przy jednoczesnej deklaracji wyznania prawosławnego lub greckokatolickiego (tab. 1-2).

Tabela 1. Struktura narodowościowa Polski w 1931 r.

\begin{tabular}{|l|r|c|c|c|}
\hline \multirow{2}{*}{ Narodowości } & \multicolumn{4}{|c|}{ Struktura narodowościowa } \\
\cline { 2 - 5 } & \multicolumn{2}{|c|}{ według danych spisu } & \multicolumn{2}{c|}{$\begin{array}{c}\text { według szacunków } \\
\text { J. Tomaszewskiego }\end{array}$} \\
\cline { 2 - 5 } & \multirow{2}{*}{ w tys. } & $\begin{array}{c}\text { w \% ogółu } \\
\text { ludności }\end{array}$ & w tys. & $\begin{array}{c}\text { w \% ogółu } \\
\text { ludności }\end{array}$ \\
\hline Polacy & 21993 & 68,9 & 20644 & 64,7 \\
Ukraińcy & $\mathbf{4 4 4 2}$ & $\mathbf{1 3 , 9}$ & $\mathbf{5 1 1 4}$ & $\mathbf{1 6 , 0}$ \\
Żydzi & 2733 & 8,6 & 3114 & 9,8 \\
Bialorusini & $\mathbf{9 9 0}$ & $\mathbf{3 , 1}$ & $\mathbf{1 9 5 4}$ & $\mathbf{6 , 1}$ \\
Niemcy & 741 & 2,3 & 780 & 2,4 \\
Rosjanie & 139 & 0,4 & 139 & 0,4 \\
Litwini & $\mathbf{8 3}$ & $\mathbf{0 , 3}$ & $\mathbf{8 3}$ & $\mathbf{0 , 3}$ \\
Czesi & 38 & 0,1 & 38 & 0,1 \\
Inni & 718 & 2,3 & 11 & 0,1 \\
Niepodana & 39 & 0,1 & - & - \\
\hline
\end{tabular}

Źródło: opracowanie własne na podstawie Statystyka Polski (1938), Drugi Powszechny Spis Ludności z dn. 9 XII 1931 r., seria C, z. 94a, J. Tomaszewski (1985a, s. 35). 
Tabela 2. Porównanie oficjalnej i szacunkowej liczby Ukraińców, Białorusinów i Litwinów w 1931 r. w województwach wschodniej Polski

\begin{tabular}{|c|c|c|c|c|c|c|c|c|c|c|}
\hline \multirow{4}{*}{ Województwo } & \multicolumn{10}{|c|}{ Narodowości } \\
\hline & \multicolumn{4}{|c|}{ Ukraińcy } & \multicolumn{4}{|c|}{ Białorusini } & \multirow{2}{*}{\multicolumn{2}{|c|}{$\begin{array}{c}\text { Litwini }^{d} \\
\text { wynik spisu }\end{array}$}} \\
\hline & \multicolumn{2}{|c|}{ wynik spisu $^{a}$} & \multicolumn{2}{|c|}{ szacunki $^{b}$} & \multicolumn{2}{|c|}{ wynik spisu } & \multicolumn{2}{|c|}{ szacunki $^{b}$} & & \\
\hline & tys. & $\%$ & tys. & $\%$ & tys. & $\%$ & tys. & $\%$ & tys. & $\%$ \\
\hline Stanisławowskie & 1018,9 & 68,8 & 1079 & 72,9 & 0,0 & 0 & - & - & 0,0 & 0,0 \\
\hline Tarnopolskie & 728,1 & 45,5 & 872 & 54,5 & 0,0 & 0 & - & - & 0,0 & 0,0 \\
\hline Lwowskie & 1067,0 & 34,1 & 1306 & 41,8 & 0,2 & 0 & - & - & 0,0 & 0,0 \\
\hline Wołyńskie & 1426,9 & 68,4 & 1445 & 69,3 & 2,4 & 0,1 & - & - & 0,1 & 0,0 \\
\hline Lubelskie & 73,8 & 3,0 & 123 & 5,0 & 1,3 & 0,05 & - & - & 0,0 & 0,0 \\
\hline Poleskie & 54,0 & 4,8 & 219 & 19,3 & 75,4 & 6,6 & 654 & 57,8 & 0,0 & 0,0 \\
\hline Białostockie $^{c}$ & 3,4 & 0,2 & 82 & 5,0 & 205,6 & 12,5 & 269 & 16,4 & 13,0 & 0,8 \\
\hline Nowogródzkie & 1,2 & 0,1 & - & - & 413,5 & 39,1 & 616 & 58,3 & 2,5 & 0,2 \\
\hline Wileńskie & 1,5 & 0,1 & - & - & 289,7 & 22,7 & 409 & 32,1 & 66,9 & 5,3 \\
\hline
\end{tabular}

${ }^{a}$ Zsumowana z formularzy spisowych liczba deklaracji języka ojczystego ukraińskiego i ruskiego. ${ }^{b}$ Szacunki według J. Tomaszewskiego (1985a). ${ }^{c}$ Szacunki według M. Barwińskiego (2004a), ${ }^{d}$ Dla Litwinów nie opracowano szczegółowych szacunków.

Źródło: opracowanie własne na podstawie Barwiński (2004a), Statystyka Polski (1938), Drugi Powszechny Spis Ludności z dn. 9 XII 1931 r., seria C, Tomaszewski (1985b).

Również inni naukowcy krytycznie podchodzili do oficjalnych wyników spisu z 1931 r. i dokonywali własnych szacunków. Ich wyniki były zbliżone do opracowań J. Tomaszewskiego, zwłaszcza w kwestii liczby Ukraińców i Białorusinów (Gomółka 1992, Chałupczak, Browarek 1998). Duże rozbieżności dotyczyły także liczby Litwinów, których spis wykazał 83 tys., natomiast B. Makowski (1986) szacował ich ówczesną liczebność na 200 tys., a H. Chałupczak i T. Browarek (1998) na 180 tys. osób. Spis powszechny został przeprowadzony podczas trwającego sporu polsko-litewskiego o Wilno i zamieszkane przez Litwinów przygraniczne powiaty. Ujawnienie rzeczywistej liczby Litwinów na spornym terytorium z pewnością było niekorzystne z punktu widzenia polskich władz. Nie opracowano jednak szczegółowych szacunków dotyczących liczby mniejszości litewskiej, ponieważ miała ona relatywnie niewielkie znaczenie demograficzne w strukturze narodowościowej ówczesnej Polski. Ponadto z powodu przynależności Litwinów do Kościoła rzymskokatolickiego statystyka wyznaniowa, tak istotna przy szacowaniu liczebności Ukraińców i Białorusinów przez J. Tomaszewskiego, w tym przypadku była nieprzydatna. 
Zaniżanie podczas spisu liczby Ukraińców dotyczyło nie tylko Galicji Wschodniej, ale także Podlasia, gdzie w 1931 r., według oficjalnych danych, zaledwie ok. 3 tys. osób zadeklarowało ukraiński jako język ojczysty, z czego ponad $70 \%$ przypadało na powiat bielski, położony między Bugiem a Narwią. Ponadto wcześniejszy spis z $1921 \mathrm{r}$. wykazał w całym województwie białostockim tylko 304 osoby narodowości rusińskiej (kategoria „,narodowość ukraińska" nie występowała w ówczesnym formularzu spisowym), przy prawie 120 tys. narodowości białoruskiej ${ }^{26}$. W samym powiecie bielskim, według danych z 1921 r., dominowali Polacy (87 tys.), przed Białorusinami (45 tys.) oraz Żydami (15 tys.). Rusinów miało być tylko 66 osób (Krysiński 1929). Jest to zjawisko zadziwiające, choćby z tego powodu, że wcześniejszy o zaledwie 2030 lat spis ludności, przeprowadzony na Białostocczyźnie przez władze carskie w 1897 r., wykazał tylko w powiecie bielskim ponad 60 tys. Rusinów (Ukraińców) i tylko 6 tys. Białorusinów (Wakar 1917b, Eberhardt 1996, Hawryluk 1999).

Wyniki spisów przeprowadzonych w okresie międzywojennym na Podlasiu pokazują, że ok. 30\% mieszkańców powiatu bielskiego stanowili Białorusini, których żadne XIX-wieczne spisy ludności w tak dużym stopniu nie wykazywały. Nastapiła za to praktycznie ,likwidacja” narodowości ukraińskiej, do początku XX w. powszechnie występującej na tym obszarze. Było to spowodowane $\mathrm{w}$ głównej mierze czynnikami politycznymi, m.in. postulatami wysuwanymi podczas I wojny światowej przez polityków związanych z rodzącym się narodowym ruchem białoruskim, którzy proponowali utworzenie państwa białoruskiego lub federacji białorusko-litewskiej w historycznych granicach Wielkiego Księstwa Litewskiego, czyli z częścią Podlasia (do Bugu) oraz północnego Polesia. Propagowane wówczas ,poszerzenie” obszaru białoruskiego było cennym argumentem dla polskich polityków. Etnos białoruski, w odróżnieniu od ukraińskiego, był przez większość ówczesnych działaczy polskich lekceważony i uważany za zdecydowanie mniej groźny dla odradzającej się Rzeczypospolitej. Ponadto oficjalne uznanie podlaskich Rusinów za Białorusinów zmniejszało liczebność Ukraińców (Hawryluk 1999). Manipulacje te były ułatwione przez nadal bardzo słabo rozwinięte, zwłaszcza wśród wiejskiej społeczności Podlasia, poczucie tożsamości narodowej oraz istniejące różnice religijne, a co za tym idzie brak poczucia jedności między wyznającymi prawosławie podlaskimi Ukraińcami a zdecydowanie dominującymi wśród Ukraińców z Galicji wyznawcami grekokatolicyzmu.

${ }^{26}$ Na podstawie Statystyka Polski... (1927). 
Ponadto miejscowa ludność prawosławna znajdowała się w zasięgu wpływów Komunistycznej Partii Zachodniej Białorusi oraz nie była zaangażowana w ówczesny konflikt ukraińsko-polski, co stanowiło dodatkowe argumenty przemawiające za jej „białoruskością” (Plit 2008). Wielu polskich badaczy z okresu międzywojennego kwestionowało tak gwałtowne zmiany struktury etnicznej na Podlasiu. Wbrew oficjalnym wynikom spisu, jeden z najwybitniejszych znawców sytuacji narodowościowej wschodniej Polski początku XX w., L. Wasilewski (1927), uznał południowo-wschodnią, prawosławną część powiatu bielskiego za ziemie ukraińskie i podkreślił, że ,powiat Bielsk wykazuje 30,5\% Białorusinów będących w rzeczywistości Ukraińcami językowo”.

Również A. Krysiński (1928, 1929), zgadzając się z L. Wasilewskim, określił całą ludność prawosławną żyjącą na obszarze wschodniej części powiatu bielskiego, między Narwią a Bugiem, za „niewątpliwie Ukraińców”. Także J. Tomaszewski (1985b) zaznaczył, choć dość lakonicznie, że „w województwie białostockim (powiecie bielskim) mieszka pewna liczba Ukraińców”. Liczebność mniejszości ukraińskiej w województwie białostockim w latach 30. XX w. można szacować na ponad 80 tys. osób (Barwiński 2004a).

W okresie międzywojennym Ukraińcy byli najliczniejszą (ok. $5 \mathrm{mln}$ ) mniejszością narodową w Polsce, zamieszkująca głównie w jej części południowo-wschodniej, należącej przed wojną do Austrii (województwo stanisławowskie, tarnopolskie, lwowskie) oraz w należącym wcześniej do Rosji województwie wołyńskim. W zdecydowanie mniejszej liczbie zamieszkiwali także południową część województwa poleskiego i białostockiego oraz województwo lubelskie i krakowskie. W 1931 r. w dwóch województwach (wołyńskim i stanisławowskim) osoby deklarujące język ojczysty ukraiński lub ruski stanowiły większość mieszkańców ${ }^{27}$. W województwach wschodnich i północno-wschodnich, mieszkało także prawie 2 mln osób deklarujących jako ojczysty język białoruski lub ,tutejszy”. Białorusini mieszkali niemal wyłącznie w czterech województwach należących przed I wojną do carskiej Rosji: poleskim (gdzie stanowili większość mieszkańców), nowogródzkim, wileńskim i białostockim. Osoby deklarujące język litewski zamieszkiwały głównie województwo wileńskie (zwłaszcza jego zachodnią i północną część) oraz północno-wschodnią część województwa białostockiego. W samym Wilnie, podczas spisu, język litewski zadeklarowało zaledwie 1,6 tys. osób, co stanowiło tylko $0,8 \%$ mieszkańców miasta (tab. 2, ryc. 5).

27 Według szacunków J. Tomaszewskiego (1985b) Ukraińcy stanowili większość mieszkańców także w województwie tarnopolskim. 


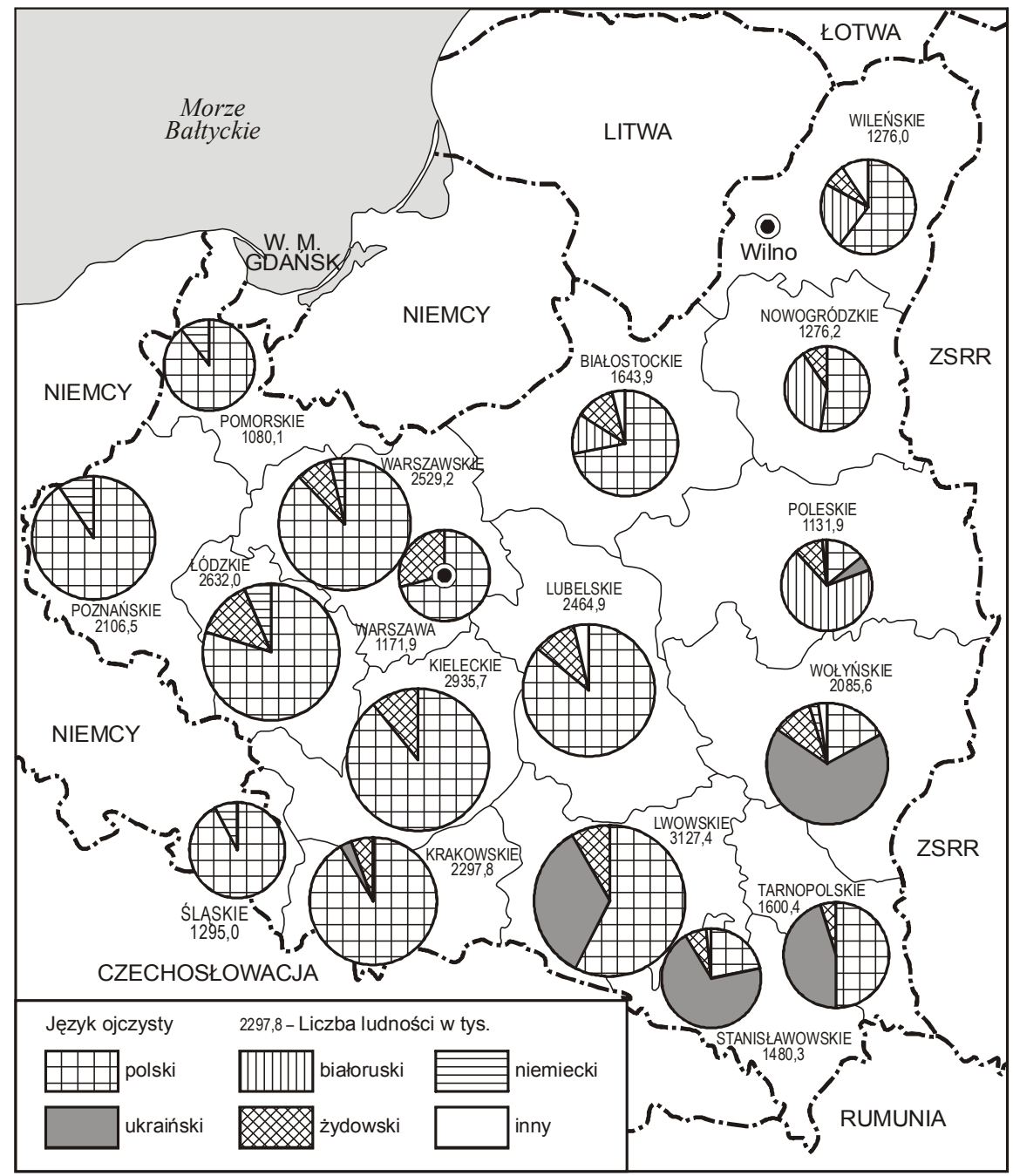

Ryc. 5. Struktura językowa mieszkańców Polski według wyników spisu z 1931 r. Źródło: P. Eberhardt (1996, s. 102)

Zarówno Ukraińcy, jak i Białorusini oraz Litwini w okresie międzywojennym byli w zdecydowanej większości ludnością wiejską. Na obszarach, gdzie stanowili duży odsetek mieszkańców, miasta były zamieszkane w większości przez Polaków i Żydów. 


\section{SYTUACJA MNIEJSZOŚCI UKRAIŃSKIEJ, ŁEMKOWSKIEJ, BIAŁORUSKIEJ I LITEWSKIEJ W POLSCE NA TLE PRZEMIAN POLITYCZNYCH PO 1944 ROKU}

\subsection{Pierwsze lata po II wojnie światowej - prześladowania, przesiedlenia, dyskryminacja}

Przed II wojną światową Polska, nawet jak na ówczesne warunki Środkowej Europy, była państwem wyjątkowo zróżnicowanym narodowościowo. Udział Polaków nie przekraczał $65 \%$ ogółu obywateli, aż 35\% mieszkańców należało do mniejszości narodowych, niejednokrotnie liczących kilkaset tysięcy, a nawet kilka milionów osób. Ponadto w niektórych regionach mniejszości przeważały, dotyczyło to głównie Ukraińców, Białorusinów i Litwinów we wschodniej Polsce, która była obszarem najbardziej zróżnicowanym narodowościowo (Tomaszewski 1985a, b, Eberhardt 1996, Chałupczak, Browarek 1998).

Porównując lata 30. oraz 50. XX w., widać bardzo duży spadek liczebności mniejszości narodowych i etnicznych w granicach Rzeczypospolitej - z ok. 11$12 \mathrm{mln}$ do zaledwie $600-700$ tys. ${ }^{28}$ Główną przyczyną tak radykalnych zmian etnicznych była II wojna światowa oraz jej następstwa demograficzne, terytorialne i polityczne, a także polityka władz komunistycznych, które zamierzały utworzyć z Polski państwo jednonarodowe. Na tak wysokie (95\%) zmniejszenie liczebności mniejszości narodowych w Polsce w latach 40. XX w. największy wpływ miały:

- wymordowanie przez hitlerowców prawie całej społeczności żydowskiej oraz romskiej,

- powojenne zmiany granic, pozostawiające główne skupiska mniejszości (zwłaszcza Ukraińców, Białorusinów i Litwinów) na ziemiach włączonych do ZSRR,

${ }^{28}$ Według szacunków różnych autorów: A. Kwileckiego (1963), J. Tomaszewskiego (1991), P. Eberhardta (1996), H. Chałupczaka, T. Browarka (1998). 
- przesiedlenia ludności niepolskiej, zwłaszcza Niemców do radzieckiej i brytyjskiej strefy okupacyjnej oraz większości Ukraińców i Łemków, a także części Białorusinów i Litwinów do ZSRR.

Po zakończeniu wojny, obok zmian liczebnych, mniejszości narodowe dotknęły również istotne zmiany polityczne i geopolityczne. W wyniku postanowień konferencji jałtańskiej i poczdamskiej Polska utraciła znaczne obszary na wschodzie, a otrzymała, mniejsze powierzchniowo, na północy i zachodzie. Bezpośrednio przy wschodniej granicy Polski utworzono w ramach ZSRR socjalistyczne republiki: ukraińską, białoruską i litewską. Polska zmieniała nie tylko swój kształt terytorialny, ale także ustrój polityczny i gospodarczy, przekształcając się w kraj socjalistyczny o ograniczonej suwerenności w radzieckiej strefie wpływów. Były to czynniki istotnie warunkujące politykę polskich władz zarówno wewnętrzną, jak i zewnętrzną, a także politykę dotyczącą mniejszości narodowych.

Zasadniczy wpływ na nowy przebieg polskiej granicy wschodniej miały decyzje ZSRR, zmierzające do zachowania większości ziem polskich zajętych we wrześniu 1939 r. w konsekwencji paktu Ribbentrop-Mołotow. Postanowiono wykorzystać zaproponowany podczas konferencji pokojowej w Wersalu w $1919 \mathrm{r}$. projekt tzw. linii Curzona ${ }^{1}$. W lipcu 1944 r., w wyniku tajnych ustaleń między tymczasowym polskim rządem komunistycznym (PKWN) i rządem radzieckim, czyli de facto pod dyktando Stalina, wytyczono wschodnią granicę Polski na podstawie linii Curzona, według jej najbardziej niekorzystnego dla Polski tzw.

\footnotetext{
${ }^{1}$ Umowna nazwa linii rekomendowanej jako tymczasowa wschodnia granica Polski przez Radę Ambasadorów 8 grudnia 1919 r. Nazwa pochodzi od nazwiska ministra spraw zagranicznych Wielkiej Brytanii lorda George'a Curzona of Kadleston. Linia Curzona biegła na północy od ujścia Czarnej Hańczy i Kanału Augustowskiego do Niemna, następnie wzdłuż Niemna do miejscowości Łosośna pod Grodnem, po czym odchylała się w kierunku południowym, dochodząc do Bugu w rejonie Niemirowa, dalej biegła na południe wzdłuż Bugu, przez Brześć, Dorohusk, do okolic Hrubieszowa i Sokala. Między Bugiem a Karpatami jej przebieg nie był jednoznacznie ustalony, istniały dwa główne warianty przebiegu granicy, w okolicach Przemyśla lub na wschód od Lwowa w stronę Stanisławowa, podstawową różnicą była kwestia przynależności państwowej Lwowa. Projekt ten nie odegrał praktycznie żadnej roli podczas ustalania polskich granic po I wojnie, natomiast miał ogromne konsekwencje dla przebiegu wschodniej granicy Polski po II wojnie światowej (Eberhardt 1993). Z pojęciem „linia Curzona" są związane określenia Ukraina Zakerzońska, Zakerzonia, Zakerzoński kraj, które bardzo rzadko występują w polskiej literaturze naukowej, natomiast są popularne wśród autorów ukraińskich oraz w ukraińskiej publicystyce i oznaczają ziemie zamieszkane do 1944 r. przez Ukraińców na zachód od linii Curzona (Gawryszewski 2005).
} 
wariantu A, który pozostawiał Lwów po stronie radzieckiej ${ }^{2}$ (ryc. 6-7). Granica ta została następnie potwierdzona wspólną decyzją władz ZSRR, USA i Wielkiej Brytanii na konferencji w Jałcie w lutym 1945 r. oraz umową z sierpnia 1945 r. między rządem radzieckim i polskim. Ostateczna linia graniczna została określona dopiero w 1948 r. po zakończeniu prac polsko-radzieckiej komisji delimitacyjnej. W wyniku tych decyzji Polska utraciła obszary, które przez ponad 600 lat były związane z polską państwowością, odgrywały ogromną rolę w polskiej tradycji i tożsamości narodowej. Szczególnie bolesna była strata wielkich ośrodków polskiej kultury - Wilna i Lwowa. Od Polski oddzielono regiony zamieszkane przez zdecydowaną większość przedwojennych obywateli polskich narodowości ukraińskiej, białoruskiej i litewskiej, ale także przez ponad 3,5 mln Polaków ${ }^{3}$.

$\mathrm{Na}$ pograniczu narodowościowym polsko-białoruskim i polsko-ukraińskim wytyczono granicę państwową, która nigdy wcześniej nie miała takiego przebiegu (ryc. 6-7). Nie ma ona żadnego uzasadnienia historycznego, a często także etnicznego, jest to granica całkowicie sztuczna, wytyczona wyłącznie według kryteriów politycznych (Eberhardt 1993). O jej sztuczności świadczą także zbliżone do przebiegu linearnego odcinki granicy między Bugiem a Karpatami, we wschodniej części Podlasia oraz w dawnych Prusach Wschodnich. Są to przykłady tzw. granicy geometrycznej, granicy nie uwzględniającej cech przyrodniczych, etnicznych, kulturowych i gospodarczych dzielonego terytorium, granicy narzuconej w wyniku ustaleń traktatowych. Tego typu granice nazywane są także - bardzo trafnie - „bliznami historii” (Barbag 1987). Również przebieg granicy wzdłuż rzeki Bug jest dowodem jej sztuczności. Jest to klasyczny przykład tzw. granicy dyplomatów, najbardziej niegeograficznej spośród tzw. granic naturalnych. W naturalnych warunkach rzeki tworzą osie rozwojowe poszczególnych regionów geograficzno-historycznych, a nie ich granice, które kształtują się w strefach wododziałowych (Piskozub 1968, 1987, Koter, Kulesza 2001).

Zmianie uległ przebieg prawie całej polskiej granicy wschodniej, a jedynym jej fragmentem, który pozostał bez większych zmian od lat 20. XX w. do dziś, jest zaledwie 104 km odcinek granicy polsko-litewskiej od Wiżajn przez Puńsk

\footnotetext{
${ }^{2}$ W marcu 1944 r. działacze komunistyczni z Ukrainy (m.in. N. Chruszczow) na sesji Rady Najwyżej Ukrainy domagali się włączenia do ZSRR niektórych ziem położonych na zachód od linii Curzona, z Przemyślem, Jarosławiem, Zamościem, Hrubieszowem, Chełmem, Tomaszowem Lubelskim. W lipcu 1944 r. wysłali w tej sprawie list do Stalina, proponując utworzenie obwodu chełmskiego, a do władz USRR napływały prośby Ukraińców z okolic Chełma i Hrubieszowa o włączenie tych ziem do ZSRR (Olejnik 2003, Drozd, Halczak 2010).
}

${ }^{3}$ Stan w połowie 1944 r. według szacunków P. Eberhardta (2010a). 
i Sejny, po Giby ${ }^{4}$. W porównaniu z pierwotnym przebiegiem linii Curzona nastapiły pewne korekty przebiegu granicy, zwłaszcza na Białostocczyźnie. Do Polski włączono zachodnią część Puszczy Białowieskiej z Białowieżą. Był to jedyny obszar leżący po wschodniej stronie linii Curzona, który przypadł Polsce. Natomiast na wysokości Augustowa granica ostatecznie nie dochodziła do linii Curzona, która w tym rejonie biegła wzdłuż Niemna (ryc. 6).

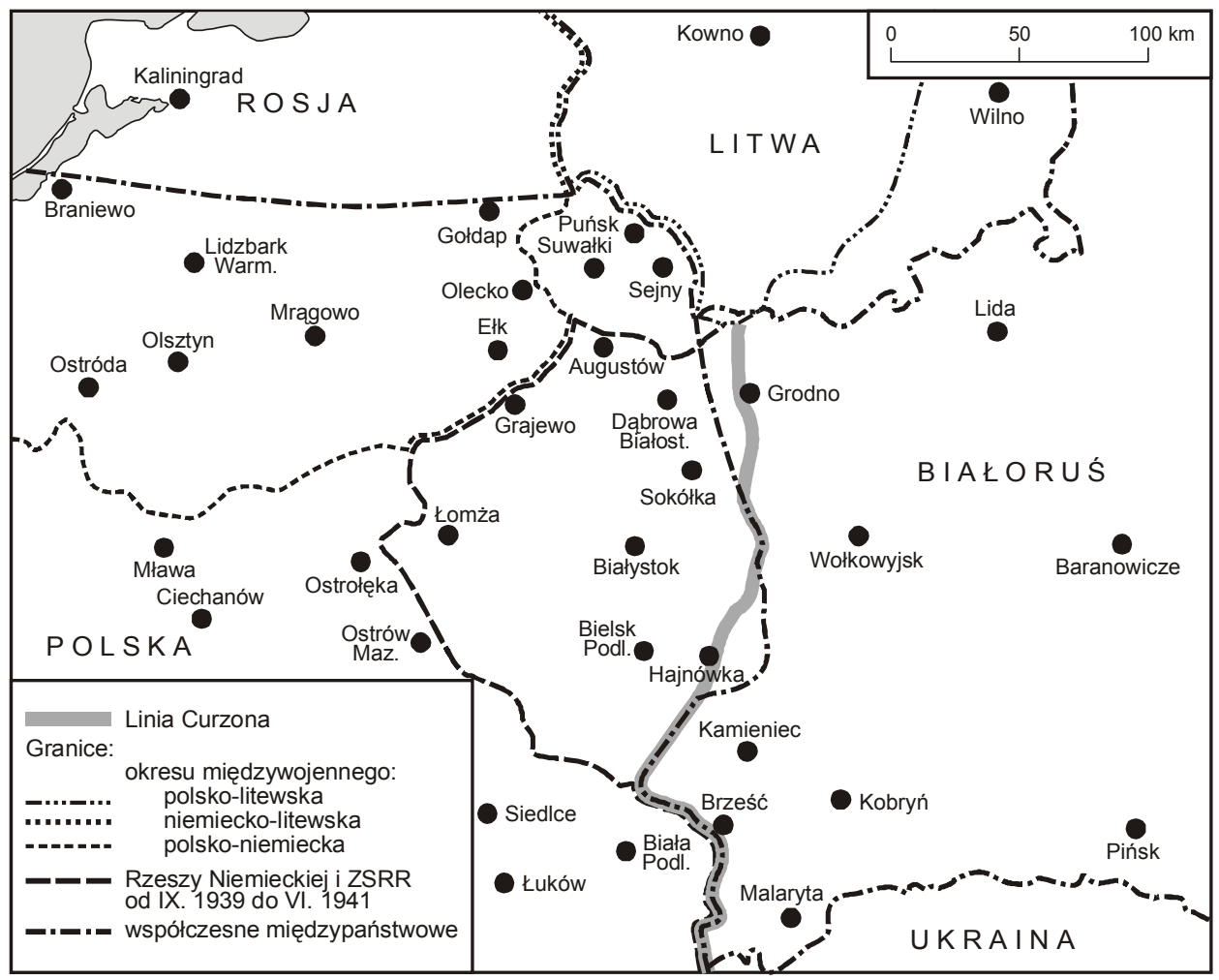

Ryc. 6. Granice międzypaństwowe oraz projekty granic na pograniczu polsko-litewsko-białoruskim w połowie XX w.

Źródło: opracowanie własne

${ }^{4}$ Pewnych zmian w porównaniu z granicą z 1939 r. dokonano tylko na terenie gminy Giby (na południowy wschód od Sejn). W ich wyniku Polska w 1946 r. utraciła pas ziemi o długości $16 \mathrm{~km}$ i szerokości $13 \mathrm{~km}$, w większości zalesiony i bagienny, zamieszkany jednak przez ludność polską (Tarka 1998). 


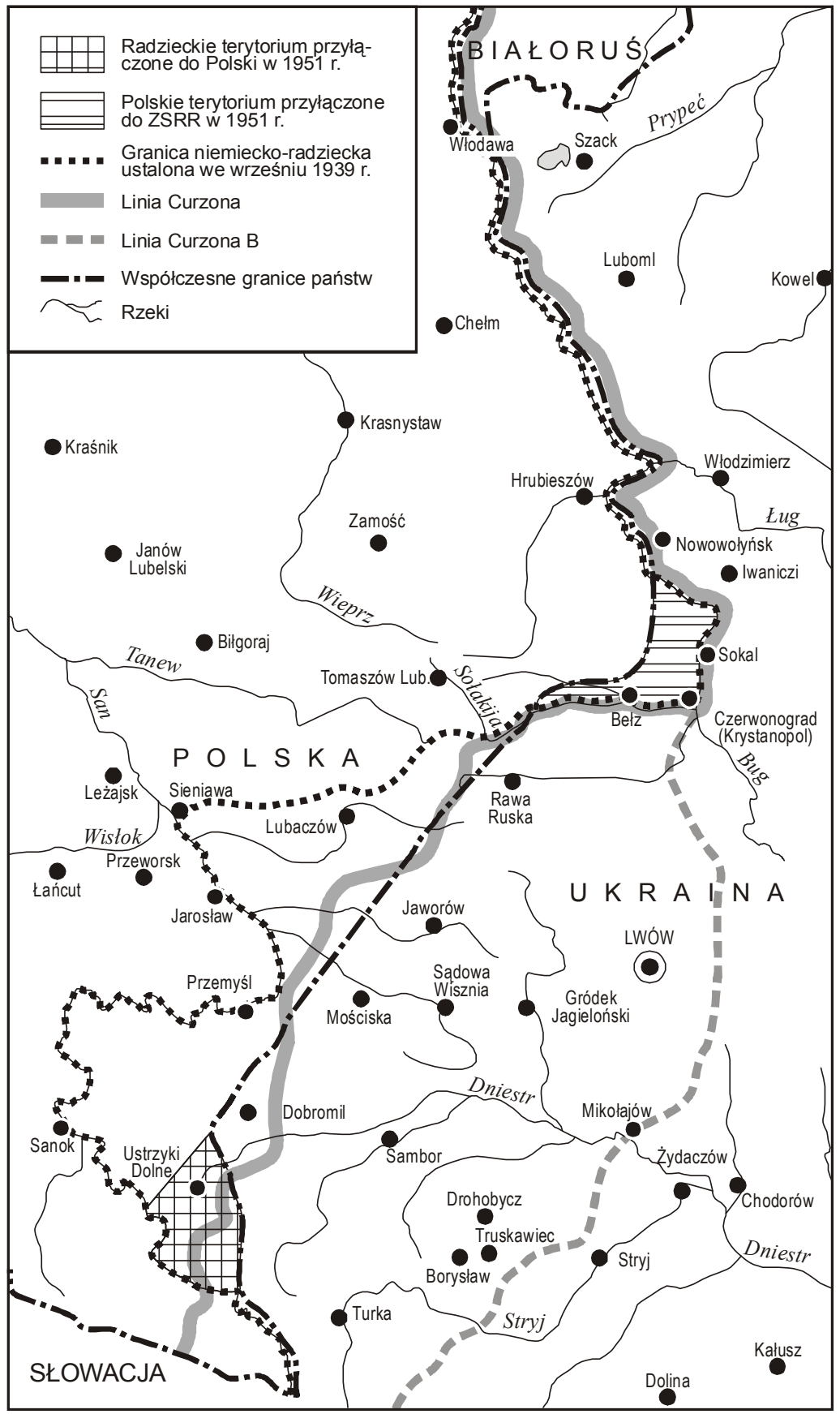

Ryc. 7. Granice międzypaństwowe oraz projekty granic na pograniczu polsko-ukraińskim w połowie XX w. Źródło: opracowanie własne 
Przebieg granicy polsko-radzieckiej uległ zmianie w 1951 r., kiedy Polskę zmuszono do podpisania umowy o wzajemnej wymianie terytoriów o powierzchni $480 \mathrm{~km}^{2}$. W konsekwencji tych ustaleń Polska utraciła obszar na zachód od Sokala, położony między Bugiem a rzeką Sołokiją. W zamian otrzymała obszar o takiej samej powierzchni we wschodniej części dorzecza górnego Sanu, w rejonie Ustrzyk Dolnych i Lutowisk, który do 1939 r. należał do Polski (ryc. 7). Główną przyczyną tej wymiany było dążenie władz radzieckich do przejęcia pokładów węgla kamiennego znajdujących się po polskiej stronie granicy, a także plany budowy zapory i zbiornika retencyjnego na Sanie. Po tej weryfikacji granica polsko-radziecka nie ulegała już zmianom (Eberhardt 1993, Gawryszewski 2005).

W następstwie tak ustalonego przebiegu wschodniej granicy polskiej, w okresie II Rzeczypospolitej największe skupiska mniejszości narodowych (Ukraińców, Białorusinów, Litwinów) znalazły się w ZSRR. Jednak mimo zmian granic, na terytorium Polski w zwartych skupiskach w 1944 r. nadal zamieszkiwały mniejszości narodowe, dla których w ZSRR utworzono sąsiadujące z Polską republiki. Według różnych szacunków, w południowo-wschodniej Polsce, od Bugu po Poprad, pozostało ok. 600-700 tys. Ukraińców ${ }^{5}$ (w tym ok. 120-130 tys. Łemków), na Podlasiu ok. 150 tys. wyznawców prawosławia - Białorusinów i Ukraińców - oraz na Suwalszczyźnie, zwłaszcza w okolicach Puńska i Sejn, ok. 7-10 tys. Litwinów (Eberhardt 2010a, Sobczyński 1996a, 2000, 2001a).

Komuniści, przejmując władzę we wschodniej i centralnej Polsce, latem 1944 r. nie mieli początkowo jednolitej polityki narodowościowej. Wyjątkiem był jednoznacznie negatywny stosunek do Niemców. Pozostałe niepolskie narodowości początkowo traktowano różnie, w zależności od ich liczebności, zwartości osadniczej, uwarunkowań historycznych, stopnia skonfliktowania z polskim społeczeństwem oraz dominujących postaw politycznych i lojalności wobec nowych władz. Członkowie PPR działający podczas okupacji na obszarze Polski dopuszczali funkcjonowanie w powojennej rzeczywistości mniejszości narodowych. Natomiast komuniści przybywający z ZSRR opowiadali się za Polską jednonarodową. Polski Komitet Wyzwolenia Narodowego (PKWN), po oficjalnym przejęciu władzy, wydał zezwolenie na otwarcie szkół białoruskich i ukraińskich ${ }^{6}$, a Żydom, jako jedynej wówczas mniejszości, pozwolono na

${ }^{5}$ Początkowo liczbę Ukraińców, którzy pozostali w nowych granicach Polski, oceniano na 494-546 tys., podczas gdy ich rzeczywista liczba była zbliżona do 700 tys. (Eberhardt 2010a).

${ }^{6}$ W roku szkolnym 1944/45 tylko w województwie rzeszowskim istniało ponad 220 ukraińskich szkół powszechnych. Rok później szkolnictwo ukraińskie zostało całkowicie zlikwidowane z powodu trwającej akcji wysiedleńczej (Drozd, Halczak 2010). 
działalność organizacyjną. W krótkim czasie, z powodu dalszego napływu polskich komunistów z ZSRR oraz uzależnienia PKWN od władz radzieckich, zaczęto realizować ideę Polski jako państwa jednolitego narodowo. Drogą do realizacji tego celu miały być zmiany granic oraz przesiedlenia ludności. Całkowicie odpowiadało to interesom radzieckim, a polskim komunistom dawało możliwość rozwiązania problemów z mniejszościami narodowymi, doprowadzenia do powstania „nowej Polski” w granicach etnicznych, która miała stanowić przeciwieństwo rozdzieranej konfliktami narodowościowymi II Rzeczypospolitej. Retoryka narodowa stała się istotną częścią propagandy komunistycznej, a idea budowy państwa narodowego fundamentem powojennej polityki narodowościowej (Mironowicz 2000, 2011, Drozd 2001, 2010, Olejnik 2003, Madajczyk 2010, Hryciuk 2011, Motyka 2011b).

Polityka nowych władz wobec mniejszości narodowych szybko uległa ujednoliceniu. Wysiłek administracji państwowej skupił się na sprawnym przeprowadzeniu akcji przesiedleńczych. Idea Polski jako państwa jednonarodowego po II wojnie nie tylko była forsowana przez władze komunistyczne, miała także szerokie poparcie społeczne, zwłaszcza wysiedlenia Niemców i Ukraińców były powszechnie akceptowane. W tej kwestii zachodziła zbieżność postaw, poglądów i oczekiwań społeczeństwa polskiego oraz władz. Także Kościół katolicki nie sprzeciwiał się wizji Polski jako państwa narodowego. $Z$ pewnością bardzo duży wpływ na takie postawy miały doświadczenia $\mathrm{z}$ okresu międzywojennego, a zwłaszcza czasu okupacji hitlerowskiej. Podczas wojny nastąpiło dramatyczne zaostrzenie podziałów narodowych, ówczesna rzeczywistość zwróciła przeciw sobie ludzi tylko z powodu odmiennej przynależności narodowej. Władze hitlerowskie i radzieckie świadomie wzmacniały i podkreślały różnice etniczne. Podziały narodowe stały się dominujące i determinujące. Jak pisał L. Olejnik (2003), „w następstwie polityki okupanta hitlerowskiego i ocen zachowania poszczególnych narodowości nastąpiło ukształtowanie się wśród Polaków silnych nastrojów niechęci do wszystkich niemal niepolskich narodowości”. W głównym stopniu dotyczyło to wrogości do Niemców i Ukraińców, ale nie tylko. Ułatwiało akceptację rozwiązań narodowościowych proponowanych przez komunistów i było przez nich wykorzystywane do umocnienia oraz legitymizacji swojej władzy. Dla większości polskiego społeczeństwa usunięcie mniejszości narodowych z nowego terytorium Polski wydawało się wówczas jednym z głównych warunków powojennej stabilizacji (Madajczyk, Berlińska 2008, Madajczyk 2010). 


\subsubsection{Przesiedlenia do ZSRR w latach 1944-1946}

We wrześniu 1944 r. tymczasowy polski rząd komunistyczny (PKWN) podpisał umowy z rządami radzieckich republik: ukraińskiej, białoruskiej i litewskiej o „wzajemnej ewakuacji ludności” ${ }^{7}$. Miały one charakter dwustronny. Na ich podstawie do Polski przesiedlano byłych obywateli Rzeczypospolitej narodowości polskiej i żydowskiej z terytoriów przyłączonych do ZSRR, ale prawa tego odmawiano przedstawicielom narodów, które utworzyły republiki ZSRR (Litwinom, Białorusinom, Ukraińcom, Rosjanom). Ponadto umowa przewidywała przesiedlenie Ukraińców, Rusinów, Białorusinów, Rosjan i Litwinów, którzy pozostali w nowych granicach Polski, do poszczególnych republik ZSRR. W ówczesnej oficjalnej dokumentacji przesiedlenie to nazywano konsekwentnie „ewakuacją”, co było pojęciem całkowicie błędnym. Polskie władze komunistyczne, podpisując porozumienie o przesiedleniu, realizowały w praktyce politykę zmierzającą do przekształcenia Polski w państwo jednorodne etnicznie i kulturowo, bez mniejszości narodowych i związanych z tym problemów oraz konfliktów (Kwilecki 1970, Misiło 1992, 1996, Pudło 1992, Sobczyński 1996a, Mironowicz 2000, Olejnik 2003, Barwiński 2008a, Pisuliński 2009, Eberhardt 2010a). Jak podkreślono $\mathrm{w}$ jednym $\mathrm{z}$ dokumentów, wymiana ludności między Polską a republikami radzieckimi ,raz na zawsze radykalnie zlikwiduje nasze zagmatwane stosunki narodowościowe" (Olejnik 2003). Z punktu widzenia ZSRR wymiana ludności na nowym pograniczu polsko-radzieckim była motywowana głównie dążeniem do etnicznego utrwalenia granicy, usunięcia (przynajmniej części) Polaków oraz uzupełnienia strat wojennych o przedstawicieli narodów wschodniosłowiańskich (Hryciuk 2011).

Wzajemne przesiedlenie ludności, jako środek wiodący do tworzenia państw narodowych, nie było oczywiście autorskim pomysłem polskich władz. W praktyce było już realizowane na początku XX w. między Grecją a Turcją oraz Bułgarią a Turcją. W latach 40 . XX w. był to pogląd powszechnie głoszony w Europie, mający także przyzwolenie państw anglosaskich. Szczególne poparcie zyskiwał wśród polityków w ZSRR, Czechosłowacji i Polsce. Jak pisze G. Hryciuk (2011), ,wysiedlenia były traktowane jako użyteczny, dogodny instrument rządzenia, będący jednym z narzędzi zdobycia i umocnienia władzy”.

Przesiedlenie miało być dobrowolne ${ }^{8}$, jednak przyjęta w układzie zasada pozostawienia ludności swobody wyboru przynależności państwowej nie była

\footnotetext{
${ }^{7}$ Pełny tekst umowy w E. Misiło (1996, s. 30-38).

8 „Ewakuacja jest dobrowolna i dlatego przymus nie może być stosowany ani bezpośrednio, ani pośrednio. Chęć ewakuowania się może być wyrażona ustnie, jak i pisemnie” - fragment umowy pomiędzy PKWN a USRR, cytat za L. Olejnik (2003, s. 273).
} 
przestrzegana podczas całego okresu przesiedlania ani na całym obszarze. Dotyczyło to głównie południowo-wschodniej Polski i Ukraińców oraz Łemków9

\section{Ukraińcy i Lemkowie}

Trwający od kilku lat krwawy konflikt polsko-ukraiński, zbrodnie dokonywane przez Ukraińską Powstańczą Armię (UPA), współpraca z Niemcami podczas okupacji oraz zdecydowanie antykomunistyczne, antyradzieckie i antypolskie nastawienie narodowych ugrupowań ukraińskich skutecznie uniemożliwiały jakiekolwiek polityczne porozumienie. Polskie władze komunistyczne, decydując się w 1944 r. na represje wobec Ukraińców, zyskiwały poparcie zarówno polskiego społeczeństwa, jak i władz radzieckich.

Przesiedlanie Ukraińców na obszar USRR rozpoczęto w połowie października 1944 r. i początkowo miało rzeczywiście charakter dobrowolny, choć oparty na intensywnej i kłamliwej kampanii propagandowej. Do marca 1945 r. opuściło Polskę zaledwie 81 tys. Ukraińców (z ok. 600-700 tys.). Wyjeżdżały głównie osoby, które miały rodziny na Ukrainie, biedota, ludzie o przekonaniach komunistycznych, mieszkańcy wsi zniszczonych w trakcie działań wojennych. Zdecydowana większość zamierzała pozostać na „ziemi ojców”, zwłaszcza że posiadała gospodarstwa rolne. Władze, widząc fiasko dobrowolnej repatriacji, postanowiły zmusić Ukraińców do wyjazdu sankcjami ekonomicznymi i administracyjnymi oraz groźbami. Nastąpiła także aktywizacja oddziałów partyzanckich, ukraińskich i polskich, których ofiarą najczęściej padała ludność cywilna. Oddziały UPA starały się hamować przesiedlenia, obawiając się utraty „zaplecza społecznego". Ochraniały ludność ukraińską, ale także dokonywały napadów na posterunki wojska i milicji oraz terroryzowały miejscową ludność polską, paląc wioski, zabijając mieszkańców. Z kolei oddziały polskiego podziemia antykomunistycznego, pacyfikując wsie ukraińskie, zastraszały i zmuszały mieszkańców do wyjazdu, stając się tym samym, paradoksalnie, sojusznikami komunistycznego aparatu bezpieczeństwa. We wzajemnych odwetowych akcjach UPA i polskiego podziemia ginęly tysiące ludzi (Mironowicz 2000, Olejnik 2003, Drozd, Halczak 2010, Eberhardt 2010a).

Od wrześniu 1945 r. w akcji wysiedlania Ukraińców i Łemków, obok oddziałów Korpusu Bezpieczeństwa Wewnętrznego, UBP i milicji, użyto dywizji Wojska Polskiego. O jakiejkolwiek ,dobrowolności” nie mogło być już mowy ${ }^{10}$.

\footnotetext{
${ }^{9}$ Ukraińcy zamieszkujący na Podlasiu zostali przez władze komunistyczne uznani za Białorusinów i podlegali przesiedleniu do BSRR.

${ }^{10}$ Według P. Eberhardta (2010a), do 15 sierpnia 1945 r., zanim użyto wojska, a przesiedlenia „miały charakter w miarę dobrowolny”, wysiedlono 222,5 tys. Ukraińców i Łemków.
} 
Przesiedlenie nabrało cech represyjnej deportacji ludności ${ }^{11}$. Oddziały wojska otaczały poszczególne wsie i wszystkich mieszkańców transportowano do punktów ewakuacyjnych, a nasteppnie do USRR ${ }^{12}$. Były przypadki rabunków, gwałtów, palenia wiosek ukraińskich oraz terroryzowania i mordowania cywilnej ludności ukraińskiej przez Wojsko Polskie. Najczęściej na brutalne postępowanie poszczególnych oddziałów wojskowych nie było reakcji władz. Represjami objęto także Kościół greckokatolicki ${ }^{13}$ oraz duchowieństwo prawosławne. Stosunek do emigracji stał się wrogi, powszechnie stawiano opór, wykorzystując różne sposoby: podawano się za Polaków, zmieniano wyznanie na rzymskokatolickie, wysyłano listy protestacyjne do władz, masowo wstępowano do PPR, ukrywano się w lasach. Oddziały UPA przeciwstawiały się wysiedleniom zbrojnie, atakując komisje przesiedleńcze, posterunki wojskowe, niszcząc infrastrukturę komunikacyjną, zastraszając ludność, paląc opuszczone wioski (Kwilecki 1970, Szcześniak, Szota 1973, Misiło 1992, Pudło 1992, Drozd 1998, 2001, 2007, 2010, Mironowicz 2000, Olejnik 2003, Dudra 2008, Pisuliński 2009, Drozd, Halczak 2010).

Ostatecznie w latach 1944-1946 opuściło wschodnią Polskę ponad 518 tys. osób. Zdecydowanie dominowali Ukraińcy - 481,2 tys. przesiedlonych, w tym z siedmiu powiatów województwa rzeszowskiego 267,4 tys., z dziewięciu

${ }^{11}$ Według L. Olejnika (2003), na zaostrzenie stanowiska władz polskich w sprawie przesiedleń bardzo duży wpływ miały naciski władz USRR, zainteresowanych jak największą skalą wyjazdów Ukraińców z Polski do USRR, w znacznym stopniu wyludnionej podczas wojny.

${ }^{12} \mathrm{Na}$ początku czerwca $1946 \mathrm{r}$. w powiecie leskim, ponad 9 tys. mieszkańców nadgranicznych wsi przepędzono przez granicę bez możliwości zabrania czegokolwiek i bez dokumentów (Drozd, Halczak 2010).

${ }^{13} \mathrm{~W}$ marcu 1946 r., na tzw. soborze lwowskim (nieważnym z kanonicznego punktu widzenia), władze ZSRR wymusiły na duchowieństwie greckokatolickim decyzję o zniesieniu unii brzeskiej i połączeniu Kościoła greckokatolickiego z Rosyjskim Autokefalicznym Kościołem Prawosławnym. Decyzja ta dotyczyła tylko ziem po stronie radzieckiej. Jednak było to w ówczesnych warunkach politycznych nakazem dla polskich władz komunistycznych rozwiązania kwestii Kościoła Unickiego w Polsce. W odróżnieniu od sytuacji w ZSRR, w Polsce nie starano się nadać likwidacji Kościoła greckokatolickiego form prawnych. Władze polskie uznały, że po przesiedleniu większości Ukraińców i Łemków na Ukrainę, w Polsce nie ma już praktycznie ani wyznawców, ani też struktur hierarchii obrządku greckokatolickiego. Wbrew faktom i obowiązującemu stanowi prawnemu uległy likwidacji diecezje, parafie i greckokatolickie domy zakonne. Większość duchownych greckokatolickich wraz z biskupami została wysiedlona do ZSRR. Grekokatolików, tj. Ukraińców i Łemków, zmuszono do nielegalnego i okazjonalnego zaspokajania swoich potrzeb religijnych w prywatnych pomieszczeniach lub z konieczności w świątyniach rzymskokatolickich bądź prawosławnych (Pudło 1992, Wojewoda 1994, Drozd, Halczak 2010). 
powiatów województwa lubelskiego 193,4 tys. oraz z trzech powiatów województwa krakowskiego 20,4 tys. (Gawryszewski 2005, ryc. 8) ${ }^{14}$. Wśród ponad 480 tys. Ukraińców, liczbę przesiedlonych Łemków szacuje się na ok. 95-97 tys. ${ }^{15}$ spośród zamieszkujących wówczas Łemkowszczyznę ok. 130-140 tys. Łemków. Według niektórych szacunków przesiedlono zdecydowanie mniej, bo 70 tys. Łemków ${ }^{16}$. W tym okresie polskie władze traktowały Ukraińców i Łemków jako jedną grupę, dlatego też wszelkie restrykcje komunistów stosowane wobec Ukraińców dotyczyły także bezpośrednio Łemków. Budziło to duże kontrowersje. Część z nich nie utożsamiała się z narodem ukraińskim, część uważała, że w ogóle nie podlega przepisom o przesiedleniu ${ }^{17}$, stanowisko lokalnych władz wobec przesiedleń Łemków także nie było jednolite. Administracja lokalna, również szczebla wojewódzkiego, niejednokrotnie protestowała przeciwko przesiedlaniu Łemków na Ukrainę (zwłaszcza w początkowym okresie przesiedleń), podkreślając ich lojalność wobec państwa polskiego, niewielkie związki z ukraińską ideologią narodową oraz niechęć do ukraińskiego podziemia. Nie spowodowało to jednak zmian postawy władz centralnych, zdeter-

${ }^{14}$ Bardzo zbliżone, choć nieco wyższe wartości podaje E. Mironowicz (2000) oraz J. Pisuliński (2009). Według E. Mironowicza do USRR przesiedlono 482,7 tys. osób, w tym z województwa rzeszowskiego 267,8 tys., lubelskiego 190,7 tys., krakowskiego 21,8 tys. Natomiast według J. Pisulińskiego przesiedlono 482,9 tys. osób, w tym z województwa rzeszowskiego 267,4 tys., lubelskiego 193,4 tys., krakowskiego 20,1 tys., z innych 1,2 tys. L. Olejnik (2003) podaje liczbę 482,1 tys. osób, natomiast S. Dudra (2008, 2010), P. Eberhardt (2010a) i E. Misiło (1996) nieco niższą wartość - 480,3 tys. P. Eberhardt (2010a) dodaje także, że po zakończeniu akcji przesiedleńczej, w drugiej połowie 1946 r., w związku z łączeniem rozdzielonych rodzin, wyjechało z Polski do USRR jeszcze 8,3 tys. Ukraińców, co łącznie daje liczbę 488,6 tys. Ukraińców i Łemków wysiedlonych z Polski w latach 1944-1946. Liczbę ponad 488 tys. wysiedlonych Ukraińców podaje także B. Szcześniak, W. Szota (1973) oraz R. Drozd (1998, 2001).

${ }^{15}$ A. Kwilecki (1970) oraz S. Dudra $(2008,2010)$ podali liczbę 96,8 tys. wysiedlonych w tym okresie Łemków, natomiast R. Drozd (2007) liczbę ok. 95 tys. (zaznaczając, że są to jedynie dane orientacyjne), w tym z powiatu Nowy Targ - ponad 1,8 tys., Nowy Sącz - ponad 17,7 tys., Gorlice - ponad 15 tys., Jasło - ponad 7 tys., Krosno - ponad 11 tys., Sanok - ok. 42 tys. Z powiatu Sanok w tym okresie wysiedlono łącznie prawie 61 tys. osób (Gawryszewski 2005), byli to zarówno Łemkowie, jak i Ukraińcy.

16 Dane m.in. według R. Reinfussa (1990) są prawdopodobnie zaniżone, jednak dokładna liczba Łemków wysiedlonych z zamieszkanych także przez Ukraińców powiatów krośnieńskiego i sanockiego jest trudna do jednoznacznego ustalenia, ponadto wśród Łemków zamieszkujących wschodnią Łemkowszczyznę powszechna była ukraińska świadomość narodowa.

${ }^{17}$ Umowa o wymianie ludności między Polską a USRR z 1944 r., na podstawie której dokonywano przesiedleń, w ogóle nie wymieniała Łemków, użyto w niej określeń Ukraińcy oraz Rusini. 
minowanych $\mathrm{w}$ wysiedleniu całej ludności uważanej za ukraińską, w tym także Łemków $^{18}$ (Mironowicz 2000, Olejnik 2003, Dudra 2008, 2010, Pisuliński 2009). Było to wyraźne odejście komunistów od polityki władz II Rzeczypospolitej, które w okresie międzywojennym, w ramach osłabiania pozycji Ukraińców, wyraźnie podkreślały i popierały odrębność Łemków od narodu ukraińskiego (Michna 1995, 2004, Moklak 1997, 2007).

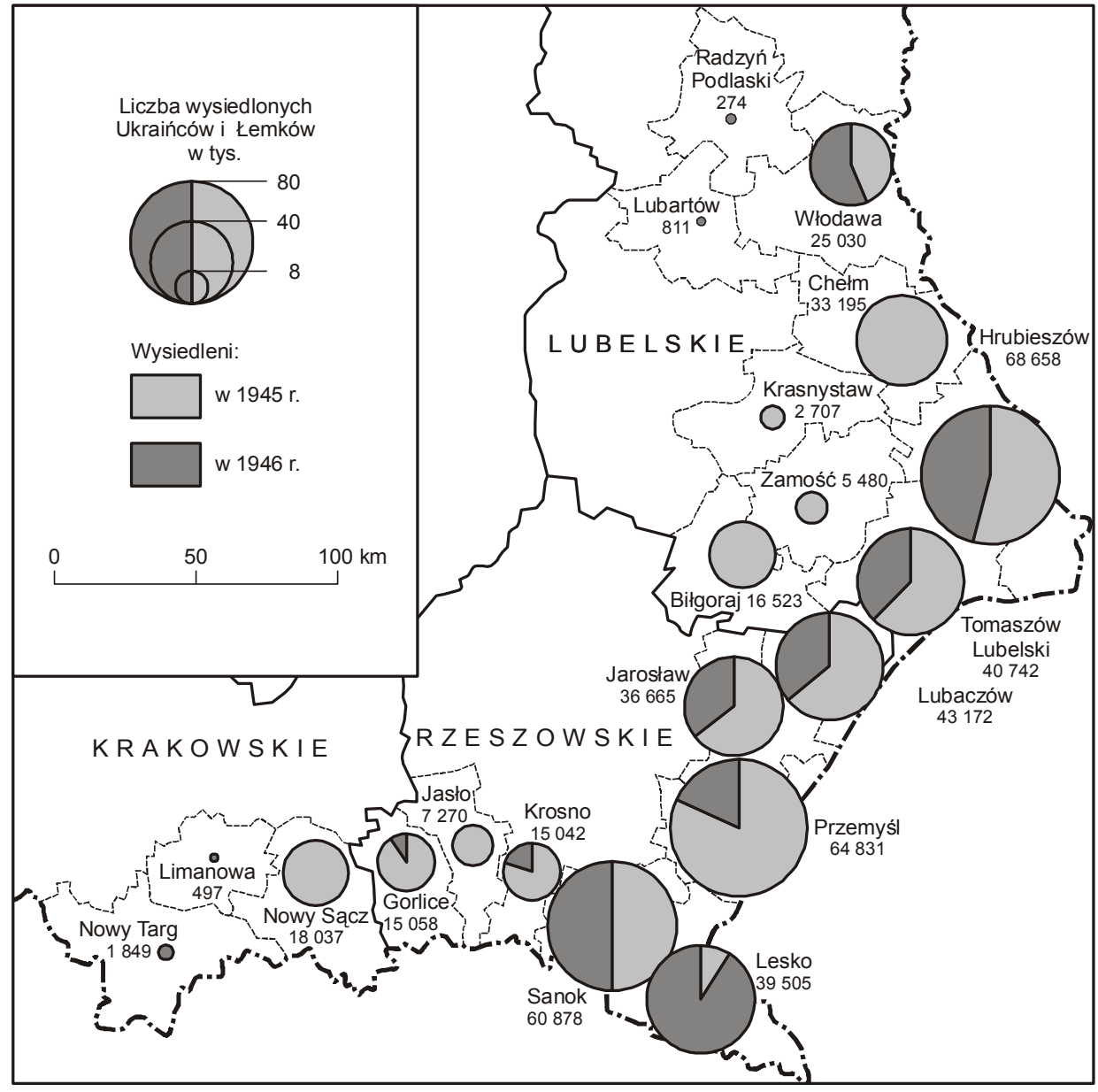

Ryc. 8. Przesiedlenia Ukraińców i Łemków z Polski do USRR w latach 1944-1946 Źródło: A. Gawryszewski (2005, s. 448)

${ }^{18}$ Podczas akcji przesiedleńczej Łemkowie masowo przekraczali granicę czechosłowacką, szukając schronienia wśród słowackich Rusnaków, jednak lokalne władze nie udzielały im żadnej pomocy, a wojsko czechosłowackie organizowało obławy i odprowadzało Łemków siłą do polskiej granicy (Drozd, Halczak 2010). 
Masowe przesiedlenie Ukraińców i Łemków na terytorium radzieckiej Ukrainy w latach 1944-1946 przyniosło przełomową i nieodwracalną zmianę ich położenia etnicznego, politycznego i terytorialnego. Objęło kilkakrotnie więcej osób niż późniejsza akcja „Wisła”, doprowadziło do usunięcia kilkuset tysięcy Ukraińców i kilkudziesięciu tysięcy Łemków nie tylko z ich ziem etnicznych, ale także z terytorium państwa polskiego, było główną przyczyną zmian specyfiki oraz odrębności etniczno-kulturowej południowo-wschodniej Polski.

W wyniku zmian granic oraz przesiedlen, pod koniec 1946 r. w Polsce pozostało zaledwie ok. 150-160 tys. Ukraińców ${ }^{19}$ (w tym ok. 30-35 tys. Łemków), spośród ponad $5 \mathrm{mln}$ zamieszkujących II Rzeczpospolitą. Niektóre okolice, zwłaszcza Bieszczady i wschodnia Łemkowszczyzna, zostały niemal wyludnione. Wiele wsi przestało istnieć (Kwilecki 1970, Nyczanka 1987, Pudło 1992, Barwiński 2001b, 2008a, Dudra 2008).

Przesiedlonych z Polski Ukraińców i Łemków władze radzieckie osiedliły na bardzo rozległym obszarze, w 17 obwodach zachodniej i południowo-wschodniej $\operatorname{USRR}^{20}$. W części zachodniej z reguły przydzielano im gospodarstwa opuszczone przez Polaków, natomiast na wschodzie kierowano do kołchozów. Zdecydowaną większość osiedlono na zachodniej Ukrainie. Dawni mieszkańcy Lubelszczyzny (zwłaszcza Chełmszczyzny i południowego Podlasia) skupili się $\mathrm{w}$ południowych regionach obwodu wołyńskiego i rówieńskiego, Łemkowie w obwodzie tarnopolskim, mieszkańcy Bieszczadów i przemyskiego w centralnych regionach obwodu lwowskiego i iwano-frankowskiego. W połowie lat 50 . XX w. na zachodniej Ukrainie przeprowadzono masową akcję propagandową zachęcającą do osiedlania się w stepowych regionach wschodniej i południowej Ukrainy. Przesiedlono, nie zawsze dobrowolnie, ok. 55 tys. osób, wśród których wysiedleńcy z Polski stanowili dużą część.

Adaptacja przesiedleńców na Ukrainie zachodziła bardzo powoli i opornie. Zetknęli się ze zniszczeniami, głodem i biedą nieporównywalnymi do sytuacji w ówczesnej Polsce. Część postanowiła wrócić w rodzinne strony, przekraczając nielegalnie granicę lub podając się za Polaków podlegających repatriacji. Szacuje się, że w ten sposób mogło powrócić do Polski nawet 10 tys. Ukraińców. Miejscowa ludność przyjmowała ich nieufnie, posługiwali się innymi dialektami języka ukraińskiego, na wschodzie zrusyfikowani mieszkańcy nazywali ich

${ }^{19}$ R. Drozd (1998) i P. Eberhardt (2010a) szacują w tym okresie łączną liczbę Ukraińców i Łemków na ok. 200 tys.

${ }^{20}$ Były to obwody: wołyński, rówieński, lwowski, drohobycki (istniał do $1951 \mathrm{r}$.), tarnopolski, stanisławowski (obecnie iwano-frankowski), sumski, charkowski, doniecki, woroszyłowohradski (obecnie ługański), zaporoski, dniepropietrowski, połtawski, kirowohradski, mikołajewski, chersoński, odeski (Kabaczij 2012). 
„Polaczkami”. Najbardziej wyrazistą społeczność tworzyli Łemkowie, którzy w niewielkim stopniu byli uważani za „swoich”. Przez wiele lat „miejscowi” i ,przesiedleńcy” żyli osobno, nie zawierali małżeństw, nie obchodzili wspólnie świąt, izolowali się we własnych grupach. Po uzyskaniu przez Ukrainę niepodległości powstały organizacje zrzeszające byłych mieszkańców południowo-wschodniej Polski: „Kongres Ukrajinciw Chołmszczyny i Pidlaszsza”, „Chołmszczyna”, „Łemkiwszczyna”, „Nadsannia”, „Ustryky” oraz liczne zespoły folklorystyczne. Nazwy nowo powstałych stowarzyszeń jednoznacznie wskazują na sentyment żywiony do dawnej „ziemi ojców”, który nie zanikł mimo upływu kilkudziesięciu lat. Głównym postulatem organizacji jest nadanie przez władze Ukrainy wysiedlonym z Polski statusu osoby deportowanej (Kabaczij 2012).

Dominujący udział (ponad 90\%) Ukraińców i Łemków wśród ogółu narodowości wysiedlonych ze wschodniej Polski do ZSRR w latach 1944-1946 nie jest zaskakujący. Ukraińcy byli najliczniejszą mniejszością narodową w międzywojennej Polsce, ponadto wyraźnie skonfliktowaną z polskimi władzami oraz społeczeństwem. Różnice interesów polsko-ukraińskich niejednokrotnie przejawiały się w tragiczny dla obu narodów sposób, zarówno podczas walk o niepodległość w latach 1918-1920, jak i w okresie międzywojennym, a szczególnie podczas krwawych walk polsko-ukraińskich w latach 1943-1947, związanych z działalnością UPA, które, zwłaszcza na Wołyniu, miały wszelkie cechy ludobójstwa. Większość Ukraińców była nastawiona wrogo do państwa polskiego i do narzuconego przez ZSRR ustroju komunistycznego. Ponadto bez ich wysiedlenia niemożliwe było przekształcenie Polski w państwo jednonarodowe. Dlatego komuniści po przejęciu władzy w 1944 r. postanowili „pozbyć się” z nowego terytorium Polski wszelkich mniejszości narodowych, a zwłaszcza mniejszości ukraińskiej. Jednym z głównych celów podpisanej w 1944 r. umowy o repatriacji było przesiedlenie całej pozostałej w nowych granicach Polski ludności ukraińskiej na obszar USRR. W regionach zamieszkanych przez Ukraińców akcja agitacyjna była najbardziej nasilona, tylko tutaj użyto oddziałów wojska, a przesiedlenie, wbrew wcześniejszym ustaleniom, miało w dużej mierze charakter przymusowy.

\section{Bialorusini}

Inaczej przedstawiała się sytuacja $\mathrm{z}$ wyznawcami prawosławia na Podlasiu pochodzenia białoruskiego i ukraińskiego, których ówczesna władza w całości uważała za Białorusinów ${ }^{21}$. Pozostawali oni lojalni wobec władz komunisty-

${ }^{21} \mathrm{~W}$ okresie powojennym polska administracja na Białostocczyźnie przyjęła zasadę automatycznego klasyfikowania ludności według kryterium religijnego, traktując 
cznych i nie podkreślali swojej odrębności narodowej. Jednak jesienią 1944 r. polscy działacze komunistyczni (pomimo ustaleń dotyczących przebiegu granicy z lipca 1944 r.) nie mieli pewności, czy Stalin ostatecznie pozostawi Białostocczyznę w Polsce. Tajny raport sporządzony we wrześniu 1944 r. przez Zarząd Polityczny Wojska Polskiego na zlecenie PKWN jednoznacznie informował, że w Białymstoku nic nie wskazuje na to, aby miasto należało do Polski. Powstawała radziecka administracja, liczne były portrety Stalina, czerwone gwiazdy i flagi, powszechna rosyjska muzyka, filmy i występy rosyjskich artystów. Spotykało się to z aprobatą miejscowych Białorusinów, którzy - według wysłanników PKWN - w sierpniu 1944 r., po wkroczeniu Armii Czerwonej zabiegali, aby Białystok został miastem radzieckim (Mironowicz 2000, 2005). Kolejnym przejawem niepewności co do przyszłości polityczno-terytorialnej Podlasia było podporządkowanie tego obszaru w grudniu 1944 r., przez prawosławnego biskupa mińskiego Bazylego, jurysdykcji Patriarchatu Moskiewskiego i utrzymująca się do lutego 1946 r. „schizma białostocka” (Plit 2008). Dysponując takimi informacjami, władze PKWN miały podstawy do obaw o przynależność państwową Białostocczyzny, zwłaszcza że żywa była pamięć o zajęciu przez Armię Czerwoną jesienią 1939 r. Podlasia oraz północno-wschodniego Mazowsza wraz z Łomżą i przyłączenia go, na prawie dwa lata, do BSRR w ramach ZSRR.

Dlatego też podpisana w tym samym czasie umowa o ,wzajemnej ewakuacji ludności" dawała polskim władzom możliwość przesiedlenia Białorusinów na wschód, poza linię Curzona i tym samym usunięcia potencjalnego pretekstu włączenia Podlasia w granice ZSRR. Jednak Białorusini nie wykazywali powszechnej chęci wyjazdu do ZSRR. Ponadto ich tradycyjnie lewicowe nastawienie stereotypowo czyniło z nich zwolenników nowego systemu, którzy mogli stać się przydatni dla władz komunistycznych. Był to istotny argument na Białostocczyźnie, gdzie wśród Polaków nie istniały żadne tradycje komunistyczne, wręcz przeciwnie, ludność polska, nauczona doświadczeniem wojny pol-

wszystkich wyznawców prawosławia na Podlasiu jako Białorusinów (Mironowicz 1993, 2000). Spowodowało to utrwalenie się w świadomości społecznej stereotypów prawosławny-Białorusin i katolik-Polak również wśród samych zainteresowanych, czyli społeczności prawosławnej. Ponadto podczas wojny i po jej zakończeniu prawosławni mieszkańcy Podlasia nie angażowali się w konflikt polsko-ukraiński, na północ od Bugu nie było ukraińskich akcji zbrojnych wymierzonych w Polaków, a obszar ten bezpośrednio graniczył z Białoruską Socjalistyczną Republiką Radziecką. Wszystkie te elementy skutecznie utrwalały powyższy stereotypowy schemat (Plit 2008). W takim podziale religijno-narodowościowym mieszkańców Podlasia nie było miejsca dla Ukraińców. 
sko-bolszewickiej oraz radziecką okupacją lat 1939-1941, była bardzo wyraźnie antykomunistyczna.

Działacze PKWN uznali, że najbezpieczniejszym rozwiązaniem będzie zaangażowanie Białorusinów do budowy polskiego aparatu władzy komunistycznej, więc bardzo szybko zaczęli stanowić główny trzon komunistycznych struktur administracyjnych, partyjnych i milicyjnych na Podlasiu. Chociaż E. Mironowicz (1993) podkreślał, iż „mitem jest twierdzenie, że budowa aparatu «władzy ludowej» na Białostocczyźnie była dziełem Białorusinów”, to faktem jest, że komórki PPR, jesienią 1944 r., powstały wyłącznie na obszarach Białostocczyzny zamieszkanych przez Białorusinów. W połowie 1945 r., Białorusini, stanowiący zaledwie $25 \%$ mieszkańców powiatu białostockiego, tworzyli $75 \%$ członków tamtejszego PPR, a w powiecie bielskim aż 84\% członków partii wywodziło się spośród tamtejszych Białorusinów, którzy stanowili 45\% ogółu mieszkańców. W zachodnich gminach powiatu bielskiego, zamieszkanych wyłącznie przez Polaków, komórki PPR w ogóle wówczas nie powstały. Było to spowodowane niechęcią, a częściej wrogością Polaków do władzy komunistycznej. Również większość urzędników oraz funkcjonariuszy milicji i urzędów bezpieczeństwa wywodziła się spośród Białorusinów, także na obszarach, gdzie dominowała ludność polska ${ }^{22}$. Jedynie wśród elit politycznych zdecydowanie większy był udział Polaków, najczęściej przysłanych spoza Podlasia.

Wynika z tego, że funkcjonowanie na Podlasiu nowej władzy - szczególnie w początkowym okresie - było możliwe jedynie dzięki włączeniu miejscowych Białorusinów w jej struktury, mimo że ogromna większość tej społeczności tradycyjnie pozostawała bierna ${ }^{23}$. Często było to powodowane niewielkim wyborem, jaki miała społeczność białoruska. Nowa władza dawała im możliwość różnego rodzaju awansu, rząd emigracyjny był natomiast kojarzony z przedwojennym okresem ograniczeń i represji, oraz - co było wówczas prawdopodobnie najistotniejsze - ze zbrojnymi oddziałami partyzanckimi, stosującymi przemoc wobec społeczności białoruskiej i ukraińskiej. Powszechny wśród Polaków pogląd o wspieraniu komunistów przez mniejszość białoruską dodat-

${ }^{22}$ Władze lokalne dbały, aby Białorusini zajmujący stanowiska w administracji, partii, milicji, nie zdradzali swego niepolskiego pochodzenia i posługiwali się wyłącznie językiem polskim, głównie dlatego, że duży udział Białorusinów w strukturach lokalnych władz był jednym z czynników utrudniających pozyskanie współpracy ludności polskiej (Mironowicz 2000, 2005).

${ }^{23} \mathrm{~W}$ maju 1945 r. w powiecie białostockim do PPR należało zaledwie 175 Białorusinów, a w powiecie bielskim 437. Jednak z powodu znikomej liczebności Polaków w organizacjach partyjnych, udział procentowy Białorusinów był bardzo wysoki (Mironowicz 1993). 
kowo potęgował antagonizmy polsko-białoruskie na Podlasiu, mimo że wśród Białorusinów dominowały postawy tymczasowości, wyczekiwania i obojętności wobec polityki (Mironowicz 1993, 1998, 2000, 2005, 2010a, Darski 1994, Chałupczak, Browarek 1998, Olejnik 2003).

Administracja lokalna początkowo nie podejmowała żadnych działań sprzyjających przesiedleniu Białorusinów do BSRR. Wręcz przeciwnie, m.in. rozwijano białoruskie szkolnictwo, jesienią 1944 r. działało na Białostocczyźnie ponad sto szkół z białoruskim językiem nauczania. Natomiast aktywnie na rzecz repatriacji działali komisarze radzieccy, którzy prowadzili agitację, obiecując wizję szczęśliwego życia „w państwie rządzonym przez robotników i chłopów”. Mimo szeroko prowadzonej akcji propagandowej, do końca 1946 r. wyjechały łącznie $\mathrm{z}$ województwa białostockiego 10793 rodziny, tj. 36388 osób ${ }^{24}$, w tym z powiatu białostockiego - 12 328, bielskiego - 10 122, sokólskiego - 9680 . Stanowili oni zaledwie ok. $20 \%$ ogółu zamieszkującej na tym obszarze społeczności prawosławnej. Wyjeżdżali głównie ludzie o przekonaniach komunistycznych i wysokim poczuciu białoruskiej tożsamości narodowej oraz osoby obawiające się represji ze strony zbrojnego podziemia. Głównymi argumentami za pozostaniem w Polsce było przywiązanie do miejsca zamieszkania i strach przed radziecką rzeczywistością (Tomaszewski 1991, Mironowicz 1993, 2000, 2005, Sadowski 1995a, Hawryluk 1999).

Czynnikiem, który zmienił sytuację ludności prawosławnej na Podlasiu, było uaktywnienie się na początku 1945 r. zbrojnego polskiego podziemia antykomunistycznego. Jego głównym celem było przywrócenie niepodległości i suwerenności zniewalanego przez Armię Czerwoną państwa polskiego. W sposób oczywisty działania te zakładały konfrontację i walkę z komunistami oraz osobami, organizacjami, grupami ich wspierającymi. Nie miało wówczas znaczenia, jakiej narodowości bądź wyznania były osoby popierające idee komunizmu (Kalisz, Łapiński 2005). Jednak Białorusini byli postrzegani przez Polaków jako społeczność zdecydowanie prorosyjska, o przekonaniach lewicowych, czynnie wspierająca - co prawda polską - ale nieakceptowaną przez większość Polaków nową władzę komunistyczną. Jak pisze E. Mironowicz (1993), „w wyniku takie-

${ }^{24}$ Według obliczeń E. Mironowicza (1993). Prawie identyczną liczbę przytoczył A. Gawryszewski (2005), według którego chęć wyjazdu z Polski do BSRR zgłosiło 47117 osób, spośród których ostatecznie wyjechało 36398 osób. Nieco niższą wartość podał L. Olejnik (2003), powołując się na raport NKWD, według którego z Białostocczyzny wysiedlono na Białoruś 35961 osób, wśród których było 27409 Białorusinów, 5894 Ukraińców, 2608 Rosjan i 53 ,innych”. Natomiast według P. Eberhardta (2010a), z województwa białostockiego do BSRR wyjechało 34411 osób, w tym z powiatu białostockiego 12 828, bielskiego 10 122, sokólskiego 9680. 
go podziału ról, we wschodniej części województwa białostockiego, gdy strzelano do milicjanta lub pepeerowca, to najczęściej strzelano do Białorusina".

Tragiczne wydarzenia $\mathrm{z}$ lat 1945-1947 na Podlasiu miały nie tylko wymiar polityczny, ale także narodowościowy i wyznaniowy ${ }^{25}$. Zbrojne działania ugrupowań polskich, które były pod względem politycznym i organizacyjnym wewnętrznie bardzo zróżnicowane, nie ograniczały się wyłącznie do walki ze strukturami komunistycznego państwa, lecz były również wymierzone bezpośrednio w Białorusinów. Jednym z celów polskiego podziemia niepodległościowego, zwłaszcza ugrupowań narodowo-katolickich (m.in. Narodowego Zjednoczenia Wojskowego), było zmuszenie ich do opuszczenia Polski. Nacisk nacjonalistycznego podziemia na wysiedlenie ludności prawosławnej z Podlasia był silniejszy, bardziej zdecydowany i brutalniejszy niż nacisk komunistycznej administracji. W dużym stopniu był determinowany postawami zajmowanymi przez część podlaskich Białorusinów podczas radzieckiej (1939-1941) oraz hitlerowskiej (1941-1944) okupacji Białostocczyzny. Większość oddziałów zbrojnych ograniczała się do rabunku, nakładania kontrybucji, zastraszania, pobić. Zdarzały się jednak przypadki pacyfikacji całych wsi, podpaleń, morderstw, stosowania odpowiedzialności zbiorowej (Mironowicz 1993, 2000, Olejnik 2003, Kalisz, Łapiński 2005). Z gmin etnicznie mieszanych, zwłaszcza z powiatu bielskiego, mieszkańcy uciekali na wschód do ZSRR lub na nowo przyłączone do Polski ziemie na zachodzie i północy. Społeczeństwo Podlasia podzieliło się na wrogie grupy według nakładających się na siebie kryteriów narodowościowych, wyznaniowych i politycznych. Wydarzenia te, praktycznie automatycznie, spowodowały opowiedzenie się prawosławnych Białorusinów po stronie nowej władzy, która stała się jedyną gwarancją pozostania na swojej ziemi i powrotu do normalnego życia (Mironowicz 1993).

W postawie polskich władz komunistycznych już pod koniec 1944 r., a zwłaszcza w latach 1945-1946, nastąpiła jednak wyraźna zmiana. Białorusini, pomimo całkowitej lojalności w stosunku do władz, stawali się niewygodni. Wynikało to z propagowania oficjalnej tezy o Polsce jako państwie jednonarodowym, bez mniejszości etnicznych i związanych z nimi problemów. Starano się dopasować rzeczywistość do propagandy. Rozpoczęto proces polonizacji administracji, szczególnie we wschodnich gminach województwa białostockiego. Władze lokalne, pod wpływem sugestii władz centralnych, zmieniły zdanie na temat repatriacji do BSRR, którą zaczęto popierać, jednak przy zachowaniu

${ }^{25}$ Przez Białorusinów były one odbierane wyłącznie w kategoriach konfliktu o charakterze narodowościowo-religijnym (Mironowicz 1993). 
zasad dobrowolności ${ }^{26}$. Nie zdecydowano się na użycie wojska, jak miało to miejsce w południowo-wschodniej Polsce, jednak opinie władz lokalnych o Białorusinach przestały być pozytywne (Tomaszewski 1991, Mironowicz 1993, 1998, 2000, 2005, 2010a, b, Darski 1994, Chałupczak, Browarek 1998, Olejnik 2003, Barwiński 2004a).

$\mathrm{Na}$ zmianę nastawienia władz wpłynęły m.in. informacje o próbach oderwania przez Białorusinów południowo-wschodniej części Białostocczyzny. Urzędnicy administracji wojewódzkiej, powołując się na anonimowe listy, twierdzili, iż w 1945 r. Białorusini organizowali zbieranie podpisów pod petycją do władz radzieckich o przyłączenie powiatu bielskiego do ZSRR. Podpisy zbierane w gminach tego powiatu rzekomo podpisało $80 \%$ mieszkańców. Było to badane przez Wojewódzki Urząd Bezpieczeństwa Publicznego (WUBP) w Białymstoku, a niektórzy sygnatariusze petycji zostali rozstrzelani przez AK (Olejnik 2003, Mironowicz 2005). Prowadzone śledztwo wykazało, że faktycznie w 1945 r. we wsiach białoruskich w powiecie bielskim były zbierane podpisy, ale pod listem do patriarchy moskiewskiego, aby ten nie wyrażał zgody na autokefalię Kościoła prawosławnego w Polsce. Nie zmieniło to faktu, iż incydent ten przyczynił się do upowszechnienia poglądów o separatystycznych dążeniach Białorusinów (Mironowicz 2005).

W 1946 r. zapoczątkowano także (trwającą do początku lat 50.) akcję aparatu bezpieczeństwa przeciwko członkom Białoruskiego Komitetu Narodowego ${ }^{27}$. Zostali oskarżeni o kolaborację z Niemcami podczas okupacji, poddani inwigilacji, zwalniani z pracy, usuwani z partii, aresztowani. Rola osób działających w Białoruskim Komitecie Narodowym jest różnie oceniana - od dbałości o rozwój narodowy Białorusinów po kolaborację z hitlerowcami i denuncjację osób zaangażowanych w działalność antyfaszystowską. Według WUBP Komitet powstał w celu współpracy z okupantem, doprowadzenia do zbliżenia ludności białoruskiej z Niemcami, zantagonizowania Białorusinów i Polaków. Podczas okupacji niektórzy członkowie Komitetu - poza prowadzeniem działalności narodowo białoruskiej - współpracowali z gestapo, zajmowali się proniemiecką

${ }^{26}$ O utrzymaniu zasady dobrowolności przy przesiedleniach Białorusinów zadecydowała postawa władz centralnych. Lokalne władze administracyjne (wojewódzkie i Państwowego Urzędu Repatriacji) w drugiej połowie 1945 r. wielokrotnie sugerowały, by dobrowolność zastąić przymusem (Mironowicz 2000, 2005).

27 Powołany za zgodą Niemców (z inicjatywy niemieckiego wywiadu) w sierpniu 1941 r. i całkowicie przez nich kontrolowany. Zajmował się m.in. organizacją zebrań, odczytów, kursów dla chętnych do pracy w administracji, nauką języka niemieckiego oraz zakładaniem szkół białoruskich, prowadzeniem zespołów artystycznych, chórów. Poszczególne Komitety prowadziły głównie działalność lokalną (Sychowicz 2009). 
propagandą, prowadzili działalność wywiadowczą, byli członkami niemieckiej policji, walczyli w utworzonych przez Niemców białoruskich batalionach. Liczbę osób należących do Białoruskiego Komitetu Narodowego na Białostocczyźnie WUBP szacował na 8-10 tys., spośród których większość opuściła Podlasie wraz z wycofującymi się oddziałami niemieckimi, a część została aresztowana jesienią 1944 r. przez Armię Czerwoną i wywieziona w głąb ZSRR (Sychowicz 2009).

Białorusini, obawiając się przymusowego przesiedlenia do ZSRR, od początku 1946 r. nie wysuwali żadnych postulatów o charakterze narodowym. Konsekwencją tego było zaprzestanie traktowania ich jako odrębnej narodowości. Władze uznały, że osoby, które czuły się Białorusinami, wyjechały do BSRR, natomiast ci, którzy pozostali, są „Polakami wyznania prawosławnego”. Całkowicie zlikwidowano szkolnictwo białoruskie oraz wszelkie formy działalności kulturalnej ${ }^{28}$. Białorusini uzyskali możliwość awansu politycznego, społecznego, gospodarczego, jednak bez jakichkolwiek możliwości rozwoju własnego życia narodowego. Jak pisał E. Mironowicz (2000), „Białorusinów potraktowano jako pełnoprawnych obywateli [...] Otrzymali pełnię praw jako Polacy, nic natomiast jako Białorusini".

O ile dane dotyczące liczby osób przesiedlonych w latach 1944-1946 z Białostocczyzny do BSRR są dokładne (36 tys.), o tyle ogólna liczba Białorusinów zamieszkujących tam w drugiej połowie lat 40. XX w. - lub raczej osób traktowanych przez władze jako Białorusini - nie jest precyzyjnie ustalona. Na podstawie analizy dostępnych dokumentów najczęściej przyjmuje się, że tuż po zakończeniu wojny na Podlasiu mieszkało ok. 150-160 tys. Białorusinów, natomiast po zakończeniu repatriacji pozostało ok. 125 tys., w tym w powiecie bielskim 86 tys., białostockim 25 tys., sokólskim 14 tys. (Mironowicz 1993, 2000, 2005, 2010a). Niższą liczbę (114,4 tys.) Białorusinów na Podlasiu w 1946 r. podał L. Olejnik (2003). Natomiast według sumarycznego spisu ludności z lutego 1946 r. w województwie białostockim było 116517 ,innych” (w przypadku tego regionu była to łączna liczba osób deklarujących podczas spisu narodowość białoruską, ukraińską, litewską, rosyjską, żydowską, tatarską). Była to prawdopodobnie wartość zaniżona, m.in. dlatego, że część ludności niepolskiej, obawiając się repatriacji do ZSRR, deklarowała wówczas narodowość polską. Jeszcze niższe wartości podał dokument Urzędu Wojewódzkiego w Białymstoku z 18 lutego 1948 r., według którego województwo białostockie zamieszkiwało wówczas 106 tys. Białorusinów, stanowiących 11,5\% ogółu mieszkańców.

${ }^{28}$ Pod koniec 1944 r. było 105 szkół z białoruskim językiem nauczania, w grudniu 1946 r. - 41, w grudniu 1947 r. - 6 (Mironowicz 2005). 
Dokument zatytułowany „Charakterystyka terenu województwa białostockiego” wspominał także o mniejszości rosyjskiej, litewskiej, żydowskiej oraz o muzułmanach, natomiast w ogóle nie odnotował mniejszości ukraińskiej na Podlasiu. Podkreślono w nim, że ludność białoruska „ukształtowanej świadomości narodowej właściwie nie posiada i ulega w bardzo dużym stopniu wpływom kultury polskiej" 29 .

\section{Litwini}

Na zmianę liczebności Litwinów w Polsce po II wojnie światowej decydujący wpływ miała ustalona na konferencji w Jałcie zmiana przebiegu wschodniej granicy Polski, w konsekwencji czego m.in. całą Wileńszczyznę włączono do ZSRR. Jedynym skupiskiem ludności litewskiej w nowych granicach Polski pozostała Suwalszczyzna, a zwłaszcza dwie przygraniczne gminy - Puńsk i Sejny. Spowodowało to drastyczny spadek liczebności mniejszości litewskiej, z przedwojennych 180-200 tys., do 10-13 tys. w pierwszych latach powojennych (w tym na Suwalszczyźnie 8-10 tys.) (Tarka 1998).

Władze wojewódzkie w Białymstoku oraz lokalne na Suwalszczyźnie słabo orientowały się w specyfice zamieszkujących ten region Litwinów. Zaniżały ich liczebność i według różnych dokumentów z lat 1944-1947 szacowały ją w sposób bardzo dowolny i zmienny, w przedziale od 1,8 tys. do 6 tys. (Tarka 1998, 2010). Zdecydowanie popierały umowę o repatriacji, a nawet rozważały możliwość przymusowego wysiedlenia Litwinów z powodu ,antypolskiego, antysowieckiego i proniemieckiego usposobienia". Mimo że przymusowe wysiedlenie zaledwie kilku tysięcy osób nie stanowiło żadnego problemu, to jednak władze centralne nie poparły starań władz wojewódzkich i lokalnych (Mironowicz 2000).

Powojenne przesiedlenia dotknęły społeczność litewską w znikomym stopniu, nie wpływając na jej liczebność w Polsce. Było to spowodowane zdecydowaną niechęcią Litwinów do wyjazdu oraz niezastosowaniem przez władze centralne bezpośredniego przymusu. Jedynie władze lokalne prowadziły działalność propagandową na rzecz „ewakuacji”, stosowały różnego rodzaju zachęty oraz wywierały presję administracyjną, mimo to zainteresowanie emigracją wśród Litwinów było marginalne. Istotną przyczyną był fakt, iż w rzeczywistości mieli wyjechać do Litewskiej Socjalistycznej Republiki Radzieckiej (LSRR), a nie do niepodległej Litwy. Liczebność mniejszości litewskiej w Pol-

${ }^{29} \mathrm{Na}$ podstawie „UWB, Charakt. wojew. białostockiego pod wzgl. narodowościowym 1948, syg. 685" http://www.bialystok.ap.gov.pl/bit/delimitacja/03/slides/str_002. html (pobrano 06.07.2011). 
sce po 1945 r. zaczęła wręcz rosnąć, głównie z powodu powrotów ok. 3-5 tys. Litwinów deportowanych przez Niemców z Suwalszczyzny w 1941 r. oraz nielegalnej repatriacji (dzięki podawaniu się za Polaków) niewielkiej liczby Litwinów z ZSRR. Część z nich osiedlała się na tzw. Ziemiach Odzyskanych. Z powodu zagrożenia repatriacją powszechne stało się ukrywanie przez Litwinów przynależności narodowej, w wyniku czego ich oficjalna liczba była znacznie niższa od rzeczywistej. Szacunki mówiące o liczbie Litwinów, objętych w latach 1944-1946 przesiedleniem na radziecką Litwę, wahają się od zaledwie kilku rodzin aż do kilkudziesięciu tysięcy osób, co jest wartością absurdalną. Najbardziej prawdopodobne dane mówią o przesiedleniu od kilkuset do około tysiąca Litwinów, jednak na podstawie zachowanych danych archiwalnych można udokumentować wyjazd zaledwie od kilkunastu do kilkudziesięciu osób ${ }^{30}$ (Chałupczak, Browarek 1998, Tarka 1998).

Dla władz w Warszawie Litwini, zamieszkujący w niewielkiej liczbie peryferyjne krańce Polski, nie stanowili istotnego problemu w polityce narodowościowej pierwszych lat powojennych, zwłaszcza w porównaniu z sytuacją mniejszości niemieckiej i ukraińskiej. Natomiast władze lokalne miały wręcz wrogi stosunek do Litwinów i oceniały tę społeczność bardzo negatywnie. W różnego rodzaju sprawozdaniach przesyłanych do Białegostoku liczne są opinie o wrogim, szowinistycznym nastawieniu Litwinów zarówno do Polaków, jak i do lokalnej administracji. Do głównych problemów - z punktu widzenia władz należał bierny opór Litwinów wobec zarządzeń administracyjnych, brak aktywności partyjnej ${ }^{31}$, liczne powroty Litwinów zza wschodniej granicy, niechęć do wyjazdów na teren LSRR, spory dotyczące nabożeństw w języku litewskim (Tarka 1998, 2010, Olejnik 2003).

Mała liczebność społeczności litewskiej oraz realne zagrożenie przesiedleniem do LSRR powodowały, iż Litwini nie uczestniczyli w walce $\mathrm{z}$ władzą komunistyczną, jednocześnie nie podejmując z nią w pierwszych latach powojennych żadnej współpracy, ani nie zgłaszając żadnych roszczeń. Na Suwalszczyźnie po 1945 r. działały nieliczne litewskie oddziały partyzanckie, były to grupy, które znalazły tu schronienie przed wojskami radzieckimi, a nieszczelna do 1947 r. granica polsko-litewska umożliwiała im częste rajdy z Polski na

${ }^{30} \mathrm{Na}$ podstawie analizy materiałów archiwalnych K. Tarka (1998) podaje, że do maja 1945 r. wyjechało z Suwalszczyzny na Litwę zaledwie 18 osób, według C. Żołędowskiego (1992) w tym samym okresie wyjechały 43 osoby „narodowości litewskiej i rosyjskiej”, natomiast według L. Olejnika (2003) do października 1946 r. z możliwości wyjazdu skorzystało tylko 14 osób z 56 zarejestrowanych.

${ }^{31}$ W lipcu 1949 r. w powiecie suwalskim do PZPR nie należał ani jeden Litwin (Olejnik 2003). 
obszar LSRR i ataki na nową radziecką administrację. Zorganizowali także szlak przerzutowy korespondencji i kurierów do zachodniej Europy i USA. Oddziały te zostały ostatecznie rozbite przez wojsko i funkcjonariuszy aparatu bezpieczeństwa w 1949 r. (Kalisz 2009).

Relacje Litwinów z Polakami oraz polskimi władzami były złe, a nawet wrogie, pełne wzajemnej niechęci i podejrzliwości. Było to spowodowane zadawnionymi antagonizmami, pamięcią o nie tak dawnych konfliktach na pograniczu polsko-litewskim i Wileńszczyźnie oraz współpracą części Litwinów z hitlerowcami podczas II wojny, choć na samej Suwalszczyźnie takich przypadków nie odnotowano. Dla polskich władz było to jednak wystarczające, aby uznać mniejszości litewską za wrogów Polski Ludowej. Dla Litwinów sposobem na przetrwanie stała się bierność oraz całkowita izolacja wewnątrz własnej społeczności (Tarka 1998, 2010, Milewski 2001).

\subsubsection{Sumaryczny spis ludności z 1946 roku}

Pierwszy po wojnie, tzw. sumaryczny spis ludności (nieimienny, z ograniczoną liczbą pytań), przeprowadzono według stanu z 14 lutego $1946 \mathrm{r}^{32}$ Zawarto w nim m.in. pytanie o narodowość (tab. 3). Jednak jego wyniki z wielu różnych przyczyn są mało wiarygodne i mało przydatne dla analizy ówczesnej struktury narodowościowej Polski. Był on zorganizowany głównie w celu określenia strat ludnościowych wywołanych wojną i okupacją, ustalenia aktualnej struktury, liczebności i rozmieszczenia Polaków oraz ustalenia liczebności i rozmieszczenia podlegającej wysiedleniu ludności niemieckiej.

Spis przeprowadzono w bardzo niestabilnej, dynamicznej sytuacji demograficznej, podczas trwających przesiedleń ludności, zarówno wysiedleń Niemców, Ukraińców, Łemków, Białorusinów, Litwinów, jak i przesiedleń ludności polskiej z ziem zajętych przez ZSRR. Ponadto w kwestionariuszu spisowym wyróżniono jedynie Polaków, Niemców i ,innych” oraz osoby, w stosunku do których toczyły się postępowania rehabilitacyjne lub weryfikacyjne, dlatego nie dał on żadnych informacji na temat ówczesnej liczebności np. Ukraińców czy Białorusinów $^{33}$. Jest także bardzo prawdopodobne, że osoby z narodowości podlegających wówczas przesiedleniom, obawiając się deportacji, mogły świadomie deklarować narodowość polską. Spis nie objął osób zatrudnionych przez wojska

${ }^{32} \mathrm{Z}$ powodu działalności UPA, spisu nie przeprowadzono w kilku gminach powiatu leskiego (Gawryszewski 2005).

${ }^{33}$ P. Eberhardt (2010a) na podstawie własnych wyliczeń oszacował ówczesną liczbę Ukraińców na 220,2 tys., a Białorusinów na 116,5 tys., natomiast A. Gawryszewski (2005) podał, że w kategorii ,inni” Ukraińcy stanowili ok. 162 tys. osób. 
radzieckie (w dużym stopniu Niemców), a w podziale na narodowości nie uwzględniono w nim żołnierzy (ponad 300 tys. osób). Nie opublikowano wyników tego spisu w odniesieniu do gmin i powiatów, co dodatkowo utrudniało ocenę ich wiarygodności. Jest bardzo prawdopodobne, że liczebność Niemców i „,innych” była zaniżona, a wyniki tego spisu nie oddają rzeczywistej struktury narodowościowej Polski w 1946 r. (Olejnik 2003).

Tabela 3. Wyniki sumarycznego spisu ludności z lutego 1946 r. dotyczące narodowości

\begin{tabular}{|c|c|c|c|c|}
\hline \multirow{2}{*}{$\begin{array}{c}\text { Ludność } \\
\text { ogółem }\end{array}$} & \multicolumn{3}{|c|}{ Narodowości } & $\begin{array}{c}\text { Postępowanie } \\
\text { rehabilitacyjne lub } \\
\text { weryfikacyjne }\end{array}$ \\
\cline { 2 - 4 } & Polacy & Niemcy & Inni & 417431 \\
\hline 23929757 & 20520178 & 2228830 & 399526 & 417 \\
\hline
\end{tabular}

Źródło: na podstawie: Statystyka Polski... (1947).

W kolejnych spisach ludności, począwszy od 1950 r. aż do 1988 r., nie uwzględniano pytań o narodowość, język ojczysty i wyznanie (Gawryszewski 2005). Władze uznały, że po zmianach granic i przesiedleniach ludności Polska przekształciła się w kraj jednolity etnicznie, a problematyka mniejszości narodowych stała się marginalna. Liczebność ludności niepolskiej była określana jedynie na podstawie różnego rodzaju, mniej lub bardziej wiarygodnych, szacunków. W urzędowych kwestionariuszach rubryka dotycząca narodowości zachowała się do końca lat 80 . ubiegłego wieku w ankietach personalnych składanych w celu otrzymania dokumentu tożsamości lub paszportu, lecz dane te pozostawały w wyłącznej gestii Ministerstwa Spraw Wewnętrznych, które jednak formalnie nie opracowywało analiz struktury narodowościowej (Sobczyński 2012). Kolejne spisy, w których zadano pytanie o narodowość, przeprowadzono dopiero w 2002 r. oraz 2011 r. $^{34}$

\subsubsection{Akcja „Wisła”}

W połowie $1946 \mathrm{r}$. oficjalnie zakończono powojenną akcję przesiedleńczą z Polski do ZSRR. Białorusinów i Litwinów pozostałych w Polsce arbitralnie uznano za Polaków. $Z$ punktu widzenia władz nadal jednak istniał ,problem ukraiński”, spowodowany pozostaniem w Polsce ok. 150-160 tys. Ukraińców i Łemków. Rząd ZSRR nie wyraził zgody na kontynuowanie przesiedleń na

${ }^{34}$ Szacunki dotyczące liczebności omawianych mniejszości w okresie PRL oraz wyniki spisów ludności z początku XXI w. zostały omówione w rozdziale czwartym. 
teren radzieckiej Ukrainy ${ }^{35}$, a pozostawienie tej ludności w dotychczasowych miejscach zamieszkania rujnowało forsowaną przez komunistów ideę jednolitej etnicznie Polski. Ponadto duże obszary południowo-wschodniej Polski nadal znajdowały się poza kontrolą polskich władz. Przesiedlenia z lat 1944-1946 osłabiły zbrojne podziemie ukraińskie, jednak go nie zlikwidowały, zdecydowanie spadła liczba ofiar, ale wciąż bardzo utrudnione było administrowanie południowo-wschodnim pograniczem Polski.

W 1947 r. polskie władze zorganizowały i przeprowadziły wojskową operację „Wisła”, czyli przymusowe przesiedlenie wszystkich pozostałych w Polsce Ukraińców na obszar tzw. Ziem Odzyskanych. Akcja „Wisła” - jej geneza, przebieg, uwarunkowania - jest szeroko opisana w literaturze naukowej, głównie historycznej, ale także politologicznej, geograficznej i socjologicznej ${ }^{36}$. Nadal budzi liczne spory, kontrowersje, emocje zarówno wśród zwykłych mieszkańców, zwłaszcza narodowości ukraińskiej i łemkowskiej, jak i wśród naukowców oraz polityków. Cześś badaczy (m.in. R. Drozd, S. Dudra, B. Halczak, I. Hałagida, E. Mironowicz, E. Misiło, G. Motyka) ocenia ją jednoznacznie negatywnie, podkreśla głównie polityczne cele akcji „Wisła”, dążenie władz polskich do asymilacji, likwidacji mniejszości ukraińskiej, martyrologię przesiedlanych Ukraińców i Łemków. Polemizujący z nimi naukowcy (m.in. P. Eberhardt, L. Olejnik) akcentują jej militarne uwarunkowania, antypolską działalność UPA, znaczenie rozbicia struktur i zaplecza zbrojnego podziemia ukraińskiego, jednocześnie wyraźnie podkreślając niehumanitarny przebieg przesiedleń oraz olbrzymie koszty moralne.

Są to kwestie bardzo trudne do jednoznacznej oceny i osądu. Nie można rozpatrywać akcji „Wisła” w oderwaniu od ówczesnych uwarunkowań historycznych i politycznych, w oderwaniu od zbrojnej działalności nacjonalistycznego podziemia ukraińskiego, korzystającego z pomocy (w większym lub mniejszym zakresie) zamieszkującej południowo-wschodnią Polskę ludności ukraińskiej. $\mathrm{Z}$ kolei $\mathrm{w}$ tym samym okresie $\mathrm{z}$ ówczesną władzą walkę zbrojną prowadziły liczne polskie ugrupowania antykomunistyczne, jednak nie powodowało to przesiedleń popierających je Polaków. Ponadto nic nie tłumaczy i nie usprawiedliwia stosowania przez władze zasady odpowiedzialności zbiorowej w stosunku do

${ }^{35}$ Jedną z przyczyn była obawa władz radzieckich, że dalszy masowy napływ Ukraińców z Polski może wzmocnić antykomunistyczną opozycję w ZSRR (Drozd 2010).

${ }^{36}$ M.in. A. Szcześniak, W. Szota (1973), A. Kwilecki (1974), M. Nyczanka (1987), H. Duć-Fajfer (1992), E. Misiło (1992, 1993), K. Pudło (1992), F. Kusiak (1994), R. Drozd (1997, 2001, 2007), G. Motyka (1999, 2011a), E. Mironowicz (2000), I. Hałagida (2002), L. Olejnik (2003), S. Dudra (2008), R. Drozd, B. Halczak (2010), P. Eberhardt (2010a), B. Halczak (2010b). 
własnych obywateli, wyłącznie według kryterium narodowościowego. Trudno też zgodzić się z tezą L. Olejnika (2003), że pojawiające się w ówczesnych dokumentach stwierdzenie o ,asymilacji Ukraińców” można rozumieć jako „ułatwienie adaptacji w nowych warunkach”. Zarówno ówczesna, jak i późniejsza praktyka polityczno-administracyjna polskich władz dobitnie wskazywała, iż chodziło o asymilację narodowościową.

Akcja „Wisła” miała dwa główne cele: doraźny cel wojskowy oraz perspektywiczny cel polityczny. Celem wojskowym była likwidacja zbrojnego podziemia ukraińskiego, położenie kresu działalności UPA na obszarze południowo-wschodniej Polski, przejęcie kontroli nad tym regionem przez polską administrację. Jednak zasadniczy był cel polityczny, czyli „rozwiązanie problemu ukraińskiego" w Polsce przez przesiedlenie i celowe rozproszenie Ukraińców na obszarze północnej i zachodniej Polski, co miało doprowadzić do ich asymilacji, polonizacji, czyli faktycznej likwidacji mniejszości ukraińskiej. Polskie władze komunistyczne postanowiły skorzystać ze stalinowskich wzorców „rozwiązywania" problemów narodowościowych za pomocą zasady zbiorowej odpowiedzialności wobec ludności cywilnej i przymusowych przesiedleń całych narodowości. Był to kolejny etap działań mających doprowadzić od przekształcenia Polski w państwo jednonarodowe.

W polskich archiwach brak jest jakiejkolwiek informacji dotyczącej współpracy władz polskich i radzieckich przy planowaniu i przeprowadzeniu akcji „Wisła”, mimo to - jak pisał L. Olejnik (2003) - „możliwość taką należy brać pod uwage”. R. Drozd (1997, 2010) uważał, że inicjatorem akcji „Wisła” nie była strona radziecka, choć nie ulega wątpliwości, że bez aprobaty Moskwy polscy komuniści nie mogli przeprowadzić takiej operacji.

W tym okresie pojawiały się pogłoski, zarówno wśród polskich mieszkańców południowo-wschodniego pogranicza, jak i lokalnych władz, o możliwości przesunięcia granicy polsko-radzieckiej na zachód. Pretekstem miało być zamieszkiwanie na tym obszarze Ukraińców oraz nadal nieustabilizowana sytuacja polityczno-militarna. Miało to wpływ na poglądy lokalnych działaczy podkreślających potrzebę całkowitej pacyfikacji tego regionu (Olejnik 2003). Wydaje się, że obawy te były formułowane na wyrost, zwłaszcza że kilka lat później, w 1951 r., Stalin nie potrzebował żadnego pretekstu, żeby narzucić polskim władzom zmianę przebiegu granicy.

Przygotowania do przymusowego wysiedlenia Ukraińców na ziemie zachodnie rozpoczęły się prawdopodobnie na początku 1947 r., choć rozmowy różnych gremiów polityczno-wojskowych dotyczące takiego scenariusza miały miejsce już w 1946 r., a nawet w połowie 1945 r. Bezpośrednim pretekstem oraz propagandowym argumentem wydania decyzji o wysiedleniu była śmierć ów- 
czesnego wiceministra obrony narodowej gen. Karola Świerczewskiego w zasadzce pod Baligrodem 28 marca 1947 r. (Mironowicz 2000, Olejnik 2003, Drozd 2010).

Akcja „Wisła” trwała od 28 kwietnia do 31 lipca 1947 r. ${ }^{37}$. Przeprowadziło ją 17-18 tys. żołnierzy Grupy Operacyjnej (GO) „Wisła” pod dowództwem gen. Stefana Mossora, wspomaganych przez blokujące granice oddziały radzieckie i czechosłowackie ${ }^{38}$. Polegała na jednoczesnym działaniu zbrojnym przeciwko UPA, przymusowym przesiedlaniu ludności oraz akcji propagandowej. $\mathrm{W}$ dokumentach podkreślono, że wysiedleniem mają być objęte „wszystkie odcienie narodowości ukraińskiej [...] z Łemkami włącznie" (Olejnik 2003).

Wysiedlenie było przymusowe bez prawa wyboru miejsca osiedlenia. Objęło całą ludność ukraińskojęzyczną z południowo-wschodniej Polski (Ukraińców, Łemków, Bojków), wszystkich, których polskie władze uznawały za Ukraińców, także członków rodzin mieszanych, funkcjonariuszy PPR, byłych komunistycznych partyzantów, żołnierzy Wojska Polskiego i Armii Czerwonej, pracowników administracji, duchowieństwo greckokatolickie i prawosławne. Nie miało żadnego znaczenia, czy wysiedlany brał udział w działalności UPA, czy też ni $^{39}$. Część Ukraińców starała się uniknąć wysiedlenia: ukrywano się w lasach, pisano podania do władz, próbowano załatwić dokumenty stwierdzające polską narodowość, zwracano się o pomoc do krewnych w USA. Jedynym skutecznym sposobem uniknięcia wysiedlenia było - wydawane przez niektórych polskich duchownych - zaświadczenie potwierdzające wyznanie rzymskokatolickie. Przesiedlono ok. 140 tys. Ukraińców ${ }^{40}$ (w tym szacunkowo ok. 30 tys. Łemków)

${ }^{37}$ Według niektórych historyków (Drozd 1997, 1998, 2010, Mironowicz 2000) wysiedlenia w ramach akcji „Wisła” trwały jeszcze w latach 1949-1950, a nawet w 1952 r. Jednak według L. Olejnika (2003) dotyczyły one ponownych wysiedleń osób, które powróciły z północnej i zachodniej Polski.

${ }^{38}$ Jednostki Wojska Polskiego (także lotnictwo) uczestniczące w akcji „Wisła” miały oficjalną zgodę na przekraczanie granicy czechosłowackiej w pościgu za oddziałami UPA (Olejnik 2003, Dudra 2008).

39 Wysiedlono także Romów wyznania greckokatolickiego, tylko Ukraińcy i Łemkowie zatrudnieni w przemyśle naftowym oraz kolejarze, pracownicy tartaków i fabryk, z powodów gospodarczych mieli zostać wysiedleni w późniejszym terminie, po zastąpieniu ich Polakami (Drozd, Halczak 2010). Z tego powodu np. w Ropience pozostawiono 635 osób, w Zagórzu 326, w Komańczy 176 (Dudra 2008).

${ }^{40}$ Trudno ustalić jedną precyzyjną liczbę. Według dokumentów z archiwum MSWiA do końca lipca 1947 r. w 428 transportach wysiedlono 136697 osób, według danych Sztabu Generalnego WP wysiedlono 140575 osób (Olejnik 2003), według dokumentacji opracowanej przez E. Misiło (1993) wysiedlono 139457 osób, według obliczeń R. Drozda (1997, 1998, 2001, 2010) do połowy sierpnia 1947 r. wysiedlono 140660 osób, natomiast łącznie z późniejszymi deportacjami liczba wysiedlonych sięgała, według niego, 150 tys. 
z 15 powiatów, w tym z siedmiu powiatów województwa rzeszowskiego 85,3 tys., z siedmiu powiatów województwa lubelskiego 44,7 tys. oraz z jednego powiatu województwa krakowskiego 10,5 tys. (ryc. 9) (Szcześniak, Szota 1973, Misiło 1992, 1993, Mironowicz 2000, Olejnik 2003, Gawryszewski 2005).

Wysiedlani Ukraińcy i Łemkowie mieli w zależności od sytuacji zazwyczaj od 24 do 48 godzin na spakowanie i przygotowanie do wyjazdu, jednak często było to kilkanaście lub zaledwie kilka godzin. Ograniczano ilość sprzętu i inwentarza, który można było zabrać, wszystko odbywało się w asyście oddziałów wojska, w atmosferze powszechnego strachu i niepewności. Według wspomnień świadków były przypadki kradzieży, podpaleń, pobicia, zabójstw (Drozd 1997, Motyka 1999, 2011a, Hałagida 2002, Dudra 2008, Drozd, Halczak 2010). W punktach załadunkowych przesiedleńcy byli dzieleni przez funkcjonariuszy Urzędu Bezpieczeństwa na trzy kategorie: A - niebezpieczni Ukraińcy, B - niepewni, C - nieszkodliwi. Podział ten miał ułatwić rozproszenie rodzin ukraińskich w nowych miejscach osiedlenia, zalecano, aby w jednej wsi umieszczać tylko jedną rodzinę zaliczaną do grupy A lub B oraz do pięciu rodzin $\mathrm{z}$ grupy $\mathrm{C}$. W praktyce takie działanie bardzo często nie było realizowane, choćby dlatego, że liczba rodzin z kategorii A i B przewyższała liczbę wsi przeznaczonych dla przesiedleńców, ponadto władze powiatowe nie zawsze dostawały listy Ukraińców z podziałem na poszczególne kategorie (Drozd 1997, Dudra 2008).

Podczas trzech miesięcy działań wojskowych GO „Wisła” zabito 623 członków Organizacji Ukraińskich Nacjonalistów i Ukraińskiej Powstańczej Armii (OUN-UPA), ujęto 796, aresztowano 1582 podejrzanych o współpracę z UPA, zlikwidowano kierownictwo i rozbito główne siły zbrojnego podziemia ukraińskiego. Kilka oddziałów UPA w czerwcu 1947 r. przekroczyło granicę z Czechosłowacją i próbowało, najczęściej bezskutecznie, przedostać się do amerykańskiej strefy okupacyjnej w Niemczech (Olejnik 2003). Akcja „Wisła” z pewnością przyspieszyła i ułatwiła likwidację zbrojnej działalności UPA w Polsce.

Podczas akcji wysiedleńczej osoby cywilne podejrzane o sprzyjanie OUN-UPA przetrzymywano w Centralnym Obozie Pracy w Jaworznie. Przebywało w nim łącznie 3873 Ukraińców - głównie chłopów (mężczyzn, kobiet i dzieci), ale także inteligencji i duchownych greckokatolickich. $Z$ powodu bardzo trudnych warunków, ciężkiej pracy, brutalnych przesłuchań, 161 osób poniosło śmierć (Drozd 1998, 2001, Olejnik 2003).

W ramach akcji „Wisła” Ukraińcy i Łemkowie zostali rozmieszczeni na obszarze północnej i zachodniej Polski (tab. 4, ryc. 9). Początkowo przesiedleńców kierowano tylko na Pomorze oraz Warmię i Mazury. Dopiero w trakcie 
akcji, kiedy okazało się, że ich liczba przekracza możliwości osadnicze tych regionów ${ }^{41}$, postanowiono skierować Ukraińców i Łemków na pozostałe obszary poniemieckie. Ostatecznie najwięcej przesiedleńców skierowano do ówczesnych województw: olsztyńskiego (55 tys.), szczecińskiego (48,5 tys.) i wrocławskiego (21,3 tys.). Byli również osiedlani w województwach: gdańskim (6,8 tys.), poznańskim (8 tys.) i białostockim (1 tys.). Ukraińców przesiedlano głównie na Warmię i Mazury oraz Pomorze, natomiast Łemków na Dolny Śląsk i ziemię lubuską ${ }^{42}$. Do województw północnej Polski przesiedlono łącznie 111383 osoby (79,2\%), a na obszar zachodniej i południowo-zachodniej Polski 29277 osób (20,8\%) (Drozd 1997, tab. 4).

Przesiedleńców z akcji „Wisła” początkowo wolno było rozmieścić w odległości nie mniejszej niż $50 \mathrm{~km}$ od granic lądowych, $30 \mathrm{~km}$ od granic morskich i miast wojewódzkich, $10 \mathrm{~km}$ od byłej granicy polsko-niemieckiej z $1939 \mathrm{r}$. oraz tak, by nie tworzyli w powiatach skupisk przekraczających $10 \%$ ogółu mieszkańców. W jednej wsi umieszczano zazwyczaj tylko kilka rodzin ukraińskich, unikano tworzenia zwartych grup osadniczych. Pełne przestrzeganie tych zarządzeń okazało się w praktyce niemożliwe, jednak pomimo to doprowadziło do bardzo silnego rozproszenia przesiedleńców. W założeniach władz miało to przyspieszyć asymilację i zapobiec w przyszłości jakimkolwiek próbom organizacji mniejszości ukraińskiej w Polsce. W ostatecznym rozmieszczeniu wysiedlonej ludności kierowano się przede wszystkim chłonnością osadniczą poszczególnych powiatów i gromad, najczęściej bez uwzględniania czynnika politycznego, który determinował całą akcję 33 (Pudło 1992, Drozd 1997, 2007, Mironowicz 2000, Hałagida 2002, Dudra 2008, Drozd, Halczak 2010).

${ }^{41}$ Wiele wskazuje na to, że w trakcie przygotowań do akcji „Wisła” władze nie zdawały sobie sprawy, ilu Ukraińców pozostało w Polsce. Początkowo szacowano, że trzeba będzie przesiedlić tylko 20 tys. osób, następnie plany sporządzane przed rozpoczęciem wysiedleń przewidywały deportację ok. 74-90 tys. osób, w trakcie realizacji okazało się, że wysiedleniu podlega ponad 140 tys. osób (Olejnik 2003, Dudra 2008).

${ }^{42} \mathrm{Na}$ obszar północnej Polski zostali wysiedleni Łemkowie z rejonu przesiedleńczego „Sanok” (obejmującego m.in. wschodnią część Łemkowszczyzny), których najwcześniej objęto akcją przesiedleńczą. Większość Łemków przesiedlono w drugim etapie i skierowana na Dolny Śląsk i ziemię lubuską. Z powiatów krośnieńskiego, jasielskiego i gorlickiego na ogólną liczbę 53 transportów, 45 skierowano do zachodniej Polski, z powiatu nowosądeckiego wszystkie transporty wysłano na Śląsk (Kwilecki 1970, 1974, Dudra 2008).

${ }^{43}$ Najpowszechniej łamanym zarządzeniem była zasada umieszczania tylko jednej rodziny z kategorii A i B w jednej wsi oraz zachowanie limitu 10\% przesiedleńców w powiecie (Drozd 1997, 1998, Dudra 2008). 
Tabela 4. Rozmieszczenie przesiedleńców z akcji „Wisła” w 1947 r. ${ }^{44}$

\begin{tabular}{|c|c|c|c|c|c|}
\hline \multicolumn{6}{|c|}{ Przesiedleńcy w województwie olsztyńskim } \\
\hline \multirow{2}{*}{ Powiat } & \multicolumn{3}{|c|}{ liczba } & \multicolumn{2}{|c|}{ odsetek } \\
\hline & transportów & rodzin & osób & na wsi & w powiecie \\
\hline Bartoszyce & 12 & 911 & 3423 & 39,1 & 20,6 \\
\hline Braniewo & 19 & 1746 & 6680 & 55,7 & 35,2 \\
\hline Giżycko & 11 & 925 & 3937 & 22,4 & 12,4 \\
\hline Iława & 12 & 914 & 4142 & 47,8 & 41,2 \\
\hline Kętrzyn & 13 & 1336 & 5506 & 29,5 & 18,2 \\
\hline Lidzbark & 11 & 839 & 3744 & 15,9 & 11,2 \\
\hline Morąg & 12 & 917 & 3969 & 16,1 & 12,1 \\
\hline Mrągowo & 4 & 278 & 1117 & 3,8 & 3,0 \\
\hline Nidzica & 3 & 211 & 747 & 5,1 & 3,8 \\
\hline Olsztyn & 2 & 148 & 610 & 1,9 & 7,1 \\
\hline Ostróda & 4 & 445 & 1597 & 5,9 & 3,7 \\
\hline Pasłęk & 15 & 1392 & 5861 & 36,3 & 25,7 \\
\hline Pisz & 2 & 162 & 566 & 4,2 & 2,8 \\
\hline Reszel & 8 & 562 & 2383 & 10,6 & 7,4 \\
\hline Susz & 6 & 778 & 3132 & 16,5 & 9,4 \\
\hline Szczytno & 2 & 150 & 566 & 2,4 & 1,7 \\
\hline Węgorzewo & 19 & 1658 & 7109 & 45,3 & 35,1 \\
\hline Razem & 155 & 13372 & 55089 & 16,9 & 11,6 \\
\hline \multicolumn{6}{|c|}{ Przesiedleńcy w województwie szczecińskim } \\
\hline \multirow{2}{*}{ Powiat } & \multicolumn{3}{|c|}{ liczba } & \multicolumn{2}{|c|}{ odsetek } \\
\hline & transportów & rodzin & osób & na wsi & w powiecie \\
\hline Białogard & 7 & 417 & 1847 & 6,7 & 3,8 \\
\hline Bytów & 6 & 452 & 1879 & 14 & 10,3 \\
\hline
\end{tabular}

${ }^{44}$ R. Drozd podkreślał, że wszystkie dane dotyczące liczby osiedlonych Ukraińców i Łemków na ziemiach zachodnich są wielkościami przybliżonymi. Historycy zajmujący się tą tematyką zaznaczają, że kwestia określenia dokładnej liczby przesiedleńców w poszczególnych powiatach napotyka wiele trudności. Liczby podawane w zachowanych archiwaliach różnią się, odmienne dane znajdują się w dokumentach Centralnego Archiwum Wojskowego i Państwowego Urzędu Repatriacyjnego. Władze osiedleńcze często same nie orientowały się, ile ludności osiedliło się na ich terenie, sytuację dodatkowo komplikowały wtórne przesiedlenia (tzw. przerzuty) w latach 1947-1948 w obrębie ziem zachodnich (Misiło 1993, Drozd 1997, Olejnik 2003, Dudra 2008). 


\begin{tabular}{|c|c|c|c|c|c|}
\hline Choszczno & 6 & 388 & 1694 & 10,2 & 7,3 \\
\hline Człuchów & 22 & 1662 & 6930 & 26 & 20,8 \\
\hline Drawsko & 9 & 478 & 2046 & 13 & 8,3 \\
\hline Gryfice & 9 & 587 & 2801 & 15,1 & 9,2 \\
\hline Kołobrzeg & 10 & 616 & 2593 & 9,3 & 7,7 \\
\hline Koszalin & 11 & 816 & 3581 & 14,4 & 8 \\
\hline Łobez & 8 & 513 & 2175 & 13,3 & 9 \\
\hline Miastko & 8 & 614 & 2420 & 16,2 & 13,6 \\
\hline Myślibórz & 4 & 419 & 1544 & 8,5 & 5,6 \\
\hline Nowogard & 4 & 408 & 1555 & 8,4 & 5,1 \\
\hline Pyrzyce & 4 & 385 & 1400 & 6,7 & 5,4 \\
\hline Sławno & 10 & 581 & 2623 & 10,2 & 7,7 \\
\hline Słupsk & 10 & 731 & 3228 & 9,8 & 4,8 \\
\hline Stargard & 12 & 874 & 3855 & 17,9 & 9,8 \\
\hline Szczecinek & 12 & 831 & 3626 & 9,6 & 6,5 \\
\hline Wałcz & 8 & 647 & 2668 & 11,6 & 6,8 \\
\hline Razem & 160 & 11419 & 48465 & 12,1 & 7,8 \\
\hline \multicolumn{6}{|c|}{ Przesiedleńcy w województwie wrocławskim } \\
\hline \multirow{2}{*}{ Powiat } & \multicolumn{3}{|c|}{ liczba } & \multicolumn{2}{|c|}{ odsetek } \\
\hline & transportów & rodzin & osób & na wsi & w powiecie \\
\hline Głogów & 8 & 196 & 1809 & 4,8 & 4,3 \\
\hline Góra & 6 & 935 & 1071 & 4,9 & 3,8 \\
\hline Kożuchów & 7 & 315 & 1887 & 9,7 & 5,0 \\
\hline Legnica & 9 & 468 & 2388 & 4,9 & 3,6 \\
\hline Lubin & 10 & 538 & 2839 & 17,1 & 14,1 \\
\hline Milicz & 3 & 244 & 907 & 3,8 & 2,9 \\
\hline Namysłów & 1 & 33 & 172 & 1,0 & 0,8 \\
\hline Oleśnica & 6 & 456 & 1692 & 5,4 & 3,4 \\
\hline Oława & 3 & 312 & 1090 & 5,0 & 3,9 \\
\hline Środa & 4 & 392 & 1166 & 13,2 & 10,1 \\
\hline Szprotawa & 7 & 279 & 1810 & 4,3 & 3,7 \\
\hline Trzebnica & 2 & 152 & 482 & 1,9 & 1,5 \\
\hline Wołów & 10 & 623 & 2895 & 9,5 & 7,6 \\
\hline Złotoryja & 4 & 199 & 1027 & 3,8 & 3,0 \\
\hline Razem & 80 & 5142 & 21235 & 6,7 & 4,7 \\
\hline
\end{tabular}




\begin{tabular}{|c|c|c|c|c|c|}
\hline \multicolumn{6}{|c|}{ Przesiedleńcy w województwie poznańskim } \\
\hline \multirow{2}{*}{ Powiat } & \multicolumn{3}{|c|}{ liczba } & \multicolumn{2}{|c|}{ odsetek } \\
\hline & transportów & rodzin & osób & na wsi & w powiecie \\
\hline Gorzów & 3 & 195 & 846 & 2,8 & 1,2 \\
\hline Międzyrzecz & 3 & 173 & 861 & 5,5 & 3,4 \\
\hline Piła & 6 & 283 & 1278 & 7,2 & 3,0 \\
\hline Skwierzyna & 3 & 153 & 677 & 7,9 & 5,4 \\
\hline Strzelce & 7 & 378 & 1780 & 7,1 & 5,8 \\
\hline Sulęcin & 2 & 135 & 643 & 4,1 & 2,8 \\
\hline Świebodzin & 4 & 255 & 1187 & 5,2 & 3,5 \\
\hline Wschowa & 1 & 43 & 250 & 1,9 & 1,7 \\
\hline Zielona Góra & 2 & 121 & 520 & 2,1 & 1,0 \\
\hline Razem & 31 & 1736 & 8042 & 4,6 & 2,9 \\
\hline \multicolumn{6}{|c|}{ Przesiedleńcy w województwie gdańskim } \\
\hline \multirow{2}{*}{ Powiat } & \multicolumn{3}{|c|}{ liczba } & \multicolumn{2}{|c|}{ odsetek } \\
\hline & transportów & rodzin & osób & na wsi & w powiecie \\
\hline Elbląg & 3 & 284 & 1139 & 13,9 & 3,0 \\
\hline Gdańsk & 2 & 254 & 927 & 2,0 & 0,2 \\
\hline Kwidzyn & 4 & 327 & 1417 & 7,2 & 4,6 \\
\hline Lębork & 6 & 426 & 1864 & 9,2 & 5,8 \\
\hline Malbork & 1 & 144 & 537 & 9,8 & 3,0 \\
\hline Sztum & 3 & 255 & 954 & 5,8 & 4,5 \\
\hline Razem & 14 & 1690 & 6838 & 5,7 & 1,8 \\
\hline \multicolumn{6}{|c|}{ Przesiedleńcy w województwie białostockim } \\
\hline \multirow{2}{*}{ Powiat } & \multicolumn{3}{|c|}{ liczba } & \multicolumn{2}{|c|}{ odsetek } \\
\hline & transportów & rodzin & osób & na wsi & w powiecie \\
\hline Ełk & 2 & 174 & 726 & 4,1 & 2,6 \\
\hline Olecko & 1 & 78 & 265 & 1,9 & 1,6 \\
\hline Razem & 3 & 252 & 991 & 3,1 & 2,2 \\
\hline
\end{tabular}

Źródło: R. Drozd (1997, s. 91, 96, 101, 104, 108). 


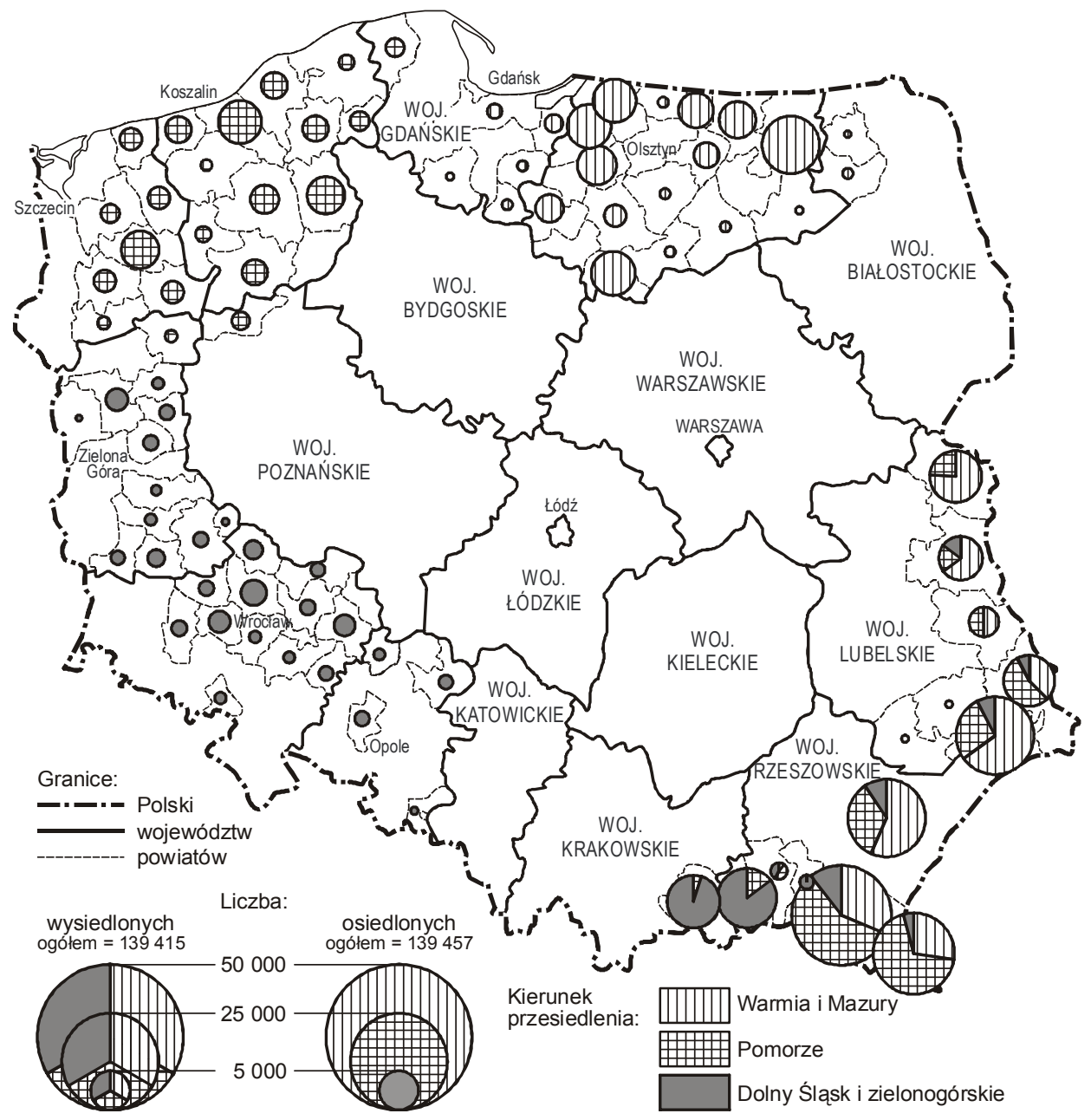

Ryc. 9. Wysiedlenie Ukraińców i Łemków w ramach akcji „Wisła” w 1947 r.

Źródło: A. Gawryszewski (2005, s. 499)

Obszar, na którym osiedlono Ukraińców i Łemków, był zdecydowanie bardziej rozległy niż ten, z którego ich wysiedlono ${ }^{45}$, całkowicie zmieniło się rozmieszczenie mniejszości ukraińskiej i łemkowskiej (ryc. 9). Stopień rozproszenia Łemków w zachodniej Polsce badał m.in. A. Kwilecki (1974). Jako przykład podał 178 rodzin (928 osób) przesiedlonych z jednej łemkowskiej wsi (Florynka) i rozmieszczonych w 30 różnych miejscowościach w sześciu powiatach, przeważnie od jednej do pięciu rodzin w jednej wsi. Mimo bardzo dużego

${ }^{45}$ Ukraińców i Łemków wysiedlono z 15 powiatów, a osiedlono początkowo na obszarze 66, docelowo 71 powiatów (Gawryszewski 2005). 
rozproszenia przesiedleńców, niektóre gminy, zwłaszcza w północnej części województwa olsztyńskiego, odznaczały się bardzo wysokim odsetkiem Ukraińców, np.: w powiecie węgorzewskim, w gminie Banie Mazurskie wynosił on $71 \%$, Kuty $-64 \%$, Budry $-50 \%$, Wegorzewo $-45 \%$. Na 92 wsie w tym powiecie aż w 57 przekroczono 40\% odsetek Ukraińców wśród ogółu ich mieszkańców. Niektóre wsie w całości zasiedlili Ukraińcy, np. w powiecie węgorzewskim Gębałka i Ziemiany, w braniewskim Podlipie, Siwy Staw, Szczepanowo, w szczecineckim Bielica. Przekroczenie limitów osadniczych spowodowało interwencję władz centralnych i żądanie dostosowania rozmieszczenia rodzin ukraińskich do wcześniejszych wymogów. W większości powiatów nie zostało to zrealizowane, głównie z powodu braku wolnych gospodarstw. Dlatego w listopadzie 1947 r. wytyczne złagodzono, zakaz osiedlania zmniejszono do pasa o szerokości $30 \mathrm{~km}$ od granic lądowych (z tym, że zakaz ten już nie dotyczył granicy z Obwodem Kaliningradzkim ${ }^{46}$ ), $10 \mathrm{~km}$ od granic morskich i $20 \mathrm{~km}$ od miast wojewódzkich, podniesiono jednocześnie dopuszczalny odsetek Ukraińców w jednej wsi do $40 \%$, przy utrzymaniu ograniczenia do $10 \% \mathrm{w}$ jednym powiecie. Oznaczało to konieczność ponownego przesiedlenia kilku tysięcy rodzin (Drozd 1997). Według stanu z 31 grudnia 1947 r., udział ludności ukraińskiej w niektórych powiatach, zwłaszcza województwa olsztyńskiego, nadal był dużo wyższy niż zakładały wytyczne, w powiecie Górowo Iławeckie wynosił 48,2\%, Węgorzewo 41,5\%, Pasłęk 31,7\%, Bartoszyce 30,3\% (Sakson 1998).

Ponowną akcję przesiedleńczą, tym razem w obrębie ziem zachodnich, najczęściej między poszczególnymi powiatami, przeprowadzono w $1948 \mathrm{r} .{ }^{47}$ Miała ona doprowadzić do zwiększenia rozproszenia Ukraińców. Była konsekwencją złej organizacji akcji przesiedleńczej, braku współpracy między administracją poszczególnych szczebli a urzędami bezpieczeństwa. Nie objęto nią wszystkich planowanych rodzin, głównie z powodu braku wolnych gospodarstw, jednak liczba powiatów, w których osiedlono Ukraińców, wzrosła z 66 do ponad 70 (Drozd 1997, Dudra 2008). Mimo to jeszcze pod koniec lat 40. XX w. w niektórych powiatach północnej części województwa olsztyńskiego, w których było najwięcej przesiedleńców a które jednocześnie należały do najbardziej wyludnionych, Ukraińcy tworzyli duże $20-40 \%$ skupiska. Największe stanowiły nadal

46 Była to szczególnie istotna zmiana, usankcjonowała bardzo liczne skupiska Ukraińców w północnej części województwa olsztyńskiego. W sierpniu 1947 r. na 55 tys. przesiedleńców w tym województwie, aż 44 tys. przebywało w „strefie zakazanej” (Olejnik 2003).

${ }^{47}$ Przesiedlenia w 1948 r., tzw. przerzuty, objęły kilka tysięcy rodzin, m.in. w województwie wrocławskim ponownie przesiedlono 296 rodzin (Drozd 1997, 2007), na ziemi lubuskiej (ówczesne województwo poznańskie) 411 rodzin (Dudra 2008). 
powiaty Górowo Iławeckie (42,5\% ogółu mieszkańców), Węgorzewo (36,8\%), Braniewo (27,5\%), Pasłęk (26,5\%), Bartoszyce (21,5\%). W powiatach położonych w innych województwach tylko sporadycznie Ukraińcy stanowili ponad 10\% ogółu mieszkańców (Olejnik 2003).

Przymusowe przesiedlenia miały miejsce także w kolejnych latach. Dotyczyły głównie osób nielegalnie powracających z ziem zachodnich. W kwietniu 1950 r. wysiedlono łemkowskich mieszkańców wsi Biała Woda, Czarna Woda, Jaworki i Szlachtowa, czyli tzw. Rusi Szlachtowskiej w powiecie nowotarskim $^{48}$. W lipcu i sierpniu 1950 r. władze wojewódzkie w Lublinie nakazały ponownie wysiedlić rodziny ukraińskie, które nielegalnie powróciły do powiatów: Biała Podlaska, Hrubieszów, Chełm, Tomaszów Lubelski, Włodawa. Ostatni transport związany pośrednio z akcją „Wisła” wysłano w 1952 r. z powiatu Biała Podlaska, z którego ponownie wysiedlono kilkudziesięciu Ukraińców objętych wcześniej akcją „Wisła” (Drozd 1998, 2010).

Położenie przesiedleńców na nowych miejscach osiedlenia było bardzo ciężkie. Stanęli przed koniecznością przystosowania się do odmiennych warunków klimatycznych, przyrodniczych, gospodarczych, społecznych, kulturowych. Lepsze budynki były już zajęte, dlatego Ukraińców i Łemków lokowano najczęściej w zniszczonych i zaniedbanych gospodarstwach ${ }^{49}$. Zostali rozproszeni, odizolowani od własnego środowiska, poddani inwigilacji, objęci zakazem swobodnego przemieszczania się (a zwłaszcza zakazem powrotu w strony rodzinne), pozbawieni prasy, książek i szkolnictwa we własnym języku oraz - co było szczególnie bolesne dla konserwatywnej, wiejskiej ludności - w konsekwencji delegalizacji Kościoła greckokatolickiego pozbawieni nabożeństw w greckokatolickich cerkwiach i opieki duszpasterskiej. Lokalnej administracji zakazano używania określeń „Ukrainiec”, „ukraiński”, oczywiście nie używano także nazwy „Łemkowie”. W oficjalnych dokumentach posługiwano się zwrotem ,przesiedleniec z akcji W'. Ponadto spotkali się z wrogim przyjęciem Polaków. Poprzednia fala osadników była złożona głównie z ludności polskiej zza Bugu, pamiętającej masakry dokonywane przez UPA na Wołyniu. Uznali oni wszystkich przesiedleńców za „ukraińskich bandytów” (Kwilecki 1964, 1970, 1974,

${ }^{48}$ Według L. Olejnika (2003) zostali oni wysiedleni w 1947 r., na przełomie 1948/ 49 powrócili w Beskidy, po czym w kwietniu 1950 r. zostali wywiezieni do województwa szczecińskiego (34 rodziny).

${ }^{49} \mathrm{~W}$ województwie szczecińskim $75 \%$ gospodarstw przydzielonych Ukraińcom było zniszczonych, z czego 45\% wymagało poważnego remontu, a 30\% odbudowy (Drozd 1998). Według danych Ministerstwa Ziem Odzyskanych, spośród 36 tys. przesiedlonych rodzin ukraińskich ponad 20 tys. osiedlono w budynkach zniszczonych w ponad 50\% i nienadających się do zamieszkania bez remontu (Olejnik 2003). 
Pudło 1992, Drozd 1997, 1998, 2010, Krakowski 1997, Mironowicz 2000, Hałagida 2002, Dudra 2008).

Dla Łemków akcja „Wisła” miała nie tylko konsekwencje terytorialne lub gospodarcze, ale także narodowe, społeczne i mentalne. Poprzez wysiedlenie zostali oficjalnie uznani za część narodu ukraińskiego. W nowych miejscach zamieszkania, na obszarze zachodniej i północnej Polski, dla mieszkających tam Polaków (najczęściej przesiedleńców zza Bugu) nie byli Łemkami, ale tylko i wyłącznie Ukraińcami, współodpowiedzialnymi za działalność UPA i zbrodnie na Wołyniu. Wykreowany przez komunistyczną propagandę bardzo negatywny, wręcz demoniczny wizerunek Ukraińca, przylgnął także do Łemków. Byli oskarżani i rozliczani za winy narodu, z którym duża część spośród nich nigdy się nie utożsamiała (Mironowicz 2007).

Wysiedlenie z 1947 r., w odróżnieniu od wysiedleń z lat 1944-1946, objęło kilkakrotnie mniejszą liczbę osób, lecz było przymusowe, bez prawa wyboru miejsca osiedlenia. Nie wpłynęło na zmniejszenie liczby Ukraińców i Łemków w Polsce, natomiast drastycznie wpłynęło na ich rozmieszczenie (ryc. 9-10). Nieodwracalnie zniszczyło specyficzną strukturę narodowościową, wyznaniową i kulturową południowo-wschodniej Polski. Nastąpiła całkowita zmiana stosunków etnicznych i religijnych, które na tym obszarze pozostawały niezmienne od kilkuset lat. Przestały istnieć wszystkie parafie greckokatolickie. Spalono lub zdewastowano dziesiątki zabytkowych drewnianych cerkwi. Zniszczeniu uległa zarówno kultura materialna, jak i duchowa. Nowo wytyczona granica między Polską a ZSRR stała się granicą narodowościową, językową i wyznaniową. Ukraińcy i Łemkowie, którzy od wieków żyli w tym regionie, w ciagu kilku lat w wyniku przesiedleń zostali usunięci ze swojej etnicznej ojczyzny i rozmieszczeni w dwóch państwach, na obszarze od Dniepru do Odry. Wysiedlenia zmieniły również strukturę etniczną, religijną, językową i kulturową północnej i zachodniej Polski. Obecność w tych regionach skupisk Ukraińców i Łemków jest wyłączną konsekwencją decyzji politycznych z 1947 r. (Barwiński 2008a).

$\mathrm{Na}$ terenach objętych akcją „Wisła” w południowo-wschodniej Polsce, a zwłaszcza w Bieszczadach i na Łemkowszczyźnie, nie nastąpiło szybkie zastąpienie jednej grupy etnicznej przez inną. W Beskidzie Niskim i Bieszczadach, na obszarze ok. 4 tys. $\mathrm{km}^{2}$ opustoszało ponad 320 wsi, a wiele $\mathrm{z}$ nich przestało istnieć. W miejsca, z których wysiedlono Ukraińców i Łemków, przybywali polscy osadnicy, głównie z pobliskich wsi, częściowo również repatrianci z ZSRR. Osadnictwo postępowało jednak bardzo powoli (głównie z powodu nieatrakcyjności rolniczej tych ziem oraz $\mathrm{z}$ obawy przed działalnością UPA) i nie zdołało doprowadzić do wypełnienia lokalnych pustek osadniczych w Karpatach (Reinfuss 1990, Pudło 1992). Według spisu ludności z 1950 r., na 
Łemkowszczyźnie mieszkało zaledwie 31,1 tys. osób. W porównaniu ze stanem z 1931 r. obszar ten utracił ponad 71\% mieszkańców, a w porównaniu z początkiem lat 40. XX w. $-76-78 \%$ mieszkańców ${ }^{50}$. Ponaddwukrotnie zmniejszyło się średnie zaludnienie wsi, pojawiły się wsie bardzo małe. W 1950 r. 1/4 wszystkich wsi na Łemkowszczyźnie była niezamieszkana. Opuszczone i ponownie niezasiedlone obszary zajmował las, którego udział wzrósł z 30\% w drugiej połowie XIX w. aż do 70\% pod koniec XX w. (Soja 2001a, b).

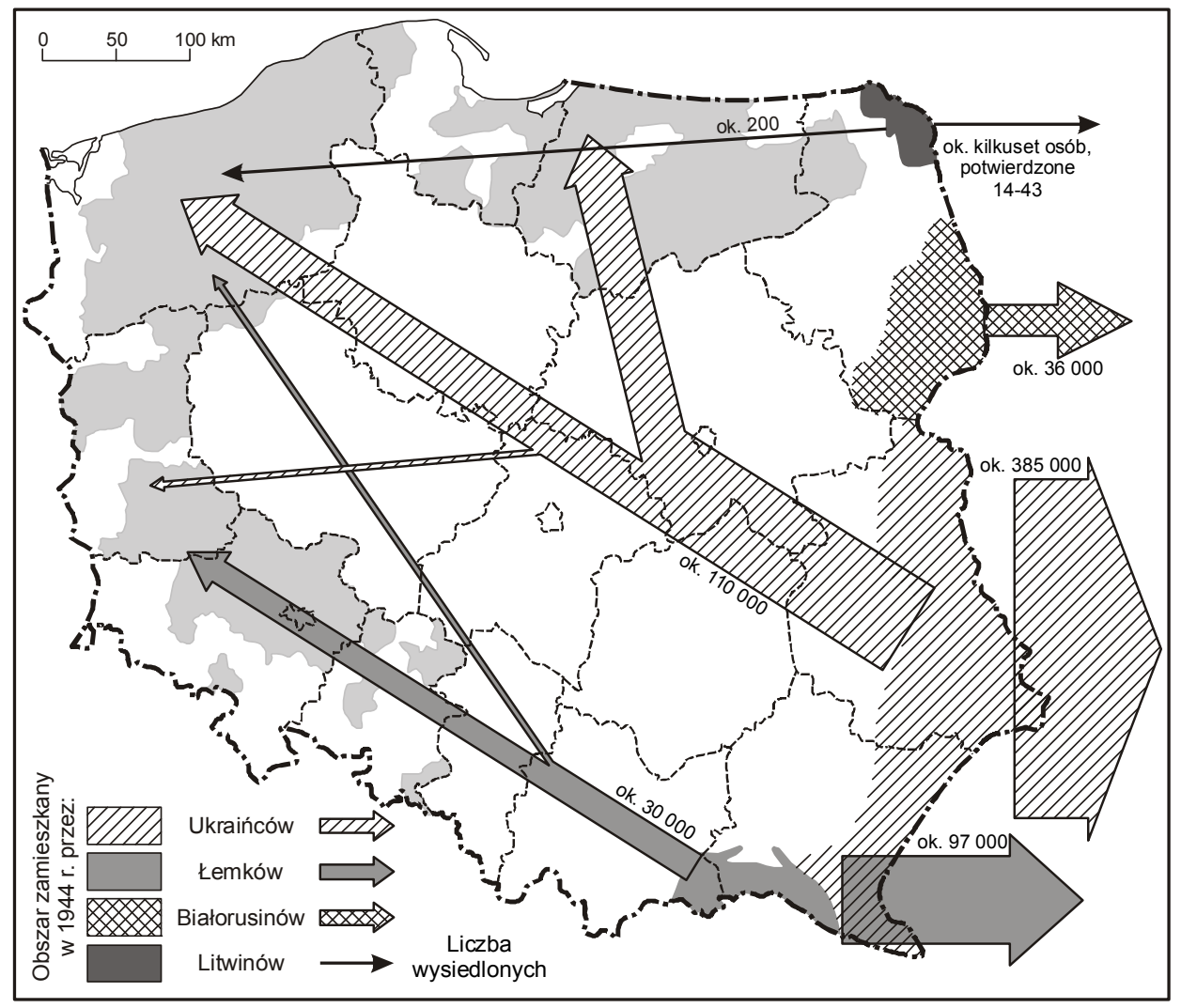

Ryc. 10. Główne kierunki i wielkość przesiedleń Ukraińców, Łemków, Białorusinów i Litwinów w latach 1944-1947

Źródło: opracowanie własne

${ }^{50}$ Według spisu ludności z 1931 r. na Łemkowszczyźnie mieszkało 107,9 tys. osób (Soja 2001a, b), natomiast w latach 40. XX w., bezpośrednio przed przesiedleniami, obszar ten zamieszkiwało szacunkowo ok. 130-140 tys. Łemków (Dudra 2010).

${ }^{51}$ Wysiedlania pojedynczych rodzin ukraińskich, łemkowskich i litewskich na ziemie zachodnie i północne trwały do początku lat 50 . XX w. 
Wysiedlenia doprowadziły do dewastacji i upadku gospodarczego przygranicznych regionów południowo-wschodniej Polski. Mienie pozostawione przez Ukraińców i Łemków zostało rozkradzione lub zniszczone, wiele opuszczonych gospodarstw rozebrano i przeniesiono, kilkadziesiąt tysięcy hektarów gruntów rolnych przeznaczono pod zalesienie, tysiące hektarów leżało odłogiem (Drozd, Halczak 2010).

Ocena wydarzeń z 1947 r. przez Ukraińców i Łemków była i pozostaje jednobrzmiąco negatywna. Zwłaszcza Łemkowie utrzymują, że zostali przesiedleni bez uzasadnienia, że była to niezasłużona, wielka krzywda (Michna 1995). Wśród wysiedlonych powszechne są opinie, że akcja „Wisła” miała na celu likwidację mniejszości ukraińskiej w Polsce, poprzez jej rozproszenie i polonizację (Krakowski 1997). Analizując powojenne wysiedlenia, często pomija się albo marginalizuje ich wymiar ludzki. To, czego nie można ująć w statystykę, czego nie pokazują tabele i mapy, czego $\mathrm{z}$ reguły nie odnajdzie się $\mathrm{w}$ archiwalnych dokumentach, a co było bezpośrednio z nimi związane - to ludzkie dramaty. Największą ceną wysiedleń była tragedia ludzi pod przymusem wyrzucanych z własnych domów, gospodarstw, świątyń, z ziemi, na której żyli od pokoleń, pozbawionych w ciągu kilku godzin dorobku całego życia, wywożonych w nieznane bez możliwości powrotu. Jest to trauma, która pozostaje w nich na zawsze.

\subsubsection{Przełom lat 40. i 50. XX wieku}

Ukraińcy i Łemkowie od początku osiedlenia w północnej i zachodniej Polsce czekali na możliwość powrotu na swą rodzinną ziemię i nie dopuszczali do siebie myśli, że pobyt „na wygnaniu” może trwać dłużej. Powszechna była wśród nich nostalgia za stronami ojczystymi, za dawnym, swojskim otoczeniem. Dochodziły do tego trudności adaptacji związane z odmiennym klimatem i krajobrazem w porównaniu z tym, do którego byli przyzwyczajeni. Na ziemiach zachodnich znaleźli się w nowych dla siebie warunkach geograficznych, kulturowych, technicznych i cywilizacyjnych. $Z$ powodu nieufnego i bardzo często wrogiego nastawienia polskich osadników, krytycznej oceny ukraińskich i łemkowskich cech etnicznych, kulturowych oraz wyznaniowych, a także administracyjnych ograniczeń w swobodzie poruszania się, czuli się „obywatelami drugiej kategorii”. Polacy powielali negatywne stereotypowe wyobrażenia „Ukraińcy-banderowca" popularyzowane przez oficjalną propagandę. Powszechne były konflikty i bójki między polskimi i ukraińskimi mieszkańcami poszczególnych wsi. Obie społeczności żyły we wzajemnej wrogości i izolacji, utrzymując kontakty wyłącznie wewnątrz własnych grup narodowych. Bardzo uciążliwa 
była ciagła inwigilacja przez funkcjonariuszy UB i MO, nękanie przesłuchaniami, rekrutowanie tajnych współpracowników. Wszystkie te elementy utrudniały stabilizację i adaptację $\mathrm{w}$ nowych warunkach. Niektórzy przesiedleńcy załamali się psychicznie i pogrążyli w apatii. Część zabrała się do pracy zarobkowej i urządzania pomieszczeń, jednakże czyniła to w przeświadczeniu, że okres pobytu w północnej i zachodniej Polsce będzie trwał krótko, dlatego początkowo ograniczano się tylko do zupełnie niezbędnych prac. Większość nie remontowała gospodarstw, nie przykładała się także do prac rolnych, chciała wrócić i nie była zainteresowana zagospodarowaniem się w nowych - niechcianych i obcych - miejscach osiedlenia (Kwilecki 1970, 1974, Drozd 1997, 1998, Dudra 2008, Drozd, Halczak 2010).

W grudniu 1948 r. władze osiedleńcze zaczęły podejmować pod naciskiem Ministerstwa Ziem Odzyskanych (MZO) działania zmierzające do uregulowania podstawowych spraw majątkowych osadników z akcji „Wisła”. Rozpoczęto nadawanie tytułów własności na już użytkowane gospodarstwa oraz przydzielanie gospodarstw tym, którzy dotąd ich nie otrzymali. Miało to na celu trwałe związanie Ukraińców i Łemków z nowymi miejscami zamieszkania. Latem, 27 lipca 1949 r., dekretem Rady Ministrów zostały przejęte przez państwo gospodarstwa oraz mienie „niepozostające w faktycznym władaniu właścicieli”, położone we wschodniej i południowej Polsce. Dekret ten praktycznie zamykał przesiedleńcom drogę powrotu na rodzinną ziemię ${ }^{52}$. Dwa miesiące później, 28 września 1949 r., na mocy kolejnego dekretu, Skarb Państwa przejął mienie Kościoła greckokatolickiego oraz ukraińskich instytucji i organizacji. Starano się nie dopuścić do odrodzenia ukraińskiego życia narodowego, kulturowego i religijnego. Po kilku latach majątek Kościoła unickiego przeszedł na własność Kościoła rzymskokatolickiego, częściowo także Polskiego Autokefalicznego Kościoła Prawosławnego, jednak nadal dużą jego częścią zarządzało państwo (Pactwa 1992, Pudło 1992, Drozd 1998).

Parafie prawosławne na tzw. Ziemiach Odzyskanych zaczęły powstawać już w 1946 r., a po akcji „Wisła” miały za zadanie objąć opieką duszpasterską przesiedleńców. Obrządek ten był przez władze traktowany zupełnie inaczej niż greckokatolicki, nie utożsamiono go z ukraińską tradycją i świadomością narodowa. Dlatego władze komunistyczne sprzyjały powstawaniu cerkwi prawosławnych, zwłaszcza w skupiskach grekokatolików. Ukraińcy i Łemkowie wy-

${ }^{52} \mathrm{~W}$ dekrecie tym nic nie wspominano m.in. o lasach, tymczasem np. na Łemkowszczyźnie w posiadaniu Łemków znajdowały się rozległe obszary leśne. Zostały one przejęte przez państwową administrację leśną całkowicie bezprawnie, co w latach 90. $\mathrm{XX}$ w. stało się podstawą licznych procesów sądowych dotyczących zwrotu lasów w Beskidach. 
znania greckokatolickiego zostali zmuszeni do nielegalnego i okazjonalnego zaspokajania swoich potrzeb religijnych $\mathrm{w}$ prywatnych pomieszczeniach lub z konieczności w świątyniach rzymskokatolickich albo prawosławnych. Stanęli wobec dylematu: uczęszczać na nabożeństwa rzymskokatolickie, czy dochować wierności obrządkowi wschodniemu, bez możliwości przynależenia do Kościoła greckokatolickiego, czyli przejść na prawosławie. Zdecydowana większość wybierała prawosławie. Większe znaczenie miała liturgia, obrządek wschodni, niż formalna przynależność administracyjna. Równie ważną przyczyną była obawa przed polonizacją, ściśle związaną z katolicyzmem. Ponadto w latach 19471952 Cerkiew prawosławna była jedyną instytucją stanowiącą wsparcie dla Ukraińców i Łemków (Pactwa 1992, Michna 1995, Dudra 2004, Drozd, Halczak 2010).

W latach 1948-1949 miały miejsce poufne konsultacje polsko-radzieckie dotyczące ludności ukraińskiej pozostałej w Polsce. Miały one związek z inicjatywą władz USRR, dotyczącą wznowienia repatriacji Ukraińców z Polski do USRR. Ostatecznie KC PZPR zdecydował o indywidualnym, pozytywnym rozpatrywaniu podań Ukraińców, chcących wyjechać do USRR, ale jednocześnie odrzucono możliwość wznowienia wzajemnej repatriacji. Polskie władze skłaniały się do takiej umowy na szczeblu ZSRR, a nie tylko USRR, ponieważ umożliwiałaby ona powroty Polaków z całego terytorium radzieckiego (Olejnik 2003).

Latem 1949 r. nastąpił nagły zwrot w polityce władz wobec Białorusinów na Podlasiu. Podjęto decyzję - i niezwłocznie przystąpiono do jej realizacji ponownego uruchomienia szkolnictwa białoruskiego. Działania te były konsekwencją zmiany polityki narodowościowej partii, walką z tzw. odchyleniem prawicowo-nacjonalistycznym, która uczyniła nieaktualne hasło Polski jednolitej etnicznie. Paradoksalnie, odbyło się to przy braku jakichkolwiek oznak zainteresowania, a nawet przy wyraźnej niechęci Białorusinów, którzy obawiali się nowych podziałów i konfliktów z Polakami oraz perspektyw dalszego kształcenia i zatrudnienia swoich dzieci. Mimo to do wiosny 1950 r. otwarto 39 białoruskich szkół podstawowych oraz dwa licea, w Hajnówce i Bielsku Podlaskim. Zgodnie z zaleceniami władz oświatowych, wszystkich prawosławnych traktowano jako Białorusinów, a katolików jako Polaków. Szkoły otwierano według struktury wyznaniowej, a nie etnicznej czy językowej. Nie tworzono równolegle żadnych innych białoruskich struktur organizacyjnych (Mironowicz 1993, 1998, 2000, 2005, Darski 1994, Chałupczak, Browarek 1998).

Poza kwestią szkolnictwa, początek lat 50. XX w. nie przyniósł zasadniczej zmiany w sytuacji mniejszości narodowych na Podlasiu. Był to okres intensywnej migracji ze wsi do miast, która przyspieszała procesy asymilacji, upo- 
dabniania się do polskiej większości. Przemiany polityczne dawały chłopom białoruskim realną szansę awansu społecznego, ekonomicznego, politycznego, dlatego też nowy ustrój był przez nich odbierany zdecydowanie pozytywnie i aktywnie popierany. System stalinowski, który dla większości Polaków był tragedią i zniewoleniem, Białorusinom stwarzał szanse wybicia się. Czynniki socjalne i społeczne były dla nich dużo istotniejsze niż narodowe. Jak pisze E. Mironowicz (2010), „w przypadku Białorusinów wszystko to, co się działo po wojnie, było przyjmowane jako zwrot ku lepszemu". Powstająca wówczas nowa, lokalna elita wywodząca się z mniejszości białoruskiej (urzędnicy, milicjanci, wojskowi, nauczyciele), powszechnie posługująca się językiem polskim i nieeksponująca swego białoruskiego pochodzenia, nie tylko bardzo szybko ulegała polonizacji, ale także aktywnie wspierała procesy polonizacyjne własnego środowiska (Mironowicz 2000, 2005, 2010).

Według L. Olejnika (2003), brak jest udokumentowanej wiedzy dotyczącej istnienia wśród Białorusinów przejawów sprzeciwu czy oporu wobec władzy komunistycznej, mimo że aparat bezpieczeństwa na początku lat 50. XX w. prowadził rozpoznanie środowisk białoruskich podejrzewanych o „działalność nacjonalistyczną".

Pod koniec 1949 r. z powiatu suwalskiego wysiedlono do województwa szczecińskiego 22 rodziny (87 osób) oskarżone o wspieranie nacjonalistycznego podziemia litewskiego. Trudno ustalić, jakie były bezpośrednie przyczyny tej decyzji, brak jest dowodów na funkcjonowanie w tym okresie na Suwalszczyźnie jakichkolwiek form podziemia litewskiego. Przesiedlenia z pogranicza polsko-litewskiego na ziemie zachodnie były także kontynuowane w $1950 \mathrm{r}$. i objęły łącznie ok. 200 osób narodowości litewskiej, miały więc większą skalę niż przesiedlenia z lat 1944-1946 (ryc. 10). Część wysiedlonych powróciła po 1956 r. (Tarka 1998). Władze nadal uznawały metodę zastraszania za najbardziej skuteczny sposób prowadzenia polityki narodowościowej.

Jednocześnie na początku lat 50. ubiegłego wieku, w ramach partyjnej ,walki z odchyleniem prawicowo-nacjonalistycznym", bycie osobą o niepolskiej narodowości przestało być - według władz - złem samym w sobie. Na pierwszy plan przed podziałami narodowościowymi wysuwają się podziały klasowe oraz akceptacja nowego ustroju. Prześladowania dotyczą głównie osób negujących rzeczywistość społeczno-polityczną, bez względu na ich narodowość. Z drugiej strony władza daje możliwość awansu zdeklarowanym komunistom, również bez względu na ich narodowość, pod warunkiem, że nie będą tej narodowości eksponować. Był to początek odchodzenia od polityki prześladowań i restrykcji wobec mniejszości narodowych w stronę polityki ich asymilacji narodowej oraz kulturowej, w już całkowicie zdominowanym przez Polaków kraju (Mironowicz 
2000, 2011). Przyczyn odejścia władz od dotychczasowych brutalnych metod postępowania i przymusowych przesiedleń można doszukiwać się zarówno w polityce wewnętrznej, jak i w uwarunkowaniach międzynarodowych. Zasadniczą przyczyną było $\mathrm{z}$ pewnością przekonanie komunistów o osiagnięciu głównych celów, czyli przekształcenia Polski w państwo w dużym stopniu jednonarodowe oraz zdobycie pełnej władzy. Ponadto walka frakcyjna o władzę w strukturach partii komunistycznej wymuszała rezygnację $\mathrm{z}$ retoryki nacjonalistycznej, a nawet jej potępienie. Duże znaczenie miał także nacisk zewnętrzny. Dalsze działania dyskryminujące mniejszości narodowe zaczynały osłabiać spójność tzw. „obozu socjalistycznego”, powodowały lokalne i regionalne konflikty (zwłaszcza między Czechosłowacją a Węgrami), przez co stały się szkodliwe dla interesów ZSRR. Nowe tendencje w polityce narodowościowej państw socjalistycznych szybko zostały prawidłowo odczytane w Warszawie (Hryciuk 2011).

Przesiedlenia ludności w pierwszych latach po zakończeniu II wojny bardzo istotnie zmienily strukturę narodowościową Polski. O skali tych zmian w latach 1945-1950 może świadczyć fakt, iż na terytorium państwa polskiego, powstałego po ustaleniach w Jałcie i Poczdamie, w 1945 r. Polacy stanowili ok. 80\% ogółu ludności, natomiast w 1950 r. już blisko 98\% (Eberhardt 2010a). Polska stała się krajem zbliżonym do modelu monoetnicznego, rozproszone i kontrolowane przez władze mniejszości narodowe zaczęły odgrywać rolę marginalną, zamierzenia władz komunistycznych zostały $\mathrm{w}$ większości zrealizowane. Ponadto $\mathrm{w}$ wyniku powojennych przesiedleń ludności wschodnia granica Polski poza nielicznymi fragmentami w okolicach Puńska i Hajnówki - stała się nie tylko polityczną granicą międzypaństwową, ale także wyraźną granicą narodowościową, językową, wyznaniową i kulturową (ryc. 10).

\subsection{Sytuacja w latach 1952-1989 - podporządkowanie, kontrola, asymilacja}

W kwietniu 1952 r. Biuro Polityczne PZPR przyjęło tajną uchwałę w sprawie „poprawy sytuacji gospodarczej ludności ukraińskiej i wzmożenia wśród niej pracy politycznej”. Przyjęcie tej uchwały było konsekwencją prac specjalnej partyjno-rządowej komisji badającej sytuację gospodarczą i polityczną Ukraińców, jednocześnie było jedną z pierwszych oznak początków liberalizacji polityki narodowościowej w powojennej Polsce. W uchwale m.in. skrytykowano traktowanie Ukraińców przez władze lokalne, jednocześnie całkowicie pomijając odpowiedzialność władz centralnych. Pojawiły się także deklaracje, które 
świadczyły o nowej polityce wobec mniejszości ukraińskiej. Biuro Polityczne PZPR zobowiązało władze wojewódzkie do likwidacji przejawów dyskryminacji gospodarczej, kulturalnej i narodowej Ukraińców, organizacji życia kulturalnego, wprowadzenia w szkołach nauki języka ukraińskiego, aktywizacji Ukraińców w organizacjach społecznych. Dopuszczano także możliwości zakładania odrębnych stowarzyszeń ukraińskich. Był to jednoznaczny sygnał dla władz lokalnych, że dalsze dyskryminowanie Ukraińców nie jest już „dobrze widziane" przez władze centralne. Jednocześnie zdecydowanie wystąpiono przeciwko Kościołowi greckokatolickiemu, wpływom „faszystów ukraińskich” i kontaktom środowiska ukraińskiego z Zachodem. Mimo wielu pozytywnych założeń, uchwała ta nie wpłynęła w istotny sposób na poprawę sytuacji środowiska ukraińskiego. Głównymi barierami był jej tajny charakter (skutecznie ograniczający wiedzę o niej), biurokracja i pasywność lokalnych władz oraz brak udziału Ukraińców w jej realizacji (Olejnik 2003).

Uchwalona 22 lipca 1952 r. Konstytucja Polskiej Rzeczypospolitej Ludowej formalnie potwierdzała równouprawnienie wszystkich narodowości zamieszkujących w Polsce ${ }^{53}$. Typowy dla okresu PRL - nie tylko w przypadku kwestii narodowościowych - był rozdźwięk między zapisami prawnymi a praktyką administracyjną oraz codzienną rzeczywistością. Mimo że w porównaniu z okresem bezpośrednich prześladowań ludności niepolskiej w drugiej połowie lat 40 . XX w. nastąpiła wyraźna poprawa w nastawieniu do poszczególnych mniejszości narodowych i etnicznych, to jednak w praktyce władze państwowe konsekwentnie dążyły do dalszej asymilacji poszczególnych narodowości.

Poprawa ta początkowo przejawiała się głównie w odrodzeniu narodowościowego szkolnictwa: białoruskiego, żydowskiego, czeskiego, słowackiego, litewskiego, ukraińskiego. W połowie 1952 r. określono szczegółowo zasady programowe w szkołach z niepolskim językiem nauczania. Pomimo oficjalnego równouprawnia nadal wyraźne były działania, zwłaszcza na szczeblu lokalnym, dążące do asymilacji mniejszości narodowych. „Odwilż” w polityce narodowościowej prowadzonej przez PZPR rozpoczęła się w połowie $1955 \mathrm{r}$. Opracowano i przyjęto wówczas szereg uchwał (realizowanych w kolejnych latach), doty-

${ }^{53}$ Artykuł 81 konstytucji z 1952 r. stanowił, iż „Obywatele Polskiej Rzeczypospolitej Ludowej niezależnie od narodowości, rasy i wyznania mają równe prawa we wszystkich dziedzinach życia państwowego, politycznego, gospodarczego, społecznego i kulturalnego. Naruszenie tej zasady przez jakiekolwiek bezpośrednie lub pośrednie uprzywilejowanie albo ograniczenie w prawach ze względu na narodowość, rasę czy wyznanie podlega karze. Szerzenie nienawiści lub pogardy, wywoływanie waśni albo poniżanie człowieka ze względu na różnice narodowości, rasy czy wyznania jest zakazane" (Dz.U. nr 33, poz. 232). Kolejna konstytucja z 1976 r. zachowała sformułowania z 1952 r. 
czących funkcjonowania stowarzyszeń, prasy i szkolnictwa. Środowiska mniejszości narodowych, dostrzegając zmieniająca się atmosferę społeczno-polityczną, zaczęly aktywniej domagać się swoich konstytucyjnych praw, uaktywniali się zwłaszcza działacze partyjni, wywodzący się z poszczególnych mniejszości narodowych. Niejednokrotnie było to skutkiem odgórnych inspiracji (Olejnik 2003).

Początek lat 50., a zwłaszcza lata 1953-1955, były także okresem rozluźnienia barier administracyjnych nałożonych na Ukraińców i Łemków bezpośrednio po akcji „Wisła”. Uzyskali większą swobodę w poruszaniu, nie musieli już zwracać się do lokalnych urzędników z zezwoleniem na wyjazd do innego powiatu czy województwa. Władze zaczęły także wydawać pozwolenie na zmianę stałego miejsca zamieszkania $\mathrm{w}$ obrębie ziem zachodnich i północnych, tworzyły się skupiska Ukraińców i Łemków (Dudra 2008). Nasiliły się także, trwające od początku lat 50. XX w. samowolne powroty na Lubelszczyznę i Rzeszowszczyznę. Według władz partyjnych do lutego 1955 r. do województwa rzeszowskiego miało powrócić 327 osób, natomiast do lubelskiego ponad tysiąc osób (w tym do powiatu włodawskiego aż 446 rodzin, a do bialskiego 76 rodzin). KC PZPR zdecydowanie zalecał władzom wojewódzkim i powiatowym likwidację samowolnych powrotów Ukraińców i odsyłanie ich do miejsc dotychczasowego zamieszkania, jednak na obszarze Lubelszczyzny powszechne było legalizowanie powrotów rodzin ukraińskich (Drozd 2011, Wysocki 2011).

\subsubsection{Zmiany polityczne w 1956 roku i ich wpływ na sytuację mniejszości narodowych}

Choć pierwsze oznaki zmiany postawy władz państwowych wobec mniejszości narodowych pojawiały się już w latach 1949, 1952, 1955, to jednak dopiero przemiany polityczne w $1956 \mathrm{r}$. doprowadziły do oficjalnego uznania przez władze różnorodności etnicznej społeczeństwa polskiego. Uchwały VII (18-28 lipca 1956 r.) oraz VIII (19-21 października 1956 r.) Plenum KC PZPR w kwestiach dotyczących zagadnień narodowościowych odrzucały nacjonalizm i szowinizm narodowy. Podkreślały równość praw wszystkich obywateli bez względu na narodowość, zapewnienie warunków nieskrępowanego rozwoju oświaty i kultury w języku ojczystym oraz pełnego udziału w życiu państwowym, społecznym i politycznym. Potępiono poglądy i metody wprowadzające podziały według narodowości i dyskryminację ze względu na pochodzenie. Spowodowało to dalszy rozwój szkolnictwa, wydawanie prasy, aktywizację społeczno-polityczną i powstanie organizacji poszczególnych mniejszości narodowych. Nastąpiło autentyczne, choć najczęściej krótkotrwale, ożywienie działal- 
ności kulturalnej i narodowej wśród ludności niepolskiej (Chałupczak, Browarek 1998, Dudra 2008).

W latach 1956-1957 problematyka narodowościowa została bardzo szeroko upubliczniona w prasie, nie tylko lokalnej, ale także ogólnopolskiej. Krytykowano postawy nacjonalistyczne, przejawy dyskryminacji, ale również bezkrytycznie przytaczano, często przesadzone, informacje i oceny liderów poszczególnych mniejszości. Tematyka narodowościowa pojawiała się w wystąpieniach na różnego rodzaju posiedzeniach PZPR, zwłaszcza szczebla centralnego, gdzie przyjmowano wiele uchwał podkreślających zasadę równouprawnienia wszystkich narodowości i krytykujących jakąkolwiek dyskryminację, jako sprzeczną z zasadami i ideami socjalizmu. Jednak zarówno w polskim społeczeństwie w dużym stopniu przywykłym do idei powojennej Polski jako państwa jednonarodowego - jak i wśród części władz partyjnych, zmiany te były przyjmowane ostrożnie i nieufnie, nadal bardzo silny był pogląd o konieczności dalszej asymilacji ludności niepolskiej, wyraźny był także wzrost nastrojów nacjonalistycznych. Na obszarach mieszanych narodowościowo powszechne stały się postawy wrogości wobec mniejszości narodowych, które oskarżano o wspieranie systemu stalinowskiego. Dotyczyło to szczególnie osób narodowości żydowskiej, ale także Białorusinów, Ukraińców, Niemców, Słowaków (Mironowicz 2000, 2011, Olejnik 2003).

Stosowaną wcześniej politykę przesiedleń i asymilacji zastąpiono polityką ograniczonej działalności społecznej i kulturalnej. Z inicjatywy władz zaczęły powstawać organizacje społeczno-kulturalne, ale wyłącznie jedna dla każdej z mniejszości. Szybko okazało się - wyraźnie było to widoczne już od 1958 r. że nowo powstałe stowarzyszenia mają niewiele wspólnego $\mathrm{z}$ faktycznym odrodzeniem działalności społecznej i kulturalnej mniejszości narodowych oraz dbaniem o ich interesy. Stały się sposobem kontroli i środkiem do umocnienia pozycji władzy komunistycznej wśród społeczności niepolskich. Zostały podporządkowane - pod względem organizacyjnym, finansowym i kadrowym MSW i były całkowicie lojalne wobec PZPR. Miały propagować i popularyzować politykę władz oraz ideały socjalizmu wśród mniejszości narodowych, służyć ich indoktrynacji, stać się swoistym „pasem transmisyjnym” przenoszącym wytyczne centrali w teren. W realiach PRL funkcjonowanie organizacji niezależnych od PZPR było wykluczone, władzom nie zależało na powstaniu silnych stowarzyszeń, autentycznie reprezentujących poszczególne narodowości. Była to „odwilż” pod pełną kontrolą. Państwo z jednej strony występowało przeciwko dyskryminacji mniejszości narodowych, z drugiej wyraźnie ograniczało autonomię organizacji narodowościowych. W styczniu 1957 r. powołano Komisję KC PZPR do Spraw Narodowościowych, a następnie analogiczne 
Komisje przy Komitetach Wojewódzkich PZPR. Ich rola sprowadzała się do koordynowania działań władz wobec mniejszości narodowych oraz narzucania partyjnych wytycznych stowarzyszeniom mniejszości narodowych. Mimo uzależnienia od władzy państwowej, braku samodzielności oraz niewielkiej liczby członków i tak przez następne kilkadziesiąt lat organizacje te odgrywały dominującą rolę w kształtowaniu życia społecznego, oświatowego i kulturalnego poszczególnych mniejszości narodowych, także dlatego, że nie miały żadnej konkurencji (Chałupczak, Browarek 1998, Mironowicz 2000, Milewski 2001, Barwiński 2008a).

Przemiany polityczne połowy lat 50. XX w. na Podlasiu przejawiały się głównie we wzrastającej wrogości wobec Białorusinów, której przyczyny tkwiły przede wszystkim w jednoznacznym poparciu udzielonym przez tę społeczność nieakceptowanemu przez Polaków systemowi stalinowskiemu i w stereotypowym utożsamianiu wszystkich Białorusinów z komunistami. Przełom lat 40. i 50. ubiegłego wieku bardzo zaostrzył różnice interesów i postaw politycznych mieszkających na Podlasiu Polaków i Białorusinów, a okres stalinowski silnie zantagonizował obie narodowości. Atmosfera 1956 r. sprzyjała manifestowaniu autentycznych poglądów politycznych, krytykowaniu praktyk stalinowskich, wysuwaniu oskarżeń, skierowanych bardzo często przeciwko działaczom politycznym niepolskiej narodowości. Wywoływało to obawy, a nawet strach Białorusinów.

Jak pisze E. Mironowicz (2000), z jednej strony „,stereotyp Białorusina komunisty oczekującego przyłączenia Białostocczyzny do ZSRR tak samo długo funkcjonował w świadomości Polaków, jak w świadomości Białorusinów stereotyp Polaka nacjonalisty i okrutnika mordującego bezbronnych chłopów z racji ich inności narodowej i religijnej”.

Z drugiej strony liberalizacja życia politycznego umożliwiła oficjalne uznanie mniejszości białoruskiej, poparcie jej przez władze państwowe, rozwój szkolnictwa. W lutym 1956 r. odbył się I Zjazd Białoruskiego Towarzystwa Społeczno-Kulturalnego ${ }^{54}$ (BTSK), które szybko rozwinęło działalność organizacyjna, powołując 10 oddziałów i 190 kół terenowych. W marcu 1956 r. wydano pierwszy numer białoruskiego tygodnika „Niwa”,55, w czerwcu 1958 r. Polskie

${ }^{54}$ Zgodnie ze statutem BTSK, głównymi celami organizacji miało być rozwijanie kultury i oświaty białoruskiej, podnoszenie świadomości narodowej, umacnianie więzi braterstwa z narodem polskim, opieka nad własnymi zabytkami, popularyzacja wiedzy o ZSRR i BSRR, włączenie Białorusinów do budownictwa socjalistycznego (Chałupczak, Browarek 1998).

${ }_{55}^{5}$ Nazwa tygodnika nawiązywała do tytułu pierwszego pisma białoruskiego wydawanego w Wilnie przed I wojną światową - „Naszej Niwy” (Mironowicz 2010). 
Radio w Białymstoku nadało pierwszą w historii audycję w języku białoruskim. Wśród Białorusinów uaktywniła się warstwa inteligencji, która w tym środowisku była praktycznie niewidoczna. Nastąpiło ożywienie działalności kulturalnej i narodowej mniejszości białoruskiej, choć nadal większość białoruskich urzędników oraz funkcjonariuszy partyjnych była zdecydowanymi zwolennikami asymilacji i udowadniania, że są „dobrymi Polakami” (Sadowski 1995a, Mironowicz 1998, 2000, Fionik 2006).

BTSK było jedną z pierwszych organizacji społeczno-kulturalnych mniejszości narodowych utworzonych $\mathrm{w}$ wyniku przemian politycznych połowy lat 50. XX w. W przypadku organizacji białoruskiej nie było żadnych problemów ze znalezieniem odpowiednich - z punktu widzenia władz partyjnych - kadr do prowadzenia prac stowarzyszenia oraz tygodnika „Niwa”. BTSK przez cały okres PRL było najbardziej „upartyjnioną” spośród wszystkich organizacji mniejszości narodowych działających wówczas w Polsce.

Powstanie BTSK całkowicie zaskoczyło Polaków na Podlasiu, spotkało się z wyraźną niechęcią, także wśród członków PZPR. Nie zdając sobie sprawy, że wszystko odbywa się z przyzwoleniem i pod kontrolą partii, wysyłano do KC PZPR listy informujące, że Białorusini zakładają organizację i przygotowują kolejny rozbiór Polski. Pojawiły się plotki o zbieraniu podpisów przez działaczy białoruskich na rzecz przyłączenia wschodniej Białostocczyzny do ZSRR, co sprawdzał Urząd Bezpieczeństwa Publicznego i MSW. Pogłoski o białoruskim separatyzmie, nigdy oficjalnie niezdementowane, pogłębiały i tak bardzo silne antagonizmy narodowościowe na Podlasiu (Mironowicz 2000, 2010a).

BTSK od samego początku prowadziło bardzo aktywną działalność wśród mniejszości białoruskiej, zwłaszcza młodzieży szkolnej i ludności wiejskiej. Była to - zgodnie ze statutem - głównie działalność kulturalna: wspieranie amatorskiego ruchu artystycznego, wystepy, festiwale, odczyty, wystawy, konkursy, festyny (Fionik 2006). Już w 1956 r., dzięki staraniom BTSK, na Uniwersytecie Warszawskim zaczęła funkcjonować Katedra Filologii Białoruskiej, a w 1958 r. powołano Białoruskie Stowarzyszenie Literackie „Białowieża”. Część ówczesnych postulatów działaczy białoruskich wykraczała jednak poza sferę kultury. Zgłaszano potrzebę dostępu Białorusinów do sejmu oraz wprowadzenia języka białoruskiego do urzędów na obszarze wschodniego Podlasia. Propozycje te zostały odrzucone w wyniku sprzeciwu władz wojewódzkich w Białymstoku. Głównym argumentem była obawa dalszego wzrostu nastrojów nacjonalistycznych wśród polskich mieszkańców Białostocczyzny (Olejnik 2003).

$\mathrm{W}$ połowie lat $50 . \mathrm{XX} \mathrm{w}$. nasiliły się zmiany w białoruskim szkolnictwie. Charakterystyczną cechą nauczania w szkołach z białoruskim językiem wykładowym było prowadzenie - wbrew nazwie szkoły - wielu przedmiotów w języ- 
ku polskim, głównie z powodu braku podręczników oraz wykwalifikowanych kadr nauczycielskich. Była to tendencja, która w tym okresie coraz bardziej się nasilała. Powszechne stało się dążenie do zastępowania szkół z białoruskim językiem nauczania szkołami, gdzie uczono języka białoruskiego tylko jako przedmiotu dodatkowego. Było to powodowane głównie presją rodziców, według których nauka języka białoruskiego sprawiała problemy z opanowaniem języka polskiego i dalszą edukacją dzieci w szkołach średnich, ponadto „,z jego znajomości nie było żadnego konkretnego pożytku, a tylko same kłopoty" ${ }^{\text {". }}$. Większą troskę o szkolnictwo białoruskie przejawiały wówczas polskie władze oświatowe niż sami Białorusini. Proces rozpadu szkolnictwa białoruskiego został powstrzymany dopiero przez działaczy nowo powstałego BTSK. W roku szkolnym 1956/57 na Podlasiu funkcjonowały 52 szkoły podstawowe i cztery szkoły średnie z białoruskim językiem nauczania oraz 118 szkół podstawowych z językiem białoruskim jako przedmiotem dodatkowym. Uczyło się w nich ogółem 11122 dzieci białoruskich (Mironowicz 2000, 2010a, Olejnik 2003).

W czerwcu 1956 r. w Warszawie miał miejsce zjazd założycielski Ukraińskiego Towarzystwa Społeczno-Kulturalnego ${ }^{57}$ (UTSK), ukazał się także pierwszy numer ukraińskojęzycznego tygodnika „Nasze Słowo”58. Ukraińcy, korzystając z liberalizacji społeczno-politycznej, domagali się m.in. anulowania skutków prawnych akcji „Wisła”, umożliwienia powrotów na obszar południowo-wschodniej Polski, rehabilitacji Ukraińców, zaprzestania dyskryminacji, rozbudowy szkolnictwa ukraińskiego, zapewnia miejsc w sejmie dla przedstawicieli narodowości ukraińskiej, zwrotu cerkwi, zezwolenia na odprawianie nabożeństw w obrządku greckokatolickim. Wybrany podczas zjazdu Zarząd Główny UTSK został zdominowany, podobnie jak w przypadku innych tego typu organizacji, przez członków PZPR. Mimo to UTSK - zwłaszcza w początkowym okresie funkcjonowania - było stowarzyszeniem narodowościowym, na forum którego najostrzej były artykułowane zarzuty wobec polityki państwa oraz postulaty o charakterze politycznym. Inne tego typu organizacje ograniczały się głównie do zagadnień kulturalno-oświatowych (Olejnik 2003, Drozd 2010).

${ }^{56}$ Cytat za E. Mironowicz (2000, s. 160).

57 Zgodnie ze statutem UTSK, głównymi celami organizacji miało być reprezentowanie interesów narodowych ludności ukraińskiej, krzewienie i popularyzowanie kultury ukraińskiej, dbanie o rozwój oświaty i szkolnictwa, umacnianie braterskich więzi z narodem polskim, organizowanie kontaktów i wymiany z USRR (Chałupczak, Browarek 1998).

${ }^{58}$ Do połowy lat 80 . XX w. było to jedyne legalne pismo w języku ukraińskim w Polsce. 
Szybko zaczęły powstawać struktury terenowe UTSK. Do końca 1956 r. oddziały wojewódzkie powstały w Gdańsku, Koszalinie, Olsztynie, Szczecinie, Wrocławiu, Zielonej Górze, Rzeszowie i Lublinie, ponadto utworzono 63 oddziały powiatowe oraz 119 kół, skupiających ok. 3 tys. członków. W ciągu dwóch kolejnych lat liczba oddziałów powiatowych zwiększyła się do 74, a kół do 270, zrzeszających ponad 7 tys. członków (Drozd, Halczak 2010). Ukraińcy podjęli także udaną próbę, choć w bardzo ograniczonej skali, budowy struktur organizacyjnych na Podlasiu, gdzie nadal całą ludność prawosławną utożsamiano z mniejszością białoruską. W czerwcu 1957 r. w Kleszczelach powstało pierwsze i jedyne wówczas na Białostocczyźnie koło UTSK, które w 1960 r. liczyło 47 członków. Zorganizowano ukraiński chór i zespół teatralny, a po kilku latach starań, w 1966 r., rozpoczęto naukę języka ukraińskiego w szkole w Kleszczelach, którą jednak władze już po roku zlikwidowały. Kilka lat później rozwiązano także podlaskie koło UTSK (Hawryluk 1999).

Jedną z istotniejszych dla Ukraińców decyzji podjętych przez władze w 1956 r. było przyjęcie uchwały dotyczącej pomocy materialnej dla ludności ukraińskiej. Na jej podstawie przyznawano Ukraińcom pożyczki remontowe i budowlane, najczęściej bezzwrotne. Głównym celem było ograniczenie nadal silnego poczucia tymczasowości, związanie Ukraińców z nowymi miejscami osiedlenia i zahamowanie powrotów do południowo-wschodniej Polski. Nastapił także rozwój szkolnictwa ukraińskiego, głównie na obszarze ziem zachodnich. W roku szkolnym 1956/57 utworzono dwie pierwsze szkoły z językiem ukraińskim jako wykładowym (licea w Legnicy i Bartoszycach), ogółem w 141 szkołach języka ukraińskiego uczyło się 2590 uczniów. Na Uniwersytecie Warszawskim otwarto Katedrę Języka Ukraińskiego, która miała zapewnić kadry dla ukraińskiego szkolnictwa (Olejnik 2003). W ciagu następnych dwóch lat otwarto kolejne szkoły podstawowe oraz liceum w Przemyślu. W roku szkolnym 1958/59 działały 183 punkty nauczania języka ukraińskiego, ogółem w różnych typach szkół możliwość nauki języka ukraińskiego miało 3287 uczniów. Był to szczytowy okres rozwoju szkolnictwa ukraińskiego w PRL (Drozd, Halczak 2010).

Według danych zebranych w pierwszej połowie 1956 r. przez MSW od władz lokalnych, w Polsce zamieszkiwało ok. 165 tys. Ukraińców, w tym w ówczesnym województwie olsztyńskim 60 tys., koszalińskim 30 tys., rzeszowskim 20 tys., lubelskim 15 tys., wrocławskim 15 tys., zielonogórskim 12 tys., szczecińskim 8 tys., gdańskim 5 tys. (Mironowicz 2000, Olejnik 2003). Były to przybliżone dane szacunkowe, ocena lokalnych urzędników, ponadto w tym okresie trwały już legalne oraz nielegalne powroty Ukraińców i Łemków do miejsc dawnego zamieszkania, które nasiliły się od 1955 r. 
Mimo że największe zmiany w polityce państwa wobec mniejszości w latach 50. XX w. nastąpiły w stosunku do Ukraińców, to najważniejsze i najpowszechniej wysuwane wówczas postulaty środowiska ukraińskiego, czyli zorganizowanie masowych powrotów na obszar południowo-wschodniej Polski, przywrócenie swobody wykonywania praktyk religijnych w obrządku greckokatolickim oraz likwidacja wszelkich konsekwencji akcji „Wisła”, nie doczekały się realizacji w drugiej połowie lat 50. XX w. i w następnych dziesięcioleciach.

Rozbudzone przemianami politycznymi nadzieje wśród Ukraińców i Łemków zakończyły się rozczarowaniem. Liczyli oni, że władze uznają wysiedlenie z 1947 r. i akcję „Wisła” za akt bezprawny, anulują dekret z 1949 r. odbierający im prawo do pozostawionych na Podkarpaciu zabudowań, ziemi i lasów, zostaną wypłacone odszkodowania oraz nastapi powtórna akcja przesiedleńcza do pierwotnych miejsc zamieszkania. Nadzieje te zostały rozbudzone m.in. decyzją XX Zjazdu KPZR z lutego 1956 r., zezwalającą na powrót do dawnych miejsc osiedlenia narodom wysiedlonym w okresie stalinowskim w ZSRR. Podobnej decyzji polski rząd jednak nie podjął, nie przeprowadzono także rehabilitacji Ukraińców oraz nie dokonano krytycznej oceny akcji „Wisła”. Mimo to część Ukraińców i Łemków powróciła na obszar południowo-wschodniej Polski. Niejednokrotnie powodowało to konflikty z nowymi, polskimi właścicielami oraz z lokalnymi władzami. Prawdopodobnie powrotów byłoby znacznie więcej, gdyby władze administracyjne (zwłaszcza lokalne) nie podejmowały działań hamujących wyjazdy, a chętni do powrotu mieli możliwość odzyskania własnych zabudowań i ziemi. Tysiące budynków zniszczono, wiele hektarów ziemi zalesiono lub zajęto przez PGR. Najłatwiej było powrócić tym, których gospodarstwa nie były przejęte przez skarb państwa lub zajęte przez polskich osadników, pozostali musieli je odkupićs9. Dotyczyło to także byłych właścicieli, którzy nie otrzymali rekompensaty za pozostawione gospodarstwo. Większość wysiedleńców postanowiła, z różnych powodów, pozostać w zachodniej i północnej Polsce. Najczęściej decyzja o pozostaniu była motywowana obawą przed ponownym rozpoczynaniem wszystkiego od początku, zagospodarowaniem się na nowych miejscach osiedlenia, lepszymi perspektywami na przyszłość na ziemiach zachodnich i północnych, kwestiami rodzinnymi, zniszczeniem lub przejęciem przez polskich osadników dawnych gospodarstw w południowo-wschodniej Polsce (Kwilecki 1970, Drozd 1998, 2010, Olejnik 2003, Dudra 2008, 2010).

${ }^{59}$ Zgodnie z rozporządzeniem ministra rolnictwa z 21 sierpnia 1956 r., powracający Ukraińcy mogli odzyskać swoje gospodarstwo pod warunkiem, że nie było ono rozdysponowane lub gdy nowy właściciel je opuścił (Drozd 2011). 
Na początku 1957 r. nasilające się naciski na władze centralne przez Ukraińców domagających się powrotów na Rzeszowszczyznę i Lubelszczyznę, a także coraz gwałtowniejsze protesty władz terenowych przeciwko powrotom wysiedlonej ludności wymuszały konieczność znalezienia kompromisu. Polegał on na powołaniu specjalnej komisji w celu sprawdzenia możliwości indywidualnych i grupowych powrotów Ukraińców oraz przyjęciu uchwały przez Sekretariat KC PZPR. W uchwale tej m.in. zobowiązano władze lokalne do intensyfikacji pomocy materialnej dla Ukraińców ułatwiającej zagospodarowanie na ziemiach północnych i zachodnich, wydawanie zezwoleń na indywidualne powroty na obszar południowo-wschodniej Polski, jeżeli gospodarstwa są wolne, zakazu samowolnych powrotów. W praktyce władze starały się ograniczać powroty poprzez pomoc gospodarczą i stabilizację sytuacji Ukraińców na ziemiach północnych, zezwolenie na prowadzenie działalności kulturalnej i oświatowej oraz odprawianie nabożeństw greckokatolickich (Drozd 2011).

W latach 1956-1958, kiedy migracje były relatywnie najłatwiejsze, powróciło 4949 rodzin $^{60}$, czyli zaledwie ok. 20 tys. Ukraińców (w tym ok. 2 tys. Łemków) spośród ok. 140 tys. wysiedlonych w 1947 r. Najwięcej rodzin ukraińskich powróciło do województwa lubelskiego, m.in. dlatego, że tamtejsze władze wojewódzkie były przychylnie nastawione do ich ponownego osiedlenia, powszechnie legalizowano powroty, podejmowano nawet decyzje sprzeczne z wytycznymi rządu a korzystne dla Ukraińców ${ }^{61}$. Ogółem od 1949 r. powróciło tu 3807 spośród ok. 9,7 tys. wysiedlonych rodzin, czyli ponad 1/3 ogółu. Szacunkowo było to ok. 15,2 tys. osób. Najwięcej z nich osiedliło się ponownie w powiatach Biała Podlaska (1940 rodzin), Włodawa (1320 rodzin), Parczew (365 rodzin), do pozostałych powiatów powróciły 182 rodziny. Do powiatów Biała Podlaska i Włodawa powróciło ok. 80\% wysiedlonych (Wysocki 2011). Z pewnością nie bez znaczenia dla wyraźnej przychylności lubelskich władz do Ukraińców w latach 50. XX w. była obecność miejscowych komunistów pochodzenia ukraińskiego na różnych szczeblach lokalnej administracji i aparatu partyjnego. Szczególną rolę odegrał, pochodzący z okolic Włodawy, ukraiński

${ }^{60} \mathrm{Na}$ podstawie danych tzw. Komisji Tkaczowa, powołanej 30 kwietnia $1957 \mathrm{r}$. przez premiera Józefa Cyrankiewicza w celu sprawdzenia możliwości indywidualnych i grupowych powrotów Ukraińców na obszar województw lubelskiego, rzeszowskiego i krakowskiego (Dudra 2010, Drozd 2011).

${ }^{61}$ W Lublinie, w sierpniu 1956 r., podjęto uchwałę, która m.in. upoważniała władze powiatowe do uchylania orzeczeń o nadaniu gospodarstw osiedleńcom i zwracanie ich dawnym właścicielom, co było sprzeczne z wytycznymi Ministerstwa Rolnictwa, wywoływało liczne protesty, w konsekwencji których władze wojewódzkie już w grudniu 1956 r. uchyliły swoją wcześniejszą uchwałę (Olejnik 2003, Wysocki 2011). 
komunista Bazyli Hołod, przedwojenny działacz KPP, następnie PPR i PZPR, od 1953 r. członek Prezydium Miejskiej Rady Narodowej w Lublinie oraz Komitetu Wojewódzkiego, a od lutego 1955 r. do października 1956 r. I sekretarz Komitetu Wojewódzkiego PZPR w Lublinie (Szumiło 2008).

Do ówczesnego województwa rzeszowskiego, głównie z powodu dużo bardziej restrykcyjnego podejścia lokalnych władz ${ }^{62}$, powróciło prawie cztery razy mniej rodzin ukraińskich i łemkowskich - 1089 (do powiatu Gorlice - 350, Ustrzyki - 170, Lesko - 110, Sanok - 65, Lubaczów - 120, inne powiaty - 274). $\mathrm{Na}$ Łemkowszczyznę, zwłaszcza do powiatu Gorlice, wróciło tak wielu Łemków, że w niektórych wsiach zaczęli stanowić większość mieszkańców, np.: w Bartnem, Bielance, Blechnarce, Koniecznej, Kunkowej, Wołowcu. Możliwości powrotów Łemków częściowo ograniczało położenie fragmentu zachodniej Łemkowszczyzny w województwie krakowskim, którego władze, poza pojedynczymi przypadkami, nie zgadzały się na ich ponowne osiedlenie (Dudra 2008, 2010, Drozd 2011).

W kolejnych latach nadal trwały powroty Ukraińców i Łemków, jednak z powodu braku zgody władz na ich masowy charakter oraz nieanulowaniu skutków prawnych akcji „Wisła” odbywały się na niewielką skalę, z nieco większym nasileniem na początku lat 60 . XX w. Nastapiła także zmiana głównych kierunków migracji. Powracający z północnej Polski częściej kierowali się nie do rodzinnych wsi, ale do miast, m.in. do Przemyśla powróciło ok. 2-3 tys. Ukraińców. Według R. Drozda (2011) ogółem wróciło w rodzinne strony ok. 20\% Ukraińców i Łemków wysiedlonych w ramach akcji „Wisła”, czyli szacunkowo ok. 28 tys. osób.

Obok spraw związanych bezpośrednio z akcją „Wisła”, kolejnym bardzo istotnym problemem dla Ukraińców była kwestia reaktywowania Kościoła greckokatolickiego w Polsce, możliwość odprawiania nabożeństw w tym obrządku oraz zwrotu jego mienia. Władze centralne zezwoliły w marcu 1957 r. na zorganizowanie sieci 17 placówek duszpasterskich w północnej i zachodniej Polsce, w których umożliwiono odprawianie greckokatolickich nabożeństw (w ramach struktur rzymskokatolickich), jednak nie zgodziły się na formalne zalegalizowanie Kościoła greckokatolickiego ani na reaktywowanie jego działalności w Karpatach (Olejnik 2003). Było to kolejnym przejawem - obok pomocy materialnej oraz rozwoju szkolnictwa ukraińskiego i działalności kulturalnej na tzw. Ziemiach Odzyskanych - bardzo konsekwentnej polityki władz, zmierzającej do powstrzymania powrotów na obszar południowo-wschodniej

${ }^{62}$ Zgodę na powrót do województwa rzeszowskiego uzyskała zaledwie co dziewiąta starająca się o to rodzina ukraińska lub łemkowska (Drozd 2011). 
Polski i związania Ukraińców z ich dotychczasowymi miejscami zamieszkania, utrwalenia rozmieszczenia mniejszości ukraińskiej ukształtowanego w konsekwencji akcji „Wisła”.

Dziesięć lat po akcji „Wisła” duchowni greckokatoliccy mogli ponownie legalnie prowadzić działalność duszpasterską, choć w bardzo ograniczonym zakresie. Nie posiadali własnych świątyń i byli całkowicie uzależnieni od miejscowych proboszczów rzymskokatolickich, bez zgody których nie mogli udzielać chrztów, ślubów, pogrzebów. Współpraca z polskimi księżmi rzymskokatolickimi, z wyjątkiem kilku incydentów, przebiegała poprawnie. Natomiast wznowienie nabożeństw greckokatolickich spowodowało odejście części wiernych od Cerkwi prawosławnej i ich powrót do grekokatolicyzmu, co doprowadziło do upadku kilku parafii prawosławnych (Drozd, Halczak 2010).

W latach 1957-1958 działacze UTSK, domagający się powrotów Ukraińców do dawnych miejsc zamieszkania oraz negujący politykę państwa, byli oskarżani o nacjonalizm i usuwani przez władze partyjne ze stowarzyszenia, powszechna była infiltracja społeczności ukraińskiej przez MSW. Od 1958 r. UTSK stało się organizacją w pełni realizująca polityczne i społeczne interesy PZPR w środowisku ukraińskim, a działalność stowarzyszenia skoncentrowała się na rozwoju szkolnictwa ukraińskiego i amatorskiego ruchu artystycznego.

W warunkach „odwilży” społeczno-politycznej uaktywnili się także Łemkowie. Początkowo angażowali się w działalność UTSK, jednak szybko rozczarowali się do tej organizacji ${ }^{63}$. W 1958 r. powstał Tymczasowy Komitet Społeczno-Oświatowy Rusinów-Łemków, który zwrócił się do I sekretarza KC KPZR Nikity Chruszczowa z listem opisującym dyskryminację Rusinów w Polsce oraz zawierającym prośbę o pomoc w umożliwieniu powrotów w Beskidy. Trudno dziś ocenić, czy bardziej świadczyło to o determinacji, czy naiwności działaczy łemkowskich. Z pewnością było echem rusofilskich sympatii części Łemków. Jednocześnie Komitet bezskutecznie domagał się od Władysława Gomułki uznania Rusinów-Łemków za odrębną od Ukraińców mniejszość narodową, uznania przesiedleń z 1947 r. za nieuzasadnione i zorganizowania powrotów na Łemkowszczyznę. Zdecydowanie sprzeciwiano się także reprezentowaniu spraw łemkowskich przez UTSK. Komitet nie został uznany przez polskie władze, które nie zrealizowały żadnego z jego postulatów (Mironowicz 2007, Dudra 2008, Drozd, Halczak 2010).

${ }^{63}$ W 1957 r. Zarząd Główny UTSK zawiesił działalność całkowicie zdominowanego przez Łemków Zarządu Wojewódzkiego UTSK w Zielonej Górze za krytykę polityki władz w sprawie powrotów Łemków w Beskidy (Dudra 2008). 
Poczucie odrębności od Ukraińców, obecne wśród Łemków od XIX w., ponownie się uzewnętrzniło w drugiej połowie lat 50. XX w. Separatystyczne (autonomiczne) tendencje części działaczy łemkowskich były wówczas wspierane przez kanadyjski Łemko-Sojuz, którego członkowie odwiedzali Polskę i zwracali się z petycjami do władz centralnych, co spowodowało oskarżanie Łemków o działalnie pod wpływem ,imperialistycznych ośrodków emigracyjnych" (Olejnik 2003).

Środowiska łemkowskie, aktywne i liczne zwłaszcza na Dolnym Śląsku (gdzie Łemkowie stanowili zdecydowaną większość ogółu przesiedlonych w 1947 r.), wyraźnie odcinały się od Ukraińców, podkreślały odrębność Łemków, brak poparcia w latach 40. ubiegłego wieku dla działalności UPA, niechęć do ukraińskiego nacjonalizmu, zdecydowaną chęć powrotu na Łemkowszczyznę. Łemkowie domagali się także usamodzielnienia organizacyjnego od UTSK. Wszelkim przejawom „separatyzmu łemkowskiego" zgodnie sprzeciwiały się zarówno władze państwowe, jak i środowiska ukraińskie, traktując tę społeczność jako regionalną grupę narodu ukraińskiego. Postawa władz była motywowana obawą, iż uznanie odrębności narodowej Łemków podważyłoby sens ich wysiedlenia w 1947 r. i odebrało argumenty uzasadniające odmowę powrotu w Beskidy (Mironowicz 2007, Dudra 2008).

Pod koniec lat 50. XX w., z powodu nasilania się konfliktu między „łemkowskimi separatystami” a Ukraińcami, w MSW gromadzono i analizowano dokumenty dotyczące historii Łemków i Łemkowszczyzny, przedwojennych konfliktów i sporów łemkowsko-ukraińskich na tle narodowościowym, wyznaniowym oraz politycznym, a nawet literaturę i poezję twórców łemkowskich. Władze starały zorientować się w genezie sporu. Według E. Mironowicza (2007), „funkcjonariusze MSW dysponowali pokaźnym zasobem dokumentów, mówiących, że w gruncie rzeczy Łemkowie byli ofiarami nacjonalizmu ukraińskiego i że zostali potraktowani po wojnie przez władze polskie jak nacjonaliści ukraińscy”. Przesłanie tych opinii do KC PZPR w żadnym stopniu nie zmieniło polityki w kwestii łemkowskiej.

Przez cały okres PRL nie wyrażono zgody na powstanie odrębnej łemkowskiej organizacji, a władze komunistyczne, uznając Łemków za część narodu ukraińskiego, dopuszczały możliwość ich aktywności społeczno-kulturalnej wyłącznie w ramach UTSK. Dlatego Łemkowie, chcący działać legalnie, byli zmuszeni do zrzeszania się $\mathrm{w}$ organizacji ukraińskiej, choć niektórzy z nich próbowali działać poprzez stowarzyszenie rosyjskie (RTSK) we Wrocławiu. W listopadzie 1959 r. w Komisji ds. Narodowościowych KC PZPR odbyła się narada poświęcona Łemkom. Zalecono działaczom UTSK większe zainteresowanie Łemkami, wprowadzenie ich do Zarządu Głównego UTSK, umożliwienie 
im działalności autonomicznej, powołanie przy UTSK Zarządu Sekcji ds. Rozwoju Regionalnej Kultury Łemkowskiej oraz Łemkowskiego Kolegium Redakcyjnego do współpracy z redakcją „Naszego Słowa”. Wkrótce zaczęto wydawać w gwarze łemkowskiej dodatek do tego tygodnika pt. „Lemkiwska Storinka”. Władze wyraźnie starały się wyciszyć konflikt, jednak działania te nie zakończyły sporów ukraińsko-łemkowskich wewnątrz UTSK. Trwały one z różnym nasileniem aż do końca lat 80 . XX w., czyli do powstania odrębnych organizacji łemkowskich. W UTSK istniały silne obawy przed „łemkowskim separatyzmem", natomiast działacze łemkowscy obawiali się zdominowania i utraty regionalnej tożsamości (Olejnik 2003, Mironowicz 2007, Dudra 2008, Drozd, Halczak 2010).

W pierwszej połowie lat 50. ubiegłego wieku na Suwalszczyźnie rozpoczęły działalność trzy litewskie amatorskie zespoły ludowe: „Sudova” w Krejwianach oraz „Ruta” w Widugierach i Szlinokiemiach, a także chór kościelny w Puńsku. Powstały one dzięki lokalnym inicjatywom, nie były w pełni kontrolowane przez władze, prowadziły działalność poza gminnymi świetlicami, występowały głównie w środowisku litewskim (w prywatnych mieszkaniach, stodołach), ale także w Suwałkach i Warszawie podczas uroczystości państwowych. Od czerwca 1956 r. opiekę nad istniejącymi oraz licznie powstającymi kolejnymi litewskimi zespołami artystycznymi (pod koniec 1956 r. było ich już 10) objął nowo powstały Dom Kultury Litewskiej w Puńsku, który stał się centrum życia kulturalnego mniejszości litewskiej (Olejnik 2003).

Jednym z głównych problemów polsko-litewskich na Suwalszczyźnie w drugiej połowie lat 50. XX w. była - bardzo ważna dla mieszkających tam rzymskokatolickich Litwinów - kwestia języka nabożeństw. Bezpośrednio po zakończeniu wojny msze w języku litewskim odprawiano w kościołach w Puńsku, Sejnach oraz, w co drugą niedzielę, w Smolanach. Już we wrześniu 1945 r. Urząd Bezpieczeństwa bezskutecznie próbował ograniczyć litewskie nabożeństwa. Jednak rok później, po śmierci litewskiego proboszcza z Sejn, kuria biskupia, mimo próśb parafian, wyznaczyła na to stanowisko księdza mówiącego wyłącznie po polsku. Gdy podobna sytuacja pojawiła się w 1949 r. w parafii w Puńsku, kuria desygnowała tam co prawda księdza Polaka, ale mówiącego w języku litewskim.

Najpoważniejszy konflikt pojawił się w 1956 r., kiedy biskup łomżyński powołał na stanowisko proboszcza parafii w Puńsku księdza nieznającego języka litewskiego. Był to pierwszy taki przypadek od powstania tej parafii, czyli od XVI w. Parafianie przyjęli księdza wrogo, uważali to za dyskryminację, w ramach protestów wysyłali listy do kurii, nie składali ofiar, uniemożliwiali odprawianie mszy. Protestujących Litwinów biskup straszył m.in. wysiedleniem przez 
władze ze strefy nadgranicznej. Sytuacja ta była skwapliwie wykorzystywana przez władze partyjne, także szczebla centralnego, do występowania $\mathrm{w}$ roli obrońcy dyskryminowanej przez hierarchię Kościelną mniejszości litewskiej. Po kilku miesiącach protestów proboszcz złożył rezygnację, a na jego miejsce biskup skierował księdza narodowości litewskiej. Zdeterminowani i dobrze zorganizowani Litwini wygrali batalię o „litewskiego kapłana” w Puńsku, jednak spory dotyczące języka nabożeństw i godzin ich odprawiania między Litwinami a kurią biskupią oraz parafianami narodowości polskiej trwały na Suwalszczyźnie z różnym natężeniem przez następne kilkadziesiąt lat, zwłaszcza w Sejnach (Tarka 1998, 2010).

W listopadzie 1956 r. zarejestrowano Litewskie Towarzystwo Społeczno-Kulturalne (LTSK), a kilka miesięcy później, w marcu 1957 r., odbył się w Puńsku zjazd założycielski. Inicjatorem powołania litewskiej organizacji był dr Bronisław Mickiewicz, Litwin z Wilna, mieszkający w Warszawie. Największym problemem podczas realizacji tej inicjatywy nie była postawa MSW, ale obawy i strach miejscowych Litwinów przed „ujawnieniem się”. Rejestracji LTSK sprzeciwiały się ponadto władze lokalne w Sejnach, jednak brak zgody na funkcjonowanie litewskiej organizacji byłby zbyt oczywistym przejawem dyskryminacji tej narodowości, zwłaszcza że wcześniej zarejestrowano stowarzyszenia mniejszości żydowskiej, rosyjskiej, białoruskiej i ukraińskiej. Dlatego też MSW nakazało władzom wojewódzkim w Białymstoku zarejestrować LTSK. Było to jedno $\mathrm{z}$ przełomowych wydarzeń $\mathrm{w}$ powojennym funkcjonowaniu mniejszości litewskiej. Wcześniej ta wiejska społeczność, obawiająca się prześladowań i wysiedleń, żyjąca we własnym gronie na peryferiach kraju, w izolacji, była ostrożna i nieufna ${ }^{64}$. Nie sprzyjało to jakiejkolwiek aktywności. Po zjeździe sytuacja się zmieniła, rozbudził on ponownie świadomość narodową Litwinów, spowodował wyraźne ożywienie ich działalności. Uaktywnienie się Litwinów na Suwalszczyźnie spowodowało także odrodzenie dawnych oskarżeń, urazów i niechęci narodowościowych oraz wzrost tendencji nacjonalistycznych zarówno wśród Litwinów, jak i Polaków. Szybko doprowadziło to do konfliktu z władzami, także dlatego, że w początkowym okresie LTSK próbowało prowadzić działalność względnie samodzielną, autonomiczną ${ }^{65}$. Taka sytuacja była nie do zaakceptowania przez władze partyjne, które nadzorowały i kontrolowały działalność wszelkich instytucji. LTSK nie mogło być wyjąt-

${ }^{64} \mathrm{~W}$ tym okresie według białostockiego Wydziału Oświaty w powiecie sejneńskim miało mieszkać ok. 8 tys. Litwinów (Tarka 2010).

${ }^{65}$ Pierwsze władze LTSK wybrano demokratycznie, a wśród 12 członków prezydium był tylko jeden członek PZPR. W późniejszych latach taka sytuacja już się nie powtórzyła (Tarka 1998). 
kiem. Organizację poddano krytyce, oskarżono o klerykalizm, separatyzm i nacjonalizm. W 1959 r. władze centralne doprowadziły do zmian w jej kierownictwie, odsuwając dotychczasowych działaczy i całkowicie podporządkowując ją PZPR i MSW. Przeniesiono także siedzibę LTSK z największego skupiska mniejszości litewskiej w Puńsku do zdominowanych przez Polaków powiatowych Sejn (Olejnik 2003, Tarka 1998, 2010).

Jedną z najważniejszych kwestii dla działaczy litewskich była sprawa szkolnictwa. Zdawali sobie sprawę ze znaczenia i przewagi szkolnictwa z litewskim językiem wykładowym nad nauką litewskiego jako przedmiotu dodatkowego w polskich szkołach. Dlatego dążyli do jak najszerszej rozbudowy właśnie tego typu edukacji. Domagali się także wprowadzenia do programów szkolnych elementów historii i geografii Litwy. W roku szkolnym 1956/57 działało pięć szkół podstawowych z litewskim językiem nauczania, dwa lata później było już osiem tego typu szkół, do których uczęszczało prawie 400 uczniów. W 1956 r., po kilku latach starań, otwarto w Puńsku liceum z litewskim językiem nauczania, do którego uczęszczało kilkudziesięciu uczniów (Tarka 1998). W kolejnych dekadach taki model edukacji w bardzo dużym stopniu przyczynił się do utrzymania litewskiej odrębności językowej i tożsamości narodowej wśród mieszkańców okolic Puńska i Sejn.

Pod koniec lat 50. XX w. zmieniono sposób finansowania organizacji narodowościowych. W listopadzie 1958 r. rząd przyjął uchwałę dającą organizacjom społecznym prawo do prowadzenia działalności produkcyjnej, handlowej i usługowej. Głównym celem było zaangażowanie wszelkiego rodzaju stowarzyszeń do samodzielnego zarabiania na swoją działalność statutową, co w konsekwencji miało doprowadzić do zmniejszenia, a następnie likwidacji dotacji z budżetu państwa. Objęło to także organizacje mniejszości narodowych.

Poszczególnym towarzystwom społeczno-kulturalnym przydzielono w $1959 \mathrm{r}$. po kilka zakładów przemysłowych lub usługowych. UTSK otrzymało wytwórnie kilimów i narzut w Kleszczelach na Podlasiu, zakłady włókiennicze w Częstochowie i Przemyślu oraz zakład chemiczny w Olkuszu, natomiast BTSK miało zarządzać dwoma przedsiębiorstwami w Warszawie (jednym produkującym tworzywa sztuczne, a drugim olejki eteryczne) oraz dwoma w województwie białostockim (żwirownią i piekarnią). LTSK nie otrzymało żadnego przedsiębiorstwa $^{66}$. Rozmieszczenie niektórych $\mathrm{z}$ tych zakładów (Warszawa, Częstochowa, Olkusz) miało niewiele wspólnego z postulowaną przez władze ,aktywizacją zawodową ludności niepolskiej” (Mironowicz 2000).

${ }^{66}$ Zakłady produkcyjne w zarządzanie, poza UTSK i BTSK, otrzymało także stowarzyszenie żydowskie, rosyjskie oraz czesko-słowackie. 


\subsubsection{Dekada lat 60. XX wieku}

Na przełomie lat 50. i 60. XX w., wraz z odejściem władz od idei października 1956 r., nastapiło zaostrzenie kursu wobec mniejszości narodowych. Jednocześnie opadła fala początkowego entuzjazmu związanego z przemianami politycznymi, wyraźnie zmniejszyła się aktywność społeczna i polityczna. Nadal wysyłano do władz (zarówno szczebla lokalnego, jak i centralnego) liczne petycje, listy i pisma z postulatami dotyczącymi spraw poszczególnych mniejszości narodowych, jednak z reguły pozostawały one bez żadnej odpowiedzi. Najczęstszą reakcją władz na tego typu działania były szykany i represje skierowane wobec sygnatariuszy listów. Zawiodły nadzieje pokładane w „polskim październiku” i w rządach Władysława Gomułki. Wszelka działalność społeczna, kulturalna, a zwłaszcza polityczna, osób wywodzących się ze środowisk mniejszości narodowych była przez władze kontrolowana i inwigilowana, nasiliły się tendencje do ograniczania roli i samodzielności organizacji narodowościowych. Rosła rola MSW w kreowaniu i realizowaniu polityki narodowościowej. Zmiany w życiu politycznym bardzo szybko przekładały się na sytuację mniejszości narodowych.

Już w listopadzie 1959 r. Komisja KC PZPR do Spraw Narodowościowych, we wstępie do dokumentu „Wnioski w sprawie dalszego rozwoju pracy kulturalno-oświatowej wśród mniejszości narodowych w Polsce" zaznaczyła, że „Towarzystwa mniejszości narodowych są polskimi organizacjami kulturalnymi. Realizują one linię partii. Służą budowie socjalizmu w Polsce, umacniają moralno-polityczną jedność naszego społeczeństwa" ${ }^{\text {"67 }}$. Pomijając kuriozalność tego fragmentu, pokazuje on traktowanie struktur organizacyjnych mniejszości narodowych przez polskie władze. Było to jasne przesłanie dla zarządów poszczególnych organizacji narodowościowych dotyczące wdrażania i upowszechniania programu partii we własnych środowiskach oraz sprzyjania asymilacji.

We wszelkich przejawach aktywności poszczególnych osób o niepolskiej narodowości i organizacji mniejszości narodowych, niezwiązanych $\mathrm{z}$, linią partii”, doszukiwano się nacjonalizmu. Zwalczanie rzeczywistych oraz domniemanych treści nacjonalistycznych stało się głównym zadaniem urzędników PZPR i MSW odpowiedzialnych za sprawy mniejszości narodowych. Nacjonalistów widziano wszędzie, zwłaszcza wśród działaczy towarzystw narodowościowych, w redakcjach czasopism, wśród inteligencji, działaczy partyjnych, ale także pośród rolników czy robotników, przejawiających jakąkolwiek aktywność na rzecz swojej grupy narodowościowej. W ocenie władz najbardziej nacjona-

${ }^{67}$ Cytat za E. Mironowicz (2000, s. 200). 
listyczna była mniejszości ukraińska. Za przejaw działalności nacjonalistycznej uważano każdą krytykę polityki narodowościowej władz, domaganie się powrotu do miejsc wysiedlenia w południowo-wschodniej Polsce, kwestionowanie oficjalnej wersji najnowszej historii Polski, a także czytanie emigracyjnej prasy, korespondencję z rodzinami z zagranicy, otrzymywanie od nich paczek, czy odmowę zapisania się do kółka rolniczego. Mniejszości narodowe objęto jeszcze ściślejszą inwigilacją (Mironowicz 2000, 2011).

W 1960 r. odbył się w Warszawie II zjazd UTSK. W niczym nie przypominał I zjazdu - jego przebieg był dokładnie zaplanowany, a delegatów nie dopuszczano do podejmowania tematów „niewygodnych”. Władze państwowe skutecznie przekształciły UTSK w posłuszne narzędzie służące interesom PZPR wśród mniejszości ukraińskiej. Skład ZG UTSK został całkowicie podporządkowany MSW, a działacze dążący do zachowania niezależności organizacji byli w niej marginalizowani lub z niej usuwani. Głównym problemem poruszanym podczas obrad była walka $z$ nacjonalizmem ukraińskim. Zmiany zachodzące w UTSK zniechęciły i rozczarowały do tej organizacji wielu działaczy, przekreśliły nadzieje na spełnienie przez władze jakichkolwiek postulatów narodowych. Liczba członków UTSK spadła o połowę, do 3466 w 1961 r., skupionych w 208 kołach (Drozd, Halczak 2010).

MSW, nadzorujące wszystkie organizacje narodowościowe, nie próbowało już wyciszać konfliktu łemkowsko-ukraińskiego wewnątrz UTSK, a nawet starało się podtrzymać ten antagonizm. Kwestia łemkowska była wykorzystywana przez władze do osłabiania ruchu ukraińskiego, do oskarżania go o nacjonalizm. Jednocześnie konsekwentnie odrzucano wciąż pojawiające się postulaty działaczy łemkowskich domagających się uznania ich za odrębną narodowość (Mironowicz 2007).

Działalność władz wobec mniejszości ukraińskiej skupiała się na dalszej asymilacji oraz konsekwentnym osłabianiu czynników podtrzymujących odrębność narodowa, m.in. ograniczaniu roli wyznania greckokatolickiego i szkolnictwa ukraińskiego, w którym systematycznie postępował regres. Stopniowo zmniejszała się zarówno liczba szkół, jak i uczęszczających do nich dzieci. Było to efektem polonizacji Ukraińców, szykan ze strony polskiego środowiska w stosunku do uczniów oraz rodziców i celowej polityki władz. W roku szkolnym 1969/70 funkcjonowały już tylko trzy szkoły podstawowe (Biały Bór, Banie Mazurskie, Jaroszówka ${ }^{68}$ ) oraz liceum w Legnicy, a także klasy ukraińskie w liceach w Bartoszycach i Górowie Iławeckim. Liczba punktów nauczania

${ }^{68}$ Rozwiązana w następnym roku szkolnym. 
języka ukraińskiego spadła do $96^{69}$ (w porównaniu z 183 dziesięć lat wcześniej), a uczyło się go ogółem 2341 uczniów (o prawie tysiąc mniej niż dziesięć lat wcześniej).

W latach 60. XX w. został zapoczątkowany proces migracji Ukraińców i Łemków (zwłaszcza młodzieży) ze wsi do miast. Jeszcze w 1963 r. dla 90\% Ukraińców podstawą utrzymania była praca w rolnictwie i leśnictwie. Młode pokolenie niechętnie pozostawało na wsi, głównie z powodu ciężkiej pracy, niskich dochodów, braku perspektyw. Istotnym czynnikiem był fakt, iż nie traktowali poniemieckich gospodarstw jako „ojcowizny”. Perspektywa życia w mieście stwarzała możliwości zdobycia wykształcenia, lepszej pracy i - co ważne - anonimowości. Jednocześnie nasilała procesy asymilacji. Migracjom sprzyjały procesy industrializacji. Powstawały skupiska Ukraińców i Łemków m.in. w Olsztynie, Słupsku, Koszalinie, Szczecinie, Gorzowie Wielkopolskim, Zielonej Górze, Lubinie, Legnicy, Wrocławiu, a także w Warszawie i Krakowie. $\mathrm{Na}$ Podkarpaciu najważniejszym skupiskiem Ukraińców stał się Przemyśl. Z czasem miasta te stały się ośrodkami inteligencji ukraińskiej (Drozd 2010, Drozd, Halczak 2010).

Pozytywnym zjawiskiem w tym okresie były próby odrodzenia ukraińskiego życia kulturalnego, zwłaszcza w województwach północnych i zachodnich. Zrodził się amatorski ruch artystyczny, powstały zespoły ludowe, chóry, kółka teatralne. Ich funkcjonowanie wspierało UTSK, mimo to większość powstałych wówczas zespołów w krótkim czasie zaprzestała działalności, głównie z powodu braku środków finansowych oraz zbyt dużego rozproszenia mniejszości ukraińskiej i łemkowskiej. Dzięki powrotom w latach 50. XX w. części przesiedleńców w Beskidy odrodziło się także życie kulturalne na Łemkowszczyźnie. W Zyndranowej powstało Muzeum Regionalnej Kultury Łemkowskiej, w Zdyni Centrum Kultury Łemkowskiej, w Bielance zaczęło gromadzić zbiory Muzeum Łemkowskie, działalność zapoczątkował zespół „Łemkowyna” (Dudra 2010).

Jednocześnie postępował proces „wrastania” Ukraińców w nowe miejsca osiedlenia. Polityka władz, mająca na celu związanie ich z ziemiami północnymi i zachodnimi poprzez ograniczenie możliwości powrotu, pomoc finansową, zorganizowanie (choć w bardzo ograniczonym zakresie) działalności kulturalnej i oświatowej, przyniosła widoczne efekty. Postępował proces adaptacji Ukraińców. Ponadto dorosło nowe pokolenie urodzone na ziemiach zachodnich i północnych, silniej związane z Pomorzem, Mazurami lub Śląskiem niż z Karpatami

${ }^{69} \mathrm{~W}$ tym w województwie olsztyńskim 60 , białostockim -7 , rzeszowskim -6 , wrocławskim - 4, szczecińskim - 4, koszalińskim - 10, gdańskim - 5 (Drozd 2010). 
czy Lubelszczyzną, migrujące do miast, coraz częściej ukrywające swoje pochodzenie narodowe, ulegające asymilacji (Drozd 1998).

Na początku lat 60 . ubiegłego wieku załamała się, zapoczątkowana zaledwie kilka lat wcześniej, działalność gospodarcza towarzystw społeczno-kulturalnych mniejszości narodowych. Zamiast planowanych zysków, wszystkie przedsiębiorstwa będące od końca lat 50. zarządzane przez organizacje narodowościowe, już od 1960 r. przynosiły duże straty. Wyjątkiem była działalność gospodarcza BTSK, które, dzięki dochodom dwóch zakładów warszawskich, osiągało zysk porównywalny $\mathrm{z}$ całym budżetem organizacji. Niepowodzenie gospodarcze organizacji narodowościowych było spowodowane nie tylko nieudolnością działaczy, brakiem ich przygotowania i doświadczenia w kierowaniu przedsiębiorstwami, ale głównie systemem dotacji, według którego organizacje niewykazujące dochodów z prowadzonej przez siebie działalności otrzymywały większe dotacje z MSW. Władze towarzystw nie miały zatem żadnej motywacji w efektywnym i zyskownym zarządzaniu przekazanymi im przedsiębiorstwami, m.in. dlatego w 1963 r. podjęto decyzję o likwidacji wszystkich przybudówek gospodarczych poszczególnych towarzystw narodowościowych. Jedynie w przypadku BTSK, z zarządzanych przez stowarzyszenie firm postanowiono powołać spółdzielnię produkcyjną „Beteska”, która miała przekazywać $20 \%$ zysków na działalność statutową towarzystwa. Jednocześnie towarzystwu zmniejszono dotację z budżetu państwa (Mironowicz 2000).

$\mathrm{Na}$ Podlasiu w latach 60. XX w. środowisko mniejszości białoruskiej podlegało dalszemu upartyjnieniu. Ponad $85 \%$ osób z ZG BTSK było członkami PZPR, wielu łączyło funkcje w BTSK ze stanowiskami w MSW i PZPR. Ich działalność dowodziła, że zazwyczaj wyżej stawiali interes partii niż narodu, który mieli reprezentować. BTSK nadal było organizacją lojalną, stabilną, przewidywalną, upowszechniającą ideały socjalizmu, niesprawiająca żadnych problemów rządzącym ${ }^{70}$. Ten konformizm zarówno działaczy białoruskich, jak i samej organizacji sprzyjał rozwojowi działalności kulturalnej, która, poza rutynową kontrolą cenzury, nie była w żaden sposób ograniczana przez władze. W 1962 r. na Białostocczyźnie działało 98 białoruskich amatorskich zespołów artystycznych. BTSK organizowało koncerty zespołów folklorystycznych, wystawy, festyny, konkursy. Nastąił rozwój kultury białoruskiej, jednak ograniczonej do postrzegania własnej odrębności w kategoriach regionalizmu, pozbawionej elementów narodowych (Mironowicz 2000, 2010).

${ }^{70} \mathrm{Na}$ początku lat 60. XX w. BTSK liczyło ok. 3,4 tys. członków skupionych w ośmiu oddziałach powiatowych i 140 kołach. Podczas kolejnych 10 lat liczebność wzrosła do 6,5 tys. członków w 190 kołach (Chałupczak, Browarek 1998). 
Według szacunków Prezydium Wojewódzkiej Rady Narodowej w Białymstoku, na początku lat 60 . XX w., w ówczesnym województwie białostockim mieszkało nieco ponad 120 tys. wyznawców prawosławia, nadal utożsamianych przez władze wyłącznie z mniejszością białoruską. Najwięcej prawosławnych zamieszkiwało powiat hajnowski - 47 tys. ( $81 \%$ ogółu mieszkańców), powiat bielski $-32,4$ tys. $(45,3 \%)$, białostocki -23 tys. $(25,9 \%)$, siemiatycki $-20,5$ tys. $(29,1 \%)$ oraz sokólski - 7,8 tys. (11,8\%) (Goss 2001).

Mimo dużej liczby Białorusinów mieszkających zwarcie w południowo-wschodniej części województwa białostockiego nadal ograniczano rolę szkolnictwa białoruskiego. Trwająca od lat 50. XX w. tendencja zastępowania szkół z białoruskim językiem nauczania szkołami polskimi, gdzie uczono języka białoruskiego tylko jako przedmiotu dodatkowego, nasiliła się. BTSK przestało się jej sprzeciwiać, a białostockie kuratorium oświaty wraz z rodzicami skutecznie nalegało na takie przekształcenia, argumentując to wyższym poziomem nauczania w polskich szkołach i troską o przyszłą edukację dzieci. Pod koniec lat 60. XX w. radykalnie zmniejszono nakłady na szkolnictwo białoruskie, zaprzestano drukowania podręczników, upowszechniano opinię (z którą zgadzało się wielu Białorusinów), że język ten nie jest w Polsce do niczego potrzebny. Przestały istnieć prawie wszystkie szkoły z białoruskim językiem wykładowym, pozostały te, w których uczono go jako przedmiotu dodatkowego, nieobowiązkowego. W roku szkolnym 1969/70 działały 164 tego typu szkoły podstawowe oraz dwa formalnie ,białoruskie” licea ${ }^{71}$ (w Bielsku Podlaskim i Hajnówce), w których uczyło się ponad 11 tys. uczniów. Nauka języka białoruskiego była prowadzona bardzo często przez osoby źle przygotowane i stała na niskim poziomie.

Liczna reprezentacja osób pochodzenia białoruskiego we władzach województwa białostockiego (funkcjonowało wręcz powszechne przekonanie o zdominowaniu KW PZPR w Białymstoku przez Białorusinów) nie przekładała się na dbanie o białoruskie interesy narodowe. Wręcz przeciwnie - urzędnicy ci ukrywali swoje pochodzenie, deklarowali narodowość polską, podkreślali lojalność wobec partii oraz Polski Ludowej, często celowo uniemożliwiali załatwienie jakiejkolwiek sprawy na rzecz środowiska białoruskiego ${ }^{72}$ (Mironowicz 2000, 2010a, b).

${ }^{71}$ Zdecydowaną większość przedmiotów uczono w języku polskim.

72 I sekretarz białostockiego KW PZPR w latach 60. XX w., Arkadiusz Łaszewicz, były działacz Komunistycznej Partii Zachodniej Białorusi, mimo licznych zaproszeń, nigdy nie pojawił się na żadnej uroczystości organizowanej przez BTSK. Włodzimierz Stankiewicz, przewodniczący BTSK w latach 1958-1960, delegowany w latach 60. jako przedstawiciel MSW na różnego rodzaju uroczystości organizowane przez BTSK, podczas przemówień zawsze używał zwrotu ,wy, Białorusini” (Mironowicz 2000). 
W 1960 r., po kilku latach starań członków ZG LTSK, zezwolono na wydawanie pierwszego po wojnie czasopisma w języku litewskim „Aušra” (Zorza). Wcześniej władze, nie mając pełnej kontroli nad środowiskiem litewskim oraz nie posiadając zaufanego zespołu redakcyjnego, nie wyrażały zgody na tworzenie pisma w języku litewskim. Mimo że „Aušra” początkowo ukazywała się bardzo rzadko i nieregularnie (zaledwie jeden lub dwa numery w ciągu roku) i jak wszystkie czasopisma była kontrolowana przez cenzurę, to szybko stała się bardzo popularna $\mathrm{w}$ środowisku polskich Litwinów ${ }^{73}$. Z pewnością było to spowodowane brakiem jakiejkolwiek konkurencji (w okresie PRL było to jedyne litewskojęzyczne wydawnictwo), ale także możliwością kontaktu z literackim językiem litewskim.

Litwini doskonale zdawali sobie sprawę, że z powodu bardzo małej liczebności oraz braku odrębności wyznaniowej, najważniejszym czynnikiem, dzięki któremu będą mogli uniknąć asymilacji i utrzymać odrębność narodową, jest zachowanie własnego języka i kultury. Głównym przejawem działalności narodowej i podstawą utrzymania litewskiej tożsamości stał się rozwój szkolnictwa oraz działalności kulturalnej. Pod koniec lat 60. XX w. funkcjonowało litewskie liceum w Puńsku (ok. 100 uczniów) oraz dziewięć litewskich szkół podstawowych (ok. 500 uczniów), ponadto język litewski był nauczany w 11 szkołach polskich (ok. 250 uczniów uczących się języka litewskiego), w tym w polskim liceum w Sejnach (ok. 30 uczniów). Ogółem z możliwości uczenia się języka litewskiego korzystało corocznie ok. 900 uczniów, czyli prawdopodobnie prawie wszystkie dzieci litewskie w wieku szkolnym na Suwalszczyźnie ${ }^{74}$. Dbano także o podnoszenie kwalifikacji zawodowych nauczycieli litewskich, kadry dostarczało liceum w Puńsku, ponadto podczas wakacji kilkunastu nauczycieli wyjeżdżało na kursy językowe do Wilna. Szkolnictwo litewskie zdecydowanie wyróżniało się in plus na tle szkolnictwa innych mniejszości narodowych w Polsce pod względem poziomu nauczania, organizacji, frekwencji, ale także udziału szkół z wykładowym językiem mniejszości. Z pewnością było to ułatwione skupieniem terytorialnym mniejszości litewskiej, ale niemożliwe do osiągnięcia bez silnego poczucia tożsamości narodowej i zrozumienia roli edukacji dzieci w utrzymaniu narodowej odrębności.

$\mathrm{W}$ latach 60. XX w. nastąpiła zmiana w postawach politycznych części Litwinów. O ile przed 1950 r. do partii nie należał ani jeden Litwin, w latach 50.

${ }^{73}$ Dopiero w 1973 r. „Aušra” została przekształcona w kwartalnik, a redakcja przeniesiona z Warszawy do Sejn (Tarka 2010).

${ }^{74}$ Liczebność ogółu Litwinów w północno-wschodniej Polsce była wówczas szacowana na ok. 8 tys. osób. 
zaledwie kilku-kilkunastu, o tyle w latach 60. do PZPR należało już ponad 200 Litwinów. Wielu pełniło funkcję radnych, łamiąc wcześniejszy monopol Polaków na sprawowanie lokalnej władzy, opanowując stopniowo miejscowy aparat partyjny i administracyjny. Był to przejaw przystosowywania się mniejszości litewskiej do rzeczywistości społeczno-politycznej, ale także w pewnym stopniu sposób na współdecydowanie o lokalnej polityce, szkolnictwie, aktywności kulturalnej. Litewscy urzędnicy i towarzysze partyjni - w odróżnieniu od białoruskich - wykorzystywali swoją pozycję w strukturach administracyjnych do dbania o interesy narodowe własnej społeczności. Jednocześnie dzięki peryferyjnemu położeniu Puńska i Sejn oraz małej liczebności, niestanowiącej problemu nawet w skali województwa białostockiego, unikali oskarżeń o „,nacjonalizm”, natomiast byli krytykowani za ,uleganie wpływom klerykalnym”.

LTSK otrzymało od władz państwowych monopol na propagowanie i rozwijanie litewskiej kultury i oświaty. Ceną było całkowite podporządkowanie i uzależnienie pod każdym względem - personalnym, merytorycznym, finansowym, organizacyjnym, a wszelkie formy aktywności były ściśle limitowane. Najważniejszym przejawem działalności LTSK było wspieranie oświaty w języku litewskim oraz amatorskich zespołów ludowych (w tym tzw. teatrów stodolanych), które przez lata odgrywały ogromną rolę w zachowaniu litewskiej kultury oraz podtrzymaniu wśród mieszkańców Suwalszczyzny litewskiej tożsamości. W kilkutysięcznym środowisku litewskim działało wówczas ok. 20 zespołów artystycznych, często reprezentujących bardzo wysoki poziom. Do najważniejszych należał chór „Dzūkija”, zespół choreograficzny „Jotva” oraz kapela „Klumpe”. Bardzo popularne były zloty o charakterze spotkań artystyczno-towarzyskich organizowane w Klejwach, Jeglińcu, Puńsku, Burbiszkach. Masowy udział w imprezach kulturalnych stanowił jeden z głównych czynników integrujących Litwinów, kształtował także świadomość narodową kolejnych pokoleń.

Głównym litewsko-polskim punktem spornym na Suwalszczyźnie w latach 60. XX w. był, trwający od 1946 r. i nadal nierozwiązany, konflikt między litewskimi parafianami a kurią biskupią, dotyczący nabożeństw w języku litewskim w bazylice w Sejnach. Władze kościelne uparcie odmawiały wydania zgody na takie nabożeństwo, proponując mniejszości litewskiej wyremontowanie kaplicy w Żegarach koło Sejn i zorganizowanie tam litewskiego ośrodka duszpasterskiego. Litwini zdecydowanie odrzucili - jak to określali - „status parafian drugiej kategorii" i nadal bezskutecznie domagali się przywrócenia litewskich nabożeństw w bazylice, wysyłając liczne listy protestacyjne nie tylko do kurii biskupiej w Łomży, ale także do sekretariatu episkopatu, prymasa Polski oraz Urzędu 
ds. Wyznań, a w latach 70. XX w. nawet do Watykanu ${ }^{75}$ (Tarka 1998, 2010, Milewski 2001). Pozbawianie Litwinów nabożeństw we własnym języku nie było tylko lokalnym wyjątkiem, podobna sytuacja miała miejsce także wobec innych rzymskokatolickich mniejszości narodowych w Polsce - Słowaków oraz części Niemców.

\subsubsection{Dekada lat 70. $\mathrm{XX}$ wieku}

Działania władz wobec mniejszości narodowych, ukierunkowane na dalszą asymilację i podporządkowanie, zostały na krótki okres zakłócone krwawymi wydarzeniami w grudniu 1970 r. na Wybrzeżu. Zmiana ekipy rządzącej oraz pierwsze przemówienia członków nowych władz stwarzały wrażenie zmiany polityki państwa, w tym także w kwestiach narodowościowych i wyznaniowych. Spowodowało to uaktywnienie się działaczy organizacji mniejszościowych (zwłaszcza terenowych oddziałów UTSK), wysyłanie listów i petycji do władz, ponowne przedstawianie swoich postulatów. Nie tylko nie spotkały się one z pozytywną reakcja, ale wywołały działania wymierzone $w$ ich sygnatariuszy dochodzenia, przesłuchania, zastraszanie, a w konsekwencji usuwanie z UTSK. Ponownie okazało się, że istnieje wyraźny rozdźwięk między retoryką władz komunistycznych a codzienną praktyką polityczno-administracyjną.

Od III plenum KC PZPR w lutym $1976 \mathrm{r}$. w polityce rządu panowały poglądy o „moralno-politycznej jedności narodu polskiego” oraz Polsce jako kraju ,,jednorodnym etnicznie", które wiązały się bezpośrednio z ograniczeniem działalności wszelkich regionalizmów, zwłaszcza wśród mniejszości narodowych i etnicznych, które postanowiono zredukować do grup folklorystycznych, całkowicie minimalizując ich problematykę narodową. Celem władz stało się wynarodowienie niepolskich narodowości, ich polonizacja. Głęboki regres dotknął szkolnictwa, życia kulturalnego i organizacyjnego mniejszości. Jeszcze bardziej wzrosła kontrola i nadzór MSW nad organizacjami narodowościowymi, których używano głównie do indoktrynacji i asymilacji własnych środowisk. Odgórnie narzucane polecenia i zadania działacze przedstawiali jako interesy i postulaty mniejszości narodowych. Jakiekolwiek podkreślanie, nawet deklarowanie poczucia niepolskiej tożsamości narodowej, było oceniane w kategoriach nacjonalistycznych i ostro krytykowane. Powszechne stało się ukrywanie przynależności do mniejszości narodowych. Nasiliły się procesy asymilacji i akulturacji do polskości. Były one potęgowane migracją mieszkańców wsi (często wywodzą-

${ }^{75}$ Protesty te szczególnie nasiliły się w drugiej połowie lat 60 . XX w. po Soborze Watykańskim II, gdy w liturgii łacinę zastąpiono językami narodowymi. 
cych się spośród mniejszości narodowych) do całkowicie zdominowanych przez ludność polską miast (Chałupczak, Browarek 1998, Drozd 1998, Mironowicz 1998, 2000, Tarka 1998).

Dążenie władz do „moralno-politycznej jedności narodu polskiego” w 1977 r. przejawiało się także w zacieraniu materialnych śladów wielowiekowej obecności Ukraińców i Łemków na obszarze południowo-wschodniej Polski. Rozebrano lub zdewastowano wiele opuszczonych cerkwi, którym udało się przetrwać wojnę i pierwsze lata powojenne. W październiku 1977 r., decyzją Ministerstwa Administracji, Gospodarki Terenowej i Ochrony Środowiska zmieniono 120 ukraińskich i łemkowskich nazw miejscowości, głównie w ówczesnych województwach krośnieńskim, przemyskim i nowosądeckim ${ }^{76}$. Działania te spowodowały sprzeciw nie tylko mniejszości ukraińskiej, łemkowskiej i UTSK, ale także Polskiej Akademii Nauk i Związku Literatów Polskich. Postępowanie władz porównywano do działań okupacyjnych władz niemieckich, które zmieniały nazwy polskie na niemieckie, podkreślano brak naukowych podstaw proponowanych zmian, domagano się przywrócenia nazw historycznych, tradycyjnych. Mimo to przez kilka kolejnych lat protesty pozostawały bez odpowiedzi, dopiero na początku $1981 \mathrm{r}$. zdecydowano się przywrócić dawne nazwy, poza dwoma (Gawryszewski 2005, Wysocki 2011). Urzędowo spolszczono również liczne nazwy na zamieszkanych przez Białorusinów obszarach Białostocczyzny (Mironowicz 2000).

Mimo ogólnego marazmu lat 70. XX w. nastąpiło ożywienie w działalności organizacyjnej UTSK. Było ono spowodowane zmianą pokoleniową wśród działaczy. W drugiej połowie tej dekady władzę w organizacji przejęło pokolenie urodzone już na ziemiach zachodnich, pozbawione osobistych negatywnych doświadczeń historycznych, aktywne i lepiej wykształcone. O ile w latach 60. działalność UTSK koncentrowała się na obszarach wiejskich i małomiasteczkowych, o tyle w latach 70. najbardziej dynamiczny rozwój przeżywały oddziały w większych miastach. Zaczęto organizować coroczny „Rajd Karpaty” oraz młodzieżowe „Jarmarki” w Gdańsku. Liczba członków UTSK w 1976 r. wzrosła do ok. 5,4 tys., zrzeszonych w 175 kołach (Drozd, Halczak 2010). Jednak bardzo silne rozproszenie terytorialne, postępujące migracje do miast, ograniczone oddziaływanie UTSK na ogół ludności ukraińskiej, konsekwentnie umacniane przez publicystykę, literaturę oraz film negatywne stereotypy związane z naro-

76 Zmiany nazw polegały głównie na ich spolszczaniu, np. Berezka na Brzózka, Horodek na Gródek, Załuże na Załęże oraz usuwaniu określenia Ruski, Ruska, Ruskie lub jego zmianie na Polski, Polska, Polskie. Niektóre zmiany były wręcz kuriozalne, np. Smerek na Świerków. 
dowością ukraińską, ograniczanie szkolnictwa, sprzyjało dalszej asymilacji Ukraińców, którzy coraz powszechniej zaczęli uważać się za Polaków pochodzenia ukraińskiego.

Polityka władz w latach 70. ubiegłego wieku doprowadziła do zapaści szkolnictwa w językach mniejszości narodowych. Było to spowodowane głównie procesem likwidacji małych, wiejskich szkół. Dzieci zaczęto dowozić do zbiorczych szkół gminnych. Był to cios dla systemu oświaty mniejszości narodowych. Punkty nauczania języka ukraińskiego, białoruskiego czy litewskiego, mieściły się najczęściej w małych wiejskich szkołach. W zbiorczych szkołach gminnych władze oświatowe $\mathrm{z}$ reguły nie wyrażały zgody na nauczanie języka mniejszości. Brakowało też chętnych dzieci do zostawania po lekcjach na dodatkowe zajęcia, zwłaszcza że czekał je często długi powrót do domu. Ponadto w lutym $1971 \mathrm{r}$. Ministerstwo Oświaty wydało rozporządzenie, w którym zobowiązało rodziców do corocznego składania deklaracji z wnioskiem, żeby ich dzieci uczyły się niepolskiego języka ojczystego. Brak takich deklaracji dawał dyrektorom szkół podstawę do rezygnacji z nauczania języka mniejszości $\mathrm{w}$ podległej im szkole. Postawa wielu rodziców - z różnych powodów niechętnych nauczaniu ich dzieci języka ojczystego - była także jedną z przyczyn stopniowej likwidacji nauki języków mniejszości narodowych w szkołach podstawowych.

Liczba punktów nauczania języka ukraińskiego na przełomie lat 70 i 80 . ubiegłego wieku spadła do zaledwie 28 (20 lat wcześniej takich punktów było 183), ponadto nadal funkcjonowało liceum ukraińskie w Legnicy oraz szkoły podstawowe w Białym Borze, Baniach Mazurskich i Górowie Iławeckim. Na naukę języka ukraińskiego uczęszczało ogółem 860 uczniów (20 lat wcześniej 3287, 10 lat wcześniej - 2341) (Drozd, Halczak 2010). W Bielsku Podlaskim w 1970 r. zlikwidowano Liceum Pedagogiczne z białoruskim językiem nauczania, które przygotowywało kadry nauczycielskie dla wiejskich szkół. Podczas dekady lat 70. XX w. na Podlasiu dramatycznie spadała liczba szkół i uczniów uczących się języka białoruskiego ${ }^{77}$, nie funkcjonowała już żadna szkoła z białoruskim językiem nauczania. Naukę tego języka pozostawiono jedynie w formie dodatkowych, nieobowiązkowych lekcji, radykalnie ograniczono nakłady finansowe na białoruskie szkolnictwo, zaprzestano drukowania podręczników. Zamykanie wielu małych, wiejskich szkół, gdzie wcześniej uczono języka białorus-

${ }^{77} \mathrm{~W}$ latach 70. XX w. liczba uczniów uczących się języka białoruskiego zmniejszyła się z 11,3 tys. uczących się w 164 szkołach podstawowych i trzech liceach do 4-4,5 tys. uczących się w 45 szkołach podstawowych i dwóch liceach (Chałupczak, Browarek 1998). 
kiego, zostało spowodowane procesami wyludniania się wsi białoruskich we wschodniej części Białostocczyzny (Mironowicz 2000). Bardzo dobrze funkcjonujące na Suwalszczyźnie pod koniec lat 60 . XX w. szkolnictwo z litewskim językiem nauczania, które było dumą mniejszości litewskiej, w następnej dekadzie znalazło się w bardzo trudnej sytuacji. Zlikwidowano większość małych wiejskich szkół litewskich i poza liceum w Puńsku dzieci mogły uczyć się języka litewskiego tylko jako przedmiotu dodatkowego w polskich szkołach, a liczba uczniów spadla do ok. 700. Mimo tego regresu dbano o jak najwyższy poziom nauczania i przygotowania zawodowego nauczycieli, zdołano wyposażyć uczniów szkół podstawowych w pełny zestaw podręczników do języka litewskiego, a w 1977 r. w Puńsku oddano do użytku nowy budynek mieszczący liceum ogólnokształcące, szkołę podstawową i zasadniczą szkołę rolniczą z litewskim językiem nauczania wraz z internatem i salą gimnastyczną (Tarka 1998).

W 1972 r. zlikwidowano reprezentacyjny zespół estradowy BTSK „Lawonicha”, rok później zamknięto jedyne Białoruskie Muzeum Etnograficzne w Białowieży ${ }^{78}$, BTSK odebrano prawo prowadzenia działalności gospodarczej (spółdzielnia produkcyjna „Beteska” została przejęta przez państwo) i przekształcono $\mathrm{w}$ organizację o charakterze partyjnym, reprezentującą wyłącznie interesy władzy. Zanikła działalność kilkudziesięciu wiejskich zespołów folklorystycznych, teatralnych, tanecznych, chóralnych. Powszechne stało się ukrywanie - bądź wypieranie się - przynależności do narodowości białoruskiej, często „ludzie białoruskiego pochodzenia starali się być bardziej polscy niż sami Polacy" (Mironowicz 1998). Głównym, a często jedynym, wyróżnikiem wobec polskiego otoczenia pozostało wyznanie prawosławne, a dominującymi grupami wśród Białorusinów byli „Polacy prawosławni” lub „Polacy pochodzenia białoruskiego" (Sadowski 1995a, Barwiński 2004a). Nasiliła się migracja, zwłaszcza młodzieży z białoruskich wiosek do Hajnówki, Bielska Podlaskiego, Siemiatycz, Białegostoku i miast zachodniej części Białostocczyzny oraz Warszawy. Wiejskie regiony południowo-wschodniego Podlasia zaczęły się wyludniać. Jak pisał E. Mironowicz (1998): „Czynnikiem aktywizującym pokolenia Białorusinów przenoszących się ze wsi do miast była przede wszystkim perspektywa awansu społecznego. Gdy białoruskość stanowiła przeszkodę w realizacji aspiracji zawodowych, była najczęściej odrzucana. [...] Ta ucieczka od własnej tożsamości była wynikiem nie tylko polityki władz komunistycznych i swoistej

${ }^{78}$ Eksponaty przekazano do Muzeum Wsi Północno-Wschodniej Polski w Ciechanowcu, zmieniono im nazwy i pokazywano jako zabytki kultury materialnej rękodzieła ludowego północno-wschodniej Polski (Mironowicz 2010). 
alergii społeczeństwa polskiego na narodową inność, lecz także wyjątkowo słabego zakorzenienia w tradycji i kulturze białoruskiej”.

Jednocześnie w latach 70. XX w. rządy I sekretarza PZPR Edwarda Gierka przyczyniły się do względnej poprawy sytuacji materialnej, zwłaszcza ludności wiejskiej, zrównały status rolników z mieszkańcami miast, zapewniając im możliwość otrzymywania emerytury za zdanie gospodarstwa na rzecz skarbu państwa. Było to bardzo istotne dla rolników, wśród których relatywnie licznie były reprezentowane mniejszości narodowe. Te decyzje sprawiły, że dekada lat 70. XX w., tzw. epoka gierkowska, przez wielu z nich, zwłaszcza Białorusinów, była i jest oceniana bardzo pozytywnie.

\subsubsection{Dekada lat 80. XX wieku}

Przemiany polityczne w Polsce w 1980 r. były bardzo różnie odbierane przez mniejszości narodowe. Spośród narodowości wywodzących się ze wschodniej Polski najsilniejsze tendencje antykomunistyczne utrzymywały się wśród Ukraińców, którzy wszelkie problemy władzy przyjmowali z satysfakcją. Dlatego też powstanie „Solidarności” spowodowało wyraźną aktywizację ukraińskich środowisk młodzieżowych i inteligenckich, negatywnie oceniających ówczesną politykę narodowościową, zarówno państwa polskiego, jak i UTSK. Z kolei część opozycji solidarnościowej szukała poparcia w środowisku mniejszości ukraińskiej, znanej z niechęci do komunizmu ${ }^{79}$. Było to nowe zjawisko, dotychczas zdecydowana większość społeczeństwa polskiego, bez względu na poglądy polityczne, przyjmowała wobec Ukraińców postawę co najmniej niechętną. Trzeba jednak pamiętać, że „Solidarność” była popierana głównie przez środowisko studentów ukraińskich i część inteligencji, większość Ukraińców zachowała bierność, nie była skłonna angażować się w sprawy „wewnątrzpolskie”.

${ }^{79}$ Na I Krajowym Zjeździe Delegatów NSZZ „Solidarność” w Gdańsku 7 października 1981 r. przyjęto „Uchwałę w sprawie mniejszości narodowych”, w której czytamy m.in. „Dbając o rozwój kultury polskiej otwartej na dorobek innych narodów, wyrażamy wolę wykazania nie mniejszej dbałości o to, by obywatele polscy należący do innych narodów i grup etnicznych - Białorusini, Cyganie, Grecy, Litwini, Łemkowie, Niemcy, Ukraińcy, Tatarzy, Żydzi i inne narodowości, znaleźli we wspólnej z Polakami ojczyźnie warunki do swobodnego rozwijania swej kultury i przekazywania jej następnym pokoleniom. Chcemy w ten sposób pozostać wierni tradycji Rzeczypospolitej wielu narodów. Bogactwo kultury polskiej to również odrębności regionalne, które winny być kultywowane. Związek nasz sprzeciwia się wszelkim podziałom narodowościowym i walczyć będzie o zagwarantowanie pełni praw obywatelskich wszystkim Polakom, niezależnie od ich przynależności narodowościowej lub pochodzenia" (Dudra 2010, s. 275). 
Podjęte przez studentów próby zmiany sytuacji politycznej oraz utworzenia niezależnego od UTSK Zrzeszenia Studentów Ukraińskich w Polsce zostały skutecznie zahamowane wprowadzeniem stanu wojennego, choć część działaczy ukraińskich nadal aktywnie uczestniczyła w opozycji solidarnościowej (Chałupczak, Browarek 1998, Drozd 1998).

Wydarzenia 1980 r. u zdecydowanej większości Białorusinów spowodowały natomiast zaniepokojenie i poczucie zagrożenia. „Solidarność” była ruchem narodowo-polskim, zdecydowanie katolickim, odrzucającym ideologię komunistyczną. Prawosławni Białorusini, bardzo często stereotypowo utożsamiani ze zwolennikami ustroju socjalistycznego, z ,ruskimi”, nie byli akceptowani przez działaczy solidarnościowych i większość polskiego społeczeństwa Podlasia. Nasilały się podziały narodowe, religijne i polityczne (Sadowski 1995a, Mironowicz 1998, 2010a). Z kolei atmosfera początku lat 80. XX w. sprzyjała wewnętrznym przemianom w BTSK, które po raz pierwszy w swojej historii oficjalnie skrytykowało politykę władz partyjnych wobec białoruskiej mniejszości narodowej. Nastąpiło również - podobnie jak w przypadku Ukraińców - ożywienie $\mathrm{w}$ środowisku coraz liczniejszej białoruskiej inteligencji, zwłaszcza studentów, nie tylko na Podlasiu, ale również w Warszawie i Lublinie, gdzie bezskutecznie próbowano zarejestrować Białoruskie Zrzeszenie Studentów. Pojawiła się białoruska literatura „drugiego obiegu" ${ }^{\text {" }}$. Jednak działania inteligencji nie miały praktycznie żadnego wpływu na postawy i poglądy większości Białorusinów, którzy traktowali ich ,jako grupę dziwaków, osób podejrzanych, którzy proponowali przyjmowanie postaw i zachowań nierokujących nadziei na żadne profity w przyszłości” (Mironowicz 1998). Nadal postępowała polonizacja, zwłaszcza w środowiskach miejskich. Głównym, często jedynym, wyróżnikiem wobec polskiego otoczenia pozostawało wyznanie prawosławne. Ulga, z jaką Białorusini przyjęli wprowadzenie stanu wojennego, została bardzo negatywnie przyjęta przez większość Polaków, pogłębiając niechęć i nieufność. Wzajemne relacje „władza-Białorusini” po 1982 r. były kontynuacją polityki narodowościowej zapoczątkowanej w latach 70. XX w. (Sadowski 1995a, Mironowicz 1998, 2010a).

Także Litwini nieufnie, a nawet wrogo, traktowali „Solidarność”. Z jednej strony krótki okres jej działalności przerwał trwające przez lata 70. XX w. milczenie o mniejszościach narodowych, a tematyka ta, choć sporadycznie, to

${ }^{80}$ W latach 1981-1989 poza cenzurą ukazało się 49 białoruskich tytułów (czasopism, biuletynów, broszur, odezw). Najczęściej były to analizy sytuacji mniejszości białoruskiej, oceny polskiej myśli narodowej i politycznej, prognozy rozwoju sytuacji politycznej, prezentacje mało znanych faktów $\mathrm{z}$ najnowszej historii Białorusi (Mironowicz 2010a). 
jednak pojawiła się publicznie po raz pierwszy od lat. W $1981 \mathrm{r}$. LTSK zorganizowało w Puńsku lituanistyczną sesję naukową. Z drugiej strony „Solidarność" była powszechnie odbierana jako ruch narodowo-polski, nacjonalistyczny, który nie rozumiał i nie zajmował się problemami mniejszości narodowych. Działacze suwalskiej „Solidarności” nie zwracali żadnej uwagi na problemy mniejszości litewskiej, a ta $\mathrm{z}$ kolei nie wiązała $\mathrm{z}$ tym ruchem żadnych nadziei. Po wprowadzeniu stanu wojennego Litwini wzięli aktywny udział w działalności Patriotycznego Ruchu Odrodzenia Narodowego (PRON) i całkowicie zdominowali wszelkie urzędy w gminie Puńsk - administrację, milicję, oświatę, służbę zdrowia (Tarka 1998).

Wyzwolona na początku lat 80 . XX w., szczególnie wśród młodzieży studenckiej, idea samodzielności, samorządności oraz upodmiotowienia mniejszości narodowych w państwie polskim nie została zdławiona restrykcjami stanu wojennego. Wprowadzone ograniczenia jedynie przytłumiły publiczną aktywność. Studenci już w następnym roku akademickim, idąc na wymuszony kompromis z władzami, zaczęli organizować się w Ogólnopolskich Radach Kultury Studentów Mniejszości Narodowych, które funkcjonowały na zasadach autonomii w oficjalnie działającym Zrzeszeniu Studentów Polskich. W tej dekadzie ukraińskie rady kultury powstały w Warszawie, Lublinie, Wrocławiu, Krakowie, Olsztynie, z kolei białoruskie powołano w Warszawie i Olsztynie, natomiast w Białymstoku utworzono wspólnie z Litwinami Białorusko-Litewską Radę Kultury Studentów. Młodzież studencka organizowała przeglądy twórczości studenckiej mniejszości narodowych, sesje popularnonaukowe, warsztaty artystyczne, wycieczki, rajdy, obozy młodzieżowe, wydawała czasopisma - w języku białoruskim „Sustreczy”, a w języku ukraińskim „Zustriczi”.

Nie wszyscy studenci wywodzący się z prawosławnych środowisk Podlasia propagowali w tym okresie działalność narodowo-białoruską. Wśród części młodzieży z Białostocczyzny, studiującej w Warszawie i Lublinie, pojawiły się inicjatywny zmierzające do reaktywowania na Podlasiu działalności ukraińskiej. W 1983 r. powstał klub poetycki „Pidlaszsza”, który wydawał pismo „Nasz Hołos”. Rok później wznowiło działalność koło UTSK w Kleszczelach, w kolejnych latach powstawały koła UTSK w Czeremsze, Bielsku Podlaskim, Hajnówce, Białymstoku. Nastapił rozwój ukraińskiej działalności kulturalnej, powstawały amatorskie zespoły, biorące udział w licznych imprezach folklorystycznych. Aktywizacja Ukraińców na Podlasiu spowodowała niezadowolenie części Białorusinów, pojawiły się zarzuty dzielenia społeczności prawosławnej i „ukrainizacji” ludności białoruskiej (Drozd, Halczak 2010).

W marcu 1987 r. odbył się w Bielsku Podlaskim Zjazd Studentów Białoruskich. Pokazał on, że młode pokolenie, mimo przeciwności ze strony państwa 
komunistycznego, a także paradoksalnie, własnej skostniałej, całkowicie upartyjnionej i uległej władzom organizacji „społeczno-kulturalnej”, będzie konsekwentnie dążyć do realizacji własnych potrzeb narodowych. Podczas zjazdu podjęto decyzję o utworzeniu samodzielnej organizacji - Białoruskiego Zrzeszenia Studentów (BZS). Wraz z rozkładem struktur komunistycznych w Polsce studenci wystąili do władz z wnioskiem o zarejestrowanie BZS, co nastapiło dopiero 29 listopada 1988 r. Dopiero kilkadziesiąt lat po wojnie zaczęła w Polsce legalnie działać druga, obok BTSK, organizacja białoruska. Pierwsze koła terenowe BZS powstały w Białymstoku, Warszawie, Olsztynie, Gdańsku i Lublinie.

Od poczattku lat 80 . XX w. następowała poprawa sytuacji grekokatolików. W 1983 r. powstała niezależna od UTSK organizacja laikatu greckokatolickiego - Bractwo Cerkiewne św. Włodzimierza. Co prawda władze nadal nie zgadzały się na legalizację tego wyznania, inwigilowały duchownych, wspierały Kościół prawosławny w jego działalności wśród grekokatolików. Nie przeszkadzały jednak w tworzeniu kolejnych placówek, zgadzały się na zagraniczne pielgrzymki wiernych oraz przyjazdy z Watykanu do Polski dostojników hierarchii greckokatolickiej. Ponadto od wyboru papieża Jana Pawła II nastawienie zarówno Stolicy Apostolskiej, jak i polskiego episkopatu do dążeń grekokatolików stało się bardziej przychylne. Nie bez znaczenia były także zachodzące w drugiej połowie lat 80 . XX w. zmiany wewnętrzne w ZSRR, które m.in. przejawiały się w złagodzeniu polityki wobec działających tam nielegalnie struktur greckokatolickich, co z kolei rzutowało na postawę władz polskich. Pod koniec tej dekady Kościół greckokatolicki w Polsce posiadał 84 placówki obsługiwane przez 61 duchownych (Drozd, Halczak 2010). Mimo kilku pozytywnych zmian i relatywnej poprawy sytuacji grekokatolików w tym czasie, ich podstawowe postulaty, powtarzane już od kilkudziesięciu lat, czyli reaktywacja Kościoła greckokatolickiego, mianowanie osobnego biskupa dla grekokatolików i zwrot katedry w Przemyślu, pozostawały niezrealizowane przez władze państwowe i przez Episkopat rzymskokatolicki. Kościół greckokatolicki nadal funkcjonował w Polsce w ograniczonym zakresie w ramach struktur Kościoła rzymskokatolickiego (Drozd 2010).

W omawianym okresie nastapiła także poprawa sytuacji szkolnictwa ukraińskiego. W roku szkolnym 1988/89 funkcjonowało 57 punktów nauczania języka ukraińskiego (ponad dwa razy więcej niż 10 lat wcześniej), szkoła podstawowa w Białym Borze, liceum ogólnokształcące w Legnicy, a także ukraińskie klasy w szkole podstawowej w Baniach Mazurskich oraz w liceum ogólnokształcącym w Górowie Iławeckim. Ogółem na naukę języka ukraińskiego uczęszczało 1430 uczniów, czyli prawie 600 więcej niż dekadę wcześniej (Drozd, Halczak 2010). 
Od początku lat $80 . \mathrm{XX}$ w. ponownie uwidocznił się proces usamodzielniania Łemków. W 1982 r. we wsi Czarne koło Uścia Gorlickiego w Beskidach, działacze łemkowscy zorganizowali warsztaty plenerowe zespołu „Łemkowyna”, które zmieniły się w nieformalny zjazd mniejszości łemkowskiej. Została zapoczątkowana coroczna tradycja „Łemkowskiej Watry”. W latach 1983-1989 „Watra” odbywała się początkowo w Hańczowej, a następnie przez kilka lat w Bartnem. Imprezę tę zorganizowały i przez dekadę prowadziły osoby, które następnie współtworzyły pierwszą po wojnie organizację łemkowską Stowarzyszenie Łemków. Szybko stała się największym i najbardziej znanym świętem kultury łemkowskiej oraz miejscem spotkań Łemków nie tylko z całej Polski, ale również ze Słowacji, Ukrainy i państw zachodnich ${ }^{81}$.

W tym czasie nastapiła także odbudowa szkolnictwa litewskiego, w dużym stopniu zlikwidowanego w poprzedniej dekadzie. Na początku lat 80 . XX w. działała tylko jedna szkoła z litewskim językiem nauczania (liceum w Puńsku), do której uczęszczało zaledwie 77 uczniów, pozostali uczyli się języka litewskiego jako przedmiotu dodatkowego w polskich szkołach. Pod koniec tej dekady szkół z litewskim językiem wykładowym było już sześć, a języka litewskiego uczyło się ok. 550 uczniów (Chałupczak, Browarek 1998). W połowie lat 80. gmina Puńsk zajmowała czołowe miejsce w Polsce pod względem działalności społecznej. Mieszkańcy gminy cechowali się ponadprzeciętną aktywnością w działalności kulturalnej oraz w różnego rodzaju czynach społecznych. Efektem była bardzo dobrze, jak na ówczesne realia, rozwinięta infrastruktura, przodujące w regionie rolnictwo oraz wysokie wskaźniki rozwoju ekonomicznego gminy. Pisano nawet o „fenomenie puńskim”. Było to możliwe do osiagnięcia nie tylko dzięki pracowitości i dobremu zorganizowaniu Litwinów, ale także dzięki silnej wewnętrznej integracji, podkreślaniu własnej odrębności i żywej tradycji wspólnej pracy we wsiach litewskich (Sadowski 1997, Tarka 1998).

Mała efektywność działań UTSK, połączona z całkowitą uległością wobec władz, powodowała narastające niezadowolenie lokalnych działaczy. Zaznaczył się podział na „konserwatystów” i „radykałów” oraz wyraźny rozdźwięk w działaniach między Zarządem Głównym a strukturami terenowymi. Na IX zjeździe UTSK w czerwcu 1988 r. postulowano reformę organizacji, jednak styl i metody pracy kierownictwa nie uległy żadnym zmianom. Marazm panował także w działalności BTSK. Coraz większa grupa Ukraińców, Łemków i Białorusinów świadomych faktu, iż oficjalne organizacje społeczno-kulturalne nie reprezen-

81 Od 1990 r. „Łemkowska Watra” jest corocznie organizowana w Zdyni. Na początku lat 90. XX w. jej organizację przejęli działacze łemkowscy ze Zjednoczenia Łemków, co wywołało konflikt między dwoma głównymi łemkowskimi organizacjami. 
tują ich poglądów oraz nie mają możliwości realnego wpływu na sytuację mniejszości narodowych w ówczesnej sytuacji polityczno-prawnej, zaczęła działać w organizacjach przykościelnych lub szukać innych alternatywnych do oficjalnych form aktywności. Trzeba też pamiętać, że bezpośrednie wpływy UTSK i BTSK wśród reprezentowanych przez te organizacje środowisk narodowościowych nigdy nie były duże. Liczba członków zarówno UTSK, jak i BTSK od lat 60 . do końca lat 80 . XX w. wahała się najczęściej między 3 tys. a 6 tys., co przy szacowanej w tym okresie liczebności Ukraińców na 180-220 tys. osób oraz Białorusinów na 160-180 tys. osób (tab. 15) stanowiło zaledwie ok. 2-3\% ogółu mniejszości ukraińskiej czy białoruskiej. Z całą pewnością nie były to organizacje masowe. Zupełnie inaczej przedstawiała się sytuacja $\mathrm{z}$ aktywnością społeczną i organizacyjną Litwinów. Szacunki dotyczące liczebności mniejszości litewskiej w Polsce od lat 60. do 80. XX w. podawały najczęściej wartość 9-12 tys. osób (tab. 15), natomiast liczba członków LTSK systematycznie rosła, od około tysiąca na początku lat 60 . do ponad 1,8 tys. w latach 80 . XX w., co świadczyło o bardzo wysokiej, ok. 15-20\% przynależności Litwinów do jedynej reprezentującej ich organizacji.

W drugiej połowie lat 80 . XX w. coraz większy wpływ na postawy mniejszości narodowych miały zmiany zachodzące w ZSRR, a zwłaszcza w sąsiadujących z Polską republikach. Szczególnie istotne były napływające informacje, które zamieszczały „Nasze Słowo”, „Niwa” i „Aušra”, o postępującym odrodzeniu narodowym wśród mieszkających tuż za wschodnią granicą Ukraińcach, Białorusinach i Litwinach, o dyskusji dotyczącej stanu kultury narodowej i języka ojczystego. Mobilizowały one do działania zwłaszcza elity intelektualne mniejszości.

W październiku 1988 r. grupa intelektualistów reprezentujących mniejszości narodowe: prof. Michał Łesiów, dr Włodzimierz Mokry, doc. Stefan Kozak (strona ukraińska), dr Jerzy Turonek (strona białoruska) i dr Bronisław Makowski (strona litewska), wystosowała list do Lecha Wałęsy z prośbą wprowadzenia do dyskusji przy „okragłym stole” problematyki mniejszości narodowych. W grudniu tego samego roku powołano Komitet Obywatelski przy przewodniczącym NSZZ „Solidarność”, w ramach którego utworzono 15 komisji, w tym Komisję Współpracy z Mniejszościami Narodowymi pod przewodnictwem Marka Edelmana. W opracowanym przez Komisję sprawozdaniu „O potrzebach mniejszości narodowych w Polsce” opowiedziano się m.in. za swobodą zakładania przez mniejszości narodowe stowarzyszeń, fundacji, partii politycznych, rozwojem kultury i oświaty, zmianami w programach szkolnych, dostępem do środków masowego przekazu (Drozd, Halczak 2010). 
Pod koniec lat 80. XX w. do społeczeństwa polskiego coraz powszechniej zaczęły docierać informacje i wydarzenia, które dowodziły, że Polska - mimo usilnie lansowanej przez władze od kilkudziesięciu lat tezy - nie jest krajem zamieszkanym jedynie przez Polaków, że w jej granicach żyje ludność niepolskiej narodowości, która dąży do umożliwienia jej nieskrępowanego rozwoju.

\subsection{Okres po 1989 roku - demokratyzacja, pluralizm, zmiany prawne}

Po II wojnie światowej polityka państwa polskiego wobec zamieszkujących go niepolskich narodowości cechowała się dążeniem do ich asymilacji, poprzez próby likwidacji ich skupisk, przesiedlania, dyskryminację, kontrolę działalności społecznej i kulturalnej oraz izolację od państw macierzystych. Mimo że w różnych okresach PRL odmienne było natężenie oraz formy i przejawy tej działalności, to przez kilkadziesiąt lat głównym celem polityki narodowościowej władz polskich było doprowadzenie do powstania społeczeństwa monoetnicznego, społeczeństwa bez mniejszości narodowych.

Zmiana polityki w stosunku do mniejszości narodowych stała się możliwa dopiero po upadku rządów komunistycznych i przejęciu władzy w Polsce przez opozycję solidarnościową w 1989 r. oraz po wprowadzonych przez nią przekształceniach ustrojowych. Demokratyczna Polska, jako państwo prawa, nie mogła dłużej prowadzić polityki dyskryminacji wobec własnych obywateli. Wprowadzono liczne regulacje prawne, które miały umożliwić swobodę działalności politycznej, narodowej, społecznej i kulturowej wszystkim narodowościom zamieszkującym w Polsce. Miało to stanowić zaprzeczenie wcześniejszej polityki asymilacji (Chałupczak, Browarek 1998, Łodziński 2005, 2010).

Nastąpiły zmiany w polityce władz państwowych wobec mniejszości. Już w sierpniu 1989 r. powołano sejmową Komisję Mniejszości Narodowych i Etnicznych pod przewodnictwem Jacka Kuronia, która miała za zadanie prawne uregulowanie sytuacji mniejszości narodowych. Komisja zapoczątkowała, trwające kilkanaście lat, prace nad ustawą o mniejszościach narodowych. Tematykę narodowościową przeniesiono z Ministerstwa Spraw Wewnętrznych (MSW) do Ministerstwa Kultury i Sztuki (MKiS), co miało pokazać, że zmienia się rola państwa $\mathrm{z}$ dotychczasowego nadzoru na opiekę. Po kilkudziesięciu latach mniejszości narodowe przestały być obiektem policyjnej kontroli. Miało to znaczenie symboliczne, ale także praktyczne, ponieważ większość problemów 
mniejszości dotyczyło kultury i edukacji ${ }^{82}$. W ramach MKiS powołano Zespół do Spraw Mniejszości Narodowych, przekształcony następnie w Biuro do Spraw Kultury Mniejszości Narodowych. W 2005 r. utworzono Komisję Wspólną Rządu i Mniejszości Narodowych i Etnicznych, w skład której weszli przedstawiciele poszczególnych narodowości oraz administracji rządowej. Programy praktycznie wszystkich ugrupowań politycznych obecnych w sejmie po $1989 \mathrm{r}$. uznawały potrzebę równouprawnienia mniejszości narodowych oraz przyznanie im praw kulturalnych i oświatowych.

Prawa mniejszości narodowych w Polsce zostały w podstawowym zakresie zagwarantowane przez Konstytucję uchwaloną w 1997 r. ${ }^{83}$, a także przez liczne inne ustawy przyjęte od 1989 r., m.in. Ustawę o gwarancjach sumienia i wyznania (1989), Prawo o stowarzyszeniach (1989), Prawo o zgromadzeniach (1990), Ustawę o systemie oświaty (1990), Prawo o partiach politycznych (1997), Ordynację wyborczą do Sejmu RP i Senatu RP (2001). Istotnym elementem ochrony praw mniejszości, zwłaszcza na początku lat 90 . XX w., było podpisanie przez Polskę wielu dwustronnych traktatów ze wszystkimi państwami sąsiedzkimi. Ponadto w ramach członkostwa w Radzie Europy, rząd polski podpisał, a po kilku latach sejm ratyfikował, Europejską Konwencję o Ochronie Praw Człowieka i Podstawowych Wolnościach (1993), Konwencję Ramową Rady Europy o Ochronie Praw Mniejszości Narodowych (2000) oraz Europejską Kartę Języków Regionalnych lub Mniejszościowych (2009). Szczególnie istotna jest ratyfikacja z 2000 r. drugiej z tych konwencji, która jest pierwszym w Europie, prawnie wiążącym dokumentem międzynarodowym poświęconym ochronie mniejszości, oraz z 2009 r., która m.in. mówi o „wspieraniu edukacji w językach mniejszości”. Oba akty prawne wymuszają także przestrzeganie podpisanych zobowiązań poprzez obowiązek składania okresowych sprawozdań.

${ }^{82}$ Po kilkunastu latach, w 2005 r., w związku z przyjęciem Ustawy o mniejszościach narodowych, etnicznych i języku regionalnym ponownie wszelkie kwestie dotyczące mniejszości przekazano Ministerstwu Spraw Wewnętrznych i Administracji, z kolei po zmianach w funkcjonowaniu administracji rządowej w 2011 r. nowo powstałemu Ministerstwu Administracji i Cyfryzacji.

${ }^{83}$ Tematyce tej został w całości poświęcony artykuł 35, który brzmi „1. Rzeczpospolita Polska zapewnia obywatelom polskim należącym do mniejszości narodowych i etnicznych wolność zachowania i rozwoju własnego języka, zachowania obyczajów i tradycji oraz własnej kultury. 2. Mniejszości narodowe i etniczne mają prawo do tworzenia własnych instytucji edukacyjnych, kulturalnych i instytucji służących ochronie tożsamości religijnej oraz do uczestnictwa w rozstrzyganiu spraw dotyczących ich tożsamości kulturowej”. W konstytucji znajdują się też inne artykuły, bezpośrednio lub pośrednio, dotyczące ochrony praw mniejszości narodowych (art. 13, 25, 27, 32, 53, 57, 58, 60) (Dz.U. nr 78, poz. 483). 
Wszelkie zmiany prawne wprowadzone po 1989 r. były zarówno konsekwencją przekształceń ustrojowych zachodzących w Polsce, nacisków poszczególnych mniejszości, jak i koniecznością dostosowania standardów prawnych do potrzeb integracji z państwami Zachodniej Europy. W ostatnich latach w prawodawstwie międzynarodowym i w polskim, dotyczącym mniejszości narodowych, zaczęto odchodzić od wcześniej obowiązującej zasady niedyskryminacji i ochrony praw człowieka na rzecz ,pozytywnej dyskryminacji”, czyli prawnych form wspierania mniejszości przez państwo (Łodziński 2002, 2005, Budyta-Budzyńska 2003, 2010, Janusz 2011).

\subsubsection{Nowe uwarunkowania prawne pierwszej dekady XXI wieku}

Najważniejszym aktem prawnym dla mniejszości narodowych i etnicznych w Polsce jest przyjęta 6 stycznia 2005 r. Ustawa o mniejszościach narodowych i etnicznych oraz o języku regionalnym ${ }^{84}$, w której zdefiniowano pojęcie mniejszości narodowej i etnicznej oraz zawarto szczegółowy wykaz praw przedstawicieli mniejszości w demokratycznej Polsce. Została ona uchwalona po licznych sporach (zwłaszcza w końcowej fazie prac) dopiero w styczniu 2005 r., mimo że prace nad nią zostały zapoczątkowane już w 1990 r. przez Jacka Kuronia. Głównymi zarzutami w stosunku do ustawy były: zasadność jej wprowadzenia i związane z tym koszty, zbytnie uprzywilejowanie mniejszości, możliwość wybuchu konfliktów etnicznych, zdefiniowanie pojęcia mniejszości narodowej i kryteriów przynależności do mniejszości, rozbudowane uprawnienia dotyczące języków mniejszości, a zwłaszcza dwujęzycznych nazw miejscowości oraz brak zasady wzajemności, ponieważ nie bierze ona pod uwagę sytuacji mniejszości polskiej w innych krajach. Z kolei zwolennicy ustawy podkreślali, że zabezpieczy ona pozycję mniejszości, wzmocni ich status, doprecyzuje i skodyfikuje przysługujące im prawa, usprawni politykę wobec mniejszości (zwłaszcza na poziomie lokalnym), ułatwi relacje mniejszości z administracją. Jest ona normą prawną w zdecydowanej większości państw środkowej Europy i stanowi nawiązanie do tradycji wielonarodowej i tolerancyjnej Rzeczypospolitej ${ }^{85}$.

Ustawa, definiując mniejszości narodowe i etniczne ${ }^{86}$, wyróżnia i obejmuje szczególną ochroną prawną dziewięć mniejszości narodowych: białoruską, czes-

${ }^{84}$ Dz.U. 2005 nr 17, poz. 141.

${ }^{85}$ Szczegółowo o samej ustawie oraz kontrowersjach związanych z jej uchwalaniem pisali m.in. S. Łodziński (2005, 2006a, 2006c, 2010) oraz M. Ślęzak (2006).

${ }^{86}$ Zostało to szerzej omówiono w rozdziale wstępnym. 
ką, litewską, niemiecką, ormiańską, rosyjska, słowacką, ukraińską, żydowską, cztery mniejszości etniczne: karaimską, łemkowską, romską i tatarską ${ }^{87}$ oraz uznaje język kaszubski za jedyny w Polsce język regionalny ${ }^{88}$. Przyjęcie ustawy było ostatecznym uznaniem przez polski parlament wielonarodowości społeczeństwa polskiego.

Nie wszystkie narodowości zamieszkujące współcześnie Polskę zostały objęte przepisami zawartymi w omawianej ustawie, głównie dlatego, że jednym z jej założeń było uregulowanie wszelkich spraw związanych $\mathrm{z}$ funkcjonowaniem tzw. mniejszości tradycyjnych, czyli narodowości od wieków związanych z państwem polskim, w odróżnieniu od „nowych” mniejszości imigranckich. Ustawa jest niewątpliwym sukcesem Łemków, którzy zostali uznani za jedną $\mathrm{z}$ czterech mniejszości etnicznych w Polsce. Zwłaszcza że przepisy wyraźnie precyzuja, iż jedyną różnicą między mniejszością narodową a etniczną jest „utożsamianie się z narodem zorganizowanym we własnym państwie”, czyli posiadanie lub brak zagranicznej ojczyzny. Jest to pierwsze oficjalne, prawne wydzielenie Łemków przez polskie władze jako osobnej grupy i tym samym wyraźne rozróżnienie od Ukraińców, którzy według tej samej ustawy są jedną z dziewięciu mniejszości narodowych w Polsce. Takiego rozróżnienia domagała się część Łemków już od drugiej połowy XIX w. Natomiast od połowy lat 90. XX w. wiele kontrowersji budzi kwestia uznania lub nieuznania narodowości śląskiej. Spory te przybrały na sile po spisie powszechnym w 2002 r., w którym narodowość śląska została zadeklarowana przez ponad 173 tys. osób, co czyniło ze Ślązaków najliczniejszą mniejszość w Polsce. Na tej podstawie przedstawiciele niezarejestrowanego Związku Ludności Narodowości Śląskiej bezskutecznie starali się o wpisanie Ślązaków jako grupy etnicznej do omawianej ustawy oraz o uznanie języka śląskiego za drugi, obok kaszubskiego, język regionalny ${ }^{89}$. Starania te nasiliły się po kolejnym spisie powszechnym w 2011 r., podczas którego narodowość śląską zadeklarowało 817 tys. osób. W wyniku tych starań i kilkakrotnych apelacjach sądowych 7 września 2012 r. zostało zarejestrowane Stowarzyszenie Osób Narodowości Śląskiej, co jednak nadal nie rozstrzyga kwestii formalnego, oficjalnego uznania narodowości śląskiej.

${ }^{87}$ Dz.U. 2005 nr 17, poz. 141, rozdz. 1.

${ }^{88}$ Kaszubi nie uzyskali oficjalnego statusu mniejszości etnicznej, jednak dzięki uznaniu języka kaszubskiego za język regionalny mogą korzystać z wielu zawartych w ustawie przywilejów dotyczących nauczania w języku kaszubskim w szkołach publicznych oraz traktowania języka kaszubskiego jako pomocniczego w urzędach i stosowania dwujęzycznych nazw miejscowości (Dz.U. $2005 \mathrm{nr}$ 17, poz. 141, rozdz. 4).

${ }^{89}$ Szerzej omawia to S. Łodziński (2005, s. 167-173). 
Zawarte obecnie w polskim prawie rozwiązania dotyczące wielu kwestii związanych z funkcjonowaniem niepolskich narodowości niejednokrotnie znacznie wyprzedzają zalecenia zawarte $\mathrm{w}$ konwencjach międzynarodowych dotyczących praw mniejszości narodowych i etnicznych. Współcześnie głównym problemem wydaje się zbyt częsty brak wzajemności uregulowań prawnych dotyczących mniejszości narodowych w Polsce oraz mniejszości polskiej w krajach sąsiednich, dotyczy to zwłaszcza Litwy i Niemiec.

Ustawa daje mniejszościom narodowym i etnicznym możliwości zachowania własnej tożsamości, odrębności kulturowej i językowej, zabrania dyskryminacji i asymilacji, reguluje kwestie praw językowych mniejszości oraz funkcjonowania oświaty. Zmienia podstawy organizacyjne polityki państwa wobec mniejszości, powołuje nowe instytucje opiniotwórcze i doradcze, mające usprawnić relacje między przedstawicielami mniejszości a władzami państwowymi (Komisja Wspólna Rządu i Mniejszości Narodowych i Etnicznych). Dla niektórych mniejszości (m.in. litewskiej) do szczególnie istotnych zapisów zawartych $\mathrm{w}$ ustawie należy prawo do zapisywania imion i nazwisk zgodnie z zasadami pisowni języka mniejszości, także w oficjalnych dokumentach. Ponadto gwarantuje możliwość używania języka mniejszości jako języka pomocniczego w urzędach $^{90}$. Warunkiem wprowadzenia tego przepisu jest minimum $20 \%$ deklaracji niepolskiej narodowości wśród ogółu mieszkańców gminy w trakcie spisu powszechnego oraz wpisanie do urzędowego rejestru gmin, w których używany jest język pomocniczy. Według wyników spisu z 2002 r. wymagany w ustawie poziom koncentracji terytorialnej osiagnęły tylko trzy mniejszości narodowe (niemiecka, białoruska i litewska) oraz deklarujący używanie języka regionalnego Kaszubi. Możliwość używania języka mniejszości jako pomocniczego istnieje w 51 gminach $^{91}$, jednak do grudnia 2012 r. została wprowadzona na wniosek lokalnych władz tylko w 31 gminach w Polsce, w tym aż w 22 językiem pomocniczym jest niemiecki (tab. 5, ryc. 11).

Ustawa wprowadza także możliwość umieszczania dodatkowych tradycyjnych nazw miejscowości, ulic i obiektów fizjograficznych w języku mniejszości (wyłącznie wyszczególnionych w ustawie), obok nazw w języku polskim (nie mogą być stosowane samodzielnie) ${ }^{92}$. Dwujęzyczne nazwy mogą być wprowadzone na wniosek rady gminy we wszystkich gminach, gdzie mniejszość

${ }^{90}$ Dz.U. 2005 nr 17, poz. 141, rozdz. 1-2.

${ }^{91}$ W tym w 41 gminach, w których udział osób deklarujących niepolską narodowość wyniósł 20\% lub więcej oraz w 10 gminach, gdzie 20\% lub więcej mieszkańców zadeklarowało używanie języka kaszubskiego.

${ }^{92}$ Nazwy te nie mogą nawiązywać do nazw z lat 1933-1945 wprowadzonych przez władze Rzeszy Niemieckiej lub ZSRR. 
stanowi minimum $20 \%$ ogółu mieszkańców oraz w dowolnej miejscowości zamieszkanej nawet $\mathrm{w}$ nieznacznym stopniu przez przedstawicieli mniejszości narodowej lub etnicznej, po konsultacjach z mieszkańcami. Konsultacje najczęściej przyjmują formę głosowania mieszkańców, w którym nie ma wymogu minimalnej frekwencji. Wniosek rady gminy musi także uzyskać pozytywną opinię Komisji Nazw Miejscowości i Obiektów Fizjograficznych ${ }^{93}$. Z powodu liberalnych przepisów, dotyczących możliwości wprowadzenia dwujęzycznych nazw, stają się one coraz bardziej popularne. Do grudnia 2012 r. na obszarze Polski zarejestrowano 798 dwujęzycznych nazw miejscowości. W ich wprowadzaniu zdecydowanie przodują dwie społeczności - Kaszubi (397 nazw w języku kaszubskim) oraz Niemcy (335 nazw w języku niemieckim). Dwujęzyczne nazwy miejscowości w języku polskim oraz kaszubskim lub niemieckim stanowią aż 92\% wszystkich tego typu nazw w Polsce. Ponadto funkcjonują nazwy miejscowości w języku litewskim, białoruskim i łemkowskim (ryc. 12). Z punktu widzenia mniejszości narodowych są one jednymi z istotniejszych sposobów zaznaczenia swojej odrębności i podtrzymania tożsamości oraz swoistym potwierdzeniem wielonarodowej historii danego regionu.

Tabela 5. Gminy, w których jest - lub według ustawy o mniejszościach narodowych może być - używany język mniejszości jako pomocniczy

(stan z 31 grudnia $2012 \mathrm{r}$.)

\begin{tabular}{|l|l|c|c|c|}
\hline \multirow{2}{*}{$\begin{array}{c}\text { Język } \\
\text { pomocniczy }\end{array}$} & Województwo & $\begin{array}{c}|c| \\
\text { z językiem } \\
\text { pomocniczym }\end{array}$ & $\begin{array}{c}\text { w których według } \\
\text { ustawy można } \\
\text { wprowadzić język } \\
\text { pomocniczy }\end{array}$ & $\begin{array}{c}\text { Udział gmin } \\
\text { z językiem } \\
\text { pomocniczym } \\
(\mathrm{w} \%)^{a}\end{array}$ \\
\hline Białoruski & podlaskie & 5 & 12 & 42 \\
Kaszubski & pomorskie & 3 & 10 & 30 \\
Litewski & podlaskie & 1 & 1 & 100 \\
Niemiecki & opolskie & 22 & 28 & 79 \\
\hline Ogółem & - & 31 & 51 & 61 \\
\hline
\end{tabular}

${ }^{a}$ Udział gmin z językiem pomocniczym w ogólnej liczbie gmin, w których według kryteriów ustawy można wprowadzić język pomocniczy danej mniejszości lub społeczności regionalnej.

Źródło: opracowanie własne na podstawie danych Ministerstwa Administracji i Cyfryzacji: www.mac.gov.pl/wp-content/uploads/2011/12/.

${ }^{93}$ Dz.U. 2005 nr 17, poz. 141, rozdz. 2. 


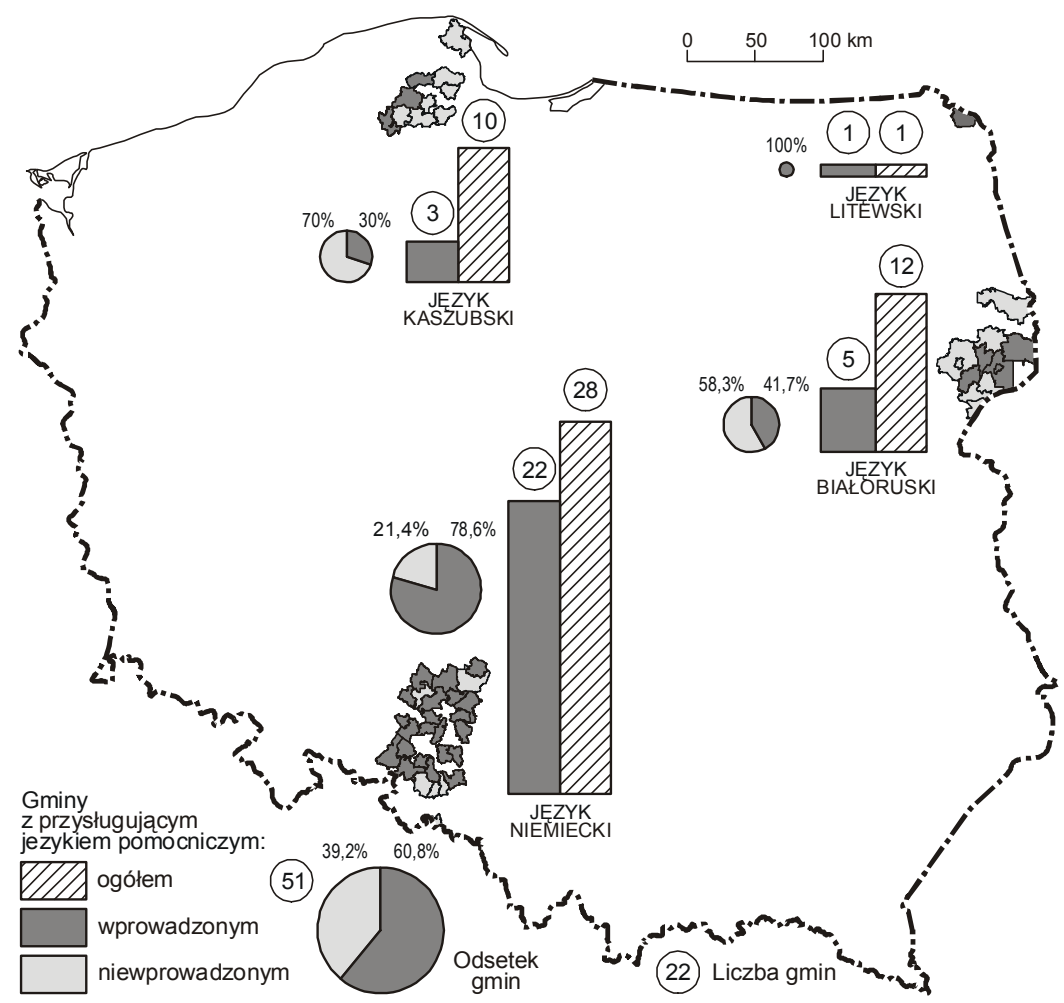

Ryc. 11. Gminy, w których jest - lub według ustawy może być - używany język mniejszości jako pomocniczy (stan z 31 grudnia 2012 r.)

Źródło: opracowanie własne na podstawie danych Ministerstwa Administracji i Cyfryzacji: www.mac.gov.pl/wp-content/uploads/2011/12/

Dwujęzyczne nazwy miejscowości budzą w Polsce spory i emocje już od początku lat 90. XX w., długo przed ich oficjalnym wprowadzeniem. Dotyczyło i dotyczy to głównie nazw polsko-niemieckich na Opolszczyźnie oraz - od niedawna - nazw łemkowskich, litewskich i białoruskich ${ }^{94}$.

Inicjatywa wprowadzenia dwujęzycznych polsko-łemkowskich nazw miejscowości na Łemkowszczyźnie wyszła nie od łemkowskich mieszkańców, lecz od Stowarzyszenia Młodzieży Łemkowskiej „Czuha”, które w lipcu 2007 r. skierowało wnioski o nadanie drugiej łemkowskiej nazwy 14 miejscowościom.

${ }^{94}$ Poza różnego rodzaju protestami werbalnymi oraz konfliktami wśród lokalnych społeczności, dwujęzyczne nazwy miejscowości są także zamalowywane lub niszczone w inny sposób. Najczęściej dotyczy to nazw polsko-niemieckich na Opolszczyźnie, natomiast nowym zjawiskiem jest niszczenie tego typu tablic na Podlasiu. W sierpniu 2011 r. zamalowano 28 tablic polsko-litewskich w gminie Puńsk, w maju 2012 r. w ten sam sposób zniszczono 12 tablic polsko-białoruskich w gminie Orla. 
Pierwszą miejscowością, do której nazwy, mimo protestów, konfliktu i wyraźnego podziału wśród mieszkańców, dodano w 2008 r. łemkowską nazwę, była Bielanka ${ }^{95}$ (gmina Gorlice). Była to pierwsza we współczesnej Polsce nazwa miejscowości pisana cyrylicą ${ }^{96}$. Część łemkowskich mieszkańców Bielanki traktuje dwujęzyczną nazwę jako symboliczną formę rekompensaty za krzywdę i niesprawiedliwość akcji „Wisła” (Stachowiak 2010).

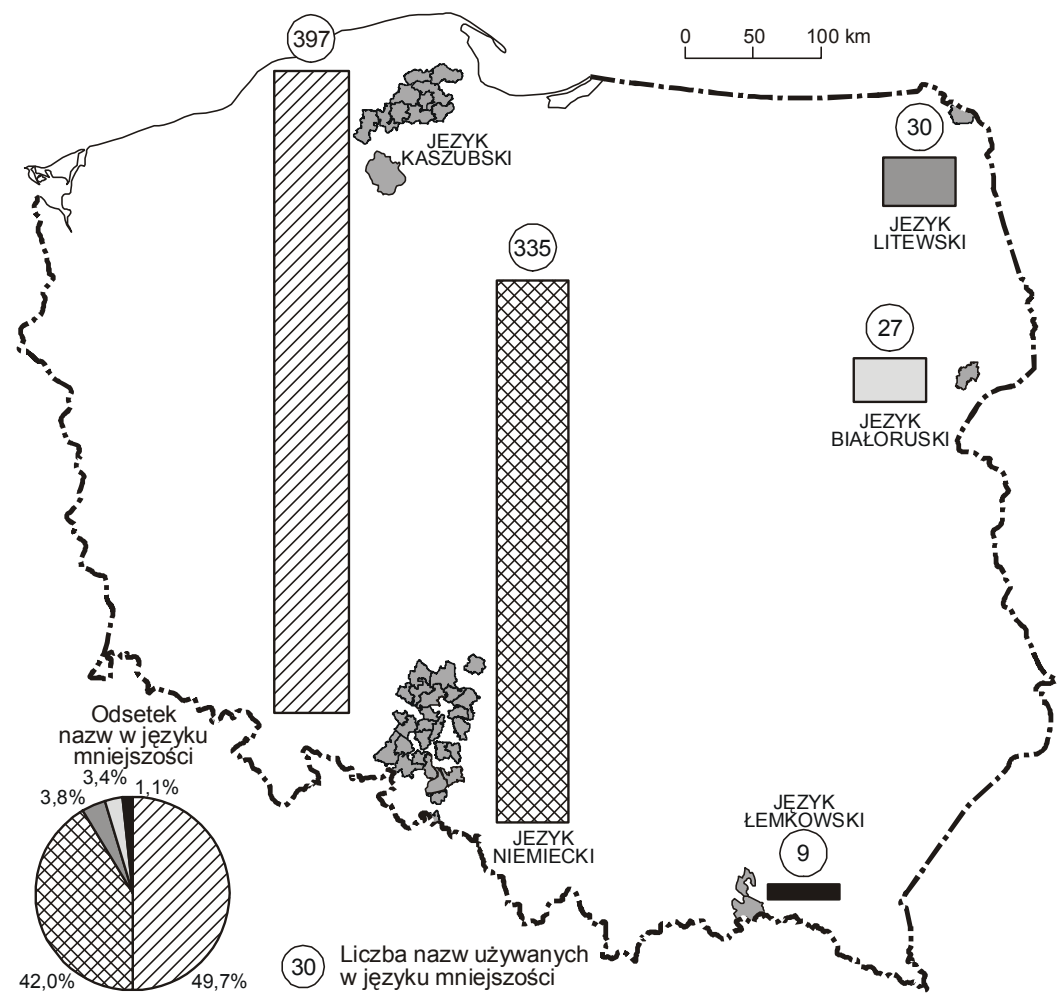

Ryc. 12. Gminy, w których są używane nazwy w językach mniejszości (stan z 31 grudnia 2012 r.)

Źródło: opracowanie własne na podstawie danych Ministerstwa Administracji i Cyfryzacji: www.mac.gov.pl/wp-content/uploads/2011/12/

${ }^{95}$ W głosowaniu w 2008 r. dotyczącym wprowadzenia łemkowskiej nazwy Bielanki (Bilianka) wzięło udział zaledwie 63 mieszkańców wsi (na 165 uprawnionych), wśród których 32 osoby były za, a 31 przeciw (Stachowiak 2010).

96 Łemkowska nazwa została wpisana do „Rejestru gmin, na których obszarze używane są nazwy w języku mniejszości” 24 listopada 2008 r., natomiast ponad dwa lata później, 11 stycznia 2011 r. oraz 17 listopada 2011 r., do rejestru wpisano 27 białoruskich nazw wsi i kolonii w gminie Orla w województwie podlaskim. 
W sierpniu 2008 r. oraz w maju 2010 r. w kilku kolejnych łemkowskich miejscowościach odbyły się konsultacje i głosowania mieszkańców w sprawie dwujęzycznych, polsko-łemkowskich nazw. Wspólną cechą wszystkich konsultacji było znikome zainteresowanie społeczności lokalnej i niska frekwencja podczas głosowania. Jedynie w przypadku Hańczowej i Małastowa większość mieszkańców opowiedziała się przeciwko wprowadzeniu drugiej nazwy. W ośmiu miejscowościach w gminie Uście Gorlickie (Blechnarce, Gładyszowie, Koniecznej, Kunkowej, Nowicy, Regietowie, Ropkach, Zdyni), większość głosujących opowiedziała się za dwujęzyczną nazwą miejscowości. Wszędzie spowodowało to konflikty i podziały wśród społeczności lokalnych (Stachowiak 2010). Dopiero w listopadzie $2011 \mathrm{r}$. nazwy te zostały wpisane przez Ministra Spraw Wewnętrznych i Administracji do „Rejestru gmin, na których obszarze używane są nazwy w języku mniejszości”, dzięki czemu mogą być oficjalnie używane, jednak nadal (wrzesień 2012 r.) władze gminy Uście Gorlickie nie zamontowały tablic z dwujęzycznymi nazwami.

Obecnie w Polsce nie ma ani jednej miejscowości z dwujęzyczną, polsko-ukraińską nazwą. Wpływ na taką sytuację ma niewątpliwie rozproszenie mniejszości ukraińskiej oraz zamieszkiwanie zdecydowanej większości Ukraińców w północnych i zachodnich regionach Polski, gdzie brak jest tradycyjnych ukraińskich nazw wsi i miasteczek.

Przepisy ustawy, mimo że podobne dla wszystkich uwzględnionych w ustawie 14 mniejszości ${ }^{97}$, w praktyce zdecydowanie najlepiej wykorzystują Niemcy, Litwini i Kaszubi. Bardzo duże rozproszenie terytorialne Ukraińców i Łemków - spowodowane w głównej mierze akcją „Wisła” - w zasadniczym stopniu utrudnia wykorzystanie przywilejów ustawy, zwłaszcza stosowania języka mniejszości jako języka pomocniczego w urzędach. Według wyników spisu ludności z 2002 r. w żadnej gminie w Polsce, nawet w tych uważanych powszechnie za typowo ukraińskie lub łemkowskie, udział osób deklarującej ukraińską czy łemkowską tożsamość nie osiagnął wymaganego ustawą minimum $20 \%$. Największy udział mniejszości ukraińskiej występował w gminie Lelkowo w województwie warmińsko-mazurskim (18,6\%), natomiast mniejszości łemkowskiej w gminie Uście Gorlickie w Beskidach (11,6\%). W świetle danych statystycznych nie ma możliwości wprowadzenia w Polsce języka ukraińskiego lub łemkowskiego jako języka pomocniczego. Rozproszenie, a zwłaszcza przesiedlenie na ziemie zachodnie i północne bardzo utrudniają także wprowadzanie tradycyjnych nazw miejscowości w języku ukraińskim i łemkowskim.

${ }^{97}$ Różnice dotyczą głównie odmiennego traktowania mniejszości narodowych oraz etnicznych w ordynacji wyborczej do sejmu. 
Inaczej wygląda sytuacja bardzo skoncentrowanej terytorialnie mniejszości litewskiej. Dzięki temu, że liczba deklaracji narodowości litewskiej w gminie Puńsk zdecydowanie przekroczyła wymagane ustawowo $20 \%$ ogółu mieszkańców (75\%), została ona w maju 2006 r. wpisana do „Urzędowego rejestru gmin, w których jest używany język pomocniczy”, a dwa lata później, w maju 2008 r. wpisano ją do „Rejestru gmin, na których obszarze używane są nazwy w języku mniejszości", wprowadzając w 30 wsiach, obok nazwy polskiej, także nazwę litewską. Gmina Puńsk, zwarcie i w większości zamieszkana przez Litwinów, z lokalną władzą zdominowaną przez Litwinów, w pełni wykorzystująca przywileje płynące $\mathrm{z}$ zapisów ustawy o mniejszościach narodowych, utrzymująca intensywne kontakty z zagraniczną ojczyzną, w pełni zasługuje na powszechne wśród jej mieszkańców miano „małej Litwy”. Natomiast zupełnie inna sytuacja jest w sąsiedniej gminie Sejny, mimo obecności litewskich instytucji (Dom Litewski, konsulat, szkoły, siedziby organizacji) oraz historycznie uwarunkowanych litewskich tradycji. Według wyników spisu powszechnego z 2002 r. w gminie dominowała ludność polska, Litwinów było niewiele mniej niż wymagane ustawą 20\% ogółu mieszkańców (18,7\%), ale jednak mniej, co skutecznie uniemożliwiało im korzystanie z zapisów ustawy o mniejszościach narodowych, wywoływało konflikty w relacjach z polską większością, powodowało poczucie zagrożenia asymilacją. Według powszechnej opinii lokalnych litewskich liderów „ustawa o mniejszościach w Sejnach nie działa”.

Na Podlasiu warunek wprowadzenia języka litewskiego jako pomocniczego spełnia tylko jedna gmina Puńsk, natomiast języka białoruskiego aż 15 gmin. Jednak na wniosek rad gmin wprowadzono go dotychczas zaledwie w pięciu gminach - pod koniec 2007 r. w gminie miejskiej Hajnówka, następnie w latach 2009-2010 w gminach wiejskich Orla, Narewka, Czyże i Hajnówka. Dopiero w styczniu 2011 r. do „Rejestru gmin, na których obszarze używane są nazwy w języku mniejszości” wpisano 27 białoruskich nazw wsi i kolonii z gminy Orla. Są to pierwsze na Podlasiu, a drugie w Polsce (po łemkowskiej Bielance) nazwy miejscowości pisane cyrylica. Nazwy białoruskie można potencjalnie wprowadzić w kilkuset podlaskich wsiach, podobnie jak na Śląsku Opolskim i Pomorzu postapiono z nazwami w języku niemieckim i kaszubskim. Jednak już wprowadzenie ich w gminie Orla spowodowało kontrowersje i protesty, głównie władz Związku Ukraińców Podlasia, według których język, jakim posługują się mieszkańcy gminy Orla, to gwary ukraińskie ${ }^{98}$, a zaproponowane przez radę

${ }^{98}$ Potwierdzają to m.in. przeprowadzone w drugiej połowie XX w. na Podlasiu badania językoznawcze przez naukowców opracowujących Atlas gwar wschodniosłowiańskich Białostocczyzny. 
gminy nazwy $\mathrm{w}$ języku białoruskim $\mathrm{w}$ większości są niezgodne $\mathrm{z}$ zapisanym $\mathrm{w}$ ustawie brzmieniem tradycyjnym oraz bezpodstawne $\mathrm{z}$ lingwistycznego punktu widzenia. $Z$ kolei władze gminy utrzymują, iż nazwy w języku białoruskim były wcześniej konsultowane ze społecznością lokalną, a także badane przez naukowców i lingwistów pod kątem poprawności językowej i zgodności z przekazami historycznymi. Zostały też pozytywnie zaopiniowane przez Komisję Nazw Miejscowości i Obiektów Fizjograficznych. Według wyników spisu powszechnego z 2002 r. w gminie Orla narodowość białoruską zadeklarowało 69\% mieszkańców, a używanie języka białoruskiego aż 72\%, natomiast narodowość ukraińską zaledwie $0,9 \%$, a używanie języka ukraińskiego 2,6\% ogółu mieszkańców. Dlatego, bez względu na różne opinie i emocje, władze gminy muszą kierować się wynikami spisu powszechnego.

Liderzy organizacji ukraińskich, łemkowskich, białoruskich i litewskich zgodnie podkreślają pozytywne znaczenie przepisów zawartych w ustawie dla funkcjonowania mniejszości narodowych w Polsce, zwłaszcza urzędowe zagwarantowanie praw mniejszości, możliwość odwołania się do zapisów ustawy w relacjach z władzami, ponadto możliwość stosowania języka mniejszości jako pomocniczego i dwujęzycznych nazw miejscowości, choć zwracają uwagę na potrzebę doprecyzowanie niektórych zapisów. Krytykują natomiast zbyt wysoki - ich zdaniem - 20\% próg dotyczący liczebności danej narodowości w gminie, konieczny do realizacji niektórych zapisów ustawy (domagają się zmniejszenia go do 10\%), realizację przepisów dotyczących szkolnictwa, zwłaszcza jego finansowania, brak zapisu obligującego władze państwowe do finansowania instytucji kultury poszczególnych mniejszości oraz niewystarczające wsparcie samorządów ${ }^{99}$.

\subsubsection{Działalność polityczna i organizacyjna mniejszości}

Zmiany ustrojowe zapoczątkowane na przełomie lat 80. i 90. XX w. spowodowały bardzo duże ożywienie działalności politycznej i organizacyjnej mniejszości narodowych i etnicznych. Demokratyzacja i liberalizacja życia politycz-

${ }^{99}$ Na podstawie wywiadów przeprowadzonych przez autora w 2012 r. z działaczami Związku Ukraińców w Polsce, Związku Ukraińców Podlasia, Towarzystwa Ukraińskiego, Stowarzyszenia Łemków, Zjednoczenia Łemków, Stowarzyszenia Młodzieży Łemkowskiej „Czuha”, Białoruskiego Towarzystwa Społeczno-Kulturalnego, Rady Programowej Tygodnika „Niwa”, Białoruskiego Zrzeszenia Studentów, Stowarzyszenia Litwinów w Polsce, Litewskiego Towarzystwa Św. Kazimierza. 
nego, społecznego oraz gospodarczego dała im możliwość normalnego funkcjonowania.

Po 1989 r. istniejące od połowy lat 50. XX w. organizacje poszczególnych mniejszości uniezależniły się od nadzoru politycznego, zmieniły nazwy i charakter działalności na bardziej narodowy. Jedynie Białoruskie Towarzystwo Społeczno-Kulturalne (BTSK) zachowało dawną nazwę oraz swój wyraźnie lewicowy charakter. Działalność społeczno-polityczna poszczególnych narodowości stała się pluralistyczna, powstało wiele nowych, często konkurencyjnych organizacji, które łamały dotychczasowy monopol towarzystw społeczno-kulturalnych. Nastapił rozpad sztucznie utrzymywanych organizacji grupujących kilka narodowości (Czechów i Słowaków, Greków i Macedończyków, Ukraińców i Łemków). Także wyznawcy prawosławia na Podlasiu samookreślili się pod względem instytucjonalnym jako Białorusini lub Ukraińcy. Wszystko to spowodowało wzrost aktywności osób wywodzących się ze środowisk mniejszości narodowych, zwiększyło zainteresowanie kwestiami etnicznymi, umożliwiło manifestowanie swej odrębności i realny udział w życiu politycznym i społecznym kraju, ale także wywołało spory na tle narodowościowym i wyznaniowym, również wewnątrz poszczególnych grup, np. Łemków i Białorusinów.

Przed 1989 r. działało zaledwie 10 organizacji narodowościowych. Już w tym samym roku zarejestrowano sześć kolejnych. Następne lata przyniosły bardzo szybki przyrost stowarzyszeń narodowościowych. W latach 1990-1992 przybywały po 23-24 organizacje rocznie. Tylko w okresie tych trzech lat zarejestrowano prawie połowę wszystkich działających obecnie stowarzyszeń. Przez kolejne trzy lata (1993-1995) nadal utrzymywał się wysoki przyrost liczby organizacji (od 17 do 21 rocznie), dzięki czemu pod koniec 1995 r. było już zarejestrowanych 137 stowarzyszeń narodowościowych. Od 1997 r. zaznaczył się wyraźny spadek dynamiki. Dopiero w latach 2004-2007 można zaobserwować pewne ożywienie w rejestracji nowych towarzystw (głównie romskich), jednak dynamika ta - przybywało od czterech do siedmiu nowych stowarzyszeń rocznie - była nieporównywalnie mniejsza niż w pierwszej połowie lat 90. XX w. Ogółem do 2008 r. zarejestrowano 191 organizacji o charakterze narodowościowym, 19 w tym okresie uległo likwidacji. W 2008 r. w Polsce funkcjonowały 172 stowarzyszenia narodowościowe i etniczne (Wyznania religijne... 2010).

Zdecydowana większość organizacji narodowościowych została założona przez przedstawicieli tzw. tradycyjnych mniejszości, zamieszkujących Polskę od kilku wieków. Według danych GUS, wśród 172 organizacji tylko kilkanaście zarejestrowano przez przedstawicieli narodowości o relatywnie krótkim rodowodzie imigracyjnym w Polsce (Greków, Macedończyków, Bułgarów, Wietnamczyków, Hindusów, Syryjczyków, Chińczyków, Somalijczyków, Jemeńczy- 
ków). Ogółem w 2008 r. swoje organizacje posiadały 24 mniejszości narodowe i etniczne ${ }^{100}$. Największą aktywnością organizacyjną charakteryzowała się mniejszość niemiecka zrzeszona w 74 organizacjach (43\% ogółu). W zdecydowanej większości były to organizacje lokalne, które, mimo formalnego deklarowania zasięgu ogólnopolskiego, ograniczały swą działalność do powiatu, gminy lub miasta. Kolejną aktywną organizacyjnie mniejszością byli Romowie, którzy zarejestrowali 31 stowarzyszeń. Według danych GUS zdecydowanie mniejszą liczbę organizacji mieli Białorusini (12), Ukraińcy (11) i Żydzi (8). Pozostałe narodowości zarejestrowały zaledwie kilka (od jednej do sześciu) organizacji ${ }^{101}$. Prawie połowa stowarzyszeń (83) deklarowała ogólnopolski zasięg działania, większość miała mniej lub bardziej lokalny charakter, obejmując swoim zasięgiem dany region, czasami nawet pojedyncze gminy czy miejscowości (Wyznania religijne... 2010).

Pod względem liczby członków organizacji narodowościowych także zdecydowanie dominowały stowarzyszenia niemieckie, które zrzeszały przeszło 235 tys. osób, czyli aż 82\% ogółu członków wszystkich stowarzyszeń narodowościowych. Poza Niemcami we własnych organizacjach najliczniej zrzeszali się Romowie, Ukraińcy, Kaszubi i Białorusini. Od wielu lat zaznacza się tendencja zmniejszania lub stagnacji liczebności stowarzyszeń narodowościowych. W ciągu ostatnich kilku lat nieznacznie wzrosła tylko liczebność organizacji romskich i łemkowskich (Wyznania religijne... 2010). Trzeba także pamiętać, że dane dotyczące liczebności organizacji narodowościowych są uzależnione praktycznie wyłącznie od rzetelności zarządów poszczególnych stowarzyszeń i niejednokrotnie mogą być zawyżone, zwłaszcza gdy się je porówna z wykazaną w trakcie spisu powszechnego w 2002 r. liczebnością poszczególnych mniejszości narodowych (tab. 15).

Zwiększenie aktywności poszczególnych mniejszości narodowych przejawiało się nie tylko we wspomnianej działalności organizacyjnej różnego rodzaju stowarzyszeń narodowościowych, ale także w aktywności politycznej - zarówno

${ }^{100}$ Były to: Niemcy (74 organizacje), Romowie (31), Białorusini (12), Ukraińcy (11), Żydzi (8), Litwini (6), Łemkowie (5), Francuzi (3), Ormianie (3), Syryjczycy (2), Rosjanie (2), Grecy (2), Bułgarzy (1), Chińczycy (1), Hindusi (1), Jemeńczycy (1), Karaimi (1), Kaszubi (1), Macedończycy (1), Słowacy (1), Somalijczycy (1), Tatarzy (1), Węgrzy (1), Wietnamczycy (1).

101 Według informacji zebranych przez autora w 2012 r., w Polsce funkcjonuje 17 organizacji białoruskich, 15 ukraińskich, 13 łemkowskich oraz siedem litewskich (tab. 6-9), choć nie wszystkie prowadzą aktywną działalność. Można przypuszczać, że inne narodowości również mają więcej organizacji niż podaje to GUS. 
w zakładaniu partii politycznych, jak i w uczestnictwie komitetów wyborczych mniejszości narodowych w wyborach parlamentarnych i samorządowych.

$\mathrm{W}$ wyborach do polskiego parlamentu kandydaci organizacji białoruskich, ukraińskich lub litewskich nie odnosili początkowo sukcesów. Dopiero umieszczenie ich członków na listach ugrupowań lewicowych nieco poprawiło tę sytuację. Zdecydowanie lepsze wyniki odnotowali w wyborach samorządowych, wyłącznie na obszarach z relatywnie dużym udziałem mniejszości narodowych, zwłaszcza na południowo-wschodnim Podlasiu i Suwalszczyźnie (Matykowski, Tobolska 1994, Matykowski 1997, 2008, Chałupczak, Browarek 1998, Kowalski 2000, Kępka 2009).

We wszystkich demokratycznych wyborach od początku lat 90. XX w. członkowie mniejszości narodowych i religijnych w Polsce charakteryzowali się bardzo wyraźnymi sympatiami lewicowymi pod względem preferencji wyborczych. Tak duże i konsekwentne poparcie dla opcji lewicowych w regionach i gminach zamieszkanych zwarcie przez Białorusinów, Ukraińców czy Litwinów można tłumaczyć bardzo różnymi czynnikami: ekonomicznymi, społecznymi, historycznymi, kulturowymi. Jednak $\mathrm{z}$ pewnością istotnym powodem takich zachowań jest jednoznaczne kojarzenie ugrupowań prawicowych z polskim nacjonalizmem i katolicyzmem, zatem oddanie głosu na lewicę, z punktu widzenia interesów narodowych, a często także religijnych ludności niepolskiej, jest jak najbardziej racjonalne (Kowalski 2000).

\section{Ukraińcy}

W trakcie przygotowań do pierwszych, częściowo wolnych, wyborów w czerwcu 1989 r. Komitet Obywatelski przy Lechu Wałęsie zaproponował działaczowi ukraińskiemu Włodzimierzowi Mokremu kandydowanie do sejmu z listy „Solidarności”. Początkowo rozważano zgłoszenie tej kandydatury w Legnicy lub Przemyślu, lecz nie wyraziły na to zgody miejscowe ,solidarnościowe" Komitety Obywatelskie, motywując to silnymi lokalnymi antagonizmami polsko-ukraińskimi. Zgodził się Komitet z Gorzowa Wielkopolskiego. Swoich kandydatów z list PZPR wystawił również ZG UTSK. Włodzimierz Mokry uzyskał mandat poselski, zdobywając $60 \%$ głosów, kandydaci UTSK nie dostali się do sejmu (Drozd, Halczak 2010). W kolejnych wyborach do parlamentu mandat poselski z listy Unii Demokratycznej, a następnie Unii Wolności, dwukrotnie zdobywał ukraiński polityk Mirosław Czech. W $2001 \mathrm{r}$. bez powodzenia ubiegał się o reelekcję w okręgu olsztyńskim. Obecnie jest członkiem Rady Głównej Związku Ukraińców w Polsce.

Na przełomie 1989 i 1990 r. (w grudniu i styczniu) odbyły się w Warszawie spotkania przedstawicieli środowisk ukraińskich, nazwane „ukraińskim okrag- 
łym stołem". Dotyczyły przyszłej struktury organizacyjnej mniejszości ukraińskiej w Polsce w zmieniającej się sytuacji politycznej i prawnej. W lutym $1990 \mathrm{r}$. UTSK na swoim ostatnim zjeździe, zgodnie z wcześniejszymi ustaleniami „okrągłego stołu”, przekształcono w Związek Ukraińców w Polsce (ZUwP). Organizacja zrzeszała wówczas 7771 członków w 181 kołach (niektóre z nich były kołami „martwymi”). Działało 47 zespołów artystycznych, skupiających 780 osób. Czesść z zespołów prezentowała bardzo wysoki poziom artystyczny, m.in. chór męski „Żurawli”, łemkowski zespół folklorystyczny „Łemkowyna”, zespół „Osławiany” (Drozd 2010, Halczak 2010a).

Ambicją nowych władz ZUwP było - zgodnie z przyjętą nazwą - reprezentowanie ogółu Ukraińców, co w silnie pluralizującej się rzeczywistości początku lat $90 . \mathrm{XX}$ w. nie było zadaniem łatwym. W pierwszych miesiącach funkcjonowania organizacja utraciła prawo do użytkowania dotychczasowej siedziby w Warszawie. Dzięki życzliwości Jacka Kuronia (wówczas posła na sejm, ministra pracy i polityki socjalnej) znaleziono nową siedzibę na Targów$\mathrm{ku}$, w prawobrzeżnej części Warszawy, gdzie organizacja działa do dziśs ${ }^{102}$. ZUwP liczy obecnie ok. 6 tys. członków, posiada 10 oddziałów (koszaliński, słupski, sanocki, przemyski, mazurski, lubuski, elbląski, legnicki, olsztyński, szczeciński), ponad 90 kół terenowych (w tym siedem kół niezależnych ${ }^{103}$ ) (ryc. 13). Prowadzi działalność społeczną, kulturalną, oświatową, wydawniczą (ściśle współpracuje z wydawnictwem „Tyrsa”), jego działacze z sukcesami kandydują w wyborach samorządowych.

Na początku lat 90. XX w. powstały w Polsce liczne organizacje ukraińskie, lecz część z nich nie wytrzymała „próby czasu”. W 2012 r. formalnie działało kilkanaście stowarzyszeń, przy czym aktywność części z nich była wyłącznie deklaratywna (tab. 6). Było to konsekwencją zarówno różnorodności środowiska mniejszości ukraińskiej, jak i rozproszenia terytorialnego. Mimo silnego pluralizmu organizacyjnego, ZUwP zachował swoją dominującą pozycję od ponad 20 lat, jest najliczniejszą i najważniejszą organizacją reprezentującą interesy mniejszości ukraińskiej w Polsce, ma także najbardziej rozbudowane struktury terenowe (ryc. 13). Większość pozostałych stowarzyszeń ukraińskich ma oficjalny

${ }^{102}$ Budynek ten, przy ul. Kościeliskiej 7, można uznać za centrum życia organizacyjnego mniejszości ukraińskiej w Polsce. Mieści się tam nie tylko Zarząd Główny ZUwP, ale także główne siedziby Związku Ukrainek w Polsce, Ukraińskiego Towarzystwa Historycznego, Organizacji Młodzieży Ukraińskiej „Płast”, wydawnictwo „Tyrsa” oraz redakcja „Naszego Słowa”.

${ }^{103}$ Koła niezależne od poszczególnych oddziałów podlegają bezpośrednio Zarządowi Głównemu ZUwP w Warszawie, funkcjonują w dużych miastach, w których nie ma licznych skupisk Ukraińców. 
status „organizacji wspierającej ZUwP”. Najaktywniejszymi organizacjami regionalnymi, posiadającymi struktury terenowe, całkowicie niezależnymi od ZUwP (choć z nim współpracującymi), jest działający na Białostocczyźnie i północnej Lubelszczyźnie Związek Ukraińców Podlasia oraz funkcjonujące na Lubelszczyźnie i Chełmszczyźnie Towarzystwo Ukraińskie.

Ważnym i symbolicznym miejscem dla stowarzyszeń ukraińskich jest Ukraiński Dom Narodowy (Narodnyj Dim) w Przemyślu, który w marcu 2011 r. został formalnie przekazany przez władze miasta ZUwP. Budynek, zlokalizowany w centrum Przemyśla (ul. Kościuszki 5), został zbudowany w latach 1901-1904 ze składek przemyskich Ukraińców, z przeznaczeniem na cele społeczno-kulturalne. Znajdowały się $\mathrm{w}$ nim siedziby ukraińskich organizacji kulturalnych, ekonomicznych i politycznych, mieścił także teatr, kino i restaurację. W 1948 r. budynek przeszedł na własność skarbu państwa, a następnie miasta. Od początku lat 90. XX w. ZUwP oraz specjalnie powołane do tego celu Stowarzyszenie „Ukraiński Dom Narodowy” prowadziły starania o jego odzyskanie. Obecnie mieści się w nim siedziba przemyskiego oddziału ZUwP, biblioteka, odbywają się wystawy, obchody świąt ukraińskich, kongresy i konferencje naukowe.

Główne postulaty organizacji ukraińskich dotyczą zwiększenia finansowania szkolnictwa ukraińskiego, powołania w głównych skupiskach mniejszości ukraińskiej Instytucji Kultury Ukraińskiej finansowanej z budżetu państwa oraz likwidacji skutków prawnych akcji „Wisła”. Spory w relacjach z lokalnymi władzami dotyczą zwłaszcza prób przywracania historycznych nazw ulic, nawiązujących do historii Ukrainy lub postaci związanych z tradycją ukraińską oraz upamiętniania akcji „Wisła”. Do głównych sukcesów działacze ukraińscy zaliczają m.in. rozwój ukraińskiej działalności kulturalnej, koniec sporu o Ukraiński Dom Narodowy w Przemyślu, obecność w mediach i w szeroko pojętej ,przestrzeni publicznej" oraz aktywność młodzieży w trakcie spisu powszechnego w 2011 r., natomiast w kategorii porażki postrzegają postępującą asymilację mniejszości ukraińskiej, trudności z przyciagnięciem młodzieży do działalności organizacyjnej, niedostateczne finansowanie szkolnictwa oraz działalności kulturalnej z budżetu państwa ${ }^{104}$.

Większość organizacji ukraińskich działających w 2012 r. w Polsce można podzielić na trzy główne kategorie:

- organizacje regionalne (Związek Ukraińców Podlasia, Towarzystwo Ukraińskie, Towarzystwo Ukraińców Podkarpacia, Towarzystwo Miłośników Skansenu Kultury Materialnej Chełmszczyzny i Podlasia w Holi),

${ }^{104} \mathrm{Na}$ podstawie wywiadów przeprowadzonych przez autora w 2012 r. z działaczami ZUwP, Związku Ukraińców Podlasia, Towarzystwa Ukraińskiego. 
- organizacje nawiązujące do tradycji z początków XX w. (Organizacja Młodzieży Ukraińskiej „Płast”, Związek Ukrainek, Stowarzyszenie „Ukraiński Dom Narodowy"),

- organizacje branżowe (Ukraińskie Towarzystwo Nauczycielskie w Polsce, Ukraińskie Towarzystwo Lekarskie, Klub Ukraińskich Prawników, Ukraińskie Towarzystwo Historyczne, Związek Ukraińskiej Młodzieży Niezależnej).

Tabela 6. Ukraińskie organizacje zarejestrowane w Polsce (stan w 2012 r.)

\begin{tabular}{|c|c|c|}
\hline $\begin{array}{c}\text { Nazwa, główna siedziba, liczba } \\
\text { oddziałów terenowych, liczba } \\
\text { członków }\end{array}$ & $\begin{array}{c}\text { Rok } \\
\text { założenia }\end{array}$ & Charakterystyka działalności \\
\hline $\begin{array}{l}\text { Stowarzyszenie „Ukraiński } \\
\text { Dom Narodowy” } \\
\text { Przemyśl, brak oddziałów, } \\
78 \text { członków }\end{array}$ & 1989 & $\begin{array}{l}\text { działalność edukacyjna, oświatowa, kulturalna, } \\
\text { dbanie o rozwój ukraińskiej tożsamości narodo- } \\
\text { wej, prowadzenie działalności Ukraińskiego Domu } \\
\text { Narodowego w Przemyślu wraz z biblioteka, } \\
\text { prowadzenie klubu dyskusyjnego „Besida”, orga- } \\
\text { nizowanie imprez i obchodów świąt ukraińskich, } \\
\text { pomoc dla zdolnych uczniów szkół ukraińskich }\end{array}$ \\
\hline $\begin{array}{l}\text { Fundacja Św. Włodzimierza } \\
\text { Chrzciciela Rusi Kijowskiej } \\
\text { Kraków, brak oddziałów }\end{array}$ & 1989 & $\begin{array}{l}\text { działalność naukowa, religijna, kulturalna, } \\
\text { edukacyjna, wydawnicza, głównym celem jest } \\
\text { wspieranie i popularyzowanie nauki i chrześci- } \\
\text { jańskiej kultury ukraińskiej oraz wzajemne pozna- } \\
\text { nie i pojednanie Polaków i Ukraińców, w ramach } \\
\text { Fundacji działa wydawnictwo „,Szwajpolt Fiol”a, } \\
\text { Galeria Sztuki Ukraińskiej, muzeum ikon, } \\
\text { biblioteka z czytelnia, ksiegarnia „Nestor” oraz } \\
\text { restauracja „Ukraiński smak”; fundacja prowadzi } \\
\text { „Ukraińskie Centrum Naukowo-Kulturalne”, } \\
\text { organizuje seminaria i konferencje naukowe, } \\
\text { wydaje liczne publikacje, m.in. książki dotyczące } \\
\text { historii, sztuki, literatury ukraińskiej, słowniki, } \\
\text { przewodniki, mapy, „Krakowskie Zeszyty } \\
\text { Ukrainoznawcze”, „Horyzonty Krakowskie” }\end{array}$ \\
\hline $\begin{array}{l}\text { Związek Ukraińców w Polsce } \\
\text { Warszawa, } 10 \text { oddziałów, } \\
\text { ok. } 90 \text { kół terenowych, w tym } \\
7 \text { kół niezależnych, } \\
\text { ok. } 6000 \text { członków }\end{array}$ & 1990 & $\begin{array}{l}\text { największa organizacja reprezentująca interesy } \\
\text { mniejszości ukraińskiej w Polsce (dawne UTSK), } \\
\text { podstawowe cele to reprezentowanie i obrona } \\
\text { praw mniejszości ukraińskiej, utrzymanie } \\
\text { ukraińskiej tożsamości narodowej, ochrona i roz- } \\
\text { wój ukraińskiej kultury i folkloru, wspieranie } \\
\text { ukraińskiego szkolnictwa i działalności społecznej, } \\
\text { kulturalnej i oświatowej, rozwój współpracy } \\
\text { między Polską a Ukraina, wydaje ukraińskojęzy- } \\
\text { czny tygodnik „Nasze Słowo” w nakładzie } 3700 \\
\text { egzemplarzy, kwartalnik „Ridna Mowa” oraz } \\
\text { rocznik „Ukraiński Almanach”, organizuje liczne } \\
\text { festiwale, m.in. Festiwal Kultury Ukraińskiej } \\
\text { w Sopocie, koncerty muzyki cerkiewnej, jarmarki, }\end{array}$ \\
\hline
\end{tabular}




\begin{tabular}{|c|c|c|}
\hline & & $\begin{array}{l}\text { obchody świąt ukraińskich, seminaria naukowe, } \\
\text { sprawuje opiekę nad miejscami pamięci history- } \\
\text { cznej, jest członkiem międzynarodowych struktur } \\
\text { ukraińskich: Światowego Kongresu Ukraińców, } \\
\text { Europejskiego Kongresu Ukraińców, Ukraińskiej } \\
\text { Ogólnoświatowej Rady Koordynacyjnej }\end{array}$ \\
\hline $\begin{array}{l}\text { Organizacja Młodzieży } \\
\text { Ukraińskiej „Płast” } \\
\text { Warszawa, brak oddziałów, } \\
150 \text { członków }\end{array}$ & 1990 & $\begin{array}{l}\text { organizacja młodzieżowa, bezpośrednio } \\
\text { nawiązująca do powstałej w } 1912 \text { r. w Galicji } \\
\text { ukraińskiej organizacji skautowej, współpracuje ze } \\
\text { Związkiem Harcerstwa Polskiego oraz z działającą } \\
\text { na Ukrainie, organizacją „Płast”, jest jednym } \\
\text { z sygnatariuszy Porozumienia Młodych } \\
\text { Euroregionu „Bug”, głównym celem jest } \\
\text { patriotyczne wychowanie młodzieży ukraińskiej, } \\
\text { dbanie o tożsamość narodową i tradycje, } \\
\text { uczestnictwo w obchodach świąt narodowych, } \\
\text { organizowanie obozów młodzieżowych }\end{array}$ \\
\hline $\begin{array}{l}\text { Związek Ukrainek } \\
\text { Warszawa, brak oddziałów, } \\
250 \text { członkiń }\end{array}$ & 1990 & $\begin{array}{l}\text { nawiązuje do tradycji bardzo licznego i funkcjo- } \\
\text { nującego w okresie międzywojennym w Galicji } \\
\text { Związku Ukrainek }\end{array}$ \\
\hline $\begin{array}{l}\text { Ukraińskie Towarzystwo } \\
\text { Nauczycielskie w Polsce } \\
\text { Biały Bór, } 8 \text { oddziałów, } \\
132 \text { członków }\end{array}$ & 1991 & $\begin{array}{l}\text { wspieranie ukraińskiej oświaty, organizowanie } \\
\text { kursów i konferencji dla nauczycieli szkół } \\
\text { z ukraińskim językiem nauczania oraz konkursów } \\
\text { i wycieczek dla uczniów szkół z ukraińskim } \\
\text { językiem nauczania, opracowywanie i wydawanie } \\
\text { programów nauczania, redagowanie czasopisma } \\
\text { oświatowego „Ridna Mowa”, nakład } 200 \text { egz. }\end{array}$ \\
\hline $\begin{array}{l}\text { Ukraińskie Towarzystwo } \\
\text { Lekarskie } \\
\text { Przemyśl, brak oddziałów }\end{array}$ & 1991 & $\begin{array}{l}\text { nawiązuje do tradycji organizacji zrzeszającej } \\
\text { lekarzy ukraińskich w Galicji, powstałej w } 1910 \text { r. } \\
\text { we Lwowie }\end{array}$ \\
\hline $\begin{array}{l}\text { Związek Ukraińców Podlasia } \\
\text { Bielsk Podlaski, } 4 \text { oddziały, } \\
\text { ok. } 140-150 \text { członków }\end{array}$ & 1992 & $\begin{array}{l}\text { działalność społeczna, polityczna, edukacyjna, } \\
\text { kulturalna, wydawnicza; podstawowym celem jest } \\
\text { odrodzenie ukraińskiej tożsamości narodowej oraz } \\
\text { języka ukraińskiego wśród prawosławnych miesz- } \\
\text { kańców Podlasia, skupia się głównie na działa- } \\
\text { niach zmierzających do zachowania i rozwoju } \\
\text { ukraińskiego dziedzictwa kulturowego na Podla- } \\
\text { siu, wydaje dwumiesięcznik społeczno-kulturalny } \\
\text { „Nad Buhom i Narwoju” w nakładzie ok. } 1 \text { tys. } \\
\text { egzemplarzy, organizuje koncerty, m.in. Festiwal } \\
\text { Kultury Ukraińskiej na Podlasiu „Podlaska } \\
\text { Jesień”, „Na Iwana, na Kupała”, Konkurs Piosenki } \\
\text { Ukraińskiej „Z podlaskiej krynicy”, wspiera dzia- } \\
\text { łalność amatorskich zespołów artystycznych (m.in. } \\
\text { „Rodyna”, „Ranok”, Strumok”, „Hiłoczka”, } \\
\text { „Tyrsa”), doprowadził do rozpoczęcia nauki } \\
\text { języka ukraińskiego w szkołach w Bielsku } \\
\text { Podlaskim, Białymstoku i Czeremsze oraz } \\
\text { w przedszkolu w Bielsku Podlaskim }\end{array}$ \\
\hline
\end{tabular}




\begin{tabular}{|c|c|c|}
\hline $\begin{array}{l}\text { Związek Ukraińskiej Młodzieży } \\
\text { Niezależnej } \\
\text { Gdańsk, } 2 \text { oddziały, } \\
60 \text { członków }\end{array}$ & 1992 & $\begin{array}{l}\text { podtrzymanie ukraińskiej tożsamości narodowej } \\
\text { wśród młodzieży, rozwijanie aktywności społecz- } \\
\text { nej, kulturalnej i oświatowej młodzieży ukraiń- } \\
\text { skiej, przeciwdziałanie procesom asymilacji } \\
\text { narodowościowej oraz kultywowanie tradycji } \\
\text { i wychowanie w ojczystej kulturze, działanie na } \\
\text { rzecz pogłębiania postaw demokratycznych, } \\
\text { tolerancji i poszanowania wszystkich narodowości, } \\
\text { organizowanie festiwali, koncertów i cyklicznych } \\
\text { imprez kulturalnych m.in., „Ukraińskie Jarmarki } \\
\text { Młodzieżowe”, „Festiwal Mniejszości Narodo- } \\
\text { wych”, „Dni Muzyki Religijnej”, „Bytowska } \\
\text { Warta”, prowadzenie w Gdańsku Ośrodka } \\
\text { Informacji Mniejszości Narodowych, organizo- } \\
\text { wanie cyklu szkoleń dla organizacji pozarządo- } \\
\text { wych w regionach o dużym udziale mniejszości } \\
\text { narodowych }\end{array}$ \\
\hline $\begin{array}{l}\text { Stowarzyszenie Ukraińców } \\
\text { Więźniów Politycznych } \\
\text { i Represjonowanych w Polsce } \\
\text { Koszalin, } 190 \text { członków }\end{array}$ & 1992 & $\begin{array}{l}\text { poprzednia nazwa, do } 2007 \text { r., to Stowarzyszenie } \\
\text { Ukraińców Więźniów Politycznych Okresu Stali- } \\
\text { nowskiego, zajmuje się ochroną miejsc pamięci, } \\
\text { cmentarzy, miejsc walk Ukraińców, odbudową } \\
\text { mogił żołnierzy UPA, budową pomników, ma } \\
\text { zdecydowanie pozytywny stosunek do tradycji } \\
\text { UPA }\end{array}$ \\
\hline $\begin{array}{l}\text { Towarzystwo Ukraińskie } \\
\text { Lublin, } 3 \text { oddziały, } \\
\text { ok. } 100 \text { członków }\end{array}$ & 1999 & $\begin{array}{l}\text { początkowo działało pod nazwą Towarzystwa } \\
\text { Opieki nad Grobami Żołnierzy Ukraińskich } \\
\text { w Lublinie, od } 2009 \text { r. pod nową nazwą prze- } \\
\text { kształciło się w organizację regionalną dbającą } \\
\text { o tożsamość narodową i kulturową Ukraińców na } \\
\text { Lubelszczyźnie i Chełmszczyźnie, organizuje } \\
\text { festiwale, koncerty, imprezy kulturalne, seminaria, } \\
\text { naukę języka ukraińskiego w szkołach, współ- } \\
\text { pracuje z prawosławnymi parafiami, upamiętnia } \\
\text { akcję, „Wisła”, otacza opieką kwaterę żołnierzy } \\
\text { armii Ukraińskiej Republiki Ludowej w Lublinie, } \\
\text { zajmuje się jej renowacją i odnowieniem, a także } \\
\text { odtworzeniem dziejów kwatery i pochowanych } \\
\text { tam osób, wspiera podobne inicjatywy na terenie } \\
\text { województwa lubelskiego i podkarpackiego, wydaje } \\
\text { książki o tematyce historycznej, do 2002 r. wyda- } \\
\text { wało czasopismo „Chołmśkyj Wisnyk”, którego } \\
\text { celem było zachowanie ukraińskich tradycji } \\
\text { regionu oraz integracja lokalnej społeczności } \\
\text { ukraińskiej }\end{array}$ \\
\hline $\begin{array}{l}\text { Towarzystwo Miłośników } \\
\text { Skansenu Kultury Materialnej } \\
\text { Chełmszczyzny i Podlasia } \\
\text { w Holi } \\
\text { Hola, brak oddziałów }\end{array}$ & 2002 & $\begin{array}{l}\text { opieka nad istniejącym od } 1985 \text { r. skansenem } \\
\text { kultury materialnej Chełmszczyzny i Podlasia } \\
\text { w Holi, obiekt eksponuje bogato wyposażone } \\
\text { drewniane zabudowania mieszkalne, sakralne } \\
\text { oraz gospodarskie typowe dla tych regionów }\end{array}$ \\
\hline
\end{tabular}




\begin{tabular}{|l|l|l|}
\hline $\begin{array}{l}\text { Towarzystwo Ukraińców } \\
\text { Podkarpacia } \\
\text { Zapałów, brak oddziałów }\end{array}$ & 2003 & $\begin{array}{l}\text { upowszechnianie i ochrona wolności i praw } \\
\text { człowieka, swobód obywatelskich oraz działań } \\
\text { wspomagających rozwój demokracji, działalność } \\
\text { na rzecz integracji europejskiej oraz współpracy } \\
\text { między społeczeństwami, podtrzymywanie } \\
\text { i upowszechnianie tradycji narodowej, rozwój } \\
\text { świadomości narodowej, obywatelskiej i kulturo- } \\
\text { wej, działalność na rzecz mniejszości narodowych } \\
\text { i etnicznych oraz języka regionalnego }\end{array}$ \\
\hline $\begin{array}{l}\text { Ukraińskie Towarzystwo } \\
\text { Harstoryczne w Polsce } \\
23 \text { członków brak oddziałów, }\end{array}$ & 2004 & $\begin{array}{l}\text { działalność naukowa, wydawnicza i popularyza- } \\
\text { torska, propagowanie wiedzy historycznej o dzie- } \\
\text { jach Ukraińców oraz relacjach polsko-ukrainskich, } \\
\text { współorganizuje seminaria i konferencje naukowe } \\
\text { we Wrocławiu, Legnicy, Zielonej Górze, } \\
\text { Gorzowie Wielkopolskim, Warszawie, Białym } \\
\text { Borze, Przemyślu, Słupsku, wydaje książki oraz } \\
\text { Zeszyty Naukowe Ukraińskiego Towarzystwa } \\
\text { Historycznego w Polsce” }\end{array}$ \\
\hline $\begin{array}{l}\text { Klub Ukraińskich Prawników } \\
\text { Kraków, brak oddziałów }\end{array}$ & - & \begin{tabular}{l} 
brak danych \\
\hline
\end{tabular}
\end{tabular}

${ }^{a}$ Szwajpolt Fiol był niemieckim drukarzem i złotnikiem, który w 1491 r. otworzył w Krakowie pierwszą na świecie drukarnię wydającą księgi liturgiczne drukowane cyrylicą w języku cerkiewnosłowiańskim.

Źródło: opracowanie własne

Struktura przestrzenna organizacji ukraińskich jest ściśle związana z ukształtowanym w konsekwencji akcji „Wisła” współczesnym rozmieszczeniem Ukraińców w Polsce. Największa koncentracja oddziałów i kół terenowych występuje w północnej i zachodniej Polsce (zwłaszcza w województwie warmińsko-mazurskim, zachodniopomorskim i lubuskim), na Podkarpaciu, szczególnie w okolicach Przemyśla i Sanoka, na Podlasiu oraz Lubelszczyźnie, a także w Warszawie i Krakowie, gdzie zlokalizowano główne siedziby sześciu ukraińskich organizacji (ryc. 13). Tak duże rozproszenie terytorialne poszczególnych organizacji, ich oddziałów oraz kół terenowych, z pewnością utrudnia, choćby z powodów logistycznych, prowadzenie aktywnej działalności. Pod tym względem z pewnością w lepszej sytuacji są organizacje litewskie czy białoruskie.

\section{Lemkowie}

Po kilkudziesięciu latach urzędowego utożsamiania wszystkich Łemków z narodem ukraińskim, od początku lat 90 . XX w. sami mogli decydować o swojej tożsamości narodowej i przynależności organizacyjnej. Spowodowało to powstanie wielu, także konkurencyjnych czy wręcz antagonistycznych, stowarzyszeń łemkowskich oraz podkreślanie przez część Łemków swojej odrębności zarówno od Polaków, jak i od Ukraińców. 

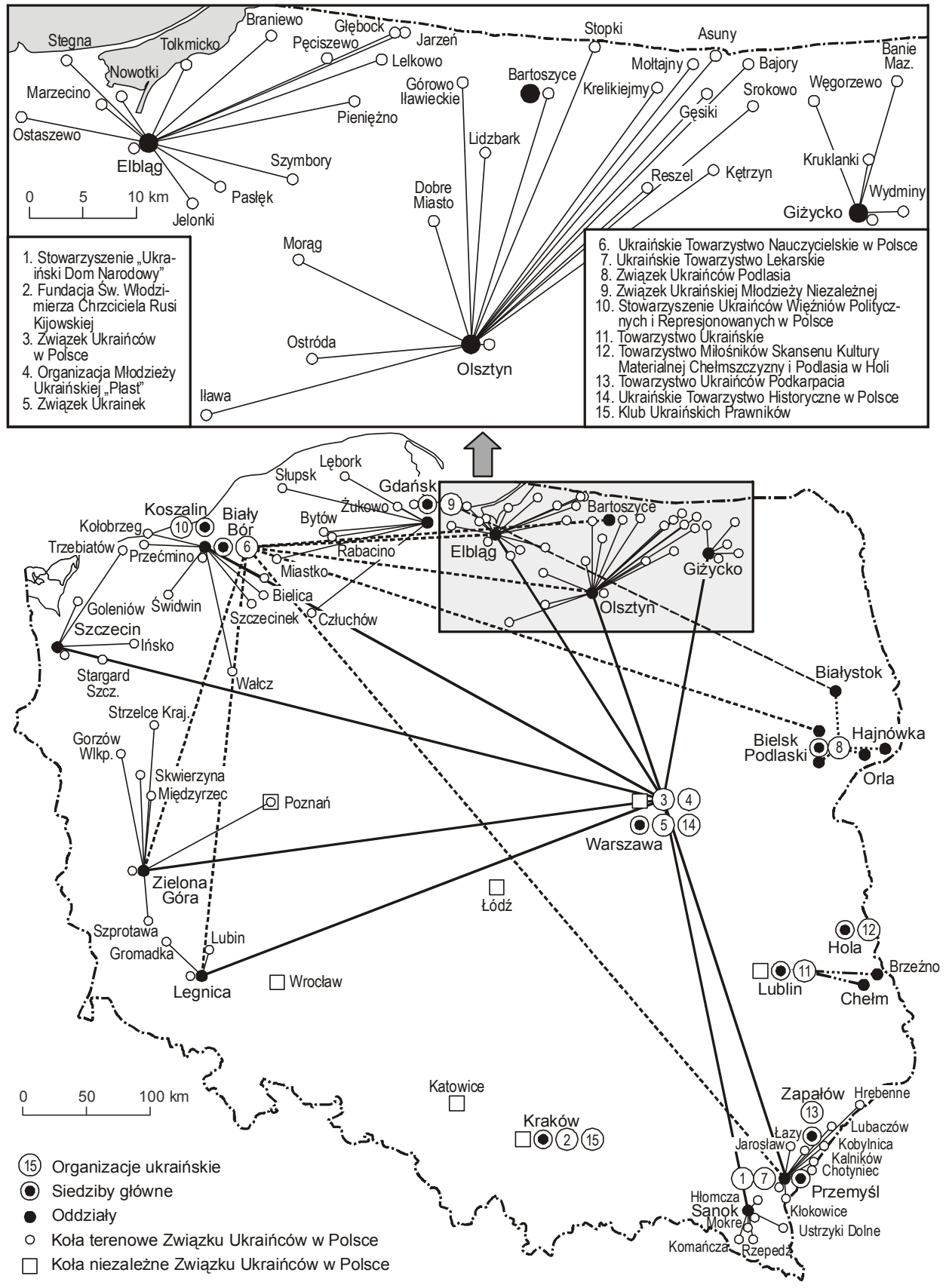

Ryc. 13. Struktura przestrzenna organizacji ukraińskich w 2012 r. Źródło: opracowanie własne 
Pierwszą powojenną organizacją łemkowską w Polsce było zarejestrowane w kwietniu 1989 r. w Legnicy Stowarzyszenie Łemków o orientacji narodowo-łemkowskiej, odcinające się od tradycji i tożsamości ukraińskiej. Reprezentuje ono opcję karpatorusińską, uważa Łemków za odrębną od Ukraińców część narodu rusińskiego (czwartego narodu wschodniosłowiańskiego) obejmującego także Rusinów na Słowacji i ukraińskiej Rusi Zakarpackiej. Działa głównie na Dolnym Śląsku, gdzie ma najlepiej rozbudowane struktury terenowe. Było jednym z inicjatorów zwołania w 1991 r. w Medzilaborcach na Słowacji Światowego Kongresu Rusinów, gdzie wybrano Światową Radę Rusinów, skupiającą działaczy rusińskich z Polski, Słowacji, Czech, Ukrainy, Wegier, Rumunii, Serbii, USA ${ }^{105}$. Światowy Kongres Rusinów propaguje ideę narodu karpatoruskiego i Rusi Karpackiej jako wspólnej ojczyzny wszystkich Rusinów. Kolejne Światowe Kongresy Rusinów odbywały się co dwa lata, w Krynicy, Ruskim Keresturze (Serbia), Budapeszcie, Użgorodzie, Pradze, Preszowie, Krynicy, Sigheti (Rumunia), Ruskim Keresturze, Petrovicach (Chorwacja) oraz w 2011 r. w Budapeszcie.

Współczesny ruch karpatorusiński oraz związane z nim pojęcia narodu rusińskiego i rusinizmu są krytykowane przez naukowców ukraińskich jako sztuczne, niekonsekwentne, motywowane politycznie próby dzielenia narodu ukraińskiego oraz popieranie ruchów separatystycznych (Halczak 2007, 2009, 2010a).

Na przełomie 1989 i 1990 r. w Gorlicach powstało Zjednoczenie Łemków o orientacji ukraińskiej, uważające Łemków za czesść narodu ukraińskiego. Szybko doszło do konfliktu między dwoma łemkowskimi organizacjami. Główny spór dotyczył łemkowskiej tożsamości, samookreślenia się, przeciwstawnych orientacji narodowych. Stowarzyszenie Łemków reprezentuje tę część ludności łemkowskiej, która odrzuca ukraińską świadomość narodową i podkreśla odrębność narodową Łemków, natomiast Zjednoczenie Łemków zrzesza tę część, która utożsamia się z narodem ukraińskim, podkreślając jednocześnie odrębność regionalną Łemków. Zjednoczenie Łemków ma oficjalny status „organizacji wspierającej Związek Ukraińców w Polsce", niejednokrotnie w oddziałach terenowych Zjednoczenia Łemków działają te same osoby co w ZUwP, a siedziby obu organizacji mieszczą się w tych samych pomieszczeniach. Jest członkiem Światowej Federacji Ukraińskich - Łemkowskich Organizacji (ŚFUŁO),

105 Poza Stowarzyszeniem Łemków, inicjatorami kongresu było Rusińskie Odrodzenie (Słowacja), Towarzystwo Rusinów Karpackich (Ukraina), Ruska Macierz (Serbia) oraz delegacje rusińskich organizacji z USA i Kanady. Obecnie w skład Światowej Rady Rusinów wchodzi 17 organizacji kulturalnych i naukowych z siedmiu państw. 
zrzeszającej Łemków z Polski, Ukrainy, Słowacji, Serbii, Chorwacji, USA i Kanady. W maju 2012 r. w Gorlicach odbył się V Kongres ŚFUŁO, którego gospodarzem było Zjednoczenie Łemków. Obecnie jest najliczniejszą organizacją łemkowską, z najbardziej rozbudowanymi strukturami terenowymi, aktywną zwłaszcza na Łemkowszczyźnie (tab. 7, ryc. 14).

Powstanie i funkcjonowanie obu organizacji jest współczesnym zinstytucjonalizowaniem istniejącego od końca XIX w. dualizmu narodowego wśród Łemków. $Z$ jednej strony rozbicie organizacyjne Łemków powoduje konfli$\mathrm{kty}^{106}$, z drugiej strony wyraża rzeczywisty, istniejący od dziesięcioleci podział narodowościowy tej grupy. Choć obie organizacje podkreślają, że jednym z ich celów jest integracja ludności łemkowskiej, to swoją działalnością skutecznie ją dezintegrują. Jednak swoista konkurencja obu organizacji powoduje ich dużą aktywność polityczną, społeczną, kulturalną, wydawniczą, z korzyścią dla ogółu społeczności łemkowskiej. Mimo powstania w późniejszych latach wielu kolejnych stowarzyszeń, nadal są to dwie największe i najaktywniejsze organizacje łemkowskie w Polsce ${ }^{107}$. Większość pozostałych organizacji jest bliższa Stowarzyszeniu Łemków, jednak podjęta w połowie lat 90. XX w. próba powołania Federacji Organizacji Łemkowskich zakończyła się niepowodzeniem, także aktywność i zakres działania części z nich odbiega od oficjalnych deklaracji i ma charakter epizodyczny (tab. 7).

Od ponad 20 lat głównymi postulatami łemkowskich organizacji jest naprawienie krzywd moralnych i materialnych wynikających z akcji „Wisła”, likwidacji jej skutków prawnych oraz oficjalne potępienie przesiedleń. Postulaty te w większości nie doczekały się realizacji ${ }^{108}$. Brak odszkodowań za akcję

106 Jednym z głównym punktów spornych, poza kwestiami narodowo-ideologicznymi, jest sprawa przejęcia na początku lat 90. XX w. przez Zjednoczenie Łemków organizacji „Łemkowskiej Watry”, przeniesienie jej z Bartnego do Zdyni i nadanie wyraźnego charakteru łemkowsko-ukraińskiego. „Watra” była zapoczątkowana i organizowana od początku lat 80 . XX w. przez osoby, które następnie współtworzyły Stowarzyszenie Łemków.

${ }^{107} \mathrm{Na}$ początku lat 90. XX w. bardzo aktywną i liczną organizacją łemkowską, przekształconą następnie w partię polityczną, był Rusiński Demokratyczny Krạg Łemków „Hospodar” z siedzibą w Bielance. Jego podstawowym postulatem i celem działania były starania o zwrot lasów odebranych Łemkom w konsekwencji akcji „Wisła”. W ostatnich latach działalność tej organizacji całkowicie zamarła.

${ }^{108} 3$ sierpnia 1990 r. senat przyjął uchwałę, w której dokonał moralnego potępienia akcji „Wisła”, sejm odłożył taką debatę na okres późniejszy (nie odbyła się), w 1997 r. prezydent A. Kwaśniewski potępił wysiedlenia, jednak nadal nie wypłacono żadnych odszkodowań i rekompensat osobom wysiedlonym, nie uchwalono ustawy reprywatyzacyjnej, nie zwrócono lasów, IPN nie stwierdził nielegalności akcji „Wisła”. 
„Wisła” oraz brak ustawy reprywatyzacyjnej - obok znikomego wsparcia finansowego przez samorządy - są podstawowymi punktami spornymi w relacjach Łemków z władzami państwowymi, są także postrzegane jako główne porażki łemkowskich organizacji. Do kategorii porażek Zjednoczenie Łemków zalicza także brak obligatoryjnej nauki o mniejszościach narodowych i etnicznych w polskich szkołach, a Stowarzyszenie Młodzieży Łemkowskiej „Czuha” słabo rozwiniętą sieć nauczania języka łemkowskiego oraz brak łemkowskiej instytucji naukowo-kulturalnej. Natomiast za sukces wszystkich stowarzyszeń trzeba z pewnością uznać rozwój działalności artystycznej, kulturalnej, edukacyjnej, wydawniczej, ochronę miejsc pamięci, stopniowe przywracanie tożsamości Łemkowszczyźnie. Ponadto Zjednoczenie Łemków za sukces uważa także opracowanie ekspertyzy prawnej, która, mimo braku ustawy reprywatyzacyjnej, umożliwia odzyskiwanie gospodarstw i lasów, Stowarzyszenie Młodzieży Łemkowskiej „Czuha” skuteczne zapoczątkowanie wprowadzania dwujęzycznych polsko-łemkowskich nazw miejscowości na Łemkowszczyźnie, natomiast największymi osiągnięciami Stowarzyszenia Łemków oraz wspierających go środowisk łemkowskich było odzyskanie w 2009 r. budynku Ruskiej Bursy ${ }^{109}$ w Gorlicach oraz uwzględnienie Łemków jako odrębnej mniejszości etnicznej w Ustawie o mniejszościach narodowych, etnicznych i języku regionalnym. W sensie prawnym jest to potwierdzenie odrębności Łemków od Ukraińców, co w swojej działalności oraz statucie podkreśla Stowarzyszenie Łemków ${ }^{110}$.

Organizacje łemkowskie działające współcześnie w Polsce można podzielić na cztery główne kategorie:

- organizacje narodowo-łemkowskie (Stowarzyszenie Łemków, Stowarzyszenie Młodzieży Łemkowskiej „Czuha”, Stowarzyszenie „Ruska Bursa”, Stowarzyszenie Miłośników Kultury Łemkowskiej, Fundacja Wspierania Mniej-

${ }^{109}$ Budynek powstały w 1909 r. jako internat dla młodzieży rusińskiej uczącej się w gimnazjum w Gorlicach. Bursa została założona i prowadzona przez łemkowskie Stowarzyszenie „Ruska Bursa”. W 1950 r. budynek został przejęty przez skarb państwa i przez kilkadziesiąt lat był użytkowany przez szpital. W 1991 r. reaktywowano Stowarzyszenie „Ruska Bursa”, które, we współpracy ze Stowarzyszeniem Łemków, skutecznie starało się odzyskać budynek. Obecnie funkcjonuje jako ośrodek kultury łemkowskiej, są w nim organizowane uroczystości, wystawy, galerie, znajduje się biblioteka, siedziba Stowarzyszenia „Ruska Bursa”, Stowarzyszenia Zespołu Pieśni i Tańca „Łemkowyna” (działalność stowarzyszenia jest zawieszona) oraz Stowarzyszenia Młodzieży Łemkowskiej „Czuha”.

${ }^{110} \mathrm{Na}$ podstawie wywiadów przeprowadzonych przez autora w 2012 r. z działaczami Stowarzyszenia Łemków, Zjednoczenia Łemków, Stowarzyszenia Młodzieży Łemkowskiej „Czuha”. 
szości Łemkowskiej „Rutenika”, Łemkowska Fundacja Oświatowa im. Jana Krynickiego),

- organizacje narodowo-ukraińskie (Zjednoczenie Łemków),

- organizacje chroniące dziedzictwo historyczno-kulturowe Łemkowszczyzny (Towarzystwo na Rzecz Rozwoju Muzeum Kultury Łemkowskiej w Zyndranowej, Stowarzyszenie Terka Karpacka),

- organizacje wspierające działalność zespołów ludowych (Łemkowski Zespół Pieśni i Tańca „Kyczera”, Stowarzyszenie Zespołu Pieśni i Tańca „Łemkowyna”, Stowarzyszenie Promocji Twórczości Łemkowskiej „Serencza”, Stowarzyszenie Wspierania Kultury Łemkowskiej „Wereteno”).

Tabela 7. Łemkowskie organizacje zarejestrowane w Polsce (stan w 2012 r.)

\begin{tabular}{|c|c|c|}
\hline $\begin{array}{c}\text { Nazwa, główna siedziba, liczba } \\
\text { oddziałów terenowych, liczba } \\
\text { członków }\end{array}$ & $\begin{array}{c}\text { Rok } \\
\text { założenia }\end{array}$ & Charakterystyka działalności \\
\hline $\begin{array}{l}\text { Stowarzyszenie Łemków } \\
\text { Legnica, } 12 \text { kół terenowych, } \\
\text { 150-160 członków }\end{array}$ & 1989 & $\begin{array}{l}\text { działalność społeczna, polityczna, kulturalna, } \\
\text { edukacyjna, wydawnicza, pierwsza powojenna } \\
\text { organizacja łemkowska w Polsce o wyraźnym } \\
\text { nastawieniu narodowo-łemkowskim, rusińskim, } \\
\text { sprzeciwiająca się utożsamianiu wszystkich } \\
\text { Łemków z narodem ukraińskim, głównymi celami } \\
\text { jest integracja Łemków, zachowanie i rozwój } \\
\text { łemkowskiej tożsamości narodowej, kultury } \\
\text { materialnej i duchowej, tradycji, nauczanie języka } \\
\text { łemkowskiego, upowszechnianie wiedzy o historii } \\
\text { Łemków, reprezentowanie mniejszości łemko- } \\
\text { wskiej, organizuje liczne imprezy kulturalne, } \\
\text { festiwale, m.in. „Łemkowska Watrę na } \\
\text { Obczyźnie”, w Michałowie, „Biennale Kultury } \\
\text { Rusińskiej”, „Łemkowską Twórczą Jesień”, } \\
\text { „Chwilę z Łemkowską Kulturą”, patronuje } \\
\text { Zespołowi Pieśni i Tańca „Łastiwoczka” oraz } \\
\text { Łemkowskiemu Zespołowi Pieśni i Tańca } \\
\text { „Kyczera”, wydaje dwumiesięcznik „Besida”, } \\
\text { było jednym z inicjatorów zwołania Światowego } \\
\text { Kongresu Rusinów, jest członkiem Światowej } \\
\text { Rady Rusinów, propaguje ideę narodu karpato- } \\
\text { ruskiego i Rusi Karpackiej jako wspólnej } \\
\text { ojczyzny wszystkich Rusinów }\end{array}$ \\
\hline $\begin{array}{l}\text { Zjednoczenie Łemków } \\
\text { Gorlice, } 34 \text { koła terenowe, } \\
1057 \text { członków }\end{array}$ & 1990 & $\begin{array}{l}\text { działalność społeczna, polityczna, kulturalna, } \\
\text { edukacyjna, wydawnicza, organizacja o wyraź- } \\
\text { nym nastawieniu narodowo-ukraińskim, mająca } \\
\text { oficjalny statut „organizacji wspierającej Związek } \\
\text { Ukraińców w Polsce”, współpracuje z szeregiem } \\
\text { organizacji mniejszości ukraińskiej w Polsce, } \\
\text { głównymi celami jest ochrona łemkowskiej } \\
\text { kultury materialnej i duchowej, propagowanie }\end{array}$ \\
\hline
\end{tabular}




\begin{tabular}{|c|c|c|}
\hline & & $\begin{array}{l}\text { wiedzy o Łemkach i Łemkowszczyźnie, utrzyma- } \\
\text { nie ścisłych związków mniejszości łemkowskiej } \\
\text { i ukraińskiej, rozwój szkolnictwa ukraińskiego, } \\
\text { popularyzowanie amatorskiego ruchu artysty- } \\
\text { cznego, organizuje liczne imprezy kulturalne, } \\
\text { m.in. coroczne Święto Kultury Łemkowskiej } \\
\text { „Łemkowska Watra” w Zdyni, „Łemkowski } \\
\text { Kermesz” w Olchowcu, Międzynarodową } \\
\text { Prezentację Twórczości Plastycznej Artystów } \\
\text { Łemkowszczyzny „Łemkowskie Jeruzalem”, } \\
\text { „Łemkowską Spartakiade”,, wydaje kwartalnik } \\
\text { „Watra” w nakładzie 1350 egz., jest członkiem } \\
\text { Swiatowej Federacji Ukraińskich - Łemkowskich } \\
\text { Organizacji }\end{array}$ \\
\hline $\begin{array}{l}\text { Stowarzyszenie „Ruska Bursa” } \\
\text { Gorlice, brak oddziałów, } \\
45 \text { członków }\end{array}$ & 1991 & $\begin{array}{l}\text { odzyskanie dawnego budynku Ruskiej Bursy } \\
\text { w Gorlicach, a obecnie jego utrzymanie i prowa- } \\
\text { dzenie jako ośrodka kultury łemkowskiej, udzie- } \\
\text { lanie pomocy materialnej, naukowej i wycho- } \\
\text { wawczej młodzieży łemkowskiej uczęzzczającej } \\
\text { do szkół w Gorlicach, działalność edukacyjna, } \\
\text { oświatowa, kulturalna, podtrzymywanie } \\
\text { łemkowskich tradycji narodowych wśród } \\
\text { młodzieży, organizowanie kursów języka } \\
\text { łemkowskiego, wykładów na temat kultury } \\
\text { i języka Łemków, imprez kulturalnych dla dzieci, } \\
\text { młodzieży i dorosłych, odczytów, koncertów, } \\
\text { przedstawień, redagowanie „Rocznika Ruska } \\
\text { Bursa”, współpracuje ze Stowarzyszeniem } \\
\text { Łemków, jest członkiem Światowej Rady } \\
\text { Rusinów }\end{array}$ \\
\hline $\begin{array}{l}\text { Łemkowski Zespół Pieśni } \\
\text { i Tańca „Kyczera” } \\
\text { Legnica, brak oddziałów }\end{array}$ & 1992 & $\begin{array}{l}\text { działalność kulturalna, artystyczna, do głównych } \\
\text { celów stowarzyszenia należy ratowanie i propa- } \\
\text { gowanie kultury łemkowskiej, inspirowanie badań } \\
\text { naukowych w zakresie łemkoznawstwa, podej- } \\
\text { mowanie działań przełamujących stereotypy } \\
\text { i uprzedzenia narodowościowe, szeroko } \\
\text { rozumiana edukacja wielokulturowa, instytu- } \\
\text { cjonalizacja życia kulturalnego i naukowego } \\
\text { Łemków na Dolnym Śląsku. Zespół prowadzi } \\
\text { jedyne w Polsce Centrum Kultury Łemkowskiej } \\
\text { z własną biblioteka, archiwum i izbą etnogra- } \\
\text { ficzną, które mieści się w należącym do } \\
\text { stowarzyszenia budynku w Legnicy; dorobek } \\
\text { stowarzyszenia to kilkaset koncertów, liczne } \\
\text { imprezy kulturalne, wystawy, konferencje } \\
\text { naukowe, konkursy, festiwale, m.in. Europejskie } \\
\text { Spotkania Mniejszości Narodowych i Etnicznych } \\
\text { „Pod Kyczerą", największy międzynarodowy } \\
\text { festiwal mniejszości narodowych organizowany } \\
\text { w Europie }\end{array}$ \\
\hline
\end{tabular}




\begin{tabular}{|c|c|c|}
\hline $\begin{array}{l}\text { Stowarzyszenie Miłośników } \\
\text { Kultury Łemkowskiej } \\
\text { Ługi (Strzelce Krajeńskie), } \\
\text { brak oddziałów, } 30 \text { członków }\end{array}$ & 1992 & $\begin{array}{l}\text { działalność kulturalna, społeczna, oświatowa, } \\
\text { głównym celem jest pielęgnowanie, rozwój } \\
\text { i upowszechnianie kultury duchowej i materialnej } \\
\text { Łemków, integracja mniejszości łemkowskiej, } \\
\text { kształtowanie młodzieżowych elit społecznych } \\
\text { i kulturalnych; organizuje występy zespołów } \\
\text { artystycznych, koncerty, festiwale, m.in. } \\
\text { „Łemkowska Watra w Ługach”, imprezy } \\
\text { kulturalne, prelekcje, seminaria, zajęcia dla dzieci } \\
\text { i młodzieży z wiedzy o kulturze i historii } \\
\text { Łemków, wycieczki, projekty kulturalno- } \\
\text {-edukacyjne, przy stowarzyszeniu działa zespół } \\
\text { „Chwylyna” }\end{array}$ \\
\hline $\begin{array}{l}\text { Towarzystwo na Rzecz Rozwoju } \\
\text { Muzeum Kultury Łemkowskiej } \\
\text { w Zyndranowej } \\
\text { Zyndranowa, brak oddziałów, } \\
31 \text { członków }\end{array}$ & 1995 & $\begin{array}{l}\text { działalność kulturalna, oświatowa, edukacyjna, } \\
\text { główne cele to ochrona dziedzictwa kulturowego } \\
\text { Łemków oraz prowadzenie Muzeum Kultury } \\
\text { Łemkowskiej w Zyndranowej, pomnażanie } \\
\text { istniejących zbiorów, inwentaryzacja, } \\
\text { udostępnianie eksponatów, publikowanie } \\
\text { katalogów i przewodników, ponadto } \\
\text { organizowanie corocznych obchodów Święta } \\
\text { Kultury Łemkowskiej „Od Rusal do Jana”, } \\
\text { „Łemkowskiej Jesieni Poetyckiej”, plenerów } \\
\text { malarstwa, rzeźby }\end{array}$ \\
\hline $\begin{array}{l}\text { Fundacja Wspierania } \\
\text { Mniejszości Łemkowskiej } \\
\text { „Rutenika” } \\
\text { Warszawa, brak oddziałów }\end{array}$ & 2001 & $\begin{array}{l}\text { działalność społeczna, kulturalna, oświatowa, } \\
\text { edukacyjna, głównym celem jest wspieranie } \\
\text { inicjatyw rozwijających poczucie tożsamości } \\
\text { narodowej i językowej mniejszości łemkowskiej } \\
\text { oraz historii i kultury Łemków, wspiera } \\
\text { finansowo działalność kulturalną Łemków, } \\
\text { wspomaga finansowo zespoły folklorystyczne, } \\
\text { organizuje i finansuje konferencje, seminaria, } \\
\text { wspiera badania naukowe, współpracuje ze } \\
\text { Stowarzyszeniem Łemków, działalność fundacji } \\
\text { jest zawieszona }\end{array}$ \\
\hline $\begin{array}{l}\text { Stowarzyszenie Zespołu Pieśni } \\
\text { i Tańca „Łemkowyna” } \\
\text { Gorlice, brak oddziałów }\end{array}$ & 2001 & $\begin{array}{l}\text { działalność kulturalna, artystyczna; stowarzy- } \\
\text { szenie powstało z przekształcenia zespołu pieśni } \\
\text { i tańca „Łemkowyna”, głównym celem jest } \\
\text { prowadzenie zespołu „Łemkowyna” oraz pro- } \\
\text { pagowanie i promocja kultury i twórczości } \\
\text { łemkowskiej, wydaje płyty zespołu, działalność } \\
\text { stowarzyszenia jest zawieszona }\end{array}$ \\
\hline $\begin{array}{l}\text { Stowarzyszenie Promocji } \\
\text { Twórczości Łemkowskiej } \\
\text { „Serencza” } \\
\text { Gorlice, brak oddziałów }\end{array}$ & 2003 & $\begin{array}{l}\text { działalność kulturalna, artystyczna; stowarzy- } \\
\text { szenie powstało z przekształcenia zespołu } \\
\text { ludowego „Serencza”, głównym celem jest } \\
\text { propagowanie oraz promocja kultury i twórczości } \\
\text { łemkowskiej, organizuje i finansuje koncerty, } \\
\text { przeglądy, festiwale z udziałem zespołu } \\
\text { „Serencza”, wydaje płyty zespołu, zapewnia } \\
\text { warunki do funkcjonowania zespołu }\end{array}$ \\
\hline
\end{tabular}




\begin{tabular}{|c|c|c|}
\hline $\begin{array}{l}\text { Stowarzyszenie Wspierania } \\
\text { Kultury Łemkowskiej } \\
\text { „Wereteno" } \\
\text { Gorlice, brak oddziałów, } \\
20 \text { członków }\end{array}$ & 2004 & $\begin{array}{l}\text { działalność kulturalna, artystyczna; stowarzy- } \\
\text { szenie powstało z przekształcenia zespołu dzie- } \\
\text { cięcego „Wereteno” z Łosia na Łemkowszczy- } \\
\text { źnie, głównym celem jest propagowanie i rozwój } \\
\text { kultury łemkowskiej, ochrona dziedzictwa } \\
\text { kulturowego Karpat, rozwój zainteresowań } \\
\text { artystycznych i talentów wśród dzieci } \\
\text { i młodzieży, edukacja międzykulturowa }\end{array}$ \\
\hline $\begin{array}{l}\text { Łemkowska Fundacja } \\
\text { Oświatowa im. Jana } \\
\text { Krynickiego } \\
\text { Gorlice, brak oddziałów }\end{array}$ & 2005 & $\begin{array}{l}\text { działalność społeczna, oświatowa, edukacyjna, } \\
\text { główne cele to pomoc stypendialna dla młodzieży } \\
\text { temkowskiej (zwłaszcza z obszaru Łemkowszczy- } \\
\text { zny) uczącej się w szkołach ponadgimnazjalnych } \\
\text { oraz studiującej, pomoc w zakwaterowaniu } \\
\text { w miejscu nauki, organizowanie edukacji } \\
\text { uzupełniającej }\end{array}$ \\
\hline $\begin{array}{l}\text { Stowarzyszenie Młodzieży } \\
\text { Łemkowskiej „Czuha” } \\
\text { Gorlice, brak oddziałów, } \\
30 \text { członków }\end{array}$ & 2007 & $\begin{array}{l}\text { działalność społeczna, polityczna, kulturalna, } \\
\text { edukacyjna, organizacja o nastawieniu narodowo- } \\
\text {-łemkowskim, współpracuje ze Stowarzyszeniem } \\
\text { Łemków, głównymi celami jest integracja } \\
\text { młodzieży łemkowskiej, wspieranie postaw } \\
\text { twórczych, popularyzowanie wiedzy na temat } \\
\text { Łemków i Łemkowszczyzny, ratowanie i rozwój } \\
\text { łemkowskiej kultury materialnej i duchowej, } \\
\text { rozwój oświaty i nauki wśród młodzieży } \\
\text { łemkowskiej, organizuje m.in. koncerty, festiwale, } \\
\text { imprezy młodzieżowe, warsztaty tańca i śpiewu, } \\
\text { obozy, wycieczki, rajdy, kursy, szkolenia, } \\
\text { aktywnie i skutecznie zabiega o wprowadzenie } \\
\text { dwujęzycznych polsko-łemkowskich nazw } \\
\text { miejscowości na Łemkowszczyźnie, jest } \\
\text { członkiem Światowego Forum Rusińskiej } \\
\text { Młodzieży przy Światowym Kongresie Rusinów, } \\
\text { propaguje ideę narodu karpatoruskiego i Rusi } \\
\text { Karpackiej jako wspólnej ojczyzny wszystkich } \\
\text { Rusinów }\end{array}$ \\
\hline $\begin{array}{l}\text { Stowarzyszenie Terka Karpacka } \\
\text { Nowica, brak oddziałów, } 22 \\
\text { członków }\end{array}$ & 2008 & $\begin{array}{l}\text { działalność kulturalna, społeczna, oświatowa, } \\
\text { kontynuuje działalność i cele statutowe } \\
\text { istniejącego w latach 2004-2008 Stowarzyszenia } \\
\text { na Rzecz Ratowania Dziedzictwa Kulturowego } \\
\text { Łemków „Terka”; główne cele to ochrona } \\
\text { i popularyzacja dziedzictwa historyczno- } \\
\text {-kulturowego Karpat, rozwój kultury łemko- } \\
\text { wskiej, prowadzenie badań naukowych } \\
\text { dotyczących historii Łemkowszczyzny, } \\
\text { wspieranie lokalnej przedsiębiorczości } \\
\text { i aktywności artystycznej, wspieranie działań } \\
\text { proekologicznych }\end{array}$ \\
\hline
\end{tabular}

Źródło: opracowanie własne. 


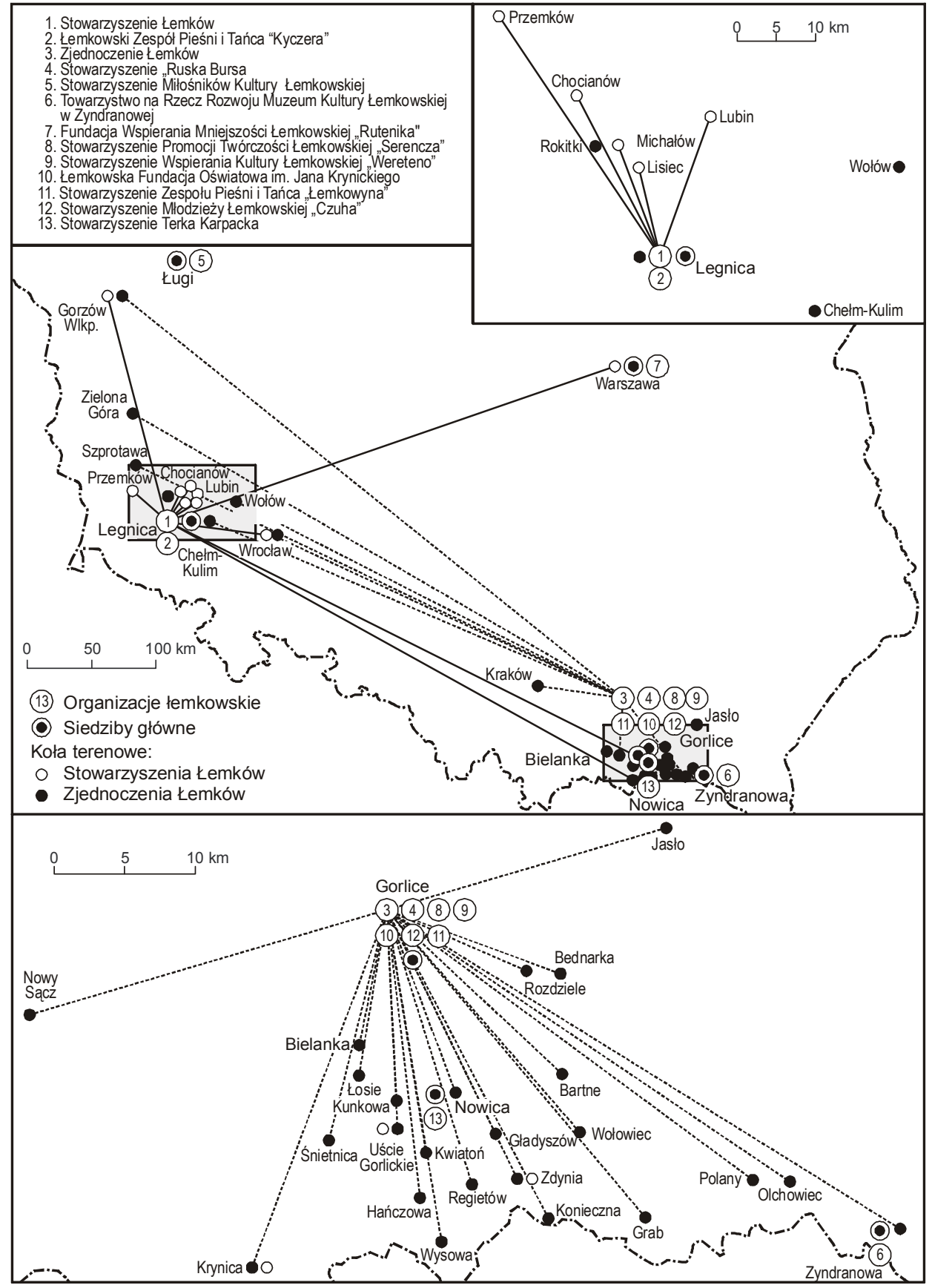

Ryc. 14. Struktura przestrzenna organizacji łemkowskich w 2012 r. Źródło: opracowanie własne 
Struktura przestrzenna łemkowskich stowarzyszeń pokazuje, jak nadal ważnym regionem jest Łemkowszczyzna (ryc. 14). Choć Łemkowie, już od kilkudziesięciu lat, zamieszkują w rozproszeniu głównie zachodnią Polskę, to zdecydowana większość organizacji ma swoje siedziby w bezpośredniej bliskości dawnych granic Łemkowszczyzny (Gorlice) lub na Łemkowszczyźnie (Zyndranowa, Nowica). Około 65\% kół terenowych Zjednoczenia Łemków znajduje się w beskidzkich wioskach, także działające głównie na Dolnym Śląsku Stowarzyszenie Łemków uruchomiło kilka kół terenowych na odległej Łemkowszczyźnie. Wszystkie łemkowskie organizacje, stowarzyszenia i fundacje prowadzą w Beskidach aktywną działalność. Polega ona m.in. na organizacji imprez kulturalnych, nauce języka, historii i kultury łemkowskiej, prowadzeniu łemkowskich muzeów, ochronie dziedzictwa historyczno-kulturowego, wydawaniu czasopism. Najważniejszą imprezą jest organizowane przez Zjednoczenie Łemków „Święto Kultury Łemkowskiej - Łemkowska Watra”, odbywające się corocznie w Zdyni. Jest to jedna $\mathrm{z}$ największych międzynarodowych imprez artystycznych w Karpatach i największa łemkowska masowa impreza na świecie. Trwający trzy dni festiwal ma charakter cykliczny i jest swoistego rodzaju połączeniem tradycji kulturowych ze współczesną formą rekreacji. Towarzyszą mu m.in. obchody rocznicowe, Łemkowska Spartakiada, wystawy, konkursy, pokazy tradycyjnych rzemiosł. Występuje kilkuset wykonawców muzyki ludowej, rockowej, folkowej, jazzowej oraz różnych teatralizowanych form scenicznych. „Watra” co roku gromadzi 6-10 tys. osób, głównie Łemków i Ukraińców z Beskidu Niskiego oraz zachodniej i północnej Polski, ale także ze Słowacji, Ukrainy, USA, Kanady.

W zachodniej Polsce corocznie odbywają się dwie kolejne „Watry” - organizowana przez Stowarzyszenie Łemków „Łemkowska Watra na Obczyźnie” w Michałowie na Dolnym Śląsku, której początki sięgają 1979 r. oraz „Łemkowska Watra” w Ługach koło Gorzowa Wielkopolskiego, organizowana od 1990 r.

\section{Białorusini}

W 1988 r., po kilku latach staran, zarejestrowano Białoruskie Zrzeszenie Studentów, które łamało monopol BTSK na oficjalne reprezentowanie spraw mniejszości białoruskiej. Rok później powstał Klub Białoruski, który początkowo miał charakter forum dyskusyjnego, skupiającego inteligencję białoruską niewidzącą możliwości współpracy z BTSK, analizującą sytuację mniejszości białoruskiej na tle przemian politycznych zachodzących na przełomie lat 80 . i 90. XX w.

Przed pierwszymi, częściowo wolnymi, wyborami do parlamentu w czerwcu 1989 r., Klub powołał Białoruski Komitet Wyborczy (BKW) i zdecydował się 
na samodzielny start $\mathrm{w}$ wyborach. Próby porozumienia między Klubem Białoruskim a „Solidarnością” nie powiodły się. Postulaty, by w jednym z okręgów na Białostocczyźnie nie wystawiać przedstawicieli Komitetu Obywatelskiego i w ten sposób umożliwić zdobycie mandatu Białorusinom, zostały zignorowane przez białostocką „Solidarność”. Bezpośrednimi konkurentami kandydatów BKW byli kandydujący z listy PZPR działacze białoruscy związani z BTSK oraz kandydaci Prawosławnego Komitetu Wyborczego (PKW) popierani przez Cerkiew. W wyborach w 1989 r. podlascy Białorusini po raz pierwszy mogli wybierać między opcją narodową reprezentowaną przez BKW, opcją religijną reprezentowaną przez PKW oraz opcją lewicową reprezentowaną przez BTSK i PZPR. Z tego ,pojedynku” zwycięsko wyszła opcja lewicowa przed narodową i religijną. Mimo że kandydaci BKW nie zdobyli żadnego mandatu, to uzyskane poparcie wyborców, wyrażające się w kilkunastu tysiącach oddanych głosów ${ }^{111}$, pozwalało optymistycznie patrzeć w przyszłość. Dlatego też członkowie Klubu Białoruskiego postanowili go rozwiązać i skupić się wyłącznie na działalności politycznej. W lutym 1990 r. powołali pierwszą po wojnie białoruską partię polityczną - Białoruskie Zjednoczenie Demokratyczne (BZD), opozycyjną do BTSK, o charakterze narodowym i liberalnym. Była to zarazem pierwsza, po upadku komunizmu, partia mniejszości narodowej w Polsce ${ }^{112}$. Program partii, poza postulatami narodowo-białoruskimi, zawierał propozycje ekonomiczne, całkowicie niezrozumiałe dla większości białoruskiego elektoratu. W wyborach samorządowych w $1990 \mathrm{r}$. BZD, poza nielicznymi wyjątkami, poniosło dotkliwą porażkę z działaczami białoruskimi związanymi z BTSK i byłą PZPR. Podobna sytuacja miała miejsce w kolejnych wyborach i w ciagu 3-4 lat partia uległa marginalizacji (Mironowicz 2010a, b).

Lewicowe sympatie prawosławnej ludności Podlasia, bardzo wyraźne w okresie władzy komunistycznej, są nadal kontynuowane w warunkach demokratycznej Polski i najpełniej znajdują wyraz w preferencjach wyborczych. Podlasie dzieli się bardzo wyraźnie na dwa obszary: zachodni - z dominacją Polaków wyznania katolickiego, o silnych tradycjach narodowych, w wolnych wyborach głosujących na opcje prawicowe, oraz wschodni - z przewagą wyznawców prawosławia, głosujących na lewicę we wszystkich kolejnych wyborach od początku lat 90. XX w. do 2011 r. Zdecydowaną większość głosów elektoratu

$111 \mathrm{Na}$ kandydata BKW do sejmu, Eugeniusza Mironowicza, głosowało 14 tys. wyborców, a na kandydata do senatu, Sokrata Janowicza - 22,5 tys. wyborców $(8,2 \%)$.

112 Bezpośrednio po II wojnie światowej, w latach 1945-1949 działało w Polsce 11 żydowskich partii politycznych, w tym trzy nielegalne. Były to jedyne partie polityczne mniejszości narodowych funkcjonujące w Polsce w latach 1945-1989 (Rykała 2007). 
prawosławnego pozyskiwał Włodzimierz Cimoszewicz, bez względu na to, czy kandydował z list SLD, czy jako „kandydat niezależny” "113. Politycy wywodzący się ze środowiska prawosławno-białoruskiego (Eugeniusz Czykwin, Jan Syczewski, Siergiej Plewa) zdobywali mandaty poselskie lub senatorskie jako kandydaci z list ugrupowań lewicowych ${ }^{114}$.

Tak duże i konsekwentne poparcie dla opcji lewicowych na wschodnim Podlasiu można tłumaczyć możliwościami awansu społecznego, politycznego i ekonomicznego stworzonymi przez władze komunistyczne dla społeczności prawosławnej, historią tego obszaru, tradycjami kulturowymi, różnicami cywilizacyjnymi, obawą przed partiami prawicowymi kojarzonymi z katolicyzmem i polskim nacjonalizmem. Z kolei zdecydowane poparcie Polaków dla konserwatywnych ugrupowań prawicowych jest wynikiem m.in. „efektu pogranicza”, wzmacniającego przywiązanie do wspólnoty narodowej oraz uwarunkowanych historycznie antykomunistycznych przekonań tutejszych katolików. Można przypuszczać, że właśnie bezpośrednie sąsiedztwo tych dwu odrębnych grup wyznaniowych wpływa na ugruntowanie podziałów politycznych i wywołuje silną polaryzację preferencji wyborczych (Kowalski 1998, 2000, Matykowski 2008, Kępka 2009).

Ten polityczno-religijny podział Podlasia został potwierdzony również wynikami referendum unijnego z czerwca 2003 r., kiedy to ponownie wyniki głosowania bardzo wyraźnie pokryły się ze strukturą wyznaniową. Obszar zamieszkany w większości przez prawosławnych był częścią Podlasia, która najwyraźniej opowiedziała się za członkostwem Polski w Unii Europejskiej (choć przy najniższej w Polsce frekwencji), z kolei w zachodniej - katolickiej części Podlasia - wiele gmin było przeciwko akcesji do UE. Można to w głównym stopniu tłumaczyć tradycyjnymi preferencjami partyjnymi - partie lewicowe bardziej opowiadały się za wstąpieniem do Unii niż prawicowe, z których część była akcesji przeciwna. Nie bez znaczenia było również wyraźne poparcie dla Unii Europejskiej wyrażone przez polskich hierarchów Kościoła prawosławnego (bardziej jednoznaczne niż episkopatu katolickiego) oraz silne wpływy

${ }^{113}$ W wyborach do senatu w 2007 r. oraz 2011 r., startując jako „kandydat niezależny", w gminach z dominacją wyznawców prawosławia zdobywał 70-90\% głosów (www.pkw.gov.pl).

114 Eugeniusz Czykwin w latach 1991-1993 zasiadał w sejmie z listy Komitetu Wyborczego Prawosławnych, w 1993 i 1997 r. bezskutecznie kandydował z list komitetów mniejszości narodowych, ponownie dostał się do sejmu w 2001 r., już jako kandydat SLD, zostając posłem tej partii także w wyborach 2005, 2007 i 2011 r. Jan Syczewski, długoletni prezes BTSK, oraz Siergiej Plewa zdobyli mandaty poselskie w 1997 r., kandydując z listy SLD. 
na zachodnim Podlasiu (zwłaszcza w dawnym województwie łomżyńskim) antyunijnego, konserwatywnego katolicyzmu.

Powszechne głosowanie przez Białorusinów na ugrupowania lewicowe, dominacja ideologii lewicowej nad tożsamością narodową, mała aktywność przekładająca się na niską frekwencję są głównymi przyczynami porażek w kolejnych wyborach i niewprowadzania swoich przedstawicieli do parlamentu przez różnego rodzaju białoruskie oraz prawosławne komitety wyborcze na Podlasiu.

Demokratyzacja życia politycznego i nierozerwalnie związana z nią wolność słowa i zrzeszania się diametralnie zmieniła sytuację Białorusinów na Podlasiu. Zlikwidowała monopol organizacyjny BTSK, stworzyła perspektywy rozwoju nie tylko kultury, ale także białoruskiej tożsamości narodowej, ożywiła działalność wydawniczą, zwiększyła ofertę wszelkiego rodzaju festiwali, przeglądów i imprez społeczno-kulturalnych, umożliwiła Białorusinom pełniejszy udział w życiu politycznym, społecznym i kulturalnym regionu. Od początku lat 90. XX w. mniejszość białoruska stała się trwałą częścią przestrzeni publicznej Podlasia.

Na początku lat 90. ubiegłego stulecia członkowie Klubu Białoruskiego byli inicjatorami powstania większości białoruskich stowarzyszeń o charakterze narodowym. W 1992 r., konsekwencją nadmiernej ingerencji władz BTSK w pracę redakcji „Niwy” było zerwanie przez dziennikarzy wszelkich związków z tą organizacją i utworzenie Rady Programowej Tygodnika „Niwa”, zrzeszającej przedstawicieli nowo powstających stowarzyszeń. W 1993 r. naukowcy białoruscy powołali Białoruskie Towarzystwo Historyczne. W tym samym roku powstał Związek Białoruski w RP, który jednoczył w formie luźnej federacji utworzone w warunkach demokratycznej Polski białoruskie organizacje narodowe zrzeszające głównie inteligencję, kładące nacisk na rozbudzenie tożsamości narodowej, kultywowanie języka i kultury białoruskiej. W skład Związku na zasadzie autonomicznej weszło Białoruskie Zjednoczenie Demokratyczne, Białoruskie Stowarzyszenie Literackie „Białowieża”, Stowarzyszenie Dziennikarzy Białoruskich, Białoruskie Zrzeszenie Studentów, Związek Młodzieży Białoruskiej oraz Rada Programowa Tygodnika „Niwa”. Stowarzyszenia te, z powodu niewielkiej aktywności Białorusinów przy jednocześnie bardzo silnym rozdrobnieniu organizacyjnym, liczą zaledwie od kilkunastu do kilkudziesięciu członków, nie posiadają struktur terenowych, działają głównie w Białymstoku, a ich aktywność organizacyjna niejednokrotnie ogranicza się do epizodycznych inicjatyw (tab. 8 , ryc. 15). 
Tabela 8. Białoruskie organizacje zarejestrowane w Polsce (stan w 2012 r.)

\begin{tabular}{|c|c|c|}
\hline $\begin{array}{c}\text { Nazwa, główna siedziba, liczba } \\
\text { oddziałów terenowych, liczba } \\
\text { członków }\end{array}$ & $\begin{array}{c}\text { Rok } \\
\text { założenia }\end{array}$ & Charakterystyka działalności \\
\hline $\begin{array}{l}\text { Białoruskie Towarzystwo } \\
\text { Społeczno-Kulturalne } \\
\text { Białystok, } 8 \text { kół terenowych, } \\
\text { ok. } 4000 \text { członków }\end{array}$ & 1956 & $\begin{array}{l}\text { od kilkudziesięciu lat największa organizacja } \\
\text { reprezentująca mniejszość białoruską w Polsce, } \\
\text { od powstania utrzymująca wyraźnie lewicowy } \\
\text { charakter, współpracująca z lewicowymi } \\
\text { organizacjami politycznymi, także podczas } \\
\text { wyborów parlamentarnych; działalność } \\
\text { kulturalno-oświatowa, wspieranie białoruskiego } \\
\text { szkolnictwa oraz kilkudziesięciu amatorskich } \\
\text { białoruskich zespołów folklorystycznych, } \\
\text { organizowanie licznych festynów ludowych, } \\
\text { konkursów recytatorskich i teatralnych, } \\
\text { przeglądów piosenek, festiwali, m.in. „Święta } \\
\text { Kupały” w Białowieży, festiwalu „Dialogi } \\
\text { Muzyczne” w Mielniku, festiwalu „Piosenka } \\
\text { Białoruska” w Białymstoku, ,Święta Kultury } \\
\text { Białoruskiej”, plenerowych spotkań artysty- } \\
\text { cznych „Biesiada Przyjacielska” w Gródku, } \\
\text { łącznie BTSK organizuje i współorganizuje na } \\
\text { Podlasiu ok. 60-70 imprez kulturalnych rocznie, } \\
\text { organizuje także występy zespołów z Białorusi, } \\
\text { współpracuje z władzami Republiki Białorusi, } \\
\text { od } 1993 \text { r. organizuje wspólnie ze Związkiem } \\
\text { Polaków na Białorusi coroczne konferencje } \\
\text { naukowe „Droga ku wzajemności” oraz } \\
\text { Spotkania Artystyczne Białystok-Grodno }\end{array}$ \\
\hline $\begin{array}{l}\text { Stowarzyszenie „Muzeum } \\
\text { i Ośrodek Kultury Białoruskiej” } \\
\text { Hajnówka, brak oddziałów, } \\
\text { ok. } 100 \text { członków }\end{array}$ & 1984 & $\begin{array}{l}\text { powołane w celu budowy i prowadzenia } \\
\text { „Muzeum i Ośrodka Kultury Białoruskiej” } \\
\text { w Hajnówce, głównym celem stowarzyszenia } \\
\text { jest zachowanie dziedzictwa kulturowego } \\
\text { Białorusinów oraz inicjowanie i upowszech- } \\
\text { nianie szeroko pojętej działalności kulturalno- } \\
\text {-oświatowej białoruskiej mniejszości narodowej } \\
\text { w Polsce, prowadzi Muzeum Kultury Biało- } \\
\text { ruskiej w Hajnówce, biblioteke, organizuje } \\
\text { wystawy, seminaria i konferencje }\end{array}$ \\
\hline $\begin{array}{l}\text { Białoruskie Zrzeszenie } \\
\text { Studentów } \\
\text { Białystok, } 3 \text { koła terenowe }\end{array}$ & 1988 & $\begin{array}{l}\text { zrzesza studentów narodowości białoruskiej, } \\
\text { działa głównie w białoruskim środowisku } \\
\text { akademickim, promuje kulturę białoruska, } \\
\text { organizuje imprezy skierowane do młodzieży, } \\
\text { m.in. rockowy Festiwal Muzyki Młodej } \\
\text { Białorusi „Basowiszcza”, prowadzi działalność } \\
\text { wydawniczą }\end{array}$ \\
\hline $\begin{array}{l}\text { Białoruskie Zjednoczenie } \\
\text { Demokratyczne } \\
\text { Białystok, brak oddziałów }\end{array}$ & 1990 & $\begin{array}{l}\text { partia polityczna o charakterze narodowo- } \\
\text {-białoruskim, opozycyjna wobec BTSK, } \\
\text { głównym celem jest ochrona praw narodowych, }\end{array}$ \\
\hline
\end{tabular}




\begin{tabular}{|c|c|c|}
\hline & & $\begin{array}{l}\text { językowych i kulturowych mniejszości } \\
\text { białoruskiej w Polsce oraz wprowadzenie } \\
\text { dwujęzycznych nazw miejscowości, bez } \\
\text { sukcesów w wyborach parlamentarnych, } \\
\text { w ostatnich latach zawiesiła działalność }\end{array}$ \\
\hline $\begin{array}{l}\text { Białoruskie Stowarzyszenie } \\
\text { Literackie „Białowieża” } \\
\text { Białystok, brak oddziałów, } \\
25 \text { członków }\end{array}$ & 1990 & $\begin{array}{l}\text { działalność kulturalna, propagowanie literatury } \\
\text { białoruskiej, wydawanie książek, opowiadań, } \\
\text { wierszy białoruskich pisarzy i poetów, } \\
\text { wydawanie rocznika „Termapiły” w nakładzie } \\
\text { 200-250 egzemplarzy }\end{array}$ \\
\hline $\begin{array}{l}\text { Związek Młodzieży Białoruskiej } \\
\text { Szczyty-Dzięciołowo, gmina } \\
\text { Orla, brak oddziałów, } \\
15 \text { członków }\end{array}$ & 1991 & $\begin{array}{l}\text { działalność kulturalno-oświatowa, propagowanie } \\
\text { białoruskiej kultury i podtrzymanie tożsamości } \\
\text { narodowej wśród młodzieży, organizowanie } \\
\text { festiwali białoruskiej poezji i piosenki, folkowo- } \\
\text {-rockowego festiwalu „,Kupalle”, rajdów } \\
\text { pieszych, turnieju młodzieży białoruskiej } \\
\text { „Turnir”, „Zimowych Spotkań Muzycznych”, } \\
\text { „Jesieni Bardów”, prowadzenie internetowej } \\
\text { bazy danych o Białorusi i Białorusinach, współ- } \\
\text { praca z Klubem Spraw Polsko-Białoruskich przy } \\
\text { II LO w Bielsku Podlaskim }\end{array}$ \\
\hline $\begin{array}{l}\text { Rada Programowa Tygodnika } \\
\text { „Niwa” } \\
\text { Białystok, brak oddziałów, } \\
15 \text { członków }\end{array}$ & 1992 & $\begin{array}{l}\text { działalność wydawnicza, wydaje tygodnik } \\
\text { „Niwa”, najważniejsze białoruskie czasopismo } \\
\text { w Polsce (obecnie z powodów politycznych } \\
\text { zakazane na Białorusi) w nakładzie ok. } 2 \text { tys. } \\
\text { egzemplarzy, ponadto wydaje książki, } \\
\text { opowiadania i wiersze białoruskich pisarzy } \\
\text { i poetów; głównymi celami jest wspieranie } \\
\text { białoruskiej tożsamości, kultury, języka, } \\
\text { opisywanie spraw dotyczących Białorusinów } \\
\text { na Białostocczyźnie }\end{array}$ \\
\hline $\begin{array}{l}\text { Stowarzyszenie Dziennikarzy } \\
\text { Białoruskich } \\
\text { Białystok, brak oddziałów, } \\
30 \text { członków }\end{array}$ & 1992 & $\begin{array}{l}\text { działalność wydawnicza, oświatowa, edukacyj- } \\
\text { na, propagowanie białoruskiej kultury i historii, } \\
\text { wydaje białoruskie pismo społeczno-kulturalne } \\
\text { „Czasopis”, miesięcznik poświęcony tematyce } \\
\text { kultury, sztuki, historii, ale także współczesnej } \\
\text { sytuacji mniejszości białoruskiej w Polsce }\end{array}$ \\
\hline $\begin{array}{l}\text { Związek Białoruski } \\
\text { w Rzeczypospolitej Polskiej } \\
\text { Białystok, brak oddziałów }\end{array}$ & 1993 & $\begin{array}{l}\text { organizacja jednocząca białoruskie ugrupowania } \\
\text { o charakterze narodowym, opozycyjna wobec } \\
\text { BTSK, zrzeszająca głównie inteligencję } \\
\text { białoruską, podstawowe cele to rozbudzenie } \\
\text { i utrzymanie białoruskiej tożsamości narodowej, } \\
\text { kultywowanie języka i kultury białoruskiej; } \\
\text { w skład Związu wchodzą działające } \\
\text { autonomicznie: Białoruskie Stowarzyszenie } \\
\text { Literackie „Białowieża”, Białoruskie } \\
\text { Towarzystwo Historyczne, Stowarzyszenie } \\
\text { Dziennikarzy Białoruskich, Rada Programowa } \\
\text { Tygodnika „Niwa”, Białoruskie Zrzeszenie } \\
\text { Studentów oraz Towarzystwo „Chatka” }\end{array}$ \\
\hline
\end{tabular}




\begin{tabular}{|c|c|c|}
\hline $\begin{array}{l}\text { Białoruskie Towarzystwo } \\
\text { Historyczne } \\
\text { Białystok, brak oddziałów }\end{array}$ & 1993 & $\begin{array}{l}\text { działalność naukowa i wydawnicza, } \\
\text { propagowanie wiedzy historycznej o Białorusi } \\
\text { i Białorusinach, ich tradycjach narodowych, } \\
\text { społecznych, kulturowych, organizuje seminaria } \\
\text { i konferencje naukowe dotyczące historii } \\
\text { politycznej, społecznej, gospodarczej Białorusi } \\
\text { oraz dziejów Białorusinów, szczególnie zajmuje } \\
\text { się obszarem pogranicza polsko-białoruskiego, } \\
\text { wydaje w cyklu półrocznym „Białoruskie } \\
\text { Zeszyty Historyczne” }\end{array}$ \\
\hline $\begin{array}{l}\text { Białoruskie Towarzystwo } \\
\text { Kulturalne „Chatka” } \\
\text { Sopot, brak oddziałów, } \\
21 \text { członków }\end{array}$ & 1993 & $\begin{array}{l}\text { dążenie do zachowania tożsamości narodowej } \\
\text { i kulturowej Białorusinów; organizowanie } \\
\text { i inspirowanie rozwoju białoruskiej twórczości } \\
\text { artystycznej, naukowej, oświatowej, literackiej } \\
\text { i wydawniczej; organizowanie współpracy } \\
\text { kulturalnej, turystycznej i naukowej z Republiką } \\
\text { Białorusi, wizyt młodzieży białoruskiej } \\
\text { w Trójmieście i na Kaszubach oraz wydarzeń } \\
\text { kulturalnych i obchodów świąt białoruskich }\end{array}$ \\
\hline $\begin{array}{l}\text { Stowarzyszenie Villa Sokrates } \\
\text { Krynki, brak oddziałów }\end{array}$ & 1999 & $\begin{array}{l}\text { propagowanie kultury białoruskiej, a zwłaszcza } \\
\text { literatury, prowadzenie działalności } \\
\text { wydawniczej (m.in. wydaje rocznik ,Annus } \\
\text { Alaruthennus”), organizowanie konferencji } \\
\text { naukowych dotyczących kultury i historii } \\
\text { Białorusi oraz pogranicza polsko-białoruskiego, } \\
\text { związków kultury białoruskiej i polskiej, } \\
\text { w Łapiczach koło Krynek organizuje coroczne } \\
\text { spotkania intelektualistów z Polski oraz krajów } \\
\text { Europy Zachodniej, Wschodniej i Ameryki } \\
\text { Północnej, czołową postacią stowarzyszenia jest } \\
\text { białoruski pisarz Sokrat Janowicz }\end{array}$ \\
\hline $\begin{array}{l}\text { Białoruskie Forum Samorządowe } \\
\text { w Rzeczypospolitej Polskiej } \\
\text { Hajnówka, brak oddziałów, } \\
20 \text { członków }\end{array}$ & 2002 & $\begin{array}{l}\text { edukacja samorządowa, prowadzenie szkoleń } \\
\text { i warsztatów dla samorządowców z Podlasia } \\
\text { oraz z Białorusi, współpraca radnych biało- } \\
\text { ruskich z poszczególnych gmin Białostocczyzny, } \\
\text { reprezentowanie mniejszości białoruskiej na } \\
\text { forum publicznym w Polsce oraz wobec } \\
\text { administracji rządowej, samorządowej i innych } \\
\text { instytucji }\end{array}$ \\
\hline $\begin{array}{l}\text { Białoruskie Kulturalno-Naukowe } \\
\text { Centrum w Poznaniu } \\
\text { Kostrzyn Wielkopolski, brak } \\
\text { oddziałów, } 50 \text { członków }\end{array}$ & 2003 & $\begin{array}{l}\text { organizowanie Dni Kultury Białoruskiej } \\
\text { w Poznaniu, wydawanie książek pisarzy } \\
\text { białoruskich oraz thumaczenia literatury } \\
\text { na język białoruski }\end{array}$ \\
\hline $\begin{array}{l}\text { Białoruskie Towarzystwo } \\
\text { Oświatowe } \\
\text { Białystok, brak oddziałów }\end{array}$ & 2003 & $\begin{array}{l}\text { działalność oświatowa i edukacyjna, wspieranie } \\
\text { białoruskiej oświaty, organizowanie kursów } \\
\text { i konferencji dla nauczycieli szkół z białoruskim } \\
\text { językiem nauczania oraz konkursów i festiwali } \\
\text { dla uczniów uczących się języka białoruskiego }\end{array}$ \\
\hline
\end{tabular}




\begin{tabular}{|c|c|c|}
\hline $\begin{array}{l}\text { Towarzystwo Kultury } \\
\text { Białoruskiej } \\
\text { Białystok, brak oddziałów, } \\
32 \text { członków }\end{array}$ & 2006 & $\begin{array}{l}\text { popularyzowanie kultury białoruskiej, } \\
\text { organizowanie Święta Kultury Białoruskiej, } \\
\text { Ogólnopolskiego Festiwalu „Piosenka } \\
\text { Białoruska”, wspieranie i patronat nad } \\
\text { białoruskimi zespołami folklorystycznymi, } \\
\text { organizowanie obchodów świát ludowych, } \\
\text { konkursów szkolnych zespołów teatralnych, } \\
\text { prezentacji zespołów kolędniczych „Gwiazda } \\
\text { i Kolęda”, wydawanie „Kalendarza Białoruskie- } \\
\text { go” w nakładzie } 1000 \text { egzemplarzy }\end{array}$ \\
\hline $\begin{array}{l}\text { Stowarzyszenie na Rzecz Dzieci } \\
\text { i Młodzieży Uczących się Języka } \\
\text { Białoruskiego „AB-BA” } \\
\text { Białystok, brak oddziałów }\end{array}$ & 2006 & $\begin{array}{l}\text { działalność edukacyjna i oświatowa, głównym } \\
\text { celem jest pomoc merytoryczna, naukowa, } \\
\text { finansowa i rzeczowa dzieciom i młodzieży } \\
\text { uczącym się języka białoruskiego, } \\
\text { organizowanie konkursów szkolnych, występów } \\
\text { artystycznych młodzieży uczącej się języka } \\
\text { białoruskiego }\end{array}$ \\
\hline
\end{tabular}

Źródło: opracowanie własne.

W okresie PRL Białorusini byli postrzegani jako najbardziej lewicowa mniejszość narodowa w Polsce. Mimo to - a może właśnie dlatego - wśród tej społeczności nastąpiły pierwsze udane próby łamania narzuconego przez władze komunistyczne monopolu organizacyjnego. Białorusini jako pierwsza mniejszość narodowa zarejestrowali opozycyjną partię polityczną na Podlasiu na początku lat 90. XX w. Powstało też najwięcej stowarzyszeń o charakterze narodowym. Z kolei BTSK, jako jedyna organizacja narodowościowa wywodząca się z PRL, po 1990 r. nie zmieniła nazwy ani profilu ideologicznego, a nowo powstałe stowarzyszenia nie uzyskały szerszego poparcia wśród społeczności białoruskiej, ich działalność ogranicza się najczęściej do nielicznych środowisk miejskich, inteligenckich, studenckich.

Nadal zdecydowanie dominującą organizacją mniejszości białoruskiej, mimo tendencji do stopniowego zmniejszania się liczby członków, jest BTSK. Tak jak w okresie PRL, tak i obecnie organizacja ta zajmuje się głównie dbaniem o białoruski folklor i kulturę ludową. Funkcjonuje jednak w zupełnie innych realiach ekonomicznych i organizacyjnych. Przed 1990 r. BTSK miało kilkadziesiąt kół terenowych i 27 etatów działaczy kultury. Obecnie, głównie w wyniku depopulacji podlaskich wsi i likwidacji większości wiejskich szkół, koła terenowe funkcjonują tylko $\mathrm{w}$ miastach powiatowych, organizacja nie ma też żadnego etatowego pracownika. Głównymi postulatami zgłaszanymi przez działaczy BTSK jest merytoryczna opieka władz centralnych i wojewódzkich nad kultura, powołanie utrzymywanej z budżetu państwa Instytucji Kultury Białoruskiej, zdecydowane zwiększenie finansowania białoruskiej działalności kultu- 
ralnej, łącznie z etatami dla pracowników. Brak ekonomicznego zabezpieczenia działalności jest zasadniczym punktem spornym $\mathrm{w}$ relacjach między BTSK a władzami centralnymi i lokalnymi, według działaczy BTSK, organizacja jest wręcz dyskryminowana finansowo z powodu jej lewicowego charakteru i dobrych relacji z rządem Białorusi. Od 2005 r. BTSK otrzymuje coraz mniejsze dotacje, a zdecydowanie większe sumy są przeznaczane na działalność Telewizji Biełsat i Radia Racja, nadających z Białegostoku. Mimo to BTSK jest najaktywniejszą i najbardziej rozpoznawalną na Podlasiu organizacją białoruską. Pozostałe białoruskie stowarzyszenia - zróżnicowane, pluralistyczne, ale mało liczebne i często o marginalnym znaczeniu - mają z reguły charakter narodowo-białoruski, propagują białoruską kulturę, historię i tożsamość, prowadzą działalność wydawnicza, dbają o zachowanie języka białoruskiego i rozwój białoruskiej oświaty, negatywnie oceniają obecne władze Białorusi, wspierają białoruską opozycję i tamtejsze organizacje pozarządowe, współpracują z Radiem Racja i Telewizją Biełsat. Większość tych organizacji powstała na początku lat 90. XX w. jako antyteza BTSK i mimo upływu 20 lat nadal utrzymują się między nimi bardzo silne antagonizmy. Nie ma praktycznie żadnej współpracy, dominuje wzajemna nieufność i niechęć. Głównymi punktami spornymi są kwestie ideologiczne oraz całkowicie odmienny stosunek do władz Republiki Białorusi i sytuacji politycznej na Białorusi ${ }^{115}$.

Obok dwóch, wyraźnie antagonistycznych, środowisk białoruskich organizacji i działaczy funkcjonujących wokół BTSK oraz Związku Białoruskiego RP, wśród podlaskich Białorusinów funkcjonuje jeszcze jedno, skupione wokół Bractwa Prawosławnego i „Przeglądu Prawosławnego”, reprezentowane przez posła Eugeniusza Czykwina. Nie akcentuje białoruskiej odrębności narodowej, natomiast podkreśla tożsamość prawosławną lub szerzej słowiańska, jest blisko związane z politycznymi ugrupowaniami lewicowymi.

Struktura przestrzenna organizacji białoruskich jest zgodna z rozmieszczeniem Białorusinów, aż 15 z 17 białoruskich organizacji ma swoje główne siedziby na Podlasiu, w tym 11 w Białymstoku (ryc. 15). Tak duża koncentracja teoretycznie powinna być elementem ułatwiającym rozwój działalności organizacyjnej, politycznej, społecznej i kulturalnej, jednak głównymi czynnikami skutecznie ją hamującymi jest mała aktywność mniejszości białoruskiej, postępująca asymilacja oraz skonfliktowanie i brak współpracy między największą organizacją a szeregiem pozostałych.

${ }^{115} \mathrm{Na}$ podstawie wywiadów przeprowadzonych przez autora w 2012 r. z działaczami BTSK, Rady Programowej Tygodnika Niwa, Białoruskiego Zrzeszenia Studentów. 


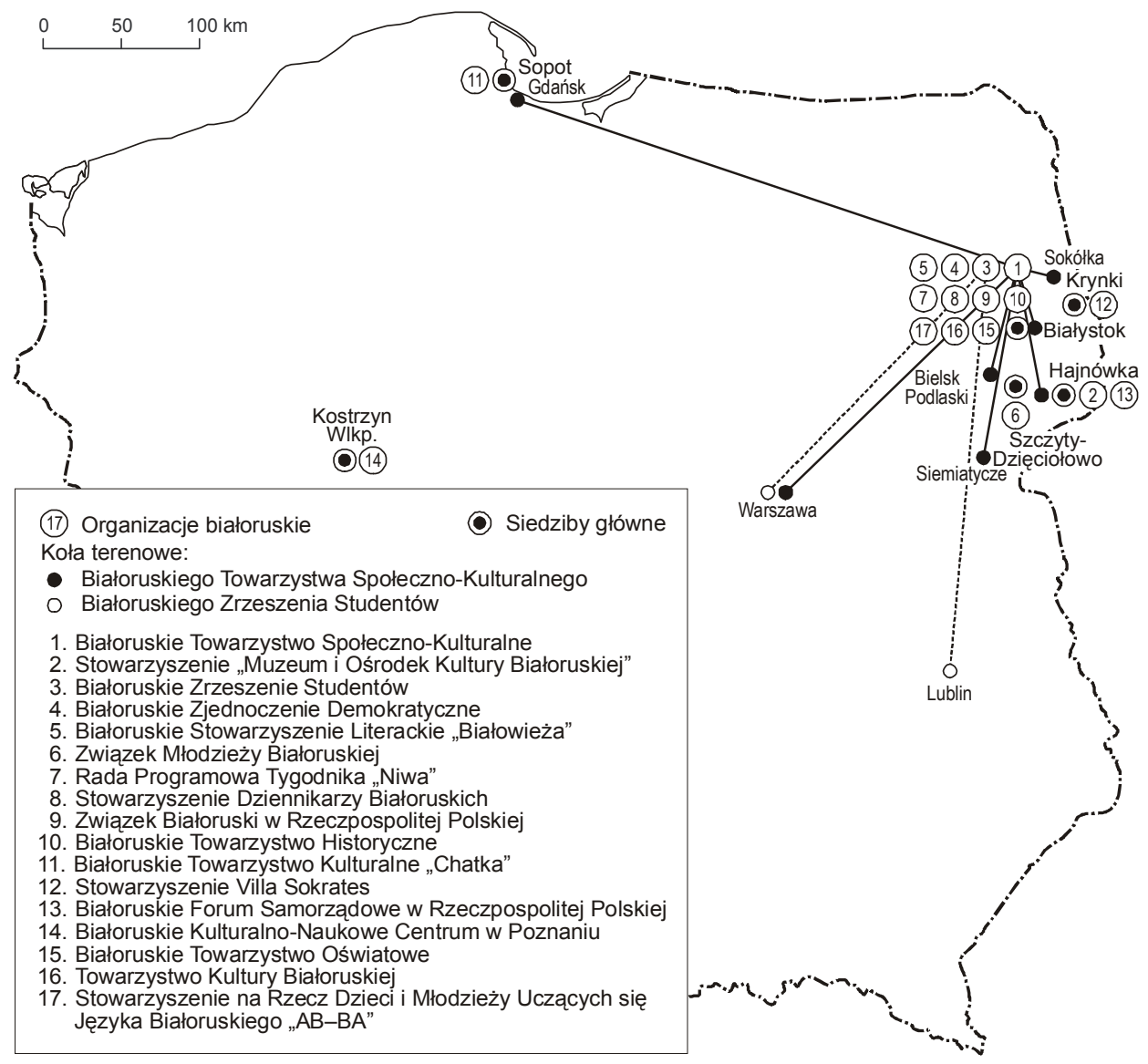

Ryc. 15. Struktura przestrzenna organizacji białoruskich w 2012 r.

Źródło: opracowanie własne

Pesymistycznie, ale jednocześnie trafnie, podsumowuje aktualną sytuację społeczno-kulturalną mniejszości białoruskiej E. Mironowicz (2010b): „Na początku nowego stulecia znacznie zmniejszyła się aktywność białoruskich organizacji. Błyskawicznie postępująca asymilacja spowodowała kurczenie się bazy społecznej, co w konsekwencji zawężało krąg osób potencjalnie zainteresowanych odbiorem wartości przekazywanych za pośrednictwem białoruskiego słowa drukowanego, mówionego czy śpiewanego [...]. Formalnie nic się nie zmieniło w ostatnich latach - pozostały wszystkie organizacje, wydawane są pisma, organizowane imprezy kulturalne, lecz mocno zawęził się krąg osób zaangażowanych w podtrzymywanie białoruskiego życia narodowego w Polsce. Wobec gwałtowanie postępującej asymilacji ludności białoruskiej wśród działaczy zanika także wiara w sens podejmowanych przez nich działań”. 


\section{Litwini}

Pierwszą organizacją, która łamała kilkudziesięcioletni monopol Litewskiego Towarzystwa Społeczno-Kulturalnego (LTSK), było reaktywowane w 1990 r. Litewskie Towarzystwo Św. Kazimierza, bezpośrednio nawiązujące do organizacji działającej w II Rzeczypospolitej. Istniejące od połowy lat 50. XX w. LTSK, na początku lat 90 . uniezależniło się od nadzoru politycznego i zmieniło charakter działalności na bardziej narodowy. Mimo wieloletniego uwikłania w realia organizacyjne systemu komunistycznego, LTSK było organizacją, która skutecznie chroniła niewielkie skupisko Litwinów przed wynarodowieniem, dbało nie tylko o rozwój działalności oświatowej i kulturalnej, ale także o podtrzymanie litewskiej tożsamości narodowej. Pozytywnie wyróżniało się na tle innych, funkcjonujących w okresie PRL, narodowościowych organizacji „społeczno-kulturalnych”. W 1992 r. LTSK, zgodnie z „duchem czasów”, przekształciło się w Stowarzyszenie Litwinów w Polsce (SLwP), które jest współcześnie najliczniejszą organizacją mniejszości litewskiej w Polsce.

Interesy mniejszości litewskiej reprezentuje obecnie siedem organizacji pozarządowych ${ }^{116}$, wszystkie o charakterze narodowym (tab. 9). Poza dwoma najstarszymi organizacjami, pozostałe mają niewielką liczbę członków i nie posiadają struktur terenowych. Szczególną pozycję wśród litewskich organizacji zajmuje Wspólnota Litwinów w Polsce, która koordynuje ich działalność, a zwłaszcza reprezentuje społeczność polskich Litwinów na zewnątrz, zarówno wobec władz w Warszawie, jak i poza granicami Polski. Cele i działalność poszczególnych organizacji są bardzo zbliżone. Najogólniej można stwierdzić, iż podstawowym celem wszystkich stowarzyszeń jest utrzymanie litewskiej tożsamości narodowej poprzez rozwój oświaty i życia kulturalnego. Podstawowym postulatem wobec władz państwowych i samorządowych jest zwiększenie finansowania litewskiego szkolnictwa, kwestie oświatowe są priorytetem dla litewskich organizacji. Działacze litewscy podkreślają bardzo dobre relacje z władzami w Puńsku (co jest całkowicie zrozumiałe, gdyż są one zdominowane przez Litwinów), przeciwstawiając je bardzo złym - ich zdaniem - relacjom w Sejnach, gdzie lokalne władze są niechętne wobec litewskich postulatów, zwłaszcza dotyczących zwiększenia finansowania szkół litewskich, ponadto stosują ,politykę faktów dokonanych” w kwestii upamiętnień, pomników, zmian nazw ulic. Punktem spornym wzbudzającym największe emocje jest cmentarz

${ }^{116}$ W 2010 r. rozwiązano dwie, działające od końca lat 90. XX w., litewskie organizacje - Towarzystwo Litewskie w Gdańsku oraz Fundację Wspierania Oświaty i Kultury Litewskiej „Seina”. 
w Berżnikach koło Sejn i znajdujące się tam pomniki ${ }^{117}$. Do głównych sukcesów działacze litewscy zaliczają utrzymanie imprez kulturalnych mimo trudności z ich finansowaniem, ochronę litewskiego dziedzictwa na Suwalszczyźnie, aktywność wydawniczą oraz otwarcie Zespołu Szkół z Litewskim Językiem Nauczania „Žiburys” w Sejnach. W kategorii porażki postrzegają likwidację, w ciagu ostatnich 10 lat, wielu małych, wiejskich szkół. Mimo relatywnie dużej liczby litewskich organizacji, zbliżonych celów i koncentracji na niewielkim obszarze, nie stanowią one dla siebie konkurencji, z reguły bezkonfliktowo współpracuja, co nie jest typowe dla innych mniejszości narodowych w Polsce $\mathrm{i}$ istotnie wzmacnia pozycję Litwinów ${ }^{118}$.

Tabela 9. Litewskie organizacje zarejestrowane w Polsce (stan w 2012 r.)

\begin{tabular}{|c|c|c|}
\hline $\begin{array}{c}\text { Nazwa, główna siedziba, liczba } \\
\text { oddziałów terenowych, liczba } \\
\text { członków }\end{array}$ & $\begin{array}{c}\text { Rok } \\
\text { założenia }\end{array}$ & Charakterystyka działalności \\
\hline $\begin{array}{l}\text { Litewskie Towarzystwo } \\
\text { Św. Kazimierza } \\
\text { Sejny, } 13 \text { oddziałów, } \\
486 \text { członków }\end{array}$ & 1990 & $\begin{array}{l}\text { kontynuuje tradycje organizacji z okresu między- } \\
\text { wojennego, podkreśla swój katolicki charakter, } \\
\text { współpracuje z Kościołem, dba o rozwój litewskiej } \\
\text { oświaty, propagowanie kultury i tradycji ludowej } \\
\text { mniejszości litewskiej, wydaje kwartalnik } \\
\text { „Śaltinis” w nakładzie } 600 \text { egzemplarzy }\end{array}$ \\
\hline $\begin{array}{l}\text { Stowarzyszenie Litwinów } \\
\text { w Polsce } \\
\text { Sejny, } 46 \text { oddziałów, } \\
\text { ok. } 1 \text { tys. członków }\end{array}$ & 1992 & $\begin{array}{l}\text { główna organizacja reprezentująca interesy } \\
\text { mniejszości litewskiej w Polsce (dawne LTSK); } \\
\text { podstawowe cele to reprezentowanie i obrona praw } \\
\text { ludności litewskiej, utrzymanie litewskiej } \\
\text { tożsamości narodowej, ochrona i rozwój litewskiej } \\
\text { kultury i folkloru, wspieranie litewskiego } \\
\text { szkolnictwa i działalności społecznej, kulturalnej } \\
\text { i oświatowej, wydaje dwutygodnik „Aušra” } \\
\text { w nakładzie 1000 egzemplarzy, organizuje } \\
\text { festiwale, m.in. Festiwal Teatrów Stodolanych, } \\
\text { Festiwal Teatrów Dziecięcych, zlot zespołów } \\
\text { „Saskrydis”, liczne konkury, m.in. recytatorskie, } \\
\text { języka litewskiego, historii i geografii Litwy }\end{array}$ \\
\hline
\end{tabular}

${ }^{117} \mathrm{Na}$ cmentarzu w Berżnikach znajdują się m.in. groby żołnierzy polskich poległych w powstaniu sejneńskim i bitwie niemeńskiej w 1920 r. oraz groby żołnierzy litewskich poległych w walkach z Polakami w 1920 r. Groby litewskie odnowiono w 2005 r. Zaraz po ich odnowieniu ustawiono obok „krzyż ponarski”, upamiętniający Polaków pomordowanych przez Niemców i Litwinów na Wileńszczyźnie w latach 1941-1944. Litwini uważają, że „krzyż ponarski” nie ma nic wspólnego z historią Suwalszczyzny oraz tutejszymi relacjami polsko-litewskimi, fałszuje lokalną historię i antagonizuje mieszkańców.

${ }^{118}$ Na podstawie wywiadów przeprowadzonych przez autora w 2012 r. z działaczami Stowarzyszenia Litwinów w Polsce oraz Litewskiego Towarzystwa Św. Kazimierza. 


\begin{tabular}{|c|c|c|}
\hline $\begin{array}{l}\text { Wspólnota Litwinów w Polsce } \\
\text { Puńsk, brak oddziałów }\end{array}$ & 1993 & $\begin{array}{l}\text { zrzesza różne litewskie organizacje, koordynuje } \\
\text { ich działalność, reprezentuje głównie interesy } \\
\text { polityczne, a także społeczne, kulturalne i gospo- } \\
\text { darcze Litwinów w stosunkach z polskimi władza- } \\
\text { mi samorządowymi i centralnymi, skonfederowana } \\
\text { ze Światową Wspólnotą Litwinów z USA }\end{array}$ \\
\hline $\begin{array}{l}\text { Stowarzyszenie Młodzieży } \\
\text { Litewskiej w Polsce } \\
\text { Puńsk, brak oddziałów }\end{array}$ & 1994 & $\begin{array}{l}\text { propagowanie litewskiej kultury i podtrzymanie } \\
\text { tożsamości narodowej wśród młodzieży, } \\
\text { organizowanie festiwali i koncertów litewskich, } \\
\text { spotkań młodzieży litewskiej, członek Światowego } \\
\text { Związku Młodzieży Litewskiej }\end{array}$ \\
\hline $\begin{array}{l}\text { Stowarzyszenie Litewskiej } \\
\text { Kultury Etnicznej w Polsce } \\
\text { Puńsk, brak oddziałów, } \\
120 \text { członków }\end{array}$ & 1997 & $\begin{array}{l}\text { popularyzowanie litewskiej kultury etnicznej oraz } \\
\text { kultury pogranicza polsko-litewskiego, ochrona } \\
\text { dziedzictwa kulturowego Suwalszczyzny, wspiera- } \\
\text { nie i patronat nad litewskimi zespołami etnografi- } \\
\text { cznymi i folklorystycznymi („Gimtině”, ,Alna”, } \\
\text { „Šalcinukas”), prowadzenie muzeum „Stara } \\
\text { Plebania”, współpraca z twórcami ludowymi, } \\
\text { organizowanie obchodów świąt kalendarzowych } \\
\text { i ludowych oraz wystaw, odczytów, konkursów }\end{array}$ \\
\hline $\begin{array}{l}\text { Stowarzyszenie Nauczycieli } \\
\text { Litwinów w Polsce } \\
\text { Puńsk, brak oddziałów, } \\
60 \text { członków }\end{array}$ & 1999 & $\begin{array}{l}\text { wspieranie litewskiej oświaty, organizowanie } \\
\text { konferencji i szkoleń dla nauczycieli szkół } \\
\text { z litewskim językiem nauczania oraz konkursów } \\
\text { dla uczniów szkół z litewskim językiem nauczania }\end{array}$ \\
\hline $\begin{array}{l}\text { Fundacja im. biskupa Antanasa } \\
\text { Baranauskasa „Dom Litewski” } \\
\text { w Sejnach } \\
\text { Sejny, brak oddziałów }\end{array}$ & 2002 & $\begin{array}{l}\text { działalność kulturalna i oświatowa, prowadzenie } \\
\text { „Domu Litewskiego” w Sejnach, prowadzenie } \\
\text { w Sejnach niepublicznego przedszkola, szkoły } \\
\text { podstawowej oraz gimnazjum z litewskim } \\
\text { językiem nauczania, wspieranie mniejszości } \\
\text { litewskiej, organizowanie koncertów, festiwali, } \\
\text { konkursów, konferencji }\end{array}$ \\
\hline
\end{tabular}

Źródło: opracowanie własne.

Po 1990 r. nastąpił także rozwój wydawnictw w języku litewskim. Czasopismo „Aušra”, wydawane wcześniej bardzo nieregularnie, od 1990 r. ukazuje się jako miesięcznik, a od 1992 r. jako dwutygodnik. Od tego samego roku jest wydawane pismo suwalskich Litwinów, kwartalnik „Suvalkietis”, a od 2005 r. Towarzystwo Św. Kazimierza wydaje kwartalnik „Šaltinis”. Z kolei od 1997 r. ukazuje się miesięcznik dla dzieci „Aušrelë”, kolportowany głównie w przedszkolach i szkołach. Wszystkie czasopisma, poza kwartalnikiem „Suvalkietis”, składa i drukuje, działające od 1993 r. w Puńsku, wydawnictwo „Aušra”, które wydaje także książki i podręczniki w języku litewskim. Od początku lat 90. XX w. drukiem wydawnictwa „Aušra” ukazało się ok. 80 tytułów książek (średnio w nakładzie od 300 do 1 tys. egzemplarzy) i broszur, poświęconych głównie tematyce etnograficznej, historii, literaturze pięknej i wspomnieniowej. 

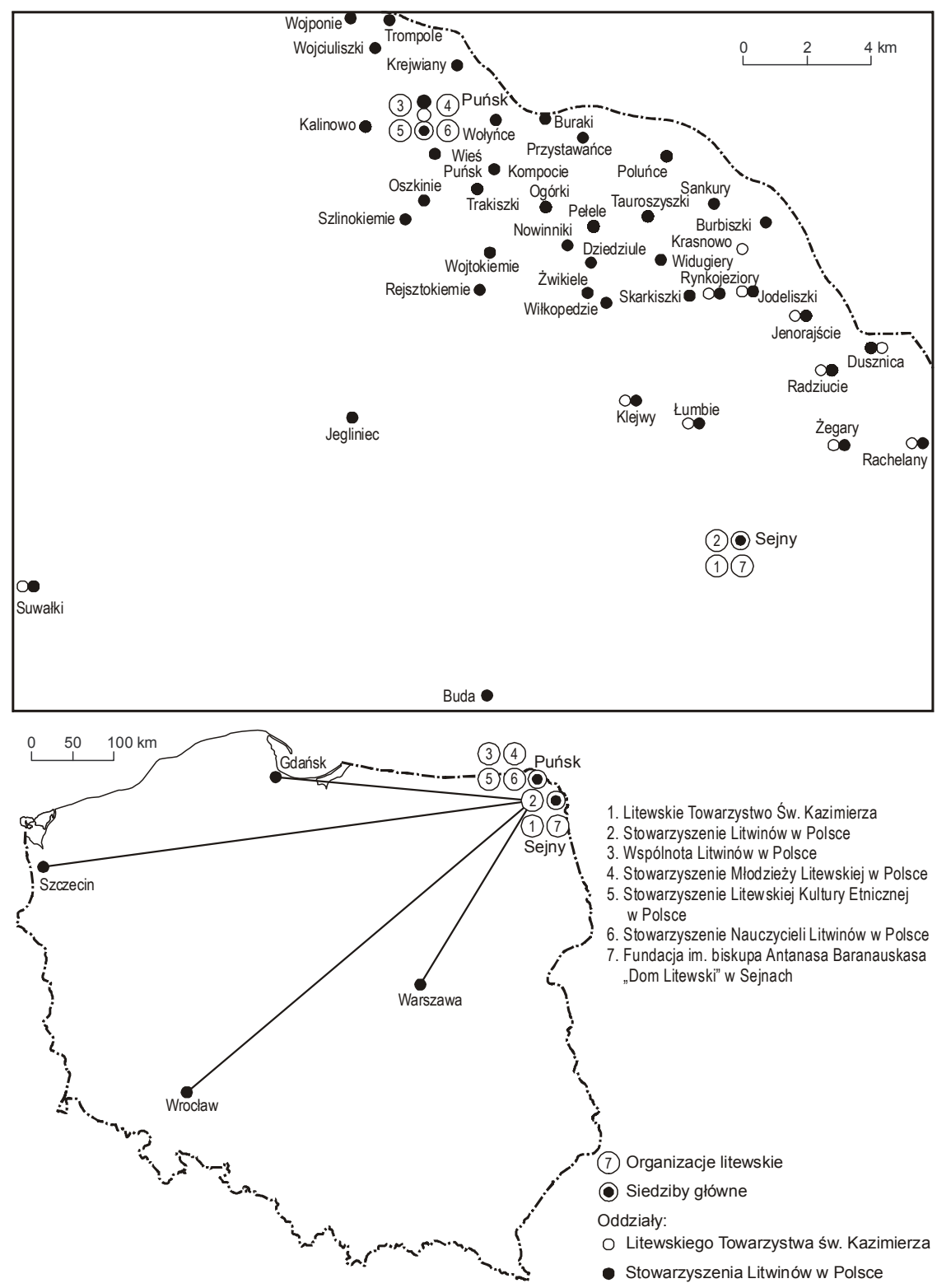

Ryc. 16. Struktura przestrzenna organizacji litewskich w 2012 r.

Źródło: opracowanie własne

Struktura przestrzenna organizacji litewskich jest odzwierciedleniem koncentracji terytorialnej Litwinów w gminach Puńsk i Sejny. W tych dwóch ośrodkach gminnych znajdują się główne siedziby wszystkich litewskich organizacji, ponadto na obszarze obu gmin, w wioskach położonych wzdłuż granicy 
polsko-litewskiej prowadzi działalność kilkadziesiąt oddziałów Stowarzyszenia Litwinów w Polsce oraz Litewskiego Towarzystwa Św. Kazimierza, jedynych organizacji o rozbudowanych strukturach terenowych (ryc. 16). Jednak współcześnie, inaczej niż jeszcze w latach 90. XX w., większość wiejskich oddziałów obu organizacji praktycznie nie funkcjonuje lub funkcjonuje okazjonalnie, aktywną działalność prowadzą głównie oddziały w Puńsku, Sejnach i Suwałkach oraz w miastach poza Suwalszczyzną.

Wśród Litwinów zamieszkujących Suwalszczyznę zarówno w okresie PRL, jak i na początku XXI w. bardzo dobrze rozwinięta jest działalność kulturalna, głównie amatorska. Nie tylko w Puńsku, Sejnach i Suwałkach, ale także w wielu okolicznych wsiach działają liczne zespoły folklorystyczne, kapele ludowe, grupy wokalno-taneczne, chóry, teatry stodolane, są organizowane różnorakie festiwale, przeglądy, konkursy, jarmarki. Nadal udział w imprezach kulturalnych stanowi główny czynnik integrujący społeczność litewską, wzmacniający jej poczucie odrębności i tożsamości narodowej.

Jedną z form podtrzymywania tradycji, połączoną z pokazem i promocją osiagnięć polskich Litwinów, są cykliczne imprezy kulturalne, na które od kilku lat przyjeżdżają coraz liczniej także mieszkańcy Litwy. Do najważniejszych tego typu spotkań należy zaliczyć: Jarmark Folklorystyczny „Żolines”, Festiwal Teatrów Stodolanych, Festiwal Teatrów Dziecięcych, zlot litewskich zespołów nad jeziorem Gaładuś w ramach imprezy Sąskrydis, Noc Świętojańską w Puńsku i Zlot Litwinów w Pszczelniku. Działalność kulturalna mniejszości litewskiej jest najbardziej widoczna w Puńsku. W nowo wybudowanym Domu Kultury Litewskiej swoją siedzibę mają m.in. chór („Dzūkija”), kapele ludowe („Klumpẻ”), zespoły tańca („Jotwa”, „Vyčiai” i dziecięcy „Puniukai”) oraz teatr stodolany. Przy litewskiej szkole podstawowej, gimnazjum, a przede wszystkim litewskim Liceum Ogólnokształcącym, działają liczne zespoły młodzieżowe (m.in. zespół wokalny „Pašešupiai”, zespół taneczny „Šalčia”, Klub Miłośników Poezji), a przy Stowarzyszeniu Litewskiej Kultury Etnicznej - zespoły folklorystyczne („Šalcinèlis”, „Alna”, „Gimtinè). W Puńsku działa także muzeum etnograficzne oraz skansen. W Sejnach działalność kulturalna społeczności litewskiej uaktywniła się w latach 90. XX w., a zwłaszcza na początku XXI w., głównie dzięki oddaniu do użytku Domu Litewskiego, zbudowanego ze środków przekazanych przez władze Republiki Litewskiej, w którym działają m.in. chór („Seinijos Aidas”), kapela ludowa (,Sainiai”), dziecięcy i młodzieżowy zespół tańca współczesnego oraz zespół estradowy (,Seina”), a także studio sztuki i teatru oraz, podobnie jak w Puńsku, teatr stodolany. Swoją siedzibę znalazł tu także Konsulat Republiki Litewskiej oraz Zarządy Główne: Stowarzyszenia Litwinów w Polsce, Towarzystwa Św. Kazimierza i Fundacji im. Biskupa Antanasa Baranauskasa. 
Liczne i zróżnicowane, oparte przede wszystkim na powszechności ruchu artystycznego, formy samorealizacji polskich Litwinów świadczą o dużej aktywności tej społeczności. Można powiedzieć, że jest to sytuacja wyjątkowa w porównaniu $\mathrm{z}$ innymi mniejszościami narodowymi w Polsce. Rozmieszczenie Litwinów pokazuje bowiem, że mamy do czynienia nie z izolowanymi, jak w przypadku wielu innych mniejszości, skupiskami, z których zazwyczaj każde dąży do posiadania jakiejś środowiskowej reprezentacji, ale skoncentrowaną na niewielkiej przestrzeni społecznością, a mimo to zdolną wytworzyć bardzo wiele inicjatyw nastawionych na kultywowanie narodowej tradycji (Rykała 2008).

Mimo koncentracji terytorialnej i korzystnych dla komitetów wyborczych mniejszości narodowych zapisów w ordynacji wyborczej, Litwinom nie udało się po 1990 r. wprowadzić swojego przedstawiciela do parlamentu. Dużo większe sukcesy wyborcze, już od początku lat 90 . XX w., odnoszą w wyborach samorządowych, w których kandydaci reprezentujący mniejszość litewską startuja z powodzeniem z list lokalnych komitetów wyborczych. Litwini od ponad 20 lat zasiadają w radzie powiatu, gminy oraz miasta Sejny, natomiast rada gminy Puńsk jest całkowicie przez nich zdominowana (łącznie ze stanowiskiem wójta), zdobywają w niej z reguły 12-14 na 15 możliwych mandatów.

Gmina Puńsk wyraźnie zaznacza się na mapie elektoralnej województwa podlaskiego. W poszczególnych wyborach parlamentarnych i prezydenckich w latach 90. XX w. oraz na początku XXI w. cechowała się wyższą frekwencją niż średnia dla województwa i zdecydowanie silniejszym poparciem dla ugrupowań lewicowych. W wyborach parlamentarnych w 2001 r. Sojusz Lewicy Demokratycznej (SLD) otrzymał w gminie Puńsk 89,5\% głosów (było to najwyższe poparcie w Polsce), w 2005 r. 84,6\%, natomiast w 2007 r. już tylko $28,8 \%$ (przy wyjątkowo niskiej frekwencji, zaledwie 36,6\%). Jednak i tym razem lewicowy komitet wyborczy (pod nazwą Lewica i Demokraci) zwyciężył w Puńsku, choć nieznacznie, przed PSL (26,3\%) oraz PO (24,4\%). W kolejnych wyborach, w 2011 r., SLD poniósł w gminie Puńsk swoją największą klęskę od 20 lat, zdobywając (przy bardzo niskiej frekwencji 33,7\%) tylko 6\% głosów i zajmując odległe piąte miejsce. Zdecydowanie największe poparcie Litwinów uzyskała Platforma Obywatelska $(38,5 \%)$ oraz PSL $(31,5 \%)^{119}$.

Doskonałe wyniki wyborcze lewicy w 2001 oraz 2005 r. w głównym stopniu były spowodowane kandydowaniem z listy SLD Witolda Liszkowskiego, działacza litewskiego, wieloletniego wójta gminy Puńsk. Poparcie Litwinów dla opcji lewicowej może być także tłumaczone wieloma innymi czynnikami, m.in. brakiem własnych, litewskich partii politycznych oraz utożsamianiem ugru-

${ }^{119}$ Na podstawie danych Państwowej Komisji Wyborczej: www.pkw.gov.pl. 
powań prawicowych z retoryką narodowo-polską. Potwierdzają to analogiczne zachowania wyborcze innych mniejszości narodowych w Polsce. Natomiast wyniki wyborów w dwóch ostatnich głosowaniach (2007 i 2011 r.), kiedy z listy lewicowej nie kandydował już Witold Liszkowski, pokazują że kwestie personalne miały dla litewskich wyborców bardzo duże znaczenie.

Także poparcie mniejszości litewskiej dla członkostwa Polski w UE było bardzo wyraźne, w gminie Puńsk 79\% głosujących opowiedziało się za przyjęciem do UE, przy średniej dla województwa podlaskiego $68,6 \%{ }^{120}$.

\subsubsection{Szkolnictwo mniejszości narodowych}

Prawo do nauki języka ojczystego lub w języku ojczystym dla mniejszości narodowych i etnicznych zostało w powojennej Polsce zagwarantowane ustawowo dopiero w 1991 r. $^{121}$ Wcześniej było określane jedynie na poziomie zarządzenia Ministra Edukacji Narodowej. W ogólnych regulacjach nauczania języka ojczystego poszczególnych mniejszości zapisano zasadę dobrowolności oraz obowiązek składania przez rodziców pisemnych wniosków dotyczących zorganizowania nauki języka mniejszości ${ }^{122}$.

${ }^{120}$ Na podstawie danych Państwowej Komisji Wyborczej: www.pkw.gov.pl.

${ }^{121}$ W Ustawie o systemie oświaty, w artykule 13 zapisano, że „szkoła i placówka publiczna umożliwia uczniom podtrzymywanie poczucia tożsamości narodowej, etnicznej, językowej i religijnej, a w szczególności naukę języka oraz własnej historii i kultury" (Dz.U. nr 67, poz. 329). W 1992 r. MEN wydało rozporządzenie w sprawie organizacji kształcenia umożliwiającego podtrzymanie poczucia tożsamości narodowej, etnicznej i językowej uczniów należących do mniejszości narodowych (Dz.U. nr 34, poz. 150). W 2003 r. wydano nową regulację ministerialną, dostosowującą wcześniejsze zapisy do reformy edukacji wprowadzającej nauczanie gimnazjalne (Dz.U. nr 220, poz. 1853). Szkolnictwu mniejszości narodowych poświęcono także artykuł 17, przyjętej w 2005 r. Ustawy o mniejszościach narodowych, etnicznych i języku regionalnym. Zgodnie z rozporządzeniem Ministra Edukacji język ojczysty może być nauczany we wszystkich typach placówek szkolnych (przedszkolach, szkołach podstawowych, gimnazjach, liceach ogólnokształcących itd.) oraz w międzyszkolnych zespołach grupujących uczniów. Regulacje prawne nakładają na resort oświaty obowiązek finansowania z budżetu państwa m.in.: bieżącej działalności szkół dla mniejszości, opracowania programów i podręczników do nauki języka ojczystego oraz historii i geografii kraju ojczystego mniejszości, dokształcania nauczycieli. Nie jest natomiast prawnie regulowany dostęp absolwentów szkół mniejszościowych do szkół wyższych.

${ }^{122}$ Regulacja, dająca możliwość tworzenia szkoły z ojczystym językiem nauczania, zakłada tworzenie klas prowadzących nauczanie w języku mniejszości już przy zgłoszeniu się siedmiu uczniów (dla szkół podstawowych i gimnazjów) i 14 (dla szkół ponadgimnazjalnych). 
Istnieje wiele form organizacyjnych nauczania języków mniejszości narodowych i etnicznych. Są to "szkoły z językiem nauczania mniejszości” (gdzie wszystkie przedmioty nauczane są w języku mniejszości, z wyjątkiem historii i geografii Polski oraz języków obcych), „szkoły dwujęzyczne” (prowadzące nauczanie $w$ dwóch równorzędnych językach: polskim oraz języku ojczystym mniejszości), „szkoły z dodatkową nauką języka mniejszości” (prowadzące nauczanie wszystkich przedmiotów w języku polskim, z wyjątkiem przedmiotu dodatkowego, którym jest język ojczysty danej mniejszości). Nauczanie w języku ojczystym organizowane jest również w ramach międzyszkolnych zespołów (gdzie analogicznie wyróżniamy trzy typy zespołów: zespoły z językiem mniejszości, zespoły dwujęzyczne i zespoły z dodatkową nauką języka mniejszości). Ponadto nauka języka mniejszości narodowych i etnicznych odbywa się na poziomie przedszkola. W systemie organizacji nauki języka mniejszości w szkołach i zespołach międzyszkolnych zdecydowanie przeważają szkoły z dodatkową nauką tego języka. Jest on najczęściej nauczany jako nieobowiązkowy przedmiot dodatkowy w szkołach podstawowych.

Gwarancje prawne dotyczące nauczania języków mniejszości w szkołach są bardzo ważnym, ale tylko wstępnym warunkiem rozwoju szkolnictwa mniejszości narodowych i etnicznych. Zależy on w głównej mierze od zainteresowania i aktywności samych mniejszości, zwłaszcza rodziców decydujących o edukacji swoich dzieci oraz od polityki władz oświatowych i samorządowych na obszarach zamieszkanych przez mniejszości narodowe.

Pod względem statystycznym po 1989 r. nastąpił dynamiczny rozwój szkolnictwa mniejszości narodowych zarówno pod względem liczby szkół, jak i liczby uczniów pobierających naukę języka mniejszości lub w języku mniejszości. Miał on jednak różną dynamikę i odmienne tendencje wśród poszczególnych narodowości. Równolegle zachodził proces progresji (w przypadku szkolnictwa ukraińskiego i łemkowskiego), stabilizacji (szkolnictwo litewskie), jak i regresji (szkolnictwo białoruskie). Spadek liczby uczniów, wyraźnie zaznaczający się po 2000 r. (zwłaszcza w szkołach podstawowych), jest spowodowany w głównej mierze postępującym niżem demograficznym, dotykającym wszystkich rodzajów szkół w Polsce (tab. 10). Aktualnie głównym problemem szkolnictwa mniejszości narodowych (podobnie jak całego systemu oświaty w Polsce) jest coraz powszechniejszy brak pieniędzy w budżetach samorządów na dalsze utrzymywanie małych, wiejskich szkół. Ich likwidacja z powodów finansowych i demograficznych będzie w najbliższej przyszłości podstawową przyczyną regresu szkolnictwa mniejszości narodowych. 
Tabela 10. Nauczanie języka ukraińskiego, łemkowskiego, białoruskiego i litewskiego w różnych rodzajach szkół w latach 1990-2011 ${ }^{123}$

\begin{tabular}{|c|c|c|c|c|c|c|c|c|}
\hline \multirow{2}{*}{$\begin{array}{c}\text { Rok } \\
\text { szkolny }\end{array}$} & \multicolumn{7}{|c|}{ Szkoły podstawowe i zespoły międzyszkolne } \\
\cline { 2 - 10 } & \multicolumn{2}{|c|}{\begin{tabular}{c} 
język ukraiński \\
\cline { 2 - 10 }
\end{tabular}} & \multicolumn{2}{c|}{$\begin{array}{c}\text { język } \\
\text { lemkowski }\end{array}$} & \multicolumn{2}{c|}{ język białoruski } & \multicolumn{2}{c|}{ język litewski } \\
\hline szkół & $\begin{array}{c}\text { liczba } \\
\text { uczniów }\end{array}$ & $\begin{array}{c}\text { liczba } \\
\text { szkół }\end{array}$ & $\begin{array}{c}\text { liczba } \\
\text { uczniów }\end{array}$ & $\begin{array}{c}\text { liczba } \\
\text { szkół }\end{array}$ & $\begin{array}{c}\text { liczba } \\
\text { uczniów }\end{array}$ & $\begin{array}{c}\text { liczba } \\
\text { szkół }\end{array}$ & $\begin{array}{c}\text { liczba } \\
\text { uczniów }\end{array}$ \\
\hline $1990 / 91$ & 42 & 1096 & - & - & 48 & 3033 & 11 & 583 \\
\hline $1991 / 92$ & 43 & 1156 & - & - & 46 & 2878 & 10 & 685 \\
\hline $1992 / 93$ & 47 & 1294 & - & - & 43 & 3030 & 10 & 593 \\
\hline $1993 / 94$ & 50 & 1525 & - & - & 41 & 2904 & 10 & 619 \\
\hline $1994 / 95$ & 55 & 1542 & - & - & 42 & 3110 & 10 & 612 \\
\hline $1995 / 96$ & 69 & 2007 & - & - & 43 & 3076 & 10 & 609 \\
\hline $1996 / 97$ & 75 & 2255 & - & - & 40 & 2904 & 13 & 636 \\
\hline $1997 / 98$ & 80 & 2154 & 4 & 51 & 38 & 2744 & 13 & 626 \\
\hline $1998 / 99$ & 83 & 2234 & 4 & 44 & 37 & 2563 & 13 & 633 \\
\hline $1999 / 00$ & 76 & 1919 & 8 & 66 & 31 & 2220 & 13 & 528 \\
\hline $2000 / 01$ & 73 & 1613 & 9 & 98 & 27 & 1988 & 13 & 446 \\
\hline $2001 / 02$ & 74 & 1648 & 12 & 92 & 26 & 1806 & 13 & 407 \\
\hline $2002 / 03$ & 80 & 1656 & 14 & 118 & 24 & 1826 & 13 & 395 \\
\hline $2003 / 04$ & 82 & 1567 & 16 & 180 & 26 & 1921 & 12 & 395 \\
\hline $2004 / 05$ & 88 & 1583 & 21 & 212 & 23 & 1766 & 12 & 409 \\
\hline $2005 / 06$ & 91 & 1498 & 20 & 164 & 25 & 1722 & 9 & 378 \\
\hline $2006 / 07$ & 90 & 1393 & 23 & 231 & 25 & 1636 & 10 & 370 \\
\hline $2007 / 08$ & 79 & 969 & 22 & 147 & 27 & 1593 & 10 & 340 \\
\hline $2008 / 09$ & 84 & 1008 & 23 & 160 & 24 & 1475 & 9 & 332 \\
\hline $2009 / 10$ & 82 & 903 & 20 & 131 & 22 & 1421 & 8 & 296 \\
\hline $2010 / 11$ & 83 & 897 & 20 & 110 & 22 & 1346 & 8 & 256 \\
\hline
\end{tabular}

${ }^{123}$ Brak jest wiarygodnych i jednoznacznych statystyk dotyczących nauczania języków mniejszości, występują istotne rozbieżności w danych GUS, MEN, kuratoriów oświaty, stowarzyszeń narodowościowych oraz w zestawieniach opracowanych przez naukowców zajmujących się tą tematyką. Różnice dotyczą zarówno liczby uczniów, jak i liczby poszczególnych typów szkół. Zamieszczone w tabeli dane GUS mogą odbiegać in minus od stanu faktycznego. 


\begin{tabular}{|c|c|c|c|c|c|c|c|c|}
\hline \multirow{3}{*}{$\begin{array}{c}\text { Rok } \\
\text { szkolny }\end{array}$} & \multicolumn{8}{|c|}{ Gimnazja i zespoły międzyszkolne } \\
\hline & \multicolumn{2}{|c|}{ język ukraiński } & \multicolumn{2}{|c|}{$\begin{array}{c}\text { język } \\
\text { łemkowski }\end{array}$} & \multicolumn{2}{|c|}{ język białoruski } & \multicolumn{2}{|c|}{ język litewski } \\
\hline & $\begin{array}{c}\text { liczba } \\
\text { szkół }\end{array}$ & $\begin{array}{c}\text { liczba } \\
\text { uczniów }\end{array}$ & $\begin{array}{l}\text { liczba } \\
\text { szkół }\end{array}$ & $\begin{array}{c}\text { liczba } \\
\text { uczniów }\end{array}$ & $\begin{array}{c}\text { liczba } \\
\text { szkół }\end{array}$ & $\begin{array}{c}\text { liczba } \\
\text { uczniów }\end{array}$ & $\begin{array}{c}\text { liczba } \\
\text { szkół }\end{array}$ & $\begin{array}{c}\text { liczba } \\
\text { uczniów }\end{array}$ \\
\hline $1999 / 00$ & 23 & 190 & 2 & 14 & 10 & 345 & 2 & 73 \\
\hline $2000 / 01$ & 34 & 414 & 5 & 29 & 10 & 632 & 2 & 131 \\
\hline $2001 / 02$ & 34 & 606 & 6 & 37 & 11 & 894 & 2 & 195 \\
\hline $2002 / 03$ & 46 & 692 & 6 & 32 & 12 & 984 & 3 & 191 \\
\hline $2003 / 04$ & 47 & 733 & 8 & 57 & 14 & 997 & 4 & 206 \\
\hline $2004 / 05$ & 56 & 770 & 10 & 90 & 13 & 1029 & 4 & 196 \\
\hline $2005 / 06$ & 60 & 805 & 13 & 109 & 13 & 962 & 5 & 177 \\
\hline $2006 / 07$ & 57 & 773 & 12 & 108 & 14 & 973 & 5 & 194 \\
\hline $2007 / 08$ & 44 & 563 & 12 & 96 & 14 & 948 & 4 & 160 \\
\hline $2008 / 09$ & 48 & 527 & 11 & 81 & 14 & 922 & 4 & 162 \\
\hline $2009 / 10$ & 47 & 513 & 8 & 72 & 14 & 859 & 3 & 167 \\
\hline $2010 / 11$ & 51 & 477 & 10 & 78 & 14 & 823 & 4 & 165 \\
\hline \multirow{3}{*}{$\begin{array}{c}\text { Rok } \\
\text { szkolny }\end{array}$} & \multicolumn{8}{|c|}{ Szkoły ponadgimnazjalne } \\
\hline & \multicolumn{2}{|c|}{ język ukraiński } & \multicolumn{2}{|c|}{$\begin{array}{c}\text { język } \\
\text { łemkowski }\end{array}$} & \multicolumn{2}{|c|}{ język białoruski } & \multicolumn{2}{|c|}{ język litewski } \\
\hline & $\begin{array}{l}\text { liczba } \\
\text { szkół }\end{array}$ & $\begin{array}{c}\text { liczba } \\
\text { uczniów }\end{array}$ & $\begin{array}{l}\text { liczba } \\
\text { szkół }\end{array}$ & $\begin{array}{c}\text { liczba } \\
\text { uczniów }\end{array}$ & $\begin{array}{l}\text { liczba } \\
\text { szkół }\end{array}$ & $\begin{array}{c}\text { liczba } \\
\text { uczniów }\end{array}$ & $\begin{array}{c}\text { liczba } \\
\text { szkół }\end{array}$ & $\begin{array}{c}\text { liczba } \\
\text { uczniów }\end{array}$ \\
\hline $1990 / 91$ & 3 & 254 & - & - & 2 & 644 & 1 & 124 \\
\hline $1991 / 92$ & 3 & 307 & - & - & 2 & 630 & 1 & 131 \\
\hline $1992 / 93$ & 3 & 348 & - & - & 2 & 621 & 1 & 119 \\
\hline $1993 / 94$ & 3 & 370 & - & - & 2 & 692 & 1 & 123 \\
\hline $1994 / 95$ & 3 & 372 & - & - & 2 & 787 & 1 & 140 \\
\hline $1995 / 96$ & 4 & 372 & - & - & 2 & 877 & 1 & 135 \\
\hline $1996 / 97$ & 5 & 427 & - & - & 2 & 923 & 1 & 141 \\
\hline $1997 / 98$ & 4 & 433 & - & - & 2 & 966 & 1 & 130 \\
\hline $1998 / 99$ & 4 & 493 & - & - & 2 & 982 & 1 & 141 \\
\hline $1999 / 00$ & 4 & 530 & - & - & 2 & 1046 & 1 & 128 \\
\hline $2000 / 01$ & 4 & 522 & - & - & 2 & 1113 & 1 & 124 \\
\hline $2001 / 02$ & 4 & 380 & - & - & 2 & 842 & 1 & 94 \\
\hline $2002 / 03$ & 5 & 366 & - & - & 4 & 854 & 1 & 73 \\
\hline
\end{tabular}




\begin{tabular}{|c|c|c|c|c|c|c|c|c|}
\hline $2003 / 04$ & 9 & 367 & - & - & 4 & 831 & 1 & 68 \\
\hline $2004 / 05$ & 7 & 358 & - & - & 2 & 827 & 1 & 74 \\
\hline $2005 / 06$ & 7 & 373 & - & - & 2 & 851 & 1 & 76 \\
\hline $2006 / 07$ & 7 & 352 & - & - & 2 & 810 & 2 & 107 \\
\hline $2007 / 08$ & 9 & 353 & - & - & 3 & 799 & 2 & 104 \\
\hline $2008 / 09$ & 7 & 314 & - & - & 3 & 777 & 2 & 92 \\
\hline $2009 / 10$ & 12 & 309 & - & - & 3 & 787 & 2 & 101 \\
\hline $2010 / 11$ & 8 & 266 & - & - & 3 & 752 & 2 & 99 \\
\hline
\end{tabular}

Źródło: opracowanie własne na podstawie E. Pogorzały (2006, s. 336-338) oraz danych GUS zamieszczonych w raporcie pt. Oświata i wychowanie w roku szkolnym 2010/2011: www.stat.gov.pl.

\section{Ukraińcy i Lemkowie}

W latach PRL władze komunistyczne z większym lub mniejszym nasileniem ograniczały naukę języka ukraińskiego w szkołach, traktując to jako jeden z najbardziej skutecznych sposobów asymilacji i wynarodowienia ukraińskich dzieci i młodzieży. Na początku lat 90. XX w. funkcjonowały w Polsce zaledwie cztery szkoły z ukraińskim językiem nauczania, do których uczęszczało 354 uczniów. Działało też 57 zespołów międzyszkolnych, w których języka ukraińskiego, jako dodatkowego przedmiotu, uczyło się 1076 uczniów (Halczak 2010a).

W latach 90. XX w. nastąpiła istotna poprawa sytuacji szkolnictwa ukraińskiego. Obecnie szkoły z ukraińskim językiem nauczania ${ }^{124}$ funkcjonują w ramach pięciu Zespołów Szkół Ogólnokształcących (w Białym Borze, Bartoszycach, Górowie Iławeckim, Legnicy i Przemyślu), ponadto w szkołach w Baniach Mazurskich i Bielsku Podlaskim działają ukraińskie klasy. Szkoły te są nie tylko głównymi ,ukraińskimi ośrodkami edukacyjnymi”, ale także centrami ukraińskiej kultury, mającymi bardzo duże znaczenie dla podtrzymania tożsamości narodowej wśród dzieci i młodzieży. Jednak nadal podstawową formą nauki języka ukraińskiego są zespoły międzyszkolne (z reguły na szczeblu szkół podstawowych), w których dzieci mają możliwość uczęszczania na dodatkowe, nieobowiązkowe lekcje języka ukraińskiego, często popołudniami lub w soboty, co jest uciążliwe dla uczniów i ich rodziców. Liczba tego typu zespołów międzyszkolnych wzrosła w roku szkolnym 1999/00 do 104, w których z edukacji

124 Wbrew nazwie, zdecydowana większość przedmiotów w tych szkołach jest nauczana w języku polskim, wyróżnia je obowiązkowa dla wszystkich uczniów nauka języka ukraińskiego, w niektórych szkołach również nauczanie w języku ukraińskim historii i geografii Ukrainy oraz religii, a także możliwość zdawania matury z języka ukraińskiego. 
korzystało 2557 uczniów, podczas gdy ponad 10 lat temu języka ukraińskiego uczyło się ogółem 3523 uczniów (Halczak 2010a). Było to więcej niż w szczytowym okresie rozwoju szkolnictwa ukraińskiego w czasach PRL, kiedy w roku szkolnym 1958/59 na lekcje języka ukraińskiego uczęszczało 3287 uczniów ${ }^{125}$. W ciągu ostatnich 10 lat zwiększyła się liczba szkół nauczających języka ukraińskiego (zwłaszcza gimnazjów), natomiast wyraźnie spadła liczba uczniów, szczególnie wśród najmłodszych roczników w szkołach podstawowych, przy dużo mniejszym spadku liczby uczniów gimnazjów i liceów. Charakterystyczną cechą szkół mniejszości ukraińskiej jest nie tylko ich znaczne rozproszenie geograficzne, ale także rozproszenie nauczania, przejawiające się relatywnie dużą liczbą szkół przy niewielkiej liczbie uczniów (tab. 10-12).

Tabela 11. Nauczanie języka ukraińskiego w roku szkolnym 2010/11

\begin{tabular}{|l|c|c|}
\hline \multicolumn{2}{|c|}{ Placówki oświatowe } & \multirow{2}{*}{ Liczba uczniów } \\
\hline Typ & Liczba & 244 \\
Przedszkola i oddziały przedszkolne & 43 & 1351 \\
Szkoła podstawowa & 80 & 630 \\
Gimnazjum & 49 & 265 \\
Liceum ogólnokształcące & 6 & 0 \\
Liceum profilowane & 0 & 9 \\
Technikum & 1 & 2499 \\
\hline Ogółem & 179 & \\
\hline
\end{tabular}

Źródło: opracowanie własne na podstawie Strategii rozwoju oświaty mniejszości ukraińskiej w Polsce.

Język ukraiński jest także nauczany na poziomie szkolnictwa wyższego, w ramach filologii ukraińskiej, filologii słowiańskiej lub ukrainistyki. Można go studiować zarówno w systemie studiów licencjackich, jak i magisterskich, na Uniwersytetach: Jagiellońskim, Warszawskim, Wrocławskim, Szczecińskim, Marii-Curie Skłodowskiej w Lublinie oraz w Państwowej Wyższej Szkole Wschodnioeuropejskiej w Przemyślu.

125 Według danych GUS w roku szkolnym 1999/00 liczba uczniów uczących się języka ukraińskiego we wszystkich rodzajach szkół była zdecydowanie niższa i wynosiła 2639, natomiast - także według GUS - w trakcie ostatnich 20 lat, najwięcej uczniów (2727) uczęszczało na lekcje języka ukraińskiego w roku szkolnym 1998/99 (Oświata i wychowanie w roku szkolnym 2010/2011: www.stat.gov.pl). 
Spadek liczby uczniów podejmujących naukę języka ukraińskiego po $2000 \mathrm{r}$. w głównym stopniu był spowodowany niewielką liczebnością oraz bardzo silnym rozproszeniem terytorialnym mniejszości ukraińskiej, niżem demograficznym oraz postępowaniem części Łemków, podejmujących decyzję o rezygnacji dzieci z nauki języka ukraińskiego na rzecz języka łemkowskiego.

Tabela 12. Struktura szkolnictwa ukraińskiego w Polsce w 2012 r.

\begin{tabular}{|c|l|l|l|}
\hline \multicolumn{5}{|c|}{ Tykoły } \\
\hline Typ & $\begin{array}{l}\text { z obowiązkową nauką } \\
\text { języka ukraińskiego }\end{array}$ & $\begin{array}{c}\text { z klasami } \\
\text { z obowiązkową nauką } \\
\text { języka ukraińskiego }\end{array}$ & $\begin{array}{l}\text { z nauczaniem języka } \\
\text { ukraińskiego jako } \\
\text { dodatkowego }\end{array}$ \\
\hline Podstawowa & $\begin{array}{l}\text { Biały Bór } \\
\text { Bartoszyce } \\
\text { Przemyśl }\end{array}$ & $\begin{array}{l}\text { Banie Mazurskie } \\
\text { Bielsk Podlaski }\end{array}$ & $\begin{array}{l}\text { Zespoły międzyszkol- } \\
\text { ne w województwie } \\
\text { dolnośląskim, } \\
\text { lubuskim, zachodnio- } \\
\text {-pomorskim, } \\
\text { warmińsko-mazur- } \\
\text { skim, pomorskim, } \\
\text { podlaskim, } \\
\text { podkarpackim }\end{array}$ \\
\hline Liceum & $\begin{array}{l}\text { Biały Bór } \\
\text { Bartoszyce } \\
\text { Górowo Iławeckie } \\
\text { Legnica } \\
\text { Przemyśl }\end{array}$ & Bielsk Podlaski \\
Biały Bór & $\begin{array}{l}\text { Górowo Iławeckie } \\
\text { Legnica } \\
\text { Przemýl }\end{array}$ & & \\
\hline
\end{tabular}

Źródło: opracowanie własne.

Pierwszy po wojnie punkt nauczania języka łemkowskiego zorganizowano w 1991 r. w szkole podstawowej w Uściu Gorlickim na Łemkowszczyźnie ${ }^{126}$. $\mathrm{W}$ ciągu kilku kolejnych lat rozpoczęto nauczanie łemkowskiego w szkołach podstawowych w Kunkowej, Krynicy i Rozdzielu w Beskidach oraz w Legnicy, Przemkowie i Malczycach na Dolnym Śląsku. Od 2001 r. język łemkowski jest nauczany także na poziomie szkolnictwa wyższego. W Akademii Pedagogicznej w Krakowie uruchomiono kierunek filologia rosyjska z językiem rusińsko-łemkowskim, który m.in. przygotowuje kadry dydaktyczne niezbędne do rozwoju szkolnictwa łemkowskiego. Pod koniec pierwszej dekady XXI w. język łemko-

${ }^{126}$ Według danych GUS pierwsze szkoły podstawowe, w których nauczano języka łemkowskiego, pojawiły się dopiero w roku szkolnym 1997/98, co jest niezgodne z informacjami z wielu różnych źródeł (m.in. Nijakowski, Łodziński 2003, Dudra 2009, 2010), według których początki nauczania języka łemkowskiego przypadają na $1991 \mathrm{r}$. (tab. 10, Oświata i wychowanie w roku szkolnym 2010/2011: www.stat.gov.pl). 
wski był nauczany jako przedmiot dodatkowy w 23 szkołach podstawowych i gimnazjach na obszarze Łemkowszczyzny oraz Dolnego Śląska ${ }^{127}$. Na lekcje uczęszczało ok. 360 uczniów. Rozwojem łemkowskiego szkolnictwa, wydawaniem podręczników, słowników, programów nauczania zajmuje się Stowarzyszenie Łemków. Nauczanie jest utrudnione rozproszeniem Łemków, narastającą asymilacją oraz brakiem przydatności tego języka w życiu zawodowym i awansie społecznym (Dudra 2010).

\section{Białorusini}

Od początku lat 70. XX w., mimo koncentracji Białorusinów na Podlasiu, nadal nie istnieje sensu stricto szkolnictwo białoruskie, czyli szkoły z białoruskim językiem nauczania. Język białoruski jest nauczany wyłącznie jako przedmiot dodatkowy w szkołach z polskim językiem wykładowym. Dotyczy to także „białoruskich” liceów w Bielsku Podlaskim i Hajnówce. Liceum i gimnazjum wchodzące w skład Zespołu Szkół w Hajnówce od 1999 r. w swojej nazwie podkreślają, że są szkołami z „dodatkową nauką języka białoruskiego”, natomiast II Liceum Ogólnokształcące im. Bronisława Taraszkiewicza w Bielsku Podlaskim nadal oficjalnie, także w swojej nazwie, używa określenia „liceum z białoruskim językiem nauczania”, mimo że wszystkie przedmioty nauczane są po polsku. Jedynym wyróżnikiem tych szkół jest obowiązkowa dla wszystkich uczniów nauka języka białoruskiego oraz możliwość zdawania matury z języka białoruskiego ${ }^{128}$. Brak nauczania większości przedmiotów po białorusku jest spowodowany m.in. protestami części rodziców oraz niektórych działaczy białoruskich, którzy uważają to za utrudnienie w późniejszych studiach i awansie młodzieży białoruskiej, wręcz za próbę tworzenia „białoruskiego getta" (Plit 2008).

Język białoruski jest także nauczany na poziomie szkolnictwa wyższego, filologię białoruską można studiować na Uniwersytecie w Białymstoku oraz Uniwersytecie Warszawskim w systemie studiów licencjackich i magisterskich.

W szkołach podstawowych i gimnazjalnych, w których istnieje możliwość dodatkowej nauki języka białoruskiego, korzysta z tego ok. 40\% uczniów. Najwięcej uczniów uczęszcza na lekcje tego języka w mieście i gminie Bielsk Podlaski i Hajnówka oraz w gminach Czyże, Narew, Orla i Dubicze Cerkiewne (Romanowska 2010). Nie przypadkowo są to gminy, w których w trakcie spisu

${ }^{127}$ Na Dolnym Śląsku są to szkoły podstawowe w Brzozie, Strzelcach Krajeńskich, Przemkowie, Lesznie Górnym, Torzymiu, Nowej Soli (Dudra 2009).

${ }^{128}$ Do liceum w Bielsku Podlaskim uczęszczało w roku szkolnym 2011/2012 385 uczniów, natomiast w Hajnówce do liceum 342, a do gimnazjum 176 uczniów. 
powszechnego w 2002 r. największy odsetek mieszkańców zadeklarował narodowość białoruską. Jednak, według danych GUS, utrzymuje się bardzo wyraźna tendencja malejąca zarówno w liczbie szkół podstawowych z możliwością dodatkowej nauki języka białoruskiego, jak i w liczbie uczniów uczących się tego języka. W roku szkolnym 1990/91 w 48 szkołach podstawowych języka białoruskiego uczyło się 3033 uczniów, 20 lat później, w zaledwie 22 szkołach podstawowych na Podlasiu, na lekcje białoruskiego uczęszczało 1346 uczniów, czyli prawie trzykrotnie mniej. Także wśród starszych uczniów, od 2000 r. w liceach, a od 2005 r. w gimnazjach, zaznacza się powolny spadek liczby uczniów. W roku szkolnym 2010/11 w 14 gimnazjach języka białoruskiego uczyło się 823 uczniów, a w trzech szkołach ponadgimnazjalnych 752 uczniów, czyli ogółem we wszystkich rodzajach szkół języka białoruskiego uczyło się 2921 uczniów $^{129}$ (tab. 10). Z powodu zamykania małych wiejskich szkół oraz z uwagi na wyraźnie malejącą liczbę uczniów w szkołach podstawowych można przypuszczać, że w najbliższych latach także w gimnazjach i liceach pogłębi się redukcja liczby młodzieży uczęszczającej na lekcje języka białoruskiego.

Słabo rozwinięte szkolnictwo białoruskie, a zwłaszcza brak nauczania w języku białoruskim, obok migracji do miast i depopulacji obszarów wiejskich wschodniego Podlasia, jest od lat jedną z podstawowych przyczyn postępującej asymilacji narodowościowej prawosławnych mieszkańców Białostocczyzny.

\section{Litwini}

Jednym z największych osiagnięć mniejszości litewskiej jest doskonale zorganizowane szkolnictwo, prezentujące się bardzo korzystnie na tle szkolnictwa innych mniejszości narodowych w Polsce, zwłaszcza przy porównaniu potencjału demograficznego mniejszości litewskiej z ukraińską lub białoruską. W 2012 r. dzieci i młodzież uczyły się języka litewskiego w 13 szkołach zlokalizowanych w dwóch gminach - Puńsk i Sejny (tab. 13) oraz w oddziałach międzyszkolnych w Suwałkach. W większości tych szkół litewski jest językiem wykładowym, co oznacza, że wszystkie przedmioty nauczane są w języku litewskim (poza językiem polskim oraz historią i geografią Polski), ponadto

${ }^{129}$ Bardzo zbliżone, choć nieco wyższe dane podaje MEN, według którego w 2012 r. języka białoruskiego uczyło się ogółem 3041 uczniów w 44 placówkach oświatowych, w tym w 23 szkołach podstawowych, 15 gimnazjach, trzech szkołach ponadgimnazjalnych oraz w trzech przedszkolach i oddziałach przedszkolnych. Najwięcej uczniów uczęszczało na lekcje białoruskiego w powiecie hajnowskim (1437) oraz bielskim (1192), ponadto w białostockim (121), sokólskim (42) oraz w mieście Białystok (249). 
dodatkowo wykładana jest historia i geografia Litwy ${ }^{130}$. Taki model nauczania Litwini stosują jako jedyna mniejszość narodowa w Polsce. Nauczanie nie tylko języka litewskiego, ale także w języku litewskim większości przedmiotów na wszystkich poziomach edukacji jest podstawą zachowania litewskiej odrębności językowej i jednym z głównych czynników utrzymywania tożsamości narodowej. Od połowy lat 90 . XX w. systematycznie spada liczba uczniów uczących się litewskiego i liczba szkół uczących w języku litewskim (wartości maksymalne to ok. 750-780 uczniów w latach 1996-1999, obecnie ok. 400-500 uczniów), jednak jest to konsekwencją nie tyle mniejszego zainteresowania nauką języka, ile niżu demograficznego docierającego do wszystkich typów szkół. Nauczaniem w języku ojczystym objęto ok. 70\% dzieci litewskich w wie$\mathrm{ku}$ szkolnym. Jest to zasługą rodziców, nauczycieli, litewskich organizacji, pomocy finansowej władz Litwy ${ }^{131}$, a także koncentracji terytorialnej Litwinów. Dobrze zorganizowane, stabilne i powszechne szkolnictwo litewskie jest jedną z głównych - jeżeli nie główną - przyczyną niewielkiego stopnia asymilacji Litwinów zamieszkujących Suwalszczyznę.

Szczególne miejsce w systemie szkolnictwa litewskiego tradycyjnie już zajmuje liceum w Puńsku (jedyna ponadgimnazjalna szkoła $z$ litewskim językiem nauczania w Polsce) oraz od niedawna Zespół Szkół z Litewskim Językiem Nauczania „Žiburys” w Sejnach. Istniejące od 1956 r. Liceum im. 11 Marca w Puńsku (od niedawna w nowym budynku) kształci głównie absolwentów szkół podstawowych z gmin Puńsk, Sejny, Szypliszki i Suwałki ${ }^{132}$. Ponad 60\% uczniów tej szkoły kontynuuje naukę na wyższych uczelniach polskich i litewskich. W trakcie ponad 55 lat działalności wykształciło liczne grono inteligencji, pracującej w dużym stopniu na rzecz społeczności litewskiej w Polsce. Ożywienie litewskiej działalności oświatowej od wielu lat obserwowane jest także w Sejnach, gdzie język litewski, jako dodatkowy, jest obecnie nauczany na wszystkich szczeblach edukacji. W latach 90. XX w. tamtejsi Litwini zainicjowali odrodzenie sejneńskich tradycji oświatowych sprzed ok. 80 lat, czyli z czasów istnienia litewskiego gimnazjum „Žiburys”. Od 2005 r., dzięki wsparciu rządu litewskiego, w Sejnach ponownie, po kilkudziesięcioletniej przerwie, istnieje możliwość nauczania dzieci i młodzieży w języku litewskim w szkole podstawowej oraz $\mathrm{w}$ gimnazjum.

${ }^{130}$ Pomimo nauczania w języku litewskim m.in. matematyki, biologii czy chemii, podręczniki do tych przedmiotów są w języku polskim, co bardzo istotnie utrudnia naukę, ale jednocześnie „wymusza” na dzieciach dwujęzyczność.

${ }^{131}$ Rząd litewski m.in. sfinansował budowę Zespołu Szkół z Litewskim Językiem Nauczania ,Žiburys” w Sejnach, wspiera także finansowo małe, wiejskie szkoły.

${ }^{132}$ W roku szkolnym 2011/12 uczęszczało do niego 94 uczniów. 
Jest także możliwość nauki języka litewskiego na poziomie szkolnictwa wyższego. Na Uniwersytecie Adama Mickiewicza w Poznaniu, w ramach Wydziału Neofilologii, działa Zakład Bałtologii ze specjalizacją filologia litewska, natomiast na Uniwersytecie Warszawskim można studiować język litewski w ramach filologii bałtyckiej. Są to studia licencjackie, z naborem co dwa lata.

Badania M. Sobeckiego (1996) z połowy lat 90 . XX w. potwierdzają bardzo duży wpływ szkolnictwa na podtrzymanie tożsamości i odrębności wśród mniejszości litewskiej. Porównanie białoruskich i litewskich licealistów wykazało znacznie wyższe poczucie tożsamości narodowej oraz wiedzy na temat kultury etnicznej Litwinów. Wśród uczniów liceum w Puńsku aż 75\% określiło się jako Litwini, natomiast $\mathrm{w}$ liceach $\mathrm{z}$ białoruskim językiem nauczania zaledwie 19\% uczniów w Hajnówce i 5\% w Bielsku Podlaskim zadeklarowało białoruską tożsamość narodową (Sobecki 1996).

Tabela 13. Szkolnictwo litewskie w Polsce w roku szkolnym 2011/12

\begin{tabular}{|l|l|l|}
\hline \multicolumn{3}{|c|}{ Szkoły } \\
\hline Typ & \multicolumn{1}{|c|}{$\begin{array}{c}\text { z litewskim jezzykiem } \\
\text { nauczania }\end{array}$} & $\begin{array}{l}\text { z nauczaniem języka litewskiego } \\
\text { jako dodatkowego }{ }^{a}\end{array}$ \\
\hline Podstawowa & $\begin{array}{l}\text { Puńsk } \\
\text { Sejny (niepubliczna) } \\
\text { Widugiery (gm. Puńsk) } \\
\text { Przystawańce (gm. Puńsk) } \\
\text { Nowiniki (gm. Puńsk) }\end{array}$ & $\begin{array}{l}\text { Sejny } \\
\text { Krasnowo (gm. Sejny) }\end{array}$ \\
\hline Gimnazjum & $\begin{array}{l}\text { Puńsk } \\
\text { Sejny (niepubliczne) }\end{array}$ & Sejny (dwa gimnazja) \\
\hline Liceum & Puńsk & Sejny \\
\hline Ogółem (13) & \multicolumn{1}{|c|}{8} & \multicolumn{1}{c|}{5} \\
\hline
\end{tabular}

${ }^{a} \mathrm{~W}$ Suwałkach funkcjonują grupy międzyszkolne, w których uczniowie uczą się języka litewskiego w swoich szkołach po lekcjach.

Źródło: opracowanie własne.

Największym problemem litewskiego (i nie tylko litewskiego) szkolnictwa jest brak pieniędzy w budżetach samorządów na utrzymanie wiejskich szkół z malejąca liczbą uczniów. W 2012 r. z powodów finansowych istniała groźba likwidacji dwóch szkół podstawowych: w Widugierach i Przystawańcach. Szkoły udało się utrzymać dzięki pieniądzom przekazanym gminie Puńsk na cele oświatowe przez rząd litewski. 


\subsection{Stosunki międzypaństwowe w kontekście sytuacji mniejszości narodowych}

Na początku lat 90 . XX w. nastapiły istotne zmiany polityczne i geopolityczne w środkowej i wschodniej Europie: upadek rządów komunistycznych, zjednoczenie Niemiec, rozwiązanie ZSRR i rozpad Czechosłowacji. Powstanie w krótkim czasie kilku niepodległych państw narodowych w bezpośrednim sąsiedztwie Polski odbiło się szerokim echem wśród poszczególnych mniejszości narodowych, zwłaszcza zamieszkujących regiony nadgraniczne. Całkowicie zmieniły się relacje polityczne i gospodarcze między demokratyczną Polską i jej nowymi suwerennymi sąsiadami, a w dużym stopniu także między rozdzielonymi granicami narodami. Rozpoczął się także proces rozszerzania obszaru integracji europejskiej, który doprowadził po kilkunastu latach do włączenia części państw Europy Środkowo-Wschodniej w struktury NATO i UE, jednocześnie pozostawiając część z nich poza strefą integracji politycznej, gospodarczej i militarnej, doprowadzając do wytyczenia nowych linii podziałów w nowych realiach politycznych i prawnych. Nie oznaczało to jednak likwidacji wcześniejszych problemów, wręcz przeciwnie - pojawiły się kolejne. Jednocześnie powstały liczne możliwości ich rozwiązywania, a poszczególne mniejszości narodowe mogły o swoich aspiracjach, problemach i konfliktach otwarcie mówić.

Przez cały okres istnienia PRL oraz ZSRR granica między obu państwami odznaczała się bardzo niskim stopniem przenikalności, stanowiła swego rodzaju „drugą żelazną kurtynę”, odgradzającą państwa socjalistyczne Europy Środkowej od ich "Wielkiego Brata” (Komornicki 2008). W latach 80. XX w. na granicy o długości $1310 \mathrm{~km}$, PRL oraz ZSRR łączyły zaledwie dwa drogowe przejścia graniczne (w Terespolu i Medyce), a ograniczenia w ruchu granicznym stały się z czasem większe niż przy wyjazdach do państw Europy Zachodniej. Granica była przede wszystkim barierą szczelnie oddzielającą Polaków od mieszkających w ZSRR Rosjan, Litwinów, Białorusinów i Ukraińców, ale także skutecznie rozdzielającą mieszkającą po obu stronach tej granicy ludność litewską, białoruską, ukraińską oraz oczywiście polską. Władze PRL, poza powojennym okresem repatriacji, wykazywały się całkowitą biernością wobec Polaków mieszkających w ZSRR. Było to konsekwencją zarówno radzieckiej polityki narodowościowej, wykluczającej jakąkolwiek ingerencję z zewnątrz, jak i braku suwerenności polskich władz. Jak pisał P. Eberhardt (1993), ,ustalona po II wojnie światowej granica polsko-radziecka była przez kilka następnych dziesięcioleci jednym z kordonów dzielących rewiry w wielkim totalitarnym obozie rozciagającym się od Łaby po Kamczatkę". 
Mimo że ponownie ukształtowana pod koniec II wojny światowej granica między Polską a ZSRR funkcjonowała zaledwie 47 lat (1944-1991), to jednak jej oddziaływanie na obszar, który rozcinała, okazało się bardzo trwałe. Wytyczenie granicy miało bezpośredni wpływ na przesiedlenia setek tysięcy ludzi, doprowadziło do prawie całkowitej izolacji obu części podzielonego terytorium, spowodowało jego istotne zróżnicowanie pod względem narodowościowo-kulturowym i polityczno-ekonomicznym. Zniszczono kształtowany przez wieki, wielokulturowy i wieloetniczny charakter pogranicza. Ponadto hermetyczność granicy sprzyjała peryferyzacji pogranicza, doprowadzając do jego zacofania gospodarczego i społecznego. Na początku lat 90. XX w. P. Eberhardt (1993) stwierdził, iż „wspólnym obowiązkiem Ukraińców, Polaków, Białorusinów i Litwinów jest przezwyciężenie tej granicy poprzez kultywowanie wszystkich tradycji świadczących o wspólnocie kulturowej i historycznej”. Cel ten jest realizowany od ponad 20 lat na poziomie relacji międzynarodowych (politycznych, społecznych i gospodarczych), na poziomie współpracy administracyjnej (głównie w ramach euroregionów), a także na poziomie kontaktów międzyludzkich (turystycznych, handlowych, zarobkowych). Z powodu uwarunkowań politycznych, narodowościowych i historycznych przebiega $\mathrm{w}$ inny sposób i z innymi rezultatami w przypadku każdego ze wschodnich sąsiadów Polski. Specyfiką tych relacji jest zamieszkiwanie mniejszości narodowych w bezpośrednim sąsiedztwie granic międzypaństwowych - polskiej po wschodniej stronie i ukraińskiej, białoruskiej i litewskiej po zachodniej stronie granicy. Niewątpliwie ma to znaczenie przy analizie stosunków międzypaństwowych, choć - jak twierdzi L. Nijakowski (2000) - nazywanie mniejszości narodowych „pomostami” w relacjach międzypaństwowych stało się już dyplomatycznym kanonem i retoryczną figurą politycznej poprawności. W praktyce politycznej, z powodu zaszłości historycznych oraz potrzeb bieżącej polityki wewnętrznej lub aktualnych interesów geopolitycznych, rola danej narodowości w dwustronnych relacjach państwa zamieszkania mniejszości i jej zagranicznej ojczyzny może być bardzo różna, niekoniecznie „pomostowa”.

Według R. Brubakera (1998), transgraniczne kontakty mniejszości narodowych z zagraniczną ojczyzną, obok relacji większości z mniejszością, odgrywają zasadniczą rolę w kształtowaniu stosunków narodowościowych w państwie, nadają im charakter trójstronny. W zależności od ich charakteru oraz intensywności mogą wzmacniać odrębność narodową mniejszości lub intensyfikować jej asymilację, mogą odgrywać rolę czynnika stabilizującego, jak i destabilizującego, a nawet konfliktogennego.

Wspieranie mniejszości narodowej przez zagraniczną ojczyznę może obejmować działania polityczno-prawne, społeczno-kulturalne i ekonomiczne. Ich 
skala jest uzależniona od siły więzi z rodakami za granicą oraz realnych możliwości wpływania na ich sytuację, wynikających zarówno z własnego potencjału polityczno-ekonomicznego, jak i rodzaju stosunków z państwem, na obszarze którego mniejszość zamieszkuje. Motywy takich działań mogą być zróżnicowane, od symbolicznego wspierania łączności z macierzystym państwem do wywoływania konfliktów etnicznych. Dla mniejszości narodowych wsparcie otrzymywane z zagranicznej ojczyzny stanowi ważny czynnik podtrzymywania tożsamości narodowej pod względem psychologicznym i organizacyjno-materialnym. Natomiast brak takiego wsparcia może powodować osłabienie więzi z macierzystym państwem (Żołędowski 2003).

$\mathrm{W}$ przypadku omawianych mniejszości, czynnikiem dodatkowo komplikującym dwustronne relacje „mniejszość narodowa-państwo macierzyste” jest różny status polityczny Litwy, Białorusi i Ukrainy oraz odmiennie przebiegające procesy transformacji ustrojowej, czego konsekwencją jest m.in. zróżnicowany stan relacji politycznych Polski ze wschodnimi sąsiadami.

Litwa, tak jak Polska, jest członkiem UE, Ukraina, pozostając poza strukturami integracji europejskiej, prowadzi zmienną politykę zagraniczną w zależności od rządzącej opcji oraz sytuacji gospodarczej, z kolei Białoruś, z powodu nieakceptowanej w państwach UE polityki wewnętrznej, znajduje się na peryferiach politycznych Europy. Łemkowie nie mają i nigdy nie mieli zagranicznej ojczyzny, natomiast przez kilkaset lat zamieszkiwali pogranicze polsko-słowackie, a z mieszkającymi na Słowacji Rusnakami tworzą wspólną społeczność rusińską. Jednak sytuacja ta w żaden sposób nie przekłada się na stosunek Słowacji do żyjących w Polsce Łemków, ani na postrzeganie państwa słowackiego przez Łemków.

\section{Ukraińcy}

Polsko-radziecka granica skutecznie utrudniała kontakty między Polakami a Ukraińcami oraz niszczyła wielokulturowy charakter pogranicza. Po obu stronach władze komunistyczne zarówno polskie, jak i radzieckie prowadziły politykę asymilacji mniejszości narodowych. W jej efekcie w ciagu 30 lat (19591989) liczba ludności polskiej na Ukrainie zmniejszyła się według oficjalnych statystyk z 363,3 tys. do 219,2 tys. osób, a w przygranicznym obwodzie lwowskim o ponad połowe, z 59,1 tys. do 26,9 tys. W Polsce, w wyniku wysiedlenia i rozproszenia Ukraińców na ziemiach północnych i zachodnich, proces asymilacji postępował jeszcze szybciej, choć brak jest oficjalnych statystyk dla tego okresu. Niszczono także ślady kultury i religii poszczególnych mniejszości.

Sytuacja uległa zmianie po upadku komunizmu w Polsce, rozwiązaniu ZSRR i powstaniu niepodległej Ukrainy w grudniu 1991 r. Polska była pierwszym 
państwem na świecie, które uznało niepodległość Ukrainy, już nazajutrz po jego formalnym ogłoszeniu. Dawna granica z totalitarnym ZSRR stała się granicą między dwoma niepodległymi państwami. Jej przekraczanie zostało znacznie ułatwione. Obok istniejącego, przez kilkadziesiąt lat jedynego, przejścia granicznego w Medyce powstały nowe - drogowe i kolejowe - w Dorohusku, Hrebennem, Hrubieszowie, Korczowej, Krościenku, Przemyślu, Werchratej, Zosinie. Nowa sytuacja polityczna dała nadzieję na ożywienie polsko-ukraińskiego pogranicza, które w czasach komunistycznych było „martwe” pod względem ekonomicznym, społecznym i kulturowym (Barwiński 2009b).

Od początku lat 90. XX w. polskie regiony przygraniczne, opierając się na istniejących wzorcach europejskich, rozpoczęły współpracę transgraniczną w ramach euroregionów. Na pograniczu polsko-ukraińskim funkcjonują dwa duże euroregiony: „Karpacki” (od 1993 r., jako drugi w Polsce) i „Bug” (od 1995 r.). Ich zasięg obejmuje m.in. całą strefę pogranicza polsko-ukraińskiego. Głównymi celami funkcjonowania euroregionów jest inicjowanie i koordynowanie działań dotyczących transgranicznej współpracy gospodarczej, naukowej, kulturalnej, oświatowej, turystycznej, ekologicznej oraz promocja regionu. Powstanie euroregionu „Karpackiego” (obejmującego szeroki obszar pogranicza Polski, Ukrainy, Słowacji, Rumunii i Węgier) wynikało także z obaw państw Europy Zachodniej przed konfliktami na tle etnicznym i odrodzeniem nacjonalizmów. Obawiano się, że ten fragment Europy może ponownie stać się zarzewiem konfliktów narodowościowych, podobnych do tych, które destabilizowały wówczas Bałkany (Ślęzak 2004). Specyficzną cechą obu euroregionów na początku ich funkcjonowania był, inaczej niż w euroregionach na granicy zachodniej i południowej, marginalny udział lokalnych władz samorządowych w ich tworzeniu i funkcjonowaniu, natomiast dominujący udział władz centralnych i wojewódzkich (Sobczyński 2001b, 2005). Po akcesji Polski do UE w 2004 r. zdecydowanie wzrosła rola władz samorządowych jako inicjatora polsko-ukraińskiej współpracy transgranicznej.

Ożywienie pogranicza widać także w dynamice ruchu granicznego. Od połowy lat 90 . XX w. utrzymywała się tendencja rosnąca, z niewielkim załamaniem w 1998 r. Zdecydowany wzrost liczby przekroczeń granicy, do ponad $19 \mathrm{mln}$ osób rocznie, miał miejsce w latach 2005-2007 (ryc. 17). Pół roku wcześniej, w maju 2004 r., nastąpiła kolejna istotna zmiana polityczna na pograniczu polsko-ukraińskim, czyli akcesja Polski do Unii Europejskiej. Jedną z konsekwencji było przekształcenie granicy polsko-ukraińskiej w zewnętrzną granicę UE wraz z wszelkimi obostrzeniami, m.in. wzmożoną kontrolą i wprowadzeniem obowiązku wizowego dla obywateli państw spoza UE. Gwałtowne zwiększenie ruchu granicznego w tym okresie było zaskakujące, zważywszy na nowe 
wymogi formalne związane z przekraczaniem granicy, dotyczące głównie tzw. wiz unijnych ${ }^{133}$. Można stwierdzić, iż to właśnie akcesja Polski do UE wpłynęła na wzrost ruchu granicznego. Polska jako członek UE stała się krajem atrakcyjnym dla wielu cudzoziemców ze wschodu, wzrosło zainteresowanie gospodarką, handlem i turystyką zarówno w Polsce, jak i na Ukrainie. Porównując ukraiński odcinek granicy z innymi polskimi fragmentami zewnętrznej granicy UE (z Rosją i Białorusia), łatwo zauważyć, że wzrost dynamiki ruchu granicznego po 2004 r. dotyczył tylko granicy z Ukraina, na której ruch stał się wyraźnie większy niż na obu pozostałych granicach ${ }^{134}$ (ryc. 17).

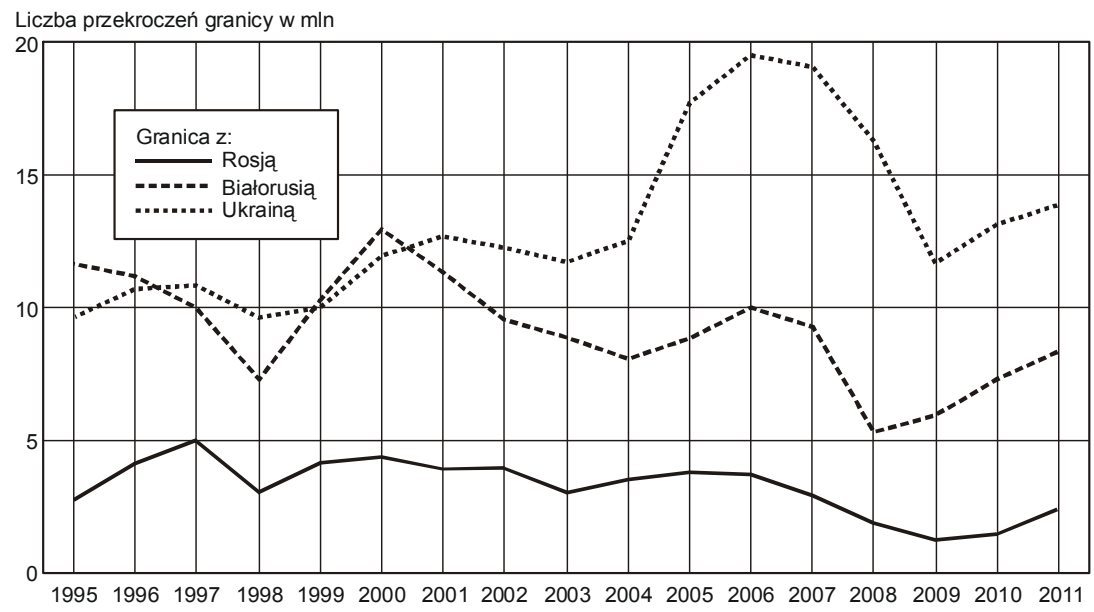

Ryc. 17. Osobowy ruch graniczny na polskim odcinku zewnętrznej granicy UE (granica z Rosją, Białorusią i Ukrainą) w latach 1995-2011 135

Źródło: opracowanie własne na podstawie: www.strazgraniczna.pl

Sytuacja uległa drastycznej zmianie trzy lata później, w momencie przystapienie Polski do układu z Schengen w grudniu 2007 r. Nałożenie na obywateli Ukrainy opłat za wizy do wszystkich państw strefy Schengen, w tym i Polski,

133 Od początku lat 90. XX w. wystarczył łatwy do uzyskania voucher, żeby przekroczyć wschodnią granicę, od 2003 r. obywatele Ukrainy musieli posiadać wizy wjazdowe do Polski, lecz były one bezpłatne, wielokrotne i łatwe do uzyskania. Po przystąpieniu Polski do UE wprowadzono tzw. wizy unijne, które były trudniejsze do uzyskania, lecz nadal, do grudnia 2007 r., dla obywateli Ukrainy bezpłatne. Polacy nie muszą posiadać wiz przy wjeździe na Ukrainę.

${ }^{134}$ Osobowy i towarowy ruch na granicy polsko-białoruskiej w głównej mierze dotyczy obywateli Rosji, dla których Białoruś jest krajem tranzytowym.

${ }^{135}$ Dotyczy wyłącznie lądowych przejść granicznych, nie dotyczy ruchu drogą lotniczą i morską. 
oraz zbiurokratyzowanie procedur ubiegania się o nie spowodowało załamanie ruchu granicznego. W ciągu zaledwie dwóch lat (2008-2009) liczba osób przekraczających granicę polsko-ukraińską spadła z ponad $19 \mathrm{mln}$ do zaledwie 11,7 mln i, mimo zarysowującej się od dwóch lat tendencji wzrostowej, nadal jest zdecydowanie niższa niż 5-7 lat temu (ryc. 17).

Radykalne zmniejszenie przyjazdów obywateli Ukrainy do Polski po 2007 r. wpłynęło na załamanie nadgranicznej wymiany handlowej, co ma negatywne konsekwencje dla części mieszkańców pogranicza. Od początku lat 90. XX w. dobre relacje Polski i Ukrainy bezpośrednio przekładały się na korzyści ekonomiczne, niezwykle ważne dla tego regionu. Wynikały one m.in. z mobilności i zaradności mieszkańców, którzy często przekraczali granicę w związku z lokalnym handlem, przemytem alkoholu i papierosów oraz poszukiwaniem pracy, ale także z powodów rodzinnych i turystycznych. Jedną z konsekwencji wymiany transgranicznej były częste, czasami stałe, kontakty mieszkańców pogranicza $\mathrm{z}$ osobami z drugiej strony granicy, $\mathrm{z}$ ich językiem i kulturą. Miało to także wpływ na postrzeganie zamieszkujących pogranicze mniejszości narodowych (Wojakowski 1999, 2002, 2007). Uszczelnienie granicy w ramach przygotowań do wejścia Polski do UE oraz zaostrzenie rygorów wizowych w grudniu 2007 r. w bardzo istotny sposób ograniczyło wzajemne kontakty.

Mówiąc o polsko-ukraińskim ruchu granicznym, trzeba pamiętać o dużej roli polskich wycieczek turystycznych, zwłaszcza na zachodnią Ukrainę których popularność w ostatnich latach bardzo wzrosła. Mają najczęściej charakter sentymentalno-historyczny i można je porównać do niemieckich wycieczek na Śląsk czy Mazury. Z roku na rok rośnie ich znaczenie ekonomiczne dla Ukraińców, a także dla Polaków na Ukrainie, ponadto są jednym z elementów wzajemnego bliższego poznania i poprawy relacji polsko-ukraińskich.

Pomimo historycznego wymiaru akcesji Polski do UE, członkowie mniejszości polskiej na Ukrainie oraz ukraińskiej w Polsce, pytani podczas badań ankietowych jesienią $2007 \mathrm{r} .{ }^{136}$ o pozytywne i negatywne zmiany w relacjach polsko-ukraińskich po wejściu Polski do UE, najczęściej odpowiadali, że żadnych zmian nie dostrzegają lub częściej wskazywali zmiany negatywne niż pozytywne. Zdecydowanie najczęściej deklarowaną zmianą negatywną było wprowadzenie nowych przepisów wizowych, które utrudniły życie mieszkańcom pogranicza po stronie ukraińskiej i polskiej. Respondenci zauważali także

136 Badania zostały przeprowadzone na obszarze Polski i Ukrainy wśród 265 mieszkańców pogranicza polsko-ukraińskiego (w tym 126 respondentów z Polski oraz 139 z Ukrainy). Respondenci z Polski to przedstawiciele mniejszości ukraińskiej, natomiast z Ukrainy - przedstawiciele mniejszości polskiej (Lis 2008). 
pozytywne zmiany w relacjach polsko-ukraińskich, choć trudno je traktować jako bezpośredni wynik rozszerzenia UE. Były one raczej efektem medialnych doniesień, w których często pojawiały się informacje o zaangażowaniu Polski w integrację Ukrainy z UE i NATO oraz wspólnej organizacji Euro 2012. Zmiany najczęściej deklarowane przez respondentów miały przede wszystkim wymiar polityczny, były konsekwencją międzynarodowych umów oraz traktatów. Porozumienia te na ogół nie mają istotnego przełożenia na relacje między Polakami a Ukraińcami, jednak mają duży wpływ na pogranicze i jego mieszkańców (np. przepisy wizowe). Negatywne efekty przystąpienia Polski do UE były bardziej zauważalne, ponieważ dotyczyły ruchu granicznego, z którym duża część mieszkańców pogranicza ma osobiste doświadczenia, z kolei pozytywne aspekty były zdecydowanie słabiej dostrzegane przez respondentów, przede wszystkim dlatego, iż nie dotyczyły ich bezpośrednio i nie miały wpływu na ich codzienne życie (Lis 2008).

Natomiast według liderów organizacji ukraińskich w Polsce, zdecydowanie pozytywnie oceniających członkostwo Polski w UE, jego najistotniejszą konsekwencją dla społeczności ukraińskiej jest monitorowanie sytuacji mniejszości przez instytucje europejskie, większa podmiotowość mniejszości, większe zrozumienia władz dla jej postulatów oraz możliwość odwołania się do instytucji europejskich ${ }^{137}$. Dopiero na dalszych miejscach znajdują się aspekty finansowe, wynikające głównie z możliwości pośredniego zdobywania środków unijnych, poprzez granty uzyskiwane w samorządach lub możliwość dofinansowania remontów zabytkowych świątyń prawosławnych i greckokatolickich.

Niepodległa Ukraina w znikomym stopniu wspiera mniejszość ukraińską w Polsce. Według działaczy organizacji ukraińskich, przez pierwsze kilkanaście lat niepodległego bytu państwa ukraińskiego tego wsparcia praktycznie nie było. Dopiero dojście do władzy prezydenta Wiktora Juszczenki w 2005 r. zapoczątkowało trwającą nadal współpracę między rządem ukraińskim a organizacjami mniejszości ukraińskiej w Polsce. Przejawia się ona w częściowym finansowaniu (głównie przez MSZ Ukrainy) dużych imprez kulturalnych, festiwali, konferencji organizowanych przez ukraińskie stowarzyszenia, współfinansowaniu przyjazdów zespołów folklorystycznych z Ukrainy, wsparciu materialnym dla szkół uczących języka ukraińskiego (komputery, książki, prasa) oraz w wizytach polityków ukraińskich na różnego rodzaju uroczystościach. W zgod-

${ }^{137}$ Zgodnie z ustawodawstwem Unii Europejskiej, nie ma możliwości zaskarżenia do instytucji unijnych państwa odmawiającego wspierania mniejszości narodowych, natomiast jest możliwość skierowanie tego typu skargi do Europejskiego Trybunału Praw Człowieka w Strasburgu, czyli instytucji Rady Europy (Budyta-Budzyńska 2010). 
nej opinii działaczy ukraińskich to wsparcie jest zdecydowanie niewystarczające, zwłaszcza po 2010 r. i przegranych przez Wiktora Juszczenkę wyborach prezydenckich. Jest także nawiązywana bezpośrednia współpraca z organizacjami z Ukrainy, m.in. z Ukraińskim Towarzystwem Oświatowym, Towarzystwem „Chołmszczyna”, szeregiem ukraińskich organizacji pozarządowych, a także z Federacją Organizacji Polskich na Ukrainie ${ }^{138}$.

Mimo licznej społeczności polskiej zamieszkującej Ukrainę ${ }^{139}$, wyraźnej (niekorzystnej dla Polaków) asymetrii w prawach przysługujących mniejszości polskiej na Ukrainie i ukraińskiej w Polsce, kwestia sytuacji mniejszości narodowych nie stanowi kluczowego tematu w oficjalnych, międzypaństwowych stosunkach polsko-ukraińskich, szczególnie w porównaniu z relacjami z Litwą lub Białorusią. Dużo istotniejszymi problemami są kwestie gospodarcze i geopolityczne. Natomiast aktywną działalność wśród kilkudziesięciu polskich organizacji na Ukrainie prowadzą organizacje pozarządowe, szczególnie Stowarzyszenie Wspólnota Polska oraz Federacja Organizacji Kresowych, a także kilka fundacji, m.in. Fundacja Pomocy Polakom na Wschodzie. Pomoc udzielana jest również przez polskie samorządy i miasta partnerskie oraz organizacje polonijne z zachodniej Europy i USA. Z kolei władze państwowe (zwłaszcza Senat RP, Ministerstwo Spraw Zagranicznych oraz Ministerstwo Kultury i Dziedzictwa Narodowego) wspierają polskie szkolnictwo na Ukrainie, biblioteki, działalność wydawniczą i kulturalną polskich organizacji, współfinansują konferencje naukowe, a także remonty świątyń, cmentarzy, miejsc pamięci. Często jest to swoista rekompensata niewystarczającego finansowania ze strony władz ukraińskich. Wsparcie z Polski, organizowane głównie przez Stowarzyszenie Wspólnota Polska, przejawia się także w inwestycjach w infrastrukturę organizacyjną i szkolną, pokrywaniu czynszów i opłat komunalnych polskich stowarzyszeń, zakupach wyposażenia biur i szkół, szkoleniach nauczycieli i instruktorów, przekazywaniu książek, stypendiach dla uczniów, organizowaniu kolonii i pomocy socjalnej ${ }^{140}$. Skala potrzeb jest oczywiście niewspółmierna do przekazywanej pomocy.

${ }^{138} \mathrm{Na}$ podstawie wywiadów przeprowadzonych przez autora w 2012 r. z liderami Związku Ukraińców w Polsce, Związku Ukraińców Podlasia, Towarzystwa Ukraińskiego.

${ }^{139}$ Według ukraińskiego spisu ludności z 2001 r. 144 tys. osób, natomiast według różnych szacunków polskich organizacji od ok. 150 tys. do 900 tys. osób.

${ }^{140}$ Pomoc finansowa o podobnej strukturze wydatków polskich władz i organizacji pozarządowych oraz fundacji jest także kierowana do Polaków oraz polskich organizacji i instytucji na Litwie i Białorusi. 
Oficjalne relacje polityczne między Polską a Ukrainą od 1991 r. były poprawne, choć nie wolne od wzajemnych uprzedzeń i stereotypów. Przełomowym momentem była dopiero tzw. pomarańczowa rewolucja na Ukrainie (21 listopada 2004 r. - 23 stycznia 2005 r.), podczas której Polska zdecydowanie i skutecznie poparła ukraińskie ugrupowania demokratyczne domagające się powtórzenia sfałszowanych wyborów oraz pełnego uniezależnienia Ukrainy od Rosji. Po objęciu urzędu prezydenta Ukrainy przez Wiktora Juszczenkę (2005-2010), Polska stała się jednym z najbliższych parterów politycznych Ukrainy, niejednokrotnie odgrywającym rolę jej ,adwokata” na forum UE i NATO. Rola ta często była utrudniana i ograniczana sporami frakcji prezydenta Juszczenki i premier Tymoszenko, a zwłaszcza wyraźnym zbliżeniem „pomarańczowych” władz Ukrainy z ugrupowaniami ukraińskich nacjonalistów ${ }^{141}$. Mimo problemów, wzajemne relacje polityczne przejawiały się w aktach symbolicznego pojednania (np. na cmentarzach we Lwowie czy na Wołyniu) i we wspólnych działaniach na arenie międzynarodowej oraz wspólnych projektach gospodarczych i sportowych. Przyznanie Polsce i Ukrainie organizacji mistrzostw Europy w piłce nożnej w 2012 r. stało się kolejnym pozytywnym czynnikiem dalszej aktywizacji współpracy polsko-ukraińskiej. Polityka kolejnych polskich rządów wobec Ukrainy, choć nie zawsze konsekwentna, miała na celu wzmocnienie mechanizmów demokratycznych oraz jak najściślejsze powiązanie Ukrainy ze strukturami zachodnioeuropejskimi, co jest niezwykle istotne z punktu widzenia polskich interesów geopolitycznych. Obecna skomplikowana wewnętrzna sytuacja polityczna Ukrainy pod rządami prezydenta Wiktora Janukowycza oraz zwrot ukraińskich elit polityczno-gospodarczych w stronę Rosji czynią tę współpracę coraz trudniejsza, a wzajemne relacje polityczne ponownie można określić najwyżej jako poprawne.

Ponadto są one silnie obciążone historią, która w przypadku dziejów polsko-ukraińskich nabiera szczególnego wymiaru. Szeroko pojęte pogranicze polsko-ukraińskie jest obszarem, na którym wielokrotnie miały miejsce krwawe konflikty etniczne, nadal żywe w zbiorowej świadomości narodu polskiego i ukraińskiego. Zaszłości historyczne i narodowe resentymenty ujawniają się m.in. w sporach wokół organizacji różnego rodzaju imprez narodowych lub kulturalnych poszczególnych mniejszości po obu stronach granicy, pomników dla uczczenia żołnierzy UPA lub ich ofiar, cmentarzy z czasów I oraz II wojny światowej. Historia, także jej współczesna ocena i interpretacja, mimo kilku-

141 Prezydent Wiktor Juszczenko przez całą kadencję prowadził politykę gloryfikowania UPA oraz OUN, m.in. przyznał Stepanowi Banderze tytuł „Bohatera Ukrainy”, co zostało uchylone decyzją sądu w 2011 r. 
krotnych gestów pojednania, nadal zdecydowanie bardziej dzieli niż łączy Polaków i Ukraińców w obu państwach ${ }^{142}$.

\section{Lemkowie}

Rusini w północnych Karpatach, zarówno mieszkający w Polsce Łemkowie, jak i słowaccy Rusnacy, pod względem pochodzenia etnicznego stanowią jedną grupę, wyraźnie odrębną od Polaków i Słowaków. Pomimo wspólnego pochodzenia nazwy „Łemko” oraz „Rusnak” mają charakter typowy regionalny, ściśle przyporządkowany do zamieszkiwanego obszaru. Okres rozbicia jedności Rusinów karpackich rozpoczął się wraz z zakończeniem I wojny światowej, jednak dopiero wydarzenia po II wojnie skutecznie rozdzieliły losy Łemków i Rusnaków, a kontakty między nimi praktycznie zanikły. Główną przyczyną były wysiedlenia Łemków z północnych Karpat, zniewolenie stalinowskim reżimem oraz restrykcyjne przepisy administracyjne, skutecznie ograniczające ruch graniczny, także między „bratnimi” państwami socjalistycznymi.

Na Słowacji Rusini nie zostali przymusowo wysiedleni, a ich liczebność po wojnie była szacowana na ok. 100 tys. osób. W 1946 r., na mocy porozumienia władz czechosłowackich i radzieckich, zorganizowano przesiedlenia Czechów i Słowaków z ZSRR do Czechosłowacji w zamian za migrację Rusinów ze Słowacji na obszar Ukrainy. Przesiedlenie to było dobrowolne. Skorzystało z niego ok. 12 tys. słowackich Rusinów, z których większość rozczarowana sytuacją materialną i społeczną w ZSRR zdołała w latach 60 . XX w. powrócić do Czechosłowacji (Mušynka 1993).

Na początku lat 50. XX w. tradycyjne na Słowacji określenia „Rusin” lub „Rusnak” zostały przez czechosłowackie władze komunistyczne urzędowo zmienione na etnonim Ukrainiec, który stał się jedynym oficjalnym określeniem Rusinów, także w spisach powszechnych. Część Rusinów, protestując przeciw uznawaniu ich za Ukraińców, w kolejnych spisach ludności deklarowała narodowość słowacką. W regionie preszowskim w 1930 r. narodowość rusińską zadeklarowało 91 tys. osób, natomiast w 1961 r., podczas spisu, w którym istniała możliwość wyboru narodowości słowackiej lub ukraińskiej (deklarowanie narodowości rusińskiej było zakazane), tę drugą podało już tylko 33 tys. osób, pozostali wybrali narodowość słowacką. Pokazuje to zarówno sprzeciw Rusinów przeciwko narzuconej przez władze ukrainizacji, jak i zachodzące wśród tej mniejszości procesy asymilacji, słowakizacji. Oba te czynniki przyczyniły się do szybkiego spadku liczby Rusinów zamieszkujących południowe stoki Karpat.

${ }^{142}$ Potwierdzają to wyniki różnego rodzaju badań socjologicznych, m.in. G. Babińskiego (1997) i A. Lisa (2008). 
Nadzieje na większe swobody dla słowackich Rusinów przyniosły wydarzenia „Praskiej Wiosny” w 1968 r. Jednak bardzo szybko okazały się one złudne (Mušynka 1993, Magocsi 2002).

W latach 70. XX w. nastapiła pewna liberalizacja przepisów administracyjnych. Nie poprawiło to jednak w zasadniczy sposób możliwości kontaktów słowackich Rusinów i polskich Łemków. Przepisy o ruchu granicznym były nadal bardzo rygorystyczne. Istniały problemy z uzyskaniem paszportu, potrzebne były specjalne zaproszenia. Na obszarze Łemkowszczyzny funkcjonowały tylko dwa drogowe i jedno kolejowe przejście graniczne. Władze Polski i Czechosłowacji nie akceptowały odrębności etnicznej Łemków (Rusinów), nadal utożsamiając ich z mniejszością ukraińską, co uniemożliwiało nawiązanie współpracy kulturalnej. Ponadto w północnych Karpatach obecność Łemków, na skutek przesiedleń, była liczebnie marginalna. Wszystkie te czynniki bardzo skutecznie ograniczały wzajemne kontakty Łemków (Rusinów) mieszkających w Polsce i na Słowacji.

Sytuacja polityczna w Polsce i Czechosłowacji w latach 1945-1989 spowodowała, na niespotykaną wcześniej skalę, podział i izolację rusińskich mieszkańców Karpat pod względem etnicznym, społecznym, kulturowym i gospodarczym. Poprawa stała się możliwa dopiero po 1989 r., czyli po odzyskaniu pełnej niepodległości przez kraje środkowej Europy. Na początku lat 90. XX w. skończyły się problemy z przekraczaniem karpackiej granicy. Paszporty stały się łatwo dostępne, obywatele Polski i Słowacji nie potrzebowali już zaproszeń ani wiz. Powstały nowe przejścia graniczne, uruchomiono stałe połączenia autokarowe między przygranicznymi miastami polskimi i słowackimi.

Kolejna istotna zmiana sytuacji politycznej i administracyjnej miała miejsce w 2004 r. i była związana z wstapieniem Polski i Słowacji do struktur UE, a trzy lata później do strefy Schengen. Dwudziestego pierwszego grudnia 2007 r. zniesiono całkowicie kontrolę graniczną między Polską a Słowacją jednoczenie umożliwiając przekraczanie granicy w dowolnym miejscu. Po raz pierwszy od kilkudziesięciu lat granica wytyczona wzdłuż północnego łuku Karpat przestała pełnić funkcję bariery, a kontakty między Łemkami (Rusinami) z południa i północy Karpat stały się, przynajmniej pod względem administracyjnym i komunikacyjnym, najłatwiejsze w historii (Barwiński, Leśniewska 2011).

Obecnie Łemkowie i Rusnacy najliczniej spotykają się z okazji różnorodnych festiwali kultury łemkowskiej. Na odbywające się w Zdyni corocznie Święto Kultury Łemkowskiej „Łemkowska Watra” przybywa kilka tysięcy Rusinów z Polski, Słowacji, Ukrainy. Równie znane i licznie odwiedzane są „Rusnalia” w Zyndranowej. Największym festiwalem słowackich Rusinów jest coroczny Festiwal Kultury Rusinów-Ukraińców Słowacji w Świdniku. 
Upadek komunizmu i zmiany ustrojowe umożliwiły także podjęcie inicjatyw prawdziwej współpracy transgranicznej. W 1993 r. powstała w Krynicy Unia Gmin Turystyczno-Uzdrowiskowych, do której należy kilka polskich i słowackich gmin karpackich. W tym samym roku województwa Polski południowo-wschodniej wraz ze swymi odpowiednikami z Ukrainy, Słowacji i Węgier, utworzyły euroregion „Karpacki”.

Obszar zamieszkany przez Rusinów (Rusnaków) na Słowacji nie ma, tak jak w przypadku polskiej Łemkowszczyzny, specyficznej, własnej nazwy ani precyzyjnie wyznaczonych granic. Nazwą najczęściej używaną w literaturze jest region preszowski, jednostka administracyjna odpowiadająca rangą polskim województwom.

Interesujące jest porównanie liczby deklaracji narodowości rusińskiej i ukraińskiej w słowackich Karpatach podczas spisów ludności w 1991, 2001 i 2011 r. (tab. 14). W 1991 r., bezpośrednio po upadku systemu komunistycznego w Czechosłowacji, podczas pierwszego od kilkudziesięciu lat spisu ludności, w którym można było podać narodowość rusińską, została ona zadeklarowana przez 17,2 tys. osób, przy 13,3 tys. deklaracji narodowości ukraińskiej. Dziesięć lat później liczba Rusinów zwiększyła się o ok. 35\%, przy jednoczesnym spadku liczby Ukraińców, natomiast w trakcie ostatniego spisu w 2011 r. aż 33,5 tys. obywateli Słowacji określiło się jako Rusini, a tylko 7,4 tys. jako Ukraińcy ${ }^{143}$. Podczas ostatnich 20 lat liczba deklaracji narodowości rusińskiej zwiększyła się dwukrotnie, natomiast o połowę zmniejszyła się liczba Ukraińców. Wyniki słowackich spisów jednoznacznie pokazały renesans rusińskich postaw narodowych „kosztem” narodowości ukraińskiej oraz niewielką skuteczność działań władz komunistycznych w Czechosłowacji, które od lat 50. do początku lat 90. XX w. starały się narzucić słowackim Rusinom ukraińską tożsamość narodową.

Tabela 14. Deklaracje narodowości rusińskiej i ukraińskiej podczas spisów ludności na Słowacji (w tys.)

\begin{tabular}{|l|c|c|c|}
\hline \multirow{2}{*}{ Narodowości } & \multicolumn{3}{|c|}{ Rok } \\
\cline { 2 - 4 } & 1991 & 2001 & 2011 \\
\hline Rusini & 17,2 & 24,2 & 33,5 \\
Ukraińcy & 13,3 & 10,8 & 7,4 \\
\hline
\end{tabular}

Źródło: opracowanie własne na podstawie: www.portal.statistics.sk

${ }^{143}$ Rusini są obecnie trzecią pod względem liczebności mniejszością narodową na Słowacji, po Węgrach i Romach, na podstawie: http://portal.statistics.sk. 
W regionie preszowskim, który w całości obejmuje obszar historycznie zamieszkany przez Rusnaków, w 2011 r. narodowość rusińską zadeklarowało 28,8 tys. osób, co dowodzi, że region ten nadal jest zdecydowanie najliczniejszym skupiskiem Rusinów. Największy ich udział - między 10\% a 45\% ogółu mieszkańców - odnotowano w przygranicznych powiatach Świdnik, Medzilaborce i Snina.

Podczas spisu powszechnego na Słowacji zadano także pytanie o wyznawaną religię. W $2011 \mathrm{r}$. w regionie preszowskim wyznanie greckokatolickie zadeklarowało 114,8 tys. osób, a prawosławne 29,5 tys. osób. Można założyć, iż większość z tych osób jest pochodzenia rusińskiego lub ukraińskiego. Porównanie danych dotyczących deklaracji wyznaniowych i narodowościowych pokazuje, iż łączna liczba wyznawców Kościołów wschodnich w regionie preszowskim (144,3 tys.) jest ponad czterokrotnie wyższa niż łączna liczba osób deklarujących narodowość rusińską i ukraińską (32,5 tys.). Obrazuje to skalę asymilacji, słowakizacji Rusinów w ciągu ostatnich kilkudziesięciu lat. Na Słowacji, podobnie jak w Polsce, tożsamość religijna tradycyjnych, w większości wiejskich społeczności, najtrudniej poddaje się asymilacji. Szybciej procesy te zachodzą w poczuciu tożsamości narodowej i językowej.

Po upadku systemu komunistycznego, problem asymilacji Rusinów nie zanikł, choć wyniki ostatnich spisów powszechnych wskazują na zahamowanie, a nawet cofnięcie się procesu słowakizacji. Różnica polega na tym, iż obecnie nie są to działania narzucone, odgórne, administracyjne, lecz jest to proces samoczynny, będący m.in. efektem nasilających się zmian gospodarczych i społecznych, dalszego napływu Słowaków w Karpaty. Natomiast pod względem regulacji prawnych oraz praktyki administracyjnej nastapiła bardzo duża poprawa sytuacji. Rusini na Słowacji objęci są ochroną prawną państwa zakazującą ich dyskryminacji, mają status mniejszości narodowej (a nie etnicznej, jak Łemkowie w Polsce), w szkołach nauczany jest język rusiński.

Wśród słowackich Rusinów występuje podobny dualizm narodowy rusińsko-ukraiński jak w Polsce. Znajduje to także odzwierciedlenie w działalności organizacyjnej. Po 1990 r., obok organizacji o proukraińskiej opcji narodowej, takich jak m.in. Stowarzyszenie Ukrainistów Słowacji (Asociacija Ukrainistiv Slovaččyny) czy Związek Rusinów-Ukraińców Słowacji (Sojuz Rusiniv-Ukrajinciv Slovaččyny), rozpoczęły swą działalność organizacje głoszące ideę odrębności narodu rusińskiego, z których najważniejsze to Odrodzenie Rusińskie (Rusins'ka Obroda) i Stowarzyszenie Rusińskiej Inteligencji Słowacji (Združinja Inteligenciji Rusyniv Slovenska).

Likwidacja barier administracyjnych na granicy polsko-słowackiej, po akcesji obu państw do Unii Europejskiej i strefy Schengen, nie wpłynęła w szcze- 
gólny sposób na aktywizację Rusinów z obu stron Karpat, nie spowodowała powstania nowych form transgranicznej rusińskiej współpracy organizacyjnej. Nie funkcjonują obecnie żadne wspólne polsko-słowackie organizacje rusińskie. Jedną z przyczyn jest z pewnością rozproszenie Łemków na terytorium Polski. Najliczniejsze oraz aktywne organizacyjnie skupiska znajdują się na Dolnym Śląsku, kilkaset kilometrów od Bardejowa, Preszowa, Świdnika, Medzilaborców, a pogranicze polsko-słowackie w Beskidzie Niskim należy do najrzadziej zaludnionych regionów Polski.

Głównym forum współpracy i rusińskiej integracji są międzynarodowe organizacje zrzeszające Rusinów (a raczej rusińskie organizacje) z wielu państw (Polski, Słowacji, Ukrainy, Węgier, Serbii, Chorwacji, Rumunii, USA, Kanady). Dla działaczy o orientacji narodowo-rusińskiej (w tym dla Stowarzyszenia Łemków) jest to aktywnie działający od początku lat 90. XX w. Światowy Kongres Rusinów z siedzibą w Preszowie, propagujący ideę narodu karpatoruskiego i Rusi Karpackiej jako wspólnej ojczyzny wszystkich Rusinów ${ }^{144}$. Dla działaczy narodowo-ukraińskich natomiast (w tym dla Zjednoczenia Łemków) takim forum współpracy jest Światowa Federacji Ukraińskich-Łemkowskich Organizacji. Liderzy poszczególnych organizacji łemkowskich, rusińskich i ukraińskich z Polski i Słowacji spotykają się na różnego rodzaju imprezach kulturalnych, festiwalach oraz kongresach i konferencjach naukowych, jednak w swojej codziennej działalności skupiają się głównie na mniejszościach we własnym kraju.

Wyniki badań przeprowadzonych w 2005 r., pośród Łemków i Rusnaków, pokazały, że pomimo podziału Karpat granicą państwową nie zanikło poczucie wspólnoty, przynależności do jednej społeczności. Aż 83\% respondentów w regionie preszowskim oraz 79\% na Łemkowszczyźnie uważało, że Rusini polscy i słowaccy tworzą jedną grupę społeczną. Spośród cech, które najbardziej ich łączą, respondenci najczęściej wymieniali religię, język, pochodzenie etniczne, więzi rodzinne oraz zamieszkiwanie w Karpatach ${ }^{145}$ (Mazurek 2005). Jednak idea przynależności Łemków i Rusnaków do szerszej wspólnoty rusińskiej, mimo że egzystuje w świadomości dużej części tych społeczności, zwłaszcza wśród działaczy ruchu karpatorusińskiego, nie ma praktycznego przełożenia na rzeczywistość, jest pewnego rodzaju mitem funkcjonującym wśród karpackich Rusinów.

${ }^{144}$ Obszernie o ruchu karpatorusińskim na Słowacji, Ukrainie i w Polsce, pisze m.in. E. Michna (2004) w pracy pt. Kwestie etniczno-narodowościowe na pograniczu słowiańszczyzny wschodniej $i$ zachodniej.

145 Badania przeprowadzono w 2004 r. wśród 195 respondentów rusińskich mieszkających w Karpatach, w tym 97 z Polski i 98 ze Słowacji (Mazurek 2005). 
Specyficzna sytuacji Łemków (Rusinów), w porównaniu np. z Ukraińcami, Białorusinami i Litwinami, przejawia się m.in. w tym, że jako grupa nie posiadają oni własnego państwa narodowego, z jego strukturami politycznymi, gospodarczymi, organizacyjnymi. Nie mogą liczyć na żadne wsparcie czy pomoc (prawną, finansową, polityczną) zagranicznej ojczyzny. Są natomiast objęci opieką i pomocą państwa, w którym zamieszkują i którego są obywatelami, nie tylko na mocy Konstytucji oraz ustaw dotyczących mniejszości narodowych, ale także na podstawie przepisów prawa międzynarodowego gwarantującego ochronę mniejszości narodowych i etnicznych.

Poczucie braku odniesienia do zagranicznej ojczyzny jest powszechne, bez względu na wyraźnie dzielące Łemków orientacje narodowe. Działacze Stowarzyszenia Łemków - co jest zrozumiałe - zdecydowanie odcinają się od państwa ukraińskiego, podkreślają, że nie mają z nim nic wspólnego, ale jednocześnie, mimo zaangażowania w ruch karpatorusiński nie traktują Słowacji czy innego państwa jako kraju macierzystego, podkreślają, że ich ojczyzną, ich państwem jest Polska. Z kolei liderzy Zjednoczenia Łemków, uważający Łemków za część narodu ukraińskiego, przyznają, że mają do państwa ukraińskiego sentyment, odczuwają z nim więź duchową, ale nie traktują Ukrainy jako swojej ojczyzny ich ojczyzną jest Polska, a zwłaszcza Łemkowszczyzna. Jedynie działacze Stowarzyszenia Młodzieży Łemkowskiej „Czuha”, kategorycznie odżegnujący się od Ukrainy i silnie zaangażowani w ruch karpatorusiński, deklarują przywiązanie do idei i historii Rusi Karpackiej jako swoistej macierzy, jednocześnie podkreślając niezmienność granic międzypaństwowych w Europie Środkowej i brak dążenia do tworzenia odrębnego rusińskiego państwa.

Liderzy organizacji łemkowskich pozytywnie oceniają zmiany spowodowane akcesją Polski do UE, choć podkreślają, że dla Łemków te zmiany nie są zbyt istotne, głównie z powodu niewielkiej skali zarówno całej społeczności, jak i samych organizacji. Za najistotniejsze uważają brak kontroli na granicach ze Słowacją, Węgrami i Rumunią, co ułatwia wzajemne kontakty i współpracę z tamtejszymi Rusinami ${ }^{146}$.

\section{Białorusini}

Po proklamacji niepodległości Republiki Białorusi w 1991 r., usamodzielnieniu byłych republik wchodzących w skład ZSRR i postępującym procesom demokratyzacji krajów Europy Środkowo-Wschodniej, powszechna była nadzie-

${ }^{146}$ Na podstawie wywiadów przeprowadzonych przez autora w 2012 r. z działaczami Stowarzyszenia Łemków, Zjednoczenia Łemków, Stowarzyszenia Młodzieży Łemkowskiej „Czuha”. 
ja na rozwój przyjaznych, partnerskich, dobrosąsiedzkich relacji ze wszystkimi nowo powstającymi wschodnimi sąsiadami Polski. Już w 1992 r. podpisano traktaty o dobrym sąsiedztwie i przyjaznej współpracy z Białorusią i Ukrainą, lecz kolejne lata zweryfikowały te oczekiwania, zwłaszcza w stosunku do Białorusi.

Władze białoruskie przejawiały zainteresowanie Białorusinami w Polsce tylko w pierwszych latach po uzyskaniu niepodległości. Zapoczątkowano pomoc materialną, głównie rzeczową, dla szkół i stowarzyszeń białoruskich, wspierano finansowo budowę Muzeum Białoruskiego w Hajnówce, domagano się od polskich władz ,zagwarantowania trwałości białoruskiego charakteru etnicznego Białostocczyzny"147. Już po kilku latach, głównie z powodu zmian politycznych na Białorusi, zainteresowanie władz w Mińsku mniejszością białoruską w Polsce ograniczyło się do minimum i zostało wyraźnie zróżnicowane w zależności od stosunku poszczególnych podlaskich organizacji białoruskich do władz politycznych oraz ugrupowań opozycyjnych na Białorusi. Z kolei przekazywanie pomocy finansowej, rzeczowej i inwestycyjnej polskich władz oraz organizacji pozarządowych dla Polaków na Białorusi często było utrudniane przez władze białoruskie, a wiele planów inwestycyjnych, zwłaszcza dotyczących polskiego szkolnictwa, nie zrealizowano z powodu braku zgody strony białoruskiej (Żołędowski 2003).

$\mathrm{W}$ połowie lat 90 . XX w. z polskiej inicjatywy podjęto próbę nawiązania transgranicznej współpracy polsko-białoruskiej w ramach licznie wówczas powstających euroregionów. W 1995 r. powołano na pograniczu polsko-ukraińskim euroregion „Bug”, do którego dołączono w 1998 r. obwód brzeski z Białorusi, natomiast w 1997 r., wspólnie z Litwą i Białorusią, utworzono euroregion „Niemen”. Jednak euroregiony w cześci białoruskiej praktycznie nie funkcjonują. Jest to spowodowane nieufnością władz białoruskich wobec Polski i UE, brakiem aktywnej współpracy, różnicami prawnymi, brakiem podmiotowości prawnej oraz finansowej samorządów białoruskich.

Dojście do władzy prezydenta Aleksandra Łukaszenki w 1994 r. rozpoczęło proces integracji politycznej z Rosją oraz resowietyzacji Białorusi, łącznie z przywróceniem flagi i godła państwowego z czasów ZSRR oraz ponownym równouprawnieniem języka rosyjskiego i białoruskiego w życiu publicznym ${ }^{148}$.

${ }^{147}$ Cytat za C. Żołędowskim (2003), s. 323.

${ }^{148}$ W latach 1991-1995 jedynym językiem urzędowym na Białorusi był białoruski. Na mocy wyników ogólnokrajowego referendum przeprowadzonego w 1995 r. wprowadzono dwa języki urzędowe: rosyjski i białoruski. Według wyników ostatniego spisu powszechnego z 2009 r., z 9,5 mln obywateli Białorusi językiem białoruskim w kontaktach domowych posługuje się zaledwie 2,2 mln osób. 
Nastąpiło stopniowe ograniczanie swobód demokratycznych i narodowych, w ciągu kilku lat władza Łukaszenki przekształciła się w autokratyczny reżim, a system polityczny Białorusi w dyktaturę. Całość życia politycznego, społecznego i gospodarczego objęto nadzorem państwa, a raczej posiadającego absolutną władzę prezydenta. Nasiliły się prześladowania nielicznej opozycji i zdecydowanie pogorszyły relacje Białorusi z państwami Europy Zachodniej, w tym z Polską. Wielokrotnie nakładane przez UE różnego rodzaju sankcje nie przyniosły istotnych zmian sytuacji politycznej na Białorusi. Nadal trwają brutalne prześladowania przeciwników politycznych, nie ma zapewnionych podstawowych swobód demokratycznych, powszechne jest łamanie praw człowieka, nie funkcjonuje współpraca polityczna z Polską oraz pozostałymi krajami UE. W wyniku polityki Łukaszenki Białoruś pozostaje poza strefą integracji europejskiej oraz nie funkcjonuje jako państwo prawa.

W 2005 r. białoruskie władze doprowadziły do rozbicia jedności Związku Polaków na Białorusi, będącego wówczas największą niezależną organizacją społeczną na Białorusi. Obecnie funkcjonują dwie polskie organizacje narodowościowe o takiej samej nazwie, jedna oficjalna, uznawana przez władze białoruskie, druga nieuznawana, dyskryminowana, współpracującą z białoruską opozycją i uznawana przez władze polskie. Mniejszość polska na Białorusi jest podzielona i wykorzystywana do bieżących rozgrywek politycznych. Część popiera dyktatorskie rządy Łukaszenki, spodziewając się różnego rodzaju przywilejów, część popiera opozycję, licząc na poprawę sytuacji Polaków po demokratyzacji Białorusi. Według wyników białoruskiego spisu powszechnego z 2009 r. narodowość polską zadeklarowało 294,5 tys. osób. Oznacza to spadek liczby Polaków o ponad 100 tys. osób w ciagu zaledwie 10 lat.

Współorganizowana i współfinansowana przez polskie władze (głównie MSZ) pomoc dla białoruskiej opozycji, organizacji pozarządowych oraz mniejszości polskiej na Białorusi jest jednym z priorytetów polskiej polityki w dziedzinie współpracy międzynarodowej na rzecz demokracji i rozwoju społeczeństwa obywatelskiego. Spotyka się ona ze zdecydowaną krytyką i przeciwdziałaniem władz białoruskich. Jednym z najbardziej spektakularnych przejawów zaangażowania polskich władz we wspieranie demokracji na Białorusi było uruchomienie na terytorium Polski Radia Racja ${ }^{149}$ oraz Telewizji Biełsat ${ }^{150}$.

${ }^{149}$ Niepubliczna stacja radiowa nadająca z Białegostoku i Białej Podlaskiej programy w języku białoruskim (dostępne także w Internecie), przeznaczone dla mniejszości białoruskiej w Polsce oraz mieszkańców Białorusi, finansowana ze środków polskiego MSZ, działająca w latach 1999-2002 oraz ponownie od 2006 r. Głównym celem rozgłośni jest umożliwienie obywatelom Białorusi dostępu do niezależnej informacji o wydarzeniach i sytuacji na Białorusi, w Polsce i na świecie. 
W 1998 r. w Białymstoku zapoczątkowano działalność Centrum Edukacji Obywatelskiej Polska-Białoruś, a w 2011 r., z inicjatywy kilku organizacji pozarządowych, otwarto w Warszawie Dom Białoruski, który ma stać się miejscem jednoczącym białoruską diasporę, koordynującym działalność emigracyjnych białoruskich środowisk demokratycznych i wspierającym represjonowanych działaczy białoruskiej opozycji, a także miejscem debaty wszystkich środowisk walczących o demokratyczną Białoruś. Ma także pełnić funkcję centrum informującego polską opinię publiczną o wydarzeniach na Białorusi.

Obecnie spośród wszystkich sąsiadujących z Polską państw, wzajemne relacje między Polską a Białorusią są z pewnością najgorsze oraz zredukowane do minimum ${ }^{151}$. Dodatkowo potęguje je charakter wspólnej granicy. Wschodnie pogranicze Polski, a zwłaszcza pogranicze polsko-białoruskie i polsko-ukraińskie, często określane jest jako łacińsko-bizantyjskie „pogranicze cywilizacyjne", jako granica cywilizacji zachodniej i wschodniej (Huntington 1997, Kowalski 1999, Pawluczuk 1999, Eberhardt 2004b, Bański 2008a, b). Biegnąca w przybliżeniu wzdłuż granicy Polski z Białorusią i Ukrainą linia podziału kulturowego, kształtującego się na podstawie tradycji zachodniego chrześcijaństwa oraz wpływów kultury prawosławnej, jest najtrwalszą linią podziału kontynentu europejskiego (Bański 2008a, b). Od 2004 r. jest ona dodatkowo wzmocniona funkcją zewnętrznej granicy UE, w wyniku czego wschodnie pogranicze Polski w sensie kulturowym i politycznym można obecnie traktować jako rubieże Europy Zachodniej, a zewnętrzną granicę UE jako główną oś podziału Europy.

Współczesna granica polsko-białoruska pełni aktualnie funkcję bariery między całkowicie odmiennymi realiami politycznymi, ekonomicznymi, prawnymi, społecznymi, kulturowymi. Wyraźnie dzieli nie tylko społeczeństwo polskie i białoruskie, ale także Białorusinów żyjących po obu stronach granicy. Różnicuje nie tylko pod względem formalnym, ale także kulturowym, mentalnym i gospodarczym, w stopniu większym niż w przypadku granicy z Ukrainą.

${ }^{150}$ Kanał telewizji satelitarnej nadający od 2007 r. programy w języku białoruskim, finansowany i prawnie wchodzący w skład Telewizji Polskiej. Wiele programów, w tym informacyjne, dostępne są także przez Internet. Główne cele stacji są tożsame z celami Radia Racja. Jest jedyną niezależną białoruskojęzyczną telewizją dostępną na Białorusi, łamiacą monopol informacyjny władz białoruskich.

${ }^{151}$ Mimo podejmowanych przez Polskę prób ich poprawy, przebieg ostatnich wyborów prezydenckich na Białorusi w grudniu $2010 \mathrm{r}$. oraz parlamentarnych w październiku 2012 r., z podejrzeniami o fałszerstwa oraz brutalnie stłumionymi masowymi demonstracjami opozycji w Mińsku, rozwiał nadzieje na poprawę stosunków polsko-białoruskich i unijno-białoruskich. 
$\mathrm{Z}$ pewnością można ją określić jako jedną z najsilniejszych barier cywilizacyjnych we współczesnej Europie.

Paradoksalnie, w konsekwencji prowadzonej przez Łukaszenkę od kilkunastu lat polityki zmierzającej do wynarodowienia Białorusinów poprzez likwidację białoruskich symboli narodowych, ograniczanie języka białoruskiego (zwłaszcza w szkolnictwie), likwidację niezależnych białoruskich organizacji i mediów, obecnie łatwiej (i bezpieczniej) być Białorusinem w Rzeczypospolitej Polskiej niż w Republice Białorusi.

Dlatego też państwo białoruskie nie jest tak istotnym punktem odniesienia dla Białorusinów z Podlasia, jak zagraniczna ojczyzna dla Litwinów czy Ukraińców. Badania socjologiczne potwierdzają, że przedstawiciele mniejszości białoruskiej jako swoją macierzystą ojczyznę powszechnie postrzegają Polskę, a nie Białoruś. Z państwem polskim czują bardzo silny związek emocjonalny, historyczny i polityczny, a społeczeństwo polskie oceniają zdecydowanie bardziej pozytywnie niż ludność białoruską mieszkającą za wschodnią granicą. W tej sytuacji w kontaktach zewnętrznych powszechnie włączają się w rolę obywateli polskich, a nie mniejszości białoruskiej (Sadowski 1995a). Potwierdzają to badania C. Żołędowskiego (2003) oraz M. Bieńkowskiej-Ptasznik (2007) porównujące mniejszość litewską i białoruską. Zgodnie stwierdzają, że Litwini identyfikują swą stolicę z Wilnem, mają wyraźne poczucie związku z państwem litewskim, są silnie zaangażowani w to, co dzieje się na Litwie. Białorusini natomiast stolicę identyfikują z Warszawą, ewentualnie z Białymstokiem, w niewielkim, marginalnym stopniu utożsamiają się z państwem białoruskim, ich stosunek do zagranicznej ojczyzny rzadko cechują pozytywne emocje, sytuację na Białorusi, a zwłaszcza politykę prezydenta Łukaszenki, oceniają na ogół obojętnie lub krytycznie.

Negatywną ocenę sytuacji politycznej na Białorusi wśród podlaskich Białorusinów, potwierdzają także badania P. Kepki (2009), lecz jedynie w odniesieniu do młodych i lepiej wykształconych respondentów, zdecydowanie popierających demokratyczną opozycję. Wśród starszych, prawosławnych mieszkańców Podlasia, dominowały pozytywne oceny systemu politycznego na Białorusi. Podkreślano dobrą i stabilną sytuację gospodarczą mieszkańców Białorusi, a prezydent Łukaszenka był postrzegany jako „dobry gospodarz”, jako „swój”. Krytykowano działania białoruskiej opozycji, według respondentów mające na celu destabilizację sytuacji politycznej, doprowadzenie do biedy i bezrobocia ${ }^{152}$.

${ }^{152}$ Badania przeprowadzono w 2009 r. w miastach Bielsk Podlaski i Hajnówka oraz w gminach Czyże, Dubicze Cerkiewne, Hajnówka, Orla, objęto nimi 200 respondentów (Kępka 2009). 
Takie oceny są m.in. pochodną, powszechnej wśród prawosławnej społeczności Podlasia, pozytywnej oceny okresu PRL oraz negatywnego stosunku do przemian demokratycznych po $1989 \mathrm{r}$.

Zróżnicowane postawy mniejszości białoruskiej wobec Białorusi przekładają się także na jej odmienne postrzeganie przez liderów białoruskich organizacji. Wśród działających w Polsce organizacji mniejszości ukraińskiej i litewskiej nie ma praktycznie żadnych różnic i podziałów dotyczących relacji z zagraniczną ojczyzną, natomiast wśród organizacji białoruskich stosunek do Republiki Białorusi, jej władz i systemu politycznego jest jedną z najważniejszych kwestii spornych i główną (obok oceny okresu PRL) linią podziału oraz konfliktu. BTSK konsekwentnie utrzymuje przyjazne relacje $\mathrm{z}$ władzami białoruskim. Współpraca przejawia się m.in. we wzajemnej wymianie zespołów folklorystycznych (przy częściowym finansowaniu przez stronę białoruską), wspólnym organizowaniu imprez kulturalnych i konferencji naukowych, wydawaniu książek. BTSK współpracuje $\mathrm{z}$ oficjalnym, uznawanym przez władze białoruskie Związkiem Polaków na Białorusi, z którym wspólnie organizuje coroczne konferencje naukowe „Droga ku wzajemności” oraz Spotkania Artystyczne Białystok-Grodno. Działacze BTSK wyjeżdżają na Białoruś, gdzie często publicznie deklarują poparcie dla polityki prezydenta Łukaszenki. Z kolei Podlasie jest odwiedzane przez białoruskich urzędników i polityków, zapraszanych przez liderów BTSK. Jednak skala wsparcia finansowego władz w Mińsku dla działalności BTSK (m.in. pomoc w wyposażeniu amatorskich zespołów ludowych, szkolenia dla nauczycieli) jest zupełnie nieporównywalna z pomocą np. władz w Wilnie dla organizacji litewskich.

Natomiast działacze organizacji białoruskich powstałych w latach 90. XX w., opozycyjnych do BTSK, zdecydowanie negatywnie oceniają władze białoruskie, podkreślają, że z „oficjalną Białorusią" nie utrzymują żadnych kontaktów i nie prowadzą żadnej współpracy. Wręcz przeciwnie - jeden z liderów białoruskich w Polsce, Eugeniusz Wappa, ma wydany przez władze w Mińsku zakaz wjazdu na Białoruś, a najważniejsze czasopismo białoruskojęzyczne w Polsce (tygodnik „Niwa”) jest tam oficjalnie zakazane. Nie oznacza to, że organizacje te nie utrzymują kontaktów z Białorusią. Współpracują z opozycją, niektórymi dziennikarzami i organizacjami pozarządowymi. Są także zaangażowane w działalność Radia Racja oraz Telewizji Biełsat. Wyraźnie identyfikują się z ideą niepodległego i demokratycznego państwa białoruskiego, wspierają narodową opozycję na Białorusi. Aktywność ta na ogół nie znajduje zrozumienia i poparcia wśród większości podlaskich Białorusinów.

Zachodzi wyraźna korelacja pomiędzy opiniami dotyczącymi sytuacji na Białorusi liderów lewicowego BTSK i głównego zaplecza tej organizacji, czyli 
starszego pokolenia wiejskiej społeczności prawosławnej oraz działaczy białoruskich ugrupowań narodowych i wspierającego te organizacje, młodego, wykształconego pokolenia Białorusinów.

Tak jak działacze stowarzyszeń białoruskich odmiennie oceniają rzeczywistość polityczną na Białorusi, tak też różnią się w ocenie sytuacji mniejszości białoruskiej po akcesji Polski do UE. Przewodniczący BTSK uważa, że przyjęcie Polski do UE nic nie zmieniło w położeniu mniejszości białoruskiej, natomiast działacze innych organizacji podkreślają pozytywną rolę europejskich standardów prawnych w ochronie praw mniejszości narodowych oraz lepszą ochronę mniejszości po akcesji do UE ${ }^{153}$.

\section{Litwini}

W ciagu ostatnich kilkudziesięciu lat relacje polsko-litewskie przechodziły kilka diametralnie różnych faz - od jawnej wrogości, poprzez „socjalistyczną przyjaźń", nieufność początku lat 90. XX w., współpracę i strategiczne partnerstwo w ramach NATO i UE na początku XXI w., aż po wyraźne ochłodzenie wzajemnych stosunków. To, jaki kształt przybiorą one w przyszłości, w dużym stopniu zależy od sytuacji polskiej i litewskiej mniejszości narodowej w obu państwach.

W okresie PRL problematyka mniejszości litewskiej nie pojawiała się w relacjach z ZSRR czy władzami Litewskiej Socjalistycznej Republiki Radzieckiej. Uległo to zmianie w nowych uwarunkowaniach geopolitycznych. Zachodzące na przełomie lat 80. i 90. XX w. wydarzenia polityczne na obszarze byłego ZSRR, a zwłaszcza na Litwie, spotkały się z powszechnym zainteresowaniem mniejszości litewskiej w Polsce, która zdecydowanie popierała walkę o suwerenność. Odzyskująca niepodległość Litwa zyskała także powszechną sympatię Polaków ${ }^{154}$, dlatego przewidywano, że stosunki polsko-litewskie staną się wzorcowe. Pomimo to właśnie z Litwą, spośród wszystkich sąsiadów, na początku lat 90. $\mathrm{XX}$ w. Polska miała najgorsze relacje. $\mathrm{Na}$ ich zaostrzenie wpłynęła postawa

${ }^{153}$ Na podstawie wywiadów przeprowadzonych przez autora w 2012 r. z działaczami BTSK, Rady Programowej Tygodnika „Niwa”, Białoruskiego Zrzeszenia Studentów.

${ }^{154}$ Dotyczyło to Polaków mieszkających w Polsce (w tym także polskich polityków wywodzących się z „Solidarności”), którzy na fali nastrojów antyradzieckich początku lat 90. XX w. powszechnie popierali niepodległościowe dążenia Litwy, natomiast większość Polaków żyjących na Litwie miała negatywny stosunek do litewskiej niepodległości, obawiając się wzrostu nacjonalizmu wśród Litwinów oraz prześladowania i dyskryminacji mniejszości polskiej. 
mniejszości polskiej na Wileńszczyźnie ${ }^{155}$, ale także nacjonalistyczne hasła głoszone przez przejmujący władzę na Litwie „Sajūdis” oraz - w dużej mierze uwarunkowana historycznie - niechęć i nieufność Litwinów wobec ludności polskiej.

Po konfliktach z początku lat 90 . XX w. w międzypaństwowych relacjach polsko-litewskich, w których problem mniejszości narodowych, zwłaszcza Polaków na Litwie, niezmiennie odgrywał istotną rolę, wzajemne stosunki uległy poprawie. W kwietniu 1994 r., po wielomiesięcznych negocjacjach, podpisano traktat „o przyjaznych stosunkach i dobrosąsiedzkiej współpracy”. W traktacie obie strony zobowiązały się do przestrzegania wszelkich zasad międzynarodowych dotyczących mniejszości narodowych, którym zagwarantowano m.in.: prawo swobodnego używania języka narodowego w życiu publicznym i prywatnym, używania imion i nazwisk w brzmieniu języka narodowego mniejszości, zakładania instytucji, organizacji, stowarzyszeń, rozwoju oświaty, uczestnictwa

${ }^{155}$ W okresie odzyskiwania niepodległości przez Litwę bardzo negatywny wydźwięk miała postawa dwóch polskich posłów do Rady Najwyższej Litewskiej Socjalistycznej Republiki Radzieckiej, którzy podczas uchwalania deklaracji niepodległości Republiki Litewskiej 11 marca 1990 r. wstrzymali się od głosu. Mimo że ich głosy nie zaważyły na wyniku głosowania, to decyzja ta nabrała symbolicznego znaczenia. W tym samym okresie część działaczy mniejszości polskiej, zwłaszcza wywodzących się z partii komunistycznej, opowiedziała się za przynależnością Litwy do ZSRR. W maju 1990 r., zdominowana przez Polaków, Rada Narodowa Rejonu Solecznickiego podjęła uchwałę o przynależności tego rejonu do ZSRR. Z kolei działacze powstałego w 1990 r. Związku Polaków na Litwie (ZPL) popierali niepodległość Republiki Litewskiej, jednak podkreślali bardzo trudne położenie ludności polskiej na Wileńszczyźnie i jej dyskryminowanie przez władze litewskie. We wrześniu 1990 r. polscy deputowani do Rad Samorząów Wileńszczyzny, przy poparciu ZPL, proklamowali powstanie Polskiego Narodowościowo-Terytorialnego Kraju, z szeroką autonomią dla mniejszości polskiej w ramach niepodległej Republiki Litewskiej, natomiast we wrześniu 1991 r. polscy deputowani Wileńszczyzny przyjęli projekt statutu Wileńsko-Polskiego Kraju Narodowo-Terytorialnego. Decyzje dotyczące autonomii podejmowane przez przedstawicieli mniejszości polskiej nie zostały uznane przez władze Litwy (autonomii sprzeciwiały się także ówczesne władze Polski) i spotkały się z jednoznacznie negatywną oceną litewskiego społeczeństwa. Ostatecznie władze litewskie zawiesiły samorządy rejonu wileńskiego i solecznickiego, wprowadzając zarząd komisaryczny, co skutecznie zablokowało jakiekolwiek dążenia autonomistyczne. Podczas referendum w sprawie niepodległości Litwy, w lutym 1991 r., frekwencja w rejonie solecznickim wyniosła zaledwie 30\%, a za niepodległością opowiedziało się 64\% głosujących (w skali Litwy odpowiednio 84\% i 90\%), co wyraźnie świadczyło o bardzo ograniczonym poparciu dla litewskiej niepodległości wśród polskiej mniejszości. Natomiast miesiąc później, podczas zbojkotowanego przez Litwinów ogólnoradzieckiego referendum w sprawie przyszłości ZSRR, w rejonie solecznickim do urn poszło aż 76\% mieszkańców (Kurcz 2005). 
w życiu publicznym na równi z pozostałymi obywatelami, ochrony tożsamości narodowej ${ }^{156}$. Skalę problemów obrazuje fakt, iż Litwa była ostatnim z nowych sąsiadów, z którym rząd polski podpisał tego typu umowę. Kilka miesięcy później w Sejnach otwarto konsulat Republiki Litewskiej, a rząd litewski rozpoczął finansowanie budowy Domu Litewskiego.

W latach 90. XX w. otwarto przejścia graniczne w Ogrodnikach i Budzisku. Były to pierwsze polsko-litewskie przejścia graniczne po II wojnie światowej. Po wejściu Polski i Litwy do UE w 2004 r., a następnie przystąpieniu obu państw do strefy Schengen w 2007 r., zostały zlikwidowane wszelkie ograniczenia przy przekraczaniu wspólnej granicy. Jest to niezwykle korzystna sytuacja dla zamieszkującej pogranicze mniejszości litewskiej na Suwalszczyźnie, zmiana, która jeszcze nie tak dawno była trudna do wyobrażenia, zwłaszcza że przez cały okres PRL władze bardzo skutecznie utrudniały mieszkającym w Polsce Litwinom kontakty z radziecką Litwą, także rodzinne.

Współpraca polsko-litewska, która została nawiązana na szczeblu władz państwowych, doprowadziła do powstania wielu wspólnych instytucji, m.in.: Komitetu Konsultacyjnego przy Prezydentach RP i RL, Zgromadzenia Poselskiego Sejmu RP i Sejmu RL (1997), Rady do Spraw Współpracy między Rządami RP i RL (1997), Polsko-Litewskiej Komisji Międzynarodowej ds. Współpracy Transgranicznej (1996), Polsko-Litewskiego Forum Samorządu Terytorialnego (1998). Ponadto współpraca polsko-litewska na szczeblu regionalnym doprowadziła do powstania: Fundacji „Pogranicze” z Sejn (1990), Polsko-Litewskiej Izby Gospodarczej (1993), Litewsko-Polsko-Rosyjskiego Komitetu ds. Regionów Przygranicznych (1997), Stowarzyszenia Samorządów Ziemi Sejneńskiej, Polsko-Litewskiego Forum Organizacji Pozarządowych. Dynamicznie i różnorodnie rozwijała się także współpraca transgraniczna, która przejawiała się m.in. w powołaniu w 1997 r. euroregionu „Niemen”, współpracy między polskimi i litewskimi gminami przygranicznymi oraz miastami partnerskimi, współpracy placówek kulturalnych i szkół, wspólnej organizacji misji handlowych i międzynarodowych targów (Rykała 2008). Nastapiła faktyczna instytucjonalizacja wzajemnych relacji politycznych, kulturalnych i społecznych. Działania te, wraz z zawieraniem kolejnych umów gospodarczych, doprowadziły na przełomie XX i XXI w. do przerodzenia się relacji polsko-litewskich jak często wówczas podkreślano „najlepszych na przestrzeni dziejów” - w strategiczne partnerstwo. Podjęto skuteczną współpracę dotyczącą członkostwa obu

${ }^{156}$ Niektóre z zapisów traktatu (np. dotyczące pisowni imion i nazwisk oraz dwujęzycznych nazw) nadal nie zostały wprowadzone przez władze litewskie. 
krajów w UE i NATO, wspólne aspiracje w polityce zagranicznej wyraźnie zbliżyły Warszawę i Wilno.

Jednak w pierwszej dekadzie XXI w., po okrzepnięciu litewskiej niepodległości, akcesji Litwy do NATO i UE, wzajemne relacje uległy pogorszeniu. Na Litwie doszły do głosu dawne urazy oraz obawy niewielkiego państwa wobec dużo większego i ludniejszego sąsiada, który przez wieki dominował politycznie nad ziemiami litewskimi, a obecnie ma na Litwie najliczniejszą mniejszość narodową. W relacjach między Polską a Litwą nieliczna mniejszość litewska w Polsce stała się dla władz w Wilnie narzędziem w rozmowach z rządem Rzeczypospolitej Polskiej. Jeżeli polskie władze domagały się respektowania praw Polaków na Litwie, rząd litewski od razu podnosił kwestię dyskryminacji Litwinów w Polsce. Po przeprowadzonych w ostatnich latach w obu państwach zmianach prawnych (w Polsce korzystnych dla mniejszości, natomiast na Litwie często niekorzystnych), a zwłaszcza przyjęciu przez polski parlament Ustawy o mniejszościach narodowych, etnicznych i języku regionalnym, sytuacja mniejszości litewskiej w Polsce jest zdecydowanie lepsza niż mniejszości polskiej na Litwie.

Dlatego nadal najważniejszym problemem w relacjach między Rzeczappospolitą Polską a Republiką Litewską jest traktowanie polskiej mniejszości narodowej na Litwie, gdzie władze litewskie wprowadziły liczne przepisy ograniczające prawa (zwłaszcza językowe i oświatowe) mniejszości narodowych. Nierozwiązanymi do dziś problemami jest m.in. polska pisownia nazwisk w dowodach tożsamości oraz dwujęzyczna pisownia nazw ulic i miejscowości. Według prawa litewskiego, na obszarze Republiki Litewskiej można używać wyłącznie litewskiej ortografii oraz nie wolno stosować dwujęzycznych nazw miejscowości, nawet na obszarach, gdzie Polacy (lub inne mniejszości narodowe) stanowią przytłaczającą większość mieszkańców.

W 2011 r. władze litewskie przyjęły ustawę oświatową, która, według litewskich Polaków, dyskryminuje polskie szkolnictwo na Litwie ${ }^{157}$. Jej przyjęcie

${ }^{157}$ Do najbardziej krytykowanych zapisów nowej ustawy oświatowej należy ujednolicenie od 2013 r. (z zachowaniem zaledwie dwuletniego okresu przejściowego), obowiązkowych egzaminów maturalnych z języka litewskiego w szkołach mniejszości narodowych oraz w szkołach litewskich (mimo istniejących różnic programowych), zwiększenie liczby lekcji języka litewskiego, wprowadzenie od września 2011 r. w szkołach mniejszości narodowych, w których do tej pory wszystkie przedmioty były wykładane w językach mniejszości, lekcji historii i geografii Litwy w języku litewskim oraz również po litewsku przedmiotu ,podstawy wychowania patriotycznego”. Ustawa ułatwia także samorządom likwidację małych, wiejskich szkół nielitewskich, co z pewnością doprowadzi do zmniejszenia liczby polskich szkół. Dla porównania, według polskiej 
spowodowało masowe demonstracje w Wilnie oraz interwencję polskich władz. Protesty Polaków nie przyniosły żadnych zmian, a nowa ustawa oświatowa stała się kolejnym zarzewiem konfliktu polsko-litewskiego. Nierozwiązanym problemem, zwłaszcza $\mathrm{z}$ powodu uciążliwych i długotrwałych procedur, jest także zwrot polskich majątków zagarniętych po II wojnie światowej przez ówczesne władze radzieckie, a obecnie władze litewskie, które są ich prawnym następcą. Poza problemami natury społecznej i historycznej są także kłopoty gospodarcze, czego przykładem jest rafineria w Możejkach, największa zagraniczna inwestycja Polskiego Koncernu Naftowego Orlen, z którą, niezmiennie od jej zakupu przez polskie przedsiębiorstwo, są problemy daleko wykraczające poza tzw. mechanizmy rynkowe, inspirowane przez stronę rosyjską i litewską.

Mimo wielu drażliwych spraw w relacjach ,państwo litewskie-mniejszość polska", organizacje i instytucje polskie na Litwie mają swobodę funkcjonowania i realne możliwości oddziaływania na miejscowe społeczeństwo polskie. W rejonie wileńskim i solecznickim duża część administracji samorządowej jest zdominowana przez przedstawicieli mniejszości polskiej, w litewskim sejmie zasiadają posłowie wybrani z list Akcji Wyborczej Polaków ${ }^{158}$, funkcjonuje (choć z licznymi problemami) szkolnictwo polskie, także na poziomie uniwersyteckim $^{159}$. Po wejściu Polski i Litwy do UE oraz tendencji do zacierania barier administracyjnych i gospodarczych między obu krajami, a także w wyniku postępującej lituanizacji Wilna, nawet litewskie środowiska niechętne mniejszości polskiej zdają sobie sprawę, że nie stanowi ona obecnie zagrożenia dla integralności terytorialnej państwa litewskiego. Jednak brak zgody na polską autonomię terytorialna, problemy z akceptacją postulatów dotyczących pisowni polskich nazwisk czy dwujęzycznych tablic oraz zapisy nowej ustawy oświa-

ustawy oświatowej lekcje historii i geografii Polski są obligatoryjnie nauczane w języku polskim we wszystkich typach szkól, obowiązkowy egzamin maturalny z języka polskiego jest także ujednolicony.

158 Podczas wyborów parlamentarnych w październiku 2012 r. Akcja Wyborcza Polaków zdobyła 5,83\% głosów, co dało jej 8 mandatów w 141-osobowym sejmie. W listopadzie 2012 r. po raz pierwszy w historii Akcja Wyborcza Polaków znalazła się w koalicji rządowej.

${ }^{159}$ W 1998 r. został założony Uniwersytet Polski w Wilnie przy Stowarzyszeniu Naukowców Polaków Litwy. Po kilku latach wygasił działalność z powodów trudności formalnoprawnych oraz finansowych. W 2007 r. w Wilnie powołano filię Uniwersytetu w Białymstoku, Wydział Ekonomiczno-Informatyczny, który prowadzi obecnie trzyletnie studia licencjackie na dwóch kierunkach: ekonomii i informatyce. Językiem wykładowym jest polski. Jest to jedyna filia polskiej uczelni poza granicami Polski oraz jedyna filia zagranicznej uczelni na Litwie. Ponadto na Uniwersytecie Wileńskim oraz Uniwersytecie Pedagogicznym w Wilnie można studiować filologię polską. 
towej wskazują na to, że Litwini nadal obawiają się polskiego separatyzmu, a wiele inicjatyw mniejszości polskiej traktują jako skierowane przeciw litewskiej suwerenności (Kowalski 2008b).

$\mathrm{Z}$ pewnością rozwiązanie dwustronnych problemów jest utrudnione nie tylko z powodu braku dobrej woli, ale także z powodu dysproporcji struktury narodowościowej w obu państwach. Litwini w Polsce są narodowością marginalną pod względem liczebnym i terytorialnym, natomiast Polacy na Litwie są najliczniejszą mniejszością narodową (w 2011 r. ok. 200 tys. osób na 3 mln ogółu ludności), istotnie kształtującą historię Litwy (dawną i XX-wieczna), ponadto licznie zamieszkującą Wilno oraz dominującą liczebnie (i politycznie) w bezpośrednim otoczeniu litewskiej stolicy ${ }^{160}$. Oczywiście nie usprawiedliwia to asymetrii we wzajemnych relacjach wobec mniejszości. Rząd Republiki Litewskiej (bez względu na zmieniające się opcje polityczne) konsekwentnie nie wypełnia wszystkich postanowień płynących z podpisanego z polskimi władzami w 1994 r. traktatu, prowadzi działania dyskryminujące Polaków, odbierane przez nich jako godzące w ich prawa językowe, oświatowe i ekonomiczne. W obliczu takich relacji narodowościowo-politycznych między sojuszniczymi, w pełni demokratycznymi państwami, członkami UE i NATO, nie powinien zaskakiwać stan relacji polsko-białoruskich czy polsko-ukraińskich.

Władze litewskie, ograniczając prawa mniejszości narodowych na własnym terytorium, jednocześnie w różnej formie - finansowej, organizacyjnej, politycznej - wspierają Litwinów poza granicami, w tym szczególnie w Polsce. Bardzo wyraźne zainteresowanie władz oraz mediów litewskich sytuacją rodaków mieszkających w Polsce jest spowodowane polsko-litewskim konfliktem na Wileńszczyźnie oraz faktem, iż są oni współcześnie w zasadzie jedyną autochtoniczną mniejszością litewską. Niewielka liczebność Litwinów w Polsce, ich koncentracja terytorialna oraz stosunkowo korzystna sytuacja ekonomiczna istotnie zwiększają efektywność tej pomocy. Zaangażowanie władz litewskich wyraża się m.in. przeznaczaniem znacznych nakładów finansowych na działalność mniejszości, zwłaszcza na kwestie związane z umacnianiem tożsamości oraz rozwojem instytucji narodowych. Z funduszy władz litewskich wybudowano w Sejnach Dom Litewski (w którym mieści się m.in. Konsulat Republiki Litewskiej, zarządy stowarzyszeń litewskich, kapele, chóry, zespoły ludowe)

${ }^{160}$ Według wyników spisu powszechnego z 2011 r., na Litwie mieszkało 200,3 tys. Polaków (spadek o 35 tys. w ciągu 10 lat), co stanowiło 6,6\% ogółu ludności, w Wilnie 88,4 tys. Polaków - 16,5\% ogółu mieszkańców. W otaczającym stolicę rejonie wileńskim Polacy stanowili ponad połowę mieszkańców, a w rejonie solecznickim prawie 80\% mieszkańców. 
oraz kompleks budynków Zespołu Szkół z Litewskim Językiem Nauczania „Žiburys”. Natomiast w Puńsku rząd litewski współfinansował (wraz z władzami samorządowymi) i umożliwił dokończenie budowy Domu Kultury Litewskiej ${ }^{161}$. Dzięki temu Litwini na Suwalszczyźnie dysponują dwoma dużymi, nowoczesnymi obiektami kulturalnymi, położonymi w niewielkiej odległości. Jest to sytuacja niespotykana wśród innych mniejszości narodowych w Polsce. Systematycznie dofinansowywane jest także szkolnictwo, działalność organizacji mniejszości litewskiej oraz wydawnictwo „Aušra”. Przewodniczący Stowarzyszenia Litwinów w Polsce podkreśla bardzo duże znaczenie wielostronnego wsparcia władz i instytucji litewskich, m.in. Ministerstwa Spraw Zagranicznych, Ministerstwa Edukacji, Instytutu Języka Litewskiego, szkół litewskich. Jednocześnie działacze litewscy zgodnie twierdzą, że relacje polsko-litewskie wpływają bardzo negatywnie na sytuację mniejszości litewskiej oraz na postrzeganie i poglądy Polaków wobec Litwinów na Suwalszczyźnie. Według nich mniejszość litewska jest „zakładnikiem polityki zagranicznej Polski i Litwy”, każde pogorszenie relacji między Warszawą a Wilnem ma przełożenie na sytuację w Puńsku i Sejnach. Uważają taką zależność za bardzo niekorzystną, krzywdzącą, wręcz niebezpieczną. Z sytuacją polityczną na Litwie bezpośrednio wiążą, według nich inspirowaną $\mathrm{z}$ zewnątrz, akcję zamalowywania dwujęzycznych, polsko-litewskich tablic $\mathrm{z}$ nazwami miejscowości $\mathrm{w}$ gminie Puńsk w sierpniu $2011 \mathrm{r}$.

Natomiast bardzo pozytywnie oceniają konsekwencje dla mniejszości litewskiej akcesji Polski i Litwy do UE, zwłaszcza możliwość swobodnego przekraczania granicy międzypaństwowej, co dla społeczności żyjącej od dziesięcioleci w strefie przygranicznej, tuż obok zagranicznej ojczyzny, ma z pewnością fundamentalne znaczenie. Zwłaszcza że nie tylko w okresie PRL, ale praktycznie od początku lat 20. XX w. ta bliskość geograficzna nie przekładała się na możliwość wzajemnych kontaktów. Granica polsko-litewska przez kilkadziesiąt lat była bardzo szczelną barierą uniemożliwiająca nie tylko normalną współpracę transgraniczną, ale także odwiedziny rodziny mieszkającej kilka czy kilkanaście kilometrów dalej. Dlatego dla mieszkających na Suwalszczyźnie Litwinów najważniejszym aspektem integracji europejskiej jest - w sensie dosłownym i praktycznym - integracja pogranicza polsko-litewskiego. Trzeba także podkreślić, że Stowarzyszenie Litwinów w Polsce było jedyną spośród

${ }^{161}$ W 2001 r. oddano do użytku Dom Polski w Wilnie, w całości sfinansowany ze środków Stowarzyszenia Wspólnota Polska, w którym swoje siedziby ma m.in. ponad 30 polskich organizacji oraz liczne zespoły artystyczne. 
badanych organizacji narodowościowych, której władze zadeklarowały, iż w ramach działalności statutowej korzystają z funduszy unijnych ${ }^{162}$.

Jedną z konsekwencji współczesnych procesów integracji politycznej, militarnej i gospodarczej kontynentu europejskiego jest wzmocnienie jego podziału na szeroko pojętą Europę Zachodnią (w ramach UE) oraz Wschodnią (nieobjętą procesami integracyjnymi). Na pograniczu Polski z Białorusią i Ukrainą linia współczesnego podziału wzmocniona w sensie dosłownym (techniczne środki ochrony granic) oraz prawnym (przepisy wizowe) nakłada się na ukształtowaną historycznie linię podziału cywilizacyjnego, kulturowego, wyznaniowego. Mimo głoszonych przez władze w Warszawie haseł prowadzenia „polskiej polityki wschodniej”, widać wyraźny odwrót na rzecz ,polityki zachodniej”. Polska pod względem politycznym, militarnym i gospodarczym jest wyraźnie zwrócona na Zachód, co skutkuje - bardzo niekorzystnym, zwłaszcza ze względów politycznych i geopolitycznych - odwróceniem się od wschodnich sąsiadów. Mimo podejmowanych przez kolejne rządy spektakularnych prób ożywienia współpracy, zwłaszcza z Ukrainą i Litwą, na prowadzenie skutecznej, pragmatycznej polityki wschodniej, a nie polityki opartej na historycznych sentymentach, Polska nie ma obecnie argumentów, zwłaszcza gospodarczych i finansowych. Ponadto często wymóg utrzymania poprawnych relacji z sąsiadującym państwem oraz interesy polskiej polityki zagranicznej dominują nad stanowczym dążeniem do rozwiązania problemów polskiej mniejszości.

Porównując współczesną strukturę etniczną oraz politykę narodowościową Polski i jej wschodnich sąsiadów, widać wyraźną asymetrię dotycząca zarówno kwestii ilościowych, jak i prawno-instytucjonalnych. W Polsce zamieszkuje zdecydowanie mniejsza liczba osób narodowości ukraińskiej, białoruskiej i litewskiej, niż liczy społeczność polska na terytorium wschodnich sąsiadów. Jednocześnie mniejszości narodowe na obszarze Polski mają większe prawa i lepsze warunki funkcjonowania niż Polacy na Ukrainie, Białorusi i Litwie.

Poprawa sytuacji prawnej mniejszości narodowych w Polsce jest związana m.in. z akcesją Polski do UE, co dostrzegają i doceniają liderzy organizacji narodowościowych, podkreślając, że główną konsekwencją członkostwa Polski w UE, z punktu widzenia społeczności, które reprezentują, nie są kwestie potencjalnych korzyści finansowych, lecz poprawa standardów prawnych dotyczących ochrony mniejszości narodowych. Jest to powszechna opinia, bardzo silnie ugruntowana w świadomości liderów organizacji narodowościowych, jednak w przypadku ustawodawstwa unijnego nie jest ona ścisła. Prawo UE nie

${ }^{162}$ Na podstawie wywiadów przeprowadzonych przez autora w 2012 r. z działaczami Stowarzyszenia Litwinów w Polsce oraz Litewskiego Towarzystwa Św. Kazimierza. 
zawiera regulacji dotyczących praw mniejszości narodowych, chociaż UE wymaga od swoich członków respektowania norm prawa międzynarodowego dotyczącego mniejszości narodowych. Ustawodawstwo unijne chroni jedynie tzw. języki mniej używane, co w praktyce może oznaczać języki niektórych mniejszości narodowych i etnicznych, ale nie wprowadza wspólnej polityki narodowościowej i w rezultacie każde państwo samo reguluje kwestie prawne związane z mniejszościami narodowymi. Prawo unijne mówi wyraźnie o zakazie dyskryminacji z powodu płci, rasy, religii, pochodzenia etnicznego, społecznego i koloru skóry, jednak w żadnym unijnym dokumencie nie wspomina się wprost o mniejszościach narodowych. Nie ma też specjalnych programów finansowego wspierania mniejszości, które mogą starać się o dofinansowanie swoich projektów jedynie w ramach ogólnych inicjatyw unijnych (m.in. funduszy strukturalnych i spójności). Zdecydowanie bardziej rozbudowana jest ochrona prawna mniejszości narodowych w ramach ustawodawstwa Rady Europy (Budyta-Budzyńska 2010, Janusz 2011).

Przy omawianiu relacji międzypaństwowych dotyczących mniejszości narodowych często powraca dyskusja o „zasadzie wzajemności” w obustronnych relacjach $^{163}$. W dyskusji oraz $\mathrm{w}$ działaniu przedstawicieli obu stron ścierają się najczęściej, jak pisze L. Nijakowski (2000), dwie wersje: wersja „starotestamentowa", nakazująca uzależniać poziom praw wobec danej mniejszości według zasady: „waszym ludziom” będzie u nas tak źle (będą mieli tak mało praw), jak „naszym” u was, oraz wersja „nowotestamentowa”, realizowana według zasady: „popatrzcie, jak u nas mają dobrze”. Trzeba mieć nadzieję, że do głosu coraz częściej będzie dochodziła ta druga wersja - i to ona - jak mówi L. Nijakowski, zastanawiając się nad relacjami Polski z zagranicznymi ojczyznami ,polskich” mniejszości - powinna być wzorem, a ta pierwsza nie jest ani dopuszczalna etycznie, ani opłacalna politycznie.

${ }^{163}$ Powiązanie sytuacji poszczególnych mniejszości narodowych w Polsce z sytuacją mniejszości polskiej w krajach sąsiedzkich jest zgodnie krytykowane przez liderów organizacji narodowościowych, szczególnie litewskich i ukraińskich. 


\section{WSPÓŁCZESNE ROZMIESZCZENIE I LICZEBNOŚĆ UKRAIŃCÓW, tEMKÓW, BIAŁORUSINÓW I LITWINÓW W POLSCE}

W ciągu ostatnich kilkudziesięciu lat zasadniczy wpływ na bardzo duże zmniejszenie liczebności mniejszości narodowych w Polsce miały zmiany granic oraz omawiane wcześniej wysiedlenia ludności. Jednak nie bez znaczenia były także, uwarunkowane różnymi czynnikami, procesy asymilacji i akulturacji mniejszości narodowych. Bardzo istotną rolę w przemianach tożsamości, polonizacji społeczności mniejszościowych odegrały migracje wewnętrzne, zarówno przymusowe przesiedlenia Ukraińców i Łemków, jak i - związane z industrializacją i urbanizacją - dobrowolne migracje, w zdecydowanej większości wiejskich społeczności, do ośrodków miejskich. Ich konsekwencją było zerwanie bezpośredniej łączności z etniczną ojczyzną, zmiana stylu życia, bardzo silne rozproszenie przestrzenne członków mniejszości, życie w otoczeniu polskiej większości, powszechnie występujące mieszane małżeństwa, całkowita dominacja języka i kultury polskiej (Barwiński 2006a). Jak pisał E. Mironowicz (1998), „ogromna większość Białorusinów mieszkających w miastach uległa asymilacji. Sami siebie zaakceptowali jako Polaków". Należy przypuszczać, że proces ten nie dotyczył wyłącznie mniejszości białoruskiej.

Pomimo niewątpliwego występowania w przeciągu ostatnich kilkudziesięciu lat procesów polonizacyjnych wśród mniejszości narodowych, nie znajdowało to odzwierciedlenia w różnorakich szacunkach dotyczących ich liczebności, według których liczba przedstawicieli omawianych mniejszości narodowych w Polsce, począwszy od lat 50. XX w., albo utrzymywała się przez lata na podobnym poziomie, albo systematycznie rosła (tab. 15).

Określenie liczebności poszczególnych grup narodowych i etnicznych w powojennej Polsce było bardzo trudne, głównie z powodu licznych ruchów migracyjnych, niesprzyjających deklaracjom narodowościowym uwarunkowań politycznych oraz braku oficjalnej statystyki narodowościowej. Pytanie o narodowość uwzględniał tylko pierwszy po wojnie spis ludności z 1946 r., jednak jego wyniki z wielu różnych, omawianych wcześniej powodów, są mało wiarygodne. W kolejnych spisach powszechnych w okresie PRL nie było pytań dotyczących 
tożsamości narodowej. Wynikało to ze stanowiska władz państwowych propagujących jednonarodowy model polskiego społeczeństwa.

Bezpośrednio po II wojnie władze państwowe kilkakrotnie podejmowały próby określenia struktury narodowościowej Polski. Miały one jednak z reguły bardzo ograniczony zasięg lokalny i wiązały się z przygotowaniami do akcji przesiedleńczych, zwłaszcza we wschodniej Polsce i na tzw. Ziemiach Odzyskanych. Także w późniejszych latach, wobec braku kryterium narodowościowego w spisach powszechnych, szacowano liczebność poszczególnych narodowości na podstawie informacji napływających od władz lokalnych. Urzędnicy gromadzili dane na podstawie własnego rozeznania środowiska lokalnego, dokumentów wydawanych przez niemieckie władze okupacyjne, analizy niektórych kart meldunkowych, kryterium wyznaniowego. Były to metody, które uniemożliwiały precyzyjne określenie liczebności ludności niepolskiej, a często prowadziły do błędnych wniosków.

Statystykę dotyczącą mniejszości narodowych w skali całego kraju podano do publicznej wiadomości po raz pierwszy dopiero w 1957 r., kiedy w prasie opublikowano dane Sejmowej Komisji Spraw Wewnętrznych. W tym okresie, w związku z powstaniem licznych organizacji poszczególnych mniejszości, zaczęły także pojawiać się szacunki prezentowane przez liderów stowarzyszeń mniejszościowych. Najczęściej były to dane znacznie zawyżone, prawdopodobnie dla podkreślenia rangi i znaczenia własnych narodowości (Olejnik 2003).

W latach 60. i 70. XX w. liczebność mniejszości narodowych nadal była określana nie przez powołane do tego instytucje (np. Główny Urząd Statystyczny), tylko przez władze administracyjne i państwowe, zwłaszcza Ministerstwo Spraw Wewnętrznych, któremu podlegały wszelkie organizacje mniejszości i cała problematyka narodowościowa. Dane te były gromadzone, tak jak wcześniej, na podstawie informacji władz lokalnych oraz władz stowarzyszeń narodowościowych, czyli miały charakter szacunkowy. Przez prawie cały okres PRL dane dotyczące liczebności poszczególnych narodowości nie ulegały praktycznie żadnym zmianom. Przez kilkadziesiąt lat podawano, że w Polsce zamieszkuje ok. 160-180 tys. Białorusinów, ok. 9-10 tys. Litwinów oraz ok. 180-200 tys. Ukraińców (tab. 15).

Sytuacja uległa zmianie na początku lat 90 . XX w. po przemianach ustrojowych w Polsce. W 1992 r. powołano w Głównym Urzędzie Statystycznym Zespół Wyznań Religijnych i Narodowości, który zajmuje się statystyką dotyczącą zagadnień narodowościowych i religijnych. Zainicjował on badania ankietowe obejmujące struktury organizacyjne mniejszości, dzięki którym systematycznie zbiera i aktualizuje dane statystyczne, dotyczące zarówno liczby organizacji i stowarzyszeń mniejszości narodowych oraz etnicznych zarejestrowanych 
w Polsce, jak i liczebności ich członków. Liczebność ustala na podstawie informacji $\mathrm{z}$ ankiet wypełnianych przez członków zarządu poszczególnych organizacji, czyli jest ona uwarunkowana rzetelnością statystyki - bardzo często szacunkowej - prowadzonej przez poszczególne organizacje. Mimo prób weryfikacji tych danych przez urzędników GUS, trudno uniknąć ich zawyżania, charakterystycznego zwłaszcza dla lat 90 . XX w. Obecnie władze organizacji narodowościowych, zwłaszcza tych największych, przesyłają do GUS bardziej realne dane dotyczące liczby ich członków, choć nadal głównie szacunkowe (Wyznania religijne... 2010).

Tabela 15. Szacunki dotyczące liczebności Białorusinów, Litwinów i Ukraińców w Polsce w drugiej połowie XX w. (w tys.)

\begin{tabular}{|c|c|c|c|l|}
\hline \multirow{2}{*}{ Rok } & \multicolumn{3}{|c|}{ Narodowości } & \multirow{2}{*}{ Szacunki na podstawie } \\
\cline { 2 - 4 } & $\begin{array}{c}\text { Biało- } \\
\text { rusini }\end{array}$ & Litwini & Ukraińcy & \\
\hline 1950 & 110 & 10 & 100 & $\begin{array}{l}\text { dane Ministerstwa Administracji Publicznej, } \\
\text { Olejnik (2003) }\end{array}$ \\
\hline 1950 & 160 & - & 150 & P. Eberhardt (2010a) \\
\hline 1954 & 148 & 9 & 162 & A. Kwilecki (1963) \\
\hline 1957 & 120 & $\begin{array}{c}\text {,kilka } \\
\text { tysięcy” }\end{array}$ & 200 & $\begin{array}{l}\text { dane sejmowej Komisji Spraw } \\
\text { Wewnętrznych, Olejnik (2003) }\end{array}$ \\
\hline 1960 & 165 & 9 & 200 & $\begin{array}{l}\text { dane Departamentu Społeczno- } \\
\text {-Administracyjnego MSW, L. Olejnik (2003) }\end{array}$ \\
\hline 1960 & 165 & 10 & 180 & A. Kwilecki (1963) \\
\hline 1960 & 170 & 10 & 180 & $\begin{array}{l}\text { Wielka encyklopedia powszechna PWN, t. 9 } \\
\text { (1967) }\end{array}$ \\
\hline 1971 & 180 & 9 & 200 & J. Byczkowski (1976) \\
\hline 1978 & 160 & 12 & 220 & A. Sakson (1991) \\
\hline 1990 & $200-250$ & $12-20$ & $300-400$ & A. Sakson (1991) \\
\hline 1992 & 215 & 9 & 265 & P. Eberhardt (1996) \\
\hline 1993 & $200-230$ & 20 & $200-220$ & M. Hołuszko (1993) \\
\hline 1993 & $250-300$ & $20-30$ & $300-400$ & $\begin{array}{l}\text { Nowa encyklopedia powszechna PWN, t. 5 } \\
\text { (1996) }\end{array}$ \\
\hline 1995 & 240 & 20 & 300 & H. Chałupczak i T. Browarek (1998) \\
\hline
\end{tabular}

${ }^{a} \mathrm{~W}$ okresie PRL nie wyróżniano Łemków jako odrębnej grupy etnicznej, szacunki dotyczyły łącznej liczby Ukraińców i Łemków.

Źródło: opracowanie własne. 
Upowszechnienie na początku lat 90. XX w. szacunkowych danych dotyczących liczebności członków licznie powstających organizacji narodowościowych, dalszy brak oficjalnych danych spisowych oraz przekonanie wielu badaczy, iż w okresie PRL władze celowo zaniżały liczebność ludności niepolskiej, spowodowały wyraźny wzrost szacowanej liczebności mniejszości narodowych (tab. 15).

Badania naukowe dotyczące struktury etnicznej współczesnej Polski, ograniczone w okresie komunistycznym, uległy ożywieniu w latach 80. XX w., a prawdziwy „boom mniejszościowy” można obserwować od początku lat 90. tego stulecia. Problematyką tą zajmowali się (oraz zajmują nadal) socjologowie (m.in. L. Adamczuk, D. Berlińska, G. Babiński, G. Gudaszewski, Z. Kurcz, A. Kwilecki, S. Łodziński, E. Michna, A. Mirga, L. Nijakowski, C. Obracht-Prondzyński, W. Pawluczuk, A. Sadowski, A. Sakson, M. Ślęzak, D. Wojakowski, P. Wróblewski), historycy (m.in.: R. Drozd, S. Dudra, B. Halczak, G. Hryciuk, P. Madajczyk, B. Makowski, E. Mironowicz, E. Misiło, J. Moklak, G. Motyka, L. Olejnik, G. Pełczyński, J. Pisuliński, K. Tarka, J. Tomaszewski, M. Waldenberg, J. Wysocki), geografowie (m.in.: M. Barwiński, P. Eberhardt, M. Flaga, A. Gawryszewski, K. Heffner, W. Janicki, M. Koter, M. Kowalski, M. Kulesza, A. Maryański, R. Matykowski, J. Mordawski, A. Rykała, M. Sobczyński, M. Soja, K. Szczygielski), demografowie (m.in.: T. Wysocki) oraz politolodzy (m.in.: T. Browarek, H. Chałupczak, K. Pudło, C. Żołędowski).

Mimo bardzo dużej liczby opracowań dotyczących struktury narodowościowej Polski, publikowanych w latach 90. XX w. oraz na początku XXI w., szacunki dotyczące liczebności poszczególnych mniejszości istotnie się różniły albo były zawarte w szerokich przedziałach, co ograniczało ich wiarygodność oraz wartość poznawczą (tab. 15-16). Było to w głównej mierze konsekwencją obiektywnych i subiektywnych problemów w badaniach kwestii etnicznych, stosowania przez naukowców różnych metod badawczych i kryteriów przynależności do mniejszości, braku możliwości odniesienia do ogólnopolskich danych urzędowych, zróżnicowanej reprezentatywności badań.

\subsection{Analiza wyników spisu powszechnego z 2002 roku}

W 1997 r. rozpoczęły się przygotowania do kolejnego spisu powszechnego planowanego początkowo na $2000 \mathrm{r}$. W ich trakcie pojawiło się kilka projektów pytań o narodowość, język i wyznanie. Po wielu dyskusjach kierownictwo GUS podjęło decyzję o ich skreśleniu z kwestionariusza spisowego. O wprowadzeniu do spisu pytań o narodowość i język w 1999 r. zadecydowali posłowie, przyj- 
mując Ustawę o narodowym spisie powszechnym (Adamczuk 2006, Łodziński 2006b). Niestety, nie podjęto decyzji o umieszczeniu w formularzu spisowym pytania o wyznanie.

Termin Narodowego Spisu Powszechnego Ludności i Mieszkań był kilkakrotnie przekładany (co zdarzyło się pierwszy raz w historii spisów powszechnych w Polsce) i ostatecznie odbył się na przełomie maja i czerwca 2002 r. Był pierwszym spisem od kilkudziesięciu lat, w którym zadano pytania dotyczące narodowości i języka używanego w domu, dzięki czemu otrzymano oficjalną liczebność oraz rozmieszczenie ludności niepolskiej na terytorium Rzeczypospolitej na początku XXI w.

Zaskakującą sytuacją w okresie przedspisowym była bardzo mała aktywność liderów poszczególnych grup narodowościowych. Praktycznie poza działalnością organizacji romskich oraz Ruchu Autonomii Śląska brak było jakichkolwiek działań wzywających do deklarowania w spisie niepolskich narodowości. Przed spisem członkowie władz głównych organizacji narodowościowych krytykowali umieszczenie pytania o narodowość w formularzu spisowym, a nawet zażądali od Sejmowej Komisji Mniejszości Narodowych i Etnicznych jego wycofania. Argumentowali, że członkowie mniejszości będą się obawiać oficjalnie zadeklarować własną, odmienną tożsamość narodowa, przez co wyniki spisu będą niewiarygodne, zaniżą rzeczywistą liczebność poszczególnych mniejszości ${ }^{1}$. Wysuwano także wattpliwości co do ochrony prywatności, danych osobowych oraz obawy związane ze skutkami ujawnienia informacji o narodowości w miejscu zamieszkania i pracy (Łodziński 2006b). Wydaje się, że zastrzeżenia wysuwane przez liderów organizacji narodowościowych wynikały głównie z obawy przed ujawnieniem liczby świadomych swej narodowej odrębności Ukraińców, Niemców, Białorusinów, Litwinów, Czechów, Słowaków, Żydów oraz przedstawicieli innych grup narodowych. Przed spisem nie można było precyzyjnie odpowiedzieć na pytanie o liczebność mniejszości narodowych w Polsce. Dane były wyłącznie orientacyjne, nieweryfikowane od lat, a szacunki, zwłaszcza podawane przez poszczególne organizacje mniejszości wydawały się niejednokrotnie zawyżone. Konfrontacja oficjalnych wyników spisu z dotychczasowymi szacunkami okazała się dla wielu działaczy narodowościowych niezwykle bolesna, a dla wielu naukowców zaskakująca i mało wiarygodna. Spis był swoistym egzaminem ze stopnia poczucia świadomości narodowej i w pewnym sensie wykazał natężenie procesów asymilacyjnych wśród poszczególnych mniejszości (Babiński 2004b, Barwiński 2006a).

${ }^{1}$ Na podstawie artykułu J. Wilczaka Kto ty jesteś?, „Polityka”, nr 16, 20.04 .2002 r., s. $30-34$. 
Podczas spisu miały miejsce protesty liderów organizacji narodowościowych, dotyczące wypełniania rubryk z pytaniem o narodowość i język ołówkiem, nieuwzględniania przez rachmistrzów deklaracji niepolskich narodowości, „automatycznego" wpisywania narodowości polskiej oraz odmowy wpisywania w formularzu narodowości śląskiej (Łodziński 2006b). Po zakończeniu spisu działacze poszczególnych mniejszości narodowych, kwestionując jego wiarygodność, podkreślali, że uchwycił on jedynie liczbę osób najbardziej uświadomionych narodowo i nieobawiających się zadeklarować swojej niepolskiej narodowości (Chałupczak 2006, Nijakowski 2006). Działacze organizacji ukraińskich, łemkowskich, białoruskich i litewskich zgodnie uważają, że wyniki spisu nie oddały rzeczywistej liczebności mniejszości narodowych w Polsce, były zdecydowanie zaniżone. Główną przyczyną tak niskich wyników była - według nich - obawa i niechęć do deklarowania niepolskiej narodowości, zwłaszcza wśród ludzi starszych, oraz postępująca asymilacja wśród młodzieży. Pojawiały się także odosobnione opinie, że pytania dotyczące narodowości są umieszczane w spisach powszechnych głównie po to, żeby władze wykazały małą liczebność mniejszości narodowych. Ponadto podkreślali - jednak wyłącznie działacze organizacji ukraińskich - liczne przypadki manipulacji i nieprawidłowości, pomijania pytania o narodowość, wypełniania formularzy spisowych ołówkiem².

Pytanie o narodowość sformułowano w najprostszy, ale jednocześnie bardzo bezpośredni sposób - „do jakiej narodowości się Pan(i) zalicza?”3. Było to wyraźne nawiązanie do spisu z 1921 r., a jednocześnie zachowanie zgodności z normami europejskimi oraz kryteriami etniczności dominującymi współcześnie w literaturze przedmiotu. Pytanie miało charakter otwarty oraz formę subiektywnej deklaracji, nie było żadnego spisu narodowości do wyboru, nie było także możliwości deklarowania złożonych, stopniowalnych tożsamości. Rachmistrze spisowi zostali zobowiązani do odnotowania każdej, ale wyłącznie jednej, odpowiedzi na temat przynależności narodowej ${ }^{4}$.

${ }^{2} \mathrm{Na}$ podstawie wywiadów przeprowadzonych w 2012 r. przez autora z działaczami Związku Ukraińców w Polsce, Związku Ukraińców Podlasia, Towarzystwa Ukraińskiego, Stowarzyszenia Łemków, Zjednoczenia Łemków, Stowarzyszenia Młodzieży Łemkowskiej „Czuha”, Białoruskiego Towarzystwa Społeczno-Kulturalnego, Rady Programowej Tygodnika „Niwa”, Białoruskiego Zrzeszenia Studentów, Stowarzyszenia Litwinów w Polsce, Litewskiego Towarzystwa Św. Kazimierza.

${ }^{3} \mathrm{~W}$ formularzu spisowym narodowość zdefiniowano jako ,deklaratywną (opartą na subiektywnym odczuciu) cechę indywidualną każdego człowieka, wyrażającą jego związek emocjonalny (uczuciowy), kulturowy lub genealogiczny (ze względu na pochodzenie rodziców) z określonym narodem".

${ }^{4} \mathrm{Na}$ podstawie ,Instrukcji metodologicznej do Narodowego Spisu Powszechnego Ludności i Mieszkań w 2002 r. dla rachmistrza spisowego" Warszawa, 2001. Wyjątek 
Spis wykazał niewielką liczebność ludności niepolskiej - inną niż polska narodowość zadeklarowało zaledwie 471,5 tys. osób ${ }^{5}$ (1,23\%), z tego 444,6 tys. posiadało obywatelstwo polskie $(1,16 \%)$, więc zgodnie $\mathrm{z}$ aktualnym stanem prawnym tylko te osoby można traktować jako członków mniejszości narodowych i etnicznych w Polsce. Liczby te potwierdziły powszechną tezę, że Polska należy do najbardziej homogenicznych narodowościowo państw w Europie ${ }^{6}$. Jednak mimo małej liczebności mniejszości, struktura narodowościowa Polski okazała się niezwykle zróżnicowana i jednocześnie rozdrobniona. W trakcie spisu wyodrębniono aż 109 różnych mniejszości (zarówno narodowych, etnicznych, jak i etniczno-regionalnych), w tym zaledwie 18 liczących ponad 1000 osób ${ }^{7}, 91$ liczących poniżej 1000 osób, połowę liczącą poniżej 100 osób oraz 36 liczących mniej niż 50 osób $^{8}$.

Nie ustalono przynależności narodowej aż 774,9 tys. osób, dotyczyło to jednak w zdecydowanej większości osób nieobecnych w trakcie spisu w miejscu zamieszkania oraz nieposiadających obywatelstwa polskiego ${ }^{9}$. W bezpośredniej rozmowie z rachmistrzem deklaracji narodowościowej odmówiło ok. 40 tys. osób (Nijakowski, Łodziński 2003, Łodziński 2006b). Można tylko przypuszczać, że byli to głównie członkowie mniejszości narodowych. Ponadto 4,2 tys. osób zadeklarowało niepolską narodowość, jednak nie precyzując jaką.

Jednym z najbardziej zaskakujących wyników spisu była bardzo duża liczba deklaracji narodowości śląskiej - 173,2 tys. (w tym posiadających polskie

stanowiły określenia „tutejszy”, ,autochton”, „swój”, które nie miały być wpisywane (Lodziński 2006b).

${ }^{5}$ Wszystkie zawarte w pracy dane liczbowe dotyczące wyników spisu z 2002 r. zostały podane na podstawie „Raportu z wyników Narodowego Spisu Powszechnego Ludności i Mieszkań 2002” GUS: www.stat.gov.pl.

${ }^{6}$ Państwo uznawane jest za jednolite etnicznie, jeżeli mniejszości narodowe i etniczne nie stanowią więcej niż 5\% obywateli, w przypadku Polski w 2002 r. ten udział był prawie pięciokrotnie mniejszy.

${ }^{7}$ Dotyczyło ogółu deklaracji narodowości niepolskiej, także osób nieposiadających polskiego obywatelstwa. Pośród deklaracji wyłącznie osób z polskim obywatelstwem, narodowości liczących ponad 1000 osób było zaledwie 12 (Ślązacy, Niemcy, Białorusini, Ukraińcy, Romowie, Łemkowie, Litwini, Kaszubi, Rosjanie, Słowacy, Żydzi, Francuzi).

${ }^{8}$ Spośród 109 wykazanych w trakcie spisu narodowości, pięć najliczniejszych (śląska, niemiecka, białoruska, ukraińska i romska) stanowiło aż 88,7\% ogółu deklaracji niepolskiej narodowości, a łącznie z pięcioma kolejnymi pod względem liczebnym mniejszościami (rosyjską, litewską, łemkowską, kaszubską, słowacką) reprezentowało aż 96,4\% wszystkich osób deklarujących podczas spisu niepolską narodowość (Szczygielski 2006).

${ }^{9}$ Wśród obywateli polskich nie ustalono narodowości w przypadku 189,9 tys. osób, w większości nieobecnych w trakcie spisu w miejscu zamieszkania. 
obywatelstwo 172,7 tys.). Ślązacy, według wyników spisu, okazali się najliczniejszą mniejszością, swoistymi zwycięzcami spisu powszechnego.

Kolejnym, charakterystycznym wynikiem spisu było wykazanie bardzo małej liczebności grup mniejszościowych, zdecydowanie odbiegającej in minus od wcześniejszych szacunków. Różnica między szacunkami a wynikami spisu była nawet dziesięciokrotna. Dotyczyło to mniejszości relatywnie licznych, jak Ukraińcy, Białorusini ${ }^{10}$, Łemkowie, i liczebnie marginalnych, jak Tatarzy, Ormianie, Czesi czy Żydzi. Mniejsze różnice dotyczyły Litwinów i Niemców, a najmniejsza różnica była w przypadku Romów (tab. 16). Z pewnością wyniki spisu obniżyły społeczną i polityczną pozycję wielu mniejszości narodowych, zwłaszcza Ukraińców i Białorusinów.

Tak duże różnice między szacunkami z lat 90 . XX w. a wynikami spisu mogą wskazywać na dwie możliwości: wcześniejsze zawyżenie rzeczywistej liczebności poszczególnych mniejszości lub jej zaniżenie poprzez procedury zastosowane w trakcie spisu powszechnego. Wydaje się, że oba te czynniki zadziałały jednocześnie, dlatego wyniki spisu z 2002 r. - tak jak wszelkich spisów powszechnych - trzeba ostrożnie interpretować, pamiętając, że subiektywne deklaracje tożsamości narodowej należą do kwestii bardzo osobistych, trudno mierzalnych i mogą ulegać zmianom w zależności od uwarunkowań politycznych, społecznych, kulturowych, gospodarczych. Dlatego też szacunki oraz statystyki dotyczące kwestii narodowościowych zawsze będą obarczone błędami.

Można założyć, że pod koniec lat 90. XX w. szacunkowa liczebność mniejszości narodowych była zawyżona. Wynikało to ze wspomnianych wyżej problemów z jej szacowaniem oraz z niedoceniania intensywności procesów asymilacji i akulturacji. Były one powodowane głównie czynnikami politycznymi, zarówno w okresie PRL, kiedy to starano się utworzyć w Polsce społeczeństwo monoetniczne, jak i w okresie demokratyzacji życia społeczno-politycznego w latach 90. XX w., kiedy to pełne polityczne uznanie mniejszości, powstanie wielu - często konkurencyjnych - organizacji, wikłanie się ich w walkę polityczną, stawiało członków mniejszości przed koniecznością dokonywania jednoznacznych wyborów. Jak pisze G. Babiński (2004b), „owo «wyjście z cienia» [...] nie zawsze rodziło skutki w postaci świadomego akcesu do mniejszości”. Asymilacji niewątpliwie sprzyjało także rozproszenie, migracje do miast, życie wśród polskiej większości, dominacja języka i kultury polskiej, mieszane małżeństwa. W latach 90. XX w. dokonała się kolejna zmiana pokoleniowa, w dorosłość weszło już drugie pokolenie urodzone i wychowane na nowych

${ }^{10}$ Szacunki A. Sadowskiego (1997) i M. Barwińskiego (2004a) dotyczące liczebności mniejszości białoruskiej (ok. 60 tys.) były zbliżone do wyników spisu. 
miejscach osiedlenia, pojawiła się nowa rzeczywistość polityczna i gospodarcza, można przypuszczać, że nastapiła wyraźna intensyfikacja procesów asymilacji wśród młodzieży.

Tabela 16. Narodowości posiadające status mniejszości narodowych i etnicznych w Polsce - porównanie szacunków z lat 90. XX w. oraz wyników spisu powszechnego z 2002 r.

\begin{tabular}{|c|c|c|c|c|}
\hline \multirow{3}{*}{ Narodowości } & \multirow{3}{*}{$\begin{array}{c}\text { Szacunkowa } \\
\text { liczebność (tys.) }\end{array}$} & \multicolumn{3}{|c|}{ Wyniki spisu powszechnego (tys.) } \\
\hline & & \multicolumn{2}{|c|}{ Narodowość (według GUS) } & \multirow{2}{*}{$\begin{array}{c}\text { Jezzyk } \\
\text { używany } \\
\text { w domu } \\
\text { (według GUS) }\end{array}$} \\
\hline & & ogółem & $\begin{array}{c}\text { z polskim } \\
\text { obywatelstwem }\end{array}$ & \\
\hline \multicolumn{5}{|c|}{ Status $^{a}{ }^{\text {mniejszości narodowych }}$} \\
\hline Niemcy & $300-360$ & 152,9 & 147,1 & 196,8 \\
\hline Bialorusini & $60-300$ & 48,7 & 47,6 & 40,2 \\
\hline Ukraińcy & 150-300 & 31,0 & 27,2 & 21,1 \\
\hline Litwini & 9-25 & 5,8 & 5,6 & 5,7 \\
\hline Rosjanie & $10-17$ & 6,1 & 3,2 & 12,1 \\
\hline Słowacy & $10-25$ & 2,0 & 1,7 & 0,8 \\
\hline Żydzi & $5-15$ & 1,1 & 1,1 & 0,24 \\
\hline Czesi & $1-5$ & 0,8 & 0,4 & 1,2 \\
\hline Ormianie & $5-15$ & 1,1 & 0,3 & 0,3 \\
\hline \multicolumn{5}{|c|}{ Status $^{a}$ mniejszości etnicznych } \\
\hline Romowie & $15-25$ & 12,9 & 12,7 & 15,7 \\
\hline Lemkowie & $50-80$ & 5,9 & 5,8 & 5,6 \\
\hline Tatarzy & $2,5-5$ & 0,5 & 0,45 & 0,01 \\
\hline Karaimi & $0,15-0,2$ & 0,04 & 0,04 & 0,0 \\
\hline \multicolumn{5}{|c|}{ Status $^{a}$ społeczności posługującej się językiem regionalnym } \\
\hline Kaszubi & $370-500$ & 5,1 & 5,1 & 52,6 \\
\hline
\end{tabular}

${ }^{a}$ Wymienionych w Ustawie o mniejszościach narodowych i etnicznych oraz o języku regionalnym.

Źródła: szacunki na podstawie: M. Hołuszko (1993), Ł. Wierzycka, M. Hołuszko, A. Rzepliński (1993), P. Eberhardt (1996, 2006), M. Sobczyński (1996a, 2000), Z. Kurcz (1997), A. Sadowski (1997), H. Chałupczak, T. Browarek (1998), J. Borzyszkowski, J. Mordawski, J. Treder (1999), L. Nijakowski, S. Łodziński (2003), S. Łodziński (2005).

Można przyjąć, że wartości liczbowe podawane w różnego rodzaju szacunkach dotyczących liczebności mniejszości narodowych i etnicznych w Polsce, 
zwłaszcza w latach 90. XX w., dotyczyły ogółu osób wywodzących się ze środowisk ludności niepolskiej. Zarówno osób o bardzo silnej tożsamości narodowej, jak i „pochodzenia” niepolskiego, o złożonej, stopniowalnej tożsamości narodowej, a także osób, które w ciągu ostatnich kilkudziesięciu czy kilkunastu lat w dużym stopniu zatraciły poczucie odrębności narodowej i obecnie uważają się za Polaków, a nie członków mniejszości narodowych.

Czynniki określające przynależność narodową najogólniej można podzielić na obiektywne i subiektywne. Do czynników obiektywnych zalicza się m.in. wspólny język, kulturę, religie, pochodzenie, zamieszkiwane terytorium, natomiast do subiektywnych przede wszystkim poczucie tożsamości narodowej jednostki, niewymuszoną deklarację przynależności do danego narodu. Zdecydowana większość szacunków dotyczących liczebności mniejszości narodowych w Polsce odwoływała się głównie do cech obiektywnych, natomiast spis powszechny dotyczył wyłącznie subiektywnej autoidentyfikacji poszczególnych osób. W społeczeństwach demokratycznych od lat subiektywne czynniki przynależności narodowej odgrywają rolę nadrzędną. Określanie struktury narodowościowej na podstawie cech subiektywnych, wolnej woli i samoświadomości jest precyzyjniejsze (co nie oznacza, że precyzyjne) niż odwoływanie się głównie do czynników obiektywnych, mogące prowadzić do przypisywania innej narodowości niż ta, z którą dana osoba się identyfikuje, i tym samym nie ukazywać aktualnego zróżnicowania narodowościowego danego obszaru.

Trzeba jednak pamiętać, że spis powszechny jest postrzegany jako przedsięwzięcie administracyjne władz państwowych, co w kontekście negatywnych doświadczeń historycznych niektórych grup narodowościowych (np. Niemców, Ukraińców, Łemków) może powodować niechęć ujawniania niepolskiej tożsamości, zwłaszcza w bezpośredniej rozmowie z rachmistrzem. Czynnikiem, który mógł wpłynąć na wyniki, był brak anonimowości, zwłaszcza w środowiskach wiejskich i małomiasteczkowych. Prawdopodobnie nie bez znaczenia dla tak niewielkiej, wykazanej $\mathrm{w}$ trakcie spisu liczebności osób niepolskiej narodowości, był nadal utrzymujący się wśród polskiego społeczeństwa niewielki poziom tolerancji oraz negatywne stereotypy, co mogło powodować niechęć do deklaracji m.in. narodowości romskiej, ukraińskiej, żydowskiej, niemieckiej czy białoruskiej.

Ponadto w spisie powszechnym z 2002 r. po raz pierwszy od kilkudziesięciu lat zadano pytanie o narodowość, sformułowane bardzo bezpośrednio, jednoznacznie. Taka nowość z pewnością wywołała konsternację wśród części ludności niepolskiej, co mogło w efekcie prowadzić do zatajenia prawdziwego pochodzenia etnicznego lub do świadomego wyboru narodowości polskiej w przypadku niewielkiego poczucia tożsamości z własną grupą mniejszościową. 
Nie było także możliwości zadeklarowania złożonej, podwójnej (stopniowalnej) tożsamości narodowej lub odwołania się do pochodzenia etnicznego.

Spis powszechny, wykazując niewielką liczebność mniejszości narodowych, zdecydowanie odbiegającą od wcześniejszych szacunków, z jednej strony ukazał skalę przeszacowania oraz natężenie procesów polonizacyjnych, które zaszły w ciągu ostatniego półwiecza, z drugiej zaś, z powodu przyjętej metody przeprowadzenia spisu i konstrukcji pytania oraz uwarunkowań społecznych, zaniżył liczebność mniejszości narodowych w Polsce. Jego wyniki, podobnie jak wszystkich tego typu spisów w państwach demokratycznych, opierały się wyłącznie na subiektywnych deklaracjach obywateli. Nie oddają one w pełni współczesnej struktury narodowościowej Polski, nie można ich jednak negować. Nie tyle pokazują rzeczywistą liczebność poszczególnych mniejszości, ile stan świadomości narodowej niepolskich narodowości. Uzyskane w trakcie spisu dane należy traktować jako wartości minimalne, jako liczbę osób o silnie ugruntowanej niepolskiej tożsamości narodowej. Od samej liczebności większą wartość poznawczą, zwłaszcza dla geografów, mają uzyskane w trakcie spisu dane dotyczące współczesnego rozmieszczenia poszczególnych mniejszości narodowych i etnicznych.

Jedną z najistotniejszych prawnych oraz praktycznych konsekwencji spisu był fakt, iż jego wyniki stały się automatycznie danymi urzędowymi, którymi muszą kierować się instytucje i organy administracji rządowej, zwłaszcza w kontekście przyjętej w 2005 r. Ustawy o mniejszościach narodowych i etnicznych oraz o języku regionalnym.

W spisie zawarto również pytanie o język „najczęściej używany w domu”" Było to nawiązanie do międzywojennego kryterium ustalania narodowości, z tym że w spisach w 1921 r. oraz w 1931 r. było zawarte pytanie o ,język ojczysty”, a nie „używany w domu”. Można było podać maksymalnie trzy języki, w tym dwa niepolskie, niezależnie od tego, czy były one używane razem z językiem polskim, czy też wyłącznie. Posługiwanie się językami niepolskimi w kontaktach rodzinnych zadeklarowało 563,5 tys. osób (w tym obywateli polskich 539,7 tys.), czyli ponad 100 tys. więcej niż niepolską narodowość. $Z$ reguły języki te były używane na przemian z językiem polskim (511 tys., w tym obywatele polscy 492,2 tys.). Prawie dziesięciokrotnie rzadziej (52,5 tys., w tym obywatele polscy 46,6 tys.) deklarowano używanie w domu wyłącznie jednego lub dwóch języków niepolskich. Z porównania deklaracji narodowościowych i językowych uzyskanych podczas spisu, poza kilkoma wyjątkami, widać niemu?"

${ }^{11}$ Pytanie brzmiało „W jakim języku (językach) rozmawia Pan(i) najczęściej w do- 
wielką przewagę liczebną deklaracji narodowościowych nad językowymi (tab. 15). Może to świadczyć o szybciej zachodzących procesach asymilacji językowej niż narodowej oraz o zmniejszaniu się roli języka jako wyróżnika przynależności etnicznej. Ogółem wyodrębniono 87 języków niepolskich, w tym wiele dialektów i gwar. Zaledwie 20 języków wymieniano częściej niż przez tysiąc osób. Zdecydowanie najczęściej deklarowano język niemiecki (204,6 tys.) oraz angielski $\left(89,9\right.$ tys.) ${ }^{12}$. Tak duża liczba deklaracji języka angielskiego, jako „języka używanego w domu”, nie ma żadnego uzasadnienia w strukturze narodowościowej Polski ${ }^{13}$. Nasuwa to podejrzenia o niezrozumienie sensu tego pytania przez część badanych. Prawdopodobnie w tym pytaniu, poza rzeczywistymi deklaracjami ,języków domowych”, była także deklarowana znajomość języków obcych, najczęściej wyniesiona ze szkoły. Taką hipotezę potwierdza również zdecydowanie wyższa liczba deklaracji używania języka niemieckiego, rosyjskiego, francuskiego i włoskiego (najpopularniejszych obok angielskiego ,jezzyków szkolnych") niż deklaracji tych narodowości ${ }^{14}$. Dlatego też wartość poznawcza danych dotyczących deklaracji językowych w przypadku tych pięciu języków jest niewielka, a liczba osób używających ich „,w kontaktach domowych" jest z pewnością zawyżona ${ }^{15}$.

Wyniki spisu jednoznacznie pokazały bardzo dużą różnorodność mniejszości narodowych i etnicznych w Polsce. Obok społeczności wielotysięcznych, od wieków kształtujących polską historię i kulturę, spis pokazał, że Polska stała się ojczyzną dla przedstawicieli kilkudziesięciu narodów, niejednokrotnie reprezentowanych przez zaledwie kilkuset lub wręcz kilkudziesięciu członków.

${ }^{12}$ Wśród osób posiadających polskie obywatelstwo używanie w kontaktach domowych języka niemieckiego zadeklarowało 196,8 tys., a angielskiego 86,3 tys. osób.

${ }^{13}$ Zsumowanie wyróżnionych w spisie narodowości, dla których język angielski był językiem ojczystym, językiem urzędowym ich kraju pochodzenia lub dawnej metropolii kolonialnej (Afroamerykanów, Amerykanów, Anglików, Australijczyków, Bengalczyków, Hindusów, Irlandczyków, Kanadyjczyków, Maltańczyków, Nepalczyków, Pakistańczyków, Syngalezów, Szkotów, Walijczyków, Zulusów), dało zaledwie 3698 osób. Trudno też przypuszczać, by wszyscy posługiwali się w domu językiem angielskim. Część prawdopodobnie używała tylko własnych języków narodowych, część języka polskiego, a część, np. Kanadyjczyków, języka francuskiego. Nawet założenie, że większość z tych osób żyło w rodzinach wieloetnicznych, w których współmałżonek oraz dzieci posługiwali się w domu językiem angielskim, nie zbliżało istotnie do wykazanej w spisie liczby prawie 90 tys. osób.

${ }_{14} \mathrm{Na}$ podstawie Głównego Urzędu Statystycznego: http://demografia.stat.gov.pl/ Baza Demografia/NSP.2002.aspx.

${ }^{15}$ Tezę tę potwierdza umieszczenie przez GUS w kolejnym formularzu spisowym w 2011 r., przy pytaniu dotyczącym ,języka, jakim zazwyczaj posługuje się Pan(i) w domu” wyraźnej informacji, że „nie należy mylić ze znajomością języka obcego”. 
Przodkowie niektórych z tych narodów pojawili się w Polsce już kilkaset (np. Mongołowie, Francuzi, Holendrzy) lub kilkadziesiąt lat temu (np. Macedończycy, Amerykanie, Palestyńczycy). Jednak wielu zaczęło na dużą skalę osiedlać się dopiero po przemianach polityczno-gospodarczych początku lat 90. XX w. Przybywali oni $-\mathrm{z}$ bardzo różnych powodów $-\mathrm{z}$ państw południowej Azji i północnej Afryki, ale także Europy Zachodniej i Ameryki Północnej. Można przypuszczać, że rozwój gospodarczy Polski oraz jej integracja z Unią Europejską będą sprzyjać dalszej imigracji i w przyszłości tzw. nowe mniejszości będą w coraz większym stopniu kształtować strukturę etniczną Polski (Barwiński 2006a).

Interesujące jest porównanie wykazanej podczas spisu struktury narodowościowej z liczebnością głównych grup wyznaniowych w Polsce ${ }^{16}$ (tab. 17). Wśród mieszkańców Polski powszechne są stereotypy jednoznacznie łączące tożsamość narodową i wyznaniową, m.in. narodowość polską, litewską, słowacką, romską z rzymskim katolicyzmem, niemiecką z protestantyzmem, żydowską z judaizmem, rosyjską i białoruską z prawosławiem, ukraińską i łemkowską z grekokatolicyzmem, a tatarską z islamem. Takie postrzeganie, choć bardzo upraszczające i uogólniające, jest w pewnym stopniu uzasadnione. Zostało uwarunkowane genezą niektórych wyznań na ziemiach polskich, w wielu przypadkach silnymi związkami między religią a narodowością, istotną rolą religii w kształtowaniu tożsamości i odrębności narodowej oraz w utrzymaniu świadomości narodowej niektórych mniejszości ${ }^{17}$. Jednocześnie podczas prób weryfikacji powyższych stereotypów z jednej strony relatywnie łatwo jest wykazać, że wśród Polaków, poza zdecydowanie dominującymi wyznawcami Kościoła rzymskokatolickiego, są także liczni protestanci, ponadto prawosławni, grekokatolicy, wyznawcy judaizmu czy wreszcie ateiści. Z drugiej strony wśród rzymskich katolików, poza osobami narodowości polskiej, litewskiej i słowackiej, romskiej, licznie reprezentowani są Niemcy i już zdecydowanie mniej licznie Czesi, Ukraińcy, Łemkowie, Białorusini, Ormianie. Z kolei wśród prawosławnych, obok Białorusinów i Rosjan, relatywnie liczną grupę stanowią Ukraińcy i Łemkowie, natomiast islam - poza mniejszością tatarską - wyznają także

${ }^{16} \mathrm{~W}$ formularzu spisu w $2002 \mathrm{r}$. nie umieszczono pytania o wyznanie, natomiast od początku lat 90. XX w. GUS prowadzi statystykę wyznaniową opartą na ankiecie statystycznej wypełnianej corocznie przez władze poszczególnych wyznań. Uzyskane dane sa publikowane co trzy lata w informatorze pt. Wyznania religijne. Stowarzyszenia narodowościowe $i$ etniczne $w$ Polsce.

17 Problematyka mniejszości religijnych w Polsce została obszernie opracowana przez A. Rykałę (2011) w pracy pt. Mniejszości religijne w Polsce - geneza, struktury przestrzenne, tło etniczne. 
licznie mieszkający w Polsce imigranci z krajów muzułmańskich. Dla żadnej ze współczesnych mniejszości w Polsce nie da się określić całkowitej zbieżności narodowości i wyznania, choć w wielu przypadkach nadal jest ona wyraźna (Sobczyński 2000, 2001a, Rykała 2006, 2011).

Tabela 17. Wyznawcy głównych nierzymskokatolickich wyznań w Polsce oraz mniejszości narodowe i etniczne stereotypowo utożsamiane $\mathrm{z}$ danym wyznaniem ( $w$ tys. osób, dane dla 2002 r.)

\begin{tabular}{|l|c|l|c|}
\hline Wyznania religijne & $\begin{array}{c}\text { Liczba } \\
\text { wyznawców } \\
\text { (szacunki GUS) }\end{array}$ & $\begin{array}{c}\text { Mniejszości } \\
\text { narodowe } \\
\text { i etniczne }\end{array}$ & $\begin{array}{c}\text { Liczba deklaracji } \\
\text { narodowości } \\
\text { (NSP) }\end{array}$ \\
\hline Prawosławie & $510,7^{b}$ & $\begin{array}{l}\text { Białorusini, } \\
\text { Rosjanie }\end{array}$ & 54,8 \\
\hline Grekokatolicyzm & $82,2^{c}$ & $\begin{array}{l}\text { Ukraińcy, } \\
\text { Łemkowie }\end{array}$ & 36,8 \\
\hline Protestantyzm & $82,7^{d}$ & Niemcy, Czesi & 153,7 \\
\hline Judaizm & $1,3^{e}$ & Żydzi & 1,1 \\
\hline Islam & $5,0^{f}$ & Tatarzy & 0,5 \\
\hline
\end{tabular}

${ }^{a}$ Dotyczy ogółu deklaracji danej narodowości podczas spisu powszechnego, nie tylko obywateli polskich.

${ }^{b}$ Polski Autokefaliczny Kościół Prawosławny oraz Wschodni Kościół Staroobrzędowy.

${ }^{c}$ Kościół greckokatolicki obrządku bizantyjsko-ukraińskiego oraz Kościół neounicki obrządku bizantyjsko-słowiańskiego.

${ }^{d}$ Kościół Ewangelicko-Augsburski oraz Kościół Ewangelicko-Reformowany.

${ }^{e}$ Związek Gmin Wyznaniowych Żydowskich.

${ }^{f}$ Muzułmański Związek Religijny.

Źródło: opracowanie własne.

Z powodu różnych metod gromadzenia danych dotyczących narodowości i wyznania, trudności w ocenie rzetelności danych dotyczących liczby wiernych poszczególnych Kościołów ${ }^{18}$ oraz częstego braku stereotypowych zależności między narodowością a wyznaniem, porównanie to ma charakter jedynie orientacyjny (tab. 17).

Z zestawienia (tab. 17) widać, iż główne mniejszości religijne w Polsce (poza protestantami) są liczniejsze niż stereotypowo przypisywane do nich narodowo-

${ }^{18}$ Dane te są ustalane na podstawie szacunków władz poszczególnych wyznań i mogą być zawyżone. Według GUS, do 2008 r. (czyli zaledwie sześć lat później) liczba wiernych Kościoła greckokatolickiego zmniejszyła się aż o 27 tys. osób, czyli 1/3 ogółu (do 55 tys.). 
ści ${ }^{19}$. Poczucie tożsamości religijnej, dużo silniejsze niż tożsamości narodowej czy językowej, najpóźniej - jeżeli w ogóle - poddaje się procesom asymilacji, zwłaszcza wśród konserwatywnych społeczności wiejskich. Najczęściej asymilacja narodowościowa zachodzi bez konwersji religijnej, czego konsekwencją jest liczna grupa osób utożsamiających się z narodem polskim, jednocześnie nienależących do Kościoła rzymskokatolickiego. Większa liczebność mniejszości religijnych niż narodowych jest kolejną przesłanką świadczącą o silnym wpływie procesów polonizacji na spadek liczebności mniejszości narodowych oraz prawdopodobnie licznej grupie osób o zróżnicowanej, stopniowalnej lub słabo wykrystalizowanej tożsamości narodowo-religijnej.

Najliczniejszym niekatolickim wyznaniem we współczesnej Polsce jest prawosławie. Badania naukowe przeprowadzone na Podlasiu pokazują, że powszechne, stereotypowe utożsamianie całej, licznie tam zamieszkującej społeczności prawosławnej, wyłącznie z Białorusinami, jest błędne. Mimo że praktycznie wszyscy Białorusini są wyznawcami prawosławia, to zaledwie co trzeci lub nawet co czwarty spośród podlaskich prawosławnych deklaruje białoruską tożsamość narodową, natomiast większość określa się jako Polacy, a niewielka część jako Ukraińcy (Sadowski 1991a, 1995a, 1997, Barwiński 2001a, 2004a, 2005a). Można przypuszczać, że - tak jak uważają E. Mironowicz (1992a, b), A. Sadowski (1995a, 1997) i M. Sobczyński (2000, 2001a) - zdecydowana większość osób deklarujących się jako Polacy-prawosławni to spolonizowani Białorusini lub Ukraińcy. Bardzo prawdopodobne jest, że współcześnie także wśród wyznawców innych mniejszości religijnych w Polsce liczne są deklaracje polskiej tożsamości narodowej, a stereotyp „Polak = katolik” nie odzwierciedla dużo bardziej skomplikowanej rzeczywistości.

${ }^{19}$ Jest to duże uproszczenie, spowodowane m.in. brakiem dokładnych danych oraz bardzo skomplikowanymi zależnościami między religią a narodowością. Wśród wszystkich wymienionych narodowości część należy do Kościoła rzymskokatolickiego (zwłaszcza wśród Niemców), są też niewierzący, ponadto część należy do innych wyznań (np. wśród Ukraińców i Łemków liczni są wyznawcy prawosławia). Z kolei wśród wiernych wyszczególnionych wyznań, poza podanymi narodowościami, licznie reprezentowani są Polacy (szczególnie wśród protestantów) oraz przybysze z krajów prawosławnych, protestanckich i muzułmańskich (współcześni imigranci i mieszkający w Polsce od pokoleń), a także członkowie rodzin heteroetnicznych. Jednak można przyjąć, że podstawową grupę wyznawców stanowią osoby wywodzące się z podanych mniejszości narodowych i etnicznych. 


\section{Ukraińcy}

Podczas spisu w 2002 r. narodowość ukraińską zadeklarowały 27172 osoby posiadające polskie obywatelstwo. Jeszcze mniej osób (21 055) zadeklarowało używanie języka ukraińskiego w „kontaktach domowych”. Były to wartości około dziesięciokrotnie niższe niż wcześniejsze szacunki, które wahały się w przedziale 150-300 tys. osób (tab. 16).

Według R. Drozda (1998), w okresie PRL, w wyniku procesów asymilacyjnych ukształtowały się trzy podstawowe grupy wśród mniejszości ukraińskiej:

- Ukraińcy o wysokim stopniu świadomości narodowej, znający język, kulturę, kultywujący tradycje narodowe i religijne,

- osoby o słabszym poczuciu świadomości narodowej, rzadko posługujące się językiem ukraińskim, ich udział w życiu społecznym Ukraińców ogranicza się do uczestnictwa $\mathrm{w}$ nabożeństwach swojego obrządku oraz sporadycznego uczestnictwa w ukraińskich imprezach kulturalnych,

- osoby posiadające tylko świadomość swego ukraińskiego pochodzenia, bardziej uważające się za Polaków niż Ukraińców.

Założenie, że zdecydowanie najliczniejsze są grupy trzecia i druga, a najmniej liczna pierwsza, natomiast w trakcie spisu to głównie pierwsza grupa deklarowała narodowość ukraińską, może tłumaczyć tak dużą różnicę między szacunkami a rezultatami spisu.

Wyniki spisu pokazały, że ukształtowane w wyniku akcji „Wisła” rozmieszczenie mniejszości ukraińskiej przez ostatnie półwiecze nie uległo istotnym zmianom. Większość Ukraińców zamieszkiwała obszary, na które ich dziadkowie i rodzice zostali wysiedleni w 1947 r. (ryc. 18-20). Zdecydowana większość mieszkała w trzech województwach północnej Polski (18 415 osób, 68\%), ich głównym skupiskiem było województwo warmińsko-mazurskie (11 881 osób, 44\%), natomiast na Podkarpaciu pozostało zaledwie 11\% spośród mieszkających w Polsce Ukraińców, stanowiąc w strefie przygranicznej ok. 0,5\% ogółu mieszkańców. Również założone w trakcie przesiedleń celowe rozproszenie Ukraińców na nowych miejscach osiedlenia zostało w pełni zrealizowane. Zaledwie w dziewięciu gminach (głównie mazurskich) udział Ukraińców nieznacznie przekraczał 10\% ogółu mieszkańców. Najliczniejszym skupiskiem było miasto i gmina Górowo Iławeckie, gdzie narodowość ukraińską zadeklarowało 1079 mieszkańców (9\% ogółu). W miastach najliczniej Ukraińcy byli reprezentowani w Przemyślu (814 osób), Olsztynie (569 osób) oraz Koszalinie (518 osób) (tab. 18). Skupiska Ukraińców w dużych miastach, zwłaszcza będących w drugiej połowie lat 40. XX w. stolicami województw, nie miały bezpośredniego związku z wysiedleniami w 1947 r. Były konsekwencją migracji z terenów wiejskich w nowych miejscach osiedlenia w północnej i zachodniej Polsce, zwłaszcza 
w trakcie intensywnych migracji ze wsi do miast w latach 60. i 70. XX w. Podczas akcji „Wisła” zakaz osiedlania Ukraińców i Łemków w miastach wojewódzkich był rygorystycznie przestrzegany.

Porównanie ,geografii wysiedleń” Ukraińców z końca 1947 r. (po zakończeniu zasadniczej części akcji „Wisła”) oraz wyników spisu z 2002 r. potwierdza tezę, że ich główne skupiska (w skali województw i powiatów) nie uległy zmianom (ryc. 9-10 oraz ryc. 18-20). Natomiast bardzo istotnie zmniejszyła się w tym okresie ich liczebność (tab. 4 oraz tab. 18).

Tabela 18. Gminy i miasta z największą liczbą Ukraińców ${ }^{a}$ oraz z największym udziałem procentowym $w$ ogólnej liczbie mieszkańców

(na podstawie wyników spisu z 2002 r.)

\begin{tabular}{|l|l|l|c|}
\hline \multicolumn{3}{|c|}{ Jednostka administracyjna } & Ukraińcy \\
\hline \multicolumn{1}{|c|}{ Gmina/miasto } & \multicolumn{1}{|c|}{ Powiat } & \multicolumn{1}{c|}{ Województwo } & Liczba \\
\hline Przemyśl miasto & Przemyśl & podkarpackie & 814 \\
Węgorzewo & węgorzewski & warmińsko-mazurskie & 695 \\
Banie Mazurskie & gołdapski & warmińsko-mazurskie & 618 \\
Górowo Iławeckie & bartoszycki & warmińsko-mazurskie & 584 \\
Lelkowo & braniewski & warmińsko-mazurskie & 576 \\
Olsztyn miasto & Olsztyn & warmińsko-mazurskie & 569 \\
Biały Bór & szczeciniecki & zachodniopomorskie & 560 \\
Pieniężno & braniewski & warmińsko-mazurskie & 531 \\
Komańcza & sanocki & podkarpackie & 521 \\
Koszalin miasto & Koszalin & zachodniopomorskie & 518 \\
\hline \multicolumn{1}{|c|}{ Gmina/miasto } & Powiat & Województwo & Odsetek \\
\hline Lelkowo & braniewski & warmińsko-mazurskie & 18,6 \\
Banie Mazur. & gołdapski & warmińsko-mazurskie & 14,9 \\
Kruklanki & giżycki & warmińsko-mazurskie & 13,4 \\
Budry & węgorzewski & warmińsko-mazurskie & 11,9 \\
Górowo Iławeckie miasto & bartoszycki & warmińsko-mazurskie & 10,7 \\
Pozezdrze & węgorzewski & warmińsko-mazurskie & 10,6 \\
Biały Bór & szczeciniecki & zachodniopomorskie & 10,7 \\
Godkowo & elbląski & warmińsko-mazurskie & 10,6 \\
Komańcza & sanocki & podkarpackie & 10,1 \\
Stubno & przemyski & podkarpackie & 8,5 \\
\hline
\end{tabular}

${ }^{a}$ Dotyczy wyłącznie osób posiadających obywatelstwo polskie.

Źródło: opracowanie własne. 


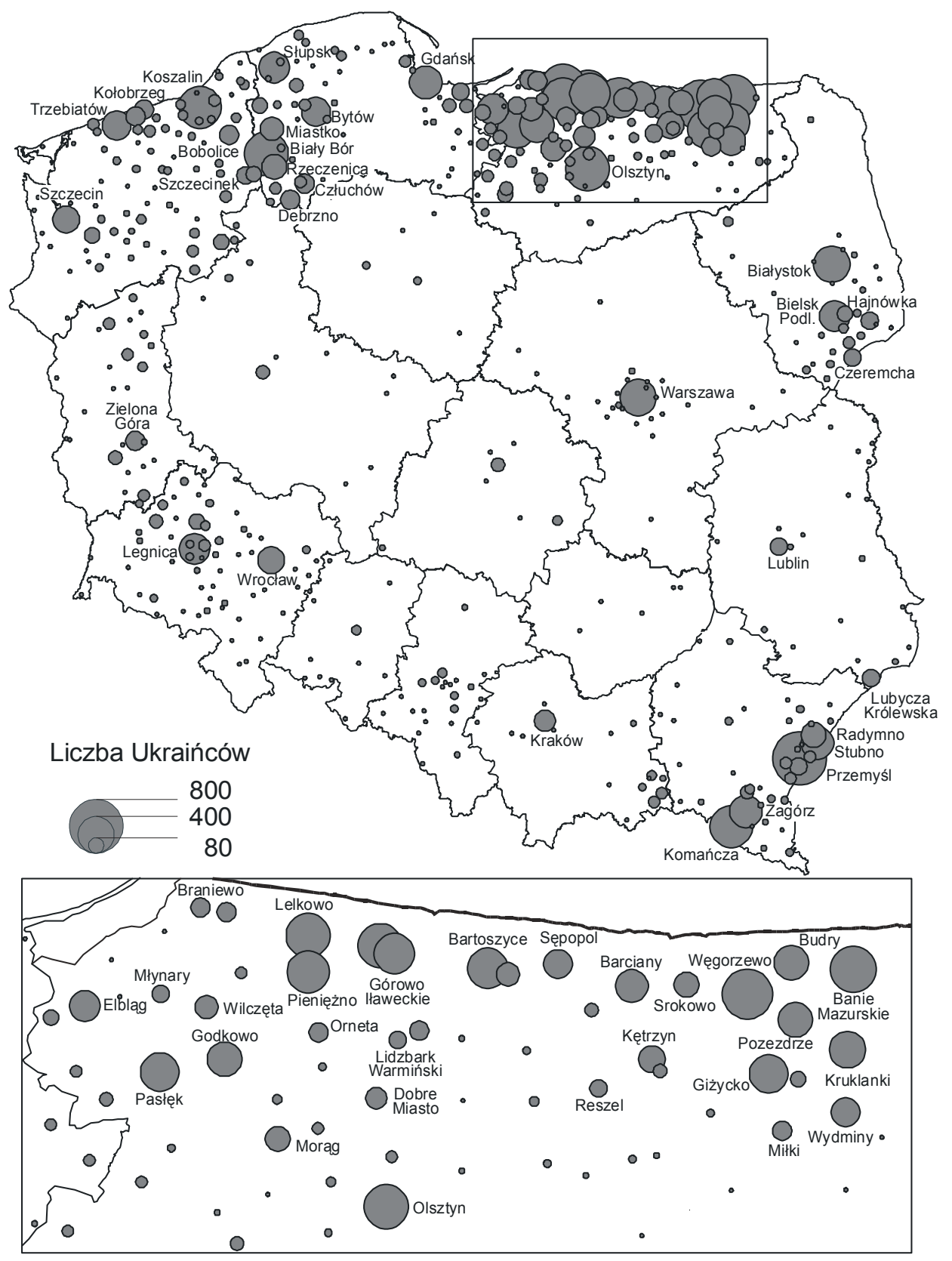

Ryc. 18. Liczba i rozmieszczenie osób deklarujących narodowość ukraińską na podstawie wyników spisu ludności z 2002 r. Źródło: opracowanie własne na podstawie danych GUS 


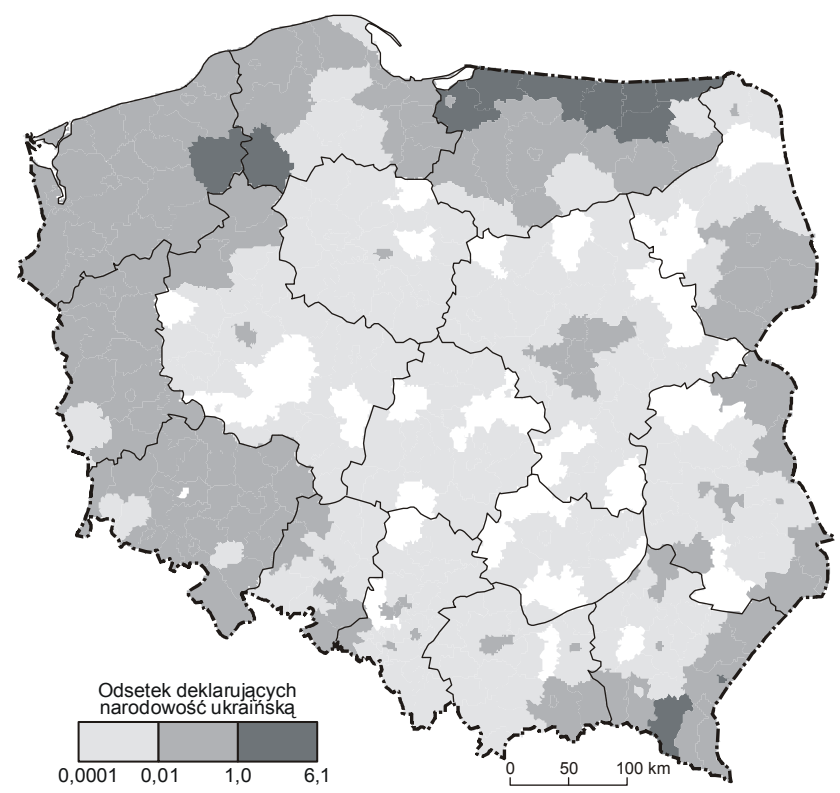

Ryc. 19. Udział procentowy osób deklarujących narodowość ukraińską (według powiatów) na podstawie wyników spisu ludności z 2002 r.

Źródło: opracowanie własne na podstawie danych GUS

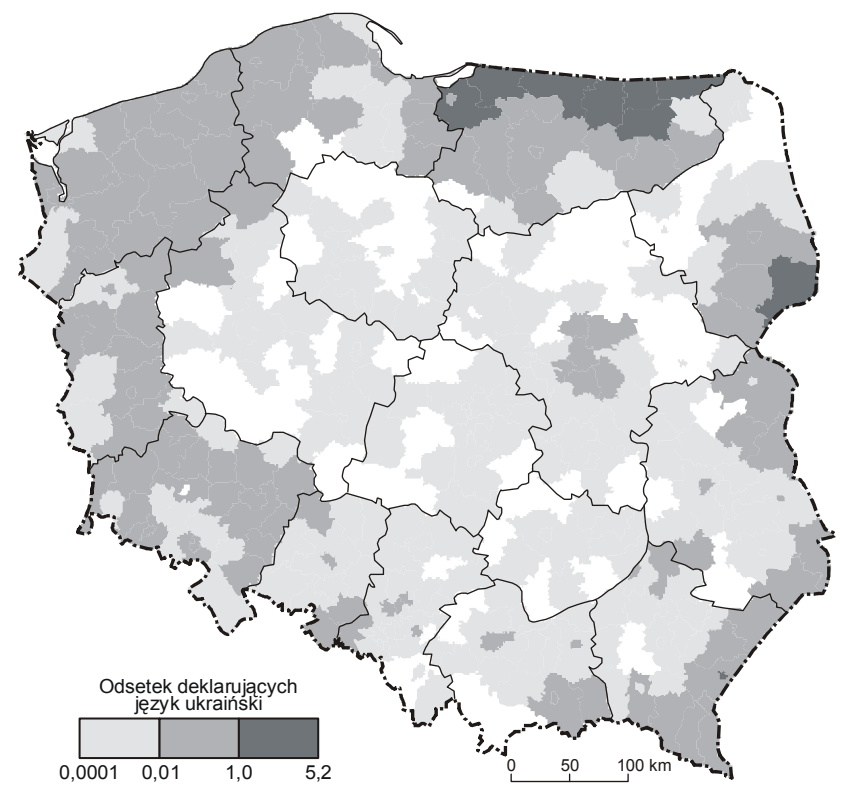

Ryc. 20. Udział procentowy osób deklarujących używanie języka ukraińskiego (według powiatów) na podstawie wyników spisu ludności z 2002 r. Źródło: opracowanie własne na podstawie danych GUS 
Porównanie liczebności i rozmieszczenia deklaracji narodowości ukraińskiej oraz deklaracji używania języka ukraińskiego wskazuje na większe znaczenie tożsamości narodowej niż językowej (ryc. 19-21). Charakterystycznym zjawiskiem jest wyraźna dominacja tożsamości narodowej na obszarach, gdzie występują najliczniejsze skupiska Ukraińców (północna część województwa warmińsko-mazurskiego, okolice Białego Boru i Koszalina), natomiast przewaga identyfikacji językowej w centralnej i wschodniej Polsce, gdzie liczebność Ukraińców jest marginalna. Jedynym regionem ze zdecydowaną dominacją ukraińskiej tożsamości językowej nad narodową jest południowo-wschodnia część województwa podlaskiego, gdzie współcześnie zachodzi proces odradzania ukraińskiej mniejszości narodowej na podstawie odrębności językowej od ludności białoruskiej $^{20}$ (ryc. 21).

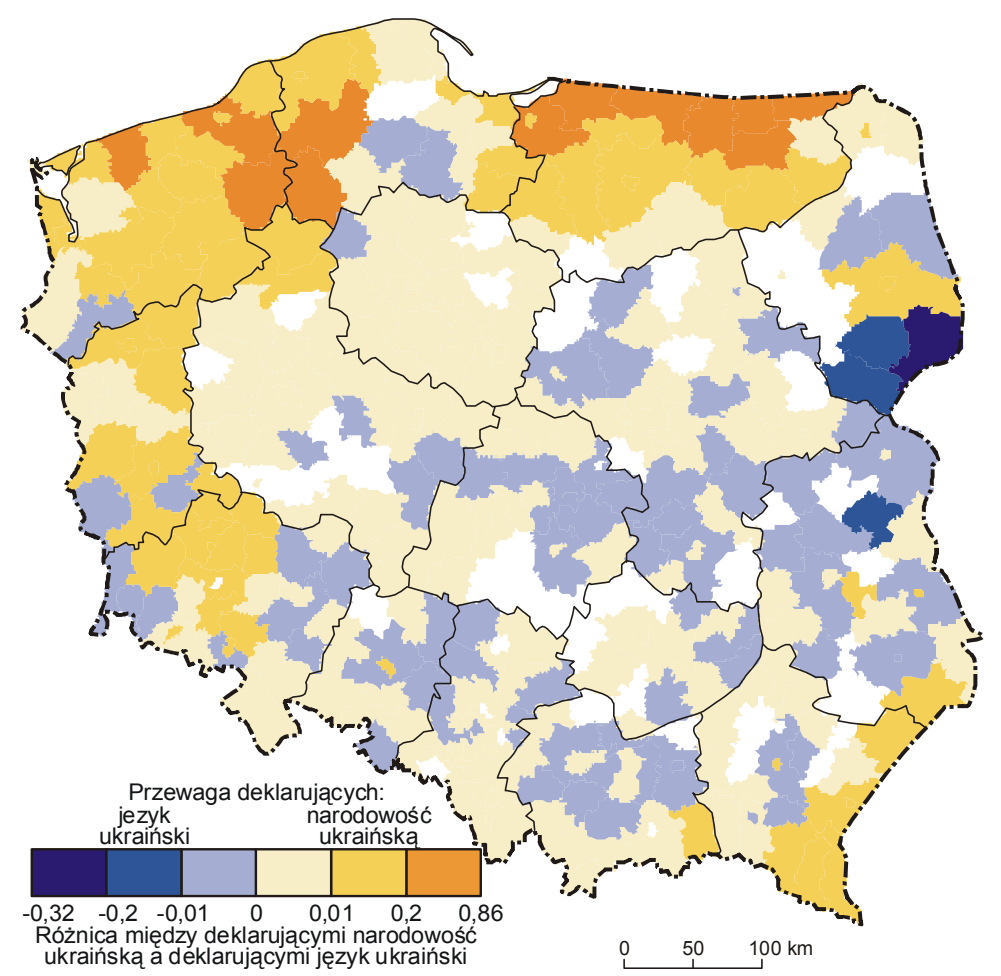

Ryc. 21. Porównanie deklaracji narodowości ukraińskiej oraz używania języka ukraińskiego (według powiatów) na podstawie wyników spisu ludności z 2002 r. Źródło: opracowanie własne na podstawie danych GUS

${ }^{20}$ Zostało to szerzej omówione w dalszej części rozdziału. 
W regionie, z którego w 1947 r. wysiedlono ok. 110 tys. Ukraińców (dzisiejsze województwo podkarpackie i lubelskie), stanowili grupę liczebnie marginalna. Według danych ze spisu, na tym obszarze mieszkało zaledwie ok. 3 tys. osób (w ok. 90\% w województwie podkarpackim) deklarujących narodowość ukraińską. Głównym skupiskiem mniejszości ukraińskiej na Podkarpaciu był Przemyśl (1,2\% ogółu mieszkańców) oraz powiaty jarosławski, przemyski, sanocki. Jednak w żadnym z tych powiatów udział Ukraińców w ogólnej liczbie ludności nie przekroczył 1\%. Największy był w gminach Komańcza (10\%) oraz Stubno (8,5\%). Mimo że w skali całego pogranicza polsko-ukraińskiego Ukraińcy byli w zdecydowanej mniejszości wobec Polaków, to jednak nadal w niektórych miejscach stanowili większość mieszkańców. Przykładami były m.in. wsie: Kalników w gminie Stubno, Chotyniec w gminie Radymno oraz Mokre w gminie Komańcza (Lis 2008).

W województwie lubelskim narodowość ukraińską zadeklarowało tylko 389 osób. Był to wynik zaskakująco mały, ponieważ na Lubelszczyznę w latach 1956-1958 powróciło zdecydowanie najwięcej spośród Ukraińców wysiedlonych w ramach akcji „Wisła”21 (3860 rodzin, czyli szacunkowo ok. 15-16 tys. osób).

Na szczególną uwagę zasługuje ponowne „wpisanie się” Ukraińców w strukturę narodowościową Podlasia, gdzie obecność tej mniejszości była z różnych powodów oficjalnie negowana przez większość XX w. oraz gdzie nie było wysiedleń w ramach akcji „Wisła”.

W województwie podlaskim podczas spisu powszechnego narodowość ukraińską zadeklarowało 1366 osób posiadających polskie obywatelstwo, nieco więcej, bo 1414 osób zadeklarowało używanie języka ukraińskiego „w kontaktach domowych". Tradycyjnie głównym skupiskiem Ukraińców na Podlasiu okazał się obszar między Bugiem a Narwią: powiat bielski (440 osób), hajnowski (350 osób), siemiatycki (102 osoby), co łącznie stanowiło 65,3\% ogółu Ukraińców na Podlasiu (rys. 22). Ponadto relatywnie dużym skupiskiem tej narodowości był Białystok (393 osoby), gdzie mieszkał co czwarty podlaski Ukrainiec. Oczywiście w skali całego województwa udział mniejszości ukraińskiej był minimalny $(0,1 \%)$, w niektórych gminach południowo-wschodniej części województwa wahał się od $1 \%$ do $1,5 \%$, najwyższy był $\mathrm{w}$ gminie Czeremcha (powiat hajnowski) i wynosił 3,13\%. Charakterystyczną cechą na terenach wiejskich była przewaga deklaracji używania języka ukraińskiego nad deklaracjami narodowości ukraińskiej, natomiast w miastach sytuacja była odwrotna, dominowała tożsamość narodowa nad językową (ryc. 22).

${ }^{21}$ Granice województwa lubelskiego z lat 50. XX w. oraz obecne są bardzo zbliżone. 
Mimo niewielkiej liczebności rozmieszczenie osób deklarujących narodowość ukraińską podczas spisu powszechnego było w głównych zarysach zgodne z historycznymi przekazami dotyczącymi osadnictwa ukraińskiego na Podlasiu oraz rozmieszczeniem Ukraińców w spisach powszechnych z 1897 i 1931 r. Najważniejszym novum było bardzo wyraźne zaznaczenie Białegostoku na podlaskiej mapie skupisk mniejszości ukraińskiej, będące konsekwencją migracji z wiejskich terenów południowo-wschodniej Białostocczyzny do podlaskich miast, w tym głównie do Białegostoku (ryc. 22). Można przypuszczać, że zdecydowana większość białostockich Ukraińców pochodziła ze wsi rozmieszczonych między Bugiem a Narwią (Barwiński 2011).

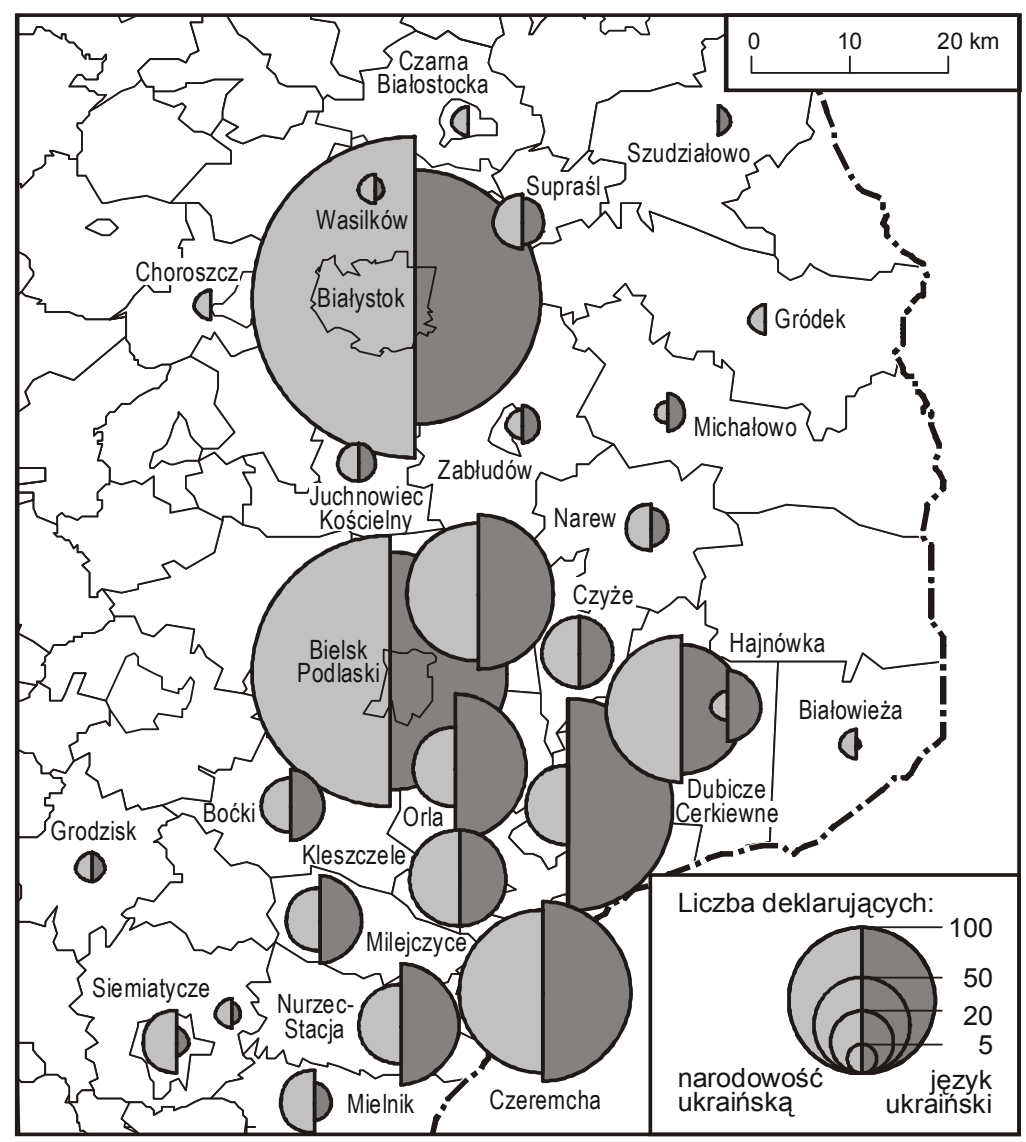

Ryc. 22. Liczba i rozmieszczenie osób deklarujących narodowość ukraińską oraz używanie języka ukraińskiego na Podlasiu (według gmin)

na podstawie wyników spisu ludności z 2002 r.

Źródło: opracowanie własne na podstawie danych GUS 
Z ukraińską autoidentyfikacją narodową na Białostocczyźnie ściśle jest związany język ukraiński. Tożsamość językowa podlaskich Ukraińców jest silniejsza niż mieszkających na Podlasiu Białorusinów oraz zamieszkujących północną i zachodnią Polskę Ukraińców (ryc. 21). Potwierdza to tezę o ponownym kształtowaniu się ukraińskiej tożsamości narodowej wśród prawosławnych mieszkańców Podlasia, głównie na gruncie odrębnego języka (Hawryluk 1995, 1999, Sadowski 1995a, Barwiński 2004a, 2005a, 2011, Wysocki 2006).

W 1999 r., trzy lata przed spisem powszechnym, na obszarze południowo-wschodniej części województwa podlaskiego, między Bugiem a Narwią, przeprowadzono badania terenowe zorganizowane przez Katedrę Geografii Politycznej i Studiów Regionalnych Uniwersytetu Łódzkiego. Głównym celem badań było ustalenie współczesnego przebiegu pogranicza etniczno-religijnego, jego przemian, zasięgu, specyfiki, zróżnicowania zamieszkujących go społeczności ${ }^{22}$. W tym celu m.in. starano się określić strukturę narodowościową, wyznaniową i językową mieszkańców badanego obszaru ${ }^{23}$.

Jednym z rezultatów badań było stwierdzenie, że drugim - po języku polskim - ojczystym językiem mieszkańców południowo-wschodniego Podlasia nie był język białoruski lub ukraiński, lecz miejscowa gwara, którą w kategoriach ojczystych określiło ponad $15 \%$ ogółu respondentów, w tym na terenach wiejskich prawie co czwarty badany (Barwiński 2004a). Deklarowanie przez część mieszkańców gwary w kategoriach języka ojczystego nie może, według A. Sadowskiego (1995a), symbolizować pełnego związku z narodową kulturą białoruską, ukraińską czy polską, ale raczej z regionalną grupą pochodzenia. Jest przejawem „tutejszości”, czyli więzi emocjonalnej głównie z zamieszkiwanym obszarem oraz lokalną społecznością. Jest również konsekwencją nakładania się pokrewnych języków słowiańskich, co doprowadziło do zatarcia, zwłaszcza w świadomości społecznej, wyraźnych granic między poszczególnymi językami narodowymi.

Obszar Podlasia jest pograniczem językowym, terenem, gdzie od wieków współistniały, przenikały oraz mieszały się różne języki: polski, białoruski, ukraiński, litewski, rosyjski. Część ludności, szczególnie wiejskiej, ma świadomość, że nie posługuje się ani językiem polskim, ani białoruskim, ani ukraińskim, lecz

${ }^{22}$ Szerzej wyniki badań zostały omówione w książce M. Barwińskiego (2004) pt. Podlasie jako pogranicze narodowościowo-wyznaniowe.

23 Badania terenowe zostały przeprowadzone w Bielsku Podlaskim, Hajnówce i Kleszczelach oraz w 103 wsiach położonych w 12 gminach (Bielsk Podlaski, Boćki, Orla, Hajnówka, Czyże, Dubicze Cerkiewne, Kleszczele, Czeremcha, Dziadkowice, Milejczyce, Nurzec-Stacja, Mielnik). Przeprowadzono łącznie 1512 wywiadów standaryzowanych na podstawie kwestionariusza. 
swoistym dialektem, który jednak jest zdecydowanie bardziej zbliżony do języków wschodniosłowiańskich (białoruskiego, ukraińskiego, rosyjskiego) niż do języka polskiego. Według Atlasu gwar wschodniosłowiańskich Białostocczy$z n y^{24}$ (1980) ,województwo białostockie nie jest jednolite pod względem językowym. Na znacznej jego cześci występują gwary wschodniosłowiańskie: na północy białoruskie, na południu ukraińskie, a pomiędzy nimi przejściowe białorusko-ukraińskie. W pasie zachodnim niemal wyłączne są gwary polskie, dalej na wschód ludność jest przeważnie dwujęzyczna, w wielu wsiach gwara polska współistnieje z gwarą białoruską lub ukraińską. Wzajemny stosunek dwóch współistniejących gwar układa się bardzo różnie” (ryc. 23).

Wyniki licznych badań naukowych potwierdzają istnienie gwar północno-ukraińskich we wschodniej i południowo-wschodniej części Podlasia (Atlas gwar... 1980, Sadowski 1995a, Hawryluk 1999, Wysocki 2006). Granica północnego zasięgu gwar ukraińskich przebiega na wschód od Hajnówki oraz na północy wzdłuż rzeki Narwi, a zachodnia granica maksymalnego zasięgu gwar wschodniosłowiańskich biegnie mniej więcej na zachód od linii Siemiatycze, Dziadkowice, Boćki, Bielsk Podlaski ${ }^{25}$. Według badań językoznawców wynika, że prawie cały obszar południowo-wschodniej części województwa podlaskiego jest położony w obrębie występowania gwar północno-ukraińskich, ponadto nie występują w tym regionie gwary białoruskie (ryc. 23).

Na tej podstawie można przypuszczać, że gwara, którą na co dzień posługuje się duża część mieszkańców południowo-wschodniej części Podlasia, zwłaszcza na terenach wiejskich, jest w rzeczywistości gwarą ukraińską lub ewentualnie dialektem dużo bardziej zbliżonym do języka ukraińskiego niż białoruskiego. Jednak nadal jest to gwara znacznie odbiegająca od ukraińskiego języka literackiego, z licznymi naleciałościami polskimi i białoruskimi. Podczas badań terenowych większość respondentów nie potrafiła jej zaklasyfikować w kategoriach narodowych, uważając gwarę za język „prosty”, „mieszany”, „gorszy”, a nawet „niekulturalny”. Powszechna jest świadomość odrębności gwary od języka białoruskiego, głównie na podstawie konfrontacji języka używanego $\mathrm{w}$ domu $\mathrm{z}$ językiem nauczanym w szkołach podstawowych oraz białoruskich liceach w Bielsku Podlaskim i Hajnówce. Z kolei dużo mniejsza jest wśród

24 Naukowcy opracowujący Atlas gwar wschodniosłowiańskich Białostocczyzny przeprowadzili w latach 50., 60. oraz 70. XX w. szereg badań językoznawczych w 114 wsiach Białostocczyzny.

${ }^{25}$ Nie oznacza to, że to tej linii sięga zwarty obszar występowania gwar wschodniosłowiańskich, a jedynie, że występują tam pojedyncze wioski, w których takich gwar się używa (Atlas gwar ... 1980). 
respondentów świadomość ukraińskiego pochodzenia gwary, mimo to była ona niekiedy określana jako „,chachłacka”26, czyli zgodnie z ludowym przezwiskiem - ukraińska (Barwiński 2004a).

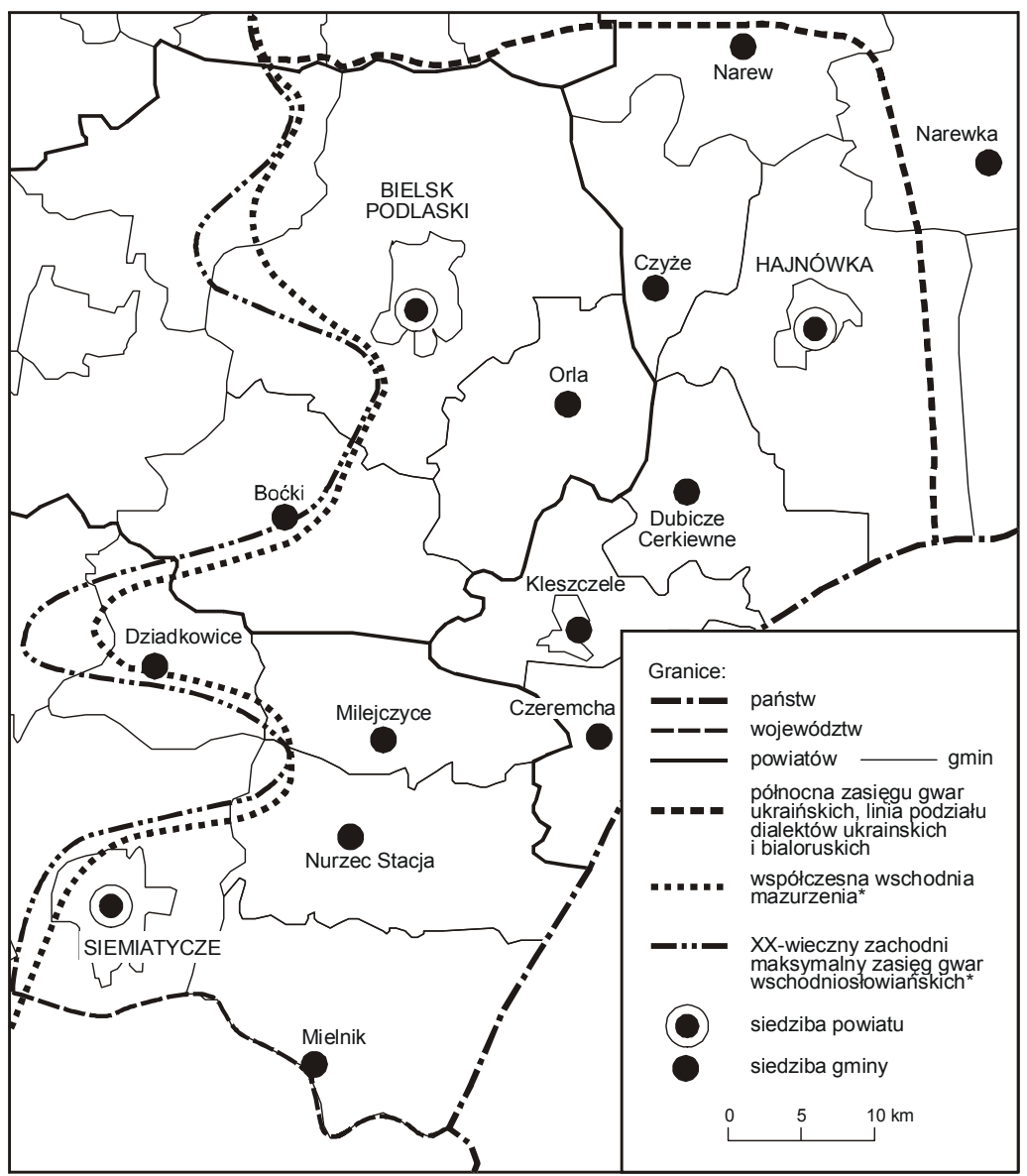

Ryc. 23. Południowo-wschodnie Podlasie na tle polsko-ruskiego pogranicza językowego

Źródło: opracowanie własne na podstawie Atlasu gwar... (1980)

Nie można automatycznie łączyć faktu powszechności występowania gwar północno-ukraińskich na obszarze między Bugiem a Narwią z ukraińską świadomością narodową zamieszkującej tam ludności, posługującej się tymi gwarami

${ }^{26}$ Określenie „,chachłacki” pochodzi od słowa Chachoł, będącego przezwiskiem, którym Rosjanie określali Ukraińców. Wywodzi się ono od charakterystycznego sposobu strzyżenia włosów, który na Podlasiu zachował się do połowy XIX w. (Hawryluk 1999). 
lub nawet uznającej je za język ojczysty. Nie potwierdzają tego badania ankietowe oraz wyniki spisu powszechnego, ponadto - co wydaje się bardzo istotne zdecydowana większość respondentów nie wie, że język, którym się posługują, należy do gwar ukraińskich, traktując go wyłącznie w kategoriach „tutejszości”. Jednak naukowo stwierdzone występowanie gwar północno-ukraińskich aż do linii Narwi jest - obok odrębnego, wołyńskiego pochodzenia etnicznego części mieszkańców tego obszaru oraz wyników XIX-wiecznych spisów ludności kolejnym dowodem na ukraiński rodowód prawosławnej ludności zamieszkującej południowo-wschodnią Białostocczyznę.

Zarówno rezultaty wspomnianych badań terenowych z 1999 r., jak i wyniki spisu powszechnego z 2002 r. pokazały, że Ukraińcy ponownie stali się częścią mozaiki narodowościowej Podlasia (Barwiński 2005b). Jednak był to udział niewielki, potwierdzający tezę, że swoista rerutenizacja części prawosławnych mieszkańców Podlasia przejawiała się głównie w formie instytucjonalnej, w dużej aktywności ukraińskich organizacji społeczno-politycznych ${ }^{27}$, w mniejszym stopniu w poczuciu ukraińskiej tożsamości narodowej. Prawosławni mieszkańcy Podlasia podczas spisu powszechnego zdecydowanie częściej wybierali deklarację narodowości polskiej lub białoruskiej niż ukraińskiej.

\section{Lemkowie}

Podczas spisu w 2002 r. narodowość łemkowską zadeklarowało 5850 osób posiadających polskie obywatelstwo, ponadto 62 osoby podały narodowość rusińską. Nieco mniej osób (5605) zadeklarowało używanie języka łemkowskiego w „kontaktach domowych”. Były to wartości - podobnie jak w przypadku Ukraińców - zdecydowanie, ponaddziesięciokrotnie niższe niż wcześniejsze szacunki, które wahały się w przedziale 50-80 tys. Było to także około pięciokrotnie mniej niż wynosiła liczba Łemków wysiedlonych w 1947 r. z Łemkowszczyzny na ziemie zachodniej i północnej Polski.

Wśród Łemków czynnikiem dodatkowym zmniejszającym ich liczebność było występowanie kilku różnych opcji tożsamości narodowej ${ }^{28}$. Część z nich uległa polonizacji, część uważała się za Ukraińców, ewentualnie za członków łemkowskiej grupy etnicznej (lub etnograficznej) będącej częścią narodu ukraińskiego, a tylko część deklarowała się jako Łemkowie lub Rusini. Te podziały narodowościowe nie są nowe, pojawiły się pod koniec XIX w., a nasiliły

${ }^{27}$ Na Podlasiu działają oddziały Związku Ukraińców Podlasia, Ukraińskiego Towarzystwa Nauczycielskiego oraz Związku Ukraińskiej Młodzieży Niezależnej.

${ }_{28}^{28}$ Pisał o tym m.in. J. Nowak (2006), opierając się na wynikach własnych badań w Beskidach po zakończeniu spisu powszechnego w 2002 r. 
w trakcie dwóch wojen światowych i w okresie międzywojennym. Deklarowanie podczas spisu przez część Łemków narodowości ukraińskiej dodatkowo wpłynęło na niewielką liczebność tej grupy. Jednak prawie 6 tys. deklaracji narodowości łemkowskiej jednoznacznie pokazało istnienie w Polsce - odrębnej nie tylko od Polaków, ale także od Ukraińców - grupy narodowościowej, szóstej pod względem liczebności, po śląskiej, niemieckiej, białoruskiej, ukraińskiej i romskiej. Nie można zgodzić się z opinią B. Halczaka (2007), który stwierdził, że „naród łemkowski z całą pewnością nie istnieje”. Przeczą temu zarówno wyniki spisu powszechnego, jak i aktualny stan prawny oraz wyniki badań prowadzonych wśród społeczności łemkowskiej (m.in. Barwiński 1995, 1998, 1999, Michna 1995, 2004, Mazurek 2005, Nowak 2006), a co najistotniejsze, przeczą temu sami Łemkowie. Rację ma T.A. Olszański (1990), pisząc, że „Łemkowie są tym, za kogo się uważają. To znaczy nie ma powodu, by odmawiać miana narodu tym, którzy za naród łemkowski się uważają, ale także by kwestionować ukraińskość tych, którzy uważają się za Ukraińców".

Na rozmieszczenie Łemków - analogicznie jak Ukraińców - zasadniczy wpływ miały powojenne przesiedlenia. W konsekwencji akcji „Wisła” ludność łemkowska została zmuszona do opuszczenia Łemkowszczyzny i rozproszona na obszarze zachodniej Polski - i w dużo mniejszym stopniu - północnej. Wyniki spisu pokazały, że rozmieszczenie Łemków ukształtowane w rezultacie akcji „Wisła” nie uległo istotnym zmianom przez ostatnie półwiecze (ryc. 9-10 oraz ryc. 24-26). W 2002 r. na Łemkowszczyźnie zamieszkiwało 28,3\% spośród osób deklarujących w spisie narodowość łemkowską (ryc. 24, 28). Większość pozostała $\mathrm{w}$ nowych miejscach osiedlenia. Ponad $70 \%$ osób deklarujących narodowość łemkowską mieszkało na obszarze tzw. Ziem Odzyskanych, z tego aż 66\% (3866 osób) w dwóch województwach: dolnośląskim (3082 osób) i lubuskim (784 osób). Na rozmieszczenie Łemków miały również wpływ procesy industrializacji w latach 60. i 70. XX w., a zwłaszcza rozbudowa Legnicko-Głogowskiego Okręgu Miedziowego (LGOM). Choć głównym skupiskiem Łemków w 2002 r. była beskidzka gmina Uście Gorlickie (jedyna gmina, gdzie stanowili ponad $10 \%$ mieszkańców), to największa koncentracja tej mniejszości występowała w regionie eksploatacji i obróbki złóż miedzi, czyli w dolnośląskich gminach Rudna (514 osób) oraz Przemków (437 osób), a także w pobliskich miastach Lubin (273 osoby) i Legnica (262 osoby) (tab. 19). Część Łemków przed wysiedleniem była zatrudniona w kopalniach ropy naftowej w okolicach Jasła i Krosna. Stanowili oni potem cenną kadrę pracowników w zagłębiu miedziowym (Żurko 1997). W trakcie spisu w 2002 r. na szeroko pojętym obszarze LGOM, czyli w powiecie głogowskim, legnickim, lubińskim i polkowickim, narodowość łemkowską zadeklarowały łącznie 2544 osoby, czyli 
aż 43,5\% ogółu wykazanej w spisie mniejszości łemkowskiej. Był to obszar największej koncentracji Łemków w Polsce (ryc. 24). Wyraźnie widoczne w tym regionie migracje do miast, związane $\mathrm{z}$ industrializacja, i w ich konsekwencji awans społeczny ludności wiejskiej mogły przyczynić się do natężenia procesów polonizacyjnych wśród części Łemków (Barwiński 2009a).

Tabela 19. Gminy i miasta z największą liczbą Łemków ${ }^{a}$ oraz z największym udziałem procentowym w ogólnej liczbie mieszkańców (na podstawie wyników spisu z 2002 r.)

\begin{tabular}{|l|l|l|c|}
\hline \multicolumn{3}{|c|}{ Jednostka administracyjna } & Łemkowie \\
\hline \multicolumn{1}{|c|}{ Gmina/miasto } & \multicolumn{1}{c|}{ Powiat } & Województwo & Liczba \\
\hline Uście Gorlickie & gorlicki & małopolskie & 725 \\
Rudna & lubiński & dolnośląskie & 514 \\
Przemków & polkowicki & dolnośląskie & 437 \\
Lubin miasto & lubiński & dolnośląskie & 273 \\
Legnica miasto & Legnica & dolnośląskie & 262 \\
Sękowa & gorlicki & małopolskie & 262 \\
Lubin gmina & lubiński & dolnośląskie & 185 \\
Chocianów & polkowicki & dolnośląskie & 181 \\
Krynica-Zdrój & nowosądecki & małopolskie & 161 \\
Radwanice & polkowicki & dolnośląskie & 157 \\
\hline \multicolumn{1}{|c|}{ Gmina/miasto } & Powiat & Województwo & Odsetek \\
\hline Uście Gorlickie & gorlicki & małopolskie & 11,6 \\
Rudna & lubiński & dolnośląskie & 7,4 \\
Sękowa & gorlicki & małopolskie & 5,6 \\
Przemków & polkowicki & dolnośląskie & 4,9 \\
Radwanice & polkowicki & dolnośląskie & 3,7 \\
Ruja & legnicki & dolnośląskie & 3,3 \\
Gromadka & bolesławiecki & dolnośląskie & 2,4 \\
Ropa & gorlicki & małopolskie & 1,9 \\
Lubin gmina & lubiński & dolnośląskie & 1,8 \\
Chocianów & polkowicki & dolnośląskie & 1,4 \\
\hline
\end{tabular}

${ }^{a}$ Dotyczy wyłącznie osób posiadających obywatelstwo polskie.

Źródło: opracowanie własne. 


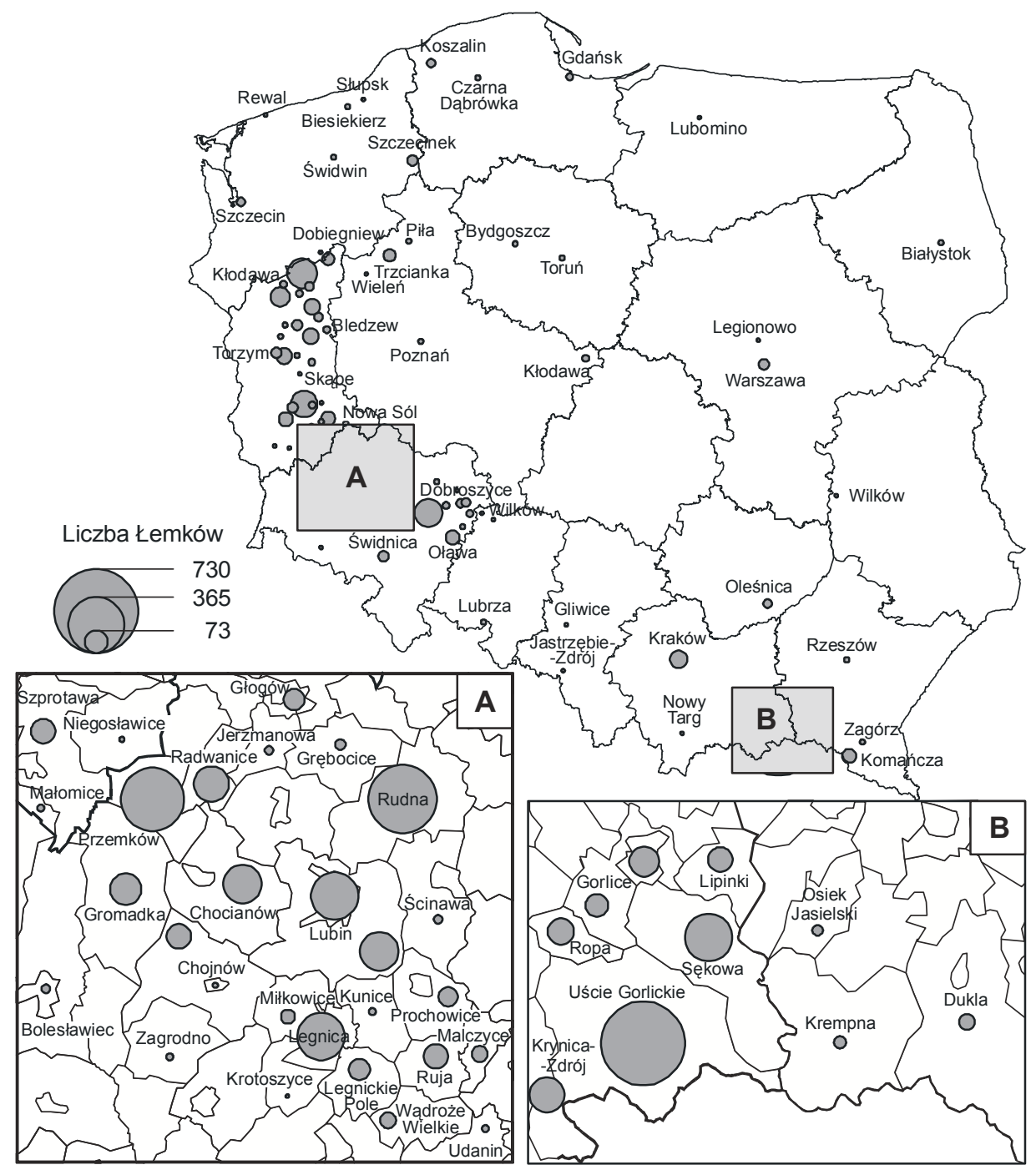

Ryc. 24. Liczba i rozmieszczenie osób deklarujących narodowość łemkowską na podstawie wyników spisu ludności z 2002 r.

Źródło: opracowanie własne na podstawie danych GUS

Porównanie rozmieszczenia i liczebności deklaracji narodowości łemkowskiej oraz deklaracji używania języka łemkowskiego pokazuje, że w powiatach z największą koncentracją Łemków (Łemkowszczyzna i Dolny Śląsk, zwłaszcza obszar LGOM) tożsamość językowa dominuje nad narodową, natomiast im mniejsza koncentracja liczebna, tym większe znaczenie identyfikacji narodowej (ryc. 27). Jest to odwrotna zależność niż w przypadku Ukraińców (ryc. 21). 


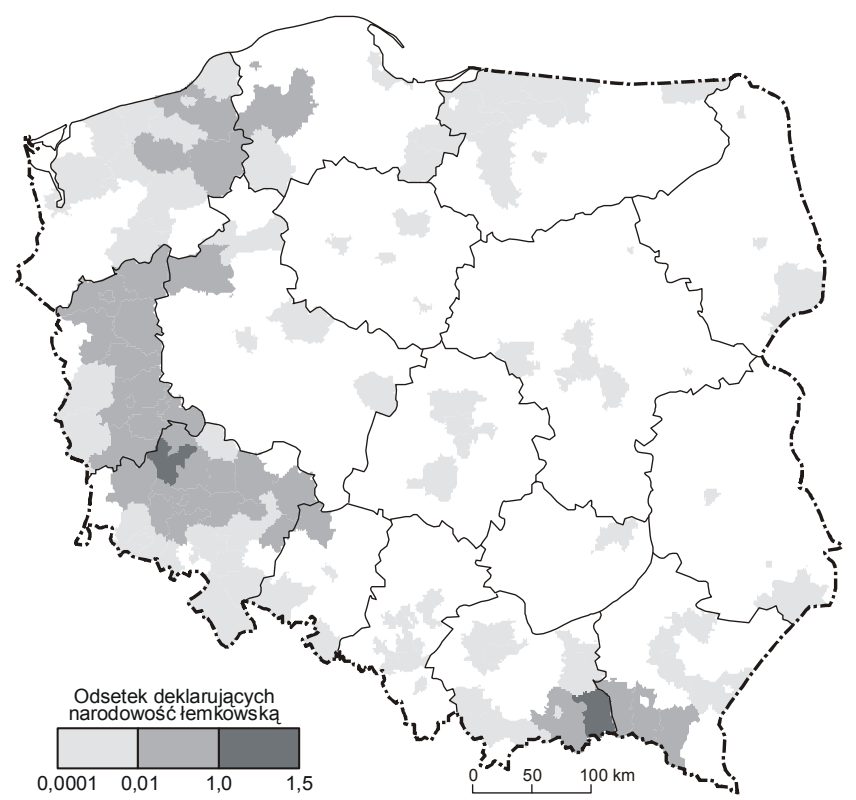

Ryc. 25. Udział procentowy osób deklarujących narodowość łemkowską (według powiatów) na podstawie wyników spisu ludności z 2002 r.

Źródło: opracowanie własne na podstawie danych GUS

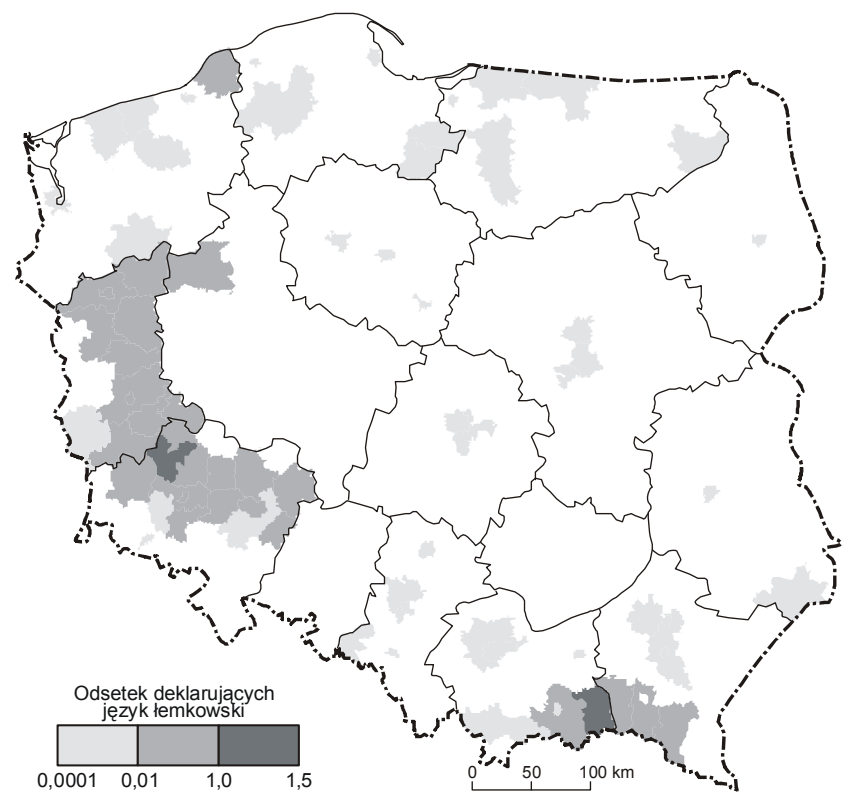

Ryc. 26. Udział procentowy osób deklarujących używanie języka łemkowskiego (według powiatów) na podstawie wyników spisu ludności z 2002 r. Źródło: opracowanie własne na podstawie danych GUS 


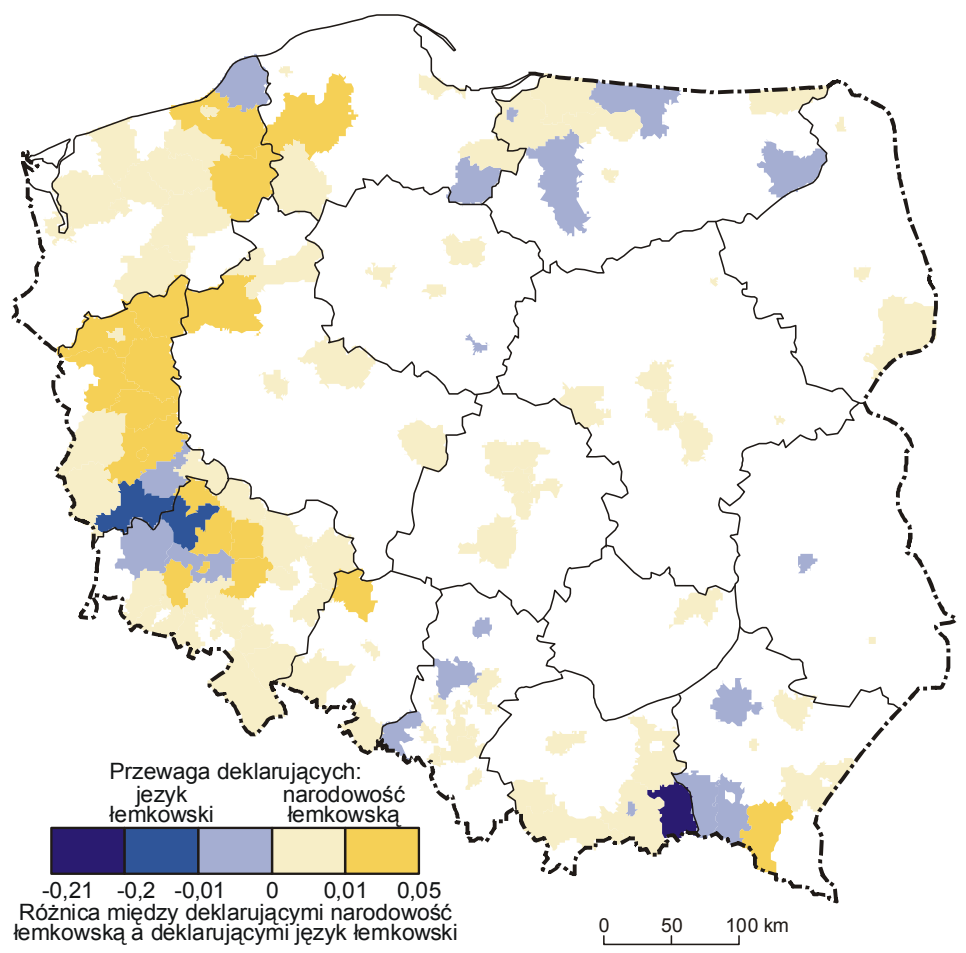

Ryc. 27. Porównanie deklaracji narodowości łemkowskiej oraz używania języka łemkowskiego (według powiatów) na podstawie wyników spisu ludności z 2002 r. Źródło: opracowanie własne na podstawie danych GUS

Charakterystycznym skupiskiem Łemków, a także - w mniejszym stopniu Ukraińców - jest Łemkowszczyzna (ryc. 28). Pomimo powrotów po 1956 r. w Beskidy kilku tysięcy Łemków, w 2002 r. na Łemkowszczyźnie narodowość łemkowską zadeklarowały tylko 1642 osoby, co stanowiło 28\% spośród ogółu deklaracji narodowości łemkowskiej w Polsce. Ponadto w tym regionie 789 osób zadeklarowało narodowość ukraińską ${ }^{29}$. Można przypuszczać, że w większości byli to Łemkowie, którzy bardziej identyfikowali się z Ukraińcami niż Łemkami, lecz w sensie etnicznym byli pochodzenia łemkowskiego. Stanowiło to łącznie 2431 osób, zaledwie ok. 4\% ogółu mieszkańców Łemkowszczyzny. Na początku XXI w. na tym obszarze pod względem narodowościowym - inaczej

${ }^{29}$ Zsumowano deklaracje narodowości łemkowskiej i ukraińskiej (wyłącznie obywateli polskich) w gminach leżących w całości lub częściowo w granicach dawnej Łemkowszczyzny: Krynica-Zdrój, Muszyna, Uście Gorlickie, Sękowa, Ropa, Lipinki, Osiek Jasielski, Krempna, Dukla, Komańcza oraz w położonym tuż przy jej granicy mieście i gminie Gorlice. 
niż w okresie międzywojennym - zdecydowanie dominowała ludność polska, natomiast Łemkowie stanowili nieliczną mniejszość etniczną (Barwiński 2009a).

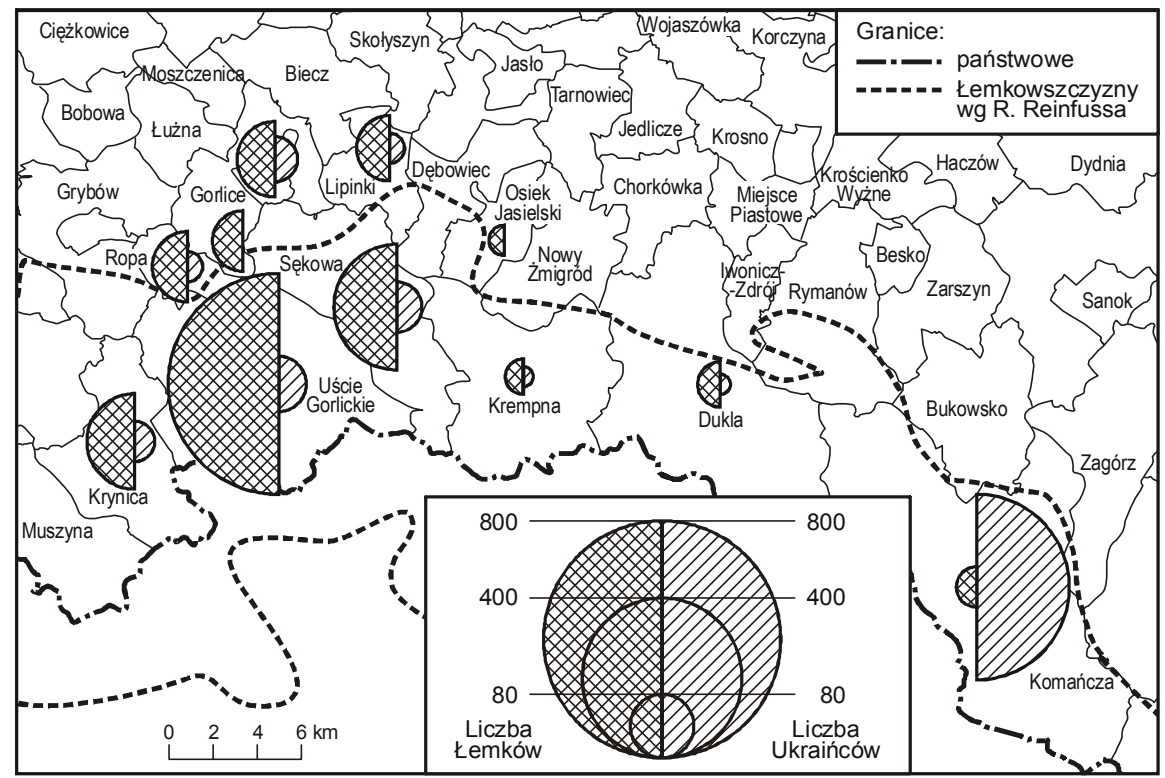

Ryc. 28. Liczba i rozmieszczenie osób deklarujących narodowość łemkowską i ukraińską na obszarze Łemkowszczyzny na podstawie wyników spisu ludności z 2002 r.

Źródło: opracowanie własne na podstawie danych GUS

Na Łemkowszczyźnie bardzo wyraźnie była widoczna koncentracja Łemków w jej części zachodniej, zwłaszcza w powiecie gorlickim, którego 1354 mieszkańców zadeklarowało narodowość łemkowską, co oznaczało, że powiat ten skupiał aż 82,5\% wszystkich Łemków na Łemkowszczyźnie ${ }^{30}$ (ryc. 28). Położona w powiecie gorlickim gmina Uście Gorlickie była największym skupiskiem Łemków zarówno w Karpatach, jak i w skali całej Polski (725 osób). Była to zarazem jedyna gmina w Polsce, w której Łemkowie stanowili ponad 10\% ogółu mieszkańców (11,6\%).

Z kolei na wschodzie Łemkowszczyzny, w gminie Komańcza, swą obecność w sposób widoczny zaznaczali Ukraińcy (521 osób, 66\% ogółu Ukraińców na Łemkowszczyźnie, ponad 10\% ogółu mieszkańców gminy), przy marginalnym udziale deklaracji narodowości łemkowskiej (zaledwie 35 osób). W tym wypadku wyniki spisu potwierdzały rezultaty badań socjologiczno-geograficznych

${ }^{30}$ Północna część powiatu gorlickiego, a zwłaszcza miasto i gmina Gorlice, znajduje się poza historycznie ukształtowanymi granicami Łemkowszczyzny. 
zarówno z połowy lat 90 . XX w., jak i z początku XXI w., według których istniała wyraźna zależność między miejscem zamieszkania Łemków w Karpatach a ich deklaracjami tożsamości narodowej. Na obszarze zachodniej Łemkowszczyzny zdecydowanie dominowały deklaracje tożsamości łemkowskiej, natomiast w części wschodniej wyraźnie rósł udział deklaracji tożsamości ukraińskiej (Barwiński 1995, 1999, Mazurek 2005). Jest to konsekwencją, siegających końca XIX w., podziałów politycznych wśród Łemków i związanych z nimi konfliktów między orientacją staroruską i ukraińską oraz silniejszych sympatii proukraińskich na obszarze wschodniej Łemkowszczyzny. Trwałe, utrzymujące się przez dziesięciolecia funkcjonowanie tego podziału narodowościowego we wschodniej Łemkowszczyźnie, mimo przesiedleń ludności, zmiany pokoleniowej, odmiennej sytuacji politycznej, niewielkiej liczebności Łemków i Ukraińców w tym regionie, jest fenomenem etnicznym, historycznym i politycznym.

Na początku XXI w. na Łemkowszczyźnie mieszka ogółem ponad 60 tys. osób. Jest to co prawda dwukrotnie więcej niż na początku lat 50. XX w., ale jednocześnie o 45\% mniej niż kilkadziesiąt lat wcześniej, w okresie międzywojennym. Nadal jest to jeden z najrzadziej zaludnionych regionów w Polsce (zaledwie 28 osób $/ \mathrm{km}^{2}$, przy średniej gęstości zaludnienia Polski 124 osoby $/ \mathrm{km}^{2}$ ), średnio w poszczególnych wsiach mieszka zaledwie 270 osób, kilkanaście procent wsi jest nadal niezamieszkanych, a udział lasów, które systematycznie zajmowały opuszczone tereny, wzrósł z 30\% w drugiej połowie XIX w. aż do 70\% pod koniec XX w. (Soja 2001).

W 2002 r. Łemkowie oraz Ukraińcy stanowili zaledwie ok. 4\% ogółu mieszkańców Łemkowszczyzny. Pomimo ich widocznej obecności, czynnych cerkwi greckokatolickich i prawosławnych, nauki języka łemkowskiego i ukraińskiego w szkołach, aktywności łemkowskich organizacji, odbywających się cyklicznie festiwali i imprez kulturalnych, pojawiających się dwujęzycznych nazw miejscowości, Karpaty są już inną krainą zarówno pod względem narodowościowym, religijnym, kulturowym, jak i gospodarczym. Dawna Łemkowszczyzna już nie istnieje, została bezpowrotnie zniszczona powojennymi przesiedleniami oraz późniejszą polityką władz komunistycznych.

Wyniki spisu z 2002 r. w przypadku Ukraińców i Łemków potwierdziły bardzo dużą skuteczność akcji „Wisła”. Po upływie 55 lat (1947-2002) można powiedzieć, że główne cele tej akcji - wysiedlenie, rozproszenie oraz w kosekwencji bardzo daleko posunięta asymilacja Ukraińców - zostały zrealizowane. Jest to kolejny przykład, doskonale obrazujący, jak można decyzjami politycznymi w stosunkowo krótkim czasie zmienić kształtowaną przez wieki strukturę etniczną danego obszaru. 
Mimo bardzo dużych podobieństw w rozmieszczeniu Ukraińców i Łemków, widać także wyraźne różnice (ryc. 18 oraz ryc. 24). Łemkowie zamieszkują głównie zachodnią Polskę, ponadto cechuje ich mniejsze rozproszenie; w 2002 r. aż 93\% ich ogółu mieszkało w trzech województwach (dolnośląskim, małopolskim i lubuskim). Z kolei Ukraińcy zamieszkują głównie północną Polskę, są bardziej rozproszeni, w trzech województwach (warmińsko-mazurskim, zachodniopomorskim i pomorskim) w 2002 r. mieszkało 68\% ogółu Ukraińców. Inna była też skala powrotów do etnicznej ojczyzny. Na Łemkowszczyźnie mieszkał prawie co trzeci spośród Łemków, natomiast na Podkarpaciu zaledwie co dziesiąty Ukrainiec.

Wykazany w spisie z 2002 r. spadek liczebności dotyczył wszystkich tzw. tradycyjnych mniejszości narodowych i etnicznych w Polsce. Wcześniejsze przeszacowanie tych narodowości było powszechne (tab. 16). Na tej podstawie można przyjąć, iż procesy asymilacji, polonizacji grup narodowościowych w Polsce w trakcie ostatnich kilkudziesięciu lat były zjawiskiem typowym, nie dotyczyły wyłącznie mniejszości objętych akcją „Wisła”, ale wszystkich narodowości niepolskich. Jednak spadek liczby Ukraińców i Łemków w latach 19472002 był relatywnie większy niż mniejszości wschodniej Polski, czyli Litwinów i Białorusinów, którzy nie zostali przymusowo wysiedleni i rozproszeni (tab. 16). Dlatego też uzasadniona wydaje się teza, iż bardzo silne rozproszenie terytorialne Ukraińców i Łemków, które było jednym z głównych celów akcji „Wisła”, miało wpływ na zwiększoną - w porównaniu z innymi mniejszościami - intensywność procesów asymilacyjnych pośród Ukraińców oraz Łemków i przyczyniło się do niewielkiej liczby deklaracji tożsamości ukraińskiej i łemkowskiej podczas spisu ludności w 2002 r.

Z pewnością na zmniejszenie liczby Ukraińców i Łemków w Polsce w ciagu ostatnich kilkudziesięciu lat miała wpływ także trwająca od początku lat 60 . XX w. emigracja do USA, Kanady i państw zachodniej Europy (Dudra 2008, Drozd, Halczak 2010). Jednak brak rzetelnych danych statystycznych uniemożliwia nawet szacunkowe określenie skali tych wyjazdów.

Przy założeniu, że podczas akcji „Wisła” wysiedlono łącznie ok. 140 tys. osób, w tym 110 tys. Ukraińców i 30 tys. Łemków, a podczas spisu ludności w 2002 r. narodowość ukraińską zadeklarowały 27172 osoby posiadające polskie obywatelstwo, natomiast łemkowską 5850 osób, to w latach 1947-2002 spadek liczby Ukraińców w Polsce wyniósł 75,3\%, a Łemków 81,5\%. Jest to porównywalne zmniejszenie liczebności obu społeczności, większe w przypadku Łemków, prawdopodobnie częściowo z powodów - omawianych powyżej kilku opcji tożsamości narodowej wśród Łemków i przyjęciu przez część z nich tożsamości ukraińskiej. 


\section{Białorusini}

Podczas spisu w 2002 r. narodowość białoruską zadeklarowało 47640 osób posiadających obywatelstwo polskie, jeszcze mniej osób (40 226) zadeklarowało używanie jezzyka białoruskiego w „kontaktach domowych”. Był to wynik istotnie odbiegający od kilkakrotnie wyższych szacunków z lat 90 . XX w. (200300 tys.), z kolei zbliżony do wartości ustalonych na podstawie badań terenowych (Sadowski 1995a, 1997, Barwiński 2004a, 2005b) i w dużym stopniu odzwierciedlał rzeczywisty stopień poczucia białoruskiej tożsamości narodowej w Polsce.

W przypadku Białorusinów spis powszechny potwierdził, że są oni nadal typowym przykładem mniejszości o bardzo silnej koncentracji terytorialnej, związanej z jednym, zamieszkiwanym od pokoleń, regionem (tab. 20, ryc. 29-31, 33-34). Prawie 97\% osób deklarujących narodowość białoruską (46 041) zamieszkiwało Podlasie, głównie jego południowo-wschodnią część, stanowiąc w ośmiu gminach ponad 40\% ogółu mieszkańców, w tym w czterech ponad 65\%, a w dwóch (Czyże i Dubicze Cerkiewne) ponad 80\% (tab. 20, ryc. 33-34). Były to zarazem gminy o największym udziale ludności niepolskiej w skali całego kraju. Mogło to świadczyć o nieznacznej mobilności tej tradycyjnie wiejskiej ludności. Jednak wyniki spisu pokazały jednocześnie, że największe liczebnie skupiska Białorusinów występowały w podlaskich miastach: Białymstoku (7,4 tys.), Hajnówce (5,9 tys.), Bielsku Podlaskim (5,6 tys.), z czego wynika, że członkowie tej mniejszości także migrowali z terenów wiejskich, jednak głównie do najbliższych podlaskich miast, gdzie prawdopodobnie zdecydowana większość z nich ulegała z czasem polonizacji.

Porównanie deklaracji rozmieszczenia i liczebności narodowości białoruskiej oraz deklaracji używania języka białoruskiego pokazuje, że obszarowi największej koncentracji liczebnej Białorusinów (południowo-wschodnia część województwa podlaskiego) odpowiadała wyraźna przewaga tożsamości narodowej nad językową. Analogiczna sytuacja, choć na mniejszą skalę, występowała także na północno-wschodnim Podlasiu oraz Mazurach. Jedynie wśród Białorusinów zamieszkujących wiejskie okolice Białegostoku wyraźnie dominowała tożsamość językowa nad narodową (ryc. 32).

Analizując to samo zjawisko na poziomie lokalnym, można zauważyć, że w miastach południowo-wschodniego Podlasia (Białystok, Bielsk Podlaski, Hajnówka, Kleszczele) wyraźnie była widoczna przewaga deklaracji narodowości białoruskiej nad deklarowaniem używania języka białoruskiego, natomiast w większości gmin wiejskich zaznaczała się nieznaczna przewaga deklaracji językowych nad narodowościowymi (ryc. 33-34). Było to konsekwencją bardzo silnej asymilacji językowej białoruskich mieszkańców podlaskich miast, spowo- 
dowanej zarówno całkowitą dominacją języka polskiego w środowiskach miejskich, jak i świadomym „odrzucaniem” języka białoruskiego jako wyróżnika swojego pochodzenia narodowościowego.

Tabela 20. Gminy i miasta z największą liczbą Białorusinów ${ }^{a}$ oraz z największym udziałem procentowym w ogólnej liczbie mieszkańców

(na podstawie wyników spisu z 2002 r.)

\begin{tabular}{|l|l|l|c|}
\hline \multicolumn{3}{|c|}{ Jednostka administracyjna } & Białorusini \\
\hline \multicolumn{1}{|c|}{ Gmina/miasto } & Powiat & Województwo & Liczba \\
\hline Białystok miasto & Białystok & podlaskie & 7369 \\
Hajnówka miasto & hajnowski & podlaskie & 5932 \\
Bielsk Podlaski miasto & bielski & podlaskie & 5565 \\
Bielsk Podlaski & bielski & podlaskie & 3584 \\
Hajnówka & hajnowski & podlaskie & 2886 \\
Orla & bielski & podlaskie & 2497 \\
Czyże & hajnowski & podlaskie & 2274 \\
Narew & hajnowski & podlaskie & 2220 \\
Narewka & hajnowski & podlaskie & 1977 \\
Dubicze Cerkiewne & hajnowski & podlaskie & 1675 \\
Gródek & białostocki & podlaskie & 1380 \\
Kleszczele & hajnowski & podlaskie & 1272 \\
\hline \multicolumn{1}{|c|}{ Gmina/miasto } & Powiat & Województwo & Odsetek \\
\hline Czyże & hajnowski & podlaskie & 82,0 \\
Dubicze Cerkiewne & hajnowski & podlaskie & 81,3 \\
Orla & bielski & podlaskie & 69,0 \\
Hajnówka & hajnowski & podlaskie & 65,0 \\
Narew & hajnowski & podlaskie & 49,4 \\
Narewka & hajnowski & podlaskie & 47,3 \\
Bielsk Podlaski & bielski & podlaskie & 46,7 \\
Kleszczele & hajnowski & podlaskie & 41,8 \\
Czeremcha & hajnowski & podlaskie & 28,7 \\
Hajnówka miasto & hajnowski & podlaskie & 26,4 \\
Gródek & białostocki & podlaskie & 23,1 \\
Bielsk Podlaski miasto & bielski & podlaskie & 20,7 \\
\hline
\end{tabular}

${ }^{a}$ Dotyczy wyłącznie osób posiadających obywatelstwo polskie.

Źródło: opracowanie własne 


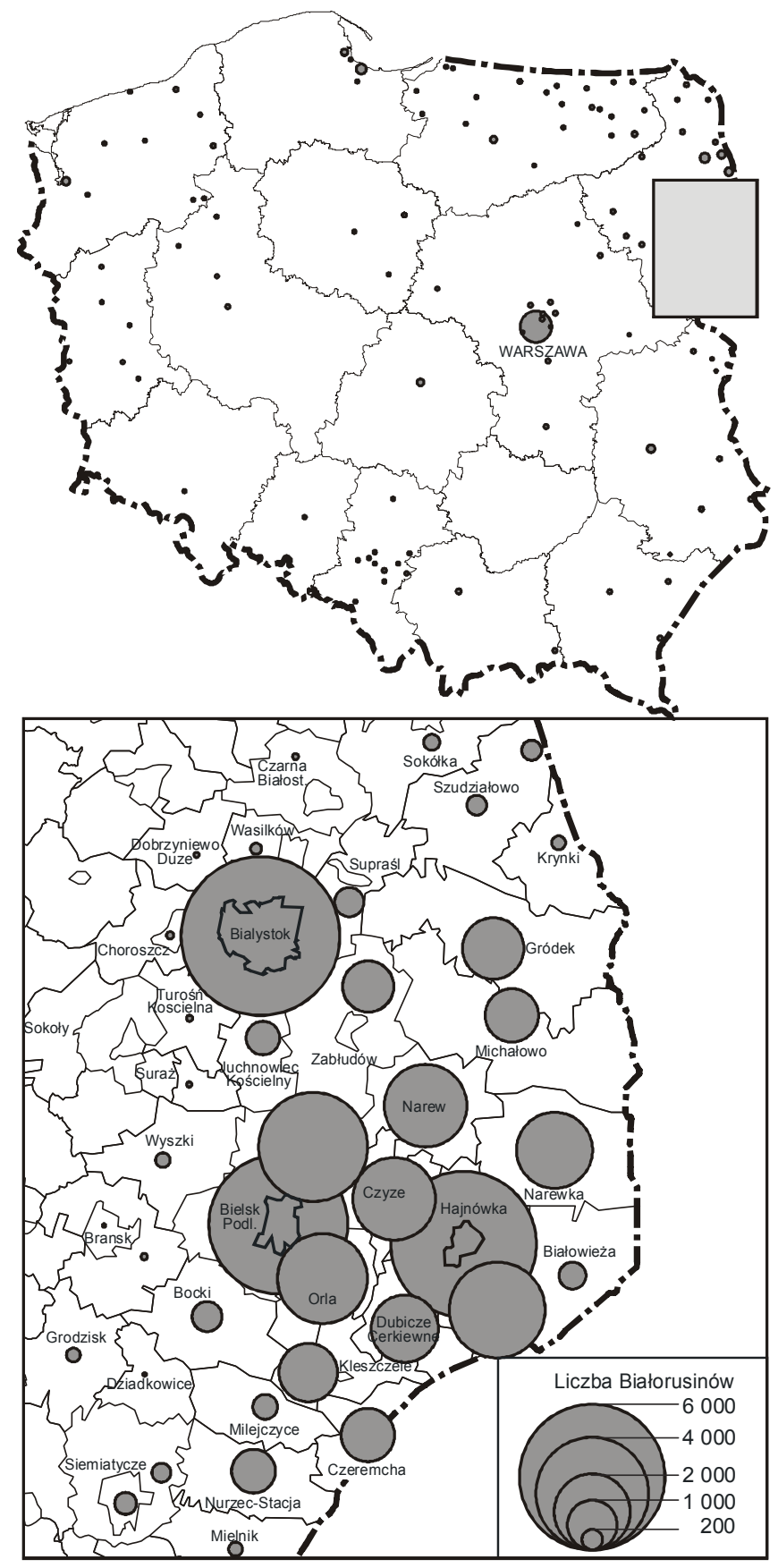

Ryc. 29. Liczba i rozmieszczenie osób deklarujących narodowość białoruską na podstawie wyników spisu ludności z 2002 r.

Źródło: opracowanie własne na podstawie danych GUS 


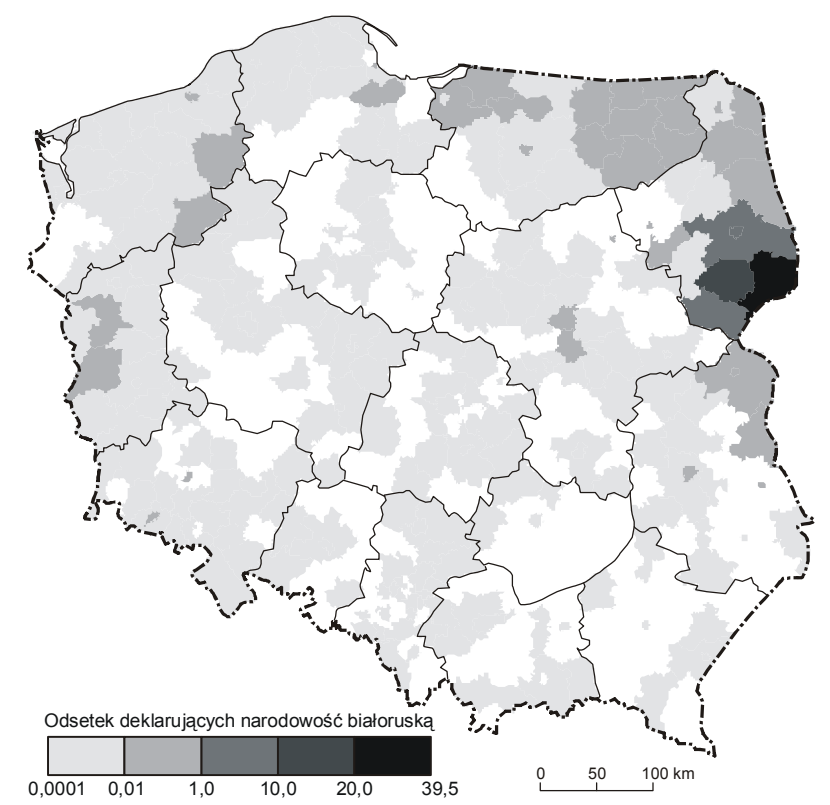

Ryc. 30. Udział procentowy osób deklarujących narodowość białoruską (według powiatów) na podstawie wyników spisu ludności z 2002 r.

Źródło: opracowanie własne na podstawie danych GUS

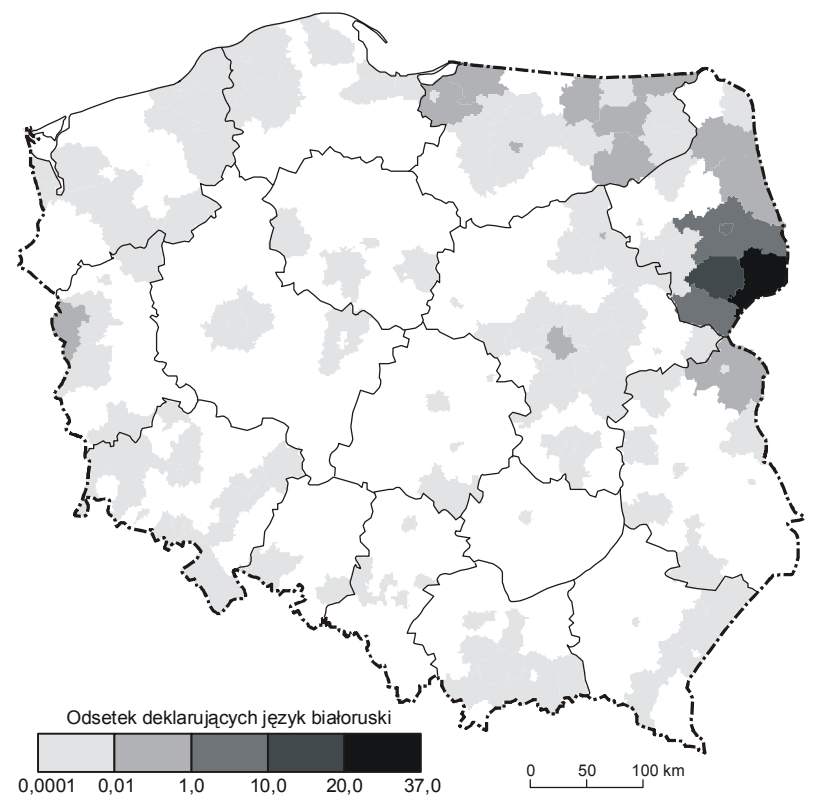

Ryc. 31. Udział procentowy osób deklarujących używanie języka białoruskiego (według powiatów) na podstawie wyników spisu ludności z 2002 r. Źródło: opracowanie własne na podstawie danych GUS 


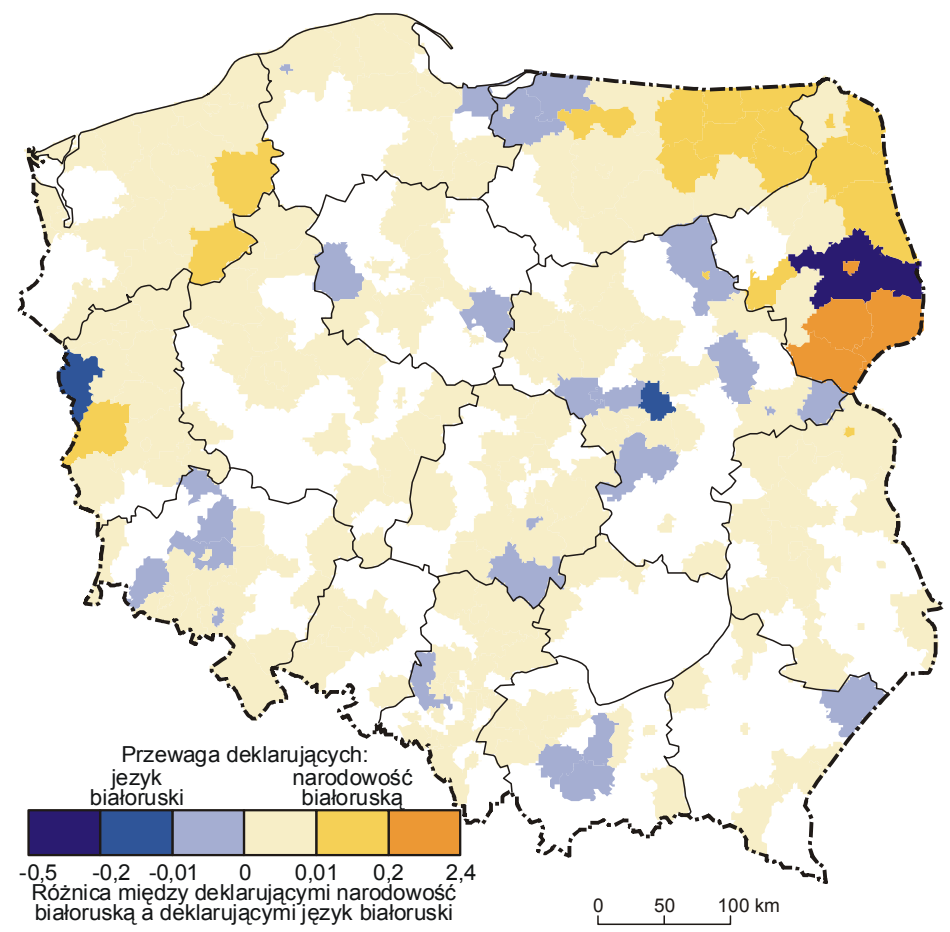

Ryc. 32. Porównanie deklaracji narodowości białoruskiej oraz używania języka białoruskiego (według powiatów) na podstawie wyników spisu ludności z 2002 r. Źródło: opracowanie własne na podstawie danych GUS

Dane uzyskane podczas spisu potwierdzały wyniki wielu badań naukowych negujących utożsamianie całej ludności prawosławnej Podlasia z Białorusinami. Podkreślały jej postępującą polonizacje, dominację autoidentyfikacji Polak-prawosławny, a także utrzymywanie się wśród niewielkiej części wyznawców prawosławia ukraińskiej tożsamości narodowej (Mironowicz 1992a, b, Hawryluk 1999, Sadowski 1995a, 1997, Barwiński 2004a, 2005a, b). Według wyników spisu, na Podlasiu 46041 osób zadeklarowało narodowość białoruską, 1366 ukraińską, a 511 rosyjską. Liczba wyznawców prawosławia, z powodu braku pytania dotyczącego wyznania w spisie w 2002 r., jest określana szacunkowo. Według danych GUS, w 2002 r. na Podlasiu było aż 355 tys. osób wyznania prawosławnego (Wyznania religijne... 2003), natomiast według szacunków A. Sadowskiego (1997) 250 tys., a K. Gossa (2001) zaledwie 165 tys. Pomimo tak dużej rozpiętości szacunków oznacza to, że na początku XXI w. zaledwie od $14 \%$ do $29 \%$ prawosławnych mieszkańców Białostocczyzny deklarowało podczas spisu narodowość białoruską, ukraińską lub rosyjską. Na obszarze wschodniego Podlasia zdecydowanie dominowała kategoria Polak-prawosławny. Pow- 
szechność tego typu tożsamości narodowo-wyznaniowej wynikała $\mathrm{z}$ bardzo silnych $\mathrm{w}$ tym regionie $\mathrm{w}$ okresie PRL i współcześnie procesów asymilacji wyznawców prawosławia do narodu polskiego, jednak bez konwersji religijnej.

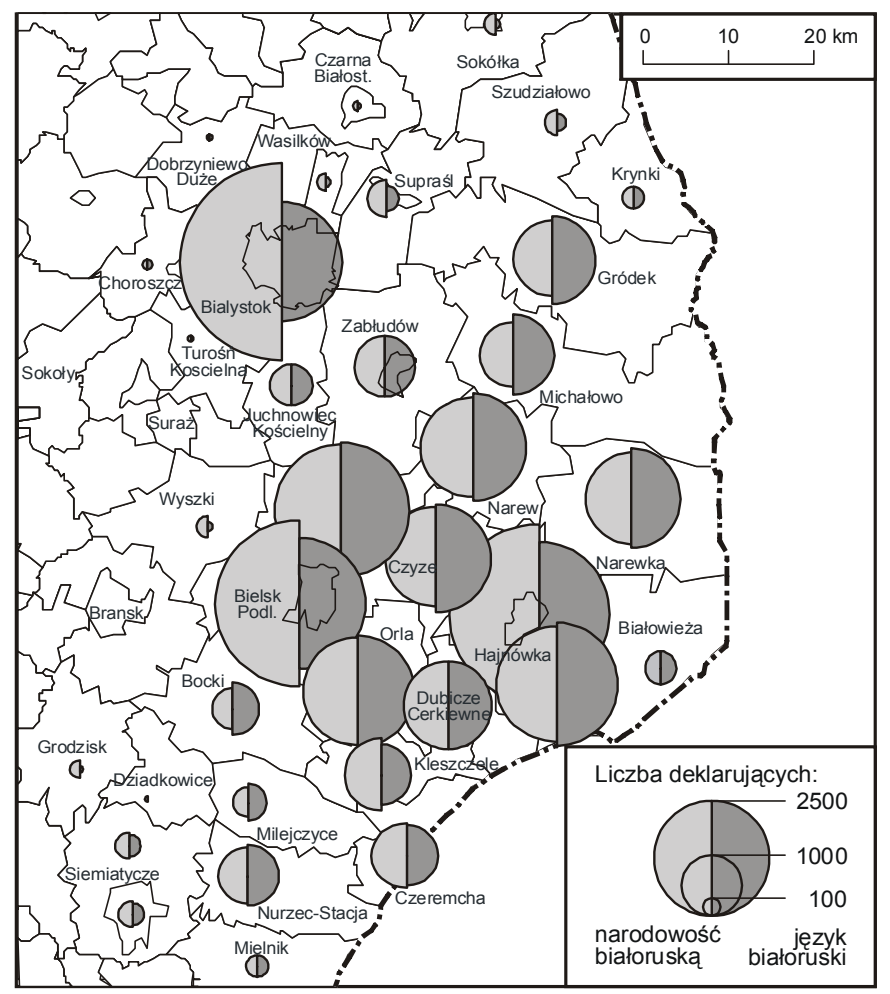

Ryc. 33. Liczba i rozmieszczenie osób deklarujących narodowość białoruską oraz używanie języka białoruskiego na Podlasiu (według gmin) na podstawie wyników spisu ludności z $2002 \mathrm{r}$. Źródło: opracowanie własne na podstawie danych GUS

Głównymi czynnikami przyspieszającymi asymilację prawosławnej społeczności Podlasia była migracja do miast, chęć awansu społecznego i ekonomicznego, mieszane małżeństwa, polonizacyjna działalność systemu edukacji oraz powszechność używania języka polskiego, a także przywiązanie do historii i kultury polskiej przy jednoczesnym niewielkim kontakcie z kulturą białoruską. Istotne znaczenie miało także częste postrzeganie białoruskości jako czegoś gorszego, mniej atrakcyjnego, a co za tym idzie ukrywanie lub wręcz odrzucanie, swojego pochodzenia (Mironowicz 1992a, b, 1998, 2000, 2010a, b, Sadowski 1995a, 1997, Barwiński 2004a, 2005a, Plit 2008). Stąd tak niewielka liczebność mniejszości białoruskiej wykazana podczas spisu, zwłaszcza w porównaniu 
z wcześniejszymi szacunkami, wahającymi się najczęściej w granicach 200-250 tys. (Eberhardt 1996, Sobczyński 1996a, Chałupczak, Browarek 1998). Asymilacja ludności prawosławnej następowała najwolniej w gminach, gdzie w szkołach nauczano jeszcze języka białoruskiego (gminy Czyże, Dubicze Cerkiewne, Orla, Hajnówka, Bielsk Podlaski, Narew, Narewka), a najszybciej tam, gdzie szkolnictwo białoruskie zlikwidowano już kilkadziesiąt lat temu (gminy powiatu sokólskiego i siemiatyckiego) (Mironowicz 2010a, b).

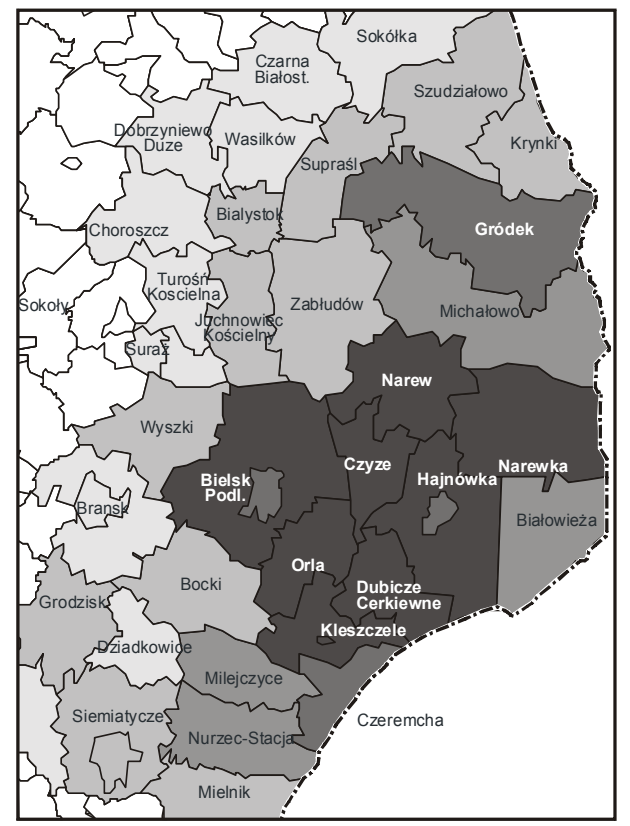

Odsetek deklarujących: narodowość białoruską

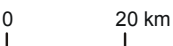

język białoruski

0,1
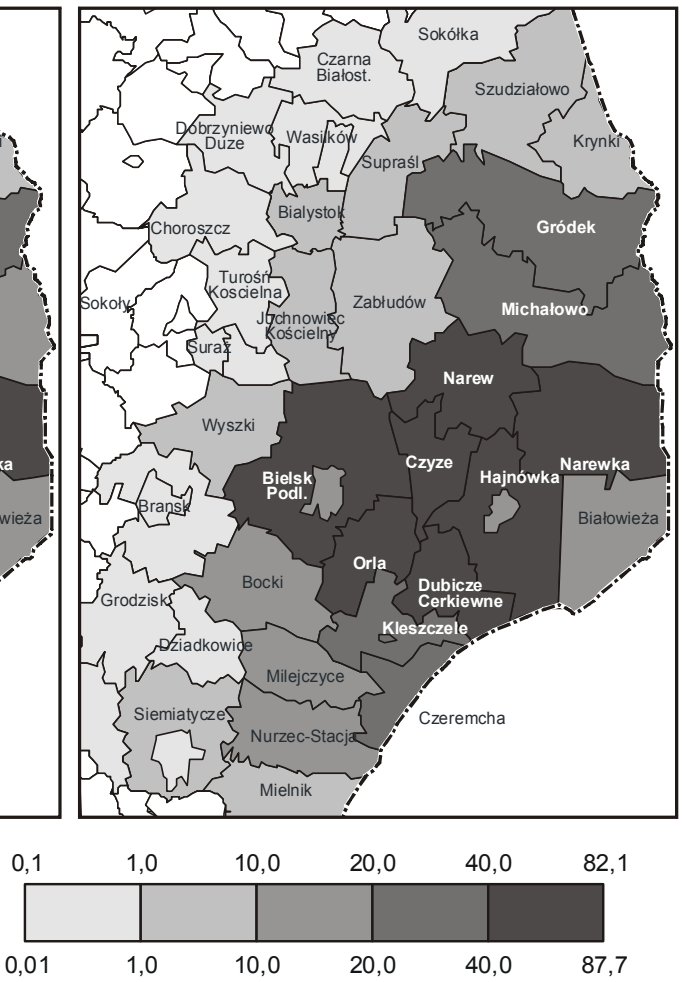

Ryc. 34. Udział procentowy osób deklarujących narodowość białoruską oraz używanie języka białoruskiego na Podlasiu (według gmin) na podstawie wyników spisu ludności z 2002 r.

Interesującym wynikiem spisu było $73 \%$ deklaracji narodowości białoruskiej na Podlasiu, przypadających na obszar między Bugiem a Narwią (ryc. 3334), czyli na ziemie, które według badań historyków i językoznawców zostały w średniowieczu zasiedlone przez osadników pochodzenia ukraińskiego i aż do okresu międzywojennego wykazywały zdecydowaną dominację Ukraińców nad Białorusinami (Wakar 1917b, Wiśniewski 1977, Sadowski 1995a, Eberhardt 1996, Makarski 1996, Hawryluk 1999). 
Często podkreśla się „ukraiński charakter etniczny” prawosławnych mieszkańców tej cześci Podlasia. Trzeba jednak podkreślić, że ten „charakter” jest prawie wyłącznie teoretyczny. W praktyce, m.in. w trakcie badań terenowych (Mironowicz 1992a, b, Sadowski 1995a, Barwiński 2004a, 2005a, b) lub podczas spisu powszechnego w 2002 r., poczucie tożsamości ukraińskiej było wśród mieszkańców tego obszaru marginalne (ryc. 22). Bliskość wyznaniowa, językowa, kulturowa i społeczna bardzo utrudniaja jednoznaczne rozgraniczenie narodowości białoruskiej i ukraińskiej na Podlasiu.

M. Koter (1995a) podkreślał, że „na pograniczu białorusko-ukraińskim (także w granicach Polski) podobieństwo kulturowe pomiędzy tymi dwoma prawosławnymi narodami jest tak silne, że ich formalne rozgraniczenie staje się niemożliwe. W rejonie Bielska Podlaskiego i Hajnówki zdarza się, że na skutek różnych sytuacji życiowych oraz poddania się odmiennej propagandzie politycznej, w obrębie tej samej rodziny ojciec jest «tutejszy», jeden syn uważa się za Białorusina, drugi za Ukraińca, a wyemancypowana córka deklaruje się jako Polka". Opinia ta bardzo trafnie oddaje specyfikę narodowościową południowo-wschodniego Podlasia.

\section{Litwini}

Rozmieszczenie Litwinów, podobnie jak Białorusinów, nie uległo istotnym zmianom od zakończenia II wojny. Jest to mniejszość o bardzo silnej koncentracji terytorialnej, autochtoniczna, zamieszkująca w większości swoją regionalną etniczną ojczyznę, tzw. małą Litwę ze stolicą w Puńsku (tab. 21, ryc. 3539). Obszar zamieszkany przez Litwinów rozciąga się wzdłuż pogranicza polsko-litewskiego, od wsi Jagliniec i Wociuliszki na północnym zachodzie do wsi Morkiszki i Podlaski na południowym wschodzie. Zachodnią granicę ich zasięgu wyznacza linia łącząca Budzisko, Szypliszki i Sejny. Zdecydowana większość Litwinów zamieszkuje zwarty obszar obejmujący ok. 50 wsi w gminach Puńsk i Sejny ${ }^{31}$.

Spośród 5639 osób deklarujących w trakcie spisu narodowość litewską, 90\% mieszkało w województwie podlaskim, zwłaszcza w nadgranicznych gminach Puńsk, Sejny oraz miasto Sejny (ryc. 36-37). Na te dwie gminy przypadło aż $81 \%$ ogółu Litwinów, a zdecydowanie największym ich skupiskiem był Puńsk, gdzie na obszarze zaledwie jednej gminy mieszkało prawie $60 \%$ polskich Litwinów, stanowiących 75\% jej mieszkańców (tab. 21, ryc. 37). Puńsk był jedną z zaledwie pięciu gmin w Polsce, w których według spisu powszechnego

${ }^{31}$ Wsie z ludnością litewską w swojej pracy szczegółowo wylicza K. Tarka (1998, s. 194-195). 
z 2002 r. ludność polska była mniejszością ${ }^{32}$. Poza Podlasiem narodowość litewską zadeklarowały tylko 542 osoby, czyli poniżej 10\% ogółu tej mniejszości. To najlepiej wyjaśnia różnice między wcześniejszymi szacunkami a wynikami spisu. Liczbę Litwinów, żyjących w rozproszeniu poza ich etniczną ojczyzną, szacowano w latach 90. XX w. od 2 tys. do znacznie ponad 10 tys. osób (Tarka 1998). Litwini zamieszkujący poza Suwalszczyzną są - odmiennie niż w północno-wschodniej Polsce - bardzo silnie rozproszeni. Mimo niewielkiej liczebności są obecni w ponad 150 powiatach, zwłaszcza na obszarze północnej i zachodniej Polski (ryc. 38). Jednak najczęściej w poszczególnych powiatach zamieszkują zaledwie 2-3 osoby deklarujące narodowość litewską, prawdopodobnie pojedyncze rodziny. Nieco większe - kilkudziesięcioosobowe skupiska Litwinów - znajdują się tylko w niektórych miastach wojewódzkich, np. Warszawie, Białymstoku, Wrocławiu, Gdańsku, Szczecinie (ryc. 35).

Tabela 21. Gminy i miasta z największą liczbą Litwinów ${ }^{a}$ oraz z największym udziałem procentowym w ogólnej liczbie mieszkańców

(na podstawie wyników spisu z 2002 r.)

\begin{tabular}{|l|l|l|c|}
\hline \multicolumn{3}{|c|}{ Jednostka administracyjna } & Litwini \\
\hline \multicolumn{1}{|c|}{ Gmina/miasto } & \multicolumn{1}{|c|}{ Powiat } & \multicolumn{1}{|c|}{ Województwo } & Liczba \\
\hline Puńsk & sejneński & podlaskie & 3312 \\
Sejny gmina & sejneński & podlaskie & 775 \\
Sejny miasto & sejneński & podlaskie & 469 \\
Suwałki miasto & Suwałki & podlaskie & 316 \\
Szypliszki & suwalski & podlaskie & 109 \\
Warszawa miasto & Warszawa & mazowieckie & 73 \\
\hline \multicolumn{1}{|c|}{ Gmina/miasto } & Powiat & Województwo & Odsetek \\
\hline Puńsk & sejneński & podlaskie & 74,9 \\
Sejny gmina & sejneński & podlaskie & 18,7 \\
Sejny miasto & sejneński & podlaskie & 7,9 \\
Szypliszki & suwalski & podlaskie & 2,7 \\
Krasnopol & sejneński & podlaskie & 0,9 \\
Suwałki miasto & Suwałki & podlaskie & 0,5 \\
\hline
\end{tabular}

${ }^{a}$ Dotyczy wyłącznie osób posiadających polskie obywatelstwo.

Źródło: opracowanie własne.

${ }^{32}$ Pozostałe gminy to położone w południowo-wschodniej części Podlasia Czyże, Dubicze Cerkiewne, Orla i Hajnówka, z liczebną przewagą mniejszości białoruskiej: www.stat.gov.pl/cps/rde/xbcr/gus/PUBL_nsp2002_tabl4_mn.xls. 


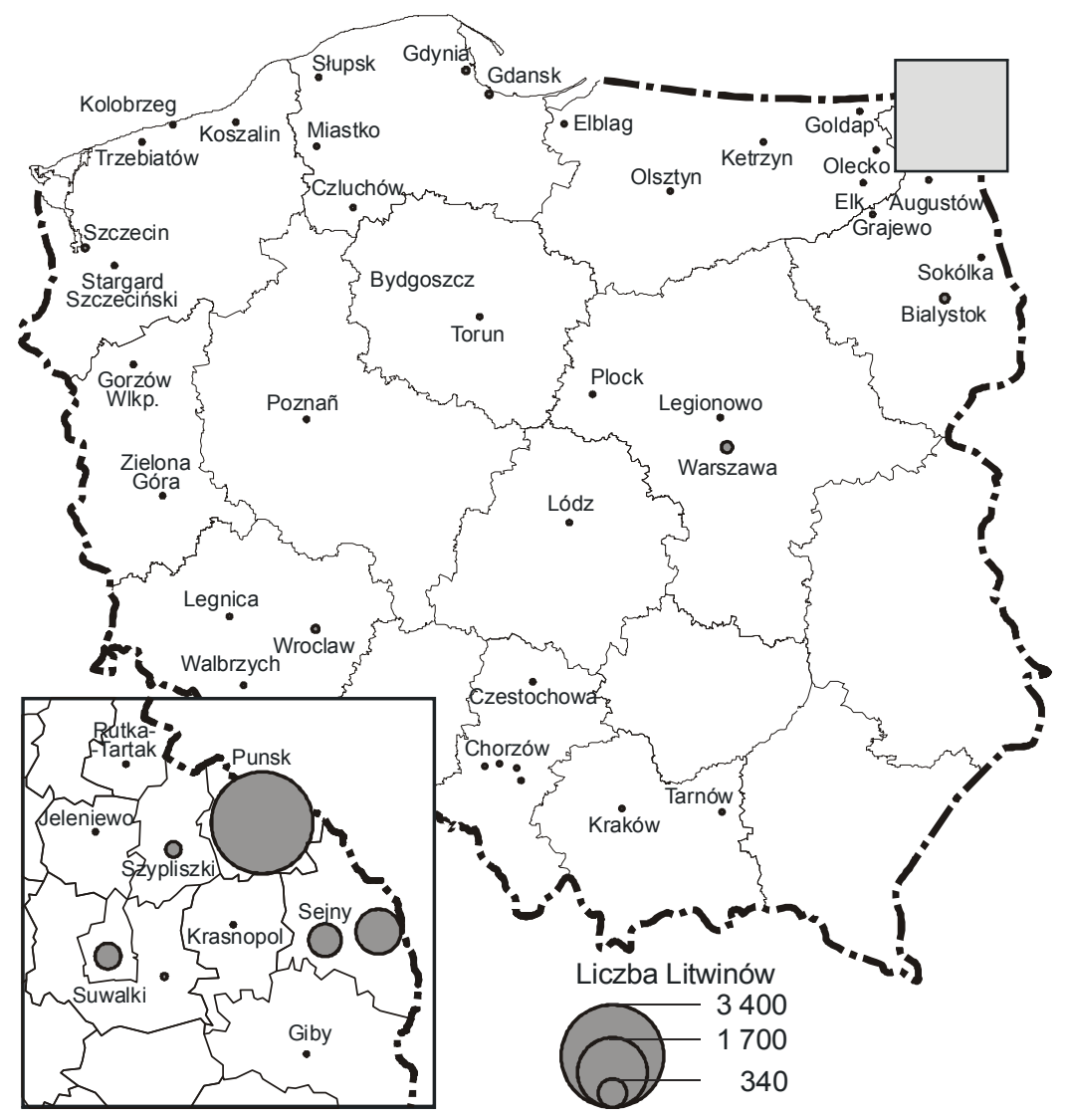

Ryc. 35. Liczba i rozmieszczenie osób deklarujących narodowość litewską na podstawie wyników spisu ludności z 2002 r. Źródło: opracowanie własne na podstawie danych GUS

Spis potwierdził także bardzo duże znaczenie języka ojczystego w podtrzymywaniu litewskiej tożsamości oraz odrębności narodowej. Używanie języka litewskiego w kontaktach domowych zadeklarowało 5838 osób, w tym 5696 osób posiadało obywatelstwo polskie. Była to niespotykana wśród innych mniejszości zbieżność deklaracji narodowościowych i językowych (ryc. 36-37). Ponadto większość, bo aż $63 \%$, osób deklarujących używanie języka litewskiego podała, że w kontaktach domowych używa wyłącznie tego języka, bez języka polskiego. Był to jedyny taki przypadek podczas spisu, wśród innych mniejszości zdecydowanie dominowało używanie języka narodowego razem z językiem polskim. 


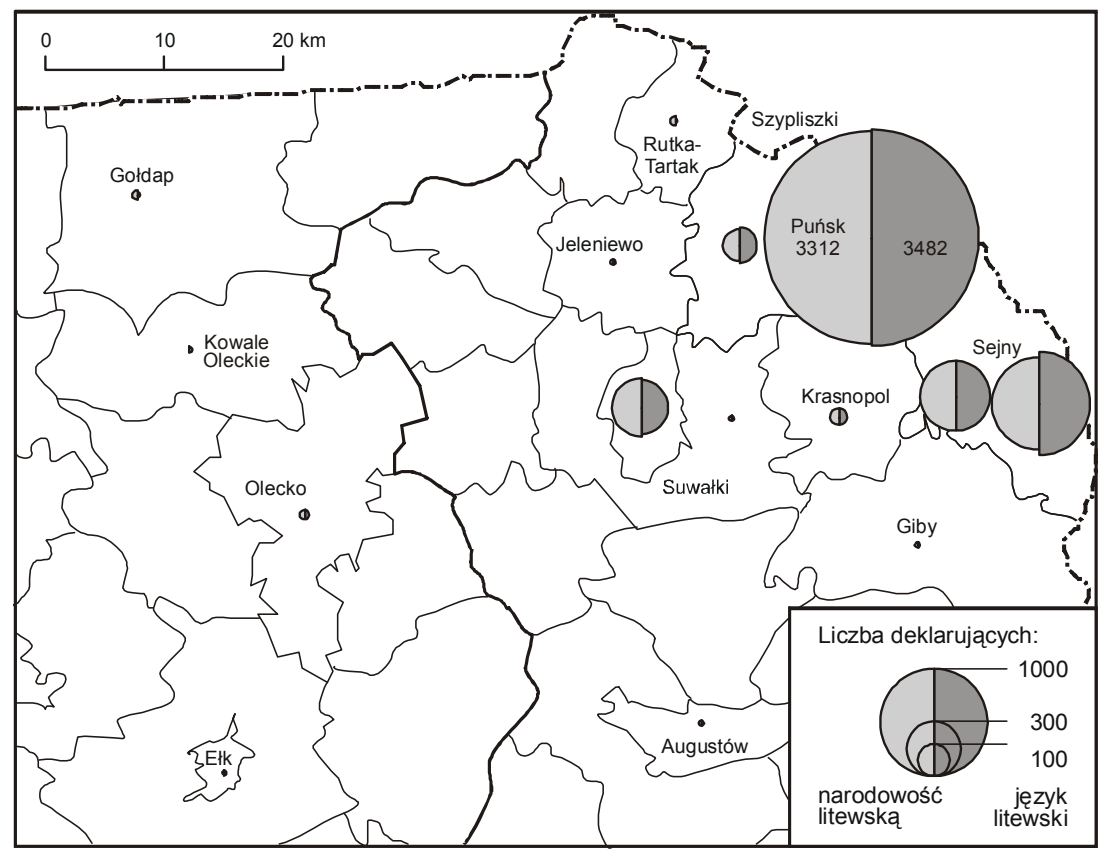

Ryc. 36. Liczba i rozmieszczenie osób deklarujących narodowość litewską oraz używanie języka litewskiego na Suwalszczyźnie (według gmin) na podstawie wyników spisu ludności z 2002 r.

Źródło: opracowanie własne na podstawie danych GUS
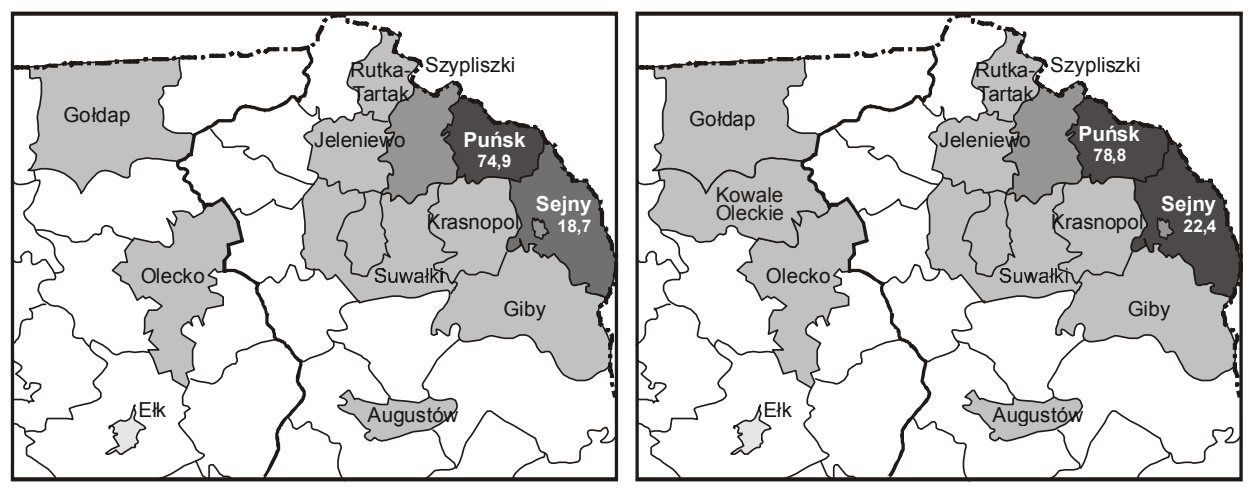

Odsetek deklarujących:
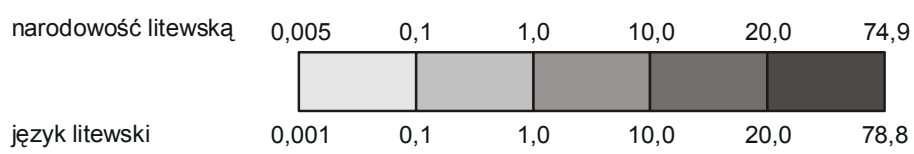

Ryc. 37. Udział procentowy osób deklarujących narodowość litewską oraz używanie języka litewskiego na Suwalszczý́nie (według gmin)

na podstawie wyników spisu ludności z 2002 r.

Źródło: opracowanie własne na podstawie danych GUS 


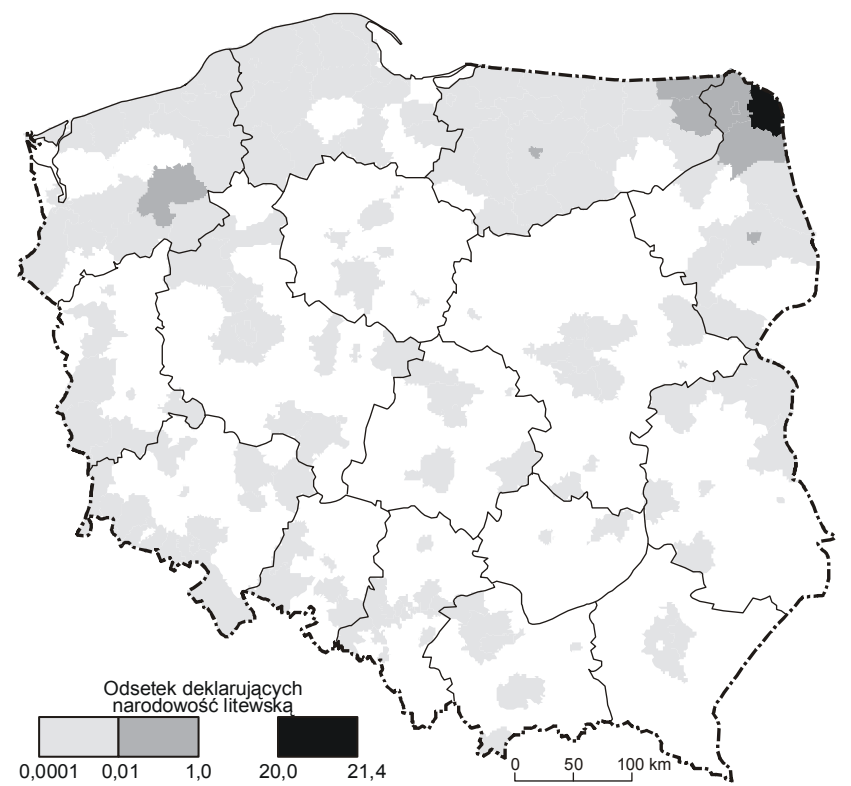

Ryc. 38. Udział procentowy osób deklarujących narodowość litewską (według powiatów) na podstawie wyników spisu ludności z 2002 r.

Źródło: opracowanie własne na podstawie danych GUS

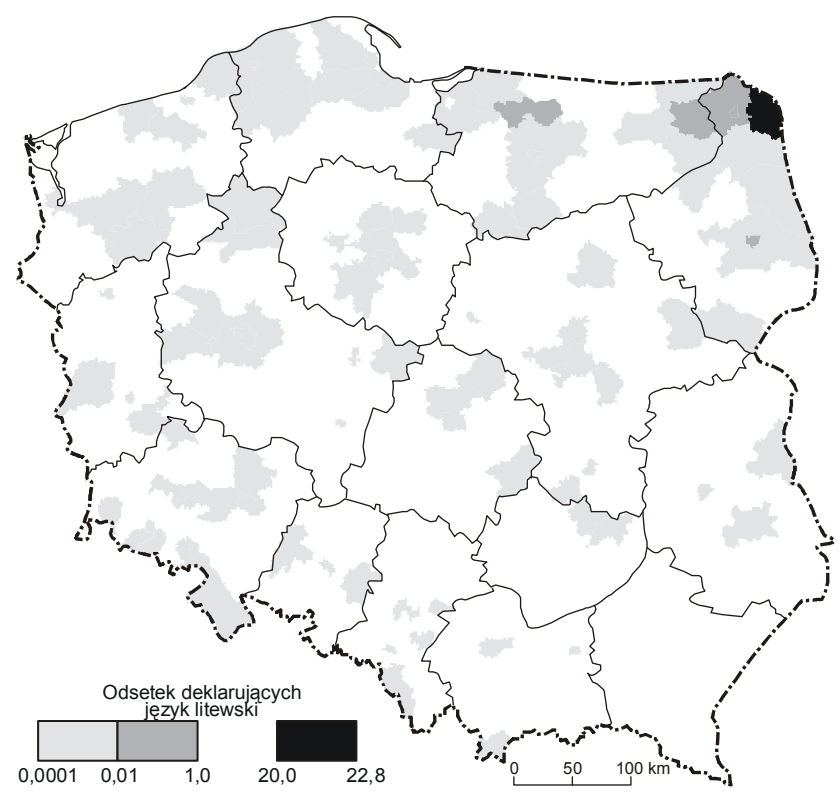

Ryc. 39. Udział procentowy osób deklarujących używanie języka litewskiego (według powiatów) na podstawie wyników spisu ludności z 2002 r. Źródło: opracowanie własne na podstawie danych GUS 
Porównanie deklaracji rozmieszczenia i liczebności narodowości litewskiej oraz deklaracji używania języka litewskiego pokazuje nieznaczną dominację tożsamości językowej nad narodową, najwyraźniej zaznaczającą się na obszarze najliczniejszego skupiska Litwinów (powiat sejneński) (ryc. 40).

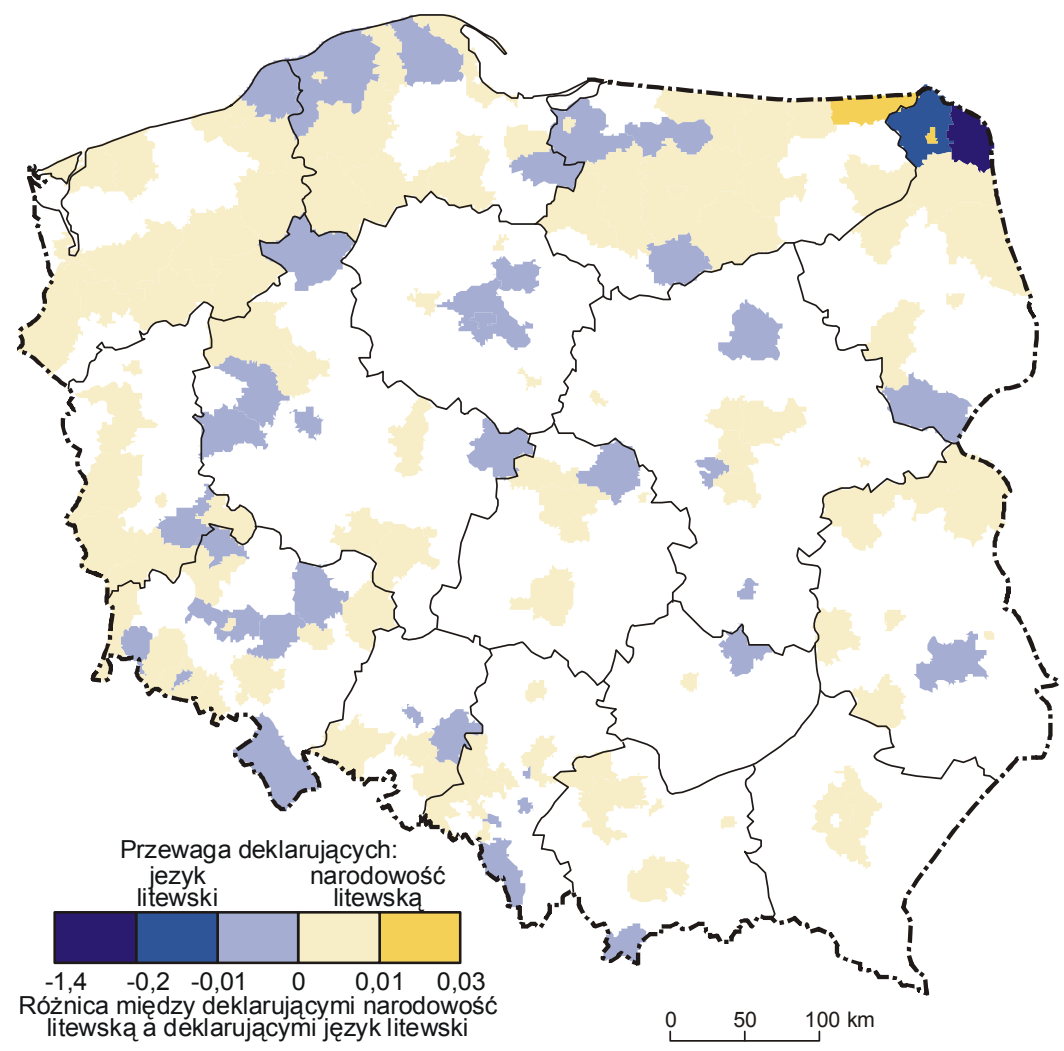

Ryc. 40. Porównanie deklaracji narodowości litewskiej oraz używania języka litewskiego (według powiatów) na podstawie wyników spisu ludności z 2002 r. Źródło: opracowanie własne na podstawie danych GUS

Porównując tę samą zależność u wszystkich czterech omawianych grup, można zauważyć, że wśród relatywnie licznych mniejszości (ukraińskiej i białoruskiej) obszarom największej koncentracji liczebnej odpowiadała wyraźna dominacja tożsamości narodowej nad językową, natomiast wśród mniejszości zdecydowanie mniej licznych (łemkowskiej i litewskiej) sytuacja była odwrotna (ryc. 21, 27, 32, 40).

Niewielka liczebność Litwinów, w połączeniu z ich bardzo wyraźnym terytorializmem, może świadczyć o silnym wpływie emigracji z polsko-litewskiego 
pogranicza do miast i związanej z nią asymilacji na spadek liczebności tej grupy. Jednak procesy asymilacyjne dotknęły Litwinów w stopniu dużo mniejszym niż Ukraińców, Łemków i Białorusinów, mimo że przynależność Litwinów do Kościoła rzymskokatolickiego teoretycznie sprzyja polonizacji. Wpłynęła na to m.in. bardzo duża koncentracja terytorialna, dobrze rozwinięte szkolnictwo oraz wyraźna odrębność językowa, która jest podstawą litewskiej tożsamości. Stąd też, $\mathrm{w}$ porównaniu $\mathrm{z}$ innymi mniejszościami, dużo mniejsza $\mathrm{w}$ przypadku Litwinów różnica między wcześniejszymi szacunkami a wynikami spisu powszechnego. Litwini, obok mniejszości romskiej i niemieckiej, należeli do najmniej przeszacowanych liczebnie narodowości (Barwiński 2009c).

Od połowy lat 50. do końca 70. XX w., szacując liczebności mniejszości litewskiej, podawano zazwyczaj wartość 9-10 tys. osób. W połowie lat 90. ubiegłego wieku H. Chałupczak i T. Browarek (1998) oszacowali liczebność Litwinów w Polsce na 20 tys., a przedstawiciele litewskich organizacji na 20-25 tys. Wartości te wydają się zdecydowanie zawyżone. Zapewne bliższe prawdy były szacunki z tego samego okresu C. Żołędowskiego (1992), który podał liczbę 9 tys., A. Sadowskiego (1997), określającego liczebność Litwinów na 7-10 tys. oraz K. Tarki (1998), który opowiadał się za liczbą ok. 10 tys. osób narodowości litewskiej. Głównym źródłem rozbieżności szacunków z lat 90 . XX w. były problemy z określeniem liczby Litwinów mieszkających poza Suwalszczyzną, w bardzo dużym rozproszeniu, głównie na obszarze północnej oraz zachodniej Polski.

Według ustalonego w wyniku spisu powszechnego w 2002 r. rozmieszczenia poszczególnych mniejszości narodowych, gminy z największym udziałem omawianych społeczności (powyżej 0,5\% ogółu mieszkańców), w których jednocześnie stanowią one najliczniejszą mniejszość, były rozmieszczone peryferyjnie na obszarze Polski. W przypadku mniejszości białoruskiej i litewskiej są to peryferia na pograniczach Polski z ich zagraniczną ojczyzna, natomiast w przypadku Ukraińców i Łemków są to głównie peryferia północne i zachodnie, wyraźnie oddalone od pierwotnych miejsc osiedlenia, w których ich udział jest nieznaczny. Zasadniczym czynnikiem wpływającymi na rozmieszczenie jest z jednej strony przywiązanie do zamieszkiwanego od pokoleń regionu oraz bliskość własnej ekumeny narodowej (Białorusini i Litwini), z drugiej strony nadal bardzo wyraźnie widoczne konsekwencje powojennych decyzji politycznych (Ukraińcy i Łemkowie) (ryc. 41).

Mniejszości autochtoniczne, nieobjęte na dużą skalę przymusowymi przesiedleniami (Białorusini i Litwini), mimo upływu kilkudziesięciu lat oraz migracji z terenów wiejskich do miast nadal skupiały się na obszarach przygranicznych. Ponad 96\% Białorusinów i 91\% Litwinów zamieszkiwało w pasie 
zaledwie $100 \mathrm{~km}$ od granicy z własnymi państwami macierzystymi (ryc. 42). Natomiast powojenne przesiedlenia trwale zmieniły rozmieszczenie Ukraińców i Łemków. W południowo-wschodnich regionach nadgranicznych, autochtonicznych dla tych mniejszości, mieszkało niespełna 30\% ogółu Łemków i zaledwie ok. 12\% Ukraińców. Z kolei ponad połowa Łemków żyła w zachodniej Polsce, w pasie od 300 do $500 \mathrm{~km}$ od swojej etnicznej Łemkowszczyzny, a zdecydowana większość Ukraińców (prawie 70\%) w odległości od 300 do 600 km od granic Ukrainy (ryc. 42).

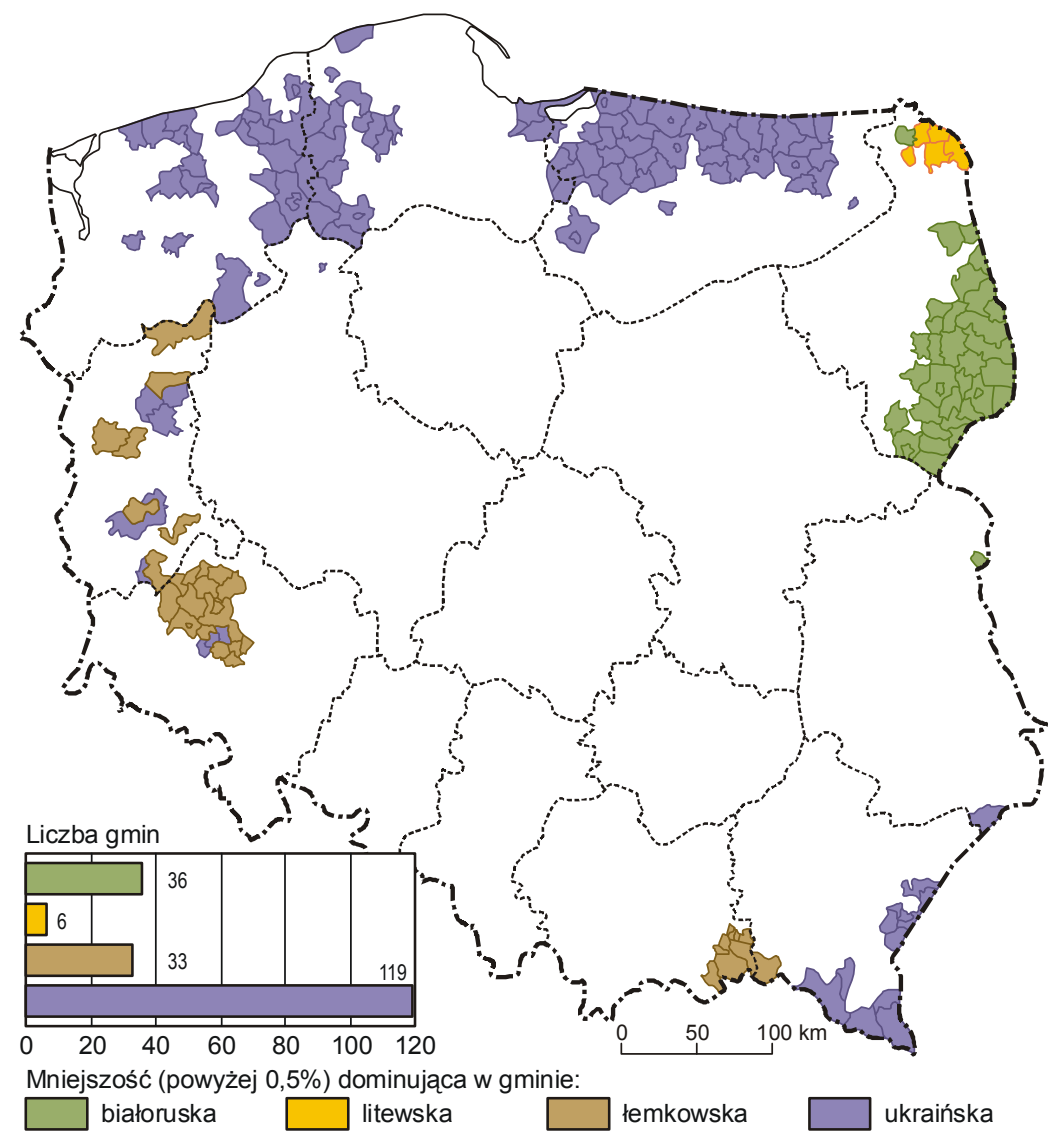

Ryc. 41. Gminy z największym udziałem mniejszości białoruskiej, litewskiej, łemkowskiej i ukraińskiej (powyżej 0,5\% ogółu mieszkańców)

na podstawie wyników spisu ludności z $2002 \mathrm{r}$.

Źródło: opracowanie własne na podstawie danych GUS 

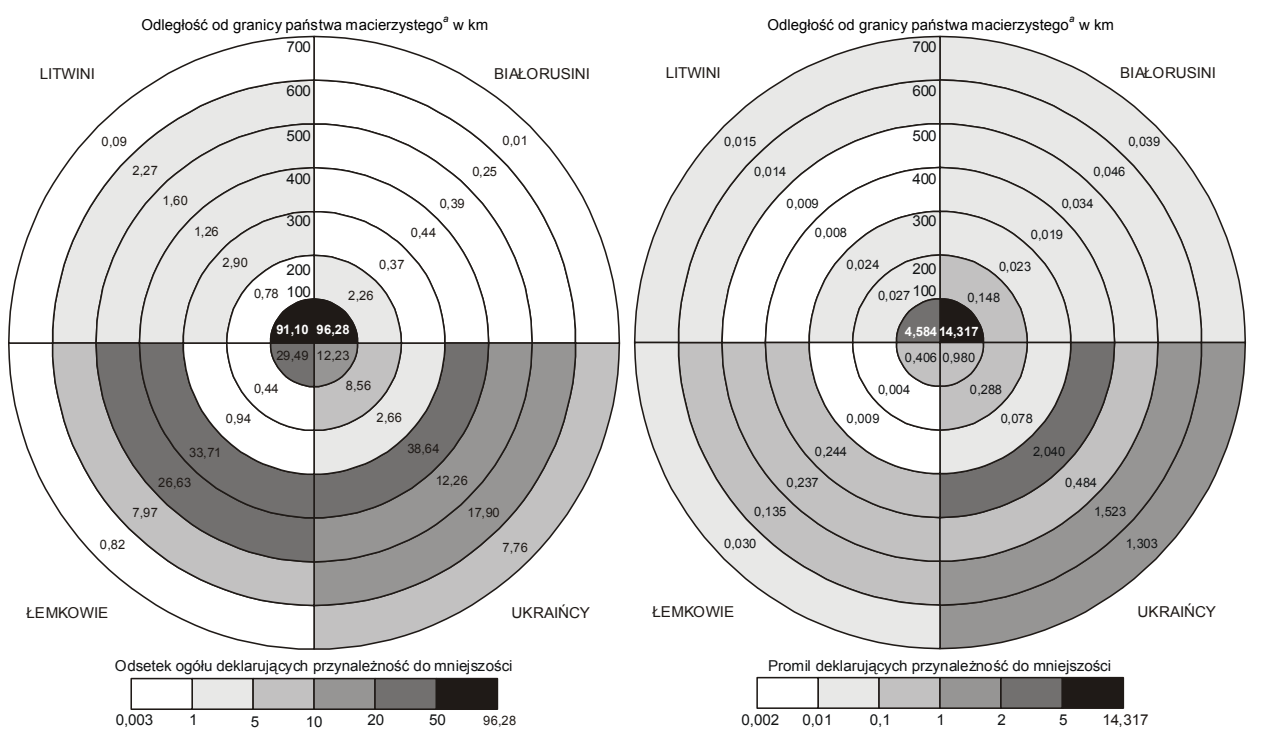

${ }^{a} \mathrm{~W}$ przypadku Łemków nieposiadających państwa macierzystego dotyczy odległości od granicy Słowacji

Ryc. 42. Udział procentowy osób deklarujących narodowość litewską, białoruską, łemkowską i ukraińską w zależności od odległości od granicy państwa macierzystego na podstawie wyników spisu ludności z 2002 r. Źródło: opracowanie własne na podstawie danych GUS
Ryc. 43. Udział osób deklarujących narodowość litewską, białoruską, łemkowską i ukraińską w ogólnej liczbie ludności w zależności od odległości od granicy państwa macierzystego na podstawie wyników spisu ludności z 2002 r. Źródło: opracowanie własne na podstawie danych GUS

Tak ukształtowane rozmieszczenie wraz z niewielką liczebnością omawianych mniejszości miało oczywiście bezpośredni wpływ na ich udział w ogólnej liczbie ludności poszczególnych regionów Polski. Mimo bardzo wyraźnej koncentracji terytorialnej Białorusinów i Litwinów stanowili oni nieznaczny udział wśród mieszkańców szeroko pojętego, stukilometrowego pogranicza polsko-białoruskiego $(14,3 \%$ ) oraz polsko-litewskiego $(4,6 \%$ ). Natomiast powojenne rozproszenie Ukraińców i Łemków, choć umożliwiło powstanie kilku charakterystycznych, lokalnych skupisk, to jednak całkowicie zmarginalizowało ich potencjał liczebny, doprowadzając do nierównomiernego ,rozmycia” tych mniejszości na terytorium Polski (ryc. 43). 


\subsection{Analiza wyników spisu powszechnego z 2011 roku}

Wiosną 2011 r. przeprowadzono kolejny spis ludności (według stanu na 31 marca 2011 r.), pierwszy od czasu, gdy Polska stała się członkiem Unii Europejskiej. Wyniki spisu m.in. dostarczyły aktualnych informacji o strukturze narodowościowej Polski, a także po raz pierwszy od 80 lat częściowych danych dotyczących struktury wyznaniowej. Spis ten został przeprowadzony według całkowicie odmiennej metody niż poprzedni. Był podzielony na - różniące się liczbą pytań w formularzu - badanie pełne oraz dużo obszerniejsze badanie reprezentacyjne, którym objęto mieszkańców $20 \%$ wylosowanych gospodarstw domowych (ponad $8 \mathrm{mln}$ osób), z zamiarem uogólnienia danych na całą populację. Kolejnymi nowościami były: możliwość indywidualnego dokonania spisu za pomocą Internetu, zadeklarowania podwójnej tożsamości narodowej oraz (tylko w badaniu reprezentacyjnym) udzielenia odpowiedzi na pytania dotyczące wyznania i języka ojczystego. Dane zbierano ze zróżnicowanych źródeł: z rejestrów państwowych, $\mathrm{z}$ samospisu internetowego, wywiadu telefonicznego prowadzonego przez ankietera statystycznego oraz $\mathrm{z}$ wywiadu rejestrowanego na przenośnym urządzeniu elektronicznym prowadzonego przez rachmistrza spisowego. Wszystkie dane gromadzono na formularzach elektronicznych, bez użycia papieru ${ }^{33}$.

Według opublikowanych na stronach internetowych Głównego Urzędu Statystycznego, tuż po zakończeniu spisu, „Komunikatów Centralnego Biura Spisowego", w badaniu reprezentacyjnym spisano $100 \%$ wylosowanych mieszkań, natomiast w badaniu pełnym, kompletne dane uzyskano dla 98,9\% populacji, dla $0,9 \%$ populacji z powodu braku możliwości ustalenia adresu przebywania dane są niekompletne, a dla $0,2 \%$ brak było wystarczających danych do przeprowadzenia spisu. Z możliwości samodzielnego wypełnienia formularza spisowego za pomocą Internetu skorzystało zaledwie $12 \%$ populacji (ok. $4,5 \mathrm{mln}$ osób $^{34}$ ). GUS poinformował także, że ,jeśli do kogoś nie zgłosił się rachmistrz spisowy lub nie zadzwonił ankieter, oznacza to, że wszystkie wymagane zakresem tematycznym informacje są zebrane $\mathrm{z}$ rejestrów, a tym samym, zgodnie

${ }^{33}$ Na podstawie: www.stat.gov.pl/gus/7852_PLK_HTML.htm.

${ }^{34}$ Wśród tej grupy udział osób wywodzących się z mniejszości narodowych i etnicznych był prawdopodobnie istotnie wyższy niż wynika to ze statystyki narodowościowej. Było to konsekwencją aktywnego propagowania tej formy spisu w środowiskach ludności niepolskiej przez organizacje mniejszości narodowych oraz bezpośredniej pomocy w wypełnianiu formularzy internetowych podczas spisu. 
z ustawą o spisie, obowiązek udziału w spisie został wypełniony" "35. Jednak dane dotyczące m.in. narodowości i języka mogą być zebrane wyłącznie za pomocą technik ankietowych, nie można ich pozyskać z żadnych rejestrów. Oznacza to, że jeżeli ktoś nie skorzystał z możliwości wypełnienia formularza spisowego poprzez Internet, nie zgłosił się do niego rachmistrz, ani nie zadzwonił ankieter, nie mógł zadeklarować własnej tożsamości narodowej, a GUS, wbrew własnym deklaracjom, nie może dysponować tego typu wiedzą, mogą to być wyłącznie dane szacunkowe ${ }^{36}$.

$\mathrm{Z}$ powodu niewielkiego zainteresowania samospisem internetowym oraz braku wizyty rachmistrza spisowego w wielu mieszkaniach, spis z 2011 r. nie wypełnił co najmniej dwóch, spośród czterech podstawowych kryteriów współczesnych spisów ludności ${ }^{37}$. Nie spełniał kryterium powszechności (nie objął wszystkich mieszkańców) oraz bezpośredniości (nie wszystkie odpowiedzi zostały uzyskane bezpośrednio od osoby spisywanej bądź w wyjątkowych przypadkach od najbliższych domowników). Spełniał jedynie kryterium jednoczesności (został przeprowadzony według stanu w ściśle określonym dniu - 31 marca 2011 r.), natomiast dyskusyjne jest, czy przy założeniu braku powszechności spełniał kryterium imienności (każdą osobę spisano z imienia i nazwiska). W istotny sposób ogranicza to wartość poznawczą uzyskanych wyników.

W formularzach spisowych w całkowicie nowy sposób sformułowano „pytania etniczne". Co prawda podstawowe pytanie było identyczne jak przed dekadą, czyli „Jaka jest Pana(i) narodowość?”38, to jednak nie było to pytanie otwarte, lecz zawierało listę 14 narodowości (polską oraz 13 ułożonych alfabetycznie mniejszości wyszczególnionych w ustawie, w tym białoruską, litewską,

${ }^{35} \mathrm{Na}$ podstawie: www.stat.gov.pl „Komunikat Centralnego Biura Spisowego nt. uczestnictwa w Narodowym Spisie Powszechnym Ludności i Mieszkań 2011”.

${ }^{36}$ GUS podkreślił, że w 86 gminach z największym (ponad 10\%) udziałem mniejszości narodowych (według danych ze spisu w 2002 r.) badanie pełne objęło wszystkich mieszkańców, którzy mieli możliwość zadeklarowania własnej tożsamości narodowej i językowej (na podstawie www.stat.gov.pl). Oznacza to, że w kilkuset gminach zamieszkanych w niewielkim stopniu przez mniejszości narodowe i etniczne nie wszyscy mieszkańcy, w tym przedstawiciele mniejszości, zadeklarowali przynależność narodową. Ponadto taka metoda w dużym stopniu eliminuje możliwość zebrania rzetelnych danych statystycznych dla mniejszości silnie rozproszonych, np. Łemkowie tylko w jednej gminie stanowili ponad 10\% ogółu mieszkańców, a m.in. Czesi, Słowacy, Rosjanie, Żydzi, Ormianie czy Tatarzy w żadnej gminie.

${ }^{37}$ Kryteria przeprowadzania spisów powszechnych omawia m.in. Z. Holzer (1989) i A. Gawryszewski (2005).

38 Pod pytaniem dodano informację ,przez narodowość należy rozumieć przynależność narodową lub etniczną - nie należy jej mylić z obywatelstwem”. 
łemkowską i ukraińską) oraz opcję ,inna”, która z kolei zawierała wykaz aż 177 narodowości, w tym m.in. śląską, kaszubską, mazurską, rusińską, bojkowska, huculską. Jeżeli ktoś nadal nie mógł znaleźć narodowości, która byłaby zgodna z jego poczuciem tożsamości, to istniała możliwość wpisania dowolnej identyfikacji spoza listy.

Zupełnie nowe było natomiast kolejne pytanie, umieszczone po raz pierwszy w polskich spisach ludności pod wpływem sugestii liderów organizacji mniejszości narodowych: „Czy odczuwa Pan(i) przynależność także do innego narodu lub wspólnoty etnicznej?”. Jeżeli „tak”, to do wyboru pojawiała się lista 191 narodowości $(14+177)$, a także istniała możliwość wpisania dowolnej narodowości spoza listy. Umieszczenie tego pytania w formularzu spisowym było odpowiedzią na apele środowisk wywodzących się spośród niepolskich narodowości, by osoby o złożonej, podwójnej tożsamości narodowej miały szanse to wyrazić. W praktyce oznaczało to możliwość zadeklarowania dwóch narodowości.

Liczebność poszczególnych mniejszości narodowych i etnicznych została ustalona na podstawie liczby deklaracji narodowościowych, wyrażonych jako odpowiedź na pierwsze lub drugie ,pytanie etniczne”. W sytuacji, gdy w pierwszym pytaniu osoba zadeklarowała narodowość polską, a równocześnie w drugim pytaniu przynależność do mniejszości narodowej lub etnicznej, została przypisana jej zadeklarowana narodowość niepolska (mniejszościowa), według odpowiedzi na drugie pytanie. Natomiast w sytuacji, gdy osoba zadeklarowała przynależność do dwóch społeczności mniejszościowych, została przypisana jej narodowość zgodnie z odpowiedzią na pierwsze pytanie ${ }^{39}$. Taki sposób zaliczania osób do poszczególnych mniejszości narodowych i etnicznych był z pewnością nowatorski (zwłaszcza zasada nadrzędności deklaracji przynależności do mniejszości nad polską tożsamością narodową), ale jednocześnie zgodny ze stanowiskiem Komisji Wspólnej Rządu i Mniejszości Narodowych i Etnicznych, wyrażonym na konferencji w Lublinie 16 września 2010 r. $^{40}$.

${ }^{39} \mathrm{Na}$ podstawie notatki Departamentu Badań Demograficznych GUS na XXXI posiedzeniu Komisji Wspólnej Rządu i Mniejszości Narodowych i Etnicznych z 22-23 lutego 2012 r. „Zasady opracowania wyników Narodowego Spisu Powszechnego Ludności i Mieszkań $2001 \mathrm{w}$ zakresie mniejszości narodowych i etnicznych oraz języka regionalnego": www.stat.gov.pl.

${ }^{40}$ We wspomnianym stanowisku znalazł się następujący tekst: „W opinii Komisji Wspólnej w przypadku zadeklarowania przynależności do narodowości polskiej i równocześnie przynależności do mniejszości narodowej lub etnicznej, przy ustalaniu liczby osób należących do mniejszości narodowych i etnicznych powinna być wzięta pod uwagę deklaracja przynależności do mniejszości. W przypadku zadeklarowania przy- 
Pytanie o język zostało sformułowane podobnie jak w poprzednim spisie, czyli „Jakim językiem (ami) zazwyczaj posługuje się Pan(i) w domu?”41. Można było zaznaczyć „,wyłącznie polski” lub „polskim i innym(i) niż polski” oraz „wyłącznie innym (i) niż polski”, za każdym razem można było podać dwa języki niepolskie. W przypadku deklaracji języka lub języków niepolskich istniała możliwość ich wyboru z listy 361 języków lub dopisania dowolnego języka spoza tej listy ${ }^{42}$.

W badaniu reprezentacyjnym poza powyższymi pytaniami dodano jeszcze, po raz pierwszy od 1931 r., pytanie o język ojczysty ${ }^{43}$ oraz wyznanie: „Do jakiego wyznania (kościoła lub związku wyznaniowego) Pan(i) należy?", które także nie miało charakteru otwartego. Zamieszczono listę siedmiu Kościołów ${ }^{44}$ oraz opcję ,inne”, zawierającą wykaz 166 wyznań. Istniała także możliwość dopisania wyznania spoza zamieszczonej listy, a także zaznaczenia, iż „nie należy się do żadnego wyznania” lub ,nie chce odpowiadać na to pytanie”. Nie było natomiast możliwości wyboru opcji niewierzący, ateista lub agnostyk ${ }^{45}$.

Struktura narodowościowa i językowa została ostatecznie ustalona na podstawie danych pozyskanych w badaniu reprezentacyjnym (objęło losowo wybrane osoby), w samospisie internetowym oraz $\mathrm{z}$ uwzględnieniem wyników badania pełnego przeprowadzonego wśród wszystkich mieszkańców 86 dobranych celowo gmin, w których (według wyników spisu z 2002 r.) przynależność do mniejszości narodowej lub etnicznej zadeklarowało minimum $10 \%$ mieszkańców (ryc. 44). Z wykorzystaniem tych trzech metod zbierania informacji GUS ustalił liczebność mniejszości narodowych i etnicznych dla całego kraju oraz poszczególnych jednostek administracyjnych ${ }^{46}$.

należności do dwóch różnych mniejszości narodowych lub etnicznych powinna zostać wzięta pod uwagę odpowiedź na pierwsze z pytań." (na podstawie: www.stat.gov.pl).

${ }^{41}$ Tym razem pod pytaniem dodano informację ,język używany w codziennych kontaktach domowych z osobami najbliższymi - nie należy mylić ze znajomością języka obcego".

${ }^{42} \mathrm{Na}$ podstawie: https://nsp2011.spis.gov.pl/nsp.form/pages/ContentPageL1.aspx.

${ }^{43}$ Wraz z informacją ,język, którego nauczył(a) się Pan(i) jako pierwszego we wczesnym dzieciństwie - np. od matki”.

44 Były to w kolejności: Kościół rzymskokatolicki, prawosławny, Świadkowie Jehowy, Kościół Ewangelicko-Augsburski, greckokatolicki, Starokatolicki Mariawitów, zielonoświątkowy.

${ }^{45} \mathrm{Na}$ podstawie: https://nsp2011.spis.gov.pl/nsp.form/long/ContentPageL1.aspx.

${ }^{46} \mathrm{Na}$ podstawie notatki Departamentu Badań Demograficznych GUS na XXXI posiedzeniu Komisji Wspólnej Rządu i Mniejszości Narodowych i Etnicznych z 22-23 lutego 2012 r. ,Zasady opracowania wyników....”: www.stat.gov.pl. 


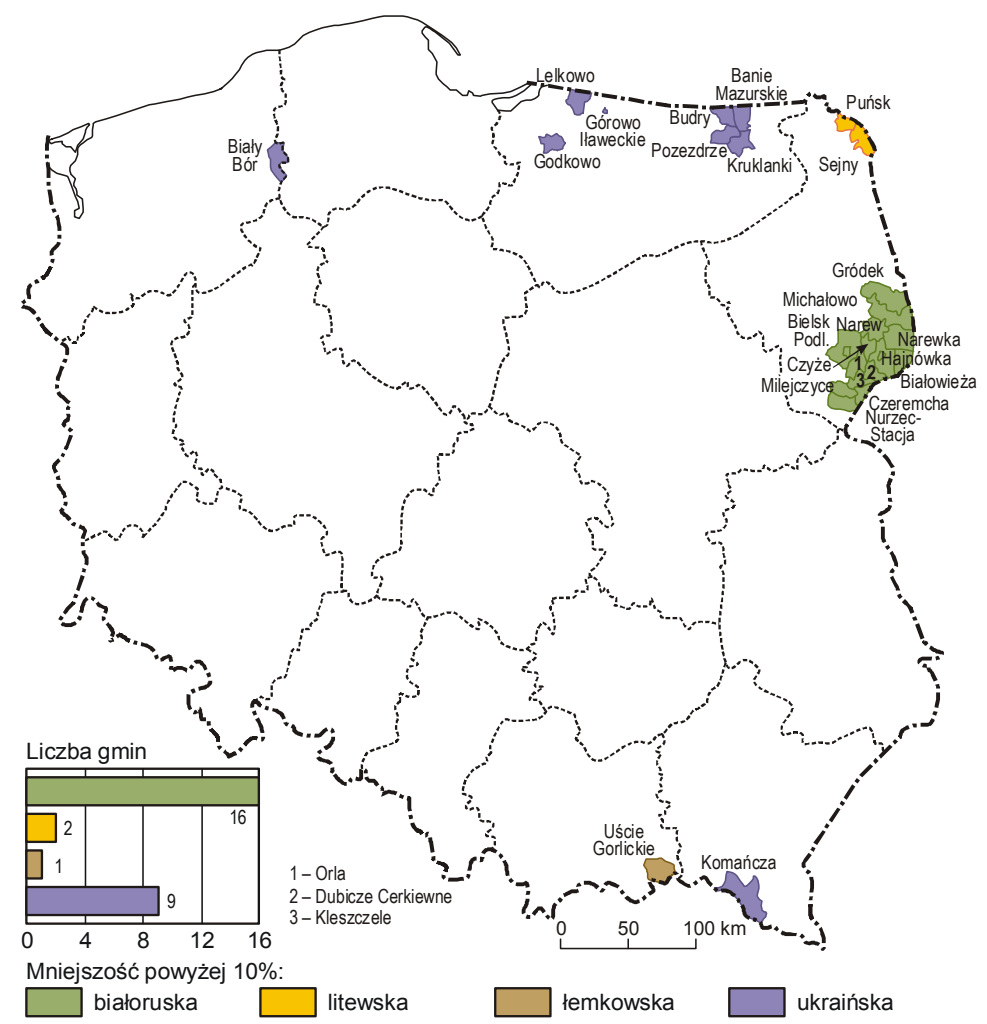

Ryc. 44. Gminy, w których w 2002 r. minimum 10\% mieszkańców zadeklarowało narodowość białoruską, litewską, łemkowską, ukraińską i wszyscy ich mieszkańcy zostali objęci badaniem pełnym podczas spisu w 2011 r. Źródło: opracowanie własne na podstawie danych GUS

Zatem struktura narodowościowa i językowa ludności Polski w 2011 r., odmienna niż podczas spisu z 2002 r., została opracowana głównie na podstawie informacji pozyskanych metodą reprezentacyjną oraz wykonanych obliczeń i szacunków, a nie na podstawie bezpośredniej rozmowy rachmistrza z respondentem podczas spisu o charakterze powszechnym.

Ponadto z powodu braku powszechności spisu oraz nasilonej po akcesji Polski do UE długookresowej emigracji, często całych rodzin, do Europy Zachodniej $^{47}$, dużym utrudnieniem w przedstawieniu struktury narodowościowej i językowej były liczne przypadki braku danych. Zostały one zredukowane przez analizę rozkładu odpowiedzi o przynależność narodową w poszczególnych miej-

${ }^{47} \mathrm{~W}$ niektórych przypadkach może występować ścisły związek między strukturą narodowościową a emigracją, np. w przypadku licznych migracji z Opolszczyzny do Niemiec. 
scowościach i gminach, co - według GUS - umożliwiło uzupełnienie brakujących danych $^{48}$. Oznacza to, że część danych spisu ludności z 2011 r., dotyczących liczebności oraz rozmieszczenia poszczególnych mniejszości narodowych i etnicznych w Polsce, ma charakter wyłącznie szacunkowy. Taki sposób przeprowadzenia spisu, pozyskiwania danych i określania struktury narodowościowej w bardzo istotny sposób ogranicza wartość poznawczą uzyskanych wyników.

W okresie przedspisowym liderzy organizacji i stowarzyszeń narodowościowych zachowywali się zupełnie odmiennie niż dziewięć lat wcześniej. Tym razem aktywnie współpracowali z parlamentem (zwłaszcza Sejmową Komisją Mniejszości Narodowych i Etnicznych) oraz Głównym Urzędem Statystycznym przy ustalaniu metody przeprowadzenia spisu powszechnego w zakresie tematyki etnicznej oraz prowadzili aktywną działalność informacyjną i propagandową wśród własnych narodowości. Zarządy organizacji narodowościowych częściowo wyzbyły się, dominującej dekadę wcześniej, nieufności oraz dostrzegły korzyści dla własnych środowisk, płynące z uzyskania jak najwyższych wyników podczas spisu, choć nadal miały obawy, czy spis zostanie rzetelnie przeprowadzony oraz czy pozwoli uzyskać wiarygodne dane dotyczące liczebności mniejszości narodowych i etnicznych. Na stronach internetowych poszczególnych organizacji umieszczano informacje dotyczące spisu powszechnego, linki do stron GUS, dokładne instrukcje wypełniania internetowych formularzy spisowych, zachęcano do uczestnictwa w spisie i deklarowania niepolskiej narodowości oraz języka, zwłaszcza za pomocą samopisu internetowego.

Niektóre organizacje (np. Związek Ukraińców w Polsce), prawdopodobnie wychodząc z założenia, że osoby o silnie wykształconej ukraińskiej tożsamości narodowej nie będą mieć dylematów podczas wypełniania formularza spisowego, skupiły swą działalność informacyjno-propagandową na - jak to określano „Polakach mających ukraińskie korzenie”, namawiając ich do deklarowania, obok narodowości polskiej, także poczucia przynależności do narodu ukraińskiego. Z kolei Zjednoczenie Łemków, zgodnie ze swym wyraźnym nastawieniem narodowo-ukraińskim, namawiało swoich członków i sympatyków do deklarowania narodowości ukraińskiej oraz jednoczesnego poczucia przynależności do łemkowskiej „wspólnoty etnicznej”. Inaczej posteppowało Stowarzyszenie Łemków, jednoznacznie nawołując do deklarowania narodowości łemkowskiej ${ }^{49}$.

Po zakończeniu spisu, liderzy organizacji narodowościowych zgodnie krytykowali sposób jego przeprowadzenia, zwłaszcza zróżnicowane metody pozy-

\footnotetext{
${ }^{48}$ Na podstawie ,Raportu z wyników NSP 2011” z 26 lipca 2012 r.: www.stat.gov.pl.

${ }^{49} \mathrm{Na}$ podstawie www.zup.ukraina.com.pl, www.lemkounion.republika.pl, www.stowarzyszenielemkow.pl, www.perepys.pl (pobrano w maju 2011 r.).
} 
skiwania danych oraz brak powszechności. Krytycznie wypowiadano się także o współpracy z GUS, natomiast chwalono możliwość wypełnienia formularza za pomocą Internetu, jednocześnie wyrażając obawy, czy GUS należycie wykorzysta dane zgromadzone tą metodą. Najbardziej podzielone opinie (nawet wśród działaczy organizacji tej samej mniejszości) dotyczyły umieszczenia drugiego pytania „etnicznego”, o poczucie „przynależności także do innego narodu”. Część liderów uważała, że jest to zmiana bardzo pozytywna, dzięki niej wyniki będą wyższe, „bardziej autentyczne”, natomiast wśród głosów krytycznych pojawiały się opinie, że może to zaburzyć liczebność osób jednocześnie deklarujących tożsamość ukraińską i łemkowską oraz jest przejawem „kombinowania” i ,życia w rozkroku" ${ }^{50}$.

Spis z 2011 r. wykazał ogółem w Polsce 38512 tys. osób, w tym 36522 tys. (94,83\%) zadeklarowało jednorodną polską tożsamość narodową. W stosunku do 521 tys. osób (1,35\%) nie ustalono przynależności narodowej. W większości dotyczyło to osób nieprzebywających w trakcie spisu w miejscu zamieszkania, w tym przebywających co najmniej od 12 miesięcy za granicą.

Wyłącznie niepolską narodowość zadeklarowało 597 tys. osób (1,55\%), w tym 46 tys. identyfikowało się z dwoma niepolskimi narodowościami. Ogółem z możliwości wyrażenia podwójnej tożsamości skorzystało 917 tys. osób, w tym 871 tys. $(2,26 \%)$ wykazało zarówno polską, jak i inną tożsamość narodowo-etniczną. Łącznie narodowość inną niż polska (w bardzo różnych konfiguracjach) zadeklarowało 1468 tys. osób (3,81\%). Dzięki możliwości wyboru narodowości z zamieszczonego w formularzu obszernego słownika etnonimów lub swobodnego zapisu dowolnej deklaracji tożsamości ogółem zanotowano ponad 200 różnorodnych niepolskich identyfikacji narodowych i etnicznych, regionalnych i lokalnych ${ }^{51}$.

Zdecydowanie mniej zróżnicowana okazała się struktura językowa. Mimo zadeklarowania niepolskiej narodowości przez 1468 tys. osób, posługiwanie się w kontaktach rodzinnych językiem innym niż polski wymieniło już tylko 889 tys. osób (2,31\%), przy czym najczęściej stwierdzano, że jest on używany na przemian z językiem polskim - 729 tys. osób (1,9 \%). Tylko ok. 160 tys. osób

${ }^{50} \mathrm{Na}$ podstawie wywiadów przeprowadzonych przez autora w 2012 r. z działaczami Związku Ukraińców w Polsce, Związku Ukraińców Podlasia, Towarzystwa Ukraińskiego, Stowarzyszenia Łemków, Zjednoczenia Łemków, Stowarzyszenia Młodzieży Łemkowskiej „Czuha”, Białoruskiego Towarzystwa Społeczno-Kulturalnego, Rady Programowej Tygodnika „Niwa”, Białoruskiego Zrzeszenia Studentów, Stowarzyszenia Litwinów w Polsce, Litewskiego Towarzystwa Św. Kazimierza.

${ }^{51}$ Na podstawie „Przynależność narodowo-etniczna ludności - wyniki spisu ludności i mieszkań 2011", notatka informacyjna GUS z 29 stycznia 2013 r.: www.stat.gov.pl. 
( $0,4 \%$ ogółu oraz zaledwie ok. $11 \%$ spośród deklarujących niepolską narodowość) stwierdziło, że rozmawia w domu wyłącznie w jednym lub dwóch językach niepolskich ${ }^{52}$.

Spośród deklaracji narodowościowych zdecydowanie najliczniejsze dotyczyły odrębności etnicznej społeczności regionalnych - Ślązaków i Kaszubów, z tym, że zwłaszcza w przypadku Kaszubów były one wyrażane w drugim pytaniu i w dużym stopniu wiązały się z jednoczesnym odczuwaniem polskiej tożsamości narodowej. Mimo to wyniki spisu wyraźnie wskazują na wzrost poczucia odrębności etnicznej grup regionalnych, nie tylko Ślązaków i Kaszubów. Po raz pierwszy w historii spisów odnotowano deklaracje przynależności regionalnych: kociewską (3 tys.), góralską (3 tys.) oraz wielkopolską (2 tys.).

Narodowość śląska, podobnie jak podczas spisu w 2002 r., była najliczniejszą spośród niepolskich deklaracji tożsamości. Ogółem odnotowano aż 847 tys. identyfikacji śląskich, w tym 436 tys. jako pierwsza deklaracja, 376 tys. jako jedyna narodowość, a 431 tys. wspólnie z deklaracją narodowości polskiej. Były one liczniejsze niż wszystkie pozostałe niepolskie identyfikacje narodowo-etniczne i to w każdej „kategorii”. Pod względem liczebnym Ślązacy całkowicie zdominowali strukturę mniejszości narodowych i etnicznych w Polsce. Jest to potwierdzenie ich dominującej pozycji z poprzedniego spisu, jednak tak imponujący wzrost liczebności (ze 173,2 tys. do 847 tys. osób) w trakcie niecałej dekady był konsekwencją zmian w metodzie przeprowadzania spisu (411 tys. osób zadeklarowało narodowość śląską w drugim pytaniu) i aktywności śląskich organizacji oraz medialnego nagłośnienia i upolitycznienia kwestii narodowości śląskiej.

Coraz liczniejsze deklarowanie narodowości śląskiej nie zmieniło jej statusu prawnego. Nadal nie jest oficjalnie uznaną mniejszością etniczną, a język śląski (którego używanie zadeklarowało podczas spisu ponad 500 tys. osób) nadal nie ma, tak jak język kaszubski (zadeklarowany przez ok. 100 tys. osób), statusu języka regionalnego.

Spośród tzw. mniejszości tradycyjnych najliczniej byli reprezentowani, podobnie jak w poprzednim spisie, Niemcy, Ukraińcy i Białorusini, z tym że mniejszość białoruska i niemiecka odnotowała niewielki spadek liczebności w porównaniu z 2002 r. W przypadku wszystkich pozostałych zbiorowości, z oficjalnym statusem mniejszości narodowych, etnicznych lub posługujących się językiem regionalnym, miał miejsce wzrost liczebności, z tym że bardzo zróżnicowany w zależności od konfiguracji odpowiedzi na pytania „etniczne”. W kilku

\footnotetext{
${ }^{52}$ Na podstawie „Raportu z wyników NSP 2011” z 26.07.2012 r.: www.stat.gov.pl.
} 
przypadkach (Kaszubi, Żydzi, Czesi) był on jednocześnie wyjątkowo silnie związany z polską tożsamością narodową (tab. 22).

Tabela 22. Narodowości posiadające status mniejszości narodowych i etnicznych w Polsce według wyników spisu z 2011 r. (w tys.) ${ }^{a}$

\begin{tabular}{|c|c|c|c|c|c|}
\hline \multirow{3}{*}{ Narodowości } & \multicolumn{5}{|c|}{ Deklarowana narodowość } \\
\hline & \multicolumn{2}{|c|}{ w pierwszym pytaniu } & \multirow[b]{2}{*}{$\begin{array}{l}\text { w drugim } \\
\text { pytaniu }\end{array}$} & & \multirow{2}{*}{$\begin{array}{l}\text { ogółem }^{b} \\
\begin{array}{|c}\text { w tym razem } \\
\text { z narodowościa } \\
\text { polską }\end{array}\end{array}$} \\
\hline & & $\begin{array}{c}\text { w tym jako } \\
\text { jedyna }\end{array}$ & & & \\
\hline \multicolumn{6}{|c|}{ Status mniejszości narodowych } \\
\hline Niemcy & 74,0 & 45,0 & 73,0 & 148,0 & 64,0 \\
\hline Ukraińcy & 38,0 & 28,0 & 13,0 & 51,0 & 21,0 \\
\hline Bialorusini & 36,0 & 30,0 & 10,0 & 47,0 & 16,0 \\
\hline Rosjanie & 8,0 & 5,0 & 5,0 & 13,0 & 7,0 \\
\hline Litwini & 6,0 & 5,0 & 2,0 & 8,0 & 3,0 \\
\hline Żydzi & 2,0 & 2,0 & 5,0 & 8,0 & 5,0 \\
\hline Słowacy & 2,0 & 2,0 & 1,0 & 3,0 & 1,0 \\
\hline Ormianie & 3,0 & 2,0 & 1,0 & 4,0 & 2,0 \\
\hline Czesi & 1,0 & 1,0 & 2,0 & 3,0 & 2,0 \\
\hline \multicolumn{6}{|c|}{ Status mniejszości etnicznych } \\
\hline Romowie & 13,0 & 10,0 & 4,0 & 17,0 & 7,0 \\
\hline Lemkowie & $\mathbf{7 , 0}$ & 6,0 & 3,0 & 11,0 & 4,0 \\
\hline Tatarzy & 1,0 & 1,0 & 1,0 & 2,0 & 1,0 \\
\hline Karaimi & - & - & - & 0,3 & - \\
\hline \multicolumn{6}{|c|}{ Status społeczności posługującej się językiem regionalnym } \\
\hline Kaszubi & 18,0 & 16,0 & 215,0 & 233,0 & 216,0 \\
\hline
\end{tabular}

${ }^{a}$ Dotyczy ogółu osób posiadających i nieposiadających obywatelstwa polskiego.

${ }^{b}$ Kolumna zawiera zestawienie odpowiedzi z dwóch pytań formularza spisowego, dane nie sumują się.

Źródło: opracowanie własne na podstawie „Przynależność narodowo-etniczna ludności - wyniki spisu ludności i mieszkań 2011”, notatka informacyjna GUS z 29 stycznia 2013 r.: www.stat.gov.pl.

Poza mniejszościami wyszczególnionymi w ustawie i przedstawionymi w tabeli 22, na uwagę zasługuje wykazana podczas spisu liczebność narodowości amerykańskiej (12 tys.), angielskiej (10 tys.), włoskiej (9 tys.) i francuskiej (8 tys.). Są to wartości zdecydowanie wyższe niż w poprzednim spisie, zarazem 
lokujące te grupy wśród kilkunastu najliczniejszych niepolskich narodowości zamieszkujących współczesną Rzeczpospolita. Trzeba jednak pamiętać, że ok. $90 \%$ tych deklaracji to podwójna identyfikacja z wskazaną na pierwszym miejscu narodowością polską.

\section{Ukraińcy}

Podczas spisu w 2011 r. narodowość ukraińską zadeklarowało ogółem 51 tys. osób $^{53}$, w tym 38 tys. (75\%), podało ją na pierwszym miejscu, a 13 tys. jako drugą deklarację tożsamości. Z możliwości podwójnej identyfikacji narodowej skorzystało 23 tys. osób utożsamiających się m.in. z narodem ukraińskim, czyli prawie połowa ogółu. W zdecydowanej większości (ponad 90\%) były to osoby deklarujące, obok ukraińskiej, jednocześnie narodowość polską. Natomiast dla 28 tys. osób (55\%) tożsamość ukraińska była jedyną identyfikacją narodową (tab. 22). Ukraińcy stanowią obecnie w Polsce czwartą pod względem liczebnym niepolską grupę ludności po Ślązakach, Kaszubach i Niemcach.

Tabela 23. Liczba osób deklarujących narodowość ukraińską w wybranych województwach według wstępnych wyników spisu z 2011 r. (w tys.) ${ }^{a}$

\begin{tabular}{|c|c|c|c|c|c|}
\hline \multirow{3}{*}{ Województwo } & \multicolumn{5}{|c|}{ Deklarowana narodowość ukraińska } \\
\hline & \multicolumn{2}{|c|}{ w pierwszym pytaniu } & \multirow[b]{2}{*}{$\begin{array}{l}\text { w drugim } \\
\text { pytaniu }\end{array}$} & \multicolumn{2}{|r|}{ ogółem $^{b}$} \\
\hline & & $\begin{array}{l}\text { w tym jako } \\
\text { jedyna }\end{array}$ & & & $\begin{array}{l}\text { w tym razem } \\
\text { z narodowością } \\
\text { polską }\end{array}$ \\
\hline $\begin{array}{l}\text { Warmińsko- } \\
\text {-mazurskie }\end{array}$ & 10,0 & 9,0 & 2,0 & 13,0 & 4,0 \\
\hline Mazowieckie & 5,0 & 3,0 & 1,0 & 6,0 & 3,0 \\
\hline Zachodniopomorskie & 4,0 & 3,0 & 1,0 & 5,0 & 2,0 \\
\hline Pomorskie & 3,0 & 2,0 & 1,0 & 4,0 & 2,0 \\
\hline Podkarpackie & 3,0 & 3,0 & 1,0 & 4,0 & 1,0 \\
\hline Dolnośląskie & 2,0 & 2,0 & 1,0 & 3,0 & 2,0 \\
\hline Podlaskie & 1,4 & 1,0 & 0,9 & 2,2 & 0,8 \\
\hline Ogółem w Polsce & 38,0 & 28,0 & 13,0 & 51,0 & 21,0 \\
\hline
\end{tabular}

${ }^{a}$ Dotyczy ogółu osób posiadających i nieposiadających obywatelstwa polskiego.

${ }^{b}$ Kolumna zawiera zestawienie odpowiedzi z dwóch pytań formularza spisowego, dane nie sumują się.

Źródło: opracowanie własne na podstawie danych WUS i GUS.

${ }^{53}$ Wszystkie opublikowane przez GUS do końca stycznia 2013 r. dane dotyczące struktury narodowościowej w świetle wyników spisu powszechnego z 2011 r. dotyczyły ogółu osób, bez rozróżnienia na nieposiadające lub posiadające obywatelstwo polskie. 
Mimo braku ostatecznych i dokładnych danych statystycznych ${ }^{54}$ można stwierdzić, że rozmieszczenie mniejszości ukraińskiej nie uległo zasadniczym zmianom w ciągu ostatniej dekady. Głównymi skupiskami Ukraińców pozostały nadal województwa północnej Polski: warmińsko-mazurskie, zachodniopomorskie i pomorskie. Na te trzy województwa przypadało ogółem $43 \%$ osób deklarujących narodowość ukraińską. Do tych, już od kilkudziesięciu lat, tradycyjnych regionów relatywnej koncentracji mniejszości ukraińskiej dołączyło województwo mazowieckie (tab. 23). Z dużym prawdopodobieństwem można przypuszczać, że z 6 tys. Ukraińców na Mazowszu zdecydowana większość zamieszkuje w Warszawie, a koncentracja ta jest konsekwencją migracji do stolicy w poszukiwaniu zarówno pracy, jak i lepszych warunków życia. Częściowo może być to także efekt imigracji z Ukrainy. Na początku 2013 r. nie można było tego jednoznacznie rozstrzygnąć z braku pełnych danych statystycznych.

\section{Lemkowie}

Narodowość łemkowską w 2011 r. zadeklarowało ogółem 11 tys. osób, w tym 7 tys. (64\%) podało ją na miejscu pierwszym, a 3 tys. wybrało jako drugą deklarację tożsamości. Z możliwości podwójnej identyfikacji narodowej skorzystało 4 tys. osób utożsamiających się m.in. z narodem łemkowskim. Prawie wszyscy spośród nich zadeklarowali, obok łemkowskiej, narodowość polską, w zdecydowanej większości na miejscu pierwszym. Wbrew wcześniejszym przypuszczeniom, liczba wspólnych deklaracji łemkowsko-ukraińskich lub ukraińsko-łemkowskich jest marginalna, jednak brak pełnych danych statystycznych uniemożliwia obecnie dokładne określenie stopnia dualizmu narodowego łemkowsko-ukraińskiego. Dla większości Łemków (55\%) własna tożsamość jest jedyną identyfikacją narodową (tab. 22). Łemkowie pod względem liczebnym stanowią obecnie, podobnie jak w 2002 r., drugą po Romach mniejszość etniczną w Polsce.

${ }^{54}$ Do końca stycznia 2013 r., czyli ponad półtora roku po zakończeniu spisu, Główny Urząd Statystyczny opublikował wyłącznie ogólne wyniki spisu dotyczące kwestii narodowościowych dla całego obszaru Polski, a niektóre Wojewódzkie Urzędy Statystyczne upubliczniły liczebność zaledwie dwóch-trzech najliczniejszych narodowości w poszczególnych województwach. Nadal brak jest pełnych danych dotyczących struktury narodowościowej według województw (zgodnie z zapowiedziami GUS miały zostać opublikowane w listopadzie 2012 r.) oraz szczegółowych danych na poziomie powiatów i gmin. 
Tabela 24. Liczba osób deklarujących narodowość łemkowską w wybranych województwach według wstępnych wyników spisu z 2011 r. (w tys.) ${ }^{a}$

\begin{tabular}{|c|c|c|c|c|c|}
\hline \multirow{3}{*}{ Województwo } & \multicolumn{5}{|c|}{ Deklarowana narodowość łemkowska } \\
\hline & \multicolumn{2}{|c|}{ w pierwszym pytaniu } & \multirow[b]{2}{*}{$\begin{array}{l}\text { w drugim } \\
\text { pytaniu }\end{array}$} & \multicolumn{2}{|r|}{ ogółem $^{b}$} \\
\hline & & $\begin{array}{l}\text { w tym jako } \\
\text { jedyna }\end{array}$ & & & $\begin{array}{l}\text { w tym razem } \\
\text { z narodowością } \\
\text { polską }\end{array}$ \\
\hline Dolnośląskie & 4,0 & 3,0 & 1,0 & 5,0 & 2,0 \\
\hline Małopolskie & 1,5 & 1,5 & 0,5 & 2,0 & 0,5 \\
\hline Ogółem w Polsce & 7,0 & 6,0 & 3,0 & 11,0 & 4,0 \\
\hline
\end{tabular}

${ }^{a}$ Dotyczy ogółu osób posiadających i nieposiadających obywatelstwa polskiego.

${ }^{b}$ Kolumna zawiera zestawienie odpowiedzi z dwóch pytań formularza spisowego, dane nie sumują się.

Źródło: opracowanie własne na podstawie danych WUS i GUS.

Głównym skupiskiem Łemków jest województwo dolnośląskie, gdzie już od kilkudziesięciu lat zamieszkuje około połowa wszystkich członków mniejszości łemkowskiej. W województwie małopolskim natomiast skupiają się w części południowo-wschodniej, czyli historycznej zachodniej Łemkowszczyźnie. Łemkowie zamieszkujący swoją dawną etniczną ojczyznę cechują się wysokim poczuciem odrębności narodowej. Dla 75\% spośród nich tożsamość łemkowska była jedyną identyfikacją narodową (tab. 24).

\section{Bialorusini}

Podczas ostatniego spisu narodowość białoruską zadeklarowało ogółem 47 tys. osób, w tym 36 tys. (77\%) podało ją na pierwszym miejscu, a 10 tys. jako drugą deklarację tożsamości. Z możliwości podwójnej identyfikacji narodowej (wraz z białoruską) skorzystało relatywnie niedużo, bo 17 tys. osób (36\% ogółu deklarujących tożsamość białoruską). Jest to zaskakująco mało, zważywszy na liczne opinie i wyniki badań świadczące o powszechności występowania wśród mniejszości białoruskiej złożonych, podwójnych tożsamości narodowych (m.in. Mironowicz 1992b, 2010b, Sadowski 1995a, b, 1997, Barwiński 2001a, c, 2004a, 2005a, c). Udział podwójnych deklaracji narodowych wśród Białorusinów był mniejszy niż w przypadku Ukraińców czy Łemków. W zdecydowanej większości (ok. 94\%) osoby deklarujące, obok białoruskiej, równocześnie inną tożsamość podały narodowość polską, częściej na miejscu pierwszym. Natomiast dla relatywnie dużej grupy (30 tys. osób, 64\% ogółu) tożsamość białoruska była jedyną identyfikacją narodową (tab. 22). Białorusini stanowią obecnie 
w Polsce piątą pod względem liczebnym niepolską grupę ludności po Ślązakach, Kaszubach, Niemcach i Ukraińcach.

Tabela 25. Liczba osób deklarujących narodowość białoruską w wybranych województwach według wstępnych wyników spisu z 2011 r. (w tys.) ${ }^{a}$

\begin{tabular}{|c|c|c|c|c|c|}
\hline \multirow{3}{*}{ Województwo } & \multicolumn{5}{|c|}{ Deklarowana narodowość białoruska } \\
\hline & \multicolumn{2}{|c|}{ w pierwszym pytaniu } & \multirow[b]{2}{*}{$\begin{array}{c}\text { w drugim } \\
\text { pytaniu }\end{array}$} & \multicolumn{2}{|c|}{ ogółem $^{b}$} \\
\hline & & $\begin{array}{c}\text { w tym jako } \\
\text { jedyna }\end{array}$ & & & $\begin{array}{c}\text { w tym razem } \\
\text { z narodowością } \\
\text { polską }\end{array}$ \\
\hline Podlaskie & 30,9 & 26,7 & 7,4 & 38,3 & 11,0 \\
\hline Mazowieckie & 2,0 & 1,0 & 1,0 & 2,0 & 1.0 \\
\hline Ogółem w Polsce & 36,0 & 30,0 & 10,0 & 47,0 & 16,0 \\
\hline
\end{tabular}

${ }^{a}$ Dotyczy ogółu osób posiadających i nieposiadających obywatelstwa polskiego.

${ }^{b}$ Kolumna zawiera zestawienie odpowiedzi z dwóch pytań formularza spisowego, dane nie sumują się.

Źródło: opracowanie własne na podstawie danych WUS i GUS.

Mniejszość białoruska tradycyjnie koncentruje się w województwie podlaskim. Mieszka tam prawie 82\% ogółu Białorusinów. Poza północno-wschodnim pograniczem Białorusini są coraz liczniej obecni na Mazowszu. Można przypuszczać, że, podobnie jak w przypadku Ukraińców, jest to konsekwencją nasilających się migracji z Podlasia do Warszawy lub imigracji z Białorusi (tab. 25).

\section{Litwini}

Podczas spisu w 2011 r. narodowość litewską zadeklarowało ogółem 8 tys. osób, w tym 6 tys. (75\%) podało ją na pierwszym miejscu, a 2 tys. jako drugą deklarację tożsamości. Z możliwości podwójnej identyfikacji narodowej skorzystało 3 tys. osób utożsamiających się m.in. z narodem litewskim, czyli prawie $40 \%$ ogółu. W zdecydowanej większości były to osoby deklarujące obok litewskiej, jednocześnie narodowość polska, częściej na miejscu pierwszym. Natomiast dla 5 tys. osób (ponad 60\%) tożsamość litewska była jedyną identyfikacją narodową (tab. 22). Litwini stanowią obecnie w Polsce nieliczna, dopiero dwunastą pod względem liczebnym niepolską grupę ludności, po Ślązakach, Kaszubach, Niemcach, Ukraińcach, Białorusinach, Romach, Rosjanach, Amerykanach, Łemkach, Anglikach i Włochach.

Województwo podlaskie jest regionem nadal skupiającym większość Litwinów, jednak wstępne wyniki spisu pokazuja, że koncentracja mniejszości litewskiej zmniejsza się (tab. 26). 
Tabela 26. Liczba osób deklarujących narodowość litewską w wybranych województwach według wstępnych wyników spisu z 2011 r. (w tys.) ${ }^{a}$

\begin{tabular}{|c|c|c|c|c|c|}
\hline \multirow{3}{*}{ Województwo } & \multicolumn{5}{|c|}{ Deklarowana narodowość litewska } \\
\hline & \multicolumn{2}{|c|}{ w pierwszym pytaniu } & \multirow[b]{2}{*}{$\begin{array}{l}\text { w drugim } \\
\text { pytaniu }\end{array}$} & \multicolumn{2}{|r|}{ ogółem $^{b}$} \\
\hline & & $\begin{array}{l}\text { w tym jako } \\
\text { jedyna }\end{array}$ & & & $\begin{array}{l}\text { w tym razem } \\
\text { z narodowością } \\
\text { polską }\end{array}$ \\
\hline Podlaskie & 4,3 & 3,9 & 0,4 & 4,7 & 0,8 \\
\hline Ogółem w Polsce & 6,0 & 5,0 & 2,0 & 8,0 & 3,0 \\
\hline
\end{tabular}

${ }^{a}$ Dotyczy ogółu osób posiadających i nieposiadających obywatelstwa polskiego.

${ }^{b}$ Kolumna zawiera zestawienie odpowiedzi z dwóch pytań formularza spisowego, dane nie sumują się.

Źródło: opracowanie własne na podstawie danych WUS i GUS.

Na województwo podlaskie przypada obecnie już tylko niecałe $60 \%$ ogółu Litwinów, co jak na specyfikę tej mniejszości jest wyraźną zmianą. Główną przyczyną są prawdopodobnie migracje z peryferyjnych, północno-wschodnich rubieży Polski do większych miast, zwłaszcza Warszawy, Gdańska, Olsztyna. Jednak bez dokładniejszych danych nie można tego obecnie jednoznacznie stwierdzić. Dzięki rozszerzeniu Unii Europejskiej możliwa jest także bardzo ułatwiona emigracja części Litwinów z Suwalszczyzny na Litwę.

\subsection{Analiza porównawcza wyników spisów powszechnych z początku XXI wieku}

Wyniki dotyczące liczebności mniejszości narodowych i etnicznych uzyskane podczas spisu w 2011 r. bardzo istotnie różnią się od danych sprzed dekady. Zdecydowanie wzrosła zarówno liczba deklaracji niepolskiej tożsamości narodowej (ponadtrzykrotnie, z 471,5 tys. do 1468 tys.), jak i liczba deklarowanych grup narodowych, etnicznych i regionalnych (dwukrotnie, ze 109 do ponad 200). Zdecydowanie najsilniejsza była dynamika wzrostu liczebności wśród społeczności etniczno-regionalnych, w przypadku Ślązaków ze 173,2 tys. do ogółem 847 tys. osób, natomiast wśród Kaszubów z zaledwie 5,1 tys. do 233 tys. osób. Ponadto, co jest dużym novum polskich spisów ludności, kilka tysięcy osób zadeklarowało także, wraz z narodowością polską, narodowość kociewską, góralską czy wielkopolską. Wśród tzw. mniejszości tradycyjnych wzrost liczebności był zdecydowanie mniejszy, mimo to wyraźny, relatywnie największy w przy- 
padku Żydów, Karaimów, Tatarów, Ormian i Rosjan. Z omawianych mniejszości największy wzrost liczebności miał miejsce w przypadku Łemków oraz Ukraińców. Tylko w przypadku dwóch spośród mniejszości wyszczególnionych w ustawie (niemieckiej i białoruskiej) odnotowano niewielki spadek liczebności (tab. 27).

Tak istotne różnice ilościowe dotyczące struktury narodowościowej między dwoma spisami, przeprowadzonymi w odstępie zaledwie dziewięciu lat na takim samym obszarze, w zbliżonych uwarunkowaniach polityczno-prawnych, przy braku silnych ruchów imigracyjnych, nie mogły być spowodowane wyłącznie naturalną ewolucją poczucia tożsamości narodowej wśród grup mniejszościowych, a tym bardziej procesami demograficznymi. Do głównych przyczyn można zaliczyć czynniki organizacyjne, w mniejszym stopniu także społeczno-polityczne:

- całkowicie odmienną metodę przeprowadzenia spisu w 2011 r., przez co należy rozumieć brak powszechności, losowy dobór części gospodarstw objętych spisem, zróżnicowany i nowy sposób pozyskiwania informacji (w tym za pomocą samospisu internetowego), zastosowanie dwóch różnych formularzy spisowych, zamieszczenie w formularzu spisowym wykazu głównych narodowości, możliwość deklaracji podwójnej tożsamości narodowej, nowatorski sposób obliczania struktury narodowościowej oraz szacowanie części wyników;

- upolitycznienie i medialne nagłośnienie sytuacji niektórych mniejszości (zwłaszcza Ślązaków);

- zmianę postaw organizacji mniejszości narodowych, które tym razem aktywnie propagowały udział w spisie oraz deklarowanie niepolskiej tożsamości narodowej;

- mniejsze obawy przed deklarowaniem niepolskiej tożsamości narodowej (co było jednym z powodów niewielkiej liczebności mniejszości narodowych w spisie w 2002 r.), brak negatywnych konsekwencji w okresie międzyspisowym ze strony władz i administracji spowodował większe zaufanie do państwa wśród środowisk mniejszości narodowych;

- dostrzeganie przez przedstawicieli mniejszości narodowych i etnicznych korzyści z dużej liczebności własnych społeczności, głównie w kontekście zapisów Ustawy o mniejszościach narodowych, etnicznych i języku regionalnym;

- odmiennie kształtujące się przemiany tożsamości narodowej poszczególnych mniejszości wywołane zróżnicowanymi procesami demograficznymi, społecznymi i edukacyjnymi przyczyniające się do zwiększenia poczucia odrębności i tożsamości lub do intensyfikacji procesów asymilacji.

Analiza wyników obu spisów pozwala na stwierdzenie, że tak znaczny wzrost liczebności niepolskich deklaracji narodowych w 2011 r. był w głównej 
mierze spowodowany odmienną metodą przeprowadzenia spisu, a zwłaszcza możliwością zadeklarowania podwójnej identyfikacji narodowej oraz zaliczaniu do mniejszości narodowej osób deklarujących tożsamość „mniejszościową” na drugim miejscu, razem z polską tożsamością narodową. Osoba deklarująca w pierwszym pytaniu narodowość polską oraz jednocześnie w drugim pytaniu np. „odczucie przynależności do narodu ukraińskiego” została przez GUS policzona jako Ukrainiec.

Taki sposób obliczania struktury narodowościowej okazał się kluczowy dla ponadtrzykrotnego wzrostu liczebności mniejszości narodowych i etnicznych w Polsce w latach 2002-2011. Z możliwości wskazania podwójnej przynależności narodowej skorzystało aż 917 tys. osób ${ }^{55}$, w tym zdecydowana większość (871 tys. osób) w ramach „podwójnej tożsamości” zadeklarowała narodowość polską, w znakomitej większości (prawie 800 tys.) na miejscu pierwszym. Wszystkie te osoby (bez względu na to, na którym miejscu umieściły narodowość polską) zostały zaliczone do mniejszości narodowych lub etnicznych, co nie zawsze musiało być zgodne z ich intencjami.

Kwestia ewentualnego wzrostu poczucia tożsamości narodowej wśród zbiorowości niepolskich, zwłaszcza tzw. mniejszości tradycyjnych, miała znaczenie drugorzędne. Porównując wyniki spisu z 2002 r. oraz deklarację niepolskiej narodowości w pierwszym pytaniu spisu z 2011 r., można wręcz zauważyć, że w ciagu ostatniej dekady, w przypadku najliczniejszych mniejszości (niemieckiej i białoruskiej) ma miejsce spadek liczebności spowodowany dalszą asymilacją do polskości (w przypadku Białorusinów) lub prawdopodobnym przyjmowaniem - obok polskiej - także identyfikacji śląskiej (w przypadku Niemców z Opolszczyzny i Górnego Śląska). Natomiast wśród Litwinów, Słowaków, Czechów i Romów widać stagnację liczebności, a wzrost w przypadku Żydów, Ukraińców, Łemków i Rosjan. Jednak relatywnie istotny wzrost liczebności dotyczący „pierwszej deklaracji” ma miejsce głównie wśród Ormian i może być konsekwencją imigracji z Armenii ${ }^{56}$ (tab. 27).

55 Dla porównania, podczas tego samego spisu jednorodną niepolską tożsamość narodową zadeklarowało 551 tys. osób (w tym zdecydowanie ponad połowa, bo aż 376 tys. tego typu deklaracji dotyczyło Ślązaków), a podczas spisu w 2002 r. narodowość niepolską zadeklarowało ogółem 471,5 tys. osób.

${ }^{56}$ Bez danych dotyczących obywatelstwa wśród przedstawicieli poszczególnych niepolskich narodowości nie można określić ewentualnego wpływu imigracji na wzrost poszczególnych grup narodowościowych, który, zwłaszcza w przypadku bardzo nielicznych zbiorowości, możne być istotny. 
Tabela 27. Narodowości posiadające status mniejszości narodowych i etnicznych w Polsce ogółem oraz według pierwszej deklaracji tożsamości narodowej - porównanie wyników spisu powszechnego z 2002 r. oraz 2011 r. (w tys.) ${ }^{a}$

\begin{tabular}{|c|c|c|c|c|}
\hline \multirow{3}{*}{ Narodowości } & \multicolumn{2}{|c|}{ Liczebność ogółem } & \multicolumn{2}{|c|}{ Jako pierwsza deklaracja } \\
\hline & \multicolumn{4}{|c|}{ Rok } \\
\hline & 2002 & 2011 & $2002^{b}$ & 2011 \\
\hline \multicolumn{5}{|c|}{ Status mniejszości narodowych } \\
\hline Niemcy & 152,9 & 148,0 & 152,9 & 74,0 \\
\hline Białorusini & 48,7 & 47,0 & 48,7 & 36,0 \\
\hline Ukraińcy & 31,0 & 51,0 & 31,0 & 38,0 \\
\hline Rosjanie & 6,1 & 13,0 & 6,1 & 8,0 \\
\hline Litwini & 5,8 & 8,0 & 5,8 & 6,0 \\
\hline Słowacy & 2,0 & 3,0 & 2,0 & 2,0 \\
\hline$\dot{Z} y d z i$ & 1,1 & 8,0 & 1,1 & 2,0 \\
\hline Ormianie & 1,1 & 4,0 & 1,1 & 3,0 \\
\hline Czesi & 0,8 & 3,0 & 0,8 & 1,0 \\
\hline \multicolumn{5}{|c|}{ Status mniejszości etnicznych } \\
\hline Romowie & 12,9 & 17,0 & 12,9 & 13,0 \\
\hline Lemkowie & 5,9 & 11,0 & 5,9 & 7,0 \\
\hline Tatarzy & 0,5 & 2,0 & 0,5 & 1,0 \\
\hline Karaimi & 0,04 & 0,3 & 0,04 & - \\
\hline \multicolumn{5}{|c|}{ Status społeczności posługującej się językiem regionalnym } \\
\hline Kaszubi & 5,1 & 233,0 & 5,1 & 18,0 \\
\hline
\end{tabular}

a Dotyczy ogółu osób posiadających i nieposiadających obywatelstwa polskiego.

b Podczas spisu w 2002 r. istniała tylko taka możliwość.

Źródło: opracowanie własne na podstawie danych GUS.

Tak jak w przypadku spisu z 2002 r. uważano, że przyjęta - bardzo jednoznaczna i bezpośrednia - metoda pozyskiwania danych statystycznych (obok obawy części mniejszości przed deklarowaniem niepolskiej tożsamości narodowej) zaniżyła jego wyniki (Babiński 2004b, Barwiński 2006a, 2009a, Chałupczak 2006), tak po opublikowaniu wstępnych rezultatów spisu z 2011 r. można przypuszczać, że tym razem bardzo zróżnicowana i liberalna metoda przeprowadzenia spisu oraz sformułowania pytań dotyczących narodowości, a zwłaszcza obliczania (a raczej szacowania) struktury narodowościowej, istotnie zawyżyła jego wyniki. Oznacza to, że dla liczbowego określenia struktury narodowościo- 
wej Polski w pierwszej dekadzie XXI w. większe znaczenie miały zastosowane podczas dwóch spisów ludności zróżnicowane metody statystyczne niż subiektywne poczucie tożsamości narodowej poszczególnych obywateli.

\section{Ukraińcy}

Podczas spisu w 2011 r. narodowość ukraińską zadeklarowało zdecydowanie więcej osób niż w 2002 r. Dotyczyło to tożsamości ukraińskiej deklarowanej na miejscu pierwszym - wzrost z 31 tys. do 38 tys. i ogólnej liczby identyfikacji ukraińskich, niezależnie od ich kolejności i współwystępowania z innymi (wzrost do 51 tys.). Ogólna liczebność mniejszości ukraińskiej w trakcie niespełna dekady wzrosła o prawie $65 \%$ (tab. 27). Głównymi przyczynami są odmienne metody przeprowadzenia obu spisów i szacowania liczebności poszczególnych narodowości, bardzo duża aktywność ukraińskich organizacji, mediów i wolontariuszy w okresie przedspisowym oraz mniejsze niż dekadę wcześniej obawy przed deklarowaniem tożsamości ukraińskiej.

Interesującym zjawiskiem jest wzrost, w porównaniu ze spisem z 2002 r., poczucia ukraińskiej tożsamości narodowej wśród mieszkańców Podlasia (z 1,4 tys. do 2,2 tys.) (tab. 28). Potwierdza to tezę o postępującej, stopniowej rerutenizacji części prawosławnej ludności Białostocczyzny (Barwiński 2004a).

Pod względem rozmieszczenia najistotniejszą zmianą jest bardzo wyraźny wzrost liczby deklaracji narodowości ukraińskiej w województwie mazowieckim (z 1,3 tys. do 6 tys.) (tab. 28). Jest on prawdopodobnie związany z migracjami do Warszawy lub z pozostaniem w tym mieście po ukończeniu studiów młodego, wykształconego pokolenia, świadomego swej ukraińskiej tożsamości i odrębności narodowej. Może o tym świadczyć bardzo wysoki udział na Mazowszu osób deklarujących narodowość ukraińską na pierwszym miejscu (83\%), przy średniej wynoszącej 75\% (tab. 28). Jednak duża liczba Ukraińców na Mazowszu nie musi dotyczyć członków ukraińskiej mniejszości narodowej w Polsce, może być konsekwencją napływu imigrantów z Ukrainy.

Podobnie jak podczas spisu w 2002 r., obszarem największej koncentracji mniejszości ukraińskiej są trzy województwa północnej Polski (tab. 28). Jednak według wyników poprzedniego spisu, na województwa warmińsko-mazurskie, zachodniopomorskie i pomorskie przypadało 68\%, a w 2011 r. już tylko 43\% ogółu deklaracji narodowości ukraińskiej. Jeszcze bardziej zmniejszył się udział samego województwa warmińsko-mazurskiego (z 44\% do 25,5\% ogólnej liczby Ukraińców w Polsce). Świadczy to o wyraźnie malejącej - i tak wcześniej niewielkiej - koncentracji tej zbiorowości i jej postępującej atomizacji terytorialnej oraz istotnym wzroście deklaracji narodowości ukraińskiej w regionach, w których do tej pory była ona marginalna (zwłaszcza na Mazowszu). 
Tabela 28. Ukraińcy, Łemkowie, Białorusini i Litwini w wybranych województwach - porównanie wyników spisu powszechnego

z 2002 r. oraz 2011 r. (w tys.) $)^{a}$

\begin{tabular}{|c|c|c|c|c|}
\hline \multirow{3}{*}{ Województwo } & \multicolumn{2}{|c|}{ Liczebność ogółem } & \multicolumn{2}{|c|}{ Jako pierwsza deklaracja } \\
\hline & \multicolumn{4}{|c|}{ Rok } \\
\hline & 2002 & 2011 & $2002^{b}$ & 2011 \\
\hline \multicolumn{5}{|c|}{ Ukraińcy } \\
\hline Warmińsko-mazurskie & 12,0 & 13,0 & 12,0 & 10,0 \\
\hline Zachodniopomorskie & 4,0 & 5,0 & 4,0 & 4,0 \\
\hline Podkarpackie & 3,3 & 4,0 & 3,3 & 3,0 \\
\hline Pomorskie & 3,0 & 4,0 & 3,0 & 3,0 \\
\hline Dolnośląskie & 1,9 & 3,0 & 1,9 & 2,0 \\
\hline Podlaskie & 1,4 & 2,2 & 1,4 & 1,4 \\
\hline Mazowieckie & 1,3 & 6,0 & 1,3 & 5,0 \\
\hline Ogółem w Polsce & 31,0 & 51,0 & 31,0 & 38,0 \\
\hline \multicolumn{5}{|c|}{ Łemkowie } \\
\hline Dolnośląskie & 3,0 & 5,0 & 3,0 & 4,0 \\
\hline Małopolskie & 1,6 & 2,0 & 1,6 & 1,5 \\
\hline Ogółem w Polsce & 5,9 & 11,0 & 5,9 & 7,0 \\
\hline \multicolumn{5}{|c|}{ Białorusini } \\
\hline Podlaskie & 46,4 & 38,3 & 46,4 & 30,9 \\
\hline Mazowieckie & 0,8 & 2,0 & 0,8 & 2,0 \\
\hline Ogółem w Polsce & 48,7 & 47,0 & 48,7 & 36,0 \\
\hline \multicolumn{5}{|c|}{ Litwini } \\
\hline Podlaskie & 5,2 & 4,7 & 5,2 & 4,3 \\
\hline Ogółem w Polsce & 5,8 & 8,0 & 5,8 & 6,0 \\
\hline
\end{tabular}

a Dotyczy ogółu osób posiadających i nieposiadających obywatelstwa polskiego.

b Podczas spisu w 2002 r. istniała tylko taka możliwość.

Źródło: opracowanie własne na podstawie danych GUS oraz WUS.

\section{Lemkowie}

W przypadku Łemków, podobnie jak Ukraińców, podczas spisu w 2011 r. wyraźnie wzrosła liczba deklaracji odrębności narodowej w porównaniu z wynikami z 2002 r. Dotyczyło to zarówno tożsamości łemkowskiej deklarowanej na miejscu pierwszym (wzrost z 5,9 tys. do 7 tys. osób), jak i ogólnej liczby identyfikacji łemkowskich, niezależnie od ich kolejności i współwystępowania 
z innymi (wzrost do 11 tys.). Liczba osób utożsamiających się z narodowością łemkowską podczas zaledwie dziewięciu lat wzrosła o ponad 85\%, czyli jeszcze wyraźniej niż w przypadku mniejszości ukraińskiej (tab. 27). Główne przyczyny są prawdopodobnie tożsame z podanymi powyżej uwarunkowaniami dynamicznego wzrostu identyfikacji ukraińskich.

Podobnie jak w 2002 r., największym skupiskiem Łemków nadal jest województwo dolnośląskie, na które przypada ok. 45\% ogółu deklaracji narodowości łemkowskiej (w 2002 r. 52,6\%), w tym prawie 60\% deklaracji na miejscu pierwszym (tab. 28).

\section{Białorusini}

Wprowadzenie możliwości deklaracji podwójnej identyfikacji narodowej, która według badań socjologicznych i geograficznych (Mironowicz 1992b, 2010b, Sadowski 1995a, b, 1997, Barwiński 2001a, c, 2004a, 2005a, c) powszechnie występuje wśród prawosławnej ludności Podlasia, wbrew oczekiwaniom nie spowodowało wzrostu liczebności narodowości białoruskiej. Wręcz przeciwnie, odnotowano jej zmniejszenie w porównaniu ze spisem z 2002 r., licząc także podwójne identyfikacje deklarowane wraz z narodowością polską (spadek z 48,7 tys. do 47 tys., a w przypadku wyłącznie ,pierwszej deklaracji” spadek z 48,7 tys. do zaledwie 36 tys.). Zatem zmiana zasad szacowania liczebności mniejszości białoruskiej nie spowodowała jej wzrostu (tab. 27). Natomiast gdyby nie ta zmiana, można przypuszczać, że odnotowano by wyraźny, ok. 30\% spadek liczby osób deklarujących narodowość białoruską.

Malejąca liczebność mniejszości białoruskiej w spisach powszechnych jest spowodowana m.in. stopniowalną identyfikacją Polak-prawosławny oraz ukrywaniem własnej tożsamości poprzez deklarowanie narodowości polskiej. Jest też odzwierciedleniem dynamiki procesów asymilacji narodowej wśród prawosławnych mieszkańców Podlasia oraz konsekwencją coraz większej mobilności tej zbiorowości. Wyludnianie białoruskich ,etnicznych wiosek” w południowo-wschodniej części Podlasia, migracje do dużych miast Podlasia, Mazowsza, Lubelszczyzny, Pomorza czy Śląska intensyfikują procesy asymilacji. Dodatkowo na spadek liczebności Białorusinów mogła także mieć wpływ emigracja do państw Zachodniej Europy nasilona po akcesji Polski do UE.

$\mathrm{Na}$ Podlasiu, które pozostało zdecydowanie najliczniejszym skupiskiem mniejszości białoruskiej, czynnikiem najsilniej jednoczącym, niepoddającym się asymilacji i zarazem zdecydowanie wyróżniającym osoby o wschodnim pochodzeniu etnicznym jest wyznanie prawosławne. Poczucie identyfikacji religijnej jest często dużo silniejsze niż niepolskiej tożsamości narodowej. Według F. Plita (2008), wiele osób, nie chcąc angażować się w podlaski dyskurs „Białorusin czy 
Ukrainiec", wybiera przynależność przede wszystkim do wspólnoty prawosławnej. Staje się ona wyznacznikiem przynależności etniczno-kulturowej, podobnie jak w dawnej Jugosławii istniała nie tylko prawnie, ale i de facto, narodowość Muzułmanie.

Z pewnością za wcześnie jest mówić o funkcjonowaniu na Podlasiu narodu prawosławnego, co nie zmienia faktu, że głównym czynnikiem różnicującym mieszkańców Białostocczyzny jest przynależność wyznaniowa. Identyfikacja religijna (prawosławno-katolicka) wyraźnie dominuje nad narodową (polsko-białoruską czy polsko-ukraińską). Zasadniczy podział kulturowy, społeczny, polityczny biegnie wzdłuż linii katolicy-prawosławni, a nie Polacy-Białorusini, Polacy-Ukraińcy czy Białorusini-Ukraińcy (Barwiński 2004a). Jest to potwierdzeniem, w skali regionalnej, zachodzących na świecie przekształceń społeczno-kulturowych. Procesom globalizacji i unifikacji polityczno-gospodarczej Europy i świata towarzyszy jednocześnie narastająca świadomość różnic cywilizacyjnych, zwłaszcza dotyczących kwestii religijnych. Podział ten jest niewątpliwie pogłębiany położeniem Podlasia na granicy - a raczej na strefowym pograniczu dzielącym południkowo Europę - pomiędzy zachodnim („łacińskim”) oraz wschodnim („,bizantyjskim”) chrześcijaństwem (Kowalski 1999, Eberhardt 2004b, Bański 2008a, b). Zwłaszcza że dla mieszkańców wschodniej Polski prawosławie jest nie tylko religią, ale również - a może przede wszystkim typem kultury (Pawluczuk 1999).

Na podstawie wstępnych wyników spisu można stwierdzić, że najistotniejszą zmianą w rozmieszczeniu mniejszości białoruskiej jest spadek koncentracji Białorusinów na Podlasiu (z 97\% w 2002 r. do 81,5\% w 2011 r.) oraz prawdopodobnie spowodowany migracjami do Warszawy wzrost liczebności Białorusinów w województwie mazowieckiem, tym bardziej że stolica już od kilku dekad jest naturalnym celem migracji mieszkańców Białostocczyzny (tab. 28).

\section{Litwini}

W porównaniu ze spisem z 2002 r., w przypadku mniejszości litewskiej możemy mówić o stagnacji liczebności. Co prawda ogólna liczba identyfikacji narodowości litewskiej wzrosła (z 5,8 tys. do 8 tys.), ale jednocześnie liczba osób deklarujących tożsamość litewską na pierwszym miejscu wzrosła tak nieznacznie (z 5,8 tys. do 6,0 tys.), że z powodu ogólnikowości dotychczas upublicznionych danych statystycznych można przyjąć, iż nie uległa zmianie (tab. 27). Jednak najistotniejszą zmianą - w świetle wyników dostępnych w styczniu 2013 r. - jest wyraźny spadek koncentracji Litwinów w województwie podlaskim. W 2002 r. na Podlasie przypadało 90\% ogółu deklaracji narodowości litewskiej, natomiast podczas ostatniego spisu już niespełna 60\% (tab. 28). 
Główną przyczyną są prawdopodobnie migracje zarówno do większych miast poza Podlasiem (głównie Warszawy, prawdopodobnie także Gdańska, Elbląga, Olsztyna), jak i na Litwę. Emigracji na Litwę sprzyja bardzo silne poczucie litewskiej tożsamości narodowej i różnorakie związki mniejszości litewskiej z państwem macierzystym. Ponadto tożsamość językowa, swoboda podróżowania, nauki, pracy i osiedlania się wynikająca $\mathrm{z}$ uwarunkowań prawnych państw należących do UE oraz bliskość geograficzna. Z Puńska i Sejn jest bliżej do Wilna czy Kowna niż do Białegostoku, nie mówiąc o Warszawie czy Gdańsku. 


\section{STUDIUM PORÓWNAWCZE SYTUACJI SPOLECZNO-POLITYCZNEJ UKRAIŃCÓW, ŁEMKÓW, BIAŁORUSINÓW I LITWINÓW W POLSCE}

Polityka narodowościowa, realizowana w Polsce w latach 1944-1989, charakteryzowała się niekonsekwencją oraz zasadniczą rozbieżnością pomiędzy głoszonymi przez władzę propagandowymi hasłami a praktyką. Internacjonalistycznej retoryce i sloganom o braterstwie narodów towarzyszyły działania zmierzające do asymilacji ludności niepolskiej, do przekształcenia PRL w państwo jednolite etnicznie. Oficjalnie deklarowana przez władze przyjaźń z narodami ZSRR, Czechosłowacji i NRD oraz równouprawnienie wszystkich narodowości rozmijały się z rzeczywistością polityczną i społeczną. Powszechne były przejawy dyskryminacji mniejszości narodowych. W pierwszych latach po wojnie postulat państwa jednonarodowego był otwarcie traktowany jako jeden z zasadniczych celów polityki państwa. Do jego realizacji angażowano nie tylko aparat administracyjny i partyjny, lecz także wojsko i służby bezpieczeństwa. Setki tysięcy Niemców i Ukraińców wysiedlono z Polski. Pozostałym przedstawicielom mniejszości narodowych i etnicznych tworzono warunki sprzyjające polonizacji. Przymusowe przesiedlenia ludności (poza granice państwa lub na jego peryferyjne obszary) stały się głównym i najbardziej skutecznym „,narzędziem” polskiej polityki narodowościowej. Można je porównać do „czystek etnicznych" powszechnie stosowanych w Europie w XX w., nie tylko w III Rzeszy i ZSRR oraz powojennej Czechosłowacji, Jugosławii czy na Węgrzech, ale także w latach 90. XX w. na Bałkanach.

Wszelkie powojenne akty prawne (począwszy od Manifestu PKWN z 1944 r.) oraz wszystkie konstytucje (począwszy od 1952 r.) formalnie głosiły zasadę równouprawnienia bez względu na narodowość, religię, pochodzenie. Gwarantowały równość wszystkich obywateli wobec państwa. Pomimo tych założeń poszczególne narodowości nie były traktowane jednakowo, a nadrzędnym celem polityki władz było dążenie do stworzenia państwa narodowego. Widać to na przykładzie odmiennej skali powojennych przesiedleń Białorusinów i Ukraińców z Polski do ZSRR. 
Białorusini nie byli przymuszani do emigracji, akcja przesiedleńcza na Białostocczyźnie nie była prowadzona zbyt intensywnie. Władze uznały, że wiejska społeczność, o słabo wykształconym poczuciu odrębności i tożsamości narodowej oraz o wyraźnych postawach i poglądach lewicowych, będzie zarówno przydatna nowej władzy, jak i podatna na asymilację. Pozytywny stosunek do mniejszości białoruskiej wynikał głównie z jej lojalnej postawy, aktywnego włączenia się w budowę Polski Ludowej, niewysuwania postulatów o charakterze narodowym, łatwości, z jaką podlegali polonizacji, generalnie „bezproblemowości”. Prawdopodobnie w prognozach polityków zajmujących się sprawami narodowościowymi byli mniejszością najbardziej podatną na asymilację (Olejnik 2003). Jak pisał G. Motyka (2011b), „Białorusini pozostali w Polsce jako potencjalni polscy komuniści”. Dlatego znaczenie Białorusinów w ówczesnej polityce państwa było relatywnie niewielkie, mimo że byli jedną z najliczniejszych grup narodowościowych w powojennej Polsce, zwarcie zamieszkującą duży, nadgraniczny region. Czynnikiem decydującym była lojalność wobec nowych władz oraz słabo skrystalizowana świadomość narodowa.

$\mathrm{Z}$ kolei najistotniejszą rolę w powojennej polityce narodowościowej, obok Niemców, odgrywali Ukraińcy (a wraz z nimi także Łemkowie). Szczególnie nieprzychylny stosunek władz oraz społeczeństwa polskiego do Ukraińców (stereotypowo również do Łemków) był konsekwencją zaszłości historycznych, konfliktogenności wzajemnych relacji, działalności zbrojnego podziemia ukraińskiego. Antypolskie i antykomunistyczne postawy dużej części Ukraińców oraz silne poczucie odrębności narodowej poddawały w wątpliwość ich skuteczną polonizację oraz były postrzegane jako zagrożenie dla funkcjonowania oraz integralności państwa polskiego. Dlatego wysiedlano ich na dużo większą skalę niż Białorusinów czy Litwinów, wychodząc z założenia, że pozostawienie skupisk Ukraińców w granicach Polski może uniemożliwić zrealizowanie planów utworzenia państwa jednonarodowego.

Tak wyraźne i istotne różnice w relacjach „państwo-mniejszość” między społecznością ukraińską i białoruską były jednym z powodów konsekwentnego popierania przez władze "białoruskiego charakteru etnicznego" całej prawosławnej ludności Podlasia.

Znaczenie Litwinów w ówczesnej polityce było, podobnie jak Białorusinów, niewielkie, jednak z zupełnie innych powodów. Litwini byli nieliczni, nie stwarzali zagrożenia dla integralności państwa oraz wprowadzanego ustroju, ponadto zamieszkiwali odległy, peryferyjny region. Decydującymi czynnikami był nieznaczny potencjał demograficzny oraz położenie głównych skupisk etnicznych.

Zróżnicowane traktowanie przez władze poszczególnych mniejszości w szczególnie jaskrawy sposób przejawiało się w negowaniu istnienia niektórych spo- 
śród nich, np. Łemków. Przed wojną oficjalne popieranie odrębności Łemków było jedną $\mathrm{z}$ wielu metod zmniejszania potencjału i znaczenia wielomilionowej mniejszości ukraińskiej. Po wojnie potraktowanie ich jako części społeczności ukraińskiej zmniejszało różnorodność narodowościową kraju i umożliwiało objęcie szczególnie restrykcyjną, antyukraińską polityką. Władze PRL nigdy nie spełniły, ani nawet nie zamierzały spełnić, podstawowego postulatu Łemków uznania ich za odrębną mniejszość. Stwarzały, co najwyżej, iluzję działaczom, że takie decyzje są możliwe w przyszłości, lecz działania te były uwarunkowane jedynie potrzebami bieżącej polityki wobec Ukraińców. W praktyce aż do 1989 r. Łemków traktowano jako część etnosu ukraińskiego.

Analizując powojenne przekształcenia struktury narodowościowej Polski, często podkreśla się silne tendencje narodowe i nacjonalistyczne władz komunistycznych, marginalizując jednocześnie, równie powszechne, tendencje dużej części polskiego społeczeństwa, jego niechęć wobec niepolskich narodowości. Mimo negatywnego stosunku większości Polaków do nowo wprowadzanego ustroju politycznego, ówczesna polityka narodowościowa władz komunistycznych była wyraźnie popierana przez większość społeczeństwa, nawet tę część, która aktywnie przeciwstawiała się nowej władzy. Zwłaszcza wysiedlenia ludności niepolskiej miały powszechne poparcie, a w latach 1944-1946 oddziały polskiego podziemia antykomunistycznego i nacjonalistycznego wręcz wspierały władze komunistyczne w przesiedleniach do ZSRR zarówno Ukraińców, jak i Białorusinów. W tym drugim przypadku nacisk zbrojnych oddziałów antykomunistycznych na wysiedlenia był zdecydowanie silniejszy i brutalniejszy niż władz komunistycznych (Mironowicz 2000, Olejnik 2003).

Postawy wrogości wobec Ukraińców były spowodowane doświadczeniami okresu międzywojennego, a zwłaszcza lat okupacji zarówno w aspekcie ich współpracy z Niemcami, jak i bezpośrednich działań zbrojnych UPA wymierzonych w Polaków, które nie zakończyły się wraz z końcem wojny.

Niechęć do Białorusinów była determinowana bardziej różnorodnymi czynnikami, szczególnie ich postawami w różnych realiach politycznych:

- działalnością w strukturach radzieckich organów bezpieczeństwa oraz administracji okupacyjnej w latach 1939-1941,

- działalnością w strukturach niemieckich organów bezpieczeństwa oraz administracji okupacyjnej w latach 1941-1944 (m.in. w Białoruskim Komitecie Narodowym),

- działalnością w strukturach radzieckich, a następnie polskich komunistycznych organów bezpieczeństwa oraz administracji od $1944 \mathrm{r}$.

Wobec Litwinów żywa była pamięć konfliktu o Wileńszczyznę, antypolskiej współpracy litewskiej policji z hitlerowcami oraz walk polsko-litewskich. 
Ukraińcy byli powszechnie utożsamiani $\mathrm{z}$ bezpośrednim zagrożeniem dla polskiej ludności, natomiast Białorusini z systemem komunistycznym. Do tego dochodziły, systematycznie powtarzające się, oskarżenia o tendencje separatystyczne inspirowane przez mniejszości narodowe (szczególnie na Podlasiu, Chełmszczyźnie i Podkarpaciu). W takiej atmosferze nietrudno było o zbieżność postaw i poglądów władz oraz większości społeczeństwa.

Mimo że w późniejszych latach polityka narodowościowa zmieniała się w zależności od potrzeb i interesów aktualnie sprawujących władzę, ponadto nadal była różna wobec poszczególnych mniejszości, to wspólną cechą wszelkich „przełomów politycznych” w powojennej Polsce (1944/45, 1955/56, 1968, 1980/81, 1989) był mniejszy lub większy wzrost nastrojów nacjonalistycznych w polskim społeczeństwie, wzrost niechęci (czasami szowinizmu, zwłaszcza w roku 1956 i 1968) wobec ludności niepolskiej oraz wywołane tym nasilanie obaw po stronie mniejszości narodowych, szczególnie Białorusinów i Żydów.

W okresie PRL, także po 1956 r., nie był możliwy udział w sprawowaniu władzy oraz prowadzenie przez przedstawicieli mniejszości narodowych samodzielnej działalności politycznej ${ }^{1}$. Nie zmieniło tego również powierzchowne przeobrażenie polityki państwa wobec mniejszości po 1956 r., w ramach której powstały towarzystwa społeczno-kulturalne poszczególnych narodowości. Zostały one całkowicie podporządkowane władzy i szybko okazały się kolejną formą kontroli nad mniejszościami narodowymi. Jedyną możliwością podtrzymywania odrębności i tożsamości narodowej było szkolnictwo we własnych językach oraz lokalna działalność kulturalna, najczęściej ograniczona wyłącznie do folkloru. Dodatkową barierą był brak zaufania pomiędzy poszczególnymi mniejszościami a formalnie reprezentującymi je władzami stowarzyszeń. Organizacje te, często słusznie, były postrzegane jako agendy państwa ustanowione w celu kontroli mniejszości. Między innymi dlatego tylko nieznaczna część społeczności mniejszościowych zaangażowała się w ich działalność.

Prowadzonej polityce asymilacji sprzyjały także ogólne procesy zmian społeczno-gospodarczych w ówczesnej Polsce - industrializacja, urbanizacja, migracje ze wsi do miast oraz związany $\mathrm{z}$ tym awans społeczny ludności wiejskiej, wzrost ruchliwości przestrzennej i społecznej, rozwój kultury masowej w języku polskim. Prowadziło to do zaniku izolacji lokalnych i regionalnych zbiorowości oraz intensyfikacji procesów asymilacji mniejszości do polskiej większości. Asymilacja mniejszości narodowych oraz ich marginalizacja, przy

${ }^{1}$ Osoby wywodzące się z mniejszości narodowych zajmowały różne, czasami eksponowane, stanowiska w strukturach partyjnych oraz administracyjnych (zwłaszcza Białorusini), jednak deklarowali się jako Polacy i prowadzili działalność zgodną z wytycznymi PZPR. 
akceptacji odrębności kulturowo-folklorystycznej oraz wyznaniowej, była jednym ze sposobów integracji społecznej, konsekwentnie realizowanej przez władze zarówno centralne, jak i lokalne w całym okresie PRL.

Procesy te były wyraźnie widoczne i skuteczne w przypadku mniejszości białoruskiej. Natomiast wzajemna wrogość, nieufność, życie w izolacji, utrzymywanie kontaktów głównie wewnątrz własnych grup narodowych (co dotyczyło zwłaszcza relacji ukraińsko-polskich, rzadziej litewsko-polskich) nie sprzyjało, tak pożądanej przez władze, asymilacji. Wręcz przeciwnie, wzmacniało poczucie odrębności i umożliwiało podtrzymanie własnej tożsamości narodowej.

Analizując opinie obecnych liderów organizacji narodowościowych, oceniających okres PRL z punktu widzenia ówczesnej sytuacji reprezentowanych przez nich mniejszości oraz porównujących go ze współczesnymi realiami, można zauważyć szereg podobieństw i prawidłowości, ale także wyraźnych różnic ${ }^{2}$.

W zgodnej opinii działaczy organizacji ukraińskich, w latach istnienia PRL aż do 1990 r. miała miejsce jawna inwigilacja i dyskryminacja Ukraińców, nie było możliwości samodzielnego funkcjonowania, działalność organizacyjna była ograniczona tylko do jednego stowarzyszenia i znajdowała się pod pełną kontrolą władz i służb bezpieczeństwa. Powszechny był bardzo negatywny stereotyp Ukraińca, podtrzymywany i rozpowszechniany przez prasę, literature, film. Paradoksalnie, ta wrogość i niechęć władz oraz dużej części społeczeństwa, według opinii liderów organizacji, pomogła utrzymać ukraińską tożsamość i odrębność. Odnosząc się do sytuacji mniejszości ukraińskiej w obecnych realiach społeczno-politycznych, podkreślają zdecydowanie gorsze finansowanie aktywności kulturalnej, brak etatów dla instruktorów, działaczy kultury, brak instytucjonalizacji działalności kulturalnej oraz wzrost polsko-katolickiego nacjonalizmu. Jednocześnie dostrzegają bardzo dużą poprawę sytuacji politycznej i prawnej, korzyści płynące z demokracji, możliwość pluralizmu organizacyjnego.

Liderzy organizacji łemkowskich, bez względu na dzielące ich różnice postaw i przekonań narodowych, jednoznacznie negatywnie oceniają okres PRL. Główną przyczyną takich opinii był brak oficjalnego uznania odrębności Łemków. Najczęściej padały stwierdzenia, że „w latach PRL oficjalnie Łemkowie nie istnieli, nie można było być Łemkiem, Łemkowie byli skazani na bycie albo Polakami albo Ukraińcami". Ponadto podkreślali dyskryminowanie Łemków

\footnotetext{
${ }^{2}$ Na podstawie wywiadów przeprowadzonych przez autora w 2012 r. z działaczami Związku Ukraińców w Polsce, Związku Ukraińców Podlasia, Towarzystwa Ukraińskiego, Stowarzyszenia Łemków, Zjednoczenia Łemków, Stowarzyszenia Młodzieży Łemkowskiej „Czuha”, Białoruskiego Towarzystwa Społeczno-Kulturalnego, Rady Programowej Tygodnika „Niwa”, Białoruskiego Zrzeszenia Studentów, Stowarzyszenia Litwinów w Polsce, Litewskiego Towarzystwa Św. Kazimierza.
} 
przez polskie władze i przez Ukraińców oraz brak własnych organizacji. Według działaczy łemkowskich, po 1989 r. nastapiła zdecydowana poprawa sytuacji. Obecnie są prawnie uznaną odrębną mniejszością, mają możliwość nauki języka łemkowskiego w szkołach, posiadają własne, pluralistyczne organizacje. Zinstytucjonalizowany podział wśród Łemków powoduje swoistą konkurencję i działa mobilizująco na działaczy o orientacji narodowo łemkowskiej i proukraińskiej. Osoby deklarujące narodowość łemkowską mogą normalnie funkcjonować, nikt ich nie dyskryminuje, jednak taka swoboda - zdaniem liderów - powoduje konformizm, rozprężenie prowadzące do zmniejszenia aktywności (zwłaszcza młodzieży) i zarazem do zwiększenia asymilacji, którą dodatkowo potęguje migracja do miast, a zwłaszcza za granicę.

Natomiast według lidera Białoruskiego Towarzystwa Społeczno-Kulturalnego, w latach PRL środowisko mniejszości białoruskiej było silne pod względem ekonomicznym i organizacyjnym, w każdej wsi była szkoła, w której z kolei działało koło BTSK, funkcjonowały liczne świetlice i kluby. BTSK miało 27 etatowych pracowników (instruktorów, działaczy kultury) finansowanych z budżetu państwa, działało bardzo aktywnie, wspierało liczne amatorskie zespoły folklorystyczne, organizowało dziesiątki festiwali i imprez kulturalnych. W dużym stopniu było to możliwe dzięki wsparciu finansowemu i logistycznemu ówczesnych władz. Natomiast współcześnie, według przewodniczącego, sytuacja organizacyjna mniejszości białoruskiej jest dużo gorsza niż w czasach Polski Ludowej. BTSK jest celowo dyskryminowane pod względem finansowym, otrzymuje bardzo niskie dotacje z budżetu, ma zaledwie jednego pracownika na pół etatu. Ponadto z powodu wyludniania się podlaskich wsi i likwidacji wielu szkół nastąpił upadek lokalnych kół BTSK, a także bardzo istotnie zmniejszyła się liczba i aktywność członków. Przewodniczący BTSK, jako jedyny spośród respondentów, wyłącznie pozytywnie ocenił okres PRL i jednocześnie jednoznacznie negatywnie ocenił sytuację obecną. Także jako jedyny skupił się na sprawach finansowych, organizacyjnych i kulturowych, całkowicie pomijając kwestie polityczne i narodowe.

Z kolei działacze organizacji białoruskich opozycyjnych do BTSK podkreślali negatywny, w ich ocenie, brak pluralizmu organizacyjnego w latach PRL i całkowite podporządkowanie jedynej białoruskiej organizacji strukturom partyjnym i rządowym. Jednocześnie doceniali ówczesne finansowe wsparcie działalności artystycznej i kulturalnej oraz dofinansowywanie czasopism wydawanych przez poszczególne towarzystwa społeczno-kulturalne. Konsekwencją były niskie ceny czasopism, a obowiązkowa prenumerata dla szkół, klubów, świetlic zapewniała wysokie nakłady. Jednak ceną była cenzura i pełna kontrola rządzącej partii nad publikowanymi treściami, które odgrywały rolę „tuby propagando- 
wej” w środowisku mniejszości narodowych. W obecnej sytuacji mniejszości białoruskiej, respondenci najbardziej doceniali pluralizm organizacyjny, natomiast w prowadzeniu działalności przeszkadzało niedostateczne wsparcie finansowe ze strony budżetu państwa oraz niewielka aktywność środowiska białoruskiego.

Liderzy organizacji litewskich jednoznacznie negatywnie oceniali lata PRL, głównie z powodów politycznej kontroli nad wszelkimi przejawami działalności narodowościowej i związanego z tym braku samodzielności. Według nich obecna sytuacja polityczna jest zdecydowanie lepsza, dużo większe są także możliwości utrzymania litewskiej odrębności i tożsamości narodowej. Najbardziej cenią nawiązanie wszechstronnej współpracy z Litwą. Jedynym negatywnym zjawiskiem początków transformacji ustrojowej w latach 90 . XX w. był silny wzrost polskiego nacjonalizmu, wyraźnie zauważalny w Sejnach, który, według nich, obecnie należy już do przeszłości.

Porównując powyższe opinie, można zauważyć wyraźnie dominującą, negatywną ocenę sytuacji politycznej mniejszości narodowych w latach PRL, zwłaszcza wśród Ukraińców, Łemków i Litwinów. Najmocniej krytykowano podporządkowanie, dyskryminację, kontrolę brak samodzielności. Jednocześnie wśród Ukraińców i Łemków powtarzały się opinie, że taka sytuacja sprzyjała konsolidacji zbiorowości mniejszościowych i ułatwiała utrzymanie odrębności od polskiej - niechętnej, a często i wrogiej - większości.

Oceniając okres PRL, obok krytyki ówczesnego systemu politycznego, liczne wypowiedzi, zwłaszcza wśród Białorusinów i Ukraińców, podkreślały bardzo dobrze rozwijającą się wówczas działalność kulturalną i aktywne wsparcie, również finansowe, władz dla działań artystycznych i folklorystycznych.

Wypowiadając się na temat sytuacji reprezentowanych przez siebie mniejszości narodowych i etnicznych w realiach III Rzeczypospolitej, większość działaczy (głównie Łemków, Litwinów i Ukraińców) podkreślała bardzo wyraźną poprawę sytuacji politycznej i prawnej, przy jednocześnie zdecydowanym pogorszeniu możliwości prowadzenia działalności kulturalnej, a zwłaszcza jej finansowania. Dyskryminację polityczną zastapiła dyskryminacja ekonomiczna. W większości doceniają pluralizację instytucjonalną własnych środowisk, natomiast krytycznie wypowiadają się o malejącej aktywności i postępującej asymilacji wśród grup mniejszościowych.

Różnice między sytuacją w latach PRL oraz współczesną zdecydowanie mocniej podkreślają liderzy organizacji powstałych po 1989 r., oni także wyraźniej deklarują pozytywne elementy aktualnej sytuacji (zwłaszcza Łemkowie). Natomiast liderzy organizacji mających rodowód w czasach PRL częściej są skłonni dostrzegać pozytywne aspekty przeszłości lub - jak w skrajnym przy- 
padku BTSK - wyłącznie pozytywne cechy okresu władzy ludowej oraz tylko negatywne przejawy współczesnej sytuacji. Jednak nawet najbardziej zagorzały przeciwnik i krytyk aktualnej rzeczywistości politycznej, społecznej i ekonomicznej powinien dostrzec (omówione we wcześniejszych rozdziałach pracy) zasadnicze przeobrażenia sytuacji polityczno-prawnej mniejszości narodowych, które dokonały się w Polsce w ciagu ostatnich kilkudziesięciu lat.

Przekształcenia prawne zapoczątkowane na przełomie lat 80. i 90. XX w., polegające na legalizacji i upodmiotowieniu grup mniejszościowych (czyli instytucjonalizacja zewnętrzna), umożliwiły samoorganizację tych grup, czyli ich instytucjonalizację wewnętrzną (organizacyjną). Zapoczątkowało to także proces odwrotny - presja wywierana na władze przez legalne i coraz lepiej zorganizowane mniejszości przyczyniła się do dalszych zmian prawnych. Proces instytucjonalizacji jest niezwykle ważny dla mniejszości, może wpływać na umocnienie, a nawet rewitalizację świadomości narodowej (Budyta-Budzyńska 2003).

Postępująca pluralizacja organizacyjna i duża liczba stowarzyszeń narodowościowych zakładanych przez poszczególne mniejszości jest często dla nich samych problemem finansowym i organizacyjnym. $Z$ reguły jest konsekwencją różnic polityczno-ideologicznych i pokoleniowych, niejednokrotnie wzmacnianych niechęciami personalnymi. Spośród omawianych mniejszości, najsilniejsze podziały wystepują wśród organizacji białoruskich i łemkowskich, natomiast najbardziej skonsolidowani instytucjonalnie są Litwini ${ }^{3}$. Do pewnego stopnia pluralizm organizacyjny jest czynnikiem naturalnym, pozytywnym, a nawet niezbędnym, obrazującym normalne w demokracji zróżnicowanie wewnętrzne poszczególnych mniejszości narodowych lub różnorodność celów, dla jakich stowarzyszenia zostały powołane. Wywołana pluralizmem konkurencja i aktywność poszczególnych grup działaczy w ostatecznym efekcie niejednokrotnie pozytywnie służy środowiskom mniejszościowym. Jednak może doprowadzić także do głębokich podziałów, wzajemnej niechęci, rozdzielania imprez kulturalnych, zakładania konkurencyjnych komitetów wyborczych i w konsekwencji rozbijania głosów w wyborach ogólnokrajowych oraz samorządowych, konfliktów personalnych. Konsekwencją takich działań jest skłócenie środowisk poszczególnych mniejszości narodowych oraz zniechęcanie ludzi do aktywnego włączania się w życie polityczne, społeczne i kulturalne własnej społeczności. Ponadto działalność części organizacji jest wyłącznie deklaratywna lub epizodyczna, okazjonalna.

Jak słusznie zauważyła M. Budyta-Budzyńska (2003), ,największym zagro-

${ }^{3}$ Obecną instytucjonalizację organizacyjną omawianych mniejszości przedstawiono w rozdziale 3.3 . 
żeniem instytucjonalizacji wewnętrznej mniejszości w Polsce nie jest słabość i inercja instytucji zajmujących się mniejszościami, ale obojętność członków mniejszości na ich sprawy narodowe i coraz słabsza świadomość narodowa. Grupy narodowościowe w Polsce w coraz mniejszym stopniu są współcześnie grupami przypisanymi, do których przynależność się dziedziczy. Można do nich należeć, ale można też «wystąpić». Coraz częściej mają charakter dobrowolnych zrzeszeń. Czy te dobrowolne zrzeszenia będą topnieć, czy też nie, zależy głównie od samych członków mniejszości i ich liderów".

Asymilacja mniejszości narodowych i etnicznych trwająca przez cały okres PRL, jak pokazują wyniki spisów powszechnych, nie zakończyła się w 1989 r. Zmieniły się jej główne mechanizmy, czynniki polityczne i ideologiczne zostały zastapione przez ekonomiczne, społeczne, kulturowe i obyczajowe. Coraz większego znaczenia nabiera wzrost mobilności społeczeństwa. Nasilające się migracje prowadzą do depopulacji tradycyjnych wiejskich skupisk poszczególnych mniejszości, zwiększają ich urbanizację, wyraźnie zmniejszają koncentrację terytorialną, co pokazały wstępne wyniki spisu ludności z 2011 r. Spośród czynników polityczno-prawnych, paradoksalnie, pełne uznanie i akceptacja odrębności narodowej poszczególnych mniejszości po 1990 r., wraz z postępującą unifikacją kulturową i obyczajową społeczeństwa, przyczyniły się do intensyfikacji asymilacji. W warunkach braku przymusowej asymilacji ze strony organów państwa, przy swobodzie instytucjonalizacji mniejszości narodowych, edukacji w języku mniejszości oraz kultywowaniu praktyk religijnych, decydującą rolę w utrzymaniu odrębności narodowej odgrywa wychowanie.

Już kilkadziesiąt lat temu J. Wiatr (1973) stwierdził, że podstawowym czynnikiem określającym przynależność narodową jest „dziedziczenie kulturalne”, czyli przekazywanie pewnych wartości, uczuć, postaw w procesie wychowania. Utrzymanie silnej tożsamości i poczucia odrębności wśród Litwinów, części Łemków i Ukraińców, w głównym stopniu jest zasługą wychowania w domu rodzinnym. Z kolei postępująca asymilacja, szczególnie widoczna wśród Białorusinów, ale występująca w różnym stopniu wśród wszystkich mniejszości narodowych i etnicznych, w głównym stopniu jest także konsekwencją wychowania w domu. Tak jak w procesie wychowania i edukacji można „dziedziczyć tożsamość narodową”, tak samo można „dziedziczyć brak tożsamości narodowej”. Instytucje państwowe $\mathrm{w}$ warunkach demokratycznego państwa prawa mogą spełniać najwyżej funkcję pomocnicza, a często wysuwane wobec nich oskarżenia środowisk mniejszości narodowych o działalność asymilacyjną niejednokrotnie bywają próbą maskowania własnych porażek.

Ewolucja powojennej polityki państwa polskiego wobec mniejszości narodowych i etnicznych przebiegała od dążenia do ich przymusowej asymilacji 
w pierwszych latach po zakończeniu wojny (według najbardziej skrajnej odmiany koncepcji integracyjnej), poprzez akceptację odrębności kulturowej i ograniczonej działalności organizacyjnej, ale bez instytucjonalnego wsparcia mniejszości (w latach 1956-1989), do obecnego modelu. Ten ostatni opiera się na trwałej akceptacji różnorodności etnicznej społeczeństwa i prowadzenia polityki ograniczonego wspierania mniejszości narodowych na podstawie specjalnych, wewnętrznych regulacji prawnych oraz pomocy państwa (według najbardziej liberalnej odmiany koncepcji integracyjnej z elementami koncepcji pluralistycznej). Nastapiło całkowite odejście od obrazu jednolitego etnicznie społeczeństwa. Mniejszości narodowe oraz reprezentujące je organizacje zostały zaakceptowane jako odrębne podmioty życia publicznego, a ich członkowie otrzymali prawa do swobodnego i publicznego wyrażania swojej przynależności etnicznej. Ewolucja ta wpisuje się nie tylko w ogólne przemiany polityczno-ustrojowe zachodzące w Polsce, ale także w zmiany prawa międzynarodowego dotyczącego mniejszości narodowych, związane z przejściem od powojennego systemu „uniwersalnych praw człowieka” do obecnego od lat 90. XX w. systemu „ochrony mniejszości”, a nie tylko „ochrony osób należących do mniejszości” (Łodziński 2002).

Nawiązując do socjologicznej typologii polityki państwa wobec mniejszości narodowych (Jasiewicz 1977), można współczesne rozwiązania przyjęte w Polsce określić jako „model akceptacji zróżnicowań w ramach liberalnej odmiany koncepcji integracyjnej”, czyli równouprawnienia osób należących do mniejszości pod względem prawnym, przy jednoczesnym wspieraniu przez administrację działalności kulturalnej ich organizacji, szkolnictwa prowadzącego naukę i nauczanie w językach mniejszości oraz mediów, ale bez jakichkolwiek form autonomii terytorialnej.

Ta sama polityka państwa realizowana wobec mniejszości, w zderzeniu z ich różnymi aspiracjami oraz cechami politycznymi, kulturowymi i społecznymi, nadaje odmienny charakter stosunkom poszczególnych mniejszości z dominującą większością. Relacje te mogą zarówno sprzyjać intensyfikacji etniczności grupy mniejszościowej, jak i ją ograniczać. Porównując sytuację omawianych mniejszości w kontekście ich stosunków z polską większością, poprzez odwołanie się do uwarunkowań zaproponowanych przez E. Nowicką (1989), można wykazać różne zależności i efekty tych relacji.

W przypadku Ukraińców i Łemków przez kilkadziesiąt lat po zakończeniu wojny, a zwłaszcza w pierwszych latach powojennych, intensyfikacji etniczności sprzyjało uświadomienie własnego upośledzenia i podporządkowania polskiej większości pod względem politycznym, społecznym, gospodarczym oraz niechęć (a niejednokrotnie także wrogość) narodu dominującego. Typowa dla 
tych zbiorowości postawa buntu i niezgody na podporządkowanie spajała je wewnętrznie, potęgowała poczucie odrębności i istotnie wzmacniała zainteresowanie własną tożsamością, zmniejszając efektywność polityki asymilacyjnej państwa. W warunkach demokracji i wolności, przy malejącym poczuciu zagrożenia, upośledzenia i podporządkowania, nastąpiło „rozprężenie” i wzrost asymilacji, zwłaszcza wśród młodego pokolenia.

W przypadku Białorusinów natomiast, wykazana w wielu badaniach bierność i akceptacja podporządkowania prowadziły do niechętnego postrzegania własnej zbiorowości jako grupy mniejszościowej. Sprzyjało to deprecjacji własnej kultury, odrzuceniu lub minimalizowaniu własnej odrębności, a w konsekwencji przyjmowaniu polskiej tożsamości językowej i narodowej, przy zachowaniu odrębności wyznaniowej, czego konsekwencją jest postępująca asymilacja Białorusinów i dominacja na obszarze południowo-wschodniej części województwa podlaskiego kategorii Polak-prawosławny.

Z kolei intensyfikacji etniczności wśród Litwinów i utrzymaniu własnej odrębności sprzyjała izolacja grupy zarówno geograficzna, jak i wobec społeczności większościowej. Niewielka liczebność, połączona z peryferyjnością, niechęcią i nieufnością wobec polskiej większości oraz wyraźną odrębnością językową, skazywała Litwinów na szukanie oparcia we własnej zbiorowości, co wzmacniało jej etniczność.

Wśród mniejszości narodowych i etnicznych można wyróżnić szereg różnych kategorii i przeprowadzić wiele ich klasyfikacji, zależnie od zastosowanych kryteriów, m.in. genezy danej grupy, zamieszkiwanego przez nią terytorium, wielkości, stopnia rozproszenia, relacji z narodem dominującym, związku z państwem zamieszkania oraz państwem macierzystym, charakteru więzi łączącej jej członków oraz odrębności od narodu większościowego (Koter 1993, Lewandowski 1993, Żołędowski 2003, Łodziński 2005, Budyta-Budzyńska 2010).

Według opracowanej przez M. Kotera (1993) geograficznej klasyfikacji współczesnych mniejszości z punktu widzenia etniczno-terytorialnego, Ukraińcy, Białorusini i Litwini mogą być zaliczeni do wspólnej kategorii „mniejszości tworzących zwarte fragmenty (odpryski) sąsiedniego narodu posiadającego swoje własne państwo [...] mającego mniej lub bardziej poprawne stosunki z narodem, pośród którego mniejszość żyje", podobnie jak Włosi we Francji, Rumunii w Serbii lub Słowacy w Polsce, przy czym Ukraińcy z powodu przymusowego przesiedlenia i celowego rozproszenia nie stanowią współcześnie „Zwartego fragmentu sąsiedniego narodu”, ponadto omawiane mniejszości zdecydowanie częściej miały „mniej [...] poprawne stosunki z narodem, pośród którego żyją". Bardziej skomplikowana jest sytuacja Łemków. Zgodnie z zapisami w ustawie są oni odrębną mniejszością etniczną i, według powyższej kla- 
syfikacji, mogą być uznani za „mniejszość stanowiącą małą samoistną narodowość bez swego własnego państwa lub autonomicznej jednostki politycznej w ramach państw federalnych, w całości zwarcie żyjącą w jednym państwie", jak np. Serbo-Łużyczanie w Niemczech lub Bretończycy we Francji. Natomiast, gdy uznamy Łemków za część narodu rusińskiego czy też karpatorusińskiego, wówczas możemy ich zaklasyfikować, według M. Kotera (1993), jako „mniejszość stanowiącą zwartą część sąsiedniego narodu (często narodowości) nieposiadającą swojego własnego państwa”, podobnie jak Katalończycy, Baskowie lub Retoromanie, jednak adekwatnie do sytuacji Ukraińców, żyjącą w rozproszeniu.

Mając świadomość, że żadna klasyfikacja nie wyczerpuje złożoności sytuacji mniejszości, oraz że niektóre rozróżnienia i oceny mogą być zbyt uogólniające lub subiektywne, można pokusić się o porównanie współczesnej sytuacji Ukraińców, Łemków, Białorusinów i Litwinów (tab. 29). Ocena przyjętych kryteriów została dokonana na podstawie wiedzy autora zgromadzonej m.in. w trakcie badań i obserwacji terenowych, ankiet $\mathrm{z}$ przedstawicielami poszczególnych mniejszości (zwłaszcza na Podlasiu i Łemkowszczyźnie), wywiadów z liderami stowarzyszeń narodowościowych, analizy wyników różnego rodzaju badań socjologicznych (m.in. Mironowicz 1992a, b, 2005, 2010a, b, Sadowski 1995a, 1997, Budyta-Budzyńska 2003, Żołędowski 2003, Michna 2004, Łodziński 2005, Bieńkowska-Ptasznik 2007, Dudra 2008).

Tabela 29. Porównanie współczesnej sytuacji Ukraińców, Łemków, Białorusinów i Litwinów według wybranych kryteriów geograficznych, politycznych i społecznych

\begin{tabular}{|c|c|c|c|c|}
\hline \multirow{2}{*}{ Kryterium } & \multicolumn{4}{|c|}{ Narodowości } \\
\hline & Ukraińcy & Łemkowie & Białorusini & Litwini \\
\hline $\begin{array}{l}\text { Charakter } \\
\text { obecności } \\
\text { w Polsce }\end{array}$ & autochtoniczny & autochtoniczny & autochtoniczny & autochtoniczny \\
\hline $\begin{array}{l}\text { Geneza } \\
\text { współczesnego } \\
\text { rozmieszczenia }\end{array}$ & $\begin{array}{l}\text { zmiany granic, } \\
\text { w zachodniej } \\
\text { i północnej } \\
\text { Polsce w wyniku } \\
\text { przesiedleń }\end{array}$ & $\begin{array}{l}\text { efekt procesu } \\
\text { narodowotwór- } \\
\text { czego, w zachod- } \\
\text { niej i północnej } \\
\text { Polsce w wyniku } \\
\text { przesiedleń }\end{array}$ & zmiany granic & zmiany granic \\
\hline $\begin{array}{l}\text { Rodzaj } \\
\text { rozmieszczenia }\end{array}$ & rozproszone & rozproszone & zwarte & zwarte \\
\hline $\begin{array}{l}\text { Relatywna } \\
\text { wielkość grupy }\end{array}$ & liczna & nieliczna & liczna & nieliczna \\
\hline $\begin{array}{l}\text { Pochodzenie } \\
\text { etniczne }\end{array}$ & $\begin{array}{l}\text { wschodniosło- } \\
\text { wiańskie }\end{array}$ & $\begin{array}{l}\text { wschodniosło- } \\
\text { wiańskie }\end{array}$ & $\begin{array}{l}\text { wschodniosło- } \\
\text { wiańskie }\end{array}$ & bałtyckie \\
\hline
\end{tabular}




\begin{tabular}{|c|c|c|c|c|}
\hline $\begin{array}{l}\text { Grupa } \\
\text { językowa }\end{array}$ & $\begin{array}{l}\text { wschodniosło- } \\
\text { wiańska }\end{array}$ & $\begin{array}{l}\text { wschodniosło- } \\
\text { wiańska }\end{array}$ & $\begin{array}{l}\text { wschodniosło- } \\
\text { wiańska }\end{array}$ & bałtycka \\
\hline $\begin{array}{l}\text { Dominujące } \\
\text { wyznanie }\end{array}$ & $\begin{array}{l}\text { greckokatolickie, } \\
\text { prawosławne }\end{array}$ & $\begin{array}{l}\text { greckokatolickie, } \\
\text { prawosławne }\end{array}$ & prawosławne & rzymskokatolickie \\
\hline $\begin{array}{l}\text { Posiadanie } \\
\text { państwa } \\
\text { macierzystego }\end{array}$ & tak & nie & tak & tak \\
\hline $\begin{array}{l}\text { Położenie } \\
\text { w stosunku do } \\
\text { państwa } \\
\text { macierzystego }\end{array}$ & $\begin{array}{l}\text { w większości } \\
\text { wyraźnie odda- } \\
\text { lone, częściowo } \\
\text { nadgraniczne } \\
\end{array}$ & - & nadgraniczne & nadgraniczne \\
\hline $\begin{array}{l}\text { Relacje } \\
\text { z państwem } \\
\text { macierzystym }\end{array}$ & $\begin{array}{l}\text { poprawne, nie- } \\
\text { zbyt intensywne, } \\
\text { okazjonalne }\end{array}$ & - & $\begin{array}{l}\text { zróżnicowane, } \\
\text { marginalne }\end{array}$ & $\begin{array}{l}\text { dobre, bardzo } \\
\text { intensywne }\end{array}$ \\
\hline $\begin{array}{l}\text { Ojczyzna } \\
\text { ideologiczna }\end{array}$ & Polska, Ukraina & Polska & Polska & Litwa \\
\hline Status prawny & $\begin{array}{l}\text { mniejszość } \\
\text { narodowa }\end{array}$ & $\begin{array}{l}\text { mniejszość } \\
\text { etniczna }\end{array}$ & $\begin{array}{l}\text { mniejszość } \\
\text { narodowa }\end{array}$ & $\begin{array}{l}\text { mniejszość } \\
\text { narodowa }\end{array}$ \\
\hline $\begin{array}{l}\text { Wykorzystanie } \\
\text { przywilejów } \\
\text { ustawy z } 2005 \text { r. }\end{array}$ & marginalne & niewielkie & niewielkie & duże \\
\hline $\begin{array}{l}\text { Stopień } \\
\text { integracji } \\
\text { wewnętrznej }\end{array}$ & duży & niewielki & niewielki & bardzo duży \\
\hline $\begin{array}{l}\text { Stopień } \\
\text { integracji } \\
\text { instytucjonalnej }\end{array}$ & duży & niewielki & niewielki & bardzo duży \\
\hline $\begin{array}{l}\text { Przyczyny } \\
\text { podziałów } \\
\text { wewnętrznych }\end{array}$ & $\begin{array}{l}\text { wyznaniowe, } \\
\text { regionalne }\end{array}$ & $\begin{array}{l}\text { narodowe, } \\
\text { wyznaniowe }\end{array}$ & $\begin{array}{l}\text { polityczne, ideo- } \\
\text { logiczne, głów- } \\
\text { nie wśród elit } \\
\end{array}$ & brak \\
\hline $\begin{array}{l}\text { Odrębność } \\
\text { narodowa }\end{array}$ & duża & zróżnicowana & niewielka & bardzo duża \\
\hline $\begin{array}{l}\text { Odrębność } \\
\text { wyznaniowa }\end{array}$ & duża & duża & duża & brak \\
\hline $\begin{array}{l}\text { Odrębność } \\
\text { językowa }\end{array}$ & niewielka & niewielka & niewielka & bardzo duża \\
\hline $\begin{array}{l}\text { Organizacja } \\
\text { nauczania } \\
\text { języka }\end{array}$ & poprawna & poprawna & niewystarczająca & bardzo dobra \\
\hline $\begin{array}{l}\text { Stopień } \\
\text { odrębności od } \\
\text { większości }\end{array}$ & duży & duży & niewielki & bardzo duży \\
\hline $\begin{array}{l}\text { Podatność na } \\
\text { asymilację }\end{array}$ & duża & duża & bardzo duża & niewielka \\
\hline
\end{tabular}

Źródło: opracowanie własne. 
Pod wieloma względami Ukraińcy, Łemkowie i Białorusi nie różnią się istotnie między sobą. Są to autochtoniczne mniejszości o podobnej genezie, od wielu wieków żyjące w ramach państwa polskiego, mające wschodniosłowiańskie pochodzenie, mówiące zbliżonymi językami, w większości będące wyznawcami tego samego lub dwóch pokrewnych wschodnich obrządków, co odróżnia je od rzymskokatolickiej większości.

Natomiast wyraźnie różnią ich szeroko pojęte relacje z zagraniczną ojczyną, a także liczebność, rozmieszczenie, stopień koncentracji terytorialnej, wykorzystanie w praktyce przywilejów zapisanych w ustawie o mniejszościach (zwłaszcza dotyczących szkolnictwa, dwujęzycznych nazw oraz języka pomocniczego w gminach), instytucjonalizacja, poczucie integracji i odrębności narodowej oraz związana $\mathrm{z}$ tym podatność na asymilację.

Ponadto Łemków wyróżnia brak zagranicznej ojczyzny i odmienny status prawny, choć w tym ostatnim przypadku różnice między mniejszością narodową a etniczną są niewielkie, dotyczą głównie kwestii elektoralnych. Odróżnia także wyraźny łemkowsko-ukraiński dualizm narodowy, dzielący tę grupę również pod względem instytucjonalnym, wpływający negatywnie na jej wewnętrzną integrację oraz liczebność (tab. 29, ryc. 45).

Z kolei w przypadku Litwinów wyraźnie odmienny język, niesłowiańskie pochodzenie i wyznanie rzymskokatolickie zdecydowanie odróżniają tę mniejszość od pozostałych. Mimo tożsamości religijnej, autochtonizmu oraz wielowiekowych wspólnych dziejów historycznych z narodem i państwem polskim, współczesna mniejszość litewska bardzo wyraźnie odróżnia się także od Polaków. Ponadto Litwini, w porównaniu z pozostałymi zbiorowościami, mimo najmniejszej liczebności wypadają najkorzystniej z punktu widzenia perspektyw zachowania odrębności, tożsamości i dbania o własne interesy narodowe. Należą do najlepiej zorganizowanych i zintegrowanych mniejszości narodowych w Polsce, umiejących korzystać z przysługujących im przywilejów prawnych, z doskonale funkcjonującym szkolnictwem, silnym poczuciem tożsamości narodowej i relatywnie wysoką odpornością na asymilację (tab. 29, ryc. 45). Wyraźne poczucie odrębności narodowej, peryferyjność i zwartość terytorialna sprzyjają izolacji Litwinów od społeczeństwa polskiego oraz ich wewnętrznej konsolidacji jako odrębnej grupy mniejszościowej. Z kolei mała liczebność oraz bezpośrednie sąsiedztwo geograficzne Litwy wzmacniają poczucie emocjonalnej bliskości z zagraniczną ojczyzną oraz więzi i kontakty z rodakami. Wydaje się, że obecnie, odmiennie niż w okresie PRL, utrzymaniu odrębności sprzyja nie tyle peryferyjność położenia i związana z tym pewnego rodzaju izolacja, ile bezpośrednia bliskość państwa macierzystego, oddzielonego tylko wewnętrzną granicą UE i związane z tym wsparcie zarówno rodaków, jak i władz litewskich. 
Jak słusznie zauważył C. Żołędowski (2003), ,centrum kulturalno-ideologiczne mniejszości litewskiej w Polsce znajduje się na Litwie, a świadomość narodowa jej członków jest $\mathrm{w}$ zasadzie tożsama ze świadomością rodaków w zagranicznej ojczyźnie". Nie można tak powiedzieć o sytuacji mniejszości ukraińskiej, a zwłaszcza białoruskiej, oraz - z oczywistych powodów - łemkowskiej.

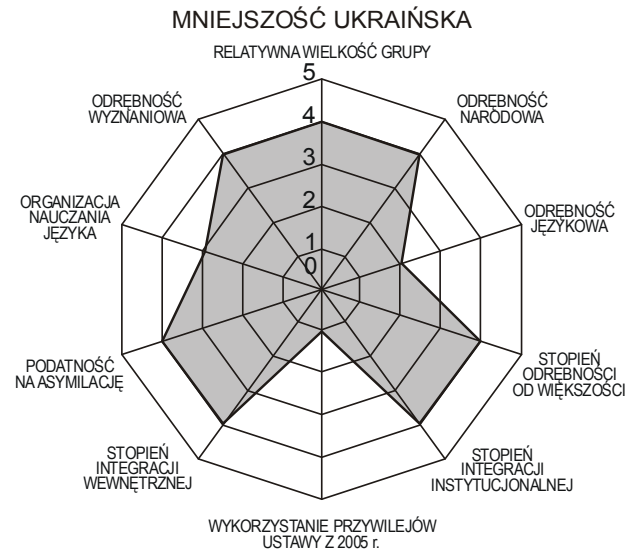

MNIEJSZOŚĆ BIAŁORUSKA

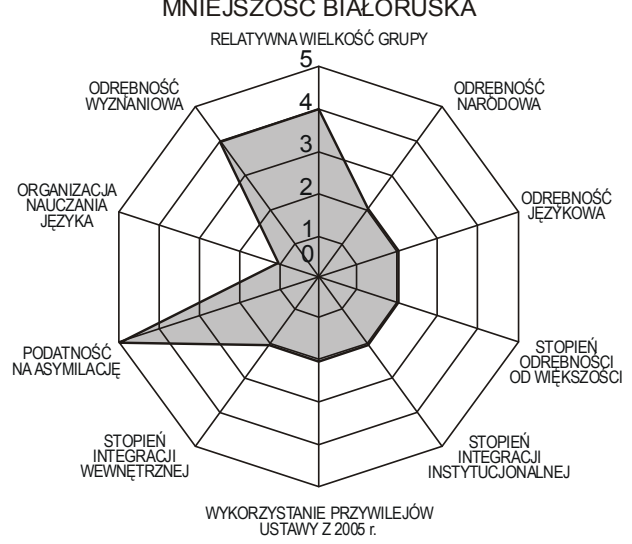

OCENA CECHY

0 - brak;

1 - marginalne, niewystarczająca;

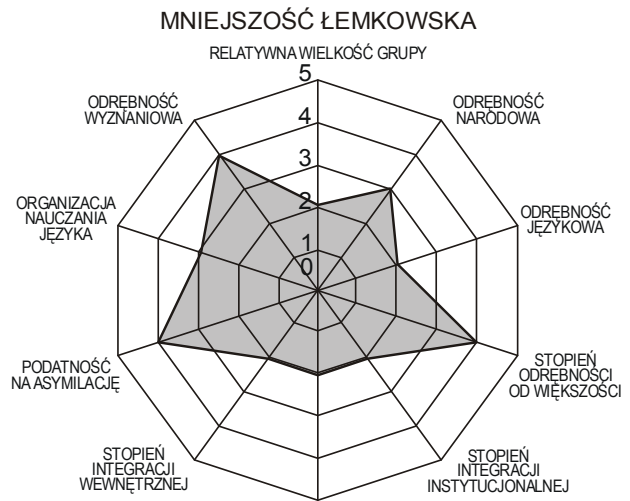

WYKORZYSTANIE PRZYWILEJÓW
USTAWY Z 2005 r.

MNIEJSZOŚĆ LITEWSKA

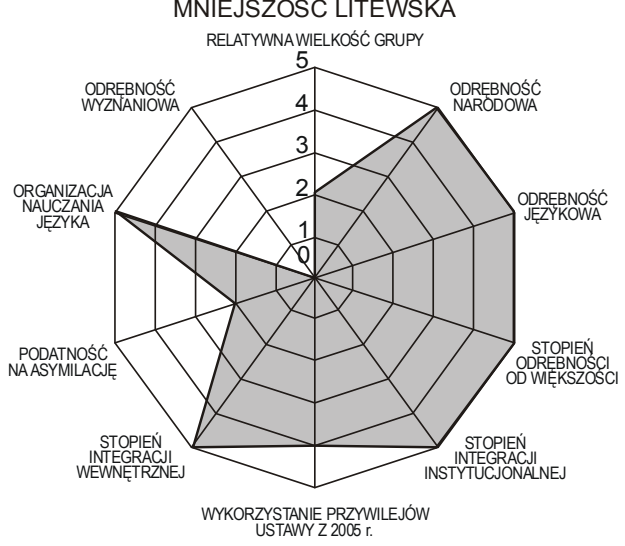

4 - duża/y, liczna;

5 - bardzo dużaly, bardzo dobra

Ryc. 45. Zróżnicowanie ocen poszczególnych cech obrazujących współczesną sytuację Ukraińców, Łemków, Białorusinów i Litwinów według wybranych kryteriów geograficznych, politycznych i społecznych Źródło: opracowanie własne

Porównanie sytuacji Litwinów i Białorusinów pokazuje, że zwarte zamieszkiwanie regionu nadgranicznego, w bezpośredniej bliskości własnego państwa 
macierzystego, nie gwarantuje pozytywnego wsparcia zagranicznej ojczyzny. Czynnikami decydującymi są stosunki polityczne między władzami państwa zamieszkania i państwa macierzystego, ich potencjał gospodarczy, funkcja pełniona przez granicę międzypaństwową, związana z tym jej „przepuszczalność” oraz rodzaj relacji transgranicznych, a także charakter więzi między mniejszością i rodakami w państwie narodowym.

Z kolei porównanie sytuacji Ukraińców, Łemków i Białorusinów dowodzi, że wbrew stereotypom nie zawsze rozproszenie i niewielka liczebność zwiększają podatność na asymilację, a zamieszkiwanie zwartego terytorium ułatwia utrzymanie odrębności narodowej. Żyjący od kilkudziesięciu lat w silnym rozproszeniu Ukraińcy i Łemkowie mają współcześnie silniejsze poczucie tożsamości i odrębności narodowej, aktywniejsze organizacje, lepiej zorganizowane szkolnictwo niż liczniejsi i zwarci terytorialnie Białorusini, którzy - jeżeli jeszcze nie powszechnie, to $\mathrm{z}$ pewnością $\mathrm{w}$ dużej części - przekształcają się z mniejszości narodowej w regionalną grupę polskiej ludności prawosławnej.

Także znaczenie zróżnicowania religijnego mniejszości narodowych oraz większości w danym państwie odbiega niekiedy od stereotypowych wyobrażeń. Co prawda w przypadku Białorusinów jest ono podstawą odrębności, nie tylko wyznaniowej, ale przede wszystkim kulturowej i cywilizacyjnej, a dla Ukraińców i Łemków odgrywa ważną rolę integrującą i wyróżniającą oraz jest istotnym czynnikiem kształtowania tożsamości narodowej. Natomiast brak różnic wyznaniowych między Litwinami a Polakami nie jest czynnikiem integrującym, a wspólne wyznanie, paradoksalnie, nie zbliża, lecz dzieli oba narody. Powodem sporów była, i nadal jest, kwestia języka nabożeństw odgrywającego rolę „dystansu kulturowego" i bardzo skutecznie podkreślającego odrębność mniejszości litewskiej od większości polskiej. W ciągu ostatnich kilkudziesięciu lat był on głównym czynnikiem konfliktogennym na pograniczu polsko-litewskim. Konflikty etniczne, które na ogół są niepożądane i destabilizujące, z punktu widzenia mniejszości mogą także pełnić funkcję pozytywną - jednoczyć i mobilizować grupę. Sytuacje kryzysowe i konfliktowe, stając się z czasem częścią narodowej mitologii i wspólnego dziedzictwa, wpływają wzmacniająco i aktywizująco, co pokazują także przykłady Ukraińców i Łemków.

Przedstawione powyżej elementy wspólne dla wszystkich lub większości spośród omawianych mniejszości z reguły zostały ukształtowane w długim procesie historycznym, wspólnego funkcjonowania na ziemiach polskich Ukraińców, Łemków, Białorusinów i Litwinów. Z kolei liczne czynniki różnicujące, są konsekwencją przeobrażeń politycznych i społecznych ostatnich kilkudziesięciu lat. Dlatego można przypuszczać, że z upływem czasu te różnice będą się pogłębiać. 


\section{WNIOSKI}

Powszechność procesów globalizacji i unifikacji społecznej oraz dominacji kultury masowej wywołuje potrzebę przynależności do lokalnej ojczyzny, a postępująca integracja polityczna i gospodarcza Europy zwrot ku etniczności, wzrost zainteresowania problematyką, często niewielkich, wspólnot narodowych, kulturowych i regionalnych. W Europie Środkowej i Wschodniej powrót do tematyki etnicznej został dodatkowo zintensyfikowany przemianami geograficzno-politycznymi oraz geopolitycznymi początku lat 90. XX w. Problematyka zróżnicowania narodowego, w warunkach totalitaryzmu thumiona, marginalizowana lub całkowicie pomijana, stała się elementem polityki wewnętrznej i zagranicznej poszczególnych państw. Harmonijne relacje pomiędzy różnymi grupami narodowymi w krajach komunistycznych okazały się kolejnym propagandowym mitem, którego upadek doprowadził do dezintegracji wielonarodowych państw oraz licznych konfliktów zbrojnych na Bałkanach i obszarze byłego ZSRR.

W przypadku Polski przejście od obrazu jednolitego etnicznie społeczeństwa do uznania jego zróżnicowania oraz upodmiotowienie mniejszości narodowych i związana $\mathrm{z}$ tym ich obecność w życiu publicznym, z powodu niewielkiej liczebności i rozproszenia poszczególnych mniejszości wywołało zainteresowanie zwłaszcza wśród naukowców, a emocje głównie w społecznościach lokalnych. Ukraińcy, Łemkowie, Białorusini i Litwini, z racji niewielkiego potencjału demograficznego, gospodarczego i politycznego nie stanowią zagrożenia dla integralności terytorialnej i politycznej Polski ani dla dominacji polskiego języka i kultury. Wręcz przeciwnie - to państwo polskie ze swoim potencjałem ludnościowym, ekonomicznym, kulturowym, językowym, medialnym, systemem szkolnictwa oraz nacjonalistycznym nastawieniem części społeczeństwa jest realnym zagrożeniem dla odrębności narodowej i kulturowej nielicznych oraz rozproszonych mniejszości.

Mimo pewnych różnic, wszystkie omawiane mniejszości są silnie zintegrowane ze społeczeństwem polskim, według integracji rozumianej ,jako branie udziału w życiu większości i współtworzeniu kultury większości bez porzucania własnych wzorów" (Budyta-Budzyńska 2010). Nie są to grupy izolowane w rozumieniu geograficznym (w pewnym stopniu dotyczy to tylko Litwinów), politycznym, społecznym, kulturowym lub gospodarczym. 
O powszechnych, zwłaszcza w socjologii, modelach integracji grup mniejszościowych można mówić m.in. wobec muzułmanów w zachodniej Europie, Romów w środkowej Europie lub Wietnamczyków w Polsce, ale z pewnością nie wobec mieszkających w Polsce Ukraińców, Łemków, Białorusinów czy Litwinów.

Mimo to Polska, choć w stopniu dużo mniejszym niż zachodnia Europa, nie uniknie wielokulturowości, gdyż żadna z omawianych mniejszości w całości nie wyemigruje ani całkowicie się nie zasymiluje. Jednak realnie istniejąca wielonarodowość jest zjawiskiem marginalnym, a Polska, mimo przekształceń polityczno-ustrojowych ostatnich lat, nadal jest jednym z najbardziej homogenicznych państw narodowych na świecie.

Postawione na początku pracy hipotezy zostały zweryfikowane pozytywnie. Nadrzędnym czynnikiem warunkującym przekształcenia narodowościowe Polski po 1944 r. była i nadal jest polityka państwa wobec mniejszości narodowych, zarówno w aspekcie negatywnym (do 1989 r.), jak i pozytywnym (od początku lat 90. XX w.). Bezpośrednią konsekwencją decyzji politycznych ostatnich kilkudziesięciu lat były zasadnicze zmiany rozmieszczenia, stopnia koncentracji terytorialnej i liczebności mniejszości narodowych oraz uwarunkowań ich sytuacji prawnej i instytucjonalnej. W polityce tej bardzo dużą rolę odgrywały mniej lub bardziej uzasadnione - obawy władz wobec niektórych mniejszości (zwłaszcza Ukraińców) lub przychylność wobec innych (np. Białorusinów). Zróżnicowane oceny potencjalnego zagrożenia lub potencjalnej „przydatności” poszczególnych mniejszości powodowały zróżnicowaną politykę państwa wobec wszystkich członków danej zbiorowości.

Dyskryminacyjne i asymilacyjne posunięcia władz PRL wobec mniejszości narodowych i etnicznych miały przyzwolenie, a niekiedy wyraźne poparcie społeczne (m.in. powojenne wysiedlenia czy kampania antysemicka w $1956 \mathrm{r}$. oraz 1968 r.). Często było ono konsekwencją nacjonalistycznej retoryki władz, wielokrotnie skutecznie wykorzystywanej wobec przeciwników politycznych oraz służącej kierowaniu niezadowolenia społecznego przeciwko ludności niepolskiej. Także ugrupowania opozycyjne wobec władz zarówno zbrojne w latach $40 . \mathrm{XX}$ w., jak i polityczne w latach 80 . tegoż wieku miały negatywny lub, w najlepszym przypadku, obojętny stosunek wobec mniejszości narodowych, tylko sporadycznie podejmując działania, które świadczyły o tym, że dostrzegają obywateli polskich niepolskiej narodowości ${ }^{1}$. Z kolei poszczególne mniejszości

${ }^{1}$ Do nielicznych wyjątków należy m.in. przyjęcie uchwały w sprawie mniejszości narodowych na I Zjeździe „Solidarności” w 1981 r. czy kampania wyborcza w 1989 r. i umieszczenie działaczy ukraińskich na listach wyborczych Komitetu Obywatelskiego przy Lechu Wałęsie. 
narodowe traktowały nieufnie i niechętnie opozycję polityczną lat 80 . XX w., głównie z powodu postrzegania jej jako ruchu narodowo-polskiego i katolickiego. Wyjątkiem była część liderów środowiska ukraińskiego wywodzących się $\mathrm{z}$ ruchów studenckich o nastawieniu antykomunistycznym.

Od początku lat 90. ubiegłego wieku sytuacja polityczno-prawna mniejszości narodowych wyraźnie zmieniła się na korzyść, nastąpiło ich upodmiotowienie i pluralizacja instytucjonalna. Towarzyszyły temu zmiany postaw mniejszości oraz ich relacji z większością polskiego społeczeństwa. Omawiane narodowości w różny sposób wykorzystały nowe uwarunkowania prawne, polityczne i ekonomiczne. Zależało to głównie od ich koncentracji terytorialnej (czynnik dużo istotniejszy niż sama liczebność), stopnia odrębności od polskiej większości (narodowej, językowej, wyznaniowej, kulturowej), wewnętrznej integracji (zwłaszcza instytucjonalnej), aktywności (zarówno elit, jak i członków mniejszości), relacji z zagraniczną ojczyzną (ich intensywności i charakteru).

Zbiorowości o silnej koncentracji terytorialnej, wyraźnej odrębności narodowej i językowej, dobrze rozwiniętym szkolnictwie, zintegrowane organizacyjnie, wspierane przez instytucje i rodaków z państwa macierzystego (Litwini) potrafią wykorzystać przywileje prawne (zwłaszcza wynikające z przepisów Ustawy o mniejszościach narodowych i etnicznych oraz o języku regionalnym) i mimo niewielkiej liczebności są $\mathrm{w}$ stanie utrzymać własną odrębność i tożsamość. Mniejszości rozproszone w wyniku przesiedleń (Ukraińcy), które jeszcze dodatkowo są podzielone i zróżnicowane pod względem tożsamości narodowej oraz rozbite instytucjonalnie (Łemkowie), borykają się z większymi problemami organizacyjnymi (dotyczącymi działalności stowarzyszeń i szkolnictwa czy uczestnictwa we władzach samorządowych), mają zdecydowanie mniejsze możliwości korzystania z przywilejów prawnych, są w większym stopniu narażone na asymilację. Mimo tych niekorzystnych uwarunkowań, podczas spisów ludności w pierwszej dekadzie XXI w. zanotowano wzrost deklaracji narodowości ukraińskiej oraz łemkowskiej. Z kolei nawet relatywnie duża liczebność, koncentracja terytorialna oraz bezpośrednia bliskość zagranicznej ojczyzny (Białorusini) nie gwarantują utrzymania odrębności narodowej. Głównymi przeszkodami jest bierność i podatność na asymilację, niewielki stopień integracji grupowej (poza silną integracją wyznaniową) oraz brak wsparcia i identyfikacji z zagraniczną ojczyzną.

Mniejszości narodowe - z definicji - nie mają w skali kraju pozycji dominującej. W Polsce, podobnie jak w wielu innych państwach, większość narodowa narzuca standardy prawne, obyczajowe, kulturowe. W warunkach państwa demokratycznego dominacja większości nie musi oznaczać dyskryminacji i upośledzenia mniejszości, wskazuje raczej na jej naturalną przewagę demogra- 
ficzna, językową, polityczną i kulturową. Państwo zapewnia obywatelom równe prawa, zabrania dyskryminacji, jednocześnie wymagając od wszystkich, także od obywateli innej narodowości, lojalności i przestrzegania obowiązującego prawa. Jednak równość polityczno-prawna nie jest równoznaczna z faktyczną równością w zakresie używania języka, kultywowania obyczajów i narzucania wzorców kulturowych, szczególnie w przypadku tak wyraźnej jak w Polsce dysproporcji liczebnej pomiędzy narodem dominującym a poszczególnymi mniejszościami.

Dlatego mniejszości narodowych i etnicznych żyjących w warunkach państwa narodowego nie wystarczy tolerować, trzeba je dodatkowo chronić i wspierać. Dotyczy to także realiów polityczno-prawnych demokratycznej i liberalnej Polski. Jak powiedział na początku XIX w. czwarty prezydent USA, James Madison, „większość może lekceważyć interesy i prawa mniejszości, dlatego wymagają one ochrony nawet w demokracji”. Mimo upływu 200 lat słowa te nadal zachowują aktualność. Odrębną kwestią są wzajemne relacje między narodem dominującym a poszczególnymi mniejszościami. Tylko w niewielkim stopniu są one uzależnione od zapisów prawnych i działań administracji państwowej, a zmiany postaw społecznych wśród większości i mniejszości są procesem powolnym i długotrwałym, silnie obarczonym stereotypami i historią.

Zamieszkujący współczesną Polskę Ukraińcy, Łemkowie, Białorusini i Litwini są częścią historycznego, kulturowego i politycznego dziedzictwa Rzeczypospolitej Obojga Narodów, dziedzictwa, z którego pod koniec XX w. wyodrębniły się niepodległe państwa - Polska, Ukraina, Białoruś i Litwa. Są świadectwem dawnej złożoności i wielokulturowości Polski, częścią jej historii, teraźniejszości i - należy mieć nadzieję, że także - przyszłości. Należą do mniejszości autochtonicznych, które mimo że „inne”, odrębne pod względem tożsamości narodowej, językowej czy wyznaniowej, są „u siebie”, z wszelkimi wynikającymi z tego prawami i obowiązkami. 


\section{LITERATURA}

Adamczuk L., 2006, Koncepcje metodologiczne badania „narodowości” w polskich spisach powszechnych (1921-2002), [w:] Adamczuk L., Łodziński S. (red.), Mniejszości narodowe w Polsce w świetle Narodowego Spisu Powszechnego z 2002 roku, Warszawa, s. 63-88.

Andreson B., 1997, Wspólnoty wyobrażone. Rozważania o źródłach i rozprzestrzenianiu się nacjonalizmu, Warszawa.

Ardener E.A., 1992, Tożsamość i utożsamianie, [w:] Mach Z., Paluch A. (red.), Sytuacja mniejszościowa i tożsamość, Kraków, s. 21-42.

Atlas gwar wschodniosłowiańskich Białostocczyzny, 1980, Glinka S., ObrębskaJabłońska A., Siatkowski J. (red.), t. 1, Wrocław-Warszawa-Kraków-Gdańsk.

Babiński G., 1980, Perspektywy ogólnej teorii stosunków etnicznych, [w:] Kubiak H., Paluch A. (red.), Założenia teorii asymilacji, Wrocław, s. 79-94.

Babiński G., 1997, Pogranicze polsko-ukraińskie. Etniczność, zróżnicowanie religijne, tożsamość, Kraków.

Babiński G., 1998, Metodologiczne problemy badań etnicznych, Kraków.

Babiński G., 2004a, Metodologia a rzeczywistość społeczna. Dylematy badań etnicznych, Kraków.

Babiński G., 2004b, Mniejszości narodowe i etniczne w Polsce w świetle spisu ludności z roku 2002, „Studia Socjologiczne”, 1 (172), s. 139-152.

Baczwarow M., Suliborski A., 2002, Kompendium wiedzy o geografii politycznej i geopolityce. Terminologia, Warszawa.

Bański J., 2008a, Polska i Europa Środkowo-Wschodnia $w$ koncepcjach podziału Europy, [w:] Eberhardt P. (red.), Problematyka geopolityczna ziem polskich, Prace Geograficzne, 218, Warszawa, s. 121-134.

Bański J., 2008b, Wschodnia Polska - rubieże Zachodu, poczqtek Wschodu, czy fragment Środkowej Europy?, [w:] Świątek D., Bednarek M., Siłka P. (red.), Współczesne problemy badawcze geografii polskiej - geografia człowieka, Dokumentacja Geograficzna, 36, Warszawa, s. 15-20.

Barbag J., 1987, Geografia polityczna ogólna, Warszawa.

Barwiński M., 1995, Łemkowie $i$ Łemkowszczyzna, praca magisterska napisana w Katedrze Geografii Politycznej i Studiów Regionalnych UŁ (promotor M. Sobczyński), Łódź.

Barwiński M., 1998, Tożsamość etniczna, kulturowa i religijna Łemków, „Kwartalnik Geograficzny", 4 (98), s. 5-10.

Barwiński M., 1999, Współczesna tożsamość etniczna i kulturowa Łemków na obszarze Łemkowszczyzny - uwarunkowania i konsekwencje, „Acta Universitatis Lodziensis, Folia Geographica Socio-Oeconomica”, 2, Łódź, s. 53-69. 
Barwiński M., 2001a, Stereotypy narodowościowo-religijne na Podlasiu, [w:] Lesiuk W., Trzcielińska-Polus A. (red.), Colloquium Opole 2000 - Stereotypy i uprzedzenia w stosunkach między Polakami, Niemcami i Czechami, Opole, s. 192-199.

Barwiński M., 2001b, Reasons and consequences of depopulation in Lower Beskid (the Carpathian Mountains) in the years 1944-1947, [w:] Wendt J., Ilieş A. (red.), Chosen problems of political geography in Central Europe, Gdańsk, s. 27-32.

Barwiński M., 2001c, Contemporary national and religious diversification of inhabitants of the Polish-Belorussian borderland - the case of Hajnówka district, [w:] Koter M., Heffner K. (red.), Changing role of border areas and regional policies, „Region and Regionalism”, No. 5, Opole-Łódź, s. 180-184.

Barwiński M., 2001d, „Tolerant borderland” - relations between multi-ethnic rural communities of Podlasie, [w:] Ilieş A., Bodocan V. (red.), Minorities in Central and Eastern Europe, „Revista Romana de Geografie Politica”, No. 2, Oradea, s. 63-72.

Barwiński M., 2002a, Pogranicze w aspekcie geograficzno-socjologicznym - zarys problematyki, „Acta Universitatis Lodziensis, Folia Geographica Socio-Oeconomica”, 4, Łódź, s. 11-23.

Barwiński M., 2002b, Wpływ zmian politycznych na kontakty Łemków (Rusnaków) z polskiej i stowackiej strony Karpat, „Acta Facultatis Studiorum Humanitatis et Naturae Universitatis Prešoviensis, Folia Geographica", 6, Prešov, s. 9-16.

Barwiński M., 2003, Lemkos as a small relict nation, [w:] Koter M., Heffner K. (red.), The role of ethnic minorities in border regions, „Region and Regionalism”, No. 6, vol. 1, Łódź-Opole, s. 39-47.

Barwiński M., 2004a, Podlasie jako pogranicze narodowościowo-wyznaniowe, Łódź.

Barwiński M., 2004b, Pojęcie narodu oraz mniejszości narodowej i etnicznej w kontekście geograficznym, politycznym i socjologicznym, „Acta Universitatis Lodziensis, Folia Geographica Socio-Oeconomica", 5, Łódź, s. 59-74.

Barwiński M., 2005a, Współczesne stosunki narodowościowo-religijne na Podlasiu, [w:] Malikowski M., Wojakowski D. (red.), Granice i pogranicza nowej Unii Europejskiej. Z badan regionalnych, etnicznych i lokalnych, Kraków, s. 172-194.

Barwiński M., 2005b, Struktura narodowościowa i językowa mieszkańców południowo-wschodniej części województwa podlaskiego - porównanie wyników badań terenowych i Narodowego Spisu Powszechnego, „Pogranicze. Studia Społeczne”, 12, s. 6784.

Barwiński M., 2005c, The contemporary ethnic and religious borderland in Podlasie Region, [w:] Koter M., Heffner K. (red.), Historical, ethnic and geographical problems of borderlands, „Region and Regionalism”, No. 7, vol. 2, Opole-Łódź, s. 81-90.

Barwiński M., 2006a, Liczebność i rozmieszczenie mniejszości narodowych i etnicznych w Polsce w 2002 roku a wcześniejsze szacunki, [w:] Bieńkowska-Ptasznik M., Krzysztofek K., Sadowski A. (red.), Obywatelstwo i tożsamość w społeczeństwach zróżnicowanych kulturowo i na pograniczach, t. 1, Białystok, s. 345-370.

Barwiński M., 2006b, Przyczyny i konsekwencje zmian zaludnienia Łemkowszczyzny $w X X$ wieku, ,Acta Facultatis Studiorum Humanitatis et Naturae Universitatis Prešoviensis, Folia Geographica”, 10, Prešov, s. 36-42. 
Barwiński M., 2008a, Konsekwencje zmian granic i przeksztatceń politycznych po II wojnie światowej na liczebność i rozmieszczenie Ukraińców, Łemków, Białorusinów i Litwinów w Polsce, [w:] Eberhardt P. (red.), Problematyka geopolityczna ziem polskich, Prace Geograficzne, 218, Warszawa, s. 217-236.

Barwiński M., 2008b, Wpływ granic oraz uwarunkowań politycznych na zmiany struktury narodowościowej i wyznaniowej na przykładzie Podlasia, [w:] Kulesza M. (red.), Czas i przestrzeń $w$ naukach geograficznych. Wybrane problemy geografii historycznej, Łódź, s. 48-65.

Barwiński M., 2009a, Rozmieszczenie i liczebność Łemków w Polsce na podstawie wyników spisu powszechnego z 2002 roku - uwarunkowania i kontrowersje, [w:] Dudra S., Halczak B., Betko I., Smigiel M. (red.), Łemkowie, Bojkowie, Rusini historia, współczesność, kultura materialna i duchowa, t. 2, Zielona Góra, s. 15-28.

Barwiński M., 2009b, The contemporary Polish-Ukrainian borderland - its political and national aspect, [w:] Sobczyński M. (red.), Historical regions divided by the borders. General problems and regional issue, „Region and Regionalism”, No. 9, vol. 1, Łódź-Opole, s. 187-208.

Barwiński M., 2009c, Mniejszość litewska na tle przemian politycznych Polski po II wojnie światowej, [w:] Kulesza M. (red.), Geografia historyczna jako determinanta rozwoju nauk humanistycznych, Legnica-Lódź, s. 48-65.

Barwiński M., 2010, Changes in the social, political and legal situation of national and ethnic minorities in Poland after 1990, [w:] Kitowski J. (red.), 20 years of socio-economic transformations in countries of Central and Eastern Europe - an attempt of accounts, „Geopolitical Studies”, vol. 16, Warszawa, s. 223-244.

Barwiński M., 2011, Ukraińcy na Podlasiu - geneza, kontrowersje, współczesność, „Acta Universitatis Lodziensis, Folia Geographica Socio-Oeconomica”, 11, Łódź, s. $123-144$.

Barwiński M., 2012, Łemkowszczyzna jako region etniczno-historyczny, [w:] Pawłowska A., Rykiel Z. (red.), Region i regionalizm w socjologii i politologii, Rzeszów, s. 136154.

Barwiński M., Leśniewska K., 2011, Lemko region - historical region in the Polish-Slovakian borderland, [w:] Heffner K. (red.), Historical regions in the structures of European Union, „Region and Regionalism”, No. 10, vol. 2, Łódź-Opole, s. 131154.

Berdychowska B. (red.), 1998, Mniejszości narodowe w Polsce. Praktyka po 1989 r., Warszawa.

Bergman A., 1984, Sprawy białoruskie w II Rzeczypospolitej, Warszawa.

Beauvois D., 2000, Rzeczpospolita polsko-litewska $w$ XVIII wieku i pięć narodów na jej obszarach w wieku XIX, [w:] Kłoczowski J. (red.), Historia Europy Środkowo-Wschodniej, t. 1, Lublin, s. 244-317.

Bieńkowska-Ptasznik M., 2007, Polacy - Litwini - Białorusini. Przemiany stosunków etnicznych na pólnocno-wschodnim pograniczu Polski, Białystok.

Bokszański Z., 1995, Obrazy narodów i grup etnicznych $w$ perspektywie historycznej, [w:] Starosta P. (red.), Zbiorowości terytorialne i więzi społeczne. Studia i szkice socjologiczne, Łódź, s. 29-35. 
Bokszański Z., 1996, Tożsamość narodowa: pojęcie i problematyka badawcza, [w:] Czyżewski M., Piotrowski A., Rokuszewska-Pawełek A. (red.), Biografia a tożsamość narodowa, Łódź, s. 27-34.

Borzyszkowski J., Mordawski J., Treder J., 1999, Historia, geografia, język i piśmiennictwo Kaszubów, Gdańsk.

Brubaker R., 1998, Nacjonalizm inaczej. Struktura narodowa i kwestie narodowe w nowej Europie, Warszawa-Kraków.

Buchowski S., 2004, Ziemia sejneńsko-suwalska 1918-1920, Sejny.

Budyta-Budzyńska M., 2003, Mniejszości narodowe - bogactwo czy problem? Instytucjonalizacja mniejszości narodowych w Polsce w latach 1989-2002, Warszawa.

Budyta-Budzyńska M., 2010, Socjologia narodu i konfliktów etnicznych, Warszawa.

Budzyński Z., 1992, Struktura terytorialna i stan wiernych Kościoła unickiego na Łemkowszczyźnie w XVIII wieku, [w:] Czajkowski J. (red.), Łemkowie $w$ historii i kulturze Karpat, Rzeszów, s. 267-285.

Burszta W., Jaskułowski K., 2005, Mniejszości narodowe i etniczne a idea państwa narodowego na poczqtku XXI wieku, [w:] Nijakowski L. (red.), Polityka państwa polskiego wobec mniejszości narodowych i etnicznych, Warszawa, s. 13-34.

Byczkowski J., 1976, Mniejszości narodowe w Europie 1945-1974 (wybrane zagadnienia), Opole.

Chałasiński J., 1966, Zagadnienie narodu, „Przegląd Socjologiczny”, 20, s. 40-41.

Chałupczak H., 2006, Liczba mniejszości narodowych $i$ etnicznych $w$ Polsce $w$ świetle powszechnego spisu ludności z 2002 roku oraz badań naukowych, [w:] Michalik E., Chałupczak H. (red.), Mniejszości narodowe $i$ etniczne $w$ procesach transformacji oraz integracji, Lublin, s. 263-270.

Chałupczak H., Browarek T., 1998, Mniejszości narodowe w Polsce 1918-1995, Lublin.

Chlebowczyk J., 1983, O prawie do bytu matych $i$ młodych narodów, WarszawaKraków.

Chodkiewicz A., 1984, Zarys historii Kościoła greckokatolickiego, Warszawa.

Czajkowski J., 1992, Dzieje osadnictwa historycznego na Podkarpaciu i jego odzwierciedlenie w grupach etnicznych, [w:] Czajkowski J. (red.), Łemkowie w historii i kulturze Karpat, Rzeszów, s. 27-167.

Czykwin E., 2010, Białoruska mniejszość narodowa. Problem asymilacji w kontekście stygmatu społecznego, [w:] Zaniewska T. (red.), Białorusini, Warszawa, s. 29-46.

Darski J., 1994, Białoruś. Historia, współczesność, konflikty narodowe, Warszawa.

Davies N., 2001, Boże Igrzysko. Historia Polski, Kraków.

Dmowski R., 1907, Myśli nowoczesnego Polaka, Lwów.

Domagała B., 1996, Mniejszość niemiecka na Warmii i Mazurach. Rodowód kulturowy, organizacja, tożsamość, Olsztyn.

Drozd R., 1997, Droga na zachód. Osadnictwo ludności ukraińskiej na ziemiach zachodnich i pótnocnych Polski w ramach akcji „Wisła”, Warszawa.

Drozd R., 1998, Ukraincy w Polsce $w$ okresie przełomów politycznych 1944-1981, [w:] Madajczyk P. (red.), Mniejszości narodowe w Polsce. Państwo i społeczeństwo polskie a mniejszości narodowe w okresach przetomów politycznych (1944-1989), Warszawa, s. 180-244. 
Drozd R., 2001, Polityka władz wobec ludności ukraińskiej w Polsce w latach 19441989, Warszawa.

Drozd R., 2007, Powojenne wysiedlenia Łemków polskich w latach 1944-1950, [w:] Dudra S., Halczak B., Ksenicz A., Starzyński J. (red.), Łemkowie, Bojkowie, Rusinihistoria, współczesność, kultura materialna i duchowa, t. 1, Legnica-Zielona Góra, s. $131-142$.

Drozd R., 2010, Ukraincy (do 1989 r.), [w:] Dudra S., Nitschke B. (red.), Mniejszości narodowe i etniczne w Polsce po II wojnie światowej, Kraków, s. 91-112.

Drozd R., 2011, Władze wobec powrotów ludności ukraińskiej na teren południowo-wschodniej Polski w 1947 r., [w:] Hytrek-Hryciuk J., Strauchold G., Syrnyk J. (red.), Internacjonalizm czy? Działania organów bezpieczeństwa państw komunistycznych wobec mniejszości narodowych (1944-1989), Warszawa-Wrocław, s. 60-76.

Drozd R., Halczak B., 2010, Dzieje Ukraińców w Polsce w latach 1921-1989, Warszawa.

Duć-Fajfer H., 1992, Łemkowie w Polsce, [w:] Magury'91, Warszawa, s. 11-31.

Dudra S., 2004, Kościót prawosławny na ziemiach zachodnich i północnych Polski po II wojnie światowej, Zielona Góra.

Dudra S., 2007, Łemkowie wobec przemian politycznych po 1956 roku, [w:] Dudra S., Halczak B., Ksenicz A., Starzyński J. (red.), Łemkowie, Bojkowie, Rusini - historia, współczesność, kultura materialna i duchowa, t. 1, Legnica-Zielona Góra, s. 143-156.

Dudra S., 2008, Poza mała ojczyznq. Łemkowie na Ziemi Lubuskiej, Wrocław.

Dudra S., 2009, Łemkowie w III Rzeczpospolitej, [w:] Dudra S., Halczak B., Betko I., Smigiel M. (red.), Łemkowie, Bojkowie, Rusini - historia, współczesność, kultura materialna i duchowa, t. 2, Zielona Góra, s. 39-52.

Dudra S., 2010, Łemkowie, [w:] Dudra S., Nitschke B. (red.), 2010, Mniejszości narodowe i etniczne w Polsce po II wojnie światowej, Kraków, s. 256-287.

Dudra S., Nitschke B. (red.), 2010, Mniejszości narodowe i etniczne w Polsce po II wojnie światowej, Kraków.

Dziewoński K., Kosiński L., 1967, Rozwój i rozmieszczenie ludności Polski w XX wieku, Warszawa.

Eberhardt P., 1993, Polska granica wschodnia 1939-1945, Warszawa.

Eberhardt P., 1994a, Przemiany narodowościowe na Białorusi, Warszawa.

Eberhardt P., 1994b, Przemiany narodowościowe na Ukrainie XX wieku, Warszawa.

Eberhardt P., 1996, Między Rosja a Niemcami, Warszawa.

Eberhardt P., 1997, Problematyka demograficzna pogranicza polsko-litewskiego, „Przegląd Geograficzny", 69 (1-2), s. 28-51.

Eberhardt P., 1998, Przemiany narodowościowe na Litwie, Warszawa.

Eberhardt P., 2004a, Polska i jej granice. Z historii polskiej geografii politycznej, Lublin.

Eberhardt P., 2004b, Koncepcja granicy między cywilizacja zachodniego chrześcijaństwa a bizantyjska na kontynencie europejskim, „Przegląd Geograficzny”, 76 (2), s. $169-187$.

Eberhardt P., 2006, Przemiany struktury etnicznej ludności Polski w XX wieku, „Sprawy Narodowościowe. Seria Nowa", 28, s. 53-74. 
Eberhardt P., 2008, Struktura narodowościowa ludności Polski, „Rocznik Nauk Społecznych, 36 (1), s. 145-170.

Eberhardt P., 2009, Liczebność i rozmieszczenie ludności ukraińskiej na przełomie XX i XXI wieku, „Sprawy Narodowościowe. Seria Nowa”, 35, s. 49-64.

Eberhardt P., 2010a, Migracje polityczne na ziemiach polskich (1939-1950), Poznań.

Eberhardt P., 2010b, Osiagnięcia naukowe polskiej geografii narodowości, „Czasopismo Geograficzne", 81 (3), s. 139-152.

Falkowski J., Pasznycki B., 1935, Na pograniczu łemkowsko-bojkowskim, Lwów.

Fionik D., 2006, 50 lat 1956-2006. Białoruskie Towarzystwo Społeczno-Kulturalne, Białystok.

Flick U., 2012, Projektowanie badania jakościowego, Warszawa.

Galicki Z., 2005, Prawnomiędzynarodowy kontekst ochrony mniejszości narodowych w Polsce, [w:] Nijakowski L. (red.), Polityka państwa polskiego wobec mniejszości narodowych i etnicznych, Warszawa, s. 51-76.

Gawryszewski A., 1969, Polskie mapy narodowościowe, wyznaniowe i językowe. Bibliografia (lata 1827-1967), Dokumentacja Geograficzna, 4, Warszawa.

Gawryszewski A., 1995, Mapy narodowościowe, wyznaniowe i językowe Polski wykonane przez autorów obcych. Bibliografia (lata 1846-1967), Dokumentacja Geograficzna", 3, Warszawa.

Gawryszewski A., 2005, Ludność Polski w XX wieku, Warszawa.

Gawryszewski A., 2008, Historia geografii ludności, [w:] Jackowski A., Liszewski S., Richling A. (red.), Historia geografii polskiej, Warszawa, s. 176-194.

Gellner E., 1991, Narody $i$ nacjonalizm, Warszawa.

Gloger Z., 1903, Geografia historyczna ziem dawnej Polski, Kraków.

Goetel W., 1935, O Łemkowszczyźnie, Kraków.

Goluba R., 2004, Niech nas rozsqdzi miecz i krew..., Poznań.

Gomółka K., 1992, Białorusini w II Rzeczypospolitej, Gdańsk.

Gomółka K., 1994, Między Polskq a Rosja. Białoruś w koncepcjach polskich ugrupowań politycznych 1918-1922, Warszawa.

Goss K., 2001, Struktura wyznaniowa mieszkańców byłego województwa białostockiego, „Pogranicze. Studia Społeczne”, 10, s. 114-136.

Gudaszewski G., 2006, Demograficzno-społeczna charakterystyka obywateli polskich deklarujacych ,,narodowość niepolska” w Narodowym Spisie Powszechnym w 2002 roku, [w:] Adamczuk L., Łodziński S. (red.), Mniejszości narodowe w Polsce w świetle Narodowego Spisu Powszechnego z 2002 roku, Warszawa, s. 89-142.

Gudkova S., 2012, Wywiad w badaniach jakościowych, [w:] Jemielniak D. (red.), Badania jakościowe. Metody i narzędzia, t. 2, Warszawa, s. 111-130.

Halczak B., 2006, O konieczności prowadzenia badań porównawczych nad mniejszościami narodowymi w Europie Środkowo-Wschodniej, [w:] Halczak B. (red.), Mniejszości narodowe w Europie Środkowo-Wschodniej po upadku komunizmu, Zielona Góra, s. 9-16.

Halczak B., 2007, Problemy tożsamości narodowej Łemków, [w:] Dudra S., Halczak B., Ksenicz A., Starzyński J. (red.), Łemkowie, Bojkowie, Rusini - historia, współczesność, kultura materialna i duchowa, t. 1, Legnica-Zielona Góra, s. 41-56. 
Halczak B., 2009, „Karpatorusinizm” w polityce zagranicznej $i$ wewnętrznej państwa polskiego w XX w., [w:] Dudra S., Halczak B., Betko I., Smigiel M. (red.), Łemkowie, Bojkowie, Rusini - historia, współczesność, kultura materialna $i$ duchowa, t. 2 , Zielona Góra, s. 53-66.

Halczak B., 2010a, Ukraińcy (po 1989 r.), [w:] Dudra S., Nitschke B. (red.), 2010, Mniejszości narodowe i etniczne w Polsce po II wojnie światowej, Kraków, s. 113126.

Halczak B., 2010b, Absurd akcji ,Wisła”, [w:] Dudra S., Halczak B., Drozd R., Betko I., Smigiel M. (red.), Łemkowie, Bojkowie, Rusini. Historia, współczesność, kultura materialna i duchowa, t. 3, Zielona Góra-Słupsk, s. 47-58.

Hałagida I, 2002, Ukraińcy na ziemiach zachodnich i pólnocnych Polski 1947-1957, Warszawa.

Haase A., 2003, Ethnic minorities at the Polish eastern border between integration and exclusion - Current prospects and problems, [w:] Heffner K., Sobczyński M. (red.), The role of ethnic minorities in border regions, „Region and Regionalism”, No. 6, vol. 2, Łódź-Opole, s. 94-106.

Hawryluk J., 1993, Z dziejów cerkwi prawosławnej na Podlasiu w X-XVII wieku, Bielsk Podlaski.

Hawryluk J., 1995, Dlaczego „Białorusini” mówiq po ukraińsku? „Nad Buhom i Narwoju", 5, s. 32-35.

Hawryluk J., 1998, „Małorusy”, „biłorusy” czy ukrajinci? Kwestia narodowa na Podlasiu w XIX-XX wieku, „Nad Buhom i Narwoju”, 3-4, s. 43-45.

Hawryluk J., 1999, „Kraje ruskie Bielsk, Mielnik, Drohiczyn”. Rusini-Ukraincy na Podlaszu-fakty i kontrowersje, Kraków.

Hencock I., 1998, Plight of the Gypsies, niepublikowany wykład, Central European University, Budapest.

Holzer Z. 1989, Demografia, Warszawa.

Hołuszko M., 1993, Mniejszości narodowe $i$ etniczne w Polsce, „Społeczeństwo Otwarte", 2.

Horbal B., 2010, Lemko studies: a handbook, New York.

Hryciuk G., 2008, Ukraińcy, [w:] Sienkiewicz W., Hryciuk G. (red.), Wysiedlenia, wypędzenia i ucieczki 1939-1959. Atlas ziem Polski, Warszawa, s. 204-229.

Hryciuk G., 2011, Wysiedlenia jako instrument polityki narodowościowej w Polsce Ludowej w latach czterdziestych XX wieku, [w:] Hytrek-Hryciuk J., Strauchold G., Syrnyk J. (red.), Internacjonalizm czy...? Działania organów bezpieczeństwa państw komunistycznych wobec mniejszości narodowych (1944-1989), Warszawa-Wrocław, s. 51-59.

Huntington S.P., 1997, Zderzenie cywilizacji i nowy kształt ładu światowego, Warszawa. Jackowski A., Liszewski A., Richling A. (red.), 2008, Historia geografii polskiej, Warszawa.

Janusz G., 1993, Zagadnienia teorii i praktyki grup etnicznych, Lublin.

Janusz G., 2011, Ochrona praw mniejszości narodowych w Europie, Lublin.

Jasiewicz K., 1977, Czynniki asymilacji narodowej, „Przegląd Socjologiczny”, 29, s. 349-391. 
Jemielniak D. (red.), 2012, Badania jakościowe. Metody i narzędzia, t. 2, Warszawa.

Joseph B., 1929, Nationality: its nature and problems, New Haven.

Kabaczij R., 2012, Wygnani na stepy. Przesiedlenia ludności ukraińskiej z Polski na potudnie Ukrainy w latach 1944-1946, Warszawa.

Kalisz P., 2009, Podziemie litewskie na Suwalszczyźnie do 1950 r., [w:] Syrnik J. (red.), Aparat bezpieczeństwa Polski Ludowej wobec mniejszości narodowych i etnicznych oraz cudzoziemców, Warszawa, s. 103-117.

Kalisz P., Łapiński P., 2005, Polskie podziemie niepodległościowe wobec ludności białoruskiej na Białostocczyźnie po 1944 roku (zarys problematyki), [w:] Milewski J., Pyżewska A. (red.), Stosunki polsko-białoruskie w województwie białostockim w latach 1939-1956, Warszawa, s. 86-96.

Kazanecki P., 1998, Mniejszość białoruska, [w:] Berdychowska B. (red.), Mniejszości narodowe w Polsce. Praktyka po 1989 r., Warszawa, s. 178-208.

Kersten K., 1963, Migracje powojenne w Polsce. Próba klasyfikacji i ogólna charakterystyka zewnętrznych ruchów ludności, [w:] Polska Ludowa. Materiały i studia, t. 2, Warszawa, s. 3-26.

Kersten K., 1974, Ksztattowanie stosunków ludnościowych, [w:] Polska Ludowa 19441950. Przemiany spoleczne, Wrocław, s. 74-176.

Kępka P., 2009, Postawy polityczne ludności prawosławnej w województwie podlaskim, praca magisterska napisana w Katedrze Geografii Politycznej i Studiów Regionalnych UŁ (promotor M. Barwiński), Łódź.

Kępski R., 2006, Mniejszość litewska w Polsce wobec przełomów politycznych (19182004), praca magisterska napisana w Katedrze Geografii Politycznej i Studiów Regionalnych UŁ (promotor M. Barwiński), Łódź.

Kirpsza A., 2008, Mniejszości narodowe $i$ etniczne $w$ prawie międzynarodowym i polskim, [w:] Mniejszości narodowe i etniczne, Kraków, s. 7-36.

Kłoczowski J., 2000a, Europa Środkowo-Wschodnia w XIV-XVII wieku, [w:] Kłoczowski J. (red.), Historia Europy Środkowo-Wschodniej, t. 1, Lublin, s. 110-243.

Kłoczowski J., 2000b, Unia polsko-litewska, [w:] Kłoczowski J. (red.), Historia Europy Środkowo-Wschodniej, t. 2, Lublin, s. 80-87.

Kłoczowski J., 2000c, Unia brzeska, [w:] Kłoczowski J. (red.), Historia Europy Środkowo-Wschodniej, t. 2, Lublin, s. 113-118.

Kłoskowska A., 1995, Otwarte i zamknięte postawy narodowe w sytuacji pogranicza, „Kultura i Społeczeństwo”, 3, s. 8-17.

Kłoskowska A., 1996, Kultury narodowe u korzeni, Warszawa.

Komornicki T., 2008, Granica polsko-białoruska jako bariera przestrzenna, [w:] Świątek D., Bednarek M., Siłka P. (red.), Współczesne problemy badawcze geografii polskiej-geografia czlowieka, Dokumentacja Geograficzna, 36, Warszawa, s. 55-61.

Kosmala G., 1993, Zmiany granic politycznych w Europie Środkowej w okresie ostatnich stu lat, Wrocław.

Koter M, 1993, Geographical classifications of ethnic minorities, [w:] Gosar A. (red.), Geography and ethnicity, „Geographica Slovenica”, No. 24, Ljubljana, s. 123-138.

Koter M., 1995a, Ludność pogranicza - próba klasyfikacji genetycznej, „Acta Universitatis Lodziensis, Folia Geographica”, 20, Łódź, s. 239-246. 
Koter M., 1995b, A genetic classification of frontier peoples and multicultural border zones in Poland, Bohemia and Slovakia, [w:] Baran V. (red.), The boundaries and their impact on the territorial structure of region and state, „Acta Universitatis Mattiae Belii Banska Bystrica, Geopgraphical Studies”, 1, Banska Bystrica, s. 37-45.

Koter M., 1997, Kresy państwowe - geneza i wtaściwości w świetle doświadczeń geografii politycznej, [w:] Handke K. (red.), Kresy-pojęcie i rzeczywistość, Warszawa, s. 9-52.

Koter M., 1998, Frontier peoples - origin and classification, [w:] Koter M., Heffner K. (red.), Borderlands or transborder regions - geographical, social and political problems, „Region and Regionalism”, No. 3, Opole-Lódź, s. 28-38.

Koter M., 2003, Multicultural border regions of Europe - form of ethnic composition and process of their differentiation, [w:] Koter M., Heffner K. (red.), The role of ethnic minorities in border regions, „Region and Regionalism”, No. 6, vol. 1, ŁódźOpole, s. 13-22.

Koter M., Kulesza M., 2001, Geographical and historical grounds of formation of borders of former and present-day Poland, [w:] Koter M., Heffner K. (red.), Changing role of border areas and regional policies, „Region and Regionalism”, No. 5, Łódź-Opole, s. 165-179.

Kowalski M., 1998, Wyznanie a preferencje wyborcze mieszkańców Białostocczyzny (1990-1997), „Przegląd Geograficzny”, 70 (3-4), s. 269-282.

Kowalski M., 1999, Kulturowe uwarunkowania stosunków polsko-litewsko-białoruskich, [w:] Kitowski J. (red.), Problematyka geopolityczna Europy Środkowej i Wschodniej, Rozprawy i Monografie Wydziału Ekonomicznego, 18, filia UMSC, Rzeszów, s. 7788.

Kowalski M., 2000, Geografia wyborcza Polski. Przestrzenne zróżnicowanie zachowań wyborczych Polaków w latach 1989-1998, „Geopolitical Studies”, vol. 7, Warszawa.

Kowalski M., 2002, Mniejszość polska na Grodzieńszczyźnie, mniejszość białoruska na Białostocczyźnie, [w:] Sadowska-Snarska C. (red.), Problemy rozwoju przygranicznych regionów wschodniej Polski, Białystok, s. 89-106.

Kowalski M., 2008a, Państwa magnackie w przestrzeni polityczno-administracyjnej I Rzeczypospolitej, [w:] Kulesza M. (red.), Czas i przestrzeń w naukach geograficznych, Łódź, s. 33-48.

Kowalski M., 2008b, Wileńszczyzna jako problem geopolityczny w XX wieku, [w:] Eberhardt P. (red.), Problematyka geopolityczna ziem polskich, Prace Geograficzne, 218, Warszawa, s. 267-298.

Krakowski J., 1997, Geograficzno-polityczne aspekty akcji Wisła, praca magisterska napisana w Katedrze Geografii Politycznej i Studiów Regionalnych UŁ (promotor M. Sobczyński), Łódź.

Krasowski I., 1992, Problem autochtonizmu Rusinów w Beskidzie Niskim, [w:] Czajkowski J. (red.), Łemkowie w historii i kulturze Karpat, Rzeszów, s. 381-387.

Krochmal A., 1992, Stosunki między grekokatolikami i prawosławnymi na Łemkowszczyźnie w latach 1918-1939, [w:] Czajkowski J. (red.), Łemkowie w historii i kulturze Karpat, Rzeszów, s. 285-299.

Krysiński A., 1928, Liczba i rozmieszczenie Białorusinów w Polsce, „Sprawy Narodowościowe", 3-4, s. 351-378. 
Krysiński A., 1929, Liczba i rozmieszczenie Ukraińców w Polsce, odbitka ze „Spraw Narodowościowych", 6/1928.

Krysiński A., 1937, Ludność ukraińska (ruska) w Polsce w świetle spisu 1931, „Sprawy Narodowościowe”, 11 (6), s. 567-591.

Kurcz Z. (red.), 1997, Mniejszości narodowe w Polsce, Wrocław.

Kurcz Z., 2005, Mniejszość polska na Wileńszczyźnie, Wrocław.

Kusiak F., 1994, Akcja ,Wisła” 1947 rok, Wrocław.

Kvale S., 2011, Prowadzenie wywiadów, Warszawa.

Kwaśniewski K., 1992, Socjologia mniejszości a definicja mniejszości narodowej, „Sprawy Narodowościowe. Seria Nowa”, 1 (1).

Kwaśniewski K., 2005, Narody i mniejszości narodowe - koncerty patriotyzmów czy konflikty szowinizmów, [w:] Nijakowski L. (red.), Polityka państwa polskiego wobec mniejszości narodowych i etnicznych, Warszawa, s. 35-50.

Kwilecki A., 1963, Mniejszości narodowe w Polsce Ludowej, „Kultura i Społeczeństwo", 4, s. 85-103.

Kwilecki A., 1964, Problemy asymilacji mniejszości narodowych na Ziemiach Zachodnich na przykładzie Łemków, Warszawa.

Kwilecki A., 1970, Fragmenty najnowszej historii Łemków, Warszawa.

Kwilecki A., 1974, Łemkowie. Zagadnienia migracji i asymilacji, Warszawa.

Landau Z., Tomaszewski J., 1977, Druga Rzeczpospolita. Gospodarka - społeczeństwo - miejsce $w$ świecie, Warszawa.

Leszczycki S., 1935, Zarys antropologiczny Łemkowszczyzny, Kraków.

Lewandowski J., 1993, Narody, religie, państwa, mniejszości, [w:] Kłoczowski J. (red.), Mniejszości narodowe i religijne w Europie Środkowo-Wschodniej, Lublin.

Lis A., 2008, Pogranicze polsko-ukraińskie jako pogranicze narodowościowo-wyznaniowe, praca magisterska napisana w Katedrze Geografii Politycznej i Studiów Regionalnych UŁ (promotor M. Barwiński), Łódź.

Łesiów M. 1995, Ukraina wczoraj $i$ dziś, Lublin.

Łodziński S., 1998, Przekroczyć własny cień. Prawne, instytucjonalne oraz społeczne aspekty polityki państwa polskiego wobec mniejszości narodowych w latach 19891997, [w:] Berdychowska B. (red.), Mniejszości narodowe w Polsce. Praktyka po 1989 r., Warszawa, s. 11-82.

Łodziński S., 2002, Ochrona praw osób należacych do mniejszości narodowych i etnicznych - perspektywa europejska, Warszawa.

Łodziński S., 2005, Równość i różnica. Mniejszości narodowe w porzqdku demokratycznym w Polsce po 1989 roku, Warszawa.

Łodziński S., 2006a, Polityka i tożsamość narodowa. Wokół wybranych sporów dotyczacych przyjmowania ustawy o mniejszościach narodowych i języku regionalnym (2005), [w:] Bieńkowska-Ptasznik M., Krzysztofek K., Sadowski A. (red.), Obywatelstwo i tożsamość $w$ spoleczeństwach zróżnicowanych kulturowo i na pograniczach, t. 1, Białystok, s. 111-130.

Łodziński S., 2006b, Trauma $i$ władza liczb. Wybrane problemy społecznego odbioru pytania o „,narodowośc”” w Narodowym Spisie Powszechnym z 2002 roku, [w:] 
Adamczuk L., Łodziński S. (red.), Mniejszości narodowe $w$ Polsce $w$ świetle Narodowego Spisu Powszechnego z 2002 roku, Warszawa, s. 171-208.

Łodziński S., 2006c, Spory wokół ustawy o ochronie mniejszości narodowych i etnicznych $w$ Polsce okresu transformacji, [w:] Michalik E., Chałupczak H. (red.), Mniejszości narodowe i etniczne w procesach transformacji oraz integracji, Lublin, s. 287-312.

Łodziński S., 2010, Polityka wobec mniejszości narodowych i etnicznych $w$ Polsce $w$ latach 1945-2008, [w:] Dudra S., Nitschke B. (red.), 2010, Mniejszości narodowe i etniczne w Polsce po II wojnie światowej, Kraków, s. 13-36.

Łosowski P., 1996, Konflikt polsko-litewski 1918-1920, Warszawa.

Łossowski P., 1997, Stosunki polsko-litewskie 1921-1939, Warszawa.

Madajczyk P. (red.), 1998, Mniejszości narodowe w Polsce. Państwo i społeczeństwo polskie a mniejszości narodowe w okresach przełomów politycznych (1944-1989), Warszawa.

Madajczyk P., 2010, Czystki etniczne i klasowe $w$ Europie XX wieku. Szkice do problemu, Warszawa.

Madajczyk P., Berlińska D., 2008, Polska jako państwo narodowe. Historia i pamięć, Warszawa-Opole.

Magocsi P.R., 2002, Encyclopedia of Rusin history and culture, Toronto.

Makarski W., 1996, Pogranicze polsko-ruskie do połowy wieku XIV. Studium językowoetniczne, Lublin.

Makowski B., 1986, Litwini w Polsce 1920-1939, Warszawa.

Markusse J., 2003, National minorities in the present European Union and their cultural and political rights in relation to developments in international law, [w:] Koter M., Heffner K. (red.), The role of ethnic minorities in border regions, „Region and Regionalism", No. 6, vol. 1, Łódź-Opole, s. 23-31.

Maryański A., 1994, Narodowości świata, Warszawa.

Matykowski R., 1997, Udziat i zróżnicowanie poparcia mniejszości narodowych w Polsce $w$ wyborach parlamentarnych $z$ dn. 21.10.1997, „Sprawy Narodowościowe. Nowa Seria", 6 (2), s. 261-272.

Matykowski R., 2008, Przestrzenne zróżnicowanie w zachowaniach wyborczych mieszkańców województwa podlaskiego, [w:] Świątek D., Bednarek M., Siłka P. (red.) Współczesne problemy badawcze geografii polskiej - geografia człowieka, Dokumentacja Geograficzna, 36, Warszawa, s. 28-33.

Matykowski R., Tobolska A., 1994, Mniejszości narodowe $w$ Polsce w świetle wyników wyborów do Sejmu z dnia 27 października 1991 roku, „Sprawy Narodowościowe. Seria Nowa", 3 (1), s. 131-143.

Mazurek T., 2005, Łemkowie i Rusnacy w Beskidach - przemiany narodowościowe i religijne, praca magisterska napisana w Katedrze Geografii Politycznej i Studiów Regionalnych UŁ (promotor M. Barwiński), Łódź.

Mazurek T., Barwiński M., 2009, Polish east border as an external border of European Union, [w:] Sobczyński M. (red.), Historical regions divided by the borders. General problems and regional issue, „Region and Regionalism”, No. 9, vol. 1, Łódź-Opole, s. 209-216. 
Michalik E., Chałupczak H. (red.), 2006, Mniejszości narodowe i etniczne $w$ procesach transformacji oraz integracji, Lublin.

Michna E. 1995, Łemkowie. Grupa etniczna czy naród?, Kraków.

Michna E., 2004, Kwestie etniczno-narodowościowe na pograniczu słowiańszczyzny wschodniej i zachodniej. Ruch rusiński na Słowacji, Ukrainie i w Polsce, Kraków.

Michna E., 2006, Relacje pomiędzy tożsamościq etniczna a obywatelstwem. Analiza porównawcza sytuacji Rusinów Karpackich na Stowacji, Ukrainie i w Polsce, [w:] Bieńkowska-Ptasznik M., Krzysztofek K., Sadowski A. (red.), Obywatelstwo i tożsamość $w$ społeczeństwach zróżnicowanych kulturowo i na pograniczach, Białystok, t. 1, s. $75-90$.

Milewski J., 2001, Litwini w Polsce Ludowej, Białystok.

Mikołajczyk B., 1996, Mniejszości w prawie międzynarodowym, Katowice.

Mikołajewska B., 1987, Nazwy etniczne jako czynnik dystansu etnicznego. Studium przypadku zróżnicowania społecznego na Podlasiu, Warszawa.

Mironowicz E., 1992a, Świadomość narodowa Białorusinów na Białostocczyźnie w latach 1918-1939 „Białostocczyzna”, 3 (27), s. 23-28.

Mironowicz E., 1992b, Świadomość narodowa społeczności prawosławnej Białostocczyzny, Warszawa, s. 109-142.

Mironowicz E., 1993, Białorusini w Polsce 1944-1949, Warszawa.

Mironowicz E., 1998, Białorusini, [w:] Madajczyk P. (red.), Mniejszości narodowe $w$ Polsce. Państwo $i$ spoleczeństwo polskie a mniejszości narodowe $w$ okresach przełomów politycznych (1944-1989), Warszawa, s. 11-65.

Mironowicz E., 2000, Polityka narodowościowa PRL, Białystok.

Mironowicz E., 2005, Polityka władz polskich wobec Białorusinów. Stosunek ludności białoruskiej do państwa polskiego (1944-1956), [w:] Milewski J., Pyżewska A. (red.), Stosunki polsko-białoruskie $w$ województwie biatostockim w latach 19391956, Warszawa, s. 77-85.

Mironowicz E., 2007, Problem łemkowski w polityce władz PRL, [w:] Dudra S., Halczak B., Ksenicz A., Starzyński J. (red.), Łemkowie, Bojkowie, Rusini - historia, wspótczesność, kultura materialna i duchowa, t. 1, Legnica-Zielona Góra, s. 249-258.

Mironowicz E., 2010a, Białorusini, [w:] Dudra S., Nitschke B. (red.), Mniejszości narodowe i etniczne w Polsce po II wojnie światowej, Kraków, s. 66-90.

Mironowicz E., 2010b, Białorusini w Polsce (1919-2009), [w:] Zaniewska T. (red.), Białorusini, Warszawa, s. 9-28.

Mironowicz E., 2011, Założenia i cele polityki narodowościowej Polski Ludowej, [w:] Hytrek-Hryciuk J., Strauchold G., Syrnyk J. (red.), Internacjonalizm czy...? Działania organów bezpieczeństwa państw komunistycznych wobec mniejszości narodowych (1944-1989), Warszawa-Wrocław, s. 29-50.

Mironowicz E., Tokć S., Radzik R., 2005, Zmiana struktury narodowościowej na pograniczu polsko-białoruskim $w X X$ wieku, Białystok.

Misiło E., 1992, Polska polityka narodowościowa wobec Ukraińców 1944-1947, [w:] Polska-Polacy-mniejszości narodowe, Wrocław-Warszawa-Kraków, s. 391-412.

Misiło E., 1993, Akcja „,Wisła”. Dokumenty, Warszawa. 
Misiło E., 1996, Repatriacja czy deportacja. Przesiedlenia Ukraińców z Polski do USRR 1944-1946, t. 1: Dokumenty 1944-1945, Warszawa.

Moklak J., 1993, Republiki łemkowskie 1918-1919, „Wierchy”, 59, s. 63-77.

Moklak J., 1997, Łemkowszczyzna w Drugiej Rzeczypospolitej. Zagadnienia polityczne $i$ wyznaniowe, Kraków.

Moklak J., 2007, Fenomen tożsamości Łemków - uwarunkowania historyczne (do 1945 r.), [w:] Dudra S., Halczak B., Ksenicz A., Starzyński J. (red.), Łemkowie, Bojkowie, Rusini - historia, wspótczesność, kultura materialna $i$ duchowa, t. 1, LegnicaZielona Góra, s. 79-88.

Motyka G., 1999, Tak było w Bieszczadach. Walki polsko-ukraińskie 1943-1948, Warszawa.

Motyka G., 2011a, Od rzezi wołyńskiej do akcji „Wisła”. Konflikt polsko-ukraiński 1943-1947, Kraków.

Motyka G., 2011b, Mniejszości narodowe w PRL w badaniach historycznych po 1989 r., [w:] Hytrek-Hryciuk J., Strauchold G., Syrnyk J. (red.), Internacjonalizm czy...? Działania organów bezpieczeństwa państw komunistycznych wobec mniejszości narodowych (1944-1989), Warszawa-Wrocław, s. 15-28.

Mušynka M., 1993, The postwar development of the regional culture of the Rusyn-Ukrainians of Czechoslovakia, [w:] Magocsi P.R. (red.), The persistence of regional cultures - Rusyn and Ukrainians in their Carpathian homeland and abroad, New York.

Nijakowski L., 2000, „Pomosty” i „,zasieki”, czyli o drogach pojednania. Mniejszości narodowe $i$ etniczne a polska polityka wschodnia, „Rubikon”, 4 (11).

Nijakowski L. (red.), 2005, Polityka państwa polskiego wobec mniejszości narodowych i etnicznych, Warszawa.

Nijakowski L., 2006, Status grup etnicznych oraz mniejszości narodowych i etnicznych w Polsce w świetle wyników Narodowego Spisu Powszechnego z 2002 roku, [w:] Adamczuk L., Łodziński S. (red.), Mniejszości narodowe $w$ Polsce $w$ świetle Narodowego Spisu Powszechnego z 2002 roku, Warszawa, s. 143-170.

Nijakowski L., Łodziński S. (red.), 2003, Mniejszości narodowe i etniczne w Polsce. Informator 2003, Warszawa.

Nikitorowicz J., 1995, Pogranicze. Tożsamość. Edukacja międzykulturowa, Białystok.

Nowak J., 2006, Dylematy tożsamościowe Łemków w świetle Narodowego Spisu Powszechnego z 2002 roku, [w:] Adamczuk L., Łodziński S. (red.), Mniejszości narodowe w Polsce w świetle Narodowego Spisu Powszechnego z 2002 roku, Warszawa, s. $227-232$.

Nowakowski K., 1992, Sytuacja polityczna na Łemkowszczyźnie w latach 1918-1939, [w:] Czajkowski J. (red.), Łemkowie w historii i kulturze Karpat, Rzeszów, s. 313351.

Nowicka E., 1989, Etniczność a sytuacja mniejszościowa, „Przegląd Polonijny”, 15 (1), s. $43-57$.

Nyczanka M., 1987, Zmiany w zaludnieniu Beskidu Niskiego i Bieszczadów w latach 1944-1947, [w:] Magury'87, Warszawa, s. 70-82.

Obracht-Prondzyński C., 2004, Mniejszości w nowej Europie - między partycypacja a separacja, [w:] Krzysztofek K., Sadowski A. (red.), Pogranicza i multikulturalizm 
w warunkach Unii Europejskiej. Implikacje dla wschodniego pogranicza Polski, t. 1, Białystok, s. 161-182.

Olejnik L., 2003, Polityka narodowościowa Polski w latach 1944-1960, Łódź.

Olszański T.A., 1990, Drogi tożsamości Łemków, [w:] Magury’90, Warszawa, s. 36-51.

Olszański T.A., 1994, Historia Ukrainy XX w., Warszawa.

Ossowski S., 1967, Ziemia i naród, Warszawa.

Ossowski S., 1984, O ojczyźnie i narodzie, Warszawa.

Otok S., 2003, Geografia polityczna. Geopolityka - państwo - ekopolityka, Warszawa.

Parczewski M., 1992, Geneza Łemkowszczyzny w świetle wyników badań archeologicznych, [w:] Czajkowski J. (red.), Łemkowie w historii i kulturze Karpat, Rzeszów, s. 11-27.

Pactwa B., 1992, Próby reintegracji społeczności Łemków w Beskidzie Niskim, [w:] Dylematy tożsamości. Studium społeczności łemkowskiej w Polsce, Katowice, s. 92-138.

Pawluczuk W., 1972, Światopoglad jednostki w warunkach rozpadu społeczności tradycyjnej, Warszawa.

Pawluczuk W., 1999, Pogranicze narodowe czy pogranicze cywilizacyjne?, „Pogranicze. Studia Społeczne”, 8, s. 23-32.

Piskozub A., 1968, Gniazdo orta białego, Warszawa.

Piskozub A., 1987, Dziedzictwo polskiej przestrzeni. Geograficzno-historyczne podstawy struktur przestrzennych ziem polskich, Wrocław.

Piskozub A., 1992, Wschodnie pogranicze Polski. Szkic geograficzno-historyczny, [w:] Dziadek S. (red.), Transport, Katowice, s. 121-141.

Pisuliński J., 2009, Przesiedlenia ludności ukraińskiej z Polski do USSR w latach 19441947, Rzeszów.

Plit F., 2008, Województwo podlaskie - region pogranicza, [w:] Świątek D., Bednarek M., Siłka P. (red.), Współczesne problemy badawcze geografii polskiej - geografia człowieka, Dokumentacja Geograficzna, 36, Warszawa, s. 7-14.

Podlaski K. (Skaradziński B.), 1990, Białorusini, Litwini, Ukraińcy, Białystok.

Pogorzała E., 2006, Szkolnictwo mniejszości narodowych i etnicznych w Polsce w okresie transformacji, [w:] Michalik E., Chałupczak H. (red.), Mniejszości narodowe $i$ etniczne w procesach transformacji oraz integracji, Lublin, s. 327-338.

Prach B., 1992, Apostolska Administracja Łemkowszczyzny, [w:] Czajkowski J. (red.), Łemkowie w historii i kulturze Karpat, Rzeszów, s. 299-312.

Pudło K., 1992, Dzieje Łemków po drugiej wojnie światowej (zarys problematyki), [w:] Czajkowski J. (red.), Łemkowie w historii i kulturze Karpat, Rzeszów, s. 351-381.

Reinfuss R., 1948, Łemkowie jako grupa etnograficzna, Prace i Materiały Etnograficzne, t. 7, Lublin.

Reinfuss R., 1987, Łemkowie w przeszłości i obecnie, [w:] Łemkowie kultura - sztuka język, Warszawa-Kraków, s. 7-21.

Reinfuss R., 1990, Śladami Łemków, Warszawa.

Reinfuss R., 1992, Zwiazki kulturowe po obu stronach Karpat w rejonie Łemkowszczyzny, [w:] Czajkowski J. (red.), Łemkowie w historii i kulturze Karpat, Rzeszów, s. $167-183$. 
Romanowska E., 2010, Szkoła białoruska w Polsce - od czasów II po III Rzeczpospolita, [w:] Zaniewska T. (red.), Białorusini, Warszawa, s. 77-106.

Rykała A., 2006, Mniejszości religijne w Polsce na tle struktury narodowościowej i etnicznej, [w:] Bieńkowska-Ptasznik M., Krzysztofek K., Sadowski A. (red.), Obywatelstwo i tożsamość $w$ spoleczeństwach zróżnicowanych kulturowo i na pograniczach, t. 1, Białystok, s. 379-412.

Rykała A., 2007, Przemiany sytuacji społeczno-politycznej mniejszości żydowskiej w Polsce po drugiej wojnie światowej, Łódź.

Rykała A., 2008, Sytuacja społeczno-kulturalna Litwinów w Polsce i ich wplyw na relacje między krajem zamieszkania a Litwa, „Acta Universitatis Lodziensis. Folia Geographica Socio-Oeconomica", 9, Łódź, s. 89-113.

Rykała A., 2011, Mniejszości religijne w Polsce - geneza, struktury przestrzenne, tło etniczne, Łódź.

Rykała A., Sobczyński M., 2003, Polish lands as a core of integration of East-Central Europe, [w:] Kitowski J. (red.), Eastern dimension of European Union, „Geopolitical Studies", 11, Warszawa, s. 473-493.

Rykiel Z., 2006, Podstawy geografii politycznej, Warszawa.

Sadowski A., 1991a, Narody wielkie i małe. Białorusini w Polsce, Kraków.

Sadowski A., 1991b, Społeczne problemy wschodniego pogranicza, Białystok.

Sadowski A., 1992, Pogranicze. Studia społeczne. Zarys problematyki, „Pogranicze. Studia Społeczne", 1, s. 5-7.

Sadowski A., 1995a, Pogranicze polsko-białoruskie. Tożsamość mieszkańców, Białystok.

Sadowski A., 1995b, Specyfika wschodniego pogranicza, [w:] Sadowski A. (red.), Wschodnie pogranicze w perspektywie socjologicznej, Białystok, s. 9-11.

Sadowski A., 1995c, Socjologia pogranicza, [w:] Sadowski A. (red.), Wschodnie pogranicze w perspektywie socjologicznej, Białystok, s. 12-19.

Sadowski A., 1997, Mieszkańcy pótnocno-wschodniej Polski. Skład wyznaniowy i narodowościowy, [w:] Kurcz Z. (red.), Mniejszości narodowe w Polsce, Wrocław, s. 7-42.

Sadowski A., 2007, Narodowościowe i etniczne zróżnicowanie III RP, [w:] Kojder A. (red.), Jedna Polska? Dawne i nowe zróżnicowania społeczne, Kraków, s. 533-558.

Sadowski A., 2009, Mniejszości narodowe na pograniczach. Pomiędzy tożsamościa narodowa a obywatelska, [w:] Jackiewicz S. (red.), Autochtoniczne mniejszości narodowe na pograniczach a ich stosunki z odseparowanym etnosem macierzystym, Białystok, s. 13-24.

Sakson A., 1991, Mniejszość niemiecka na tle innych mniejszości narodowych we współczesnej Polsce, „Przegląd Zachodni”, 47, s. 1-23.

Sakson A., 1998, Stosunki narodowościowe na Warmii i Mazurach 1945-1997, Poznań.

Sapoliga M., 1992, Granice i główne cechy kultury Łemków w południowo-wschodniej Słowacji, [w:] Czajkowski J. (red.), Łemkowie w historii i kulturze Karpat, Rzeszów, s. 249-267.

Serczyk W., 2001, Historia Ukrainy, Wrocław.

Serczyk W., 2003, Pogranicze polsko-ukraińskie jako element świadomości narodowej w XVII-XVIII wieku, [w:] Budziński Z., Kamińska-Kwak J. (red.), Dwa pogranicza. 
Galicja Wschodnia i Górny Śląs. Historia - problemy - odniesienia, Rzeszów, s. 62-69.

Shils E., 1996, Naród, narodowość i nacjonalizm a społeczeństwo obywatelskie, „Sprawy Narodowościowe. Seria Nowa”, 5 (1), s. 9-30.

Smith A., 1986, The ethnic origin of nation, Oxford.

Smoleński J., 1935, Łemkowie i Łemkowszczyzna, [w:] O Łemkowszczyźnie, Kraków, s. 7-16.

Sobczak L., 1982, Mniejszości narodowe w Polsce, „Czasopismo Geograficzne”, 2, s. 205-208.

Sobczyński M., 1996a, Les minorités nationales en Pologne, Die nationalen Minderheiten in Polen, Mniejszości narodowe w Polsce, „Euromag. La revue des enjeux de l'Europe”, 17/18 „La Pologne et l'Europe”, s. 32-39.

Sobczyński M., 1996b, Co to jest naród?, opracowanie niepublikowane, maszynopis w Katedrze Geografii Politycznej i Studiów Regionalnych UŁ, Łódź.

Sobczyński M., 2000, Struktura narodowościowo-wyznaniowa Polski, „Acta Universitatis Lodziensis, Folia Geographica Socio-Oeconomica”, 3, Łódź, s. 157-174.

Sobczyński M., 2001a, The ethnic and religious structure of Poland, [w:] Antonsich M., Kolossov V., Pagnini P. (red.), Europe between political geography and geopolitics, vol. 2, Roma, s. 639-650.

Sobczyński M., 2001b, Perception of Polish-Ukrainian and Polish-Russian transborder co-operation by the inhabitants of border voivodships, [w:] Koter M., Heffner K. (red.), Changing role of border areas and regional policies, „Region and Regionalism", No. 5, Łódź-Opole, s. 64-72.

Sobczyński M., 2005, Percepcja wspótpracy transgranicznej Polski z sqsiadami pośród mieszkańców pograniczy, [w:] Malikowski M., Wojakowski D. (red.), Granice i pogranicza nowej Unii Europejskiej. Z badań regionalnych, etnicznych $i$ lokalnych, Kraków, s. 55-76.

Sobczyński M., 2008a, Zmienność funkcji granic międzynarodowych na ziemiach polskich od czasów Rzeczypospolitej szlacheckiej do przystapienia Polski do Układu z Schengen, [w:] Eberhardt P. (red.), Problematyka geopolityczna ziem polskich, Prace Geograficzne, 218, Warszawa, s. 29-54.

Sobczyński M., 2008b, Historia geografii politycznej, [w:] Jackowski A., Liszewski S., Richling A. (red.), Historia geografii polskiej, Warszawa, s. 219-236.

Sobczyński M., 2008c, Stan i perspektywy rozwoju geografii politycznej w Polsce, [w:] Liszewski S., Łoboda J., Maik W. (red.), Stan i perspektywy rozwoju geografii w Polsce. Raport z pracy Komitetu Nauk Geograficznych Polskiej Akademii Nauk w kadencji 2003-2006, Bydgoszcz, s. 188-201.

Sobczyński M., 2012, Interakcja „badacz - podmiot badania” w studiach nad mniejszościami narodowymi w Polsce, opracowanie niepublikowane, maszynopis w Katedrze Geografii Politycznej i Studiów Regionalnych UŁ, Łódź.

Sobczyński M., Barwiński M., 2009, Wptyw przemian terytorialnych i struktury wewnętrznej ziem ukraińskich na położenie geopolityczne Rzeczypospolitej, [w:] Franz M., Pietkiewicz K.. (red.), Od Zborowa do NATO (1649-2009). Studia z dziejów stosunków polsko-ukraińskich od XVII do XXI wieku. Politologia, Toruń, s. 42-105. 
Sobczyński M., Grabowska E., 1993, Metodologiczne problemy badania mniejszości narodowych i religijnych, Geopolitical and social problems of the former socialistic countries, Conference Papers, Soczewka.

Sobecki M., 1996, Młodzież białoruska i litewska w polskich liceach, „Społeczeństwo Otwarte", 1, s. 30-33.

Sobecki M., 1997, Funkcja etniczno-kulturowa szkół mniejszości narodowych, Białystok.

Soja M., 2001a, Zmiany zaludnienia Łemkowszczyzny w latach 1869-1998, [w:] Kortus B. (red.), Człowiek i przestrzeń, Kraków, s. 79-88.

Soja M., 2001b, The cultural and ethnic diversity of the population of Łemkowszczyzna (Lemko Region) in the $19^{\text {th }}$ and $20^{\text {th }}$ century, [w:] Koter M., Heffner K. (red.), Changing role of border areas and regional policies, „Region and Regionalism”, No. 5, Łódź-Opole, s. 212-221.

Soja M., 2010, Cykle rozwojowe ludności Karpat Polskich w XIX i XX wieku, Kraków.

Sommer B., Sommer R., 1997, A practical guide to behavioral research. Tool and techniques, Oxford.

Stachowiak A., 2010, Dwujęzyczne nazwy miejscowości a dialog międzykulturowy na Łemkowszczyźnie, [w:] Dudra S., Halczak B., Drozd R., Betko I., Smigiel M. (red.), Łemkowie, Bojkowie, Rusini. Historia, wspótczesność, kultura materialna i duchowa, t. 3, Zielona Góra-Słupsk, s. 159-163.

Statystyka Polski, 1927, Pierwszy Powszechny Spis Rzeczypospolitej Polskiej z dnia 30 września 1921, t. 19: Województwo białostockie, Warszawa.

Statystyka Polski, 1938, Drugi Powszechny Spis Ludności z dnia 9 XII 1931 roku, Seria $C$, Warszawa.

Statystyka Polski, 1947, Seria D - Powszechny sumaryczny spis ludności z dnia 14 lutego 1946 r., z. 1, Warszawa.

Sychowicz K., 2009, Aparat bezpieczeństwa w województwie białostockim wobec bytych członków Białoruskiego Komitetu Narodowego (1945-1956), [w:] Syrnik J. (red.), Aparat bezpieczeństwa Polski Ludowej wobec mniejszości narodowych i etnicznych oraz cudzoziemców, Warszawa, s. 118-140.

Szamel D., 1998, Litwini w Polsce, [w:] Berdychowska B. (red.), Mniejszości narodowe w Polsce. Praktyka po 1989 r., Warszawa, s. 209-230.

Szcześniak A., Szota W., 1973, Droga do nikqd. Działalność organizacji ukraińskich nacjonalistów i jej likwidacja w Polsce, Warszawa.

Szczygielski K., 2006, Geografia mniejszości narodowych i etnicznych w Polsce. Ujęcie ilościowe, Opole.

Szul R., 2009, Język, naród, państwo. Język jako zjawisko polityczne, Warszawa.

Szumiło M., 2008, Bazyli Hołod (1907-1963) - kariera ukraińskiego komunisty z ziemi włodawskiej, [w:] Bem M., Duszyk A. (red.), Życiorysy w trzy kultury wpisane. Włodawskie biografie, Radom-Włodawa, s. 287-298.

Szwed R., 2010, Kultura i tożsamość wschodniego pogranicza Polski, „Sprawy Narodowościowe. Seria Nowa”, 36, s. 51-75.

Ślęzak M., 1999, Problem identyfikacji narodowej Ukrainców na Łemkowszczyźnie i Podlasiu, [w:] Malikowski M., Wojakowski D. (red.), Między Polska a Ukraina. Pogranicze - mniejszości, wspótpraca regionalna, Rzeszów, s. 83-94. 
Ślęzak M., 2004, Mniejszości narodowe w polityce państwa polskiego $w$ latach 19892000 - zmiana świadomości władz państwa czy przymus zewnętrzny? (na przykładzie mniejszości ukraińskiej), [w:] Krzysztofek K., Sadowski A. (red.), Pogranicza i multikulturalizm $w$ warunkach Unii Europejskiej. Implikacje dla wschodniego pogranicza Polski, t. 2, Białystok, s. 129-142.

Ślęzak M., 2006, Ustawa o mniejszościach narodowych i etnicznych - główne kierunki zmian, [w:] Bieńkowska-Ptasznik M., Krzysztofek K., Sadowski A. (red.), Obywatelstwo i tożsamość w społeczeństwach zróżnicowanych kulturowo i na pograniczach, t. 1, Białystok, s. 131-138.

Śliwiński M., 1992, Świadomość narodowa, świadomość pogranicza, „Kultura i Społeczeństwo", 4.

Tarka K., 1998, Litwini w Polsce 1944-1997, Opole.

Tarka K., 2010, Litwini, [w:] Dudra S., Nitschke B. (red.), Mniejszości narodowe i etniczne w Polsce po II wojnie światowej, Kraków, s. 148-163.

Tarnowycz J., 1936, Ilustrowana istoria Lemkiwszczyny, Lwów.

Tomaszewski J., 1985a, Ojczyzna nie tylko Polaków, Warszawa.

Tomaszewski J., 1985b, Rzeczpospolita wielu narodów, Warszawa.

Tomaszewski J., 1991, Mniejszości narodowe w Polsce w XX wieku, Warszawa.

Tomaszewski J., Landau Z., 2005, Polska w Europie i świecie 1918-1939, Warszawa.

Torzecki R., 1993, Polacy i Ukraincy. Sprawa ukraińska w czasach II wojny światowej na terenach II Rzeczypospolitej, Warszawa.

Trajdos T., 1990, Osadnictwo na Łemkowszczyźnie, [w:] Magury’90, Warszawa, s. 24 36.

Trajdos T., 1992, Poczatki osadnictwa Wołochów na Rusi Czerwonej, [w:] Czajkowski J. (red.), Łemkowie w historii i kulturze Karpat, Rzeszów, s. 199-210.

Turonek J., 1993, Białoruś pod okupacja niemiecka, Warszawa.

Urbański Z., 1932, Mniejszości narodowe w Polsce, Warszawa.

Wakar W., 1917a, Rozwój terytorialny narodowości polskiej, cz. 2: Statystyka narodowościowa Królestwa Polskiego, Warszawa.

Wakar W., 1917b, Rozwój terytorialny narodowości polskiej, cz. 3: Statystyka narodowościowa kresów wschodnich, Warszawa.

Waldenberg M., 1992, Kwestie narodowe w Europie Środkowo-Wschodniej, Warszawa.

Waldenberg M., 2000, Narody zależne i mniejszości narodowe w Europie Środkowo-Wschodniej. Dzieje konfliktów i idei, Warszawa.

Wasilewski L., 1911, Ukraina i sprawa ukraińska, Kraków.

Wasilewski L., 1917, Kresy Wschodnie, Warszawa-Kraków.

Wasilewski L., 1925, Litwa i Białoruś. Zarys historyczno-polityczny stosunków narodowościowych, Warszawa-Kraków.

Wasilewski L., 1927, Istotna liczba Ukraińców w Polsce, „Sprawy Narodowościowe”, 5-6, s. 227-236.

Wasilewski L., 1929, Sprawy narodowościowe w teorji $i$ w życiu, Warszawa-Kraków.

Wiatr J., 1973, Naród i państwo. Socjologiczne problemy kwestii narodowej, Warszawa.

Wielki atlas historyczny, 2009, Olczak E., Tazbir J. (red.), Warszawa. 
Wierzycka Ł., Hołuszko M., Rzepliński A., 1993, Uwagi o mniejszościach narodowych $w$ Polsce. Osiagnięcia i porażki w ochronie ich praw. Spoleczeństwo otwarte, Warszawa.

Wiśniewski J., 1970, Podlasie, [w:] Słownik starożytności słowiańskich, t. 4, Wrocław.

Wiśniewski J., 1977, Osadnictwo wschodniosłowiańskie Białostocczyzny - geneza, rozwój oraz zróżnicowanie i przemiany etniczne, „Acta Baltico-Slavica”, 4, Białystok.

Wiśniewski J., 1980, Zarys dziejów osadnictwa na Białostocczyźnie, [w:] Glinka S., Obrębska-Jabłońska A., Siatkowski J. (red.), Atlas gwar wschodniosłowiańskich Białostocczyzny, t. 1, Wrocław-Warszawa-Kraków-Gdańsk, s. 14-27.

Wojakowski D., 1999, Charakter pogranicza polsko-ukraińskiego - analiza socjologiczna, [w:] Malikowski M., Wojakowski D. (red.), Między Polskq a Ukrainq. Pogranicze - mniejszości, wspótpraca regionalna, Rzeszów, s. 61-81.

Wojakowski D., 2002, Polacy i Ukraińcy. Rzecz o pluralizmie i tożsamości na pograniczu, Kraków.

Wojakowski D., 2007, Swojskość i obcość w zmieniajacej się Polsce, Warszawa.

Wojewoda W., 1994, Zarys historii Kościoła greckokatolickiego w Polsce $w$ latach 1944-1989, Kraków.

Wróbel P., 1990, Ksztattowanie się białoruskiej świadomości narodowej a Polska, Warszawa.

Wysiedlenia, wypędzenia i ucieczki 1939-1959. Atlas ziem Polski, 2008, Sienkiewicz W., Hryciuk G. (red.), Warszawa.

Wysocki J., 2011, Ukraińcy na Lubelszczyźnie w latach 1944-1989, Lublin.

Wysocki R., 2006, Dylematy wyboru tożsamości narodowej. Ludność ukraińska na pólnocnym Podlasiu $w$ warunkach demokratyzacji systemu politycznego $w$ Polsce w latach 1989-2004 [w:] Halczak B. (red.), Mniejszości narodowe w Europie Środkowo-Wschodniej po upadku komunizmu, Zielona Góra, s. 175-210.

Wysocki T., 2005, Struktura narodowościowa mieszkańców Polski w 1931 roku na podstawie deklarowanego języka traktowanego jako ojczysty, „Sprawy Narodowościowe. Seria Nowa”, 26, s. 29-56.

Wysocki T., 2006, Osoby niepolskiej narodowości i języka w Polsce $w$ świetle NSP 2002, „Studia Demograficzne”, 2 (150), s. 96-125.

Wysocki T., 2008, Kwestie terminologiczne odnoszace się do badania struktur narodowościowych populacji. Próba wyjaśnienia odnoszqca się do okresu międzywojennego, „Sprawy Narodowościowe. Seria Nowa”, 33, s. 75-99.

Wysocki T., 2010, Zmiany w strukturze narodowościowej mieszkańców Polski w XX wieku i ich konsekwencje dla procesów demograficznych, Łódź.

Wyznania religijne. Stowarzyszenia narodowościowe $i$ etniczne w Polsce 2000-2002, 2003, Adamczuk L., Gudaszewski G. (red.), Warszawa.

Wyznania religijne. Stowarzyszenia narodowościowe $i$ etniczne w Polsce 2006-2008, 2010, Gudaszewski G., Chmielewski M. (red.), Warszawa.

Zaborski B., 1937, Liczba i rozmieszczenie mieszkańców Polski według języków i wyznań (uwagi ogólne w świetle spisu 1931 r.), ,Sprawy Narodowościowe”, 11 (1-2), s. $75-86$. 
Zaborski B., Wrzosek A., 1939, Antropogeografia, [w:] Wielka geografia powszechna, t. 3, Warszawa.

Zaniewska T. (red.), 2010, Białorusini, Warszawa.

Znaniecki F., 1990, Wspótczesne narody, Warszawa.

Zubrzycki D., 1849, Granice między polskim a ruskim narodem w Galicji, Lwów.

Zupančič J., 2003, Minorities: how long will they have a „bridge function”?, [w:] Heffner K., Sobczyński M. (red.), The role of ethnic minorities in border regions, „Region and Regionalism”, No. 6, vol. 2, Łódź-Opole, s. 7-16.

Żerelik R., 1997, Mniejszość ukraińska w Polsce po II wojnie światowej, [w:] Kurcz Z. (red.), Mniejszości narodowe w Polsce, Wrocław, s. 43-50.

Żołędowski C., 1992, Rozmieszczenie i liczebność mniejszości litewskiej w Polsce, Warszawa, s. 177-186.

Żołędowski C., 2003, Białorusini i Litwini w Polsce, Polacy na Białorusi i Litwie. Uwarunkowania wspótczesnych stosunków między większościq i mniejszościami narodowymi, Warszawa.

Żołędowski C., 2006, Sytuacja mniejszości narodowych we współczesnej Polsce wświetle teorii marginalizacji, Warszawa.

Żurko J., 1997, Łemkowie - między grupq etnicznq a narodem, [w:] Kurcz Z. (red.), Mniejszości narodowe w Polsce, Wrocław, s. 51-62.

\section{Źródła internetowe}

Bazy danych o organizacjach pozarządowych i instytucjach www.bazy.ngo.pl

Biuro Statystyczne Republiki Słowackiej www.portal.statistics.sk

Główny Urząd Statystyczny www.stat.gov.pl

Ministerstwo Spraw Wewnętrznych i Administracji www.mswia.gov.pl

Ministerstwo Administracji i Cyfryzacji www.mac.gov.pl

Nad Buhom i Narwoju www.nadbuhom.free.ngo.pl

Państwowa Komisja Wyborcza www.pkw.gov.pl

Stowarzyszenie Łemków www.stowarzyszenielemkow.pl

Stowarzyszenie „Ruska Bursa” www.ruskabursa.org

Strona Internetowa Litwinów w Polsce www.punskas.pl

Towarzystwo Ukraińskie www.ukr-tov.pl

Ukraińskie Towarzystwo Historyczne w Polsce www.uitp.net.pl

Zjednoczenie Łemków www.lemkounion.republika.pl

Związek Młodzieży Białoruskiej www.sonca.org

Związek Ukraińców Podlasia www.zup.org.pl

Związek Ukraińców w Polsce www.zup.ukraina.com.pl 


\section{OD REDAKCJI}

Doktor Marek Barwiński od 1996 r. jest zatrudniony w Katedrze Geografii Politycznej i Studiów Regionalnych Uniwersytetu Łódzkiego, początkowo na stanowisku asystenta, a od 2002 r. na stanowisku adiunkta. Tytuł doktora w zakresie nauk geograficznych uzyskał na podstawie rozprawy pt. Podlasie jako pogranicze narodowościowo-wyznaniowe.

Specjalizuje się w geografii politycznej i historycznej. Jego zainteresowania badawcze koncentrują się przede wszystkim na problematyce mniejszości narodowych i etnicznych oraz granicach i pograniczach. Jest autorem i współautorem kilkudziesięciu prac naukowych opublikowanych w wydawnictwach krajowych i zagranicznych.

Za osiagnięcia naukowe oraz dydaktyczne kilkakrotnie otrzymał nagrody Rektora Uniwersytetu Łódzkiego oraz Dziekana Wydziału Nauk Geograficznych. Pełni funkcję członka Zarządu Głównego Polskiego Towarzystwa Geograficznego oraz członka Prezydium Komitetu Głównego Olimpiady Geograficznej. 

ANEKS 


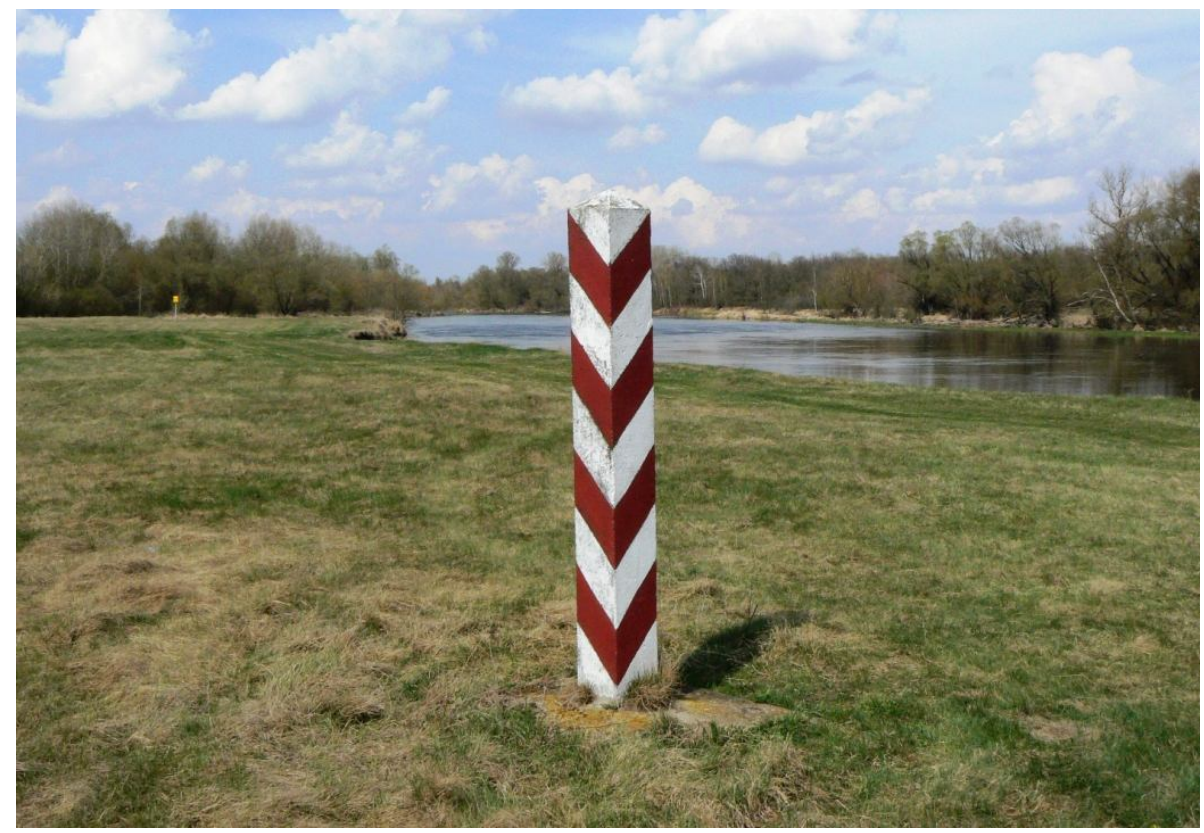

Granica polsko-białoruska wzdłuż Bugu - fragment linii Curzona w okolicach Janowa Podlaskiego (fot. autor)

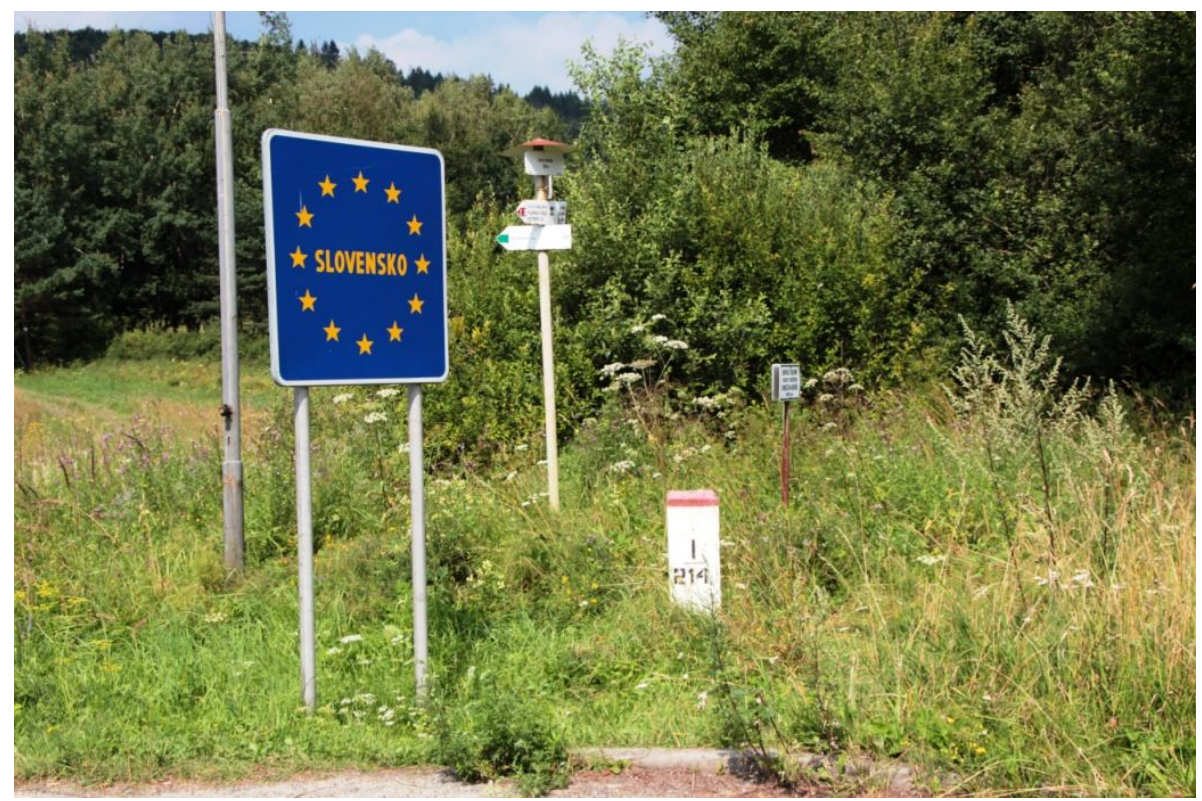

Granica polsko-słowacka na Łemkowszczyźnie w okolicach Koniecznej (fot. autor) 


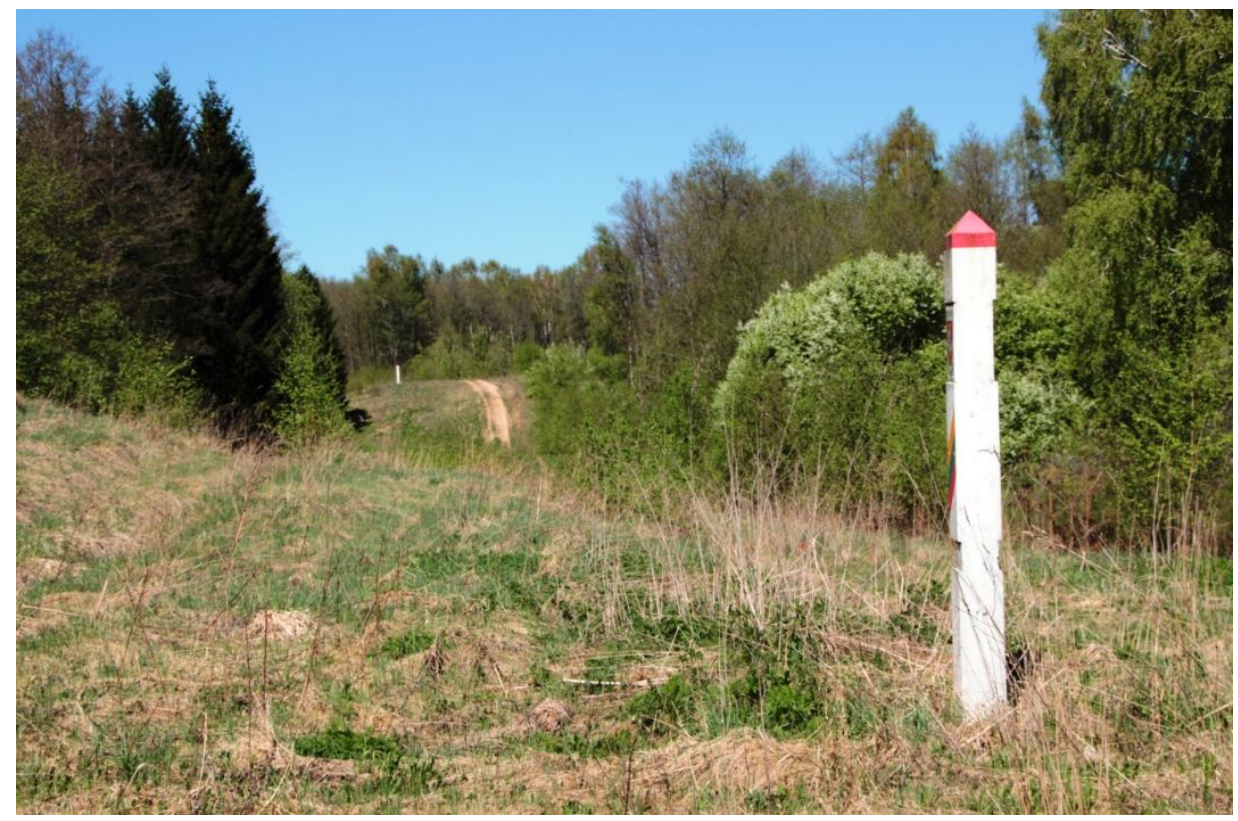

Granica polsko-litewska istniejąca od 1919 r. w okolicach Puńska na Suwalszczyźnie (fot. autor)

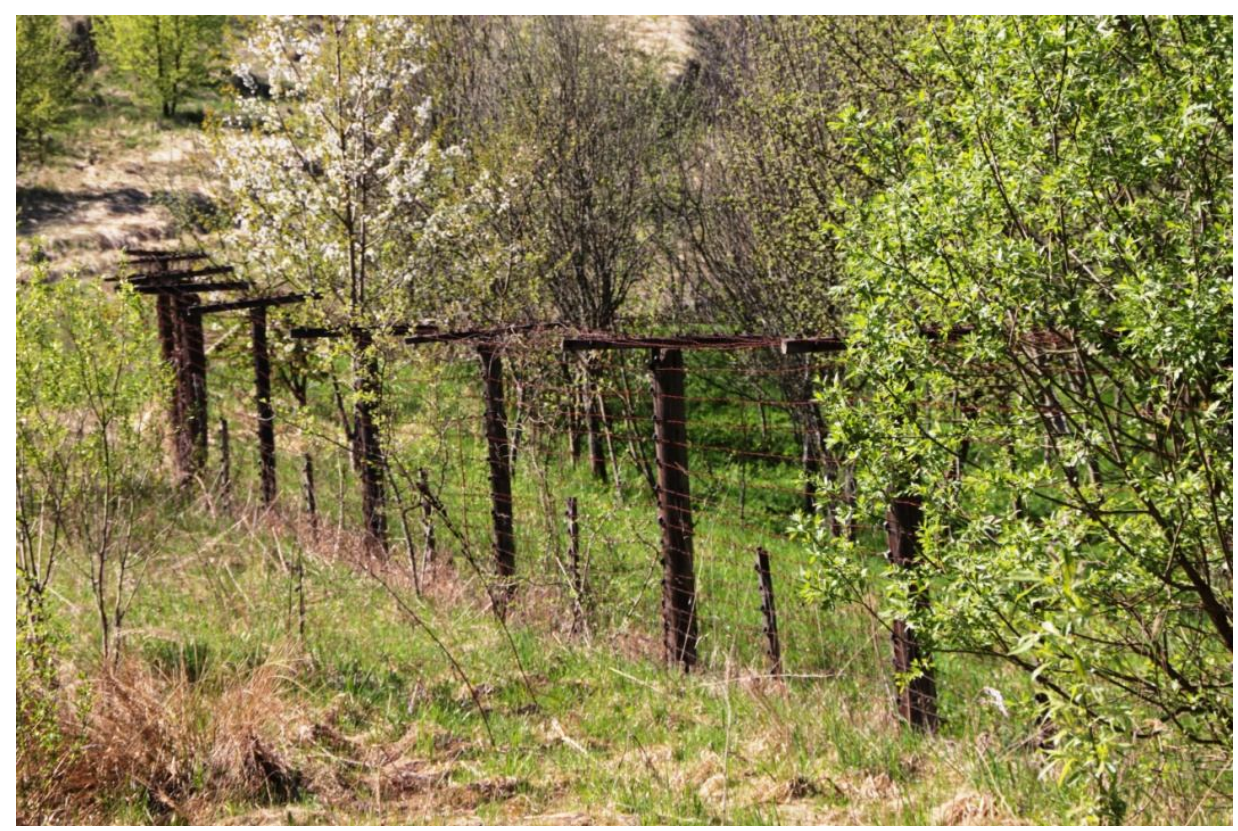

Zasieki na dawnej granicy między ZSRR a Polską - kilkaset metrów na wschód od granicy, obecnie po stronie litewskiej w okolicach jeziora Gaładuś (fot. autor) 


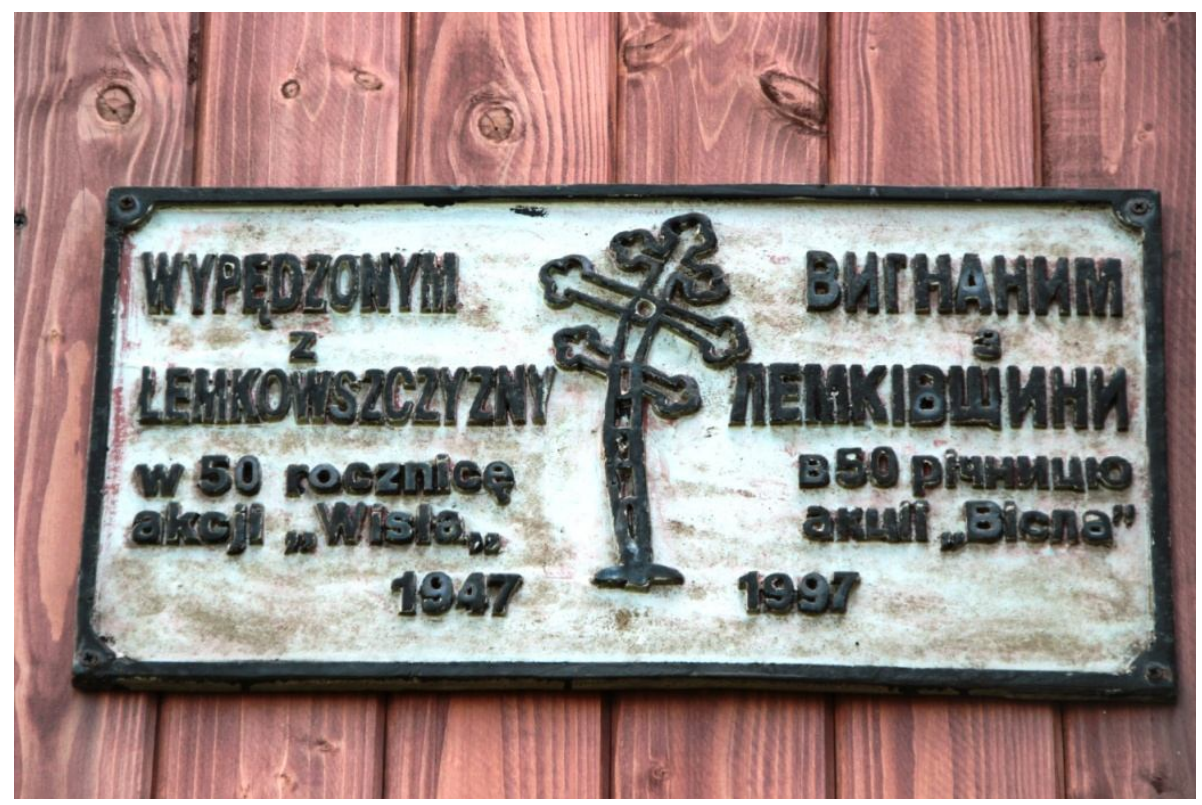

Tablica w Koniecznej upamiętniająca wysiedlenia Łemków podczas akcji „Wisła” (fot. autor)

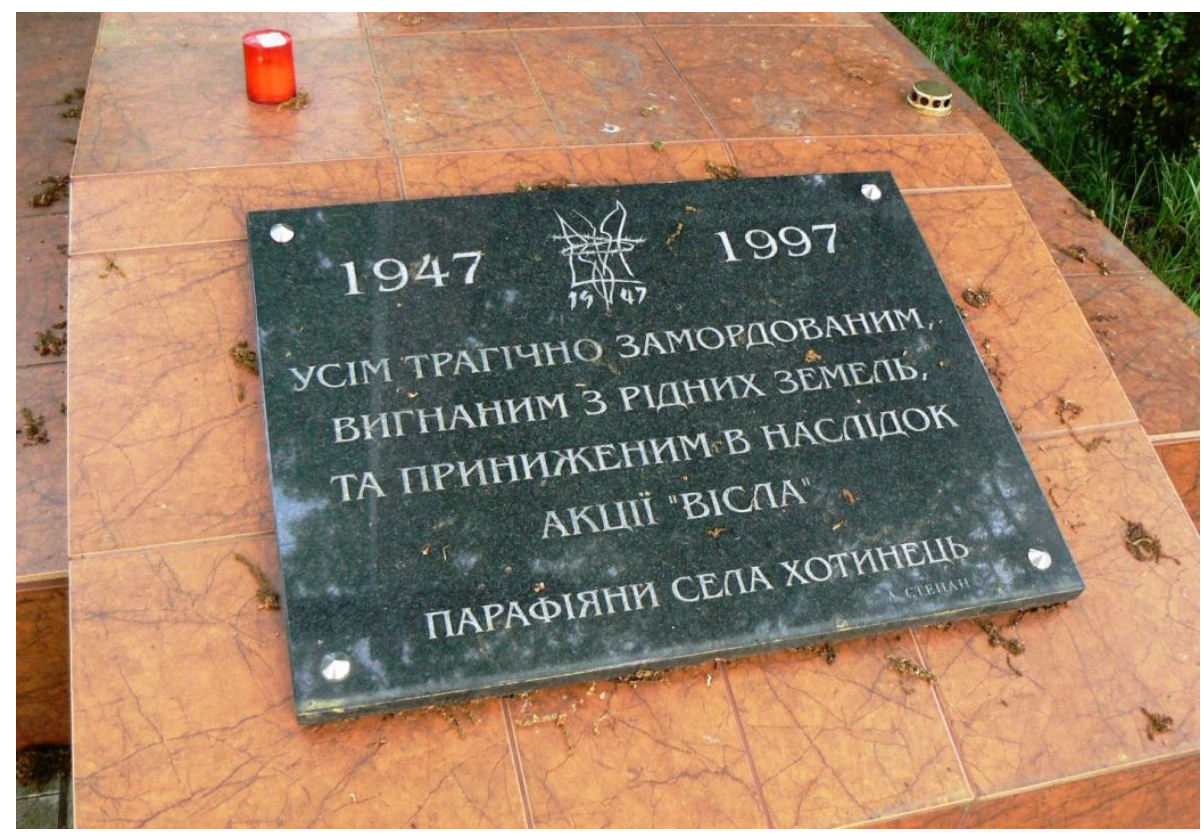

Tablica w Chotyńcu upamiętniająca wysiedlenia Ukraińców podczas akcji „Wisła” (fot. autor) 


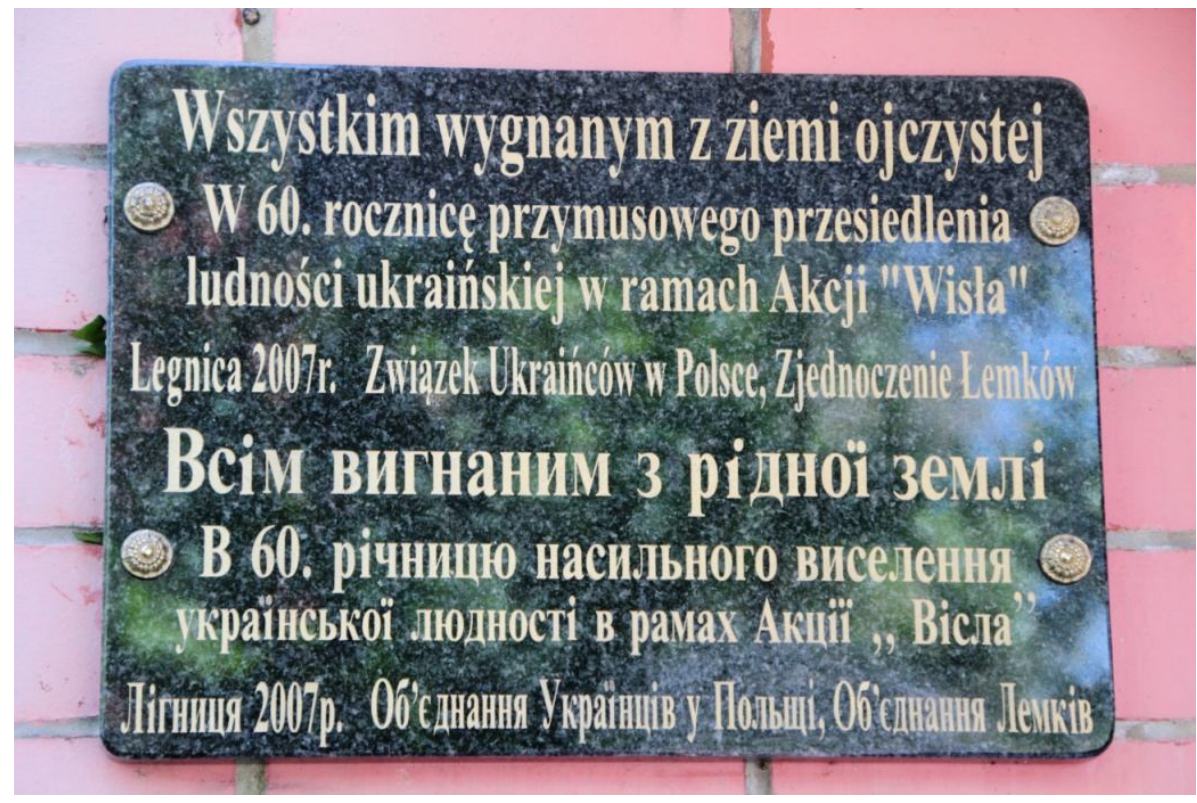

Tablica w Legnicy upamiętniająca wysiedlenia Ukraińców podczas akcji „Wisła” (fot. autor)

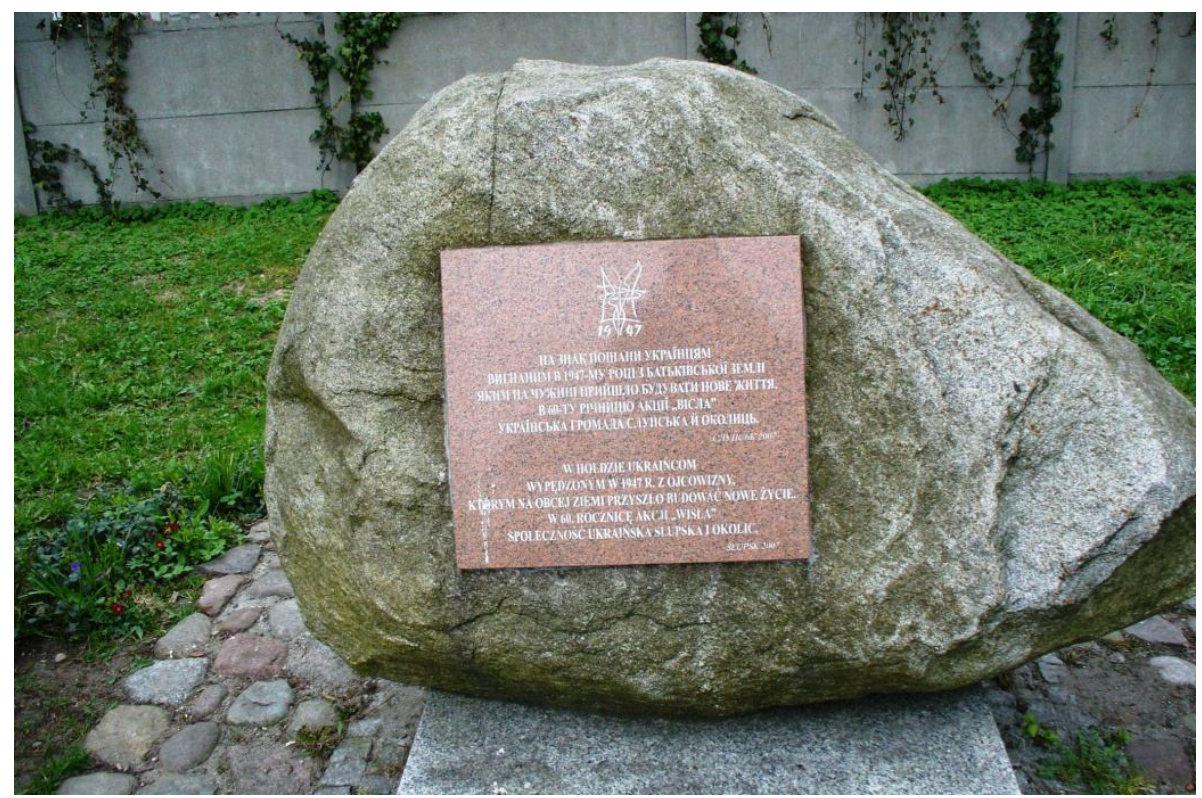

Tablica w Słupsku upamiętniająca wysiedlenia Ukraińców podczas akcji „Wisła” (fot. autor) 


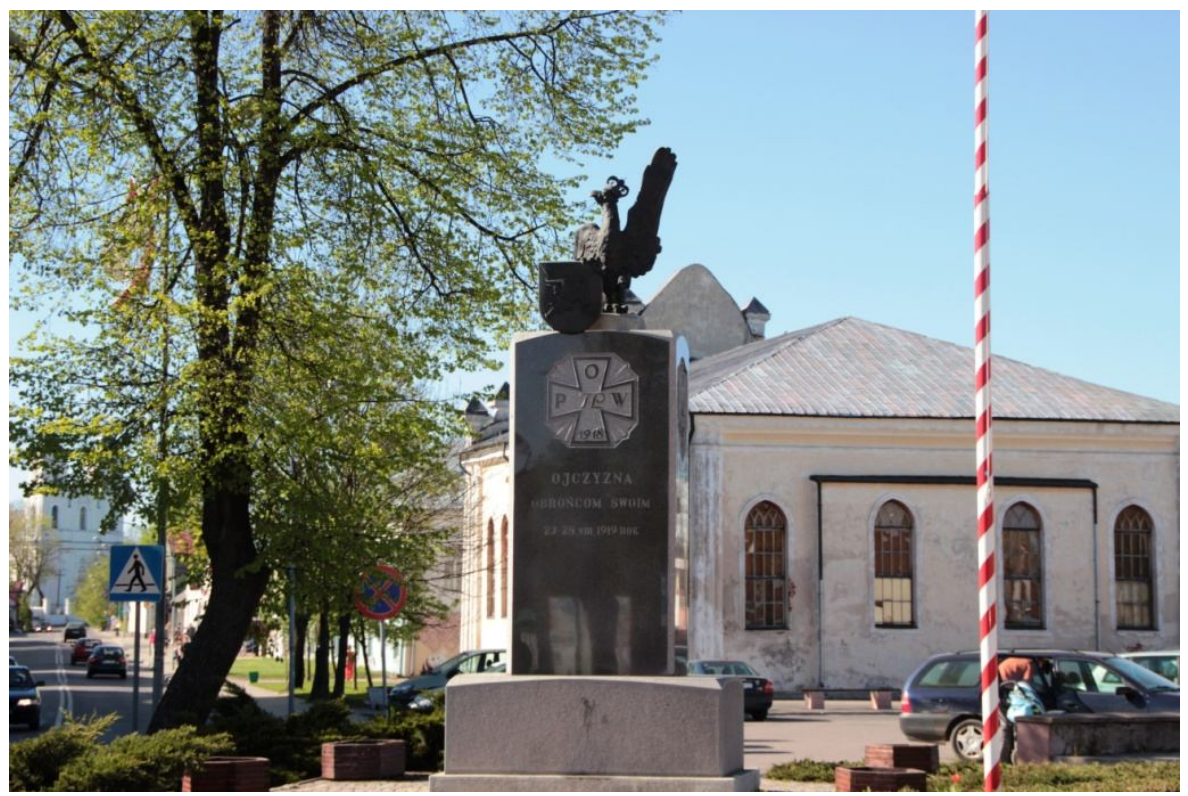

Pomnik w Sejnach ku czci Polaków walczących z Litwinami w powstaniu sejneńskim w 1919 r. (fot. autor)

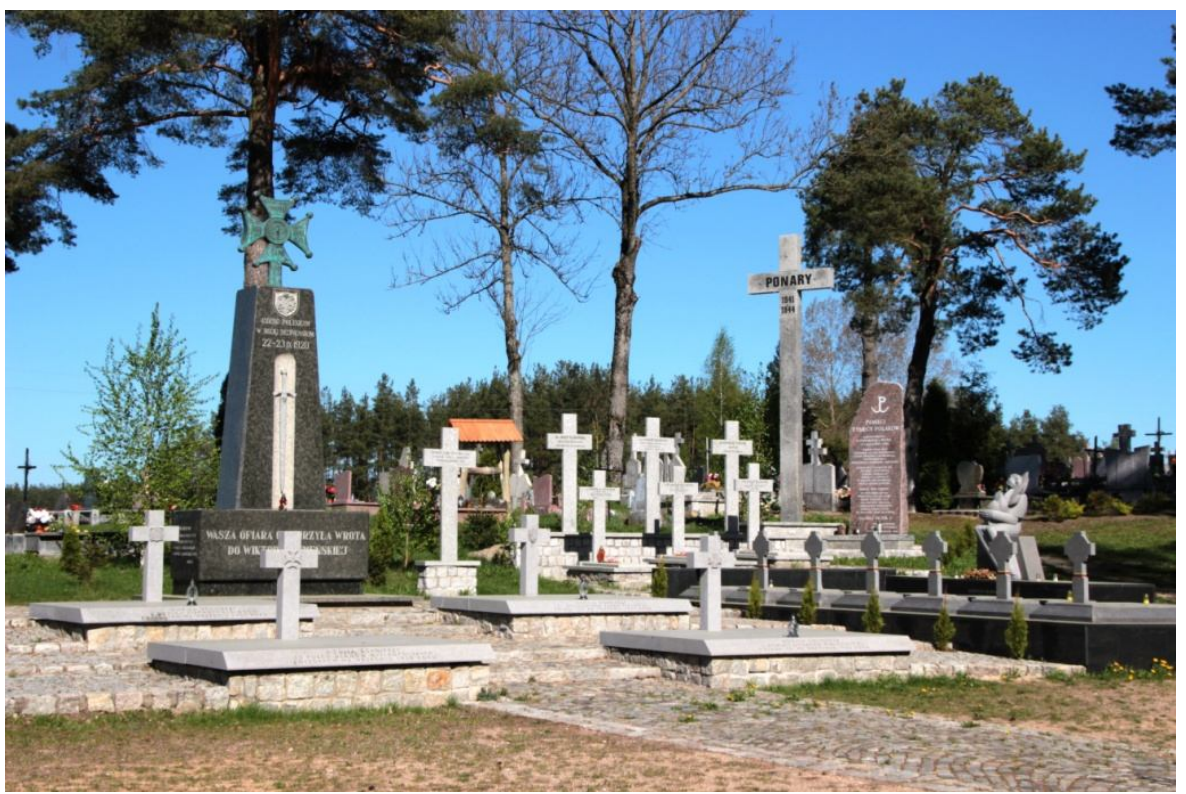

Cmentarz w Berżnikach (gmina Sejny) z grobami żołnierzy polskich i litewskich poległych w latach 1919-1920 oraz „,krzyżem ponarskim” upamiętniającym Polaków zamordowanych przez Niemców i Litwinów na Wileńszczyźnie w latach 1941-1944 (fot. autor) 


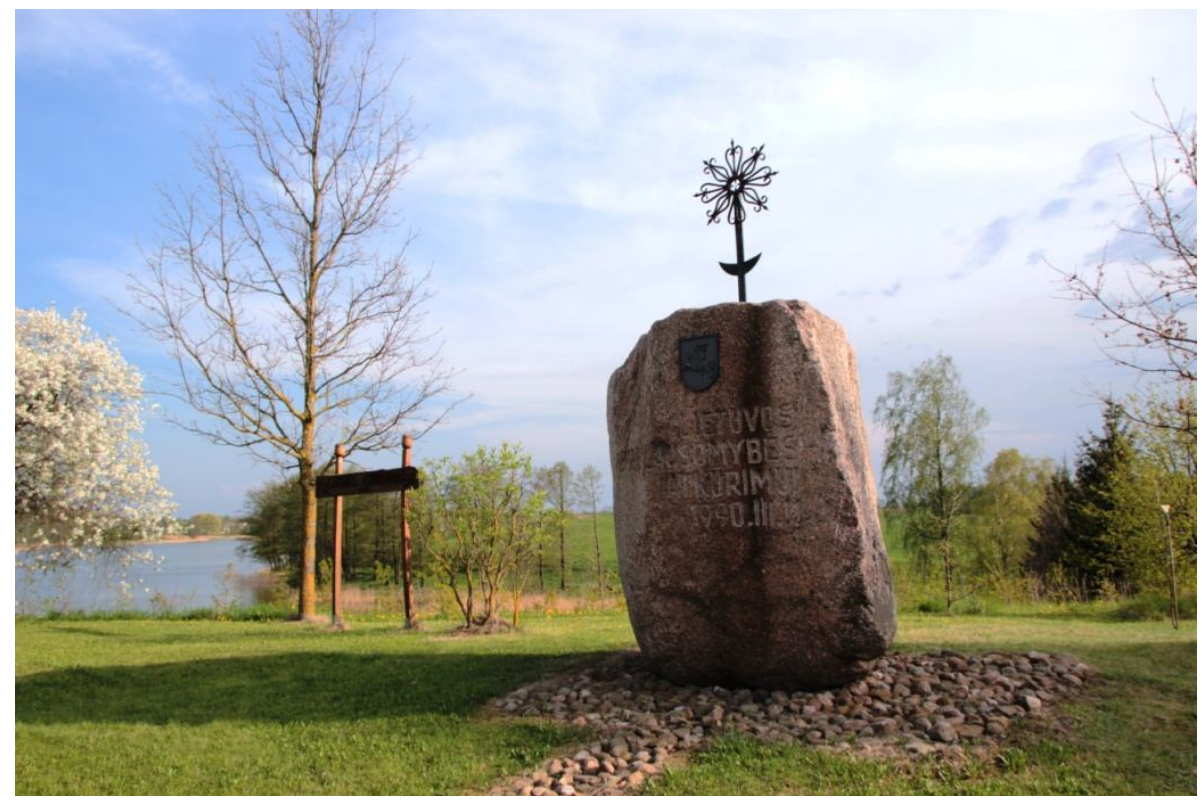

Kamień w gminie Puńsk z napisem upamiętniającym proklamację niepodległości Litwy 11 marca 1990 r. (fot. autor)

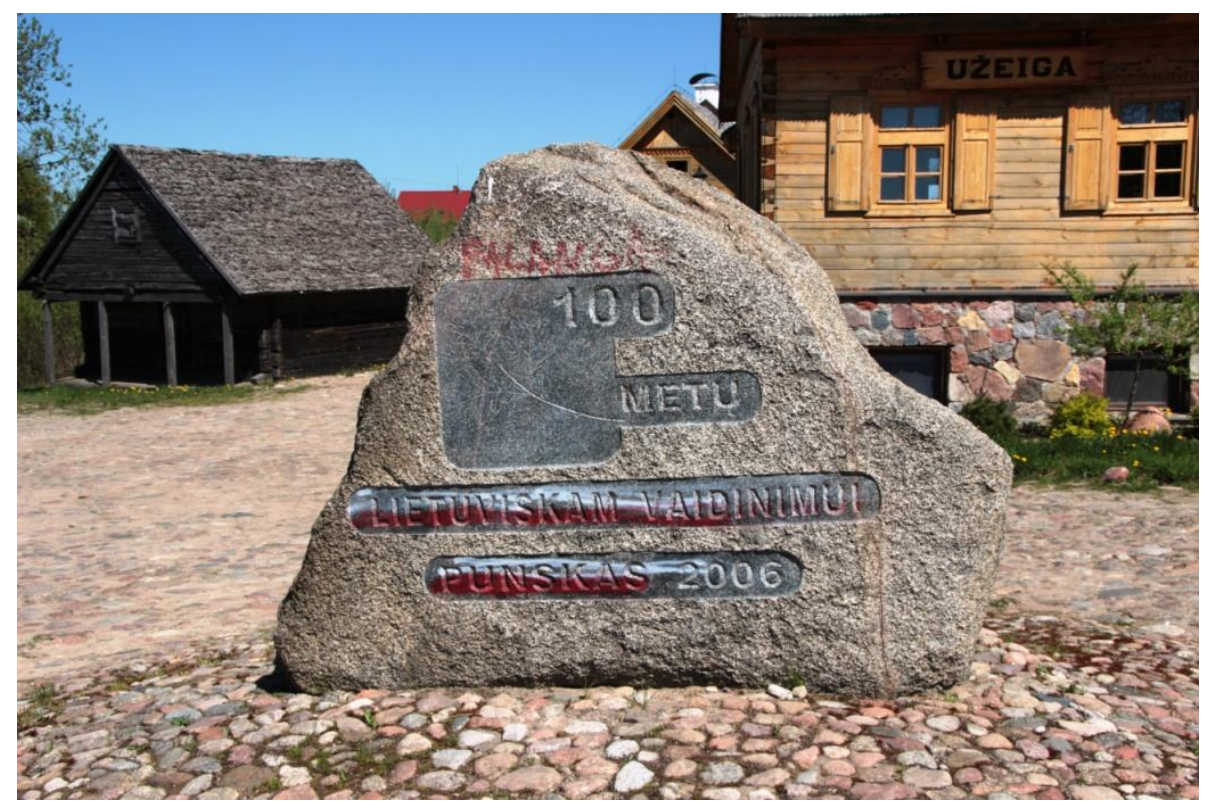

Obelisk w Puńsku - zniszczony w sierpniu 2011 r. napis upamiętniający 100-lecie litewskich teatrów stodolanych

(fot. autor) 


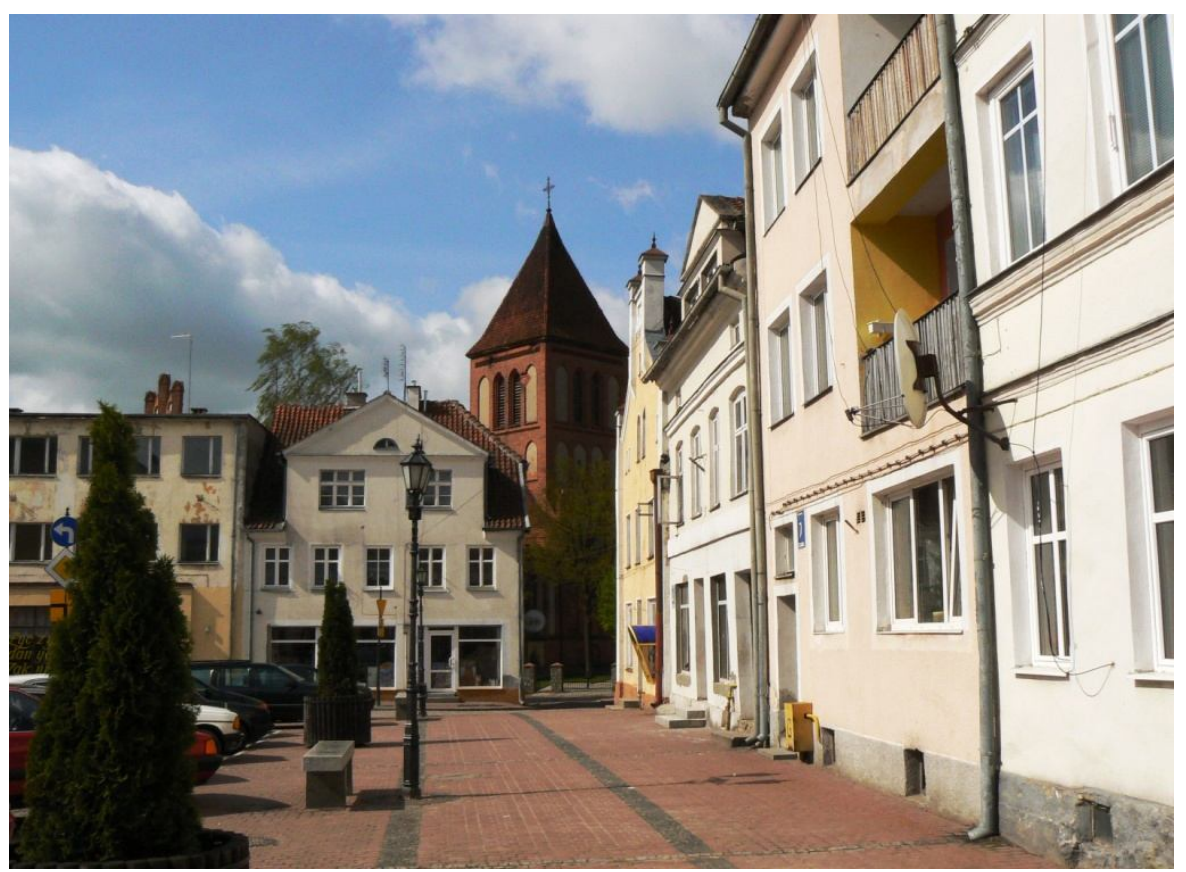

Górowo Iławeckie - jedno z najliczniejszych skupisk mniejszości ukraińskiej na Warmii i Mazurach oraz w Polsce (fot. autor)

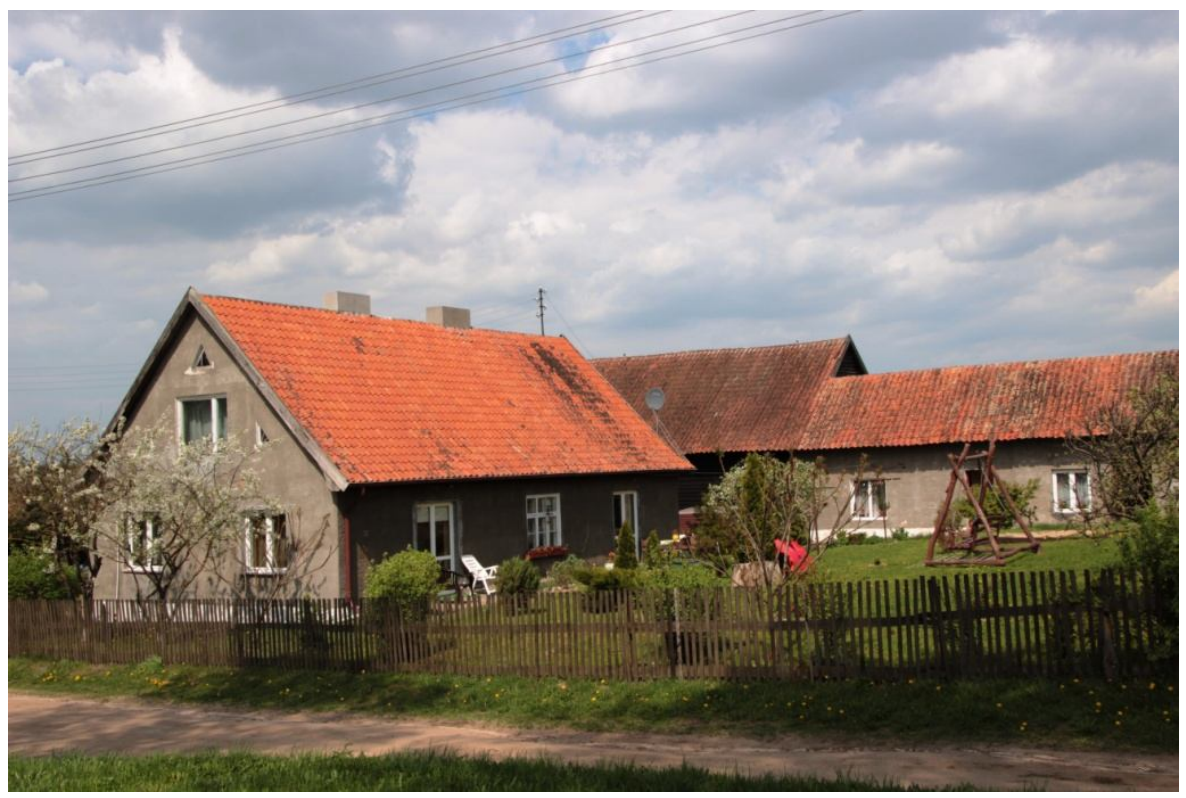

Poniemieckie gospodarstwo na Mazurach w gminie Banie Mazurskie - do tego typu gospodarstw przesiedlano Ukraińców podczas akcji „Wisła” (fot. autor) 


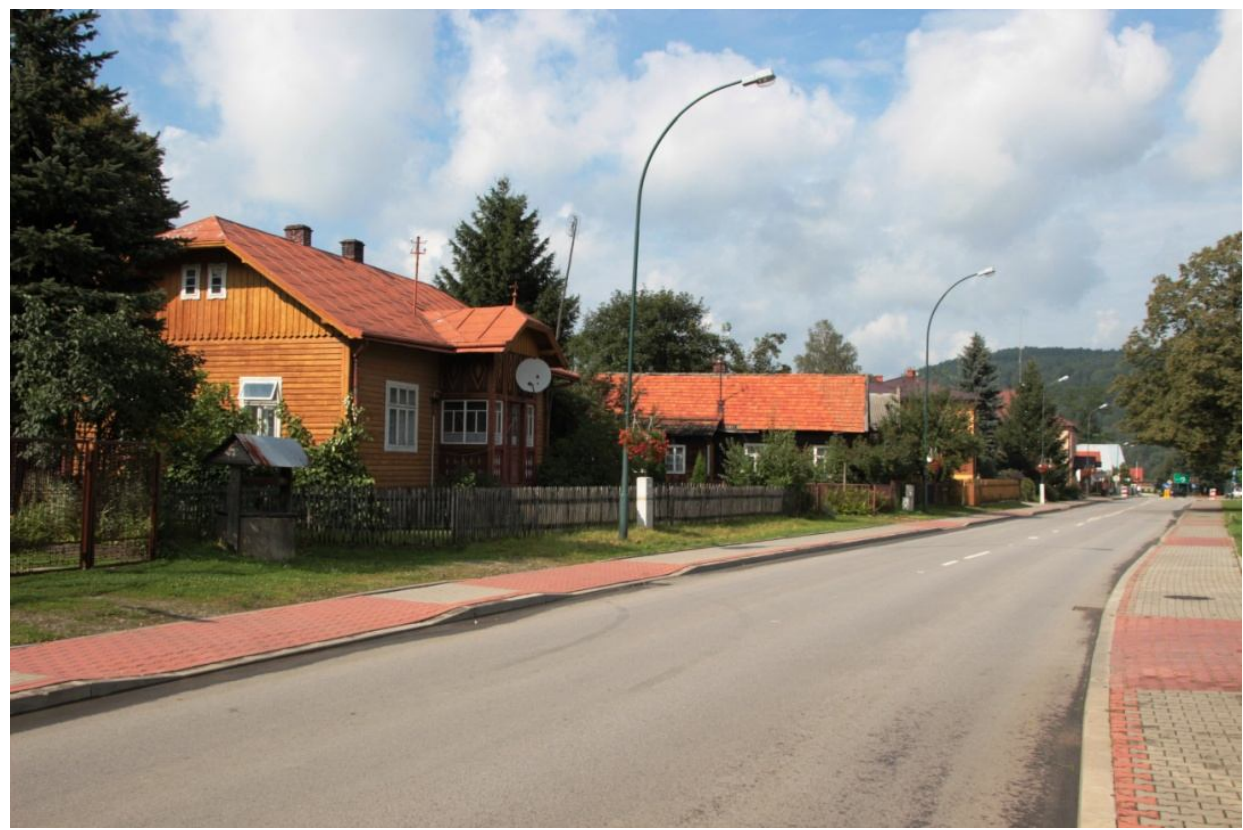

Uście Gorlickie na Łemkowszczyźnie - siedziba gminy będącej jednym z największych skupisk mniejszości łemkowskiej (fot. autor)

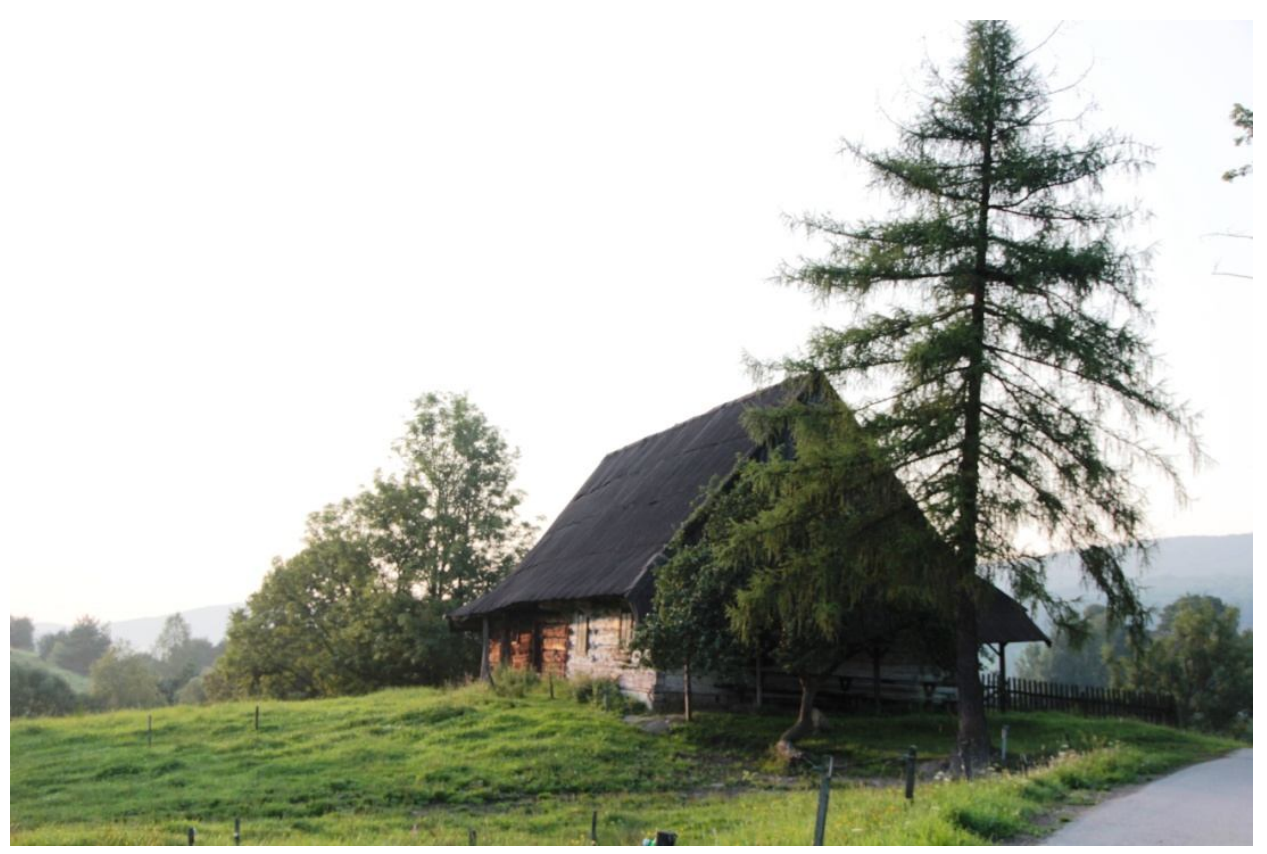

Łemkowska chata w Bartnem w gminie Sękowa w Beskidzie Niskim (fot. autor) 


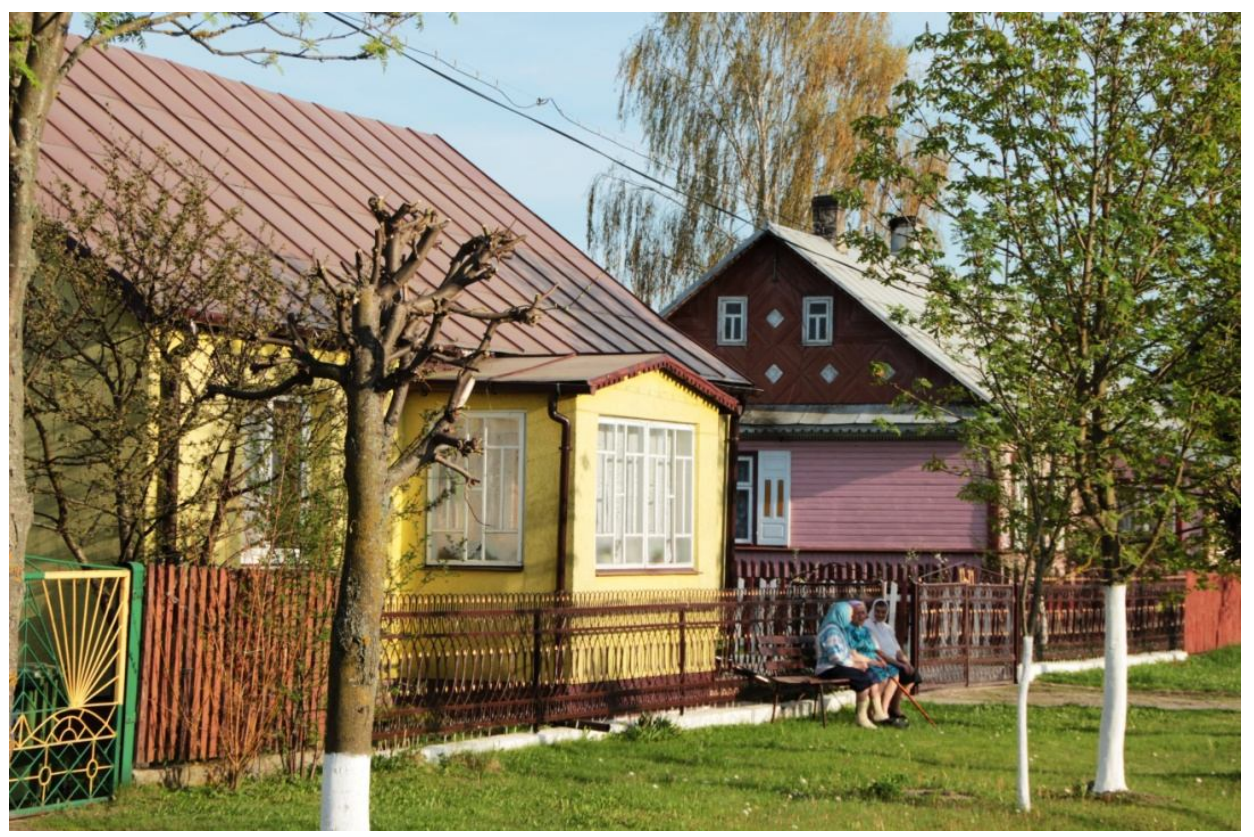

Czyże na Podlasiu - siedziba gminy będącej jednym z największych skupisk mniejszości białoruskiej (fot. autor)

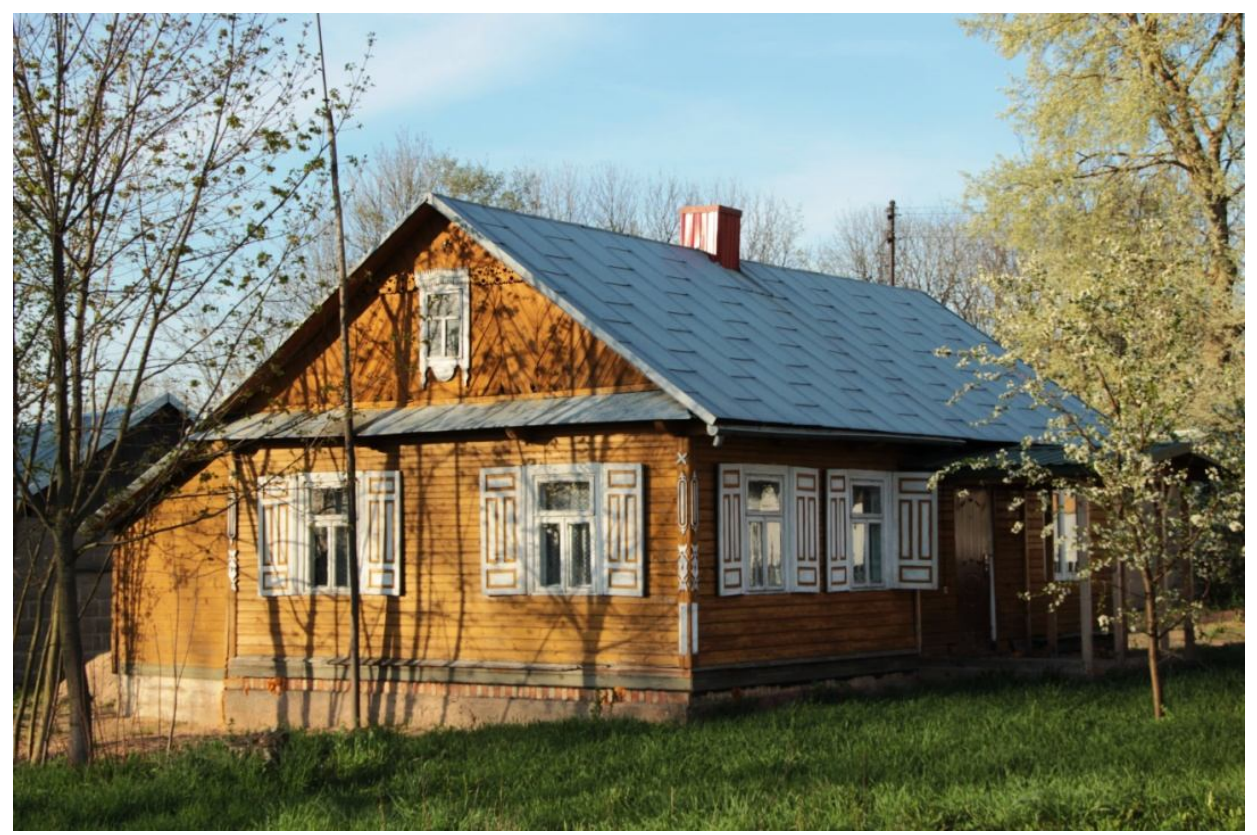

Typowy dom we wsiach wschodniego Podlasia zamieszkanych przez Białorusinów (fot. autor) 


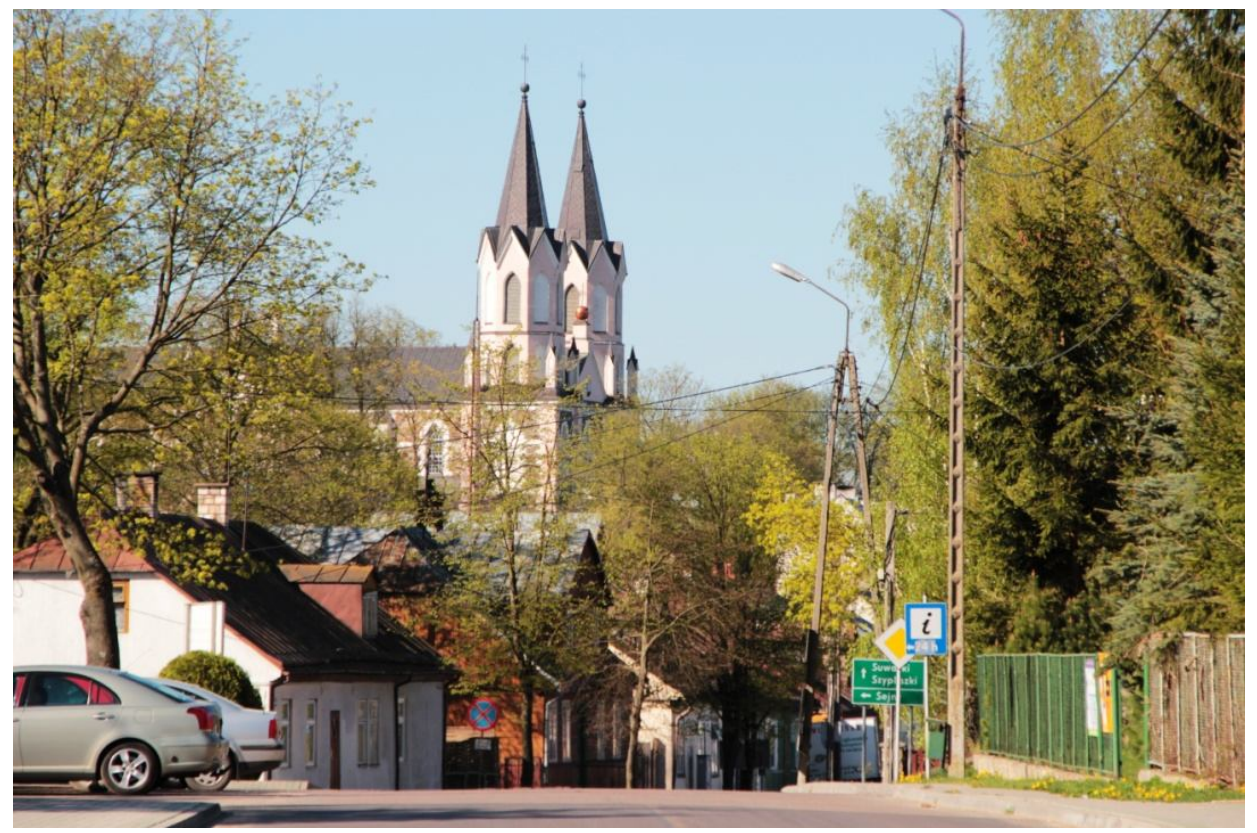

Puńsk na Suwalszczyźnie - nieformalna stolica mniejszości litewskiej (fot. autor)

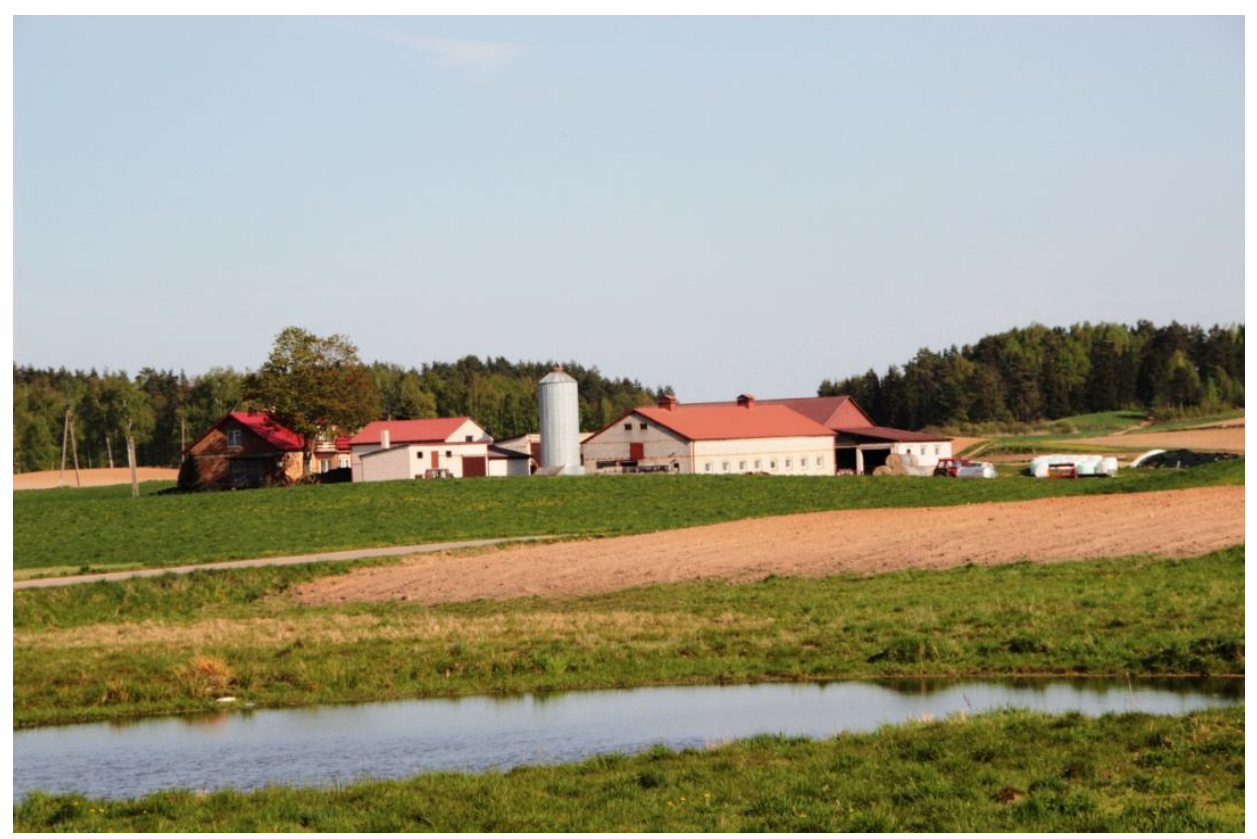

Zabudowania litewskiego gospodarstwa rolnego typowego dla gminy Puńsk (fot. autor) 


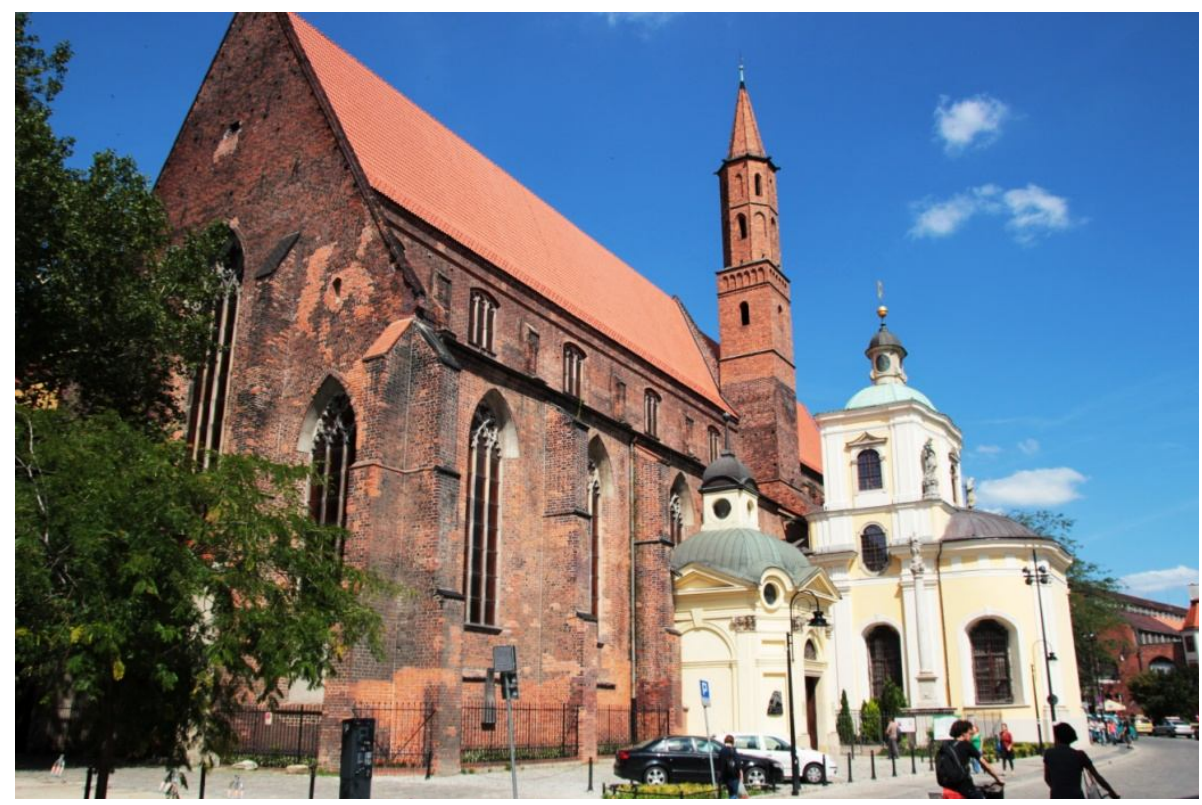

Katedra greckokatolicka we Wrocławiu w gotyckim kościele (fot. autor)

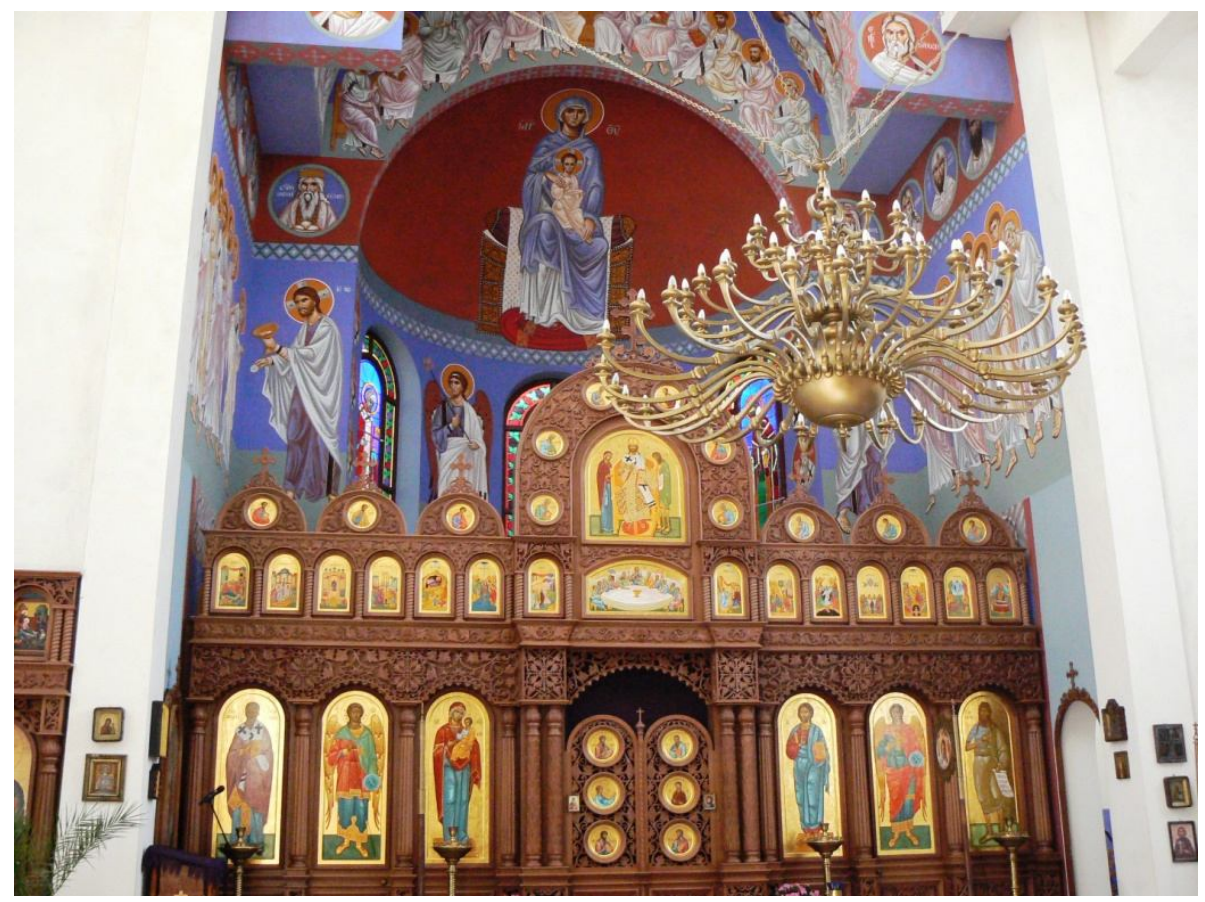

Wnętrze współczesnej cerkwi prawosławnej w Szczecinie (fot. autor) 


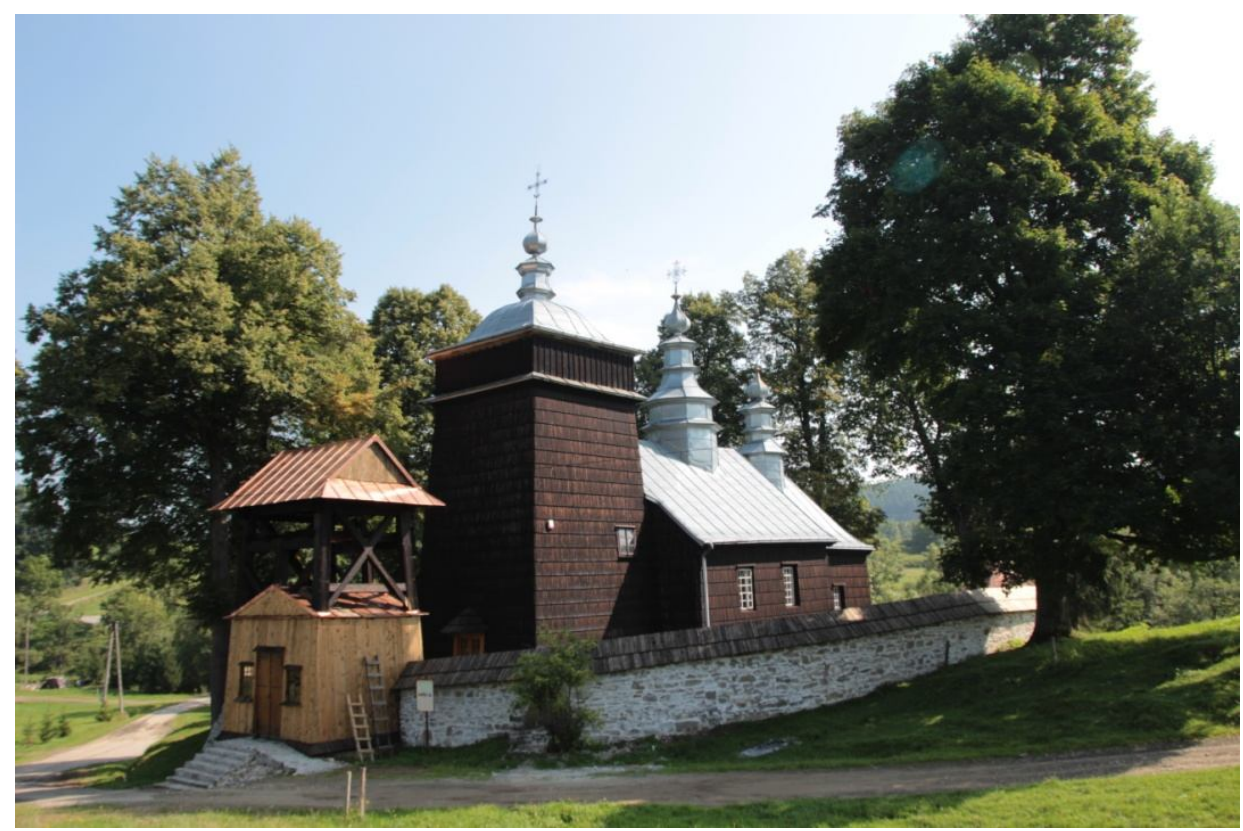

Zabytkowa cerkiew greckokatolicka (po akcji „Wisła” prawosławna) w Zdyni na Łemkowszczyźnie (fot. autor)

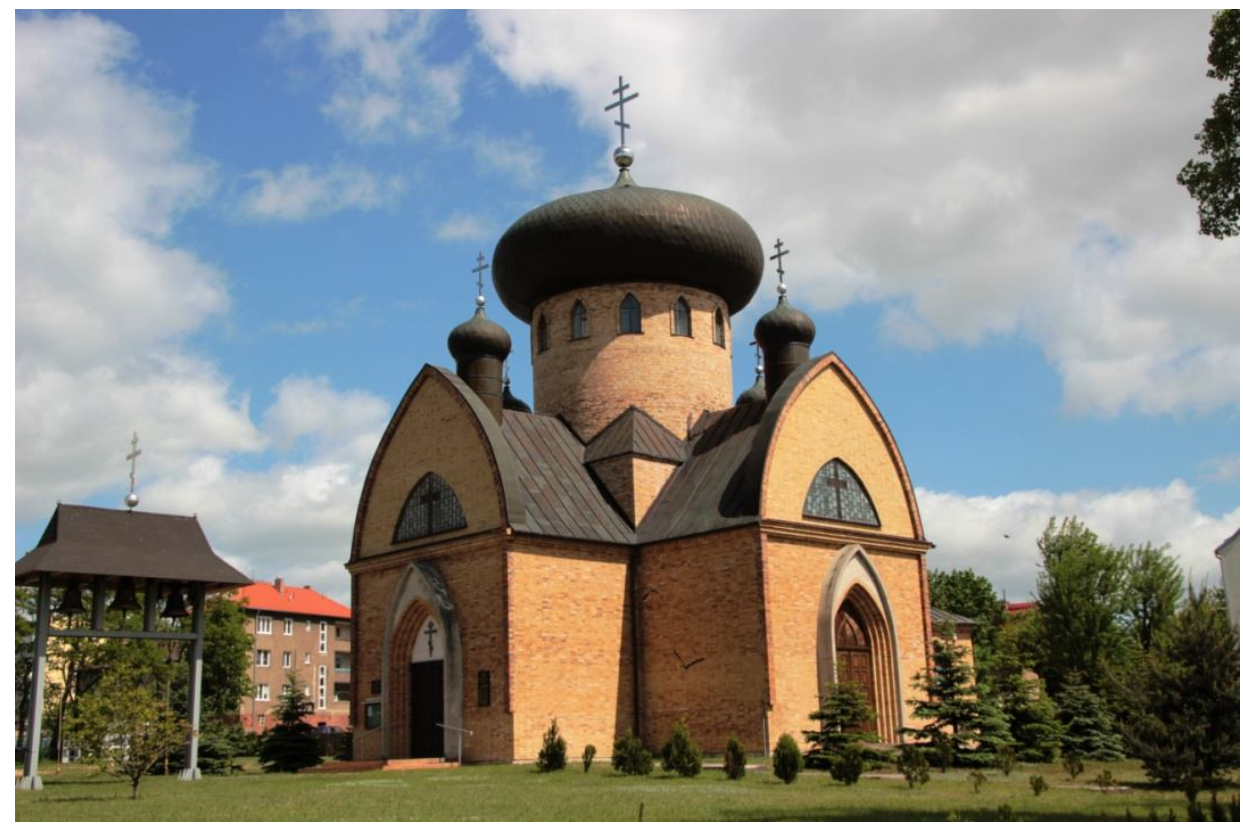

Współczesna cerkiew greckokatolicka w Gorzowie Wielkopolskim (fot. autor) 


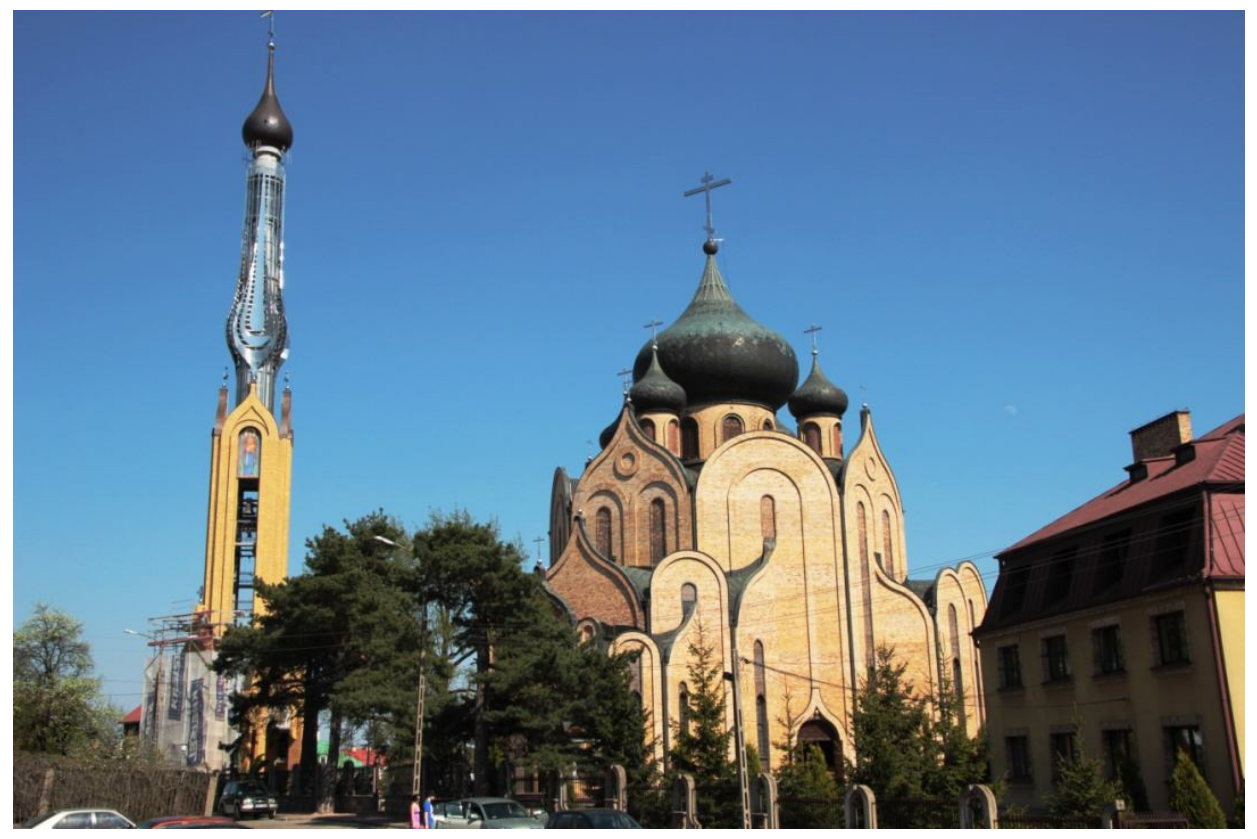

Największa w Polsce cerkiew prawosławna w Białymstoku (fot. autor)

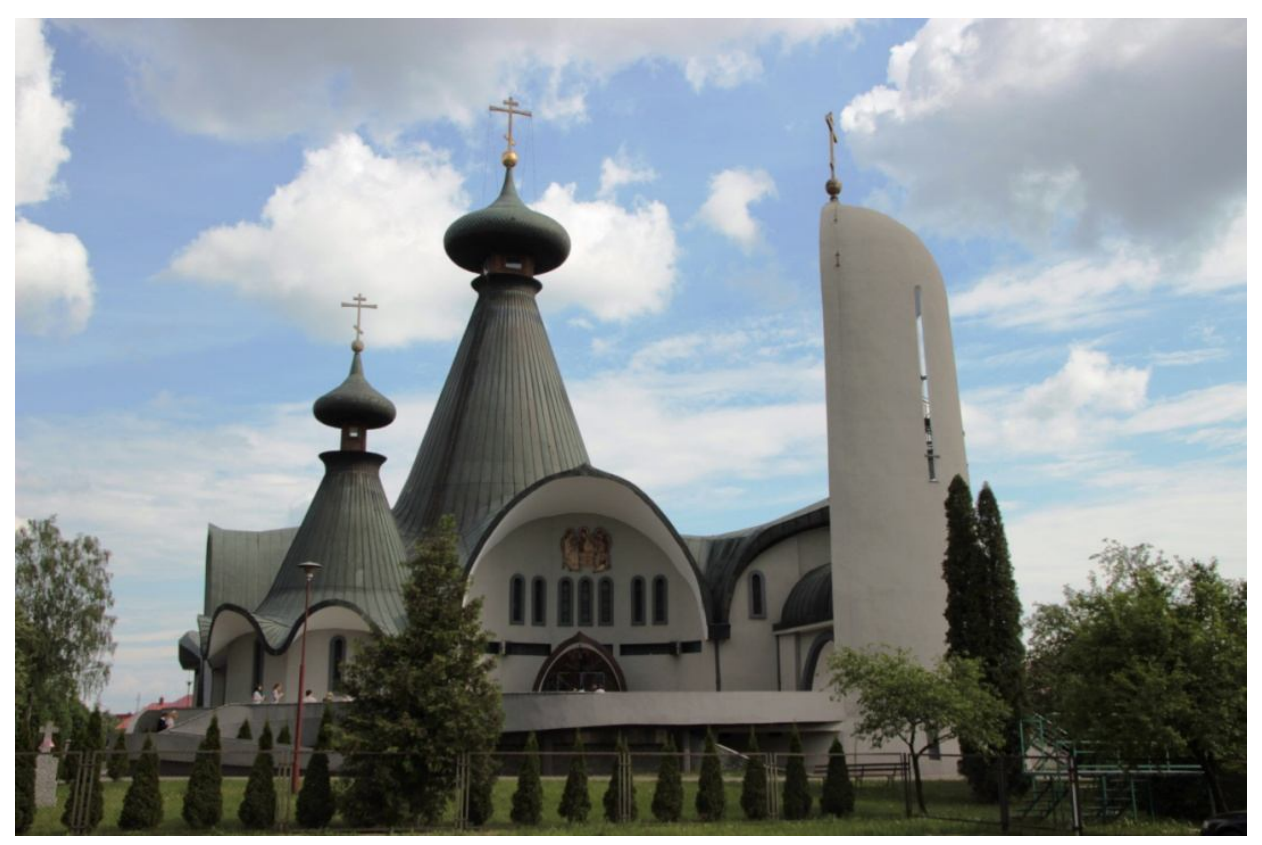

Cerkiew prawosławna w Hajnówce

(fot. autor) 


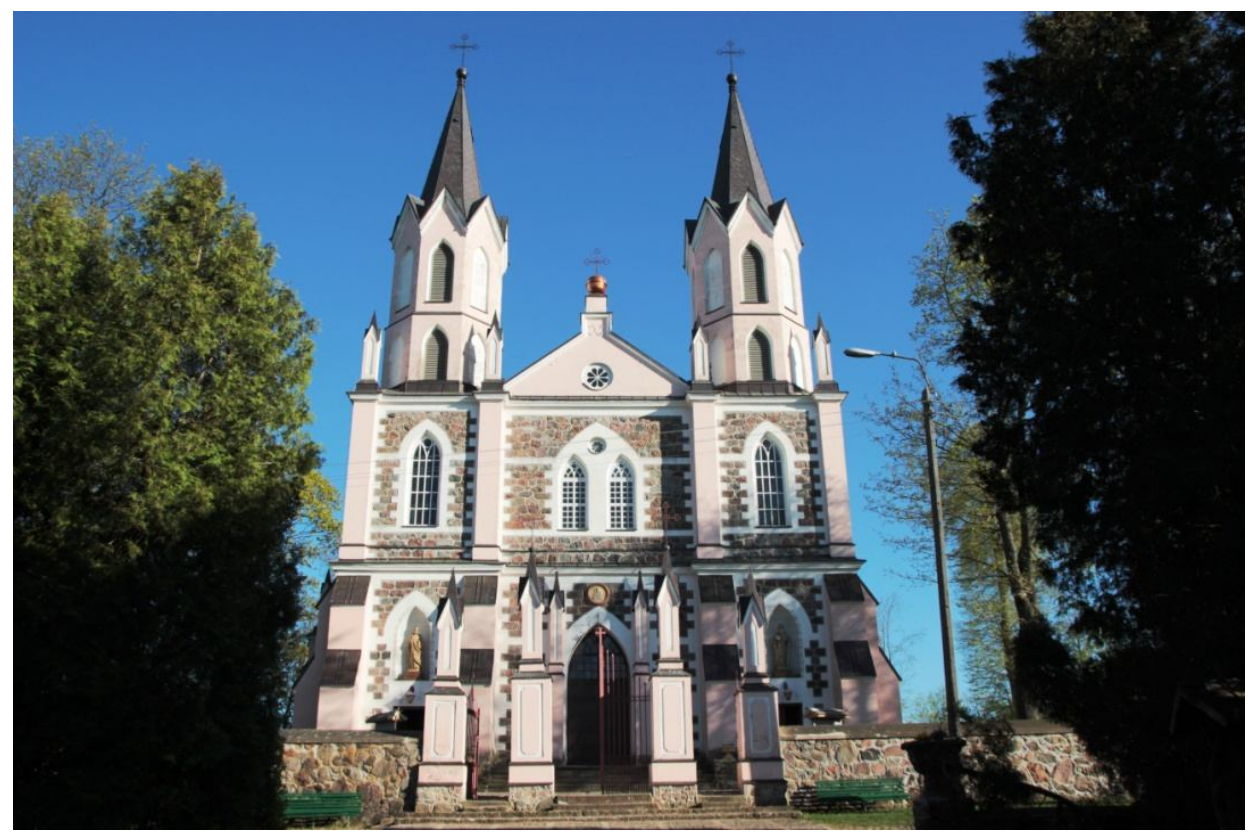

Kościół rzymskokatolicki w Puńsku z mszami odprawianymi w języku litewskim i polskim (fot. autor)

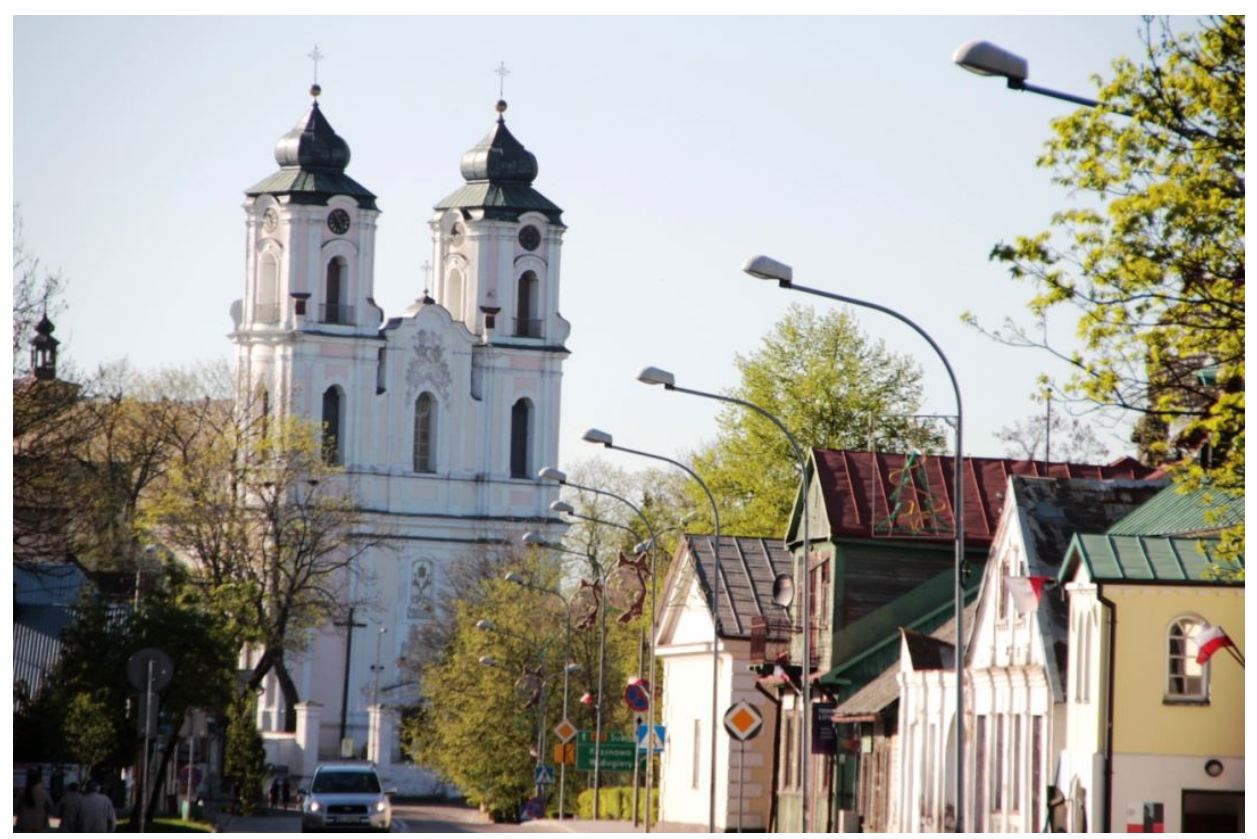

Bazylika rzymskokatolicka w Sejnach - przez kilkadziesiąt lat miejsce sporu o msze w języku litewskim, zakończonego w 1983 r. (fot. autor) 


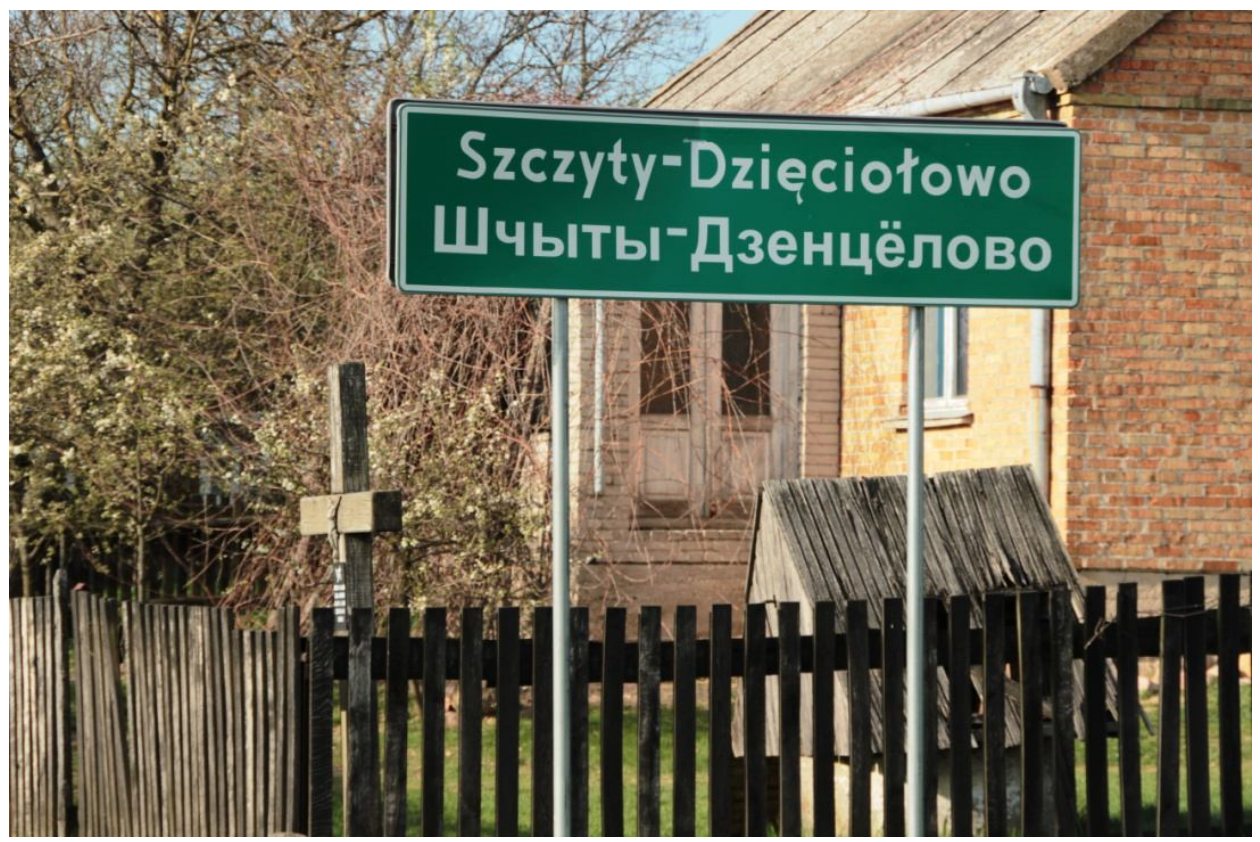

Polska i białoruska nazwa miejscowości w gminie Orla (fot. autor)

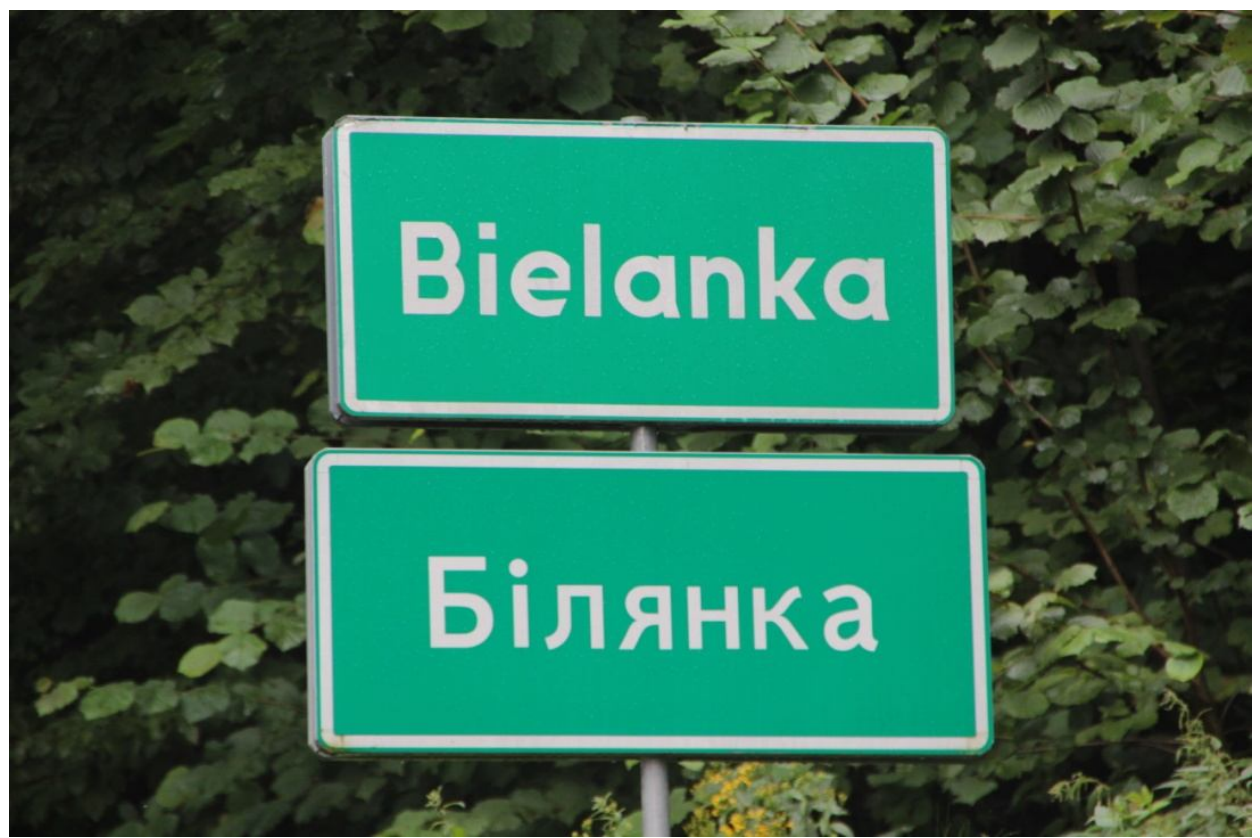

Polska i łemkowska nazwa miejscowości w gminie Gorlice (fot. autor) 


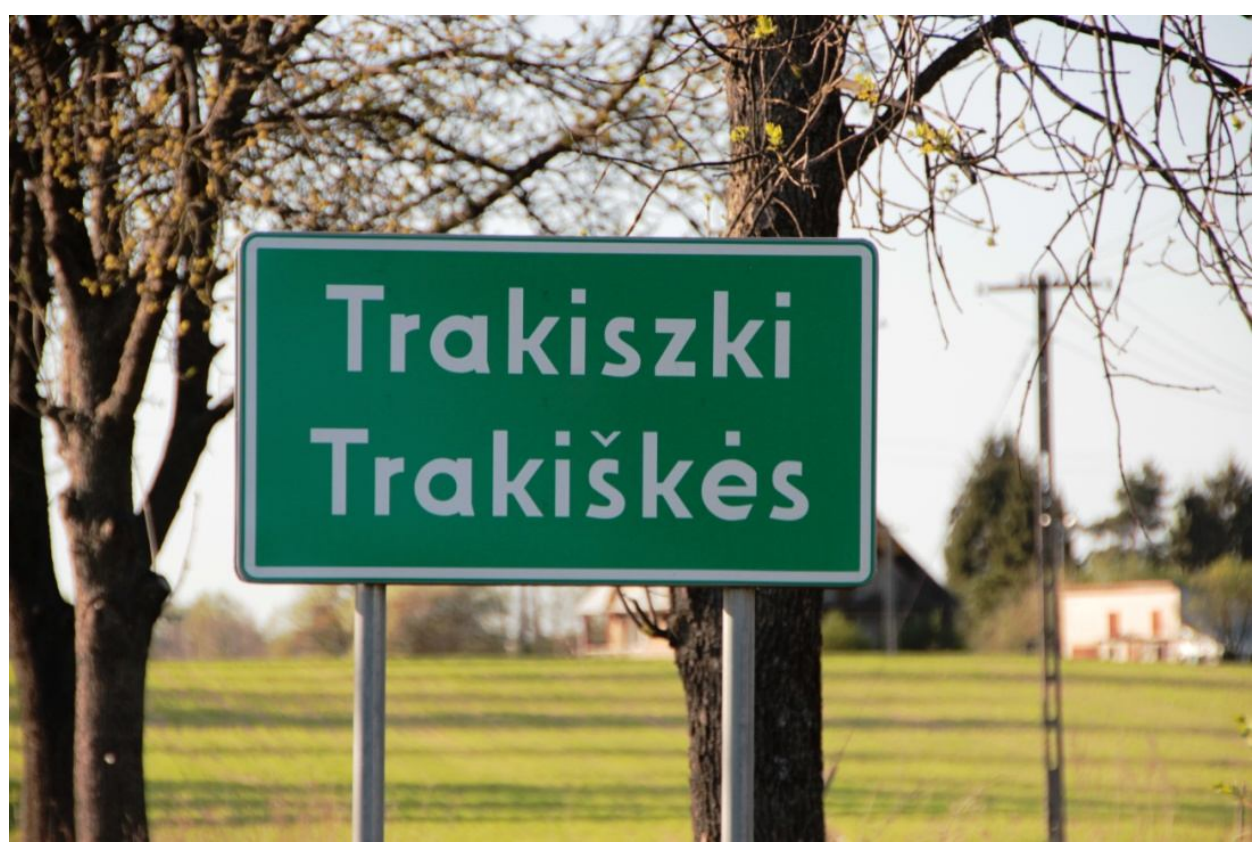

Polska i litewska nazwa miejscowości w gminie Puńsk (fot. autor)

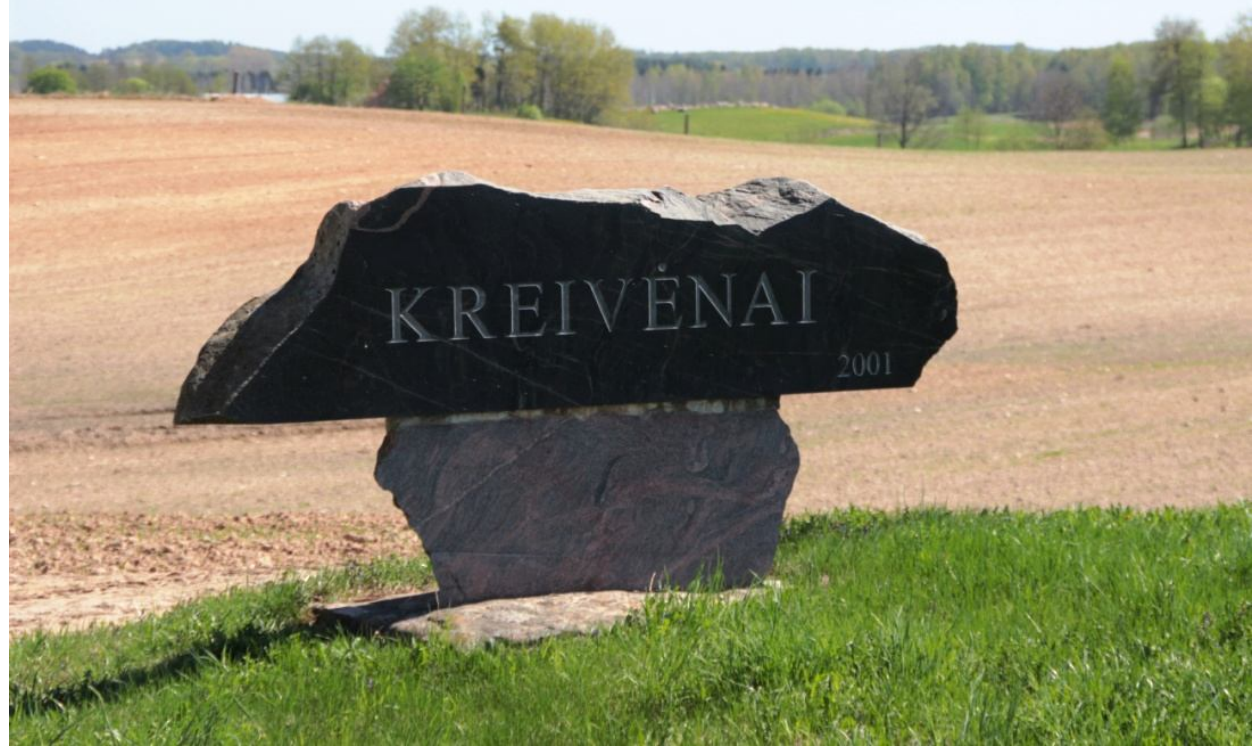

Krejwiany - w gminie Puńsk litewskie nazwy miejscowości umieszczano już przed przyjęciem ustawy z 2005 r., która je legalizowała (fot. autor) 


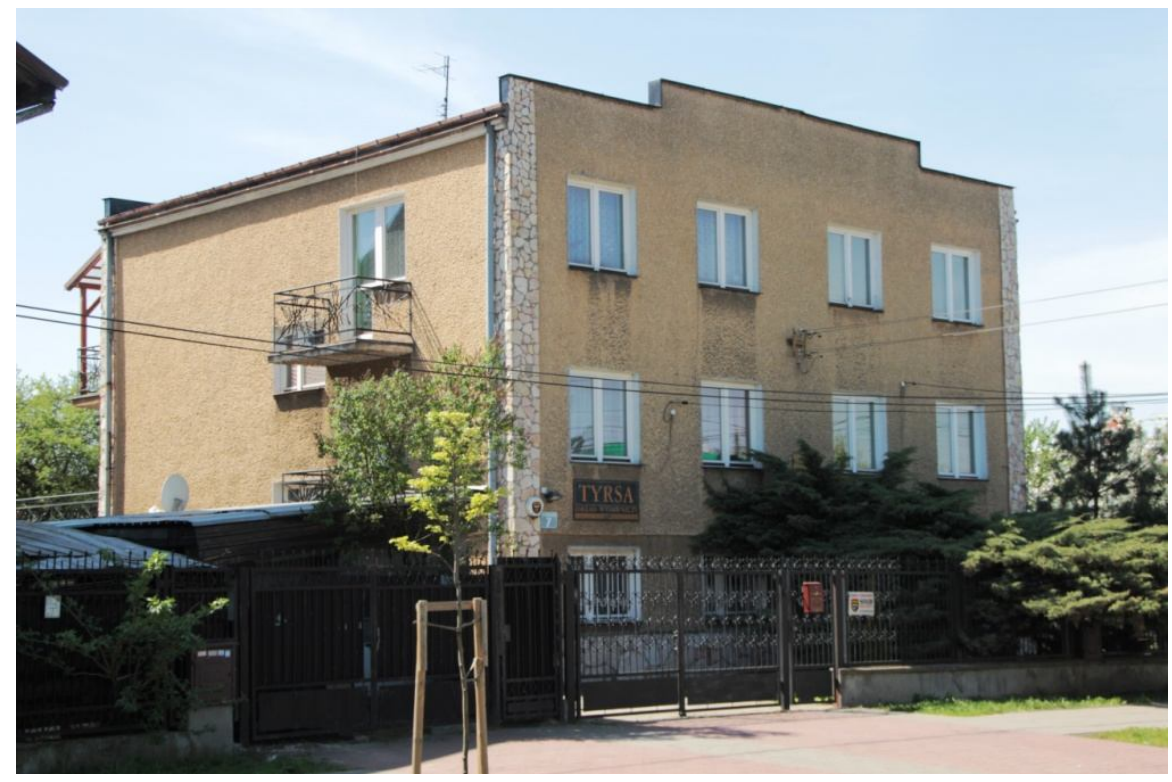

Budynek w Warszawie należący do Związku Ukraińców w Polsce, siedziba ZG ZUwP, Ukraińskiego Towarzystwa Historycznego, Organizacji Młodzieży Ukraińskiej „Płast”, Związku Ukrainek w Polsce, redakcji „Naszego Słowa”, wydawnictwa „Tyrsa” (fot. autor)

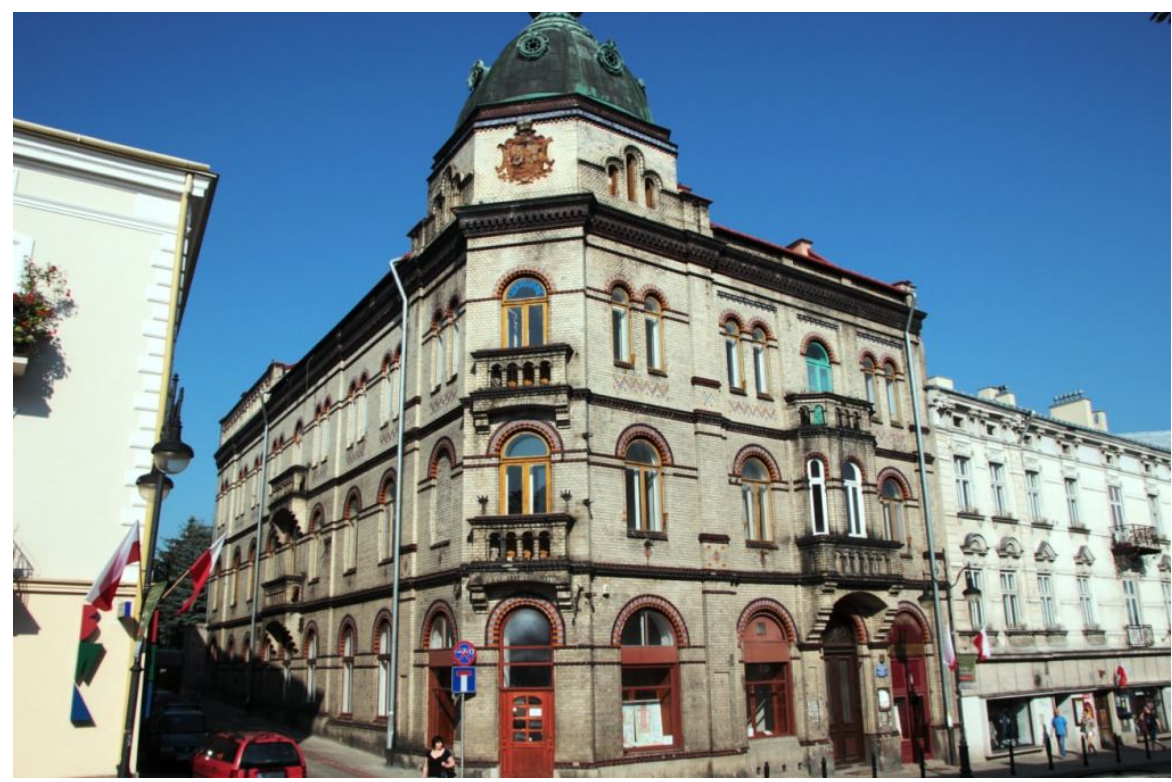

Ukraiński Dom Narodowy w Przemyślu, wybudowany na początku XX w. z przeznaczeniem na siedzibę ukraińskich organizacji i instytucji, przekazany w marcu $2011 \mathrm{r}$. Związkowi Ukraińców w Polsce, m.in. siedziba oddziału i koła ZUwP (fot. autor) 


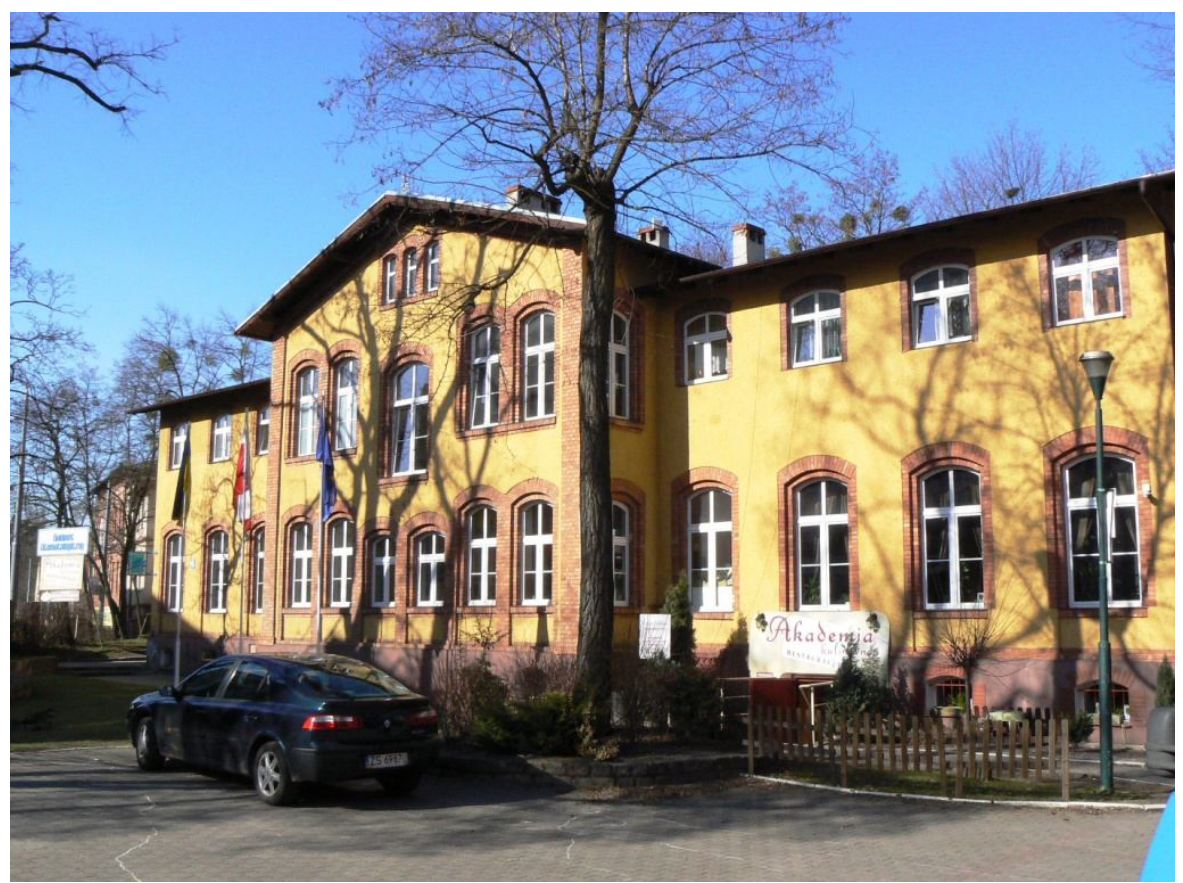

Budynek w Szczecinie należący do Związku Ukraińców w Polsce - siedziba oddziału i koła ZUwP (fot. autor)

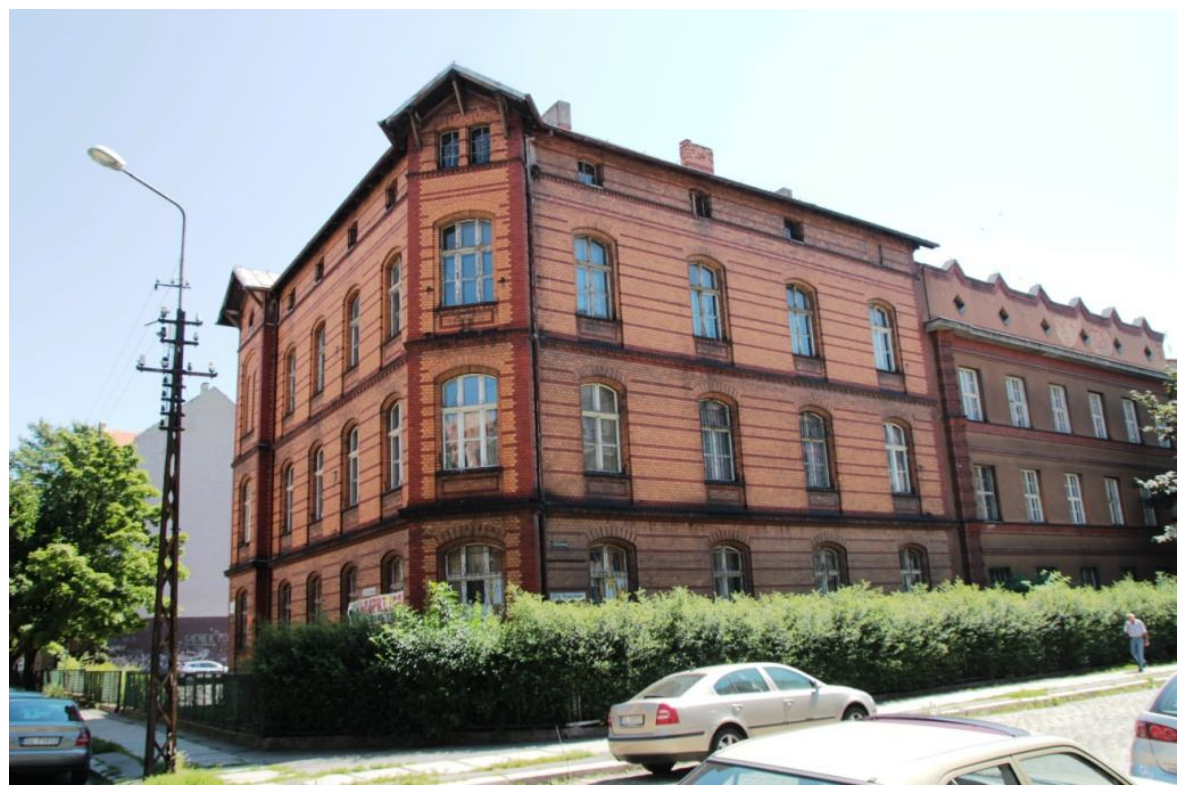

Budynek w Legnicy należący do Łemkowskiego Zespołu Pieśni i Tańca „Kyczera”siedziba Zarządu Głównego Stowarzyszenia Łemków (fot. autor) 


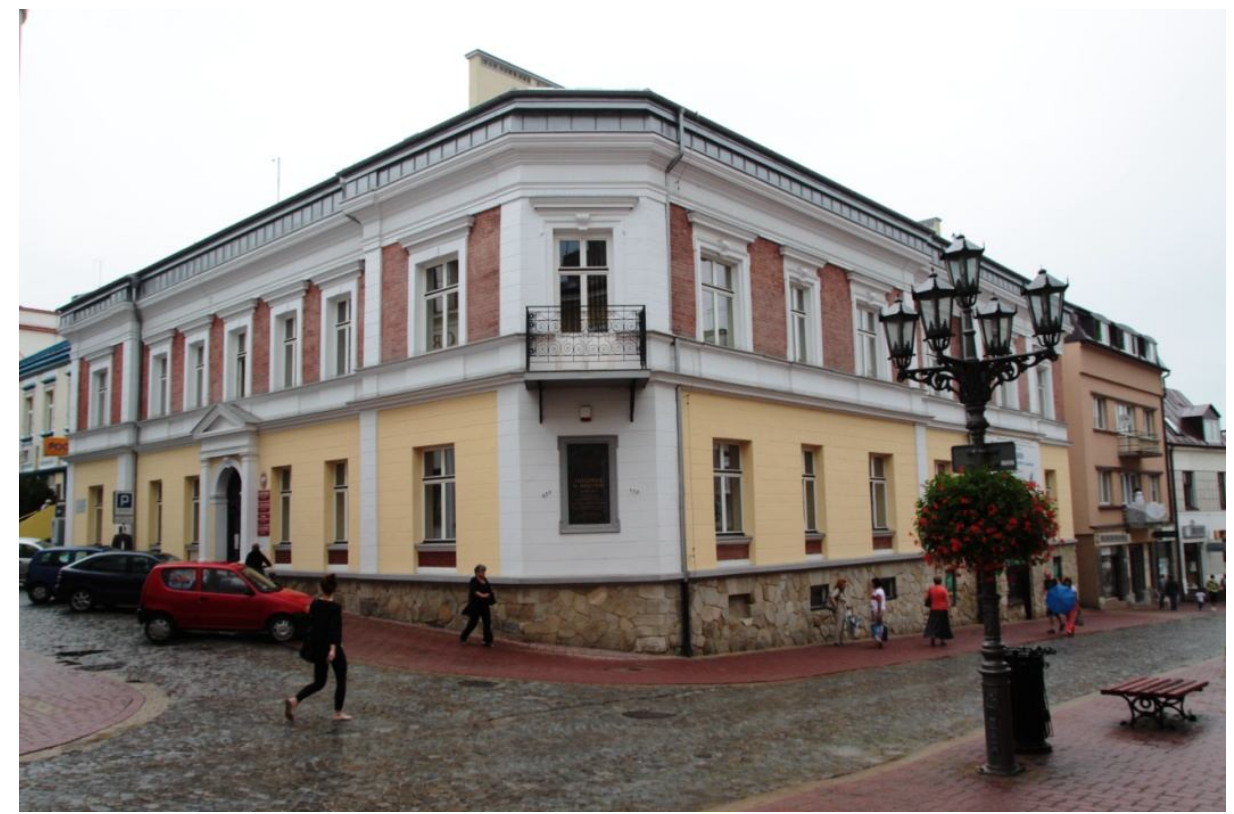

Budynek w Gorlicach - m.in. siedziba Zarządu Głównego Zjednoczenia Łemków (fot. autor)

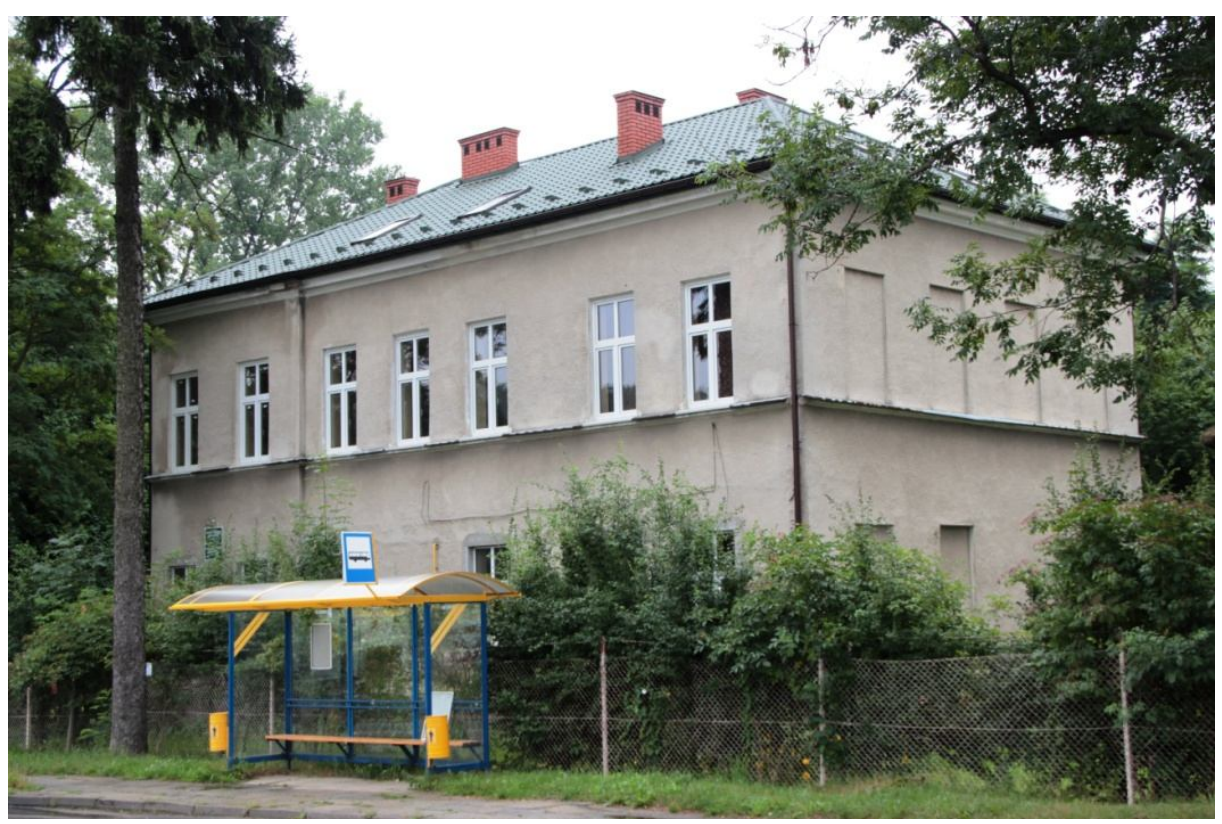

Budynek „Ruskiej Bursy” w Gorlicach - w pierwszej połowie XX w. internat dla młodzieży łemkowskiej, w 2009 r. zwrócony Łemkom, obecnie ośrodek kultury łemkowskiej, m.in. siedziba Stowarzyszenia „Ruska Bursa” (fot. autor) 


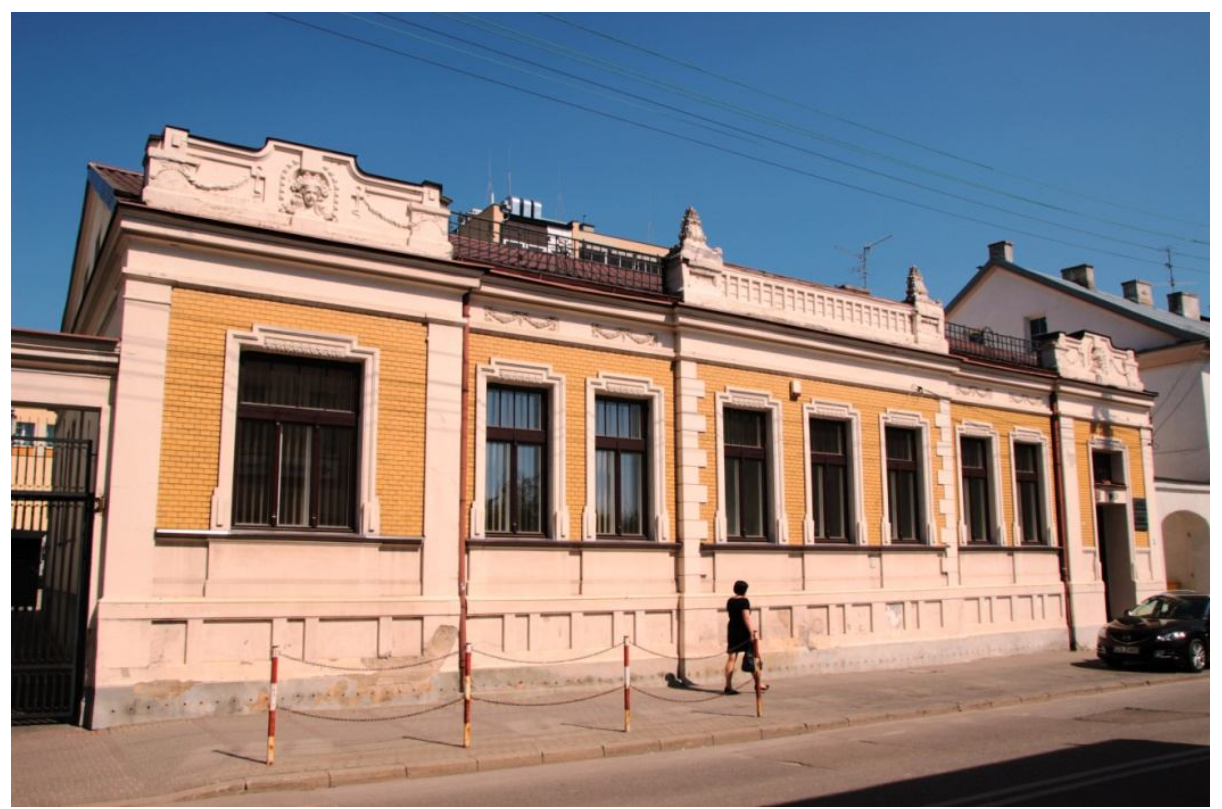

Budynek w Białymstoku należący do Białoruskiego Towarzystwa Społeczno-Kulturalnego - siedziba Zarządu Głównego BTSK (fot. autor)

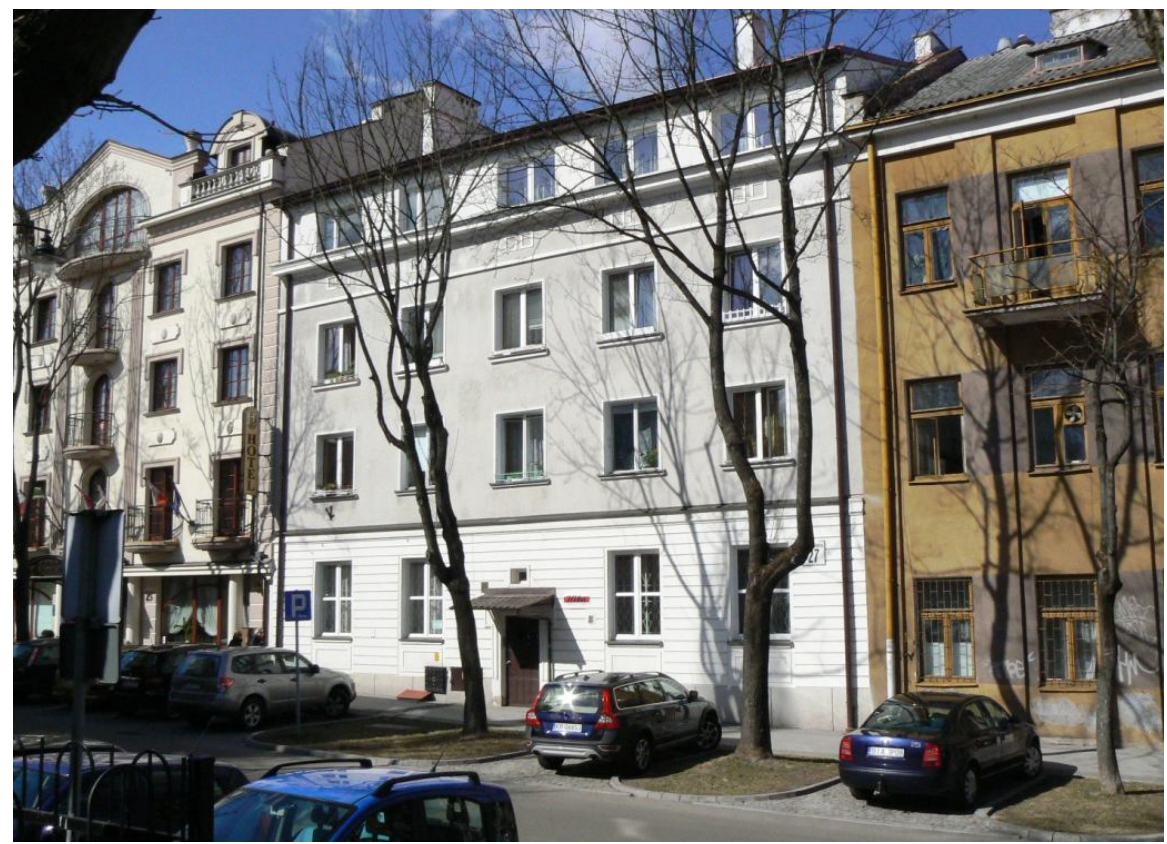

Budynek w Białymstoku - m.in. siedziba Rady Programowej Tygodnika „Niwa” oraz Białoruskiego Zrzeszenia Studentów (fot. autor) 


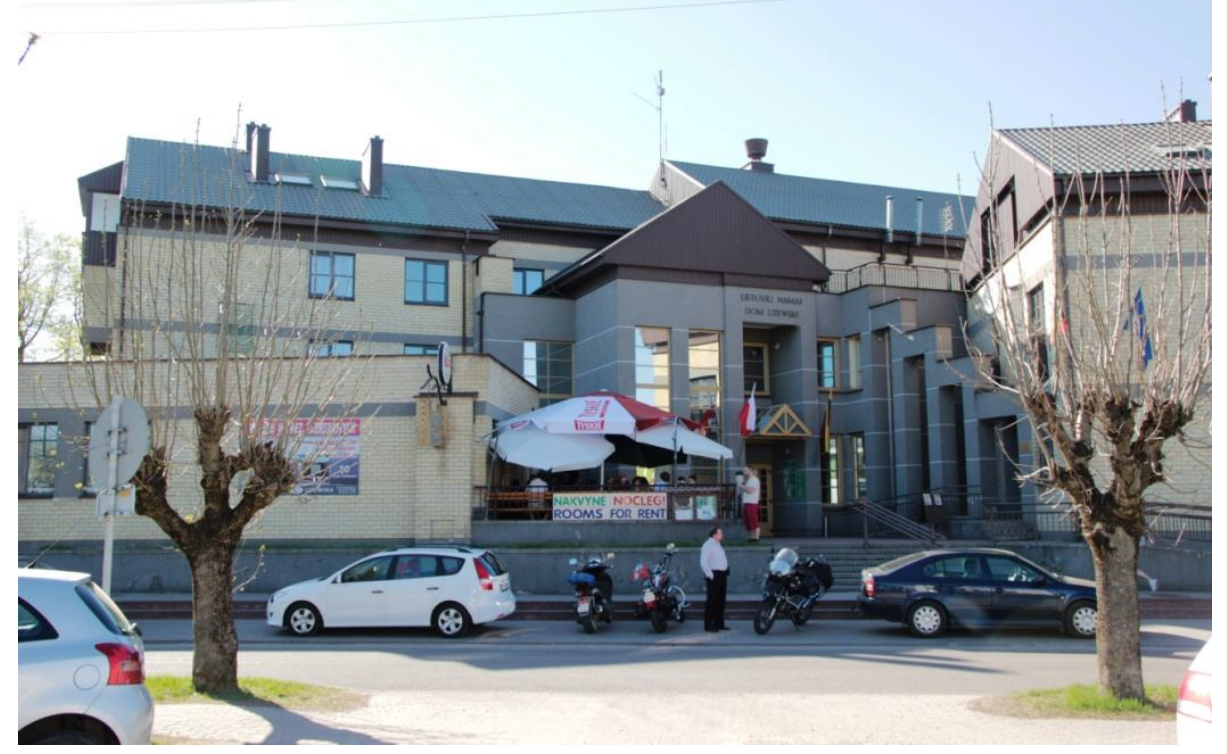

Dom Litewski w Sejnach - siedziba Stowarzyszenia Litwinów w Polsce, Litewskiego Towarzystwa Św. Kazimierza, Fundacji im. biskupa Antanasa Baranauskasa, konsulatu Republiki Litewskiej oraz licznych zespołów artystycznych (fot. autor)

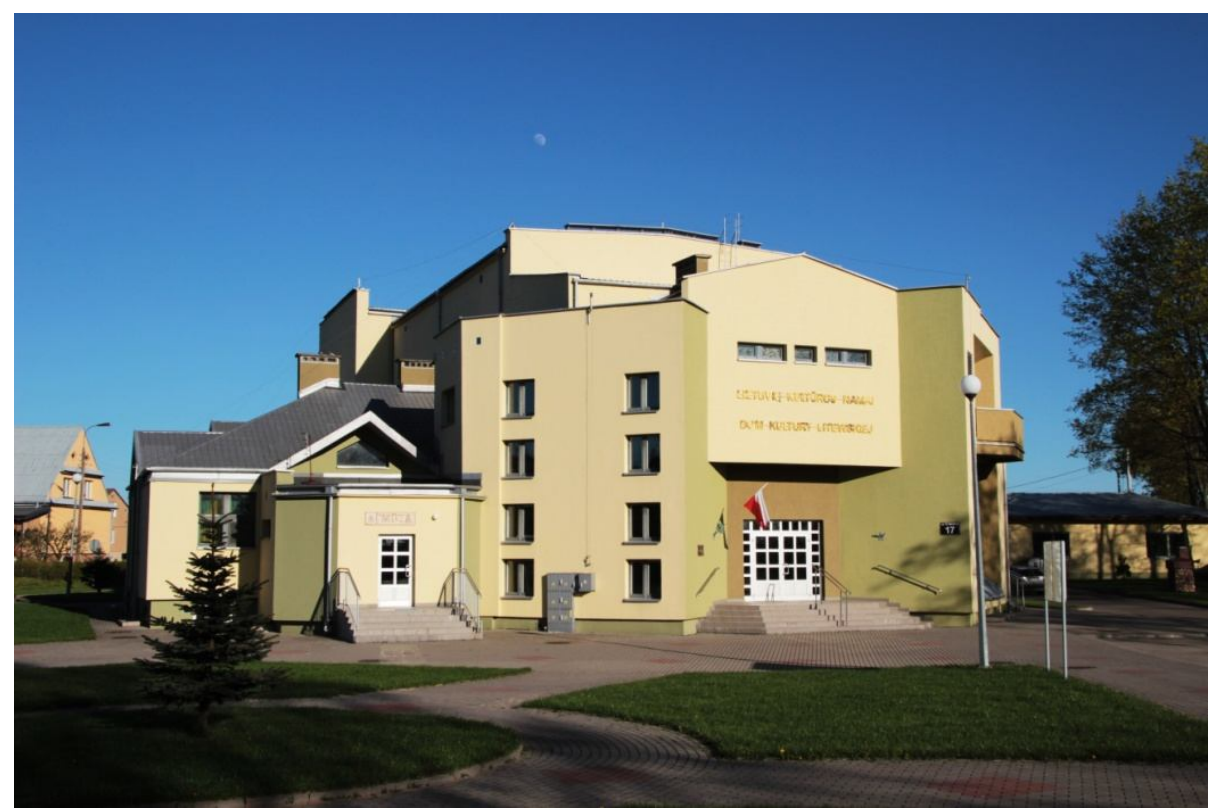

Dom Kultury Litewskiej w Puńsku - m.in. siedziba muzeum etnograficznego, chóru, zespołów ludowych i tanecznych oraz teatrów stodolanych (fot. autor) 


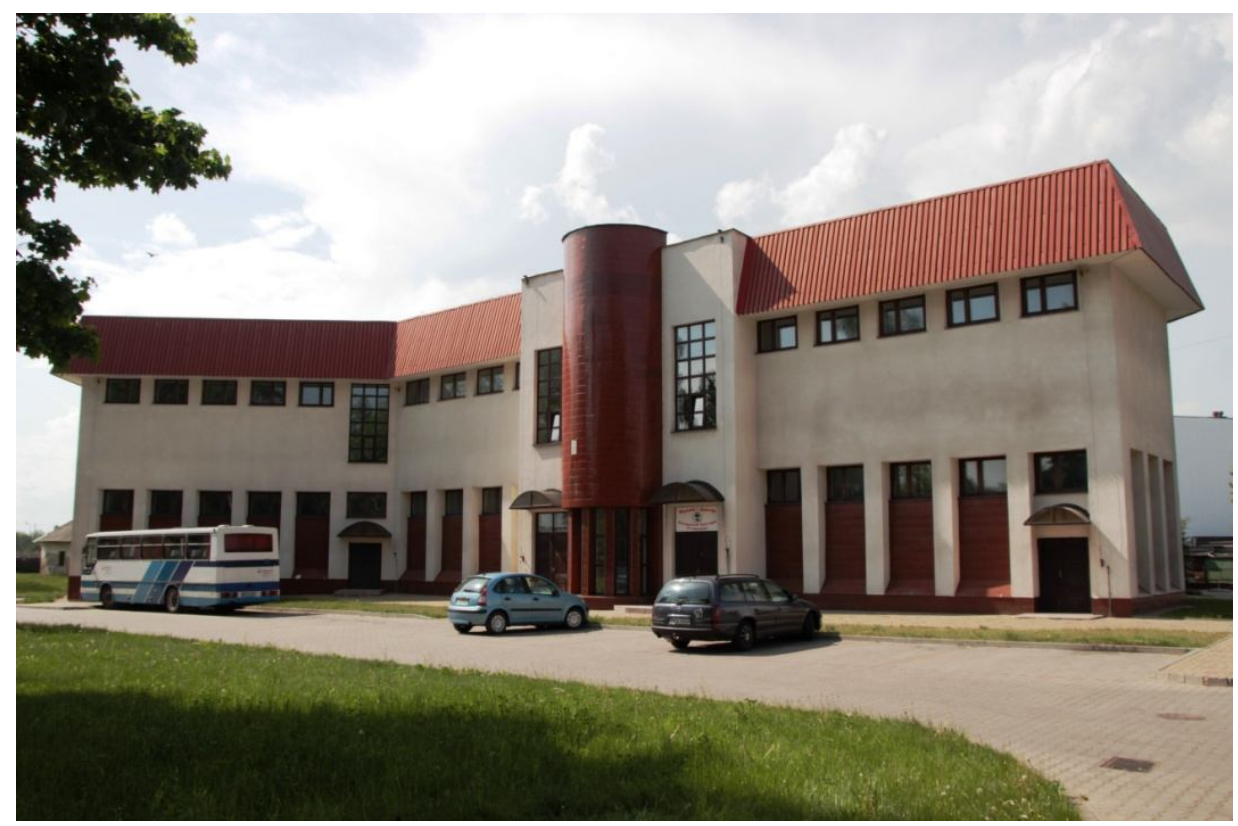

Muzeum i Ośrodek Kultury Białoruskiej w Hajnówce (fot. autor)

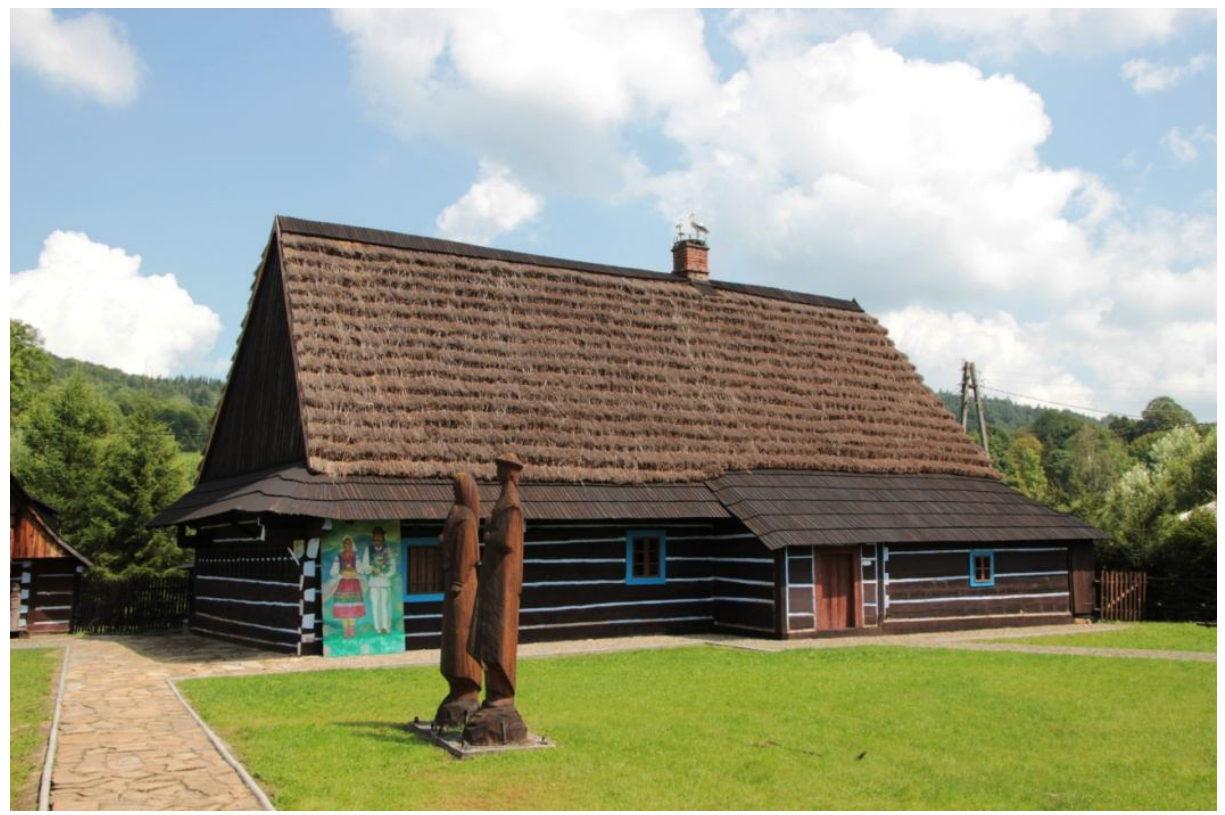

Muzeum-Skansen Kultury Łemkowskiej w Zyndranowej (fot. autor) 


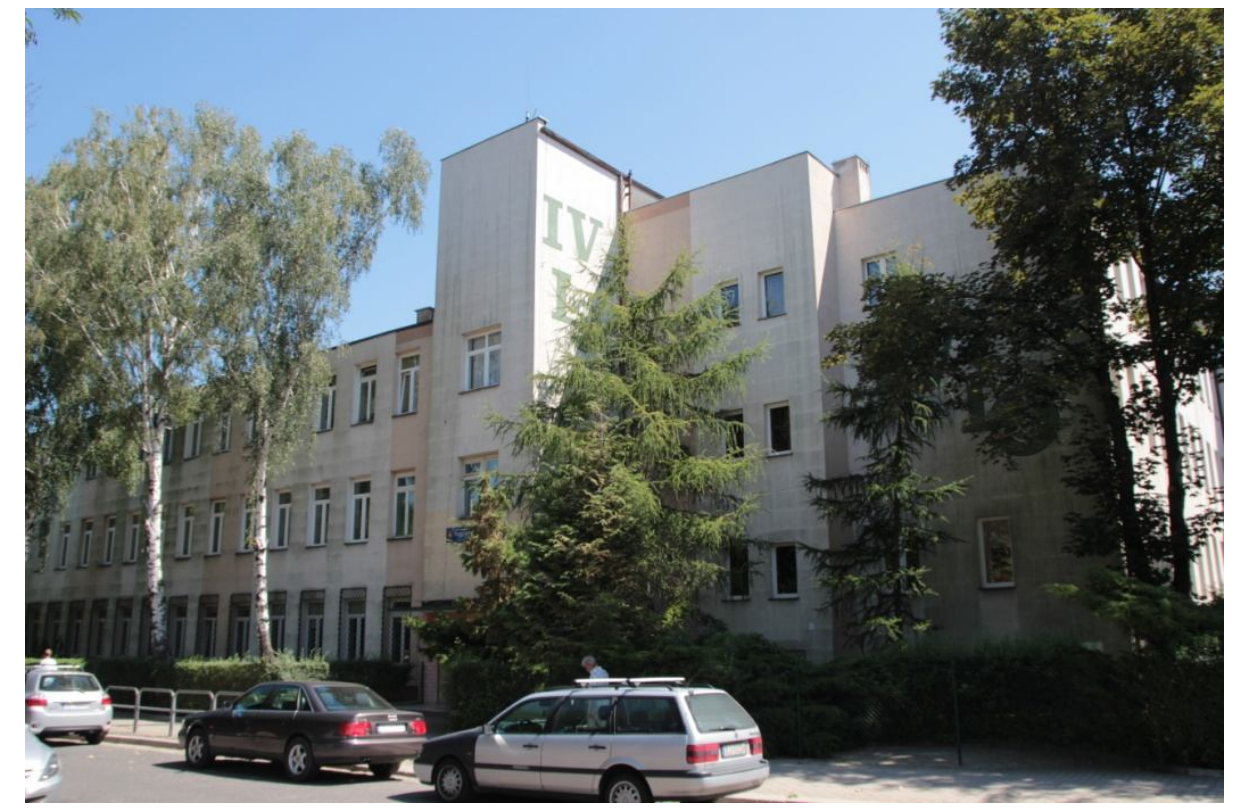

Zespół Szkół Ogólnokształcących nr 4 (IV Liceum Ogólnokształcące, Gimnazjum nr 10) w Legnicy z ukraińskim językiem nauczania (fot. autor)

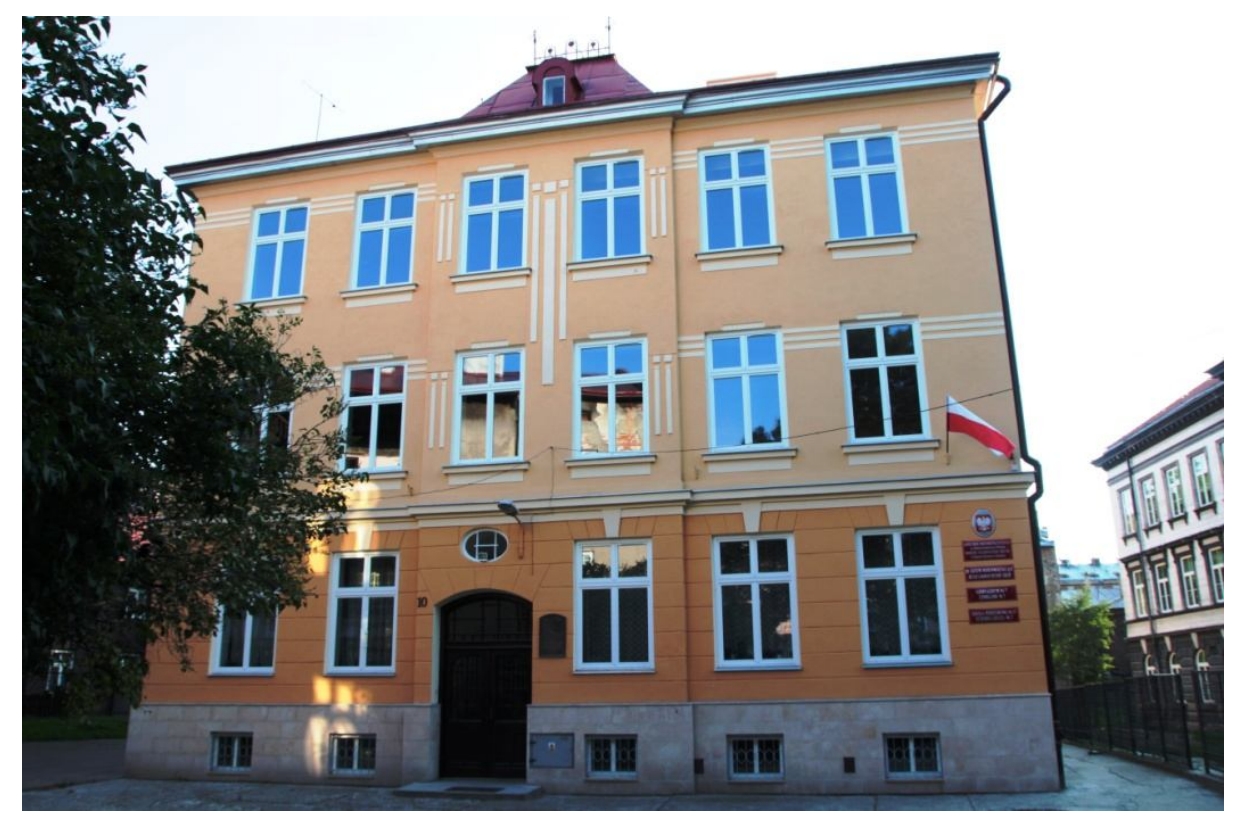

Zespół Szkół Ogólnokształcących nr 2 (Szkoła Podstawowa nr 17, Gimnazjum nr 7 i III Liceum Ogólnokształcące) w Przemyślu z ukraińskim językiem nauczania (fot. autor) 


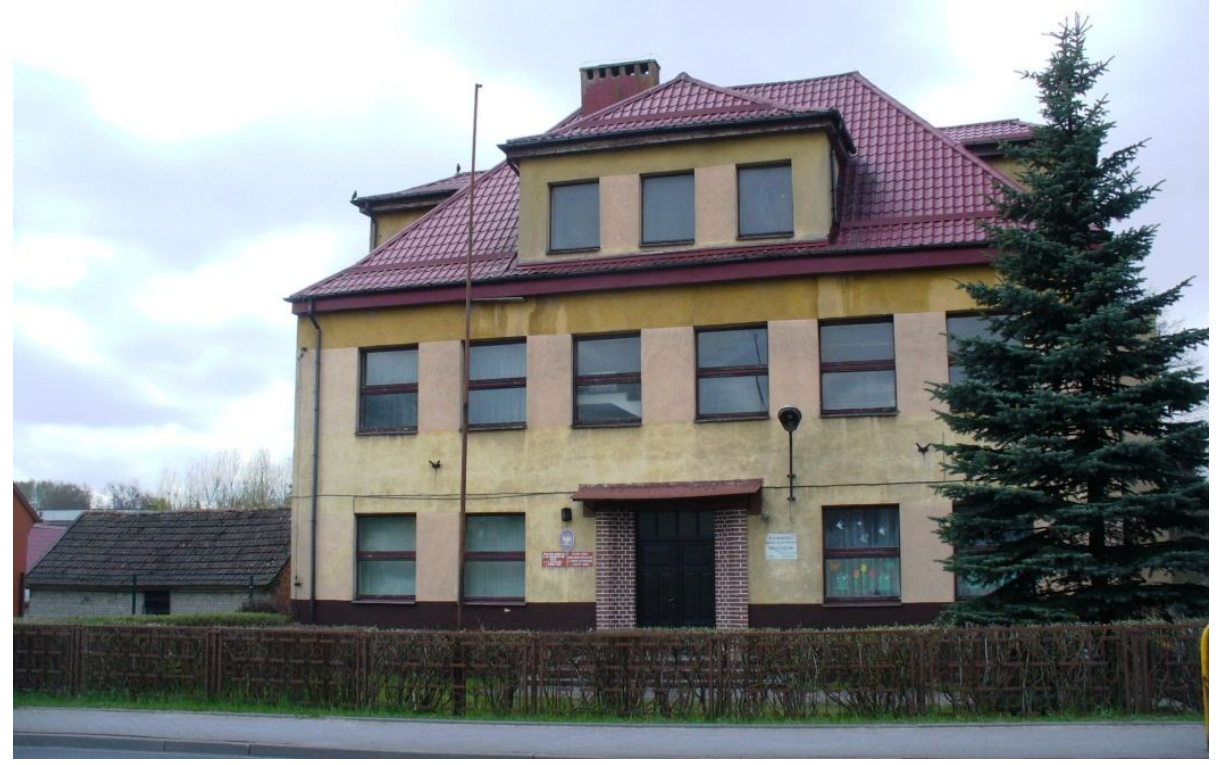

Zespół Szkół nr 2 (Szkoła Podstawowa nr 2, Gimnazjum, I Liceum Ogólnokształcące) w Białym Borze z ukraińskim językiem nauczania (fot. autor)

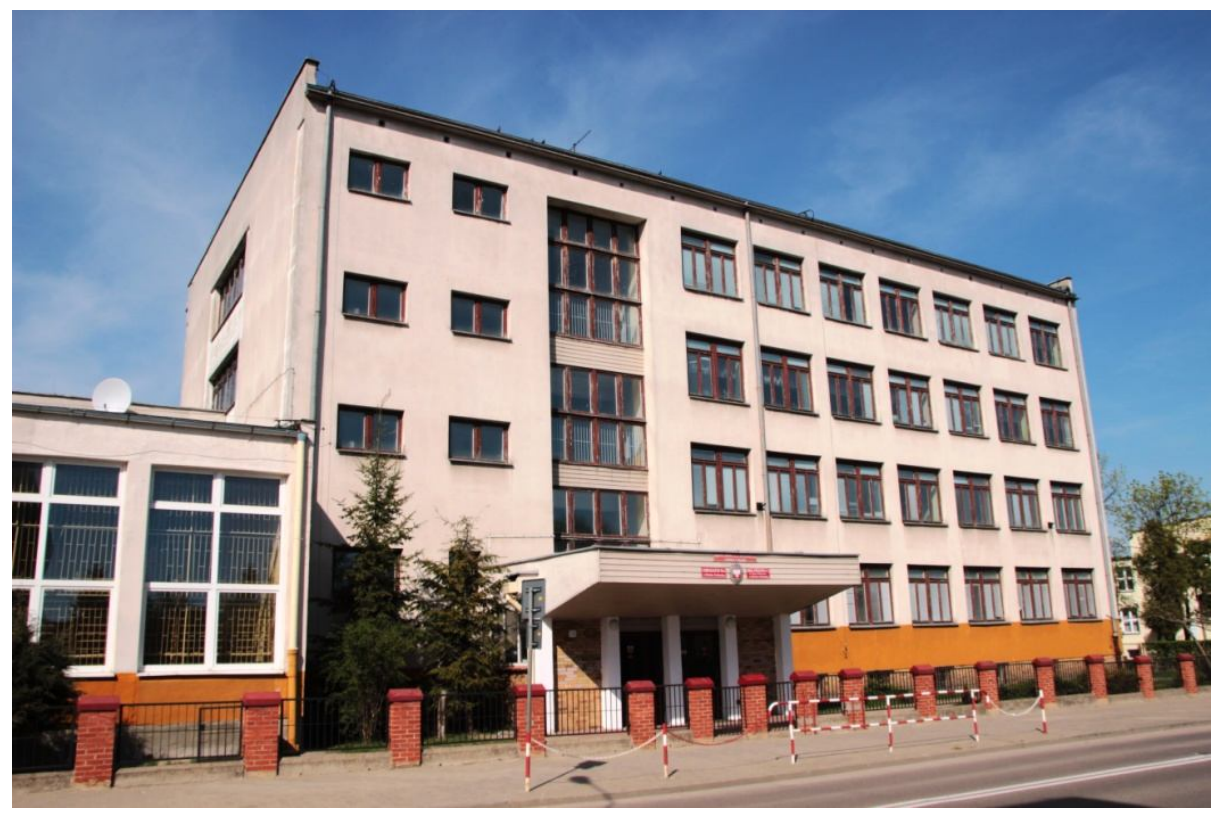

Zespół Szkół (Szkoła Podstawowa nr 4, Gimnazjum nr 2) w Bielsku Podlaskim z klasami z językiem ukraińskim (fot. autor) 


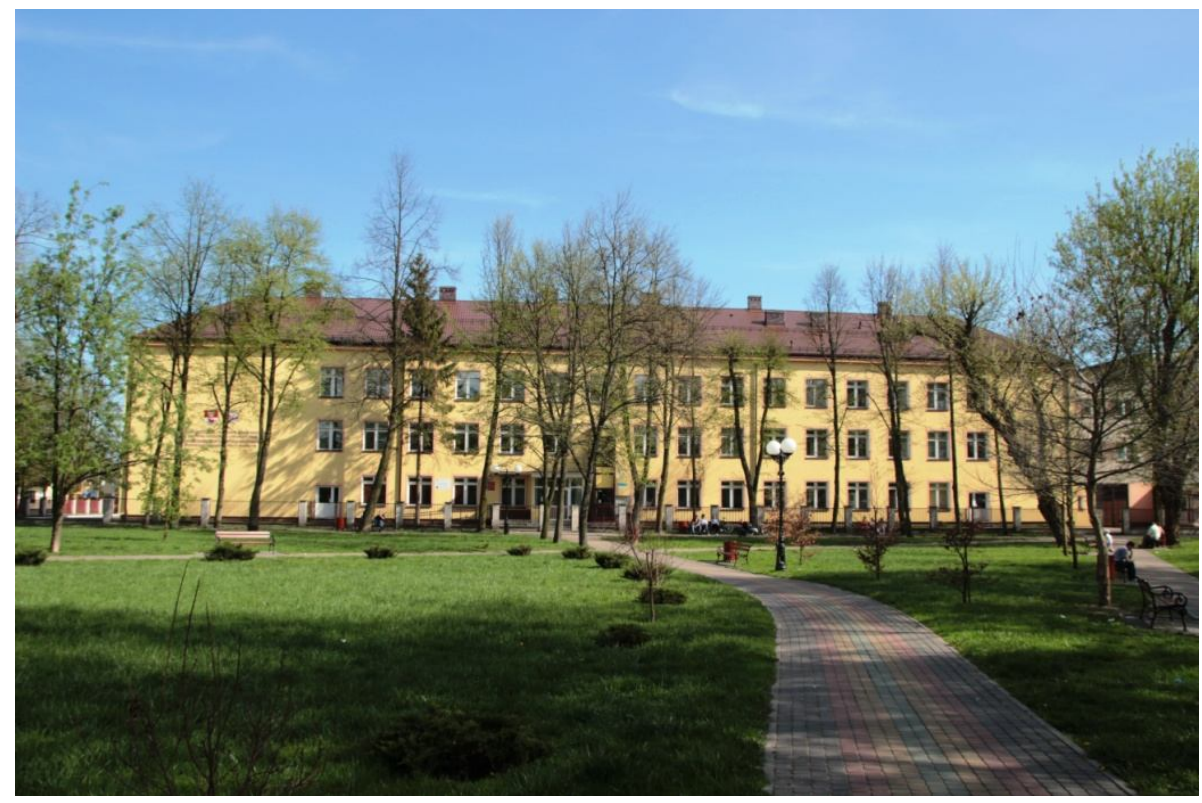

II Liceum Ogólnokształcące w Bielsku Podlaskim z białoruskim językiem nauczania (fot. autor)

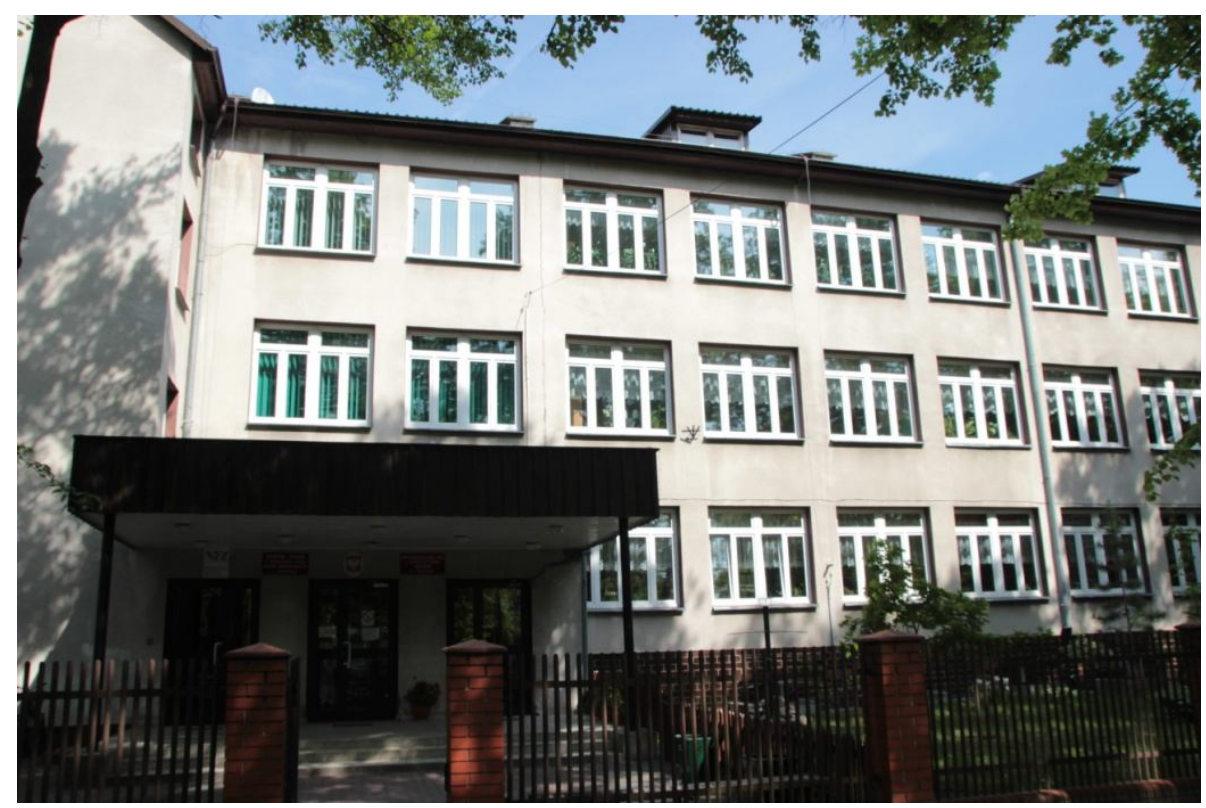

Zespół Szkół (gimnazjum i liceum) w Hajnówce $\mathrm{z}$ dodatkową nauką języka białoruskiego

(fot. autor) 


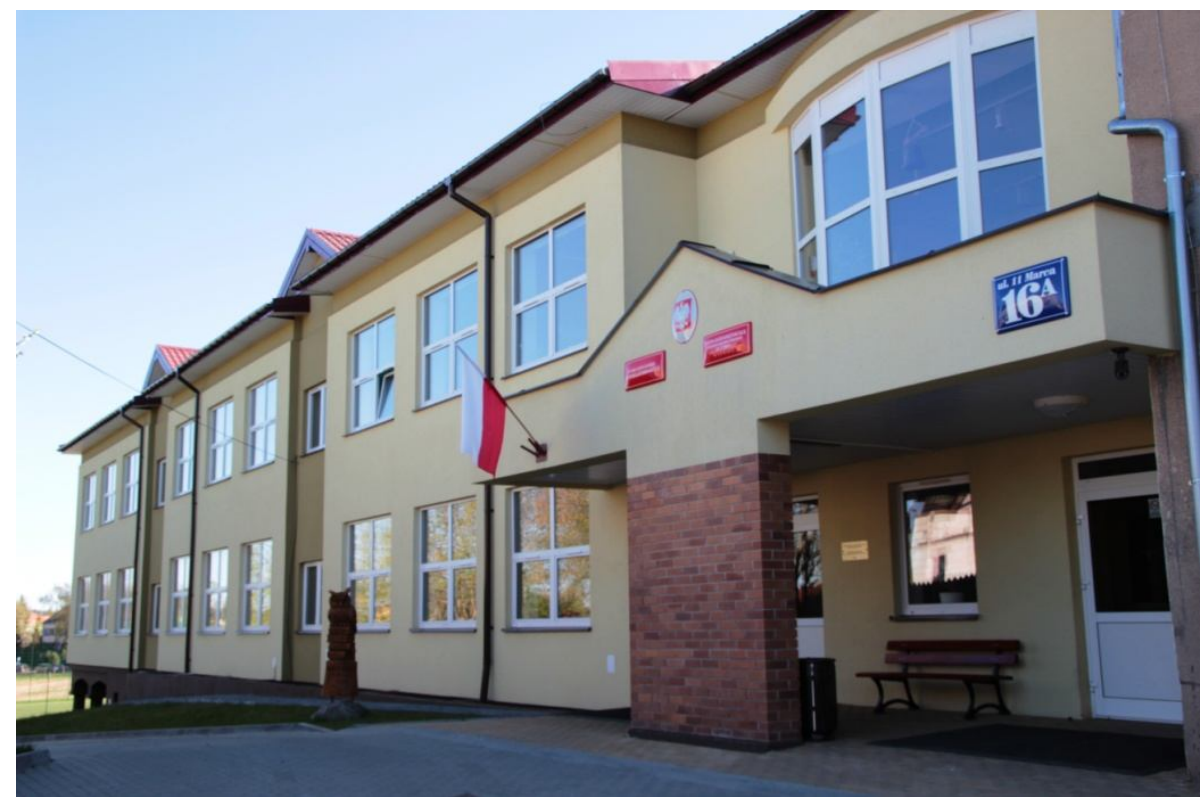

Liceum Ogólnokształcące w Puńsku z litewskim językiem nauczania (fot. autor)

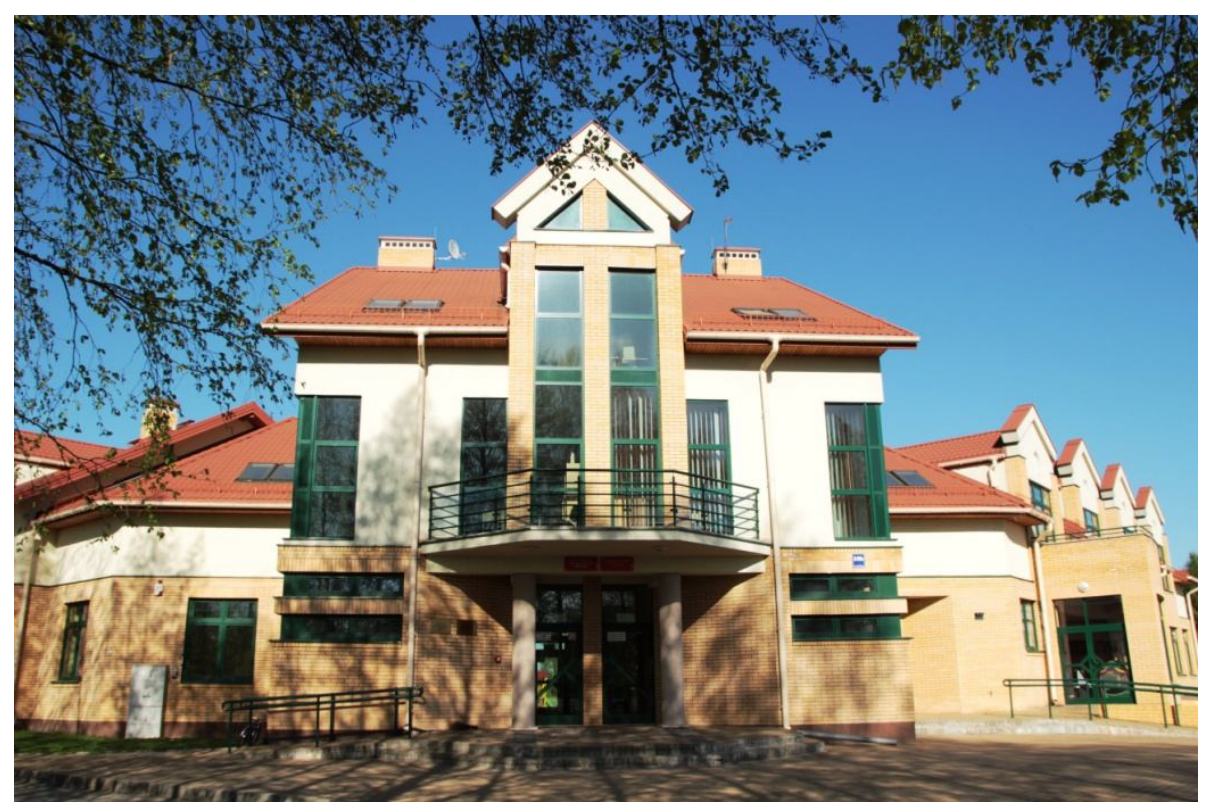

Zespół Szkół „Žiburys” (szkoła podstawowa i gimnazjum) w Sejnach z litewskim językiem nauczania (fot. autor) 
